\title{
Crack-Arrest Behavior in SEN Wide Plates of Low-Upper-Shelf \\ Base Metal Tested Under Nonisothermal Conditions: WP-2 Series
}

Manuscript Completed: July 1990

Date Published: August 1990

Prepared by

D. J. Naus, J. Keeney-Walker, B. R. Bass, G. C. Robinson, Jr.,

S. K. Iskander, R. J. Fields, ${ }^{1}$ R. deWit, ${ }^{1}$ S. R. Low, ${ }^{1}$ C. W. Schwartz, ${ }^{2}$

D. J. Alexander, I.-B. Johansson ${ }^{3}$

Oak Ridge National Laboratory

Operated by Martin Marietta Energy Systems, Inc.

Oak Ridge National Laboratory

Oak Ridge, TN 37831

'National Institute of Standards and Technology, Gaithersburg, MD 20849

2Department of Mechanical Engineering, University of Maryland, College Park, MD 20742

3Royal Institute of Technology, 10044 Stockholm, Sweden

Prepared for

Division of Engineering

Office of Nuclear Regulatory Research

U.S. Nuclear Regulatory Commission

Washington, DC 20555

NRC FIN B0119

Under Contract No. DE-AC05-840R21400

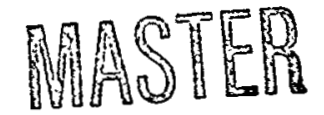

DISTRIBUTION OF THIS DOCUMENT IS UNLIMITED 


\section{DISCLAIMER}

This report was prepared as an account of work sponsored by an agency of the United States Government. Neither the United States Government nor any agency thereof, nor any of their employees, makes any warranty, express or implied, or assumes any legal liability or responsibility for the accuracy, completeness, or usefulness of any information, apparatus, product, or process disclosed, or represents that its use would not infringe privately owned rights. Reference herein to any specific commercial product, process, or service by trade name, trademark, manufacturer, or otherwise does not necessarily constitute or imply its endorsement, recommendation, or favoring by the United States Government or any agency thereof. The views and opinions of authors expressed herein do not necessarily state or reflect those of the United States Government or any agency thereof. 


\section{DISCLAIMER}

Portions of this document may be illegible in electronic image products. Images are produced from the best available original document. 


\section{ABSTRACT}

Current pressure vessel safety assessment methods are based largely on Sects. III and XI of the American Society of Mechanical Engineers Boiler and Pressure Vessel Code (ASME B\&PVC). These documents take the position that the fracture-toughness correlations cannot be assumed for a crack-arrest toughness value $>220 \mathrm{MPa} \cdot \sqrt{\mathrm{m}}$ for light-water reactor pressure vessel steels. This limit is imposed largely because until recently essentially no crack-arrest toughness $\left(K_{I_{a}}\right)$ data existed at or above this level and because Charpy tests show that impact energy levels exhibit an upper-shelf behavior. Certain pressurized-thermal-shock scenarios can lead to conditions where the driving force $\left(\mathrm{K}_{\mathrm{I}}\right)$ on a propagating crack increases to levels in excess of the ASME limit.

The Heavy-Section Steel Technology (HSST) Program at the Oak Ridge National Laboratory under the sponsorship of the Nuclear Regulatory Commission is conducting analytical and experimental studies aimed at understanding the circumstances that would initiate the growth of an existing crack in a reactor pressure vessel (RPV) and the conditions leading to arrest of a propagating crack. Objectives of these studies are to determine (1) if the material will exhibit crack-arrest behavior when the driving force on a crack exceeds the ASME limit, (2) the relationship between $\mathrm{K}_{\mathrm{Ia}}$ and temperature, and (3) the interaction of fracture modes (arrest, stable crack growth, unstable crack growth, and tensile instability) when arrest occurs at high temperatures. In meeting these objectives, crack-arrest data are being developed over an expanded temperature range through tests involving large thermally shocked cylinders, pressurized thermally shocked vessels, and wide-plate specimens. The wide-plate specimens provide the opportunity for a significant number of data points to be obtained at relatively affordable costs. These tests are designed to provide fracture-toughness measurements approaching or above the onset of the Charpy upper-shelf regime in a rising toughness region and with an increasing driving force.

The HSST wide-plate crack-arrest tests are being performed at the National Institute of Standards and Technology, Gaithersburg, Maryland, in their 27-MN capacity testing machine. The third series of tests, which used a Charpy low-upper-shelf base metal, are discussed. Each test used $a 1 \times 1 \times 0.1 \mathrm{~m}$ or $1 \times 1 \times 0.15 \mathrm{~m}$ thick single-edge-notched plate specimen $(a / w=0.2)$ that was subjected to a linear thermal gradient along the plane of crack propagation. The thermal gradient was applied to the specimen by cooling the notched edge and heating the other edge. Through selection of the crack-tip temperature and transverse temperature profile, the initiation load and depth of crack propagation was changed from test to test. During each test, strain and temperature measurements were obtained as functions of position and time. Load, crack-opening-displacement, accelerometer, dynamic displacement, and acoustic-emission data were also obtained as functions of time.

Results obtained from the WP-2 series of crack-arrest tests have produced crack-arrest toughness values well above the limit recognized by current ASME Code guidelines with arrests occurring at temperatures 
up to $102^{\circ} \mathrm{C}$ above the material drop-weight nil-ductility transition temperature $\left(\mathrm{DW}_{\mathrm{NDT}}=60^{\circ} \mathrm{C}\right.$ ) and up to $12^{\circ} \mathrm{C}$ above the onset of Charpy upper-shelf energy (temperature onset $\simeq 150^{\circ} \mathrm{C}$ ). Crack propagation has been predominantly cleavage until arrest occurred, and even for very high driving forces, ductile tearing occurred only after arrest. The fracture data support (1) the use of current linear-elastic fracturemechanics concepts to analyze cleavage run-arrest events, (2) the analytical treatment of cleavage run-arrest and ductile fracture modes as separate events, and (3) the fact that cleavage arrest can and does occur above the ASME 1imit. 
CONTENTS

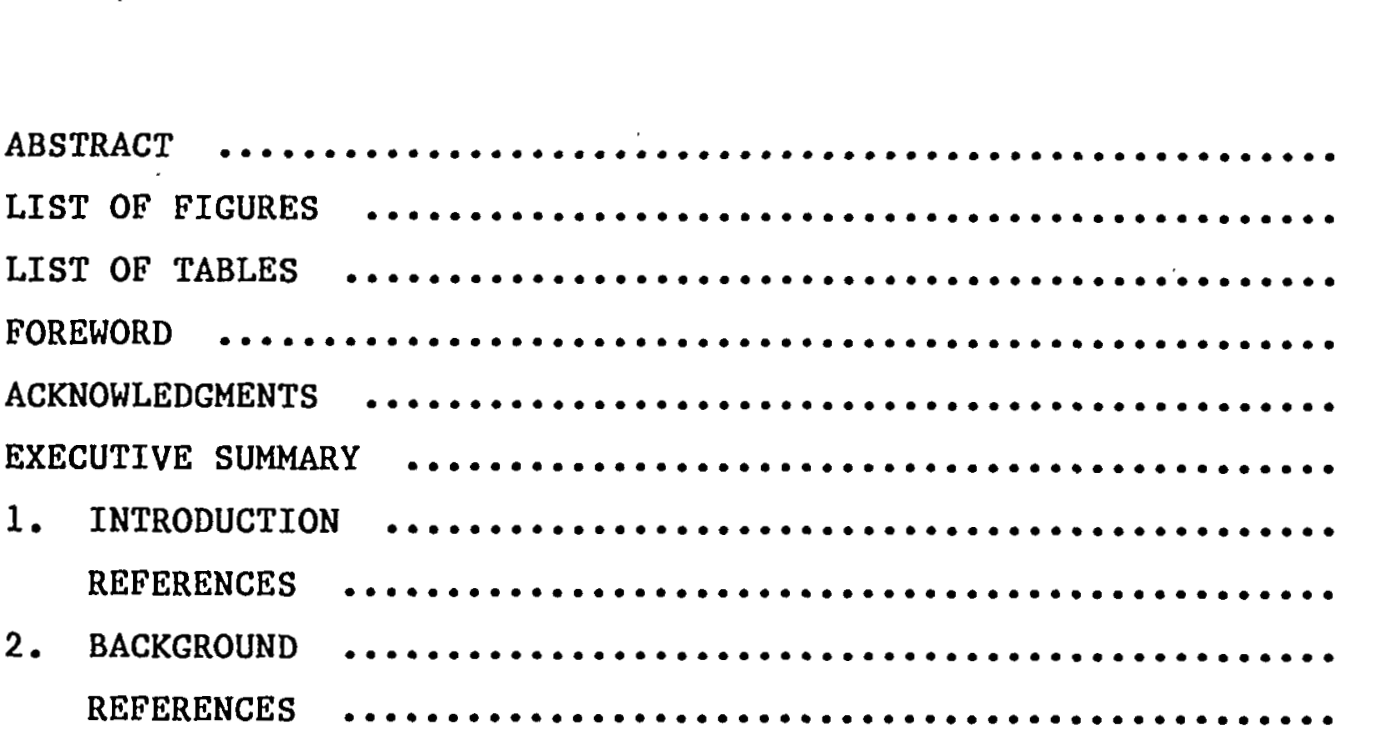

Page

ABSTRACT

iii

vii

xix

$\mathbf{x i}$

xxxi

xxxiii

3. Characterization OF WIDE-PLATE SERIES 2 MATERIAL $\ldots \ldots \ldots \ldots . .8$

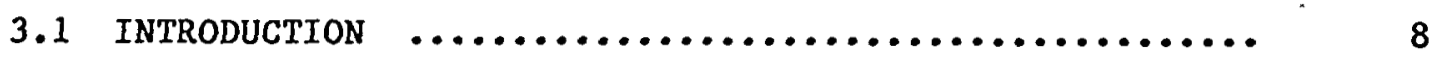

3.2 DROP-WEIGHT TESTING $\ldots \ldots \ldots \ldots \ldots \ldots \ldots \ldots \ldots \ldots \ldots . . . . . . .10$

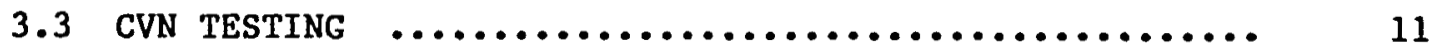

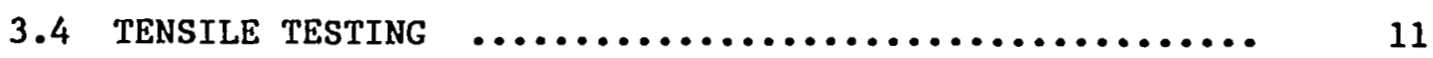

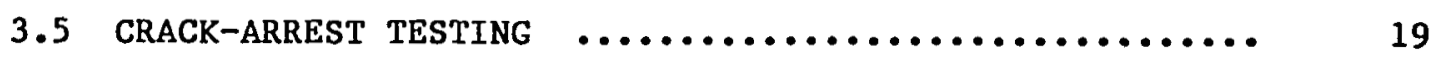

3.6 FRACTURE-TOUGHNESS TESTING $\ldots \ldots \ldots \ldots \ldots \ldots \ldots \ldots \ldots . \ldots \ldots$

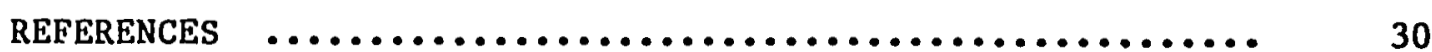

4. SPECIMEN PREPARATION, INSTRUMENTATION, AND TESTING

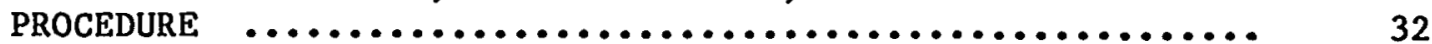

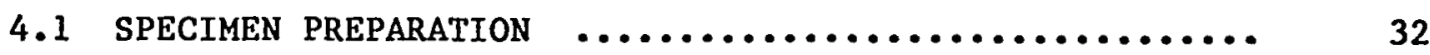

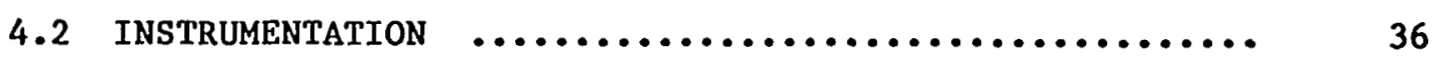

4.3 HEATING-COOLING-INSULATION SYSTEMS $\ldots \ldots \ldots \ldots \ldots \ldots \ldots . . . . .61$

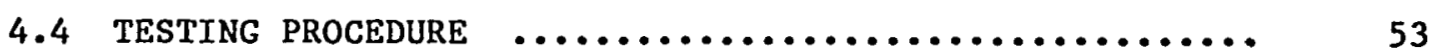

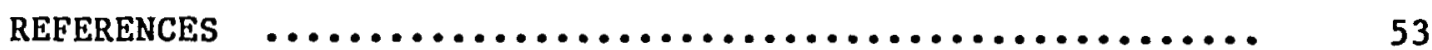

5. SUMMARY OF WIDE-PLATE CRACK-ARREST TESTS WP-2.1
THROUGH WP- $2.6 \quad \ldots \ldots \ldots \ldots \ldots \ldots \ldots \ldots \ldots \ldots \ldots \ldots \ldots \ldots \ldots \ldots \ldots \ldots \ldots \ldots \ldots \ldots \ldots \ldots \ldots$

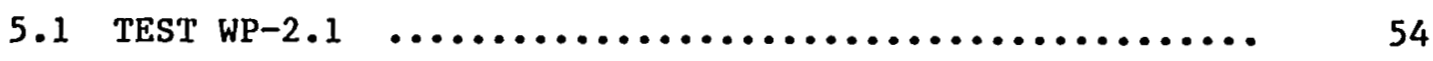

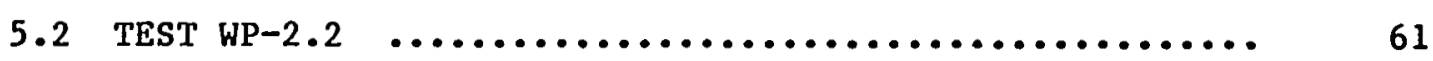

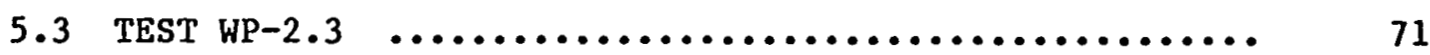

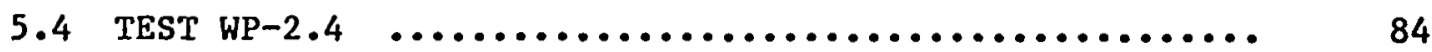

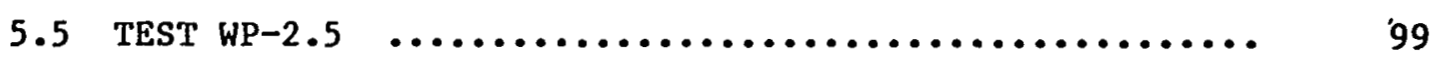




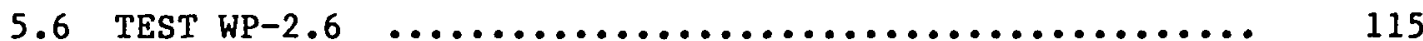

REFERENCE

6. POSTTEST ANALYSES, CRACK-ARREST TOUGHNESS RESULTS,

AND COMPARISON OF DATA WITH OTHER LARGE-SCALE TEST

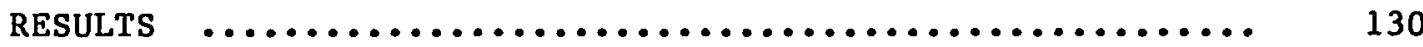

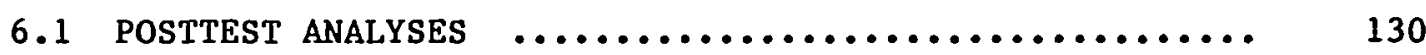

6.1 .1 Posttest 3-D Static Analyses ................. 130

6.1.2 Posttest 2-D Static and Dynamic Analyses ...... 133

6.2 CRACK-ARREST TOUGHNESS RESULTS .................. 145

6.3 COMPARISON OF WIDE-PLATE CRACK-ARREST TOUGHNESS

DATA WITH OTHER LARGE-SCALE TEST RESULTS ........... 148

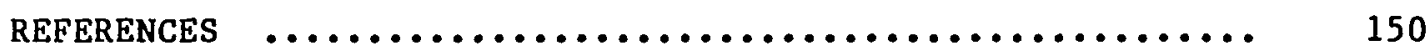

7. CONCLUSIONS ................................. 153

APPENDIX A. SUMMARY OF INSTRUMENTATION RESULTS $\ldots \ldots \ldots \ldots \ldots \ldots \ldots$

APPENDIX B. EFFECTS OF LOAD-POINT BOUNDARY CONDITIONS

AND ANALYSIS METHOD ON WIDE-PLATE CRACK-

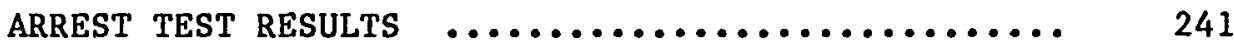

APPENDIX C. EFFECTS OF TUNNELING $\ldots \ldots \ldots \ldots \ldots \ldots \ldots \ldots \ldots \ldots \ldots \ldots . \ldots \ldots$ 


\section{LIST OF FIGURES}

Figure

$\underline{\text { Page }}$

2.1 Summary of large-specimen, high-temperature crackarrest data.$\ldots \ldots \ldots \ldots \ldots \ldots \ldots \ldots \ldots \ldots \ldots \ldots \ldots \ldots \ldots \ldots$

3.1 Allocation of $21 / 4 \mathrm{Cr}-1$ Mo 159-mm-thick LUS steel

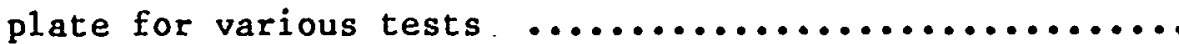

3.2 CVN test results in $\mathrm{T}$-L orientation for material from halves of wide-plate specimens WP-2.1 and $-2.5 \ldots \ldots$

3.3 Curve fits of CVN impact energy vs temperature for characterization block PTCl (2 $1 / 4 \mathrm{Cr}-1$ Mo stee1) for $T-L$ orientation and at various plate depths .......

3.4 Comparison of $W P-2$ material tensile strength test results with $99 \%$ confidence interval obtained from PTCl characterization block material tests ............

3.5 Typical room-temperature stress-strain curve for material obtained from characterization block PTCl in direction transverse to material rolling orientation

3.6 Comparison of posttest crack-arrest toughness $\left(K_{a}\right)$ values obtained for specimens fabricated from plate halves of specimens $\mathrm{WP}-2.1$ and -2.5 with those obtained from PTCl material and ASME $\mathrm{K}_{\mathrm{Ia}}$ curve

3.7 Comparison of regression fits of crack-arrest toughness data for all PTC1 ( $\mathrm{T}-\mathrm{L}$ and $\mathrm{T}-\mathrm{S}$ orientations) material data and for WP-2 and PTCl materials ( $\mathrm{T}-\mathrm{L}$ orientation)

3.8 Comparison of crack-arrest toughness test results obtained from PTCl and PTSE-2 LUS $21 / 4 \mathrm{Cr}-1$ Mo

3.9 Comparison of posttest initiation toughness $\left(\mathrm{K}_{J c}\right)$ for specimens fabricated from plate halves of specimens WP-2.1 and -2.5 with range of values exhibited for specimens fabricated from PTC1 characterization block

3.10 Graphical output from analysis of a typical fracture toughness test at $80^{\circ} \mathrm{C}$ using single-specimen unloading compliance method $\ldots \ldots \ldots \ldots \ldots \ldots \ldots \ldots \ldots$

3.11 Comparison of $\mathrm{J}$-integral $\left(\mathrm{J}_{\mathrm{m}}\right)$ resistance curves at three temperatures for specimens obtained from WP-2.5 material at midthickness in $\mathrm{T}-\mathrm{L}$ orientation $\ldots \ldots \ldots \ldots$

4.1 Schematic of HSST wide-plate crack-arrest specimen ..... 32

4.2 Wide-plate test specimen undergoing hydrogen charging of an EB weld 
4.3 Schematic of chevron configuration of crack front ......

4.4 Overall specimen dimensions for (a) tests WP-2.1 and -2.2 , (b) tests WP-2.3 and -2.4 , and (c) tests

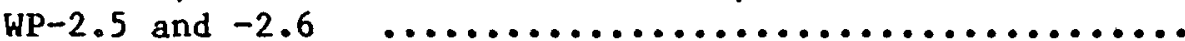

4.5 Out-of-plane deviation vs axial position from top load pin

4.6 Thermocouple locations for wide-plate, crackarrest specimens (a) WP-2.1 and -2.4 ; (b) WP-2.2, -2.3 , and 2.6 ; and (c) $\mathrm{WP}-2.5 \ldots \ldots \ldots \ldots \ldots \ldots \ldots \ldots \ldots \ldots \ldots \ldots \ldots$

4.7 Schematic of HSST wide-plate, crack-arrest data

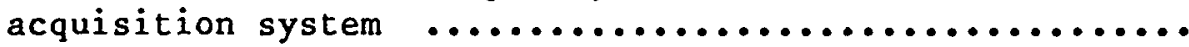

4.8 Strain-gage locations for wide-plate, crack-arrest specimens (a) WP-2.1 and -2.5 , (b) WP-2.2,

(c) WP-2.3, and (d) WP-2.4

4.9 Strain-gage locations for wide-plate, crack-arrest specimen WP $2.6 \quad \ldots \ldots \ldots \ldots \ldots \ldots \ldots \ldots \ldots \ldots \ldots \ldots \ldots \ldots$

4.10 HSST wide-plate, crack-arrest test specimen installed in NIST testing machine $\ldots \ldots \ldots \ldots \ldots \ldots \ldots \ldots$

5.1 Transverse temperature profiles at approximate time of crack initiation-arrest events: WP-2 series ....... 56

5.2 Fracture surfaces of WP-2 series specimens .......... 57

5.3 Actual and ideal temperature distributions across specimen width $(a)$ at start of test, (b) at $9.2-\mathrm{MN}$ load, and $(c)$ at $\sim 10 \mathrm{~s}$ before initiation of

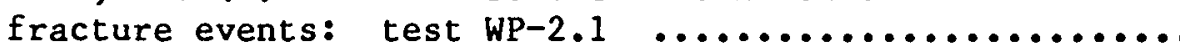

5.4 Load history for test WP-2.1 $\ldots \ldots \ldots \ldots \ldots \ldots \ldots \ldots \ldots \ldots \ldots . \ldots \ldots$

5.5 Fracture surface of specimen WP-2.1 $\ldots \ldots \ldots \ldots \ldots \ldots \ldots \ldots . \ldots 6$

5.6 Reduction-in-thickness contour map of specimen

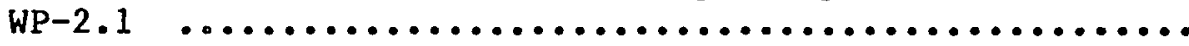

5.7 Strain-gage-derived crack-front position vs time:

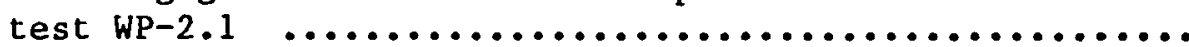

5.8 Actual and ideal temperature distributions across specimen width during warm prestressing: test WP-2.2

5.9 Load vs (a) time and (b) front-face COD during

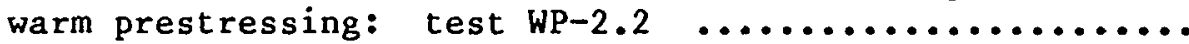

5.10 Actual and ideal temperature distributions across specimen width (a) at start of loading and (b) just before initiation of cleavage crack run-arrest events: test WP-2.2 $\ldots \ldots \ldots \ldots \ldots \ldots \ldots \ldots \ldots \ldots \ldots \ldots \ldots$ 
5.12 Fracture surface of specimen wP-2.2 $\ldots \ldots \ldots \ldots \ldots \ldots \ldots .70$

5.13 Reduction-in-thickness contour map of specimen WP-2.2

5.14. Strain-gage-derived crack-front position vs time: test WP-2.2

5.15 Actual and ideal temperature distributions across specimen width (a) at start of test and (b) a few

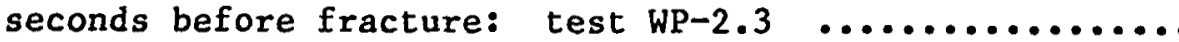

5.16 Fracture surface of specimen WP-2.3

5.17 Close-up of cleavage and loss-of-cleavage regions (a) without cleavage run-arrest events highlighted, and $(b)$ with cleavage run-arrest events highlighted: test WP-2.3

5.18 Reduction-in-thickness contour map of specimen WP -2.3

5.19 Strain-gage-derived crack-front position vs time for (a) results for first $50 \mathrm{~ms}$ of test and (b) results for entire $\sim 950 \mathrm{~ms}$ of test: test WP-2.3

5.20 Actual and ideal temperature distributions across specimen width at approximate time of specimen

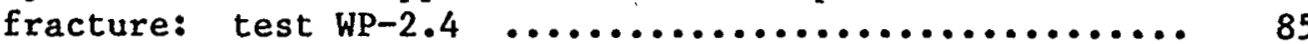

5.21 Load history for test $w P-2.4 \ldots \ldots \ldots \ldots \ldots \ldots \ldots \ldots \ldots \ldots$

5.22 Fracture surface of specimen WP-2.4 $\ldots \ldots \ldots \ldots \ldots \ldots \ldots . . . \ldots 6$

5.23 Close-up of initial flaw and region of pop-in:

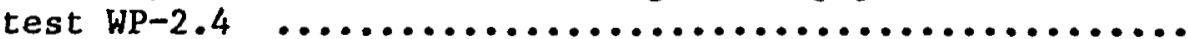

5.24 Pop-in detected by strain gages $1-3$ on plate front face and 13 and 14 on plate back face: test $\mathrm{WP}-2.4$

5.25 Reduction-thickness contour map of specimen WP-2.4 .....

5.26 Strain-gage-derived crack-front position vs time:

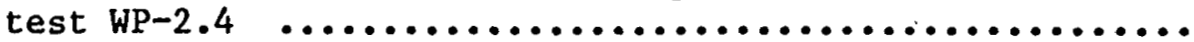

5.27 Fracture surface of specimen WP-2.4, showing how the fracture surface was sectioned for further examination

5.28 A view of a portion of tip of precrack for specimen WP-2.4, Sect. 1 (Fig. 5.27)

5.29 Detail of ductile tearing from EB weld flaw, Sect. 1 (Fig. 5.27)

5.30 Apparent initiation site for first crack runarrest event, Sect. 1 (Fig. 5.27) 
5.31 Section 2 (Fig. 5.27) showing first arrest event on part of fracture surface ....................

5.32 Apparent initiation site for second crack runarrest event, Sect. 2 (Fig. 5.27) .................

5.33 Actual and ideal temperature distributions across specimen width (a) at start of test, (b) at crack pop-in event, and $(c)$ at approximate time of fracture events: test $\mathrm{WP}-2.5 \ldots \ldots \ldots \ldots \ldots \ldots \ldots$

5.34 Load history for test WP-2.5 ..................... 101

5.35 Fracture surface for specimen WP-2.5 .............. 102

5.36 Close-up of fracture surface for specimen WP-2.5 ..... 103

5.37 Close-up of initial EB weld-generated crack and region of pop-in: test $W P-2.5 \quad \ldots \ldots \ldots \ldots \ldots \ldots \ldots \ldots \ldots \ldots$

5.38 Pop-in as detected by strain gages $1-3$ on plate front face and 13 and 14 on plate back face: test WP-2.5

5.39 High-resolution strain-gage records for companion crack-line gages during pop-in event: test WP-2.

5.40 High-resolution accelerometer records during the pop-in event: test WP-2.5

5.41 Strain-gage-derived crack-front position vs time: test WP-2.5

5.42 Fracture surface of specimen WP-2.5, showing how the fracture surface was sectioned for further examination

5.43 Precrack and initial tearing from specimen WP-2.5, Sect. A (Fig. 5.42)

5.44 View of apparent initiation site for first crack run-arrest event, Sect. A (Fig. 5.42)

5.45 First arrest location from Sect. B (Fig. 5.42)

5.46 Ductile tearing strip from Sect. B (Fig. 5.42) after first crack run-arrest event

5.47 Actual and ideal temperature distribution across specimen width during warm prestressing: test WP-2.6

5.48 Load vs (a) time, (b) front-face COD, and

(c) back-face COD during warm prestressing:

test WP-2.6

5.49 Actual and ideal temperature distributions across specimen width (a) at start of loading and (b) just before initiation of cleavage crack run-arrest events: test WP-2.6 
5.50 Load history for test WP-2.6 $\ldots \ldots \ldots \ldots \ldots \ldots \ldots \ldots \ldots \ldots$

5.51 Fracture surfaces of bottom and top plate halves of specimen WP $-2.6 \quad \ldots \ldots \ldots \ldots \ldots \ldots \ldots \ldots \ldots \ldots \ldots \ldots \ldots$

5.52 Close-up of cleavage and loss-of-cleavage regions

(a) without and (b) with arrest locations high-

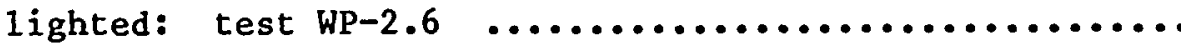

5.53 Reduction-in-thickness contour map of specimen

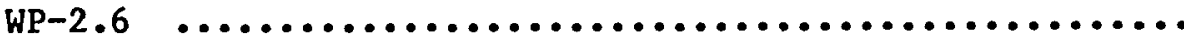

5.54 Strain-gage-derived crack-front position vs time: test WP-2.6

6.1 Example of finite-element model used for dynamic analysis of wide-plate crack-arrest tests .............

6.2 Detail of crack-tip region from 3-D finite-element model of 102-mm-thick wide-plate specimen...$\ldots \ldots \ldots$.

6.3 Statically calculated crack lengths: test WP-2.4 ..... 134

6.4 Determination of arrest toughness at initiation load of $8.85 \mathrm{MN}$ : test WP-2.4

6.5 Complete static and stability analyses for initiation load of $8.85 \mathrm{MN}$ : test WP-2.4 $\ldots \ldots \ldots \ldots \ldots \ldots$

6.6 Dynamic-analysis, crack-depth history: test WP-2.4

6.7 Dynamic factor, static toughness, quasi-static displacement-controlled factor, and crack velocity vs instantaneous crack length: test WP-2.4 $\ldots \ldots \ldots \ldots$

6.8 Crack-depth history from front-face strain gages: test WP-2.4

6.9 Calculated stress-intensity factor vs time from generation-mode dynamic analysis (fixed-1oad case): test WP-2.4

6.10 Actual and computed strain histories for frontface crack-1ine gages $1-4$ : test WP-2.4

6.11 Actual and computed strain histories for crackline gages $5,17,7$, and 8 : test WP-2.4 $\ldots \ldots \ldots \ldots \ldots$

6.12 Actual and computed strain histories for frontface crack-1ine gages 9-12: test WP-2.4

6.13 Actual and generation-mode dynamic analysis computed COD at $a / w=0.15$ for front-face gage (fixed-load case): test WP-2.4

6.14 Fixed-load, generation-mode, dynamic finiteelement crack-arrest toughness results for HSST wide-plate tests 
6.15 Relationship of WP-2 series initiation and arrest events to CVN energy vs temperature curve ............

6.16 HSST wide-p1ate crack-arrest data (fixed-1oad, generation-mode dynamic finite-element calculations) show trend consistent with other large-

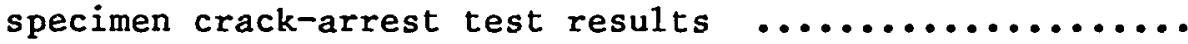

A.1 Strain histories for companion crack-line gages: test WP-2.1 (gages $1-4$ and 13-15) $\ldots \ldots \ldots \ldots \ldots \ldots \ldots$

A.2 Strain histories for companion crack-line gages:

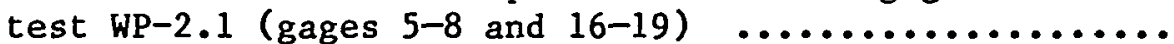

A.3 Strain histories for companion crack-1ine gages:

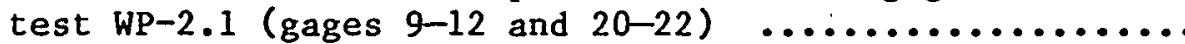

A.4 Near- and far-field strain histories: test WP-2.1 (gages 23, 24, 26, and 27) $\ldots \ldots \ldots \ldots \ldots \ldots \ldots \ldots \ldots \ldots \ldots$

A.5 Strain histories for gages $1-4$ showing crack passing under strain gage 1 and arresting before reaching strain gage 2: test WP-2.1

A.6 Strain histories for gages 2-5 showing crack passing under strain gages 2 and 3 , arresting momentarily before passing under strain gage 4, and arresting before passing under gage 5 :

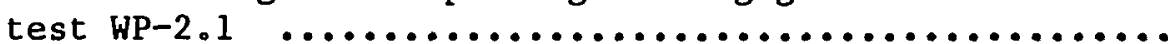

A.7 Strain histories for gages $2-5$ showing momentary arrest between gages 3 and 4 : test WP-2.1 .......... 162

A.8 Twenty-millisecond records of strain gages 4-7 showing previous crack run-arrest events and crack passing under gage 5 and arresting before reaching gages 6 and 7 : test wP-2.1 $\ldots \ldots \ldots \ldots \ldots$

A.9 Fifty-millisecond records of strain gages 5-8 showing fibrous tearing after a cleavage arrest just past gage 5 , followed by cleavage fracture, reinitiation just past gage 6 , another arrest, and cleavage fracture reinitiation that passes under gage 8 and arrests: test WP-2.1 ............... 164

A.10 Strain histories of gages 9-12 showing fibrous

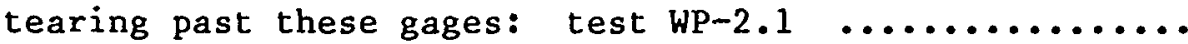

A.11 Strain histories for gages 13-16 showing crack passing under gages 13 and 14 before

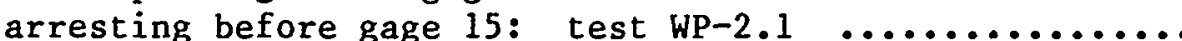

A.12 Strain histories for gages 15-18 showing crack passing under gage 15 , reinitiating, passing under gage 16, arresting, reinitiating, passing under gage 17, arresting, reinitiating, and passing under gage 18: test WP-2.1 $\ldots \ldots \ldots \ldots \ldots \ldots \ldots$ 
A.13 Strain histories for gages 19-22 showing fibrous tearing past these gages: test WP-2.1 $\ldots \ldots \ldots \ldots \ldots \ldots \ldots$

A.14 AE results for various time resolutions: test $W P-2.1 \quad \ldots \ldots \ldots \ldots \ldots \ldots \ldots \ldots \ldots \ldots \ldots \ldots \ldots \ldots \ldots \ldots$

A.15 Longitudinal acceleration results at various time resolutions measured by top and bottom "damped" accelerometers mounted $3.653 \mathrm{~m}$ above and $3.655 \mathrm{~m}$ below crack plane, respectively: test WP-2.1

A.16 Front and back COD histories obtained from gages mounted at $\mathrm{a} / \mathrm{w}=0.15$ : test $\mathrm{wP}-2.1 \quad \ldots \ldots \ldots \ldots \ldots \ldots \ldots$

A.17 Strain histories for companion crack-line gages showing cleavage crack passing these gages: test WP-2.2 (gages 1,2, and 13)

A.18 Strain histories for companion crack-line gages showing cleavage crack passing these gages: test WP-2.2 (gages $3,4,15$, and 16)

A.19 Strain histories for companion crack-1ine gages showing cleavage crack propogating past gages 5 and 17 and arresting just past gages 6 and 18: test WP-2.2

A.20 Strain histories for companion crack-1ine gages showing cleavage crack passing these gages followed by cleavage crack run-arrest events: test WP-2.2 (gages $7,8,19$, and 20 ) $\ldots \ldots \ldots \ldots \ldots \ldots$

A.21 Strain histories for front-face crack-line gages showing arrest of cleavage crack propagation past gage 9 with subsequent fibrous crack propagation past gages 10-12: test WP-2.2

A.22 Strain history for near-field gage 21 (a) during cleavage run-arrest events and $(b)$ during entire fracture process: test WP-2.2 ....................

A.23 Strain histories for far-field gages 22-25 during cleavage run-arrest events: test WP-2.2 $\ldots \ldots \ldots \ldots \ldots \ldots$

A.24 Strain histories for far-field gages 22-25 during entire fracture process: test WP-2.2 $\ldots \ldots \ldots \ldots \ldots \ldots \ldots$

A.25 Front- and back-face COD histories at two time resolutions: test WP-2.2 $\ldots \ldots \ldots \ldots \ldots \ldots \ldots \ldots \ldots \ldots \ldots$

A.26 Dynamic displacement and longitudinal acceleration histories at two time resolutions: test WP-2.2 $\ldots \ldots \ldots$

A.27 Strain histories for companion crack-1ine gages:

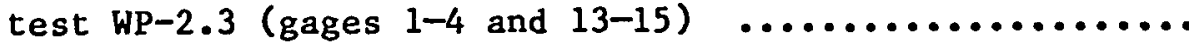

A.28 Strain histories for companion crack-1ine gages: test WP-2.3 (gages 5-8 and 16-19) 
A.29 Strain histories for companion crack-1ine gages: test WP-2.3 (gages $9-12$ and $20-22$ ) .................. 186

A.30 Crack run-arrest events as detected by near- and far-field strain gages: test WP-2.3 (gages 24,26 , and 27)

A.31 Strain histories for gages 1-4 showing crack passing under gages 1 and 2 and arresting before reaching gages 3 and 4: test WP-2.3

A.32 Strain histories for gages $1-4$ showing reinitiation of crack propagation as detected by gages 1 and 2 and crack passing gage 3 with a subsequent arrest before reaching gage 4 : test WP-2.3 $\ldots \ldots \ldots \ldots \ldots \ldots \ldots$

A.33 Strain histories for gages 5-8 showing propagation of the crack past gage 5 , a subsequent arrest before reaching gage 6 , and reinitiation with the crack propagating past gages $6-8$ : test WP-2.3 ........

A.34 Strain histories for gages $5-8$ showing crack passing gages $6-8$ : test WP-2.3 $\ldots \ldots \ldots \ldots \ldots \ldots \ldots \ldots \ldots$

A.35 Strain histories for gages 9-12 showing crack

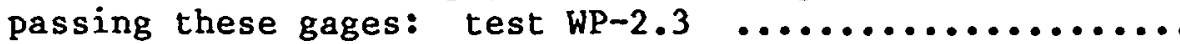

A.36 Strain histories for back-face gages 13-15 showing crack passing gages 13 and 14 and then arresting

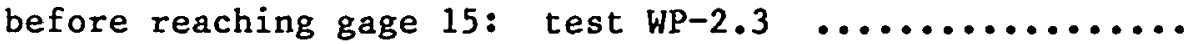

A.37 Strain histories for back-face gages 13-15 showing multiple crack run-arrest events: test WP-2.3

A.38 Strain histories for back-face gages 17 and 18 showing early crack run-arrest events followed much later by crack passing gage 18: test WP-2.3 ......

A.39 Strain histories for back-face gages 19-22 showing propagation of crack past these gages: test WP-2.3 ...

A.40 Longitudinal acceleration results at two levels of time resolution measured by top and bottom "damped" accelerometers mounted $3.585 \mathrm{~m}$ above and $3.589 \mathrm{~m}$ below the crack plane, respectively: test WP-2.3

A.41 Bottom displacement gage results (a) during initial crack run-arrest events and $(b)$ during entire test: test WP-2.3

A.42 COD gage results during initial crack run-arrest

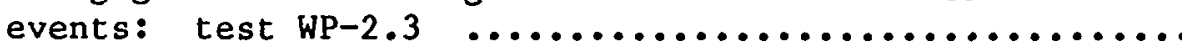

A.43 AE results for various time resolutions: test WP-2.3 
A.44 Strain histories for companion crack-1ine gages: test WP-2.4 (gages $1-4$ and 13-15) .................. 202

A.45 Strain histories for companion crack-line gages: test WP-2.4 (gages $5-8$ and 16-19) $\ldots \ldots \ldots \ldots \ldots \ldots \ldots \ldots$

A.46 Strain histories for companion crack-line gages:

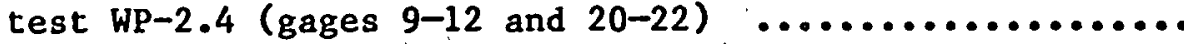

A.47 Initiation of first crack run-arrest event as detected by strain gage 1 for two time resolutions: test WP-2.4 $\ldots \ldots \ldots \ldots \ldots \ldots \ldots \ldots \ldots \ldots \ldots \ldots$

A.48 Propagation of crack during first crack run-arrest event as detected by companion crack-1ine gages 2 and 3 and 13 and 14: test WP-2.4 $\ldots \ldots \ldots \ldots \ldots \ldots \ldots$

A.49 Arrest and reinitiation of crack propagation as detected by companion crack-1ine gages 4 and 15 at two levels of time resolution: test WP-2.4

A.50 Additional crack run-arrest events as detected. by companion crack-1ine gages 5 and 6 and 16 and 17: test WP-2.4 $\ldots \ldots \ldots \ldots \ldots \ldots \ldots \ldots \ldots \ldots \ldots \ldots \ldots$

A.51 Additional crack run-arrest events as detected by companion crack-1ine gages 7 and 8 and 18 and 19: test WP-2.4

A.52 Ductile tearing as detected by companion crackline gages 9 and 10 and 20 and 21: test WP-2.4

A.53 Ductile tearing as detected by crack-line gages 11,12 , and 22 : tèst WP-2.4 $\ldots \ldots \ldots \ldots \ldots \ldots \ldots \ldots \ldots \ldots$

A.54 Crack run-arrest events as monitored by near-

field strain gages 23 and 25 and far-field

strain gages 26 and 27 : test WP-2.4

A.55 AE results at different'levels of time resolutions: test WP- 2.4

A.56 Longitidual acceleration during test measured by "damped" accelerometer mounted $4.041 \mathrm{~m}$ below

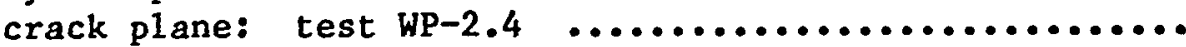

A.57 Longitidual acceleration during test measured by "shock" accelerometer mounted $4.038 \mathrm{~m}$ below crack plane: test WP-2.4 ........................

A.58 Front- and back-face COD at various time spans after fracture initiation: test WP-2.4 $\ldots \ldots \ldots \ldots \ldots \ldots .$.

A.59 Strain histories for companion crack-line gages: test WP-2.5 (gages $1-4$ and 13-15) ...................

A.60 Strain histories for companion crack-1ine gages: test WP-2.5 (gages 5-8 and 16-19) 
A.61 Strain histories for companion crack-1ine gages:

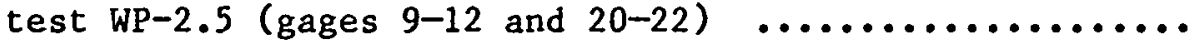

A.62 Near- and far-field strain histories: test WP-2.5 (gages 23, 24, 26, and 27)

A.63 Strain histories for front-face gages 1-3, indicating that crack passes gages 1 and 2 and arrests before reaching gage 3 $(t=0.344 \mathrm{~ms}):$ test WP-2.5

A.64 Strain histories for front-face gages 5, 6, 9, and 10 indicating multiple crack run-arrest

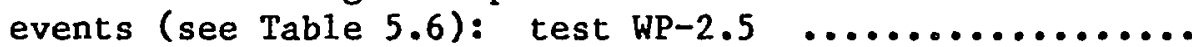

A.65 Strain histories for back-face gages 13-15 indicating that crack passes gages 13 and 14 with a subsequent arrest $(t=0.54 \mathrm{~ms})$ before reaching gage 15: test $\mathrm{WP}-2.5 \quad \ldots \ldots \ldots \ldots \ldots \ldots \ldots \ldots \ldots$

A.66 Strain histories for back-face gages 15-18, indicating that crack passes gages 15 and 16 , arrests $(t=8.16 \mathrm{~ms})$ before reaching gage 17 , reinitiates $(t=11.16 \mathrm{~ms})$, passes under gage 17 , arrests $(t=11.49 \mathrm{~ms})$ before reaching gage 18, reinitiates ( $t=19.11 \mathrm{~ms})$, and then passes under gage 18: test $W P-2.5 \quad \ldots \ldots \ldots \ldots \ldots \ldots \ldots \ldots \ldots \ldots$

A.67 Strain histories for back-face gages 19-22 showing crack passing gage 19, arresting ( $t=27.95 \mathrm{~ms})$, converting to fibrous tearing, and then passing under gages 20-22: test WP-2.5 $\ldots \ldots \ldots \ldots \ldots \ldots \ldots \ldots$

A.68 Accelerometer outputs during first crack runarrest event: test $\mathrm{WP}-2.5 \quad \ldots \ldots \ldots \ldots \ldots \ldots \ldots \ldots \ldots \ldots \ldots$

A.69 Front- and back-face coDs during the fracture event: test WP-2.5 $\ldots \ldots \ldots \ldots \ldots \ldots \ldots \ldots \ldots \ldots \ldots \ldots \ldots \ldots$

A.70 Strain histories for front-face crack-line gages:

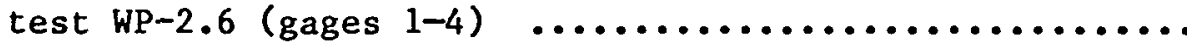

A.71 Strain histories for front-face crack-line gages:

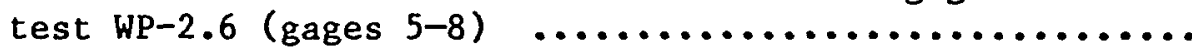

A.72 Strain histories for front-face crack-line gages:

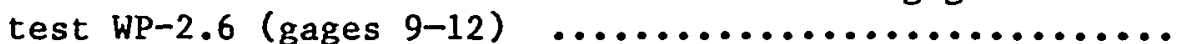

A.73 Strain histories for back-face crack-1ine gages: test WP-2.6 (gages 13-16)

A.74 Strain histories for back-face crack-line gages: test WP-2.6 (gages 17-20)

A.75 Strain history for near-field gage 21 at two time resolutions: test WP-2.6 
xvii

Figure

$\underline{\text { Page }}$

A.76 Strain histories for far-field gages 22-25 during

entire fracture process: test WP $-2.6 \quad \ldots \ldots \ldots \ldots \ldots \ldots \ldots$

A.77 Front- and back-face COD histories at two time

resolutions: test $W P-2.6 \quad \ldots \ldots \ldots \ldots \ldots \ldots \ldots \ldots \ldots \ldots \ldots$

A.78 Longitudinal acceleration (at two levels of time resolution) measured by top and bottom "damped" accelerometers mounted $3.491 \mathrm{~m}$ above and $3.398 \mathrm{~m}$ below crack plane, respectively: test WP-2.6

A.79 Dynamic displacement history at two levels of time resolution of a point $3.393 \mathrm{~m}$ below the crack plane during (a) cleavage crack run-arrest events and $(b)$ entire fracture: test WP-2.6 ..........

B.1 $K$ vs time results from linear generation-mode analyses: test WP-2.4 $\ldots \ldots \ldots \ldots \ldots \ldots \ldots \ldots \ldots \ldots \ldots \ldots$

B.2 CMOD from 1 inear generation-mode analyses:

test WP-2.4

B.3 Acceleration vs time data measured by "damped" accelerometer near the lower load point: test WP-2.4

B.4 Influence of test frame inertia on computed $\mathrm{K}$

vs time: test WP-2.4 .......................... 246

B.5 Influence of test frame inertia on computed CMOD: test WP-2.4

B.6 Influence of test frame inertia on computed load-point axial displacement: test WP-2.4

B.7 Computed nodal accelerations at "damped" accelerometer location near lower load point (1inearly elastic fixed-load analysis, lumped mass at load point): test WP-2.4

B.8 Computed nodal accelerations at load point (1inearly elastic fixed-load analysis, lumped mass at load point): test WP -2.4

B.9 Computed velocities at load point ( 1 inearly elastic fixed-load analysis, lumped mass at

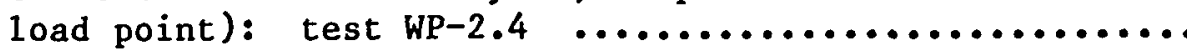

B.10 Effect of analysis method and boundary condition on calculated crack-arrest toughness values for test WP-2.4 $\ldots \ldots \ldots \ldots \ldots \ldots \ldots \ldots \ldots \ldots \ldots \ldots$

C.1 Idealization of crack tunneling in (a) lowtoughness and $(b)$ high-toughness material (Ref.C.3) 
C.2 Illustration of superposition principle for determining the stress-intensity factor (Ref. C.3)

C.3 Smith's model for restraining effect of ligaments (Ref. C.4)

C.4 Extension of Smith's approach to triangular ligament geometry

C.5 Comparison of Popelar's and Smith's tunneling correction approaches for parabolic and triangular ligament geometrics ................... 259

C.6 Fracture surface of WP-1 series specimens $\ldots \ldots \ldots \ldots \ldots \ldots$...... 261

C.7 Corrected crack-arrest toughness vs temperature for WP-1 test series ......................... 262 
3.1 Results of drop-weight testing on $21 / 4 \mathrm{Cr}-1$ Mo material from $1 / 2 t$ depth of broken halves of specimens $\mathrm{WP}-2.1$ and -2.5 ( $\mathrm{T}-\mathrm{L}$ orientation)

3.2 Charpy impact test results for $21 / 4 \mathrm{Cr}-1$ Mo material from broken halves of specimens WP-2.1 and -2.5 ( $T-L$ orientation)

3.3 Curve-fit parameters of CVN impact energy:

WP-2 series material (T-L orientation) $\ldots \ldots \ldots \ldots \ldots \ldots \ldots$

3.4 Curve-fit parameters of CVN impact energy: PTCl characterization block (T-L orientation)

3.5 Summary of results for drop-weight and CVN impact tests: broken halves of WP-2.1 and WP-2.5 specimens and $\mathrm{PTCl}$ characterization block

3.6 Ténsile properties of transverse-oriented specimens machined from broken halves of specimens WP-2.1

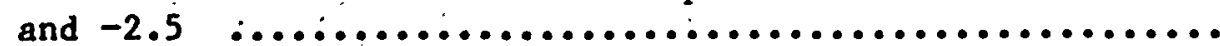

3.7 Tensile properties of specimens machined transverse to rolling direction of material from characterization block PTC1

3.8 Crack-arrest toughness data from specimens WP-2.1 and -2.5 material for both weld-embrittled and duplex specimens in $\mathrm{T}-\mathrm{L}$ orientation $\ldots \ldots \ldots \ldots \ldots \ldots \ldots$

3.9 Crack-arrest $\left(K_{a}\right)$ data for PTCl material (T-L

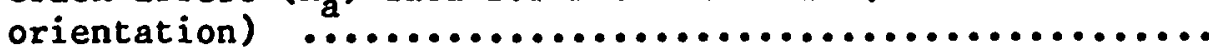

3.10 Transition region fracture-toughness results from posttest characterization using $25-\mathrm{mm} \mathrm{C}(\mathrm{T})$ specimens $(1 / 2 t)$ machined from broken halves of specimens WP-2.1 and -2.5 (T-L orientation) $\ldots \ldots \ldots \ldots \ldots \ldots \ldots$

3.11 Ductile-shelf fracture-toughness results from posttest characterization using $25-\mathrm{mm} \mathrm{C}(T)$ specimens $(1 / 2 t)$ machined from broken half of specimen WP-2.5 (T-L orientation)

$4.1 \mathrm{WP}-2$ series test specimen dimensions $\ldots \ldots \ldots \ldots \ldots \ldots \ldots \ldots$

4.2 Presence and location of accelerometer and dynamic displacement instrumentation used in WP-2 series

5.1 Summary of HSST wide-plate crack-arrest test conditions and results for specially heat treated 2 1/4 $\mathrm{Cr}-1$ Mo steel: WP-2 series 
5.2 Crack position vs time and velocity: test WP-2.1 $\ldots \ldots \ldots 3$

5.3 Crack position vs time and velocity: test WP-2.2 $\ldots \ldots \ldots 73$

5.4 Crack position vs time and velocity: test WP-2.3 ..... 81

5.5 Crack position vs time and velocity: test WP-2.4 ..... 90

5.6 Crack position vs time and velocity: test WP-2.5 ..... 109

5.7 Crack position vs time and velocity: test WP-2.6 $\ldots \ldots \ldots 125$

6.1 Summary of WPSTAT results for WP-2 series tests $\ldots \ldots \ldots \ldots$

6.2 Summary of application-mode dynamic analyses for WP-2 series tests .............................. 139

6.3 Summary of generation-mode (fixed-load) dynamic analysis results for test $W P-2.4 \ldots \ldots \ldots \ldots \ldots \ldots \ldots \ldots \ldots$

6.4 Summary of HSST wide-plate crack-arrest test conditions and crack-arrest toughness values for specially heat-treated $21 / 4 \mathrm{Cr}-1$ Mo steel: WP-2 series ....................................... 146

B.1 Summary of computed results for test $W P-2.4 \ldots \ldots \ldots \ldots$

B.2 Computed crack-arrest toughness values for wide-plate crack-arrest test WP-2.4 .................. 249

C.1 Ligament geometry parameters for WP-1 test series

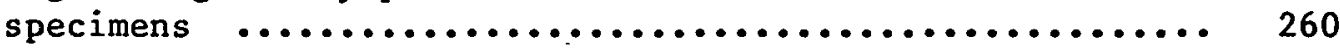

C.2 Corrections for tunneling effects in WP-1 test 


\section{FOREWORD}

The work reported here was performed at Oak Ridge National Laboratory under the Heavy-Section Steel Technology (HSST) Program, W. E. Pennel1, Program Manager. The program is sponsored by the office of Nuclear Regulatory Research of the U.S. Nuclear Regulatory Commission (NRC). The technical monitor for the NRC is M. E. Mayfield.

This report is designated HSST Report 103. Prior and future reports in this series are listed below.

1. S. Yukawa, Evaluation of Periodic Proof Testing and Warm Prestressing procedures for Nuclear Reactor Vessels, HSSTP-TR-1, General Electric Company, Schenectady, N.Y. (July 1, 1969).

2. L. W. Loechel, The Effect of Testing Variables on the Transition Temperature in SteeI, MCR-69-189, Martin Marietta Corporation, Denver, Colo. (November 20, 1969).

3. P. N. Randal1, Gross strain Measure of Fracture Toughness of Steels, HSSTP-TR-3, TRW Systems Group, Redondo Beach, Calif. (November 1, 1969).

4. C. Visser, S. E. Gabrielse, and W. VanBuren, A Two-Dimensional Elastic-Plastic Analysis of Fracture Test Specimens, WCAP-7368, Westinghouse Electric Corporation, PWR Systems Division, Pittsburgh, Pa. (October 1969).

5. T. R. Mager and F. O. Thomas, Evaluation by Linear Elastic Fracture Mechanics of Radiation Damage to Pressure Vessel Steels, WCAP-7328 (Rev.), Westinghouse Electric Corporation, PWR Systems Division, Pittsburgh, Pa. (October 1969).

6. H. O. Shabbits, W. H. Pryle, and E. T. Wessel, Heavy-Section Fracture Toughness Properties of A533 Grade B Class 1 Steel Plate and Submerged ArC Weldment, WCAP-7414, Westinghouse Electric Corporation, PWR Systems Division, Pittsburgh, Pa. (December 1969).

7. F. J. Loss, Dynamic Tear Test Investigations of the Fracture Toughness of Thick-Section Steel, NRL-7056, Naval Research Laboratory, Washington, D.C. (May 14, 1970).

8. P. B. Crosley and E. J. Ripling, Crack Arrest Fracture Toughness of A533 Grade B Class 1 Pressure Vessel Steel, HSSTP-TR-8, Materials Research Laboratory, Inc., Glenwood, I11. (March 1970).

9. T. R. Mager, Post-Irradiation Testing of 2T Compact Tension Specimens, WCAP-7561, Westinghouse Electric Corporation, PWR Systems Division, Pittsburgh, Pa. (August 1970).

10. T. R. Mager, Fracture Toughness Characterization Study of A533, Grade $B$, Class 1 Steel, WCAP-7578, Westinghouse Electric Corporation, PWR Systems Division, Pittsburgh, Pa. (October 1970).

11. T. R. Mager, Notch Preparation in Compact Tension Specimens, WCAP-7579, Westinghouse Electric Corporation, PWR Systems Division, Pittsburgh, Pa. (November 1970). 
xxii

12. N. Levy and P. V. Marcal, Three-Dimensional Elastic-plastic Stress and Strain Analysis for Fracture Mechanics, Phase I: Simple Flawed Specimens, HSSTP-TR-12, Brown University, Providence, R.I. (December 1970).

13. W. 0. Shabbits, Dynamic Fracture Toughness Properties of Heavy Section A533 Grade B Class 1 Steel Plate, WCAP-7623, Westinghouse Electric Corporation, PWR Systems Division, Pittsburgh, Pa. (December 1970).

14. P. N. Randa11, Gross Strain Crack Tolerance of A 533-B Steel, HSSTP-TR-14, TRW Systems Group, Redondo Beach, Calif. (May 1, 1971).

15. H. T. Corten and R. H. Sailors, Relationship Between Material Fracture Toughness Using Fracture Mechanics and Transition Temperature Tests, T\&AM Report 346, University of Illinois, Urbana, I11. (August 1, 1971).

16. T. R. Mager and V. J. McLaugh1in, The Effect of an Environment of High Temperature Primary Grade Nuclear Reactor water on the Fatigue Crack Growth Characteristics of A533 Grade B Class 1 Plate and Weldment Material, WCAP-7776, Westinghouse Electric Corporation, PWR Systems Division, Pittsburgh, Pa. (October 1971).

17. N. Levy and P. V. Marcal, Three-Dimensional Elastic-Plastic Stress and Strain Analysis for Fracture Mechanics, Phase II: Improved Modelling, HSSTP-TR-17, Brown University, Providence, R.I. (November 1971).

18. S. C. Grigory, Tests of 6-in.-Thick Flawed Tensile Specimens, First Technical Summary Report, Longitudinal Specimens Numbers I Through 7, HSSTP-TR-18, Southwest Research Institute, San Antonio, Tex. (June 1972).

19. P. N. Randal1, Effects of Strain Gradients on the Gross strain Crack Tolerance of $A 5.33-B$ Steel, HSSTP-TR-19, TRW Systems Group, Redondo Beach, Calif. (June 15, 1972).

20. S. C. Grigory, Tests of 6-Inch-Thick Flawed Tensile Specimens, Second Technical Summary Report, Transverse Specimens Numbers 8 Through 10, Welded Specimens Numbers 11 Through 13, HSSTP-TR-20, Southwest Research Institute, San Antonio, Tex. (June 1972).

21. L. A. James and J. A. Williams, Heavy Section Steel Technology Program Technical Report No. 21, The Effect of Temperature and Neutron Irradiation Upon the Fatigue-Crack Propagation Behavior of ASTM A533 Grade B, Class I Steel, HEDL-TME 72-132, Hanford Engineering Development Laboratory, Richland, Wash. (September 1972).

22. S. C. Grigory, Tests of 6-Inch-Thick Flawed Tensile Specimens, Third Technical Summary Report, Longitudinal Specimens Numbers 14 Through 16, Unflawed Specimen Number 17, HSSTP-TR-22, Southwest Research Institute, San Antonio, Tex. (October 1972).

23. S. C. Grigory, Tests of 6-Inch-Thick Tensile Specimens, Fourth Technical Summary Report, Tests of I-Inch-Thick Flawed Tensile 
Specimens for Size Effect. Evaluation, HSSTP-TR-23, Southwest Research Institute, San Antonio, Tex. (June 1973).

24. S. P. Ying and S. C. Grigory, Tests of 6-Inch-Thick Tensile Specimens, Fifth Technical Summary Report, Acoustic Emission Monitoring of One-Inch and Six-Inch-Thick Tensile Specimens, HSSTP-TR-24, Southwest Research Institute, San Antonio, Tex. (November 1972).

25. R. W. Derby, J. G. Merkle, G. C. Robinson; G. D. Whitman, and F. J. Witt, Test of 6-Inch-Thick Pressure Vessels. Series 1: Intermediate Test Vessels $\mathrm{V}-1$ and $V-2$, ORNL-4895, Oak Ridge National Laboratory, Oak Ridge, Tenn. (February 1974).

26. W. J. Stelzman and R. G. Berggren, Radiation strengthening and Embrittlement in Heavy Section Steel Plates and Welds, ORNL-4871, Oak Ridge National Laboratory, Oak Ridge, Tenn. (June 1973).

27. P. B. Crosley and E. J. Ripling, Crack Arrest in an Increasing K-Field, HSSTP-TR-27, Materials Research Laboratory, Inc., Glenwood, I11. (January 1973).

28. P. V. Marcal, P. M. Stuart, and R. S. Bettes, Elastic-plastic Behavior of a Longitudinal Semi-Elliptic Crack in a Thick Pressure Vessel, HSSTP-TR-28, Brown University, Providence, R.I. (June 1973).

29. W. J. Stelzman, R. G. Berggren, and T. N. Jones, ORNL Characterization of Heavy-Section Steel Technology Program plates 01, 02 and 03, NUREG/CR-4092 (ORNL/TM-9491), Oak Ridge National Laboratory, Oak Ridge, Tenn. (April 1985).

30. Canceled.

31. J. A. Williams, The Irradiation and Temperature Dependence of Tensile and Fracture Properties of ASTM A533, Grade B, Class 1 Steel Plate and Weldment, HEDL-TME 73-75, Hanford Engineering Development Laboratory, Richland, Wash. (August 1973).

32. J. M. Steichen and J. A. Williams, High Strain Rate Tensile Properties of Irradiated ASTM A533 Grade B Class I Pressure VesseI Steel, Hanford Engineering Development Laboratory, Richland, Wash. (Ju1y 1973).

33. P. C. Riccardella and J. L. Swedlow, A Combined Analytical-Experimental Fracture Study of the Two Leading Theories of ElasticPlastic Fracture ( $J$-Integral and Equivalent Energy), WCAP-8224, Westinghouse Electric Corporation, Pittsburgh, Pa. (October 1973).

34. R. J. Podlasek and R. J. Eiber, Final Report on Investigation of Mode III Crack Extension in Reactor Piping, Battelle Columbus Laboratories, Columbus, Ohio (December 14, 1973).

35. T. R. Mager, J. D. Landes, D. M. Moon, and V. J. McLaugh1in, Interim Report on the Effect of Low Frequencies on the Fatigue Crack Growth Characteristics of $A 533$ Grade $B$ Class 1 plate in an Environment of High-Temperature Primary Grade Nuclear Reactor Water, WCAP-8256, Westinghouse Electric Corporation, Pittsburgh, Pa. (December 1973). 
xxiv

36. J. A. Williams, The Irradiated Fracture Toughness of ASTM A533, Grade B, Class I Steel Measured with a Four-Inch-Thick Compact Tension Specimen, HEDL-TME 75-10, Hanford Engineering Development Laboratory, Richland, Wash. (January 1975).

37. R. H. Bryan, J. G. Merkle, M. N. Raftenberg, G. C. Robinson, and J. E. Smith, Test of 6-Inch-Thick Pressure Vessels. Series 2: Intermediate Test Vessels $\mathrm{V}-3, \mathrm{~V}-4$, and $\mathrm{V}-6$, ORNL-5059, Oak Ridge National Laboratory, Oak Ridge, Tenn. (November 1975).

38. T. R. Mager, S. E. Yanichko, and L. R. Singer, Fracture Toughness Characterization of HSST Intermediate Pressure Vessel Material, WCAP-8456, Westinghouse Electric Corporation, Pittsburgh, $\mathrm{Pa}$. (December 1974).

39. J. G. Merkle, G. D. Whitman, and R. H. Bryan, An Evaluation of the HSST Program Intermediate Pressure Vessel Tests in Terms of LightWater-Reactor Pressure Vessel Safety, ORNL/TM-5090, Oak Ridge National Laboratory, Oak Ridge, Tenn. (November 1975).

40. J. G. Merkle, G. C. Robinson, P. P. Holz, J. E. Smith, and R. H. Bryan, Test of 6-In.-Thick Pressure Vessels. Series 3: Intermediate Test Vessel $\mathrm{V}-7$, ORNL/NUREG-1, Oak Ridge National Laboratory, Oak Ridge, Tenn. (August 1976).

41. J. A. Davidson, L. J. Ceschini, R. P. Shogan, and G. V. Rao, The Irradiated Dynamic Fracture Toughness of ASTM A533, Grade B, Class I Steel Plate and Submerged Arc Weldment, WCAP-8775, Westinghouse Electric Corporation, Pittsburgh, Pa. (October 1976).

42. R. D. Cheverton, Pressure Vessel Fracture Studies Pertaining to a PWR LOCA-ECC Thermal Shock: Experiments TSE-1 and TSE-2, ORNL/ NUREG/TM-31, Oak Ridge National Laboratory, Oak Ridge, Tenn. (September 1976).

43. J. G. Merkle, G. C. Robinson, P. P. Holz, and J. E. Smith, Test of 6-In.-Thick Pressure Vessels. Series 4: Intermediate Test Vessels $V-5$ and V-9 with Inside Nozzle Corner Cracks, ORNL/NUREG-7, Oak Ridge National Laboratory, Oak Ridge, Tenn. (August 1977).

44. J. A. Williams, The Ductile Fracture Toughness of Heavy Section Steel Plate, NUREG/CR-0859, Hanford Engineering Development Laboratory, Richland, Wash. (September 1979).

45. R. H. Bryan, T. M. Cate, P. P. Holz, T. A. King, J. G. Merkle, G. C. Robinson, G. C. Smith, J. E. Smith, and G. D. Whitman, Test of 6-in.-Thick Pressure Vessels. Series 3: Intermediate Test Vessel V-7A Under Sustained Loading, ORNL/NUREG-9, Oak Ridge National Laboratory, Oak Ridge, Tenn. (February 1978).

46. R. D. Cheverton and S. E. Bolt, Pressure Vessel Fracture Studies Pertaining to a PWR LOCA-ECC Thermal Shock: Experiments TSE-3 and TSE-4 and Update of TSE-1 and TSE-2 Analysis, ORNL/NUREG-22, Oak Ridge National Laboratory, Oak Ridge, Tenn. (December 1977).

47. D. A. Canonico, Significance of Reheat Cracks to the Integrity of Pressure Vessels for Light-Water Reactors, ORNL/NUREG-15, Oak Ridge National Laboratory, Oak Ridge, Tenn. (July 1977). 
48. G. C. Smith and P. P. Holz, Repair Weld Induced Residual Stresses in Thick-Walled Steel Pressure Vessels, NUREG/CR-0093 (ORNL/NUREG/ TM-153), Oak Ridge Nationa1 Laboratory, Oak Ridge, Tenn. (June 1978).

49. P. P. Holz and S. W. Wismer, Half-Bead (Temper) Repair Welding for HSST Vessels, NUREG/CR-0113 (ORNL/NUREG/TM-177), Oak Ridge National Laboratory, Oak Ridge, Tenn. (June 1978).

50. G. C. Smith, P. P. Holz, and W. J. Stelzman, Crack Extension and Arrest Tests of Axially Flawed Steel Model Pressure Vessels, NUREG/CR-0126 (ORNL/NUREG/TM-196), Oak Ridge National Laboratory, Oak Ridge, Tenn. (October 1978).

51. R. H. Bryan, P. P. Holz, J. G. Merkle, G. C. Smith, J. E. Smith, and W. J. Stelzman, Test of 6-in.-Thick Pressure Vessels. Series 3: Intermediate Test Vessel $V-7 B$, NUREG/CR-0309 (ORNL/ NUREG-38), Oak Ridge National Laboratory, Oak Ridge, Tenn. (October 1978).

52. R. D. Cheverton, S. K. Iskander, and S. E. Bolt, Applicability of LEFM to the Analysis of PWR Vessels Under LOCA-ECC Thermal Shock Conditions, NUREG/CR-0107 (ORNL/NUREG-40), Oak Ridge National Laboratory, Oak Ridge, Tenn. (October 1978).

53. R. H. Bryan, D. A. Canonico, P. P. Holz, S. K. Iskander, J. G. Merkle, J. E. Smith, and W. J. Stelzman, Test of 6-in.-Thick Pressure Vessels, Series 3: Intermediate Test Vessel $\mathrm{V}-8$, NUREG/CR0675 (ORNL/NUREG-58), Oak Ridge National Laboratory, Oak Ridge, Tenn. (December 1979).

54. R. D. Cheverton and S. K. Iskander, Application of Static and Dynamic Crack Arrest Theory to TSE-4, NUREG/CR-0767 (ORNL/NUREG57), Oak Ridge National Laboratory, Oak Ridge, Tenn. (June 1979).

55. J. A. Williams, Tensile Properties of Irradiated and Unirradiated Welds of $A 533$ Steel Plate and A508 Forgings, NUREG/CR-1158 (ORNL/ Sub/79-50917/2), Hanford Engineering Development Laboratory, Richland, Wash. (July 1979).

56. K. W. Carlson and J. A. Williams, The Effect of Crack Length and Side Grooves on the Ductile Fracture Toughness Properties of ASTM A533 Steel, NUREG/CR-1171 (ORNL/Sub/79-50917/3), Hanford Engineering Development Laboratory, Richland, Wash. (October 1979).

57. P. P. Holz, Flaw Preparations for HSST Program Vessel Fracture Mechanics Testing; Mechanical-Cyclic Pumping and Electron-Beam Weld-Hydrogen Charge Cracking Schemes, NUREG/CR-1274 (ORNL/NUREG/ TM-369), Oak Ridge National Laboratory, Oak Ridge, Tenn. (May 1980).

58. S. K. Iskander, Two Finite Element Techniques for Computing Mode I Stress Intensity Factors in Two- or Three-Dimensional Problems, NUREG/CR-1499 (ORNL/NUREG/CSD/TM-14), Computer Sciences Division, Union Carbide Corp. Nuclear Division, Oak Ridge, Tenn. (February 1981). 
xxvi

59. P. B. Crosley and E. J. Ripling, Development of a standard Test for Measuring $K_{\text {a }}$ with a Modified Compact Specimen, NUREG/CR-2294 (ORNL/Sub/81-7755/1), Materials Research Laboratory, Glenwood, I11. (August 1981).

60. S. N. Atluri, B. R. Bass, J. W. Bryson, and K. Kathiresan, NozFLAW: A Finite Element Program for Direct Evaluation of Stress Intensity Factors for Pressure Vessel Nozzle-Corner Flaws, NUREG/CR-1843 (ORNL/NUREG/CSD/TM-18), Computer Sciences Division, Oak Ridge Gaseous Diffusion Plant, Oak Ridge, Tenn. (March 1981).

61. A. Shukla, W. L. Fourney, and G. R. Irwin, Study of Energy Loss and Its Mechanisms in Homalite 100 During Crack Propagation and Arrest, NUREG/CR-2150 (ORNL/Sub/79-7778/1), University of Maryland, College Park, Md. (August 1981).

62. S. K. Iskander, R. D. Cheverton, and D. G. Ball, OCA-I, A Code for Calculating the Behavior of Flaws on the Inner Surface of a Pressure Vessel Subjected to Temperature and Pressure Transients, NUREG/CR-2113 (ORNL/NUREG-84), Oak Ridge National Laboratory, Oak Ridge, Tenn. (August 1981).

63. R. J. Sanford, R. Chona, W. L. Fourney, and G. R. Irwin, A photoelastic Study of the Influence of Non-Singular Stresses in Fracture Test Specimens, NUREG/CR-2179 (ORNL/Sub/79-7778/2), University of Maryland, College Park, Md. (August 1981).

64. B. R. Bass, S. N. Atluri, J. W. Bryson, and K. Kathiresan, OR-FLAW: A Finite Element Program for Direct Evaluation of $K$-Factors for User-Defined Flaws in Plate, Cylinders, and Pressure-Vessel Nozzle Corners, NUREG/CR-2494 (ORNL/CSD/TM-165), Oak Ridge National Laboratory, Oak Ridge, Tenn. (April 1982).

65. B. R. Bass and J. W. Bryson, ORMGEN-3D: A Finite Element Mesh Generator for 3-Dimensional Crack Geometries, NUREG/CR-2997, Vo1. 1 (ORNL/TM-8527/V1), Oak Ridge National Laboratory, Oak Ridge, Tenn. (December 1982).

66. B. R. Bass and J. W. Bryson, ORVIRT: A Finite Element Program for Energy Release Rate Calculations for 2-Dimensional and 3-Dimensional Crack Models, NUREG/CR-2997, Vol. 2 (ORNL/TM-8527/V2), Oak Ridge National Laboratory, Oak Ridge, Tenn. (February 1983).

67. R. D. Cheverton, S. K. ${ }^{3}$ Iskander, and D. G. Ba11, PWR Pressure Vessel Integrity During Overcooling Accidents: A Parametric Analysis, NUREG/CR-2895 (ORNL/TM-7931), Oak Ridge National Laboratory, Oak Ridge, Tenn. (February 1983).

68. D. G. Ball, R. D. Cheverton, J. B. Drake, and S. K. Iskander, OCAII, A Code for Calculating Behavior of 2-D and 3-D Surface Flaws in a Pressure Vessel Subjected to Temperature and Pressure Transients, NUREG/CR-3491 (ORNL-5934), Oak Ridge National Laboratory, Oak Ridge, Tenn. (February 1984).

69. A. Sauter, R. D. Cheverton, and S. K. Iskander, Modification of OCA-I for Application to a Reactor Pressure Vessel with Cladding on the Inner Surface, NUREG/CR-3155 (ORNL/TM-8649), Oak Ridge National Laboratory, Oak Ridge, Tenn. (May 1983). 
70. R. D. Cheverton and D. G. Ball, OCA-P, A Deterministic and Probabilistic Fracture-Mechanics Code for Application to Pressure Vessels, NUREG/CR-3618 (ORNL-5991), Oak Ridge National Laboratory, Oak Ridge, Tenn. (May 1984).

71. J. G. Merkle, An Examination of the Size Effects and Data Scatter observed in Small Specimen Cleavage Fracture Toughness Testing, NUREG/CR-3672 (ORNL/TM-9088), Oak Ridge National Laboratory, Oak Ridge, Tenn. (April 1984).

72. C. E. Pugh et al., Heavy-Section Steel Technology Program - FiveYear Plan FY 1983-1987, NUREG/CR-3595 (ORNL/TM-9008), Oak Ridge National Laboratory, Oak Ridge, Tenn. (April 1984).

73. D. G. Ball, B. R. Bass, J. W. Bryson, R. D. Cheverton, and J. B. Drake, Stress Intensity Factor Influence Coefficients for Surface Flaws in Pressure Vessels, NUREG/CR-3723 (ORNL/CSD/TM-216), Oak Ridge National Laboratory, Oak Ridge, Tenn. (February 1985).

74. W. R. Corwin, R. G. Berggren, and R. K. Nanstad, Charpy Toughness and Tensile Properties of Neutron Irradiated Stainless Steel Submerged-Arc Weld Cladding Overlay, NUREG/CR-3927 (ORNL/TM-9309), Oak Ridge National Laboratory, Oak Ridge, Tenn. (September 1984).

75. C. W. Schwartz, R. Chona, W. L. Fourney, and G. R. Irwin, SAMCR: A Two-Dimensional Dynamic Finite Element Code for the Stress Analysis of Moving CRacks, NUREG/CR-3891 (ORNL/Sub/79-7778/3), University of Maryland, College Park, Md. (November 1984).

76. W. R. Corwin, G. C. Robinson, R. K. Nanstad, J. G. Merkle, R. G. Berggren, G. M. Goodwin, R. L. Swain, and T. D. Owings, Effects of Stainless Steel Weld Overlay Cladding on the Structural Integrity of Flawed steel plates in Bending, series I, NUREG/CR-4015 (ORNL/ TM-9390), Oak Ridge National Laboratory, Oak Ridge, Tenn. (April 1985).

77. R. H. Bryan, B. R. Bass, S. E. Bolt, J. W. Bryson, D. P. Edmonds, R. W. McCulloch, J. G. Merkle, R. K. Nanstad, G. C. Robinson, K. R. Thoms, and G. D. Whitman, Pressurized-Thermal-Shock Test of 6-in.-Thick Pressure Vessels. PTSE-1: Investigation of Warm Prestressing and Upper-Shelf Arrest, NUREG/CR-4106 (ORNL-6135), Oak Ridge National Laboratory, Oak Ridge, Tenn. (April 1985).

78. R. D. Cheverton, D. G. Ball, S. E. Bolt, S. K. Iskander, and R. K. Nanstad, Pressure Vessel Fracture Studies Pertaining to the PWR Thermal-Shock ISSue: Experiments TSE-5, TSE-5A, and TSE-6, NUREG/ CR-4249 (ORNL-6163), Martin Marietta Energy Systems, Inc., Oak Ridge National Laboratory, Oak Ridge, Tenn. (June 1985).

79. R. D. Cheverton, D. G. Ball, S. E. Bolt, S. K. Iskander, and R. K. Nanstad, Pressure Vessel Fracture Studies Pertaining to the PWR Thermal-Shock Issue: Experiment TSE-7, NUREG/CR-4304 (ORNL-6177), Martin Marietta Energy Systems, Inc., Oak Ridge National Laboratory, Oak Ridge, Tenn. (August 1985).

80. R. H. Bryan, B. R. Bass, S. E. Bolt, J. W. Bryson, J. G. Merkle, R. K. Nanstad, and G. C. Robinson, Test of 6-in.-Thick Pressure Vessels. Series 3: Intermediate Test Vessel V-8A-Tearing 
xxviii

Behavior of Low Upper-Shelf Material, NUREG/CR-4760 (ORNL-6187), Martin Marietta Energy Systems, Inc., Oak Ridge National Laboratory, Oak Ridge, Tenn. (May 1987).

81. R. D. Cheverton and D. G. Ball, A Parametric Study of PWR Pressure Vessel Integrity During Overcooling Accidents, Considering Both 2-D and 3-D Flaws, NUREG/CR-4325 (ORNL/TM-9682), Martin Marietta Energy Systems, Inc., Oak Ridge National Laboratory, Oak Ridge, Tenn. (August 1985).

82. E. C. Rodabaugh, Comments on the Leak-Before-Break Concept for Nuclear Power Plant Piping Systems, NUREG/CR-4305 (ORNL/Sub/8222252/3), E. C. Rodabaugh Associates, Inc., Hilliard, Ohio (August 1985).

83. J. W. Bryson, ORVIRT.PC: A 2-D Finite Element Fracture Analysis Program for a Microcomputer, NUREG/CR-4367 (ORNL-6208), Martin Marietta Energy Systems, Inc., Oak Ridge National Laboratory, Oak Ridge, Tenn. (October 1985).

84. D. G. Ball and R. D. Cheverton, Adaptation of OCA-P, a Probabilistic Fracture-Mechanics Code, to a Personal Computer, NUREG/CR-4468 (ORNL/CSD/TM-233), Martin Marietta Energy Systems, Inc., Oak Ridge National Laboratory, Oak Ridge, Tenn. (January 1986).

85. J. W. Bryson and B. R. Bass, ORMGEN.PC: A Microcomputer Program for Automatic Mesh Generation of 2-D Crack Geometries, NUREG/CR4475 (ORNL-6250), Martin Marietta Energy Systems, Inc., Oak Ridge National Laboratory, Oak Ridge, Tenn. (March 1986).

86. G. D. Whitman, Historical Summary of the Heavy-Section Steel Technology Program and Some Related Activities in Light-Water Reactor Pressure Vessel Safety Research, NUREG/CR-4489 (ORNL-6259), Martin Marietta Energy Systems, Inc., Oak Ridge National Laboratory, Oak Ridge, Tenn. (March 1986).

87. C. Inversini and J. W. Bryson, ORPLOT.PC: A Graphic Utility for ORMGEN.PC and ORVIRT.PC, NUREG/CR-4633 (ORNL-6291), Martin Marietta Energy Systems, Inc., Oak Ridge National Laboratory, Oak Ridge, Tenn. (June 1986).

88. J. J. McGowan, R. K. Nanstad, and K. R. Thoms, Characterization of Irradiated Current-Practice Welds and A533 Grade B Class 1 Plate for Nuclear Pressure Vessel Service, NUREG/CR-4880 (ORNL/TM10387), Martin Marietta Energy Systems, Inc., Oak Ridge National Laboratory, Oak Ridge Tenn. (July 1988).

89. K. V. Cook and R. W. McClung, Flaw Density Examinations of a Clad Boiling Water Reactor Pressure Vessel Segment, NUREG/CR-4860 (ORNL/TM-10364), Martin Marietta Energy Systems, Inc., Oak Ridge National Laboratory, Oak Ridge, Tenn. (April 1987).

90. D. J. Naus et al., Crack-Arrest Behavior in SEN Wide Plates of Quenched and Tempered A 533 Grade B Steel Tested Under Nonisothermal Conditions, NUREG/CR-4930 (ORNL-6388), Martin Marietta Energy Systems, Inc., Oak Ridge National Laboratory, Oak Ridge, Tenn. (August 1987). 
xxix

91. D. B. Barker et al., A Report on the Round Robin Program Conducted to Evaluate the Proposed ASTM Standard Test Method for Determining the Plane Strain Crack Arrest Fracture Toughness, $K_{I a^{\prime}}$ of Ferritic Materials, NUREG/CR-4966 (ORNL/Sub/79-7778/4), University of Maryland, College Park, Md. (January 1988).

92. W. H. Bamford, A Summary of Environmentally Assisted Crack-Growth Studies Performed at Westinghouse Electric Corporation Under Funding from the Heavy-Section Steel Technology Program, NUREG/CR-5020 (ORNL/Sub/82-21598/1), Westinghouse Electric Corp., Pittsburgh, Pa. (May 1988).

93. R. H. Bryan et al., Pressurized-Thermal-Shock Test of 6-in.-Thick Pressure Vessels. PTSE-2: Investigation of Low Tearing Resistance and Warm Prestressing, NUREG/CR-4888 (ORNL-6377), Martin Marietta Energy Systems, Inc., Oak Ridge National Laboratory, Oak Ridge, Tenn. (December 1987).

94. J. H. Giovanola and R. W. Klopp, Viscoplastic Stress-Strain Characterization of A533B Class I Steel, NUREG/CR-5066 (ORNL/Sub/87SA193/1), SRI International, Menlo Park, Calif. (to be published).

95. L. F. Miller et al., Neutron Exposure Parameters for the Metallurgical Test Specimens in the Fifth Heavy-Section Steel Technology Irradiation Series Capsules, NUREG/CR-5019 (ORNL/TM-10582), Martin Marietta Energy Systems, Inc., Oak Ridge National Laboratory, Oak Ridge, Tenn. (March 1988).

96. Canceled.

97. D. J. Naus, J. Keeney-Walker, B. R. Bass, S. E. Bolt, R. J. Fields, R. deWit, and S. R. Low III, High-Temperature Crack-Arrest Behavior in 152-mm-Thick SEN Wide Plates of Quenched and Tempered A 533 Grade B Class I Steel, NUREG/CR-5330 (ORNL/TM-11083), Martin Marietta Energy Systems, Inc., Oak Ridge National Laboratory, Oak Ridge, Tenn. (April 1989).

98. K. V. Cook, R. A. Cunningham, Jr., and R. W. McClung, Detection and Characterization of Indications in Segments of Reactor Pressure Vessels, NUREG/CR-5322 (ORNL/TM-11072), Martin Marietta Energy Systems, Inc., Oak Ridge National Laboratory, Oak Ridge, Tenn. (August 1989).

99. R. D. Cheverton, W. E. Pennel1, G. C. Robinson, and R. K. Nanstad, Impact of Radiation Embrittlement on Integrity of Pressure Vessel Supports for Two PWR Plants, NUREG/CR-5320 (ORNL/TM-10966), Martin Marietta Energy Systems, Inc., Oak Ridge National Laboratory, Oak Ridge, Tenn. (February 1989).

100. D. J. Naus et al., SEN Wide-Plate Crack-Arrest Tests Utilizing A 533 Grade B Class 1 Material: WP-CE Test Series, NUREG/CR-5408 (ORNL/TM-11269), Martin Marietta Energy Systems, Inc., Oak Ridge National Laboratory, Oak Ridge, Tenn. (November 1989).

101. D. J. Naus et al., High-Temperature Crack-Arrest Tests Using 152-mm-Thick SEN Wide Plates of Low-Upper-Shelf Base Material: Tests WP-2.2 and WP-2.6, NUREG/CR-5450 (ORNL/TM-11352), Martin 
Marietta Energy Systems, Inc., Oak Ridge, National Laboratory, Oak Ridge, Tenn. (March 1989).

102. L. F. Miller et al., Neutron Exposure Parameters for the Metallurgical Test Specimens, in the Sixth Heavy-Section Steel Technology Irradiation Series Capsules, NUREG/CR-5409 (ORNL/TM-11267), Oak Ridge National Laboratory, Oak. Ridge, Tenn. (to be published).

103. This report. 
The" authors wish to acknowledge the significant contributions made to 'this testing program by those"who are not otherwise referred to in this report: D. E. Harne at the National Institute of Standards and Technology (performance of tests); G: R. Irwin, D. B. Barker, J. W. Dally, and W. L. Fourney at the University of Maryland (assistance in development of specimen design, instrumentation and testing techniques, and analysis of test results); $R$. K. Nanstad and $E$. $T$. Manneschmidt of the Metals and Ceramics (M\&C) Division at Oak Ridge National Laboratory (ORNL) (material characterization); S. E. Bolt and W. F. Jackson of the Engineering Technology Division (ETD) at ORNL (specimen preparation, special test fixturing design, and fabrication); and C. E. Pugh and J. G. Merkle of the ETD at ORNL (test program definition). 
xxxiii

\section{EXECUTIVE SUMMARY}

The pressurized-thermal-shock (PTS) issue for pressurized-water reactors (PWRs) involves a broad range of fracture phenomena. In PTS scenarios, flaws in the inner surface of the reactor pressure vessel (RPV) have a high propensity to propagate because they are located in the region of highest stress and lowest fracture toughness (lowest temperature and greatest irradiation damage). If such flaws begin to propagate radially through the vessel wall, they will extend into regions of higher fracture toughness because of the higher temperatures and less irradiation damage. Certain PTS scenarios lead to conditions where the driving force on a propagating crack increases to levels well in excess of the ASME crack-arrest fracture-toughness 1 imit $(220 \mathrm{MPa} \cdot \sqrt{\mathrm{m}})$ contained in the American Society of Mechanical Engineers Boiler and Pressure Vessel Code (ASME B\&PVC). Assessment of the integrity of an RPV under such a postulated crack run-arrest condition requires prediction of the arrest potential; the potential for reinitiation including stable and unstable ductile crack growth; and structural instability of the remaining vessel-wall ligament.

Work being conducted under Task H.5 of the Heavy-Section Stee1 Technology (HSST) Program at Oak Ridge National Laboratory is concerned with understanding the ability of RPV materials to arrest running cracks as they propagate into regions of higher toughness and conditions of increasing values for the stress-intensity factor. As a part of this task, the HSST Program in late FY 1984 initiated an investigation of the run-arrest behavior of cracks in large plates that possess steep toughness gradients. These tests use wide-plate $(1 \times 1 \times 0.1 \mathrm{~m}$ or $1 \times 1 \times 0.15 \mathrm{~m}$ ) specimens that possess a single-edge notch (crack) that initiates cleavage propagation at low temperature and arrests in a region of increased fracture toughness. The toughness gradient is achieved through a linear transverse temperature profile across the plate. The experiments require the application of large tensile loads and are being conducted at the National Institute of Standards and Technology in Gaithersburg, Maryland. The overall objectives of these tests are to determine (1) if RPV materials will exhibit crack-arrest behavior when the driving force on a crack exceeds the ASME 1 imit $(220 \mathrm{MPa} \cdot \sqrt{\mathrm{m}})$; (2) the relationship between crack-arrest toughness and temperature for $\mathrm{K}_{\mathrm{Ia}}>220 \mathrm{MPa} \cdot \sqrt{\mathrm{m}}$; and (3) the interaction of fracture modes (arrest, stable crack growth, unstable crack growth, and tensile instability) when arrest occurs at high temperatures.

In meeting these objectives, three series of wide-plate tests have been conducted: WP-1 (A 533 grade B class 1 steel), WP-CE (second heat of A 533 grade B class 1 steel), and WP-2 [1ow-upper-shelf (LUS) base material]. This report contains results for the six tests that comprised the WP-2 series, which utilized a Charpy LUS base material (specially heat treated $21 / 4 \mathrm{Cr}-1$ Mo steel). Following are highlights of each chapter to aid readers who are interested only in certain aspects of the report. 


\section{INTRODUCTION}

Limitations imposed by the $A S M E B \& P V C$ are discussed. Objectives of the crack-arrest studies and program goals are presented.

\section{Background}

Prior crack-arrest studies and their limitations are discussed. A summary of large-specimen crack-arrest toughness data is presented in Fig. 2.1.

\section{MATERIAL CHARACTERIZATION}

A description of the Charpy LUS material used in the WP-2 test series is provided. Drop-weight (Table 3.1), Charpy V-notch (Table 3.2), tensile (Table 3.6), crack-arrest toughness (Table 3.8), and transition-region (Table 3.10 ) and ductile shelf (Table 3.11) fracture toughness properties are provided. Equations (3.2) and (3.5) present the relations for $\mathrm{K}_{a}$ and $\mathrm{K}_{\mathrm{Ic}}$, respectively, that were used in the analysis of the test results.

\section{SPECIMEN PREPARATION, INSTRUMENTATION, AND TESTIMG PROCEDURE}

Procedures used for precracking and assembling the test articles are outlined. Instrumentation used to obtain pertinent data during a test (load, strain, temperature, crack-opening-displacement, dynamic displacement), as well as the data acquisition system, are described. The heating, cooling, and insulation systems used to produce the desired specimen transverse temperature profile are delineated. The technique used to conduct a wide-plate crack-arrest test (Fig. 4.9) is presented.

\section{SUMMARY OF WIDE-PLATE CRACK-ARREST TESTS WP-2.1 THROUGH WP-2.6}

General test conditions (Table 5.1) for each wide-plate test are delineated, and transverse temperature profiles for each test are summarized (Fig. 5.1). The highlights for each test, as well as pertinent test data, are reiterated. Fracture surfaces for each test specimen are presented (Fig. 5.2). 


\section{POSTTEST ANALYSES, CRACK-ARREST TOUGHNESS RESULTS, AND COMPARISON OP DATA WITH OTHER \\ LARGE-SCALE TEST RESULTS}

Posttest static and dynamic fracture analyses conducted for each wide-plate crack-arrest test are described. The development and use of dynamic analysis methods were required to incorporate the significant dynamic effects exhibited by the wide-plate specimens; that is, multiple crack run-arrest events occurred in each test over a relatively short time (up to seven crack run-arrest events in $<7 \mathrm{~ms}$ ). Crack-arrest toughness results determined by dynamic analyses (fixed-load and generation-mode) are presented (Table 6.4). The relationship between fixedload, generation-mode, crack-arrest toughness values for tests in the WP-2 series, as well as for other wide-plate crack-arrest tests (WP-1 and WP-CE test series), and the $\mathrm{K}_{\mathrm{IR}}$ curve of the ASME B\&PVC is shown (Fig. 6.14). The HSST wide-plate crack-arrest test results are compared with other large-scale test results (Fig. 6.16).

\section{CONCLUSIONS}

Results of the investigation are summarized. Wide-plate tests demonstrate that crack-arrest values above the $220 \mathrm{MPa} \cdot \sqrt{\mathrm{m}} 1$ imit in the ASME Code are achievable and that crack arrest can and does occur at temperatures up to and slightly above those that correspond to the onset of Charpy upper-shelf behavior. 


\title{
CRACK-ARREST BEHAVIOR IN SEN WIDE PLATES OF LOW-UPPER-SHELF BASE METAL TESTED UNDER NONISOTHERMAL CONDITIONS: WP-2 SERIES
}

\author{
D. J. Naus \\ R. J. Fields \\ J. Keeney-Walker R. DeWit \\ B. R. Bass \\ S. R. Low \\ G. C. Robinson, Jr. \\ S. K. Iskander \\ C. W. Schwartz \\ D. J. Alexander \\ I.-B. Johansson
}

\section{INTRODUCTION}

In pressurized-therma1-shock (PTS) scenarios, flaws on the inner surface of a reactor pressure vessel (RPV) have a high propensity to propagate because they are in the region of highest thermal stress and lowest fracture toughness (i.e., lowest temperature and greatest irradiation damage). If such $\mathrm{flaws}$ begin to propagate radially through the vessel wall, they will extend into regions of higher fracture toughness because of the higher temperatures and less irradiation damage. Assessment of the integrity of an RPV under such a postulated crack runarrest scenario requires prediction of the arrest potential; the potential for reinitiation, including stable and unstable ductile crack growth; and structural instability of the remaining vessel-wall 1igament.

Current light-water reactor (LWR) pressure-vessel safety assessment methods are based largely on Sects. III and XI of the American Society of Mechanical Engineers Boiler and Pressure Vessel Code (ASME $B \& P V C)$. The fracture-toughness correlations contained in the ASME B\&PVC embody the position that one cannot assume a crack-arrest toughness value $\left(\mathrm{K}_{\mathrm{Ia}}\right)>220 \mathrm{MPa} \cdot \sqrt{\mathrm{m}}$ for $\mathrm{LWR}$ pressure-vessel steels. The imposition of this limit is based partly on the fact that no $\mathrm{K}_{\mathrm{Ia}}$ data existed at or above this level and because Charpy and "small" $\mathrm{C}(\mathrm{T})$-specimens exhibit an upper-shelf behavior. Therefore, the nature of crack-arrest behavior and $\mathrm{K}_{\mathrm{Ia}}$ extrapolations to temperatures higher than that at which this limit occurred could not be presumed.

The ASME limit does not impose difficulties in making assessments for LWR pressure vessels undergoing thermal shock transients with very low accompanying pressure levels. However, PTS scenarios could lead to conditions under which the driving force on a propagating crack increases to levels well in excess of the current ASME limit. Thus, safety assessment methods for this type of condition would require an understanding of the following points.

1. If the driving force on a crack exceeds $220 \mathrm{MPa} \cdot \sqrt{\mathrm{m}}$ by a significant margin, can the material exhibit crack-arrest behavior?

2. If the material exhibits high $\mathrm{K}_{\mathrm{Ia}}$ values with increasing temperature, what is the relationship between $\mathrm{K}_{\mathrm{Ia}}$ and temperature? That 
is, does a temperature 1 imit exist above which cleavage crack propagation cannot continue regardless of how high the driving force?

3. If crack arrest occurs at high temperatures where the material behavior is typically dominated by ductile behavior, then what interactions exist between the various fracture modes, including arrest, stable crack growth, unstable crack growth, and tensile instability?

The pressurized-water reactor (PWR) PTS issue has been under intensive investigation at Oak Ridge National Laboratory (ORNL) since 1973 in the form of two Nuclear Regulatory Commission (NRC)-sponsored programs: Integrated Pressurized Thermal Shock (IPTS) and Heavy-Section Steel Technology (HSST). The IPTS Program is primarily concerned with an overall estimate of the frequency of vessel failure for specific PWR plants and thus included the identification of dominant transients, as well as the contributions of design and operating features of these plants. One important component of the IPTS study is a probabilistic fracture-mechanics analysis of the reactor vessel and, in particular, the role of crack-arrest in mitigating the consequences of the postulated PTS transients. Results of the IPTS studies ${ }^{1,2}$ indicated that crack arrest in the probabilistic fracture-mechanics model does not substantially influence the calculated frequency of vessel failure. However, the influence could be different if $K_{I a}(T)$ was significantly different than that assumed for $\mathrm{K}_{\mathrm{Ia}}>220 \mathrm{MPa} \cdot \sqrt{\mathrm{m}}$. Furthermore, there are still significant questions regarding flaw behavior for low-uppershelf (LUS) materials. Thus, the HSST Program is continuing to pursue these areas of uncertainty.

The primary objective of the wide-plate crack-arrest studies under the HSST Program is to generate data for understanding the crack-arrest behavior of prototypical RPV steels at temperatures near and above the onset of the Charpy upper-shelf region. Program goals include (1) extending the existing $\mathrm{K}_{\mathrm{Ia}}$ data bases to values above those associated with the upper 1 imit in the $A S M E B \& P V C$; (2) clearly establishing that cleavage crack arrest occurs before fracture-mode conversion; (3) observing the relationship between arrest data and machine/specimen compliance behavior; and (4) validating the predictability of crack arrest, stable tearing, and/or unstable tearing sequences for ductile materials. In the present study, the program objectives and goals were investigated for a material that met the American Society of Testing Materials (ASTM) A 387 grade 22 chemical composition ( $21 / 4 \mathrm{Cr}-1$ Mo) but was specially heat treated to produce a base metal having a low Charpy upper-shelf toughness and a high transition temperature. 


\section{REFERENCES}

1. R. D. Cheverton and D. G. Ball, "The Role of Crack Arrest in the Evaluation of PWR Pressure Vessel Integrity During PTS Transients," Eng. Fract. Mech. 23(1), 71-80, 1986.*

2. R. D. Cheverton and D. G. Ba11, "A Reassessment of PWR Pressure Vessel Integrity During Overcooling Accidents, Considering 3-D Flaws," J. Pressure Vessel Technology 106, November 1984.*

*Available in public technical libraries. 


\section{BACRGROUND}

Under the HSST Program, crack-arrest data have been generated over an expanded temperature range in tests involving large thermally shocked cylinders ${ }^{1,2}$ (TSCs), pressurized thermally shocked vessels ${ }^{3,4}$ (PTSVs), stub-panel specimens, 5 and wide-plate specimens.6-8 The TSCs and PTSVs also provide data under multiaxial transient and high-restraint loadings for validation of fracture models and analysis methods. A therma1-shock experiment (TSE) has also been conducted in France. 9 While the HSST and French TSEs have generated a significant number of data points, the driving force in these experiments has been thermal stress only, and, consequently, crack-arrest data have not ranged above $\sim 150 \mathrm{MPa} \cdot \sqrt{\mathrm{m}}$. An important conclusion of the TSEs is that the $\mathrm{K}_{\mathrm{Ia}}$ data from these highly restrained propagations fall well within the range of $\mathrm{K}_{\mathrm{Ia}}$ data from the small laboratory specimens and above the ASME reference toughness $\left(K_{I R}\right)$ curve, which provides a lower bound of crack arrest $\left(\mathrm{K}_{\mathrm{Ia}_{a}}\right)$ and dynamic fracture toughness $\left(\mathrm{K}_{\mathrm{Id}}\right)$ as a function of the temperature relative to the reference nil-ductility temperature $\left(\mathrm{RT}_{\mathrm{NDT}}\right)$. The HSST pressurizedthermal-shock experiments (PTSEs) can provide higher $\mathrm{K}_{\mathrm{Ia}}$ values under similar highly restrained conditions, as evidenced by the first two PTSEs, which produced $\mathrm{K}_{\mathrm{Ia}}$ data as high as $\sim 420 \mathrm{MPa} \cdot \sqrt{\mathrm{m}}$ at temperatures up to $\sim 90^{\circ} \mathrm{C}$ above the drop-weight NDT for the vessel insert material $\left(\sim 75^{\circ} \mathrm{C}\right)$. Although the stub-panel test series has just begun, early indications are that those tests can be used to provide crack-arrest toughness values at temperatures up to those corresponding to the Charpy upper-transition region. Crack-arrest tests that used wide-plate specimens fabricated from A 533 grade B class 1 material have produced $K_{I a}$ data $>500 \mathrm{MPa} \cdot \sqrt{\mathrm{m}}$ (fixed-load, generation-mode analysis) at temperatures up to $115^{\circ} \mathrm{C}$ above the material $\operatorname{RT}_{\mathrm{NDT}}\left(-23^{\circ} \mathrm{C}\right)$.

Crack-arrest data for RPV-grade materials were also developed under an Electric Power Research Institute (EPRI) Program (EPRI Research Program RP-2180-3) conducted by Combustion Engineering, Inc. (CE).10 The analytical/experimental program was conducted to determine the response of precracked specimens subjected to thermal and mechanical loadings in the range of temperature and pressure conditions that might occur in PWR primary coolant systems during extreme cooldown/depressurization/repressurization situations. The test specimen used to study the effects of a crack running from a brittle material into a ductile material was a moment-modified compact-tension specimen (MMCT). Material toughness was varied in the direction of crack propagation by cooling one edge by liquid nitrogen chill blocks and heating the other edge with electrical resistance heaters. A rising stress-intensity factor was achieved by imposing an initial high tensile stress across the specimen test section. Thermal gradient stresses were simulated by wedge-loading a fatigue precrack. The wedge-loading was applied in small increments until a crack-propagation event occurred. The MMCT tests produced $\mathrm{K}_{\mathrm{Ia}}$ data as high as $\sim 150 \mathrm{MPa} \cdot \sqrt{\mathrm{m}}$ at temperatures up to $\sim 51^{\circ} \mathrm{C}$ above $\mathrm{RT}_{\mathrm{NDT}}$.

Recently, considerable testing of wide-plate specimens has been done in Japan.11-16 Some of the specimens are referred to as double- 
tension specimens ${ }^{14}$ because they used a notched tensile-loaded tab attached to the edge of the specimen as an auxiliary crack-starting device. Other Japanese tests employed ESSO specimens 17 and produced $\mathrm{K}_{\mathrm{Ia}}$ data as high as $\sim 380 \mathrm{MPa} \cdot \sqrt{\mathrm{m}}$ at temperatures up to $\sim 90^{\circ} \mathrm{C}$ above $\mathrm{RT}_{\mathrm{NDT}}$.

Figure 2.1 presents a summary of $\mathrm{K}_{\mathrm{Ia}}$ data for the HSST Program TSEs, PTSEs, stub-pane1 experiments, and wide-plate tests (WP-1 series); the French TSE; the CE/EPRI MMCT tests; and the Japanese tests. As shown in the figure, few crack-arrest toughness measurements were made above $150 \mathrm{MPa} \cdot \sqrt{\mathrm{m}}$, except for data produced in the HSST Program PTSEs and wide-plate tests and the Japanese wide-plate specimens. To meet the HSST Program objective of understanding the crack-arrest behavior of prototypical RPV steels at temperatures near and above the onset of the Charpy upper-shelf region, either PTSEs or wide-plate tests were required. Because the wide-plate tests have the ability to provide a significant number of data points $\left(\mathrm{K}_{\mathrm{Ia}}>220 \mathrm{MPa} \cdot \sqrt{\mathrm{m}}\right)$ at relatively reasonable cost, they were selected for use in the investigation.

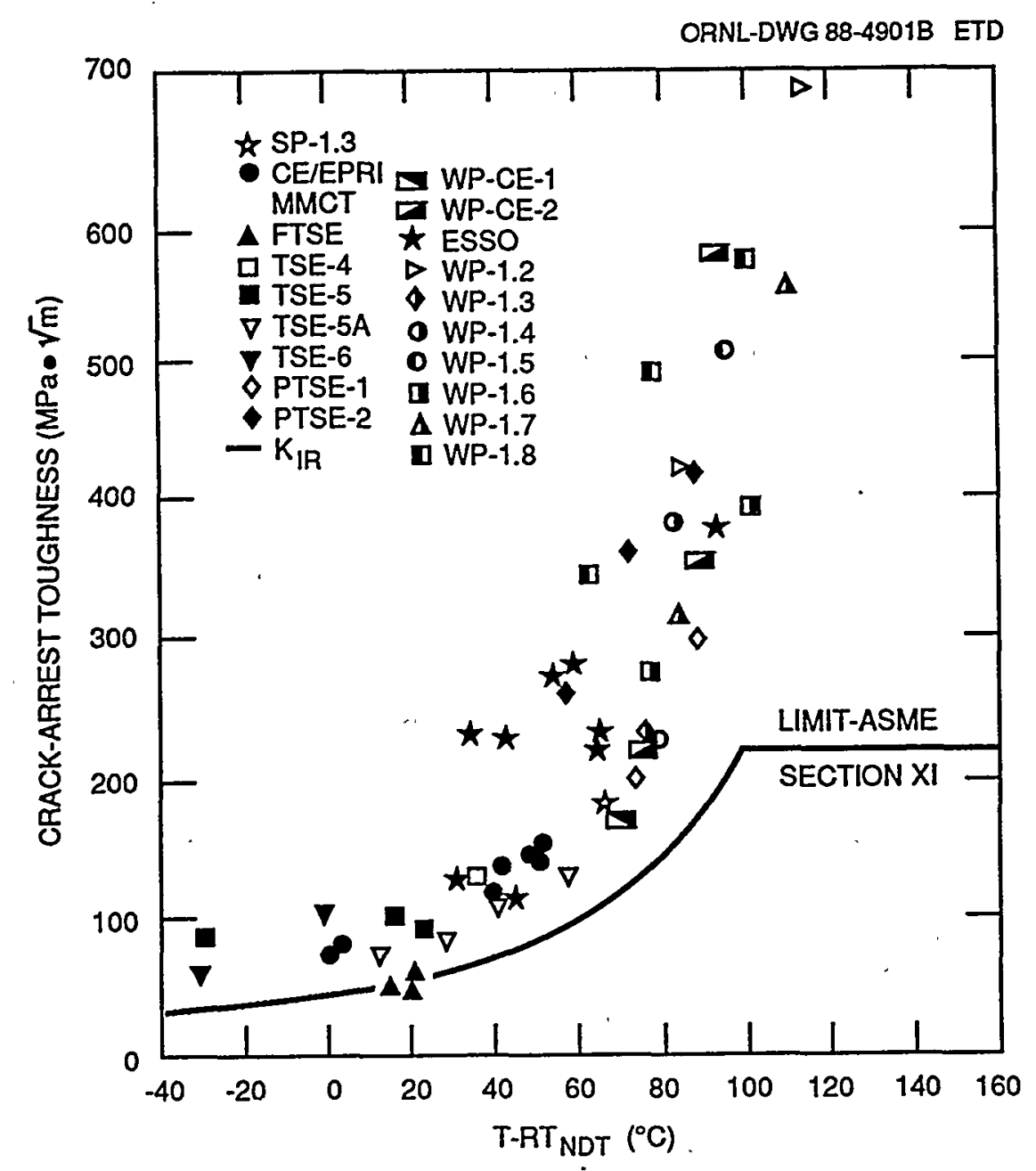

Fig. 2.1. Summary of large-specimen, high-temperature crack-arrest data. 


\section{REFEREHCES}

1. R. D. Cheverton et al., Martin Marietta Energy Systems, Inc., Oak Ridge Nat1. Lab., Pressure Vessel Fracture Studies Pertaining to the PWR Thermal-Shock ISsue: Experiments TSE-5, TSE-5A, and TSE-6, USNRC Report NUREG/CR-4249 (ORNL-6163), June 1985.*

2. R. D. Cheverton et a1., Martin Marietta Energy Systems, Inc., Oak Ridge Nat1. Lab., Pressure Vessel Fracture Studies Pertaining to the PWR Thermal-Shock Issue: Experiment TSE-7, USNRC Report NUREG/CR-4304 (ORNL-6177), August 1985.*

3. R. H. Bryan et al., Martin Marietta Energy Systems, Inc., Oak Ridge Nat1. Lab., Pressurized-Thermal-Shock Test of 6-in.-Thick pressure Vessels. PTSE-1: Investigation of Warm Prestressing and UpperShelf Arrest, USNRC Report NUREG/CR-4106 (ORNL-6135), April 1985.*

4. R. H. Bryan et al., Martin Marietta Energy Systems, Inc., Oak Ridge Nat1. Lab., Pressurized-Thermal-Shock Test of 6-in.-Thick Pressure Vessels. PTSE-2: Investigation of Low Tearing Resistance and Warm Prestressing, USNRC Report NUREG/CR-4888 (ORNL-6377), December $1987 . *$

5. C. E. Pugh et al., "Crack-Arrest Toughness Determination from StubPanel Specimen Tests," Vol. F, pp. 37-42 in Transactions of the loth International Conference on Structural Mechanics in Reactor Technology, Anaheim, Calif., August 14-18, 1989, American Association for Structural Mechanics in Reactor Technology, Los Angeles, $1989 . t$

6. D. J. Naus et al., Martin Marietta Energy Systems, Inc., Oak Ridge Nat1. Lab., Crack-Arrest Behavior in SEN Wide Plates of Quenched and Tempered A 533 Grade $B$ Steel Tested Under Nonisothermal Conditions, USNRC Report NUREG/CR-4930 (ORNL-6388), August 1987.*

7. D. J. Naus et al., Martin Marietta Energy Systems, Inc., Oak Ridge Natl. Lab., High-Temperature Crack-Arrest Behavior in 152-mm-Thick SEN Wide Plates of Quenched and Tempered $A 533$ Grade $B$ Class 1 Steel, USNRC Report NUREG/CR-5330 (ORNL/TM-11083), April 1989.*

8. D. J. Naus et al., Martin Marietta Energy Systems, Inc., Oak Ridge Natl. Lab., SEN Wide-Plate Crack-Arrest Tests Utilizing A 533 Grade B Class I Material: WP-CE Test Series, USNRC Report NUREG/CR-5408 (ORNL/TM-11269), October 1989.*

9. A. Pellissier-Tanon, P. Sollogoub, and B. Houssin, "Crack Initiation and Arrest in an SA 508 Class-3 Cylinder Under Liquid Nitrogen Therma1-Shock," Paper G/F 1/8, Vol. G/H, pp. 137-42 in Transactions of the 7 th International Conference on Structural Mechanics in Reactor Technology, August 1983, Elsevier Publishing Co., Inc., New York, 1983.t 
10. R. Y. Schonenberg and D. M. Norris, "Moment Modified Compact Tension Specimen for Measuring Crack Arrest Toughness," Nucl. Eng. and Des. 96, 277-86 (1986). ${ }^{\dagger}$

11. Japan Welding Council, Structural Integrity of Very Thick Steel Plate for Nuclear Reactor Pressure Vessels, JWES-AE-7806, 1977 (in Japanese).

12. T. Kanazawa, S. Machida, and T. Teramoto, "Preliminary Approaches to Experimental and Numerical Study of Fast Crack Propagation and Crack Arrest," PP. 39-58 in Fast Fracture and Crack Arrest, ASTM STP 627, American Society for Testing and Materials, Philadelphia, $\mathrm{Pa} ., 1977 . *$

13. N. Ohashi et al., "Fracture Toughness of Heavy Section LWR Pressure Vessel Steel Plate Produced by Basic Oxygen Furnace and Ladle Refining Process," pp. 391-96 in Proceedings of the Fourth International Conference on Pressure Vessel Technology, Vol. 1, I. Mech. E. , $1980 .{ }^{\dagger}$

14. T. Kanazawa et al., "Study on Fast Fracture and Crack Arrest," Experimental Mechanics 21(2), 77-88 (February 1981).t

15. S. Machida, Y. Kawaguchi, and M. Tsukamoto, "An Evaluation of the Crack Arrestability of $9 \% \mathrm{Ni}$ Steel Plate to an Extremely Long Brittle Crack," Journal of the Society of Naval Architects of Japan $150,511-17$ (1981) (translation ORNL-tr-5052).t

16. T. Kanazawa, S. Machida, and H. Yajima, "Recent Studies on Brittle Crack Propagation and Arrest in Japan," in Fracture Mechanics Technology Applied to Material and Structure Design, G. C. Sih, N. E. Ryan, and R. Jones, Eds. (Martinua Ni jhoff, The Hague, 1983), pp. $81-100$.

17. Y. Nakano, "Stress Intensity Factor During Brittle Crack Propagation and Arrest in ESSO Specimen," in Proceedings of the 18th National Symposium in $X-R a y$ Study on Deformation and Fracture Solids, July 13-14, 1981, The Society of Materials Science, Japan. $\dagger$

*Available for purchase from National Technical Information Service, Springfield, VA 22161.

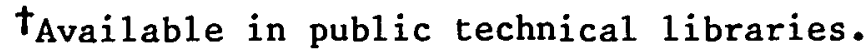




\section{CHARACTERIZATION OF WIDE-PLATE SERIES 2 MATERIAL}

\subsection{INTRODUCTION}

The chemical composition of the material used in the WP-2 series of wide-plate experiments is in accordance with ASTM Standard Specification for Pressure Vessel Plates, Alloy Steel, Chromium-Molybdenum (A 387), grade 22 ( $21 / 4 \mathrm{Cr}-1 \mathrm{Mo})$. A 159-mm-thick plate was procured by Babcock and Wilcox (B\&W) for the HSST Program to provide material for the second series of wide-plate tests (WP-2) and the second pressurizedthermal-shock experiment (PTSE-2). ${ }^{2}$ It was specially heat treated to produce LUS toughness and a high transition temperature.

Allocation of the material is shown in Fig. 3.1. Material characterization for pretest analyses of PTSE- 2 and WP- 2 has been conducted with the characterization piece PTCl. Charpy V-notch (CVN), tensile, drop weight, hardness, fracture-toughness, crack-arrest toughness, and metallographic results have been reported previously.3-5 The pretest characterization and the physical properties also have been included in the final report on the PTSE-2 experiments. ${ }^{2}$

The purpose of posttest characterization is to determine (using a smaller number of specimens than would normally be used to fully characterize the material) if the wide-plate properties are significantly different from those inferred from characterization block PTCl. PTCI received a stress-relief heat treatment of $524 \pm 14^{\circ} \mathrm{C}$ for $7.25 \mathrm{~h}$. The wide plates and a characterization block WPQl were stress-relieved as one piece at $552 \pm 14^{\circ} \mathrm{C}$ for $7 \mathrm{~h}$. The plate stock used for PTSE-2 and the wide-plate tests was found to exhibit anomalous variations in properties thought to be associated with the primary heat treatment process. The properties of the WP-2 series material have been determined to be similar to those of PTCl, although PTC1 received a stressrelief heat treatment, which differed slightly from that of the wide plates and WPQ1. Block WPQ1 was not representative of the wide-plate material and is mentioned solely for completeness (the results of tests on WPQ1 are given in Ref. 1).

The posttest characterization of the WP-2 series material was conducted with specimens machined from the broken halves of plates WP-2.1 and -2.5. All characterization was performed in the T-L orientation; that is, the fracture plane of the test specimens was parallel to the fracture plane of the wide plates. Drop-weight NDT temperature, CVN, tensile, initiation fracture toughness, J-R, and crack-arrest tests have been performed. The results of the posttest characterization are compared with those from block PTCl. For purposes of analyzing the results of the wide-plate structural tests, the differences between the PTCl and wide-plate material found in the $\mathrm{CVN}$, tensile, and crack-arrest tests may be considered insignificant. However, for material from the wide plates, the NDT temperatures are higher by $\sim 10 \mathrm{~K}$, and the initiation fracture toughness $K_{J c}$ is noticeably lower than for PTCl. 
CRÖPPED ENDS

HT HEAT TREATMENT STUDY

PT PTSE-2 LUS MATERIAL

$1 \quad$ INSERT FOR VESSEL

PTPQ WELD PROCEDURE QUALIFICATION

WP CHARACTERIZATION MATERIAL

Q QUALIFICATION BY B\&W

WP WIDE PLATE LUS MATERIAL

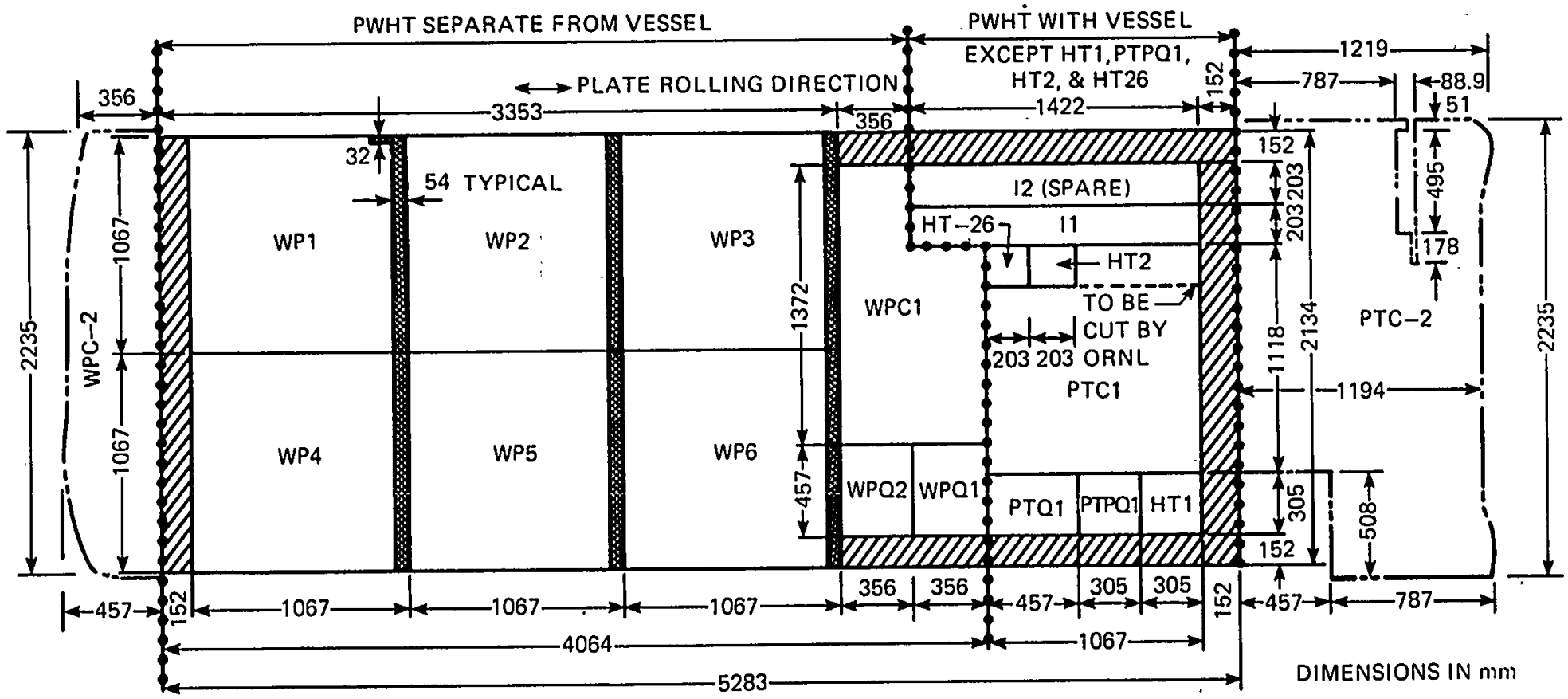

Fig. 3.1. Allocation of $21 / 4 \mathrm{Cr}-1$ Mo 159-mm-thick LUS steel plate for various tests. 


\subsection{DROP-WEIGHT TESTING}

Drop-weight testing was conducted with standard P-3 specimens per ASTM Standard Method for Conducting Drop-Weight Test to Determine Nil-Ductility Transition Temperature of Ferritic Steels (E 208-85). In accordance with E-208-85, a single-pass-weld crack starter bead was used to prepare the drop-weight specimens. This standard explicitly states that, although the drop-weight test is insensitive to specimen orientation, all specimens should be of a single orientation, which must be noted in the test report. The specimen orientation used was T-L (for a crack propagating along the surface on either side of the crack starter bead).

The results of individual specimens for material from midthickness $(1 / 2 t)$ of each of the two plates are given in Table 3.1. The NDT temperature was determined to be 60 and $55^{\circ} \mathrm{C}$ for material from plates WP2.1 and -2.5 , respectively. Note that NDT for material from characterization block PTCl at $1 / 4 \mathrm{t}$ was $49^{\circ} \mathrm{C}$; although there was insufficient material for a full determination, a tentative pretest NDT for specimens machined from a portion of WP-2.4 was estimated to be $60^{\circ} \mathrm{C}$ (see p. 62 of Ref. 5). This value agrees with the posttest value obtained for WP-2.1 material. The $5^{\circ} \mathrm{C}$ difference between NDT for plates WP-2.1 and -2.5 may not be significant, considering the variability that this material has exhibited; an NDT of $60^{\circ} \mathrm{C}$ is used in this report.

Table 3.1. Results of drop-weight testing on $21 / 4 \mathrm{Cr}-1$ Mo material from $1 / 2 \mathrm{t}$ depth of broken halves of specimens WP-2.1 and -2.5 ( $\mathrm{T}-\mathrm{L}$ orientation)

\begin{tabular}{|c|c|c|c|c|c|}
\hline \multirow{2}{*}{ Specimen } & \multirow{2}{*}{$\begin{array}{c}\text { Test } \\
\text { temperature } \\
\left({ }^{\circ} \mathrm{C}\right)\end{array}$} & \multicolumn{4}{|c|}{ Test results } \\
\hline & & Break & No & break & NDT \\
\hline \multicolumn{6}{|c|}{ WP-2.I material } \\
\hline \multirow{4}{*}{$\begin{array}{l}\text { WP2.101 } \\
\text { WP2.110 } \\
\text { WP2.112 }\end{array}$} & 65 & & & $\checkmark$ & \\
\hline & 60 & $\checkmark$ & & & \\
\hline & 65 & & & $\checkmark$ & 60 \\
\hline & $W P-2.5$ & material & & & \\
\hline WP2.505 & 65 & & & $\checkmark$ & \\
\hline WP2 .503 & 60 & & & 1 & \\
\hline WP2.502 & 55 & & & $\checkmark$ & \\
\hline WP2 2.506 & 50 & & & d & \\
\hline WP2.512 & 45 & $\checkmark$ & & & \\
\hline HP2 .508 & 50 & 1 & & & \\
\hline WP2.509 & 55 & $\checkmark$ & & & \\
\hline WP2.501 & 60 & & & $\checkmark$ & 55 \\
\hline
\end{tabular}




\subsection{CVN TESTING}

CVN testing has been performed on 12 specimens from the $1 / 2 t$ depth of each of plates WP-2.1 and -2.5. In addition, 12 specimens were tested from the $1 / 4 \mathrm{t}$ depth of plate WP-2.1. All specimens were in the $\mathrm{T}-\mathrm{L}$ orientation and tested at the same temperature intervals. The temperature ranged from 25 to $250^{\circ} \mathrm{C}$ for comparing with previous work. 1,3

Table 3.2 gives the data obtained during CVN testing. Figure 3.2 shows plots of the CVN test results vs temperature for all three material regions (WP-2.1 at $1 / 4 t$, WP-2.1 at $1 / 2 t$, and WP-2.5 at $1 / 2 t$ depths) and hyperbolic tangent curve fits. The curve fit parameters are presented in Table 3.3. For comparison, the corresponding parameters for PTCl are given in Table 3.4 (reproduced from Ref. 3 ).

If the CVN' energies of material from the three regions are compared, there is a small difference in the upper-shelf-energy (USE) levels that range from 61 to $65 \mathrm{~J}$, a $\pm 3 \%$ variation about the mean. The range of variation of USE of PTCI was approximately $\pm 12 \%$ about a mean of $57 \mathrm{~J}$. For both WP-2 and PTC1 materials, USE decreases consistently with increases in plate depth.

The WP-2 material exhibits relatively little difference in energy absorbed in the midtransition region (at $100^{\circ} \mathrm{C}$ ). The greatest differences $( \pm 10 \mathrm{~J})$ were exhibited in the lower-transition region around NDT. The knee of the upper shelf is reached at $\sim 150^{\circ} \mathrm{C}$ when judged by the attainment of $100 \%$ shear fracture appearance (see Table 3.2 and Fig. 3.2). This temperature compares favorably with the results for PTC1 (Fig. 3.3). The midcurve transition temperatures, which range from 76 to $82^{\circ} \mathrm{C}$, compare well with those of PTCl, 74 to $81^{\circ} \mathrm{C}$ (Table 3.4 ). The results of drop-weight and CVN testing are summarized in Table 3.5 .

An $\mathrm{RT}_{\mathrm{NDT}}$ (in accordance with Subarticle NB-2330 of ASME B\&PVC, Sect. III) cannot be determined because a minimum 68-J CVN impact energy was not attained for specimens fabricated from either the WP-2.1 or the -2.5 plate materials (see Table 3.2).

\subsection{TENSILE TESTING}

Tensile tests were performed using 6.3-mm-diam specimens. The results are given in Table 3.6 and plotted in Fig. 3.4 together with the 99\% confidence band of the tensile test results using material from characterization block PTCl. The tests on PTCl were obtained using 4.52-, 6.35-, and 12.7-mm-diam specimens, and the results are given in Table 3.7 .

The $0.2 \%$ yield strength is highly dependent on prior straining history. Figure 3.5 shows a typical stress-strain curve from a roomtemperature tensile test on a 12.7-mm-diam specimen from PTCl material and illustrates the difficulty of defining the $0.2 \%$ yield, strength because of the very short linear portion of the diagram. Moreover, if the material were strained even to values $<0.2 \%$ yield and then unloaded, this can increase the $0.2 \%$ yield strength. This is because the 1 inear portion of the stress strain diagram will be extended and the $0.2 \%$ offset line will intersect the stress-strain curve at a higher stress. 
Table 3.2. Charpy impact test results for $21 / 4 \mathrm{Cr}-1 \mathrm{Mo}$ material from broken halves of specimens WP-2.1 and -2.5 ( $\mathrm{T}-\mathrm{L}$ orientation)

\begin{tabular}{|c|c|c|c|c|}
\hline Specimen & $\begin{array}{c}\text { Test } \\
\text { temperature } \\
\left({ }^{\circ} \mathrm{C}\right)\end{array}$ & $\begin{array}{c}\text { Energy } \\
(\mathrm{J})\end{array}$ & $\begin{array}{l}\text { Lateral } \\
\text { expansion } \\
(\mathrm{mm})\end{array}$ & $\begin{array}{c}\text { Appearance } \\
\text { (\% shear) }\end{array}$ \\
\hline \multicolumn{5}{|c|}{ WP-2.1 (1/4t depth) } \\
\hline WP2101 & 30 & 7.1 & 0.0508 & 0 \\
\hline WP2 102 & 30 & 6.1 & 0.0254 & 0 \\
\hline ผP2103 & 60 & 18 & 0.254 & 10 \\
\hline WP2 104 & 60 & 26 & 0.343 & 10 \\
\hline WP2 105 & 100 & 39 & 0.546 & 40 \\
\hline WP2106 & 100 & 41 & 0.597 & 40 \\
\hline WP2107 & 150 & 64 & 1.04 & 99 \\
\hline พP2108 & 150 & 63 & 1.08 & 99 \\
\hline WP2109 & 200 & 60 & 0.94 & 100 \\
\hline WP2110 & 200 & 59 & 1.04 & 100 \\
\hline WP2111 & 250 & 61 & 1.05 & 100 \\
\hline WP2112 & 250 & 60 & 1.09 & 100 \\
\hline \multicolumn{5}{|c|}{ WP-2.I (1/2t depth) } \\
\hline WP2121 & 30 & 6.8 & 0.0254 & 0 \\
\hline WP2122 & 30 & 6.8 & 0.0254 & 0 \\
\hline WP2 123 & 60 & 15 & 0.178 & 0 \\
\hline WP2124 & 60 & 14 & 0.178 & 0 \\
\hline WP2125 & 100 & 45 & 0.737 & 40 \\
\hline WP2126 & 100 & 39 & 0.686 & 50 \\
\hline WP2131 & 150 & 68 & 1.09 & 99 \\
\hline WP2132 & 150 & 65 & 1.09 & 99 \\
\hline WP2129 & 200 & 60 & 1.09 & 100 \\
\hline WP2130 & 200 & 60 & 0.94 & 100 \\
\hline WP2 2127 & 250 & 56 & 1.07 & 100 \\
\hline WP2128 & 250 & 57 & 1.02 & 100 \\
\hline \multicolumn{5}{|c|}{ WP-2.5 (1/2t depth) } \\
\hline WP2501 & 30 & 7.1 & 0.0508 & 0 \\
\hline HP2502 & 30 & 8.5 & 0.0508 & 10 \\
\hline WP2503 & 60 & 29 & 0.381 & 20 \\
\hline WP2504 & 60 & 23 & 0.305 & 30 \\
\hline WP2505 & 100 & 43 & 0.66 & 40 \\
\hline WP2506 & 100 & 42 & 0.711 & 50 \\
\hline WP2507 & 150 & 66 & 1.12 & 99 \\
\hline WP2508 & 150 & 69 & 1.12 & 100 \\
\hline WP2509 & 200 & 64 & 1.07 & 100 \\
\hline WP2510 & 200 & 65 & 1.12 & 100 \\
\hline WP2511 & 250 & 62 & 1.12 & 100 \\
\hline WP2512 & 250 & 59 & 1.04 & 100 \\
\hline
\end{tabular}


ORNL-DWG 89-5007 ETD
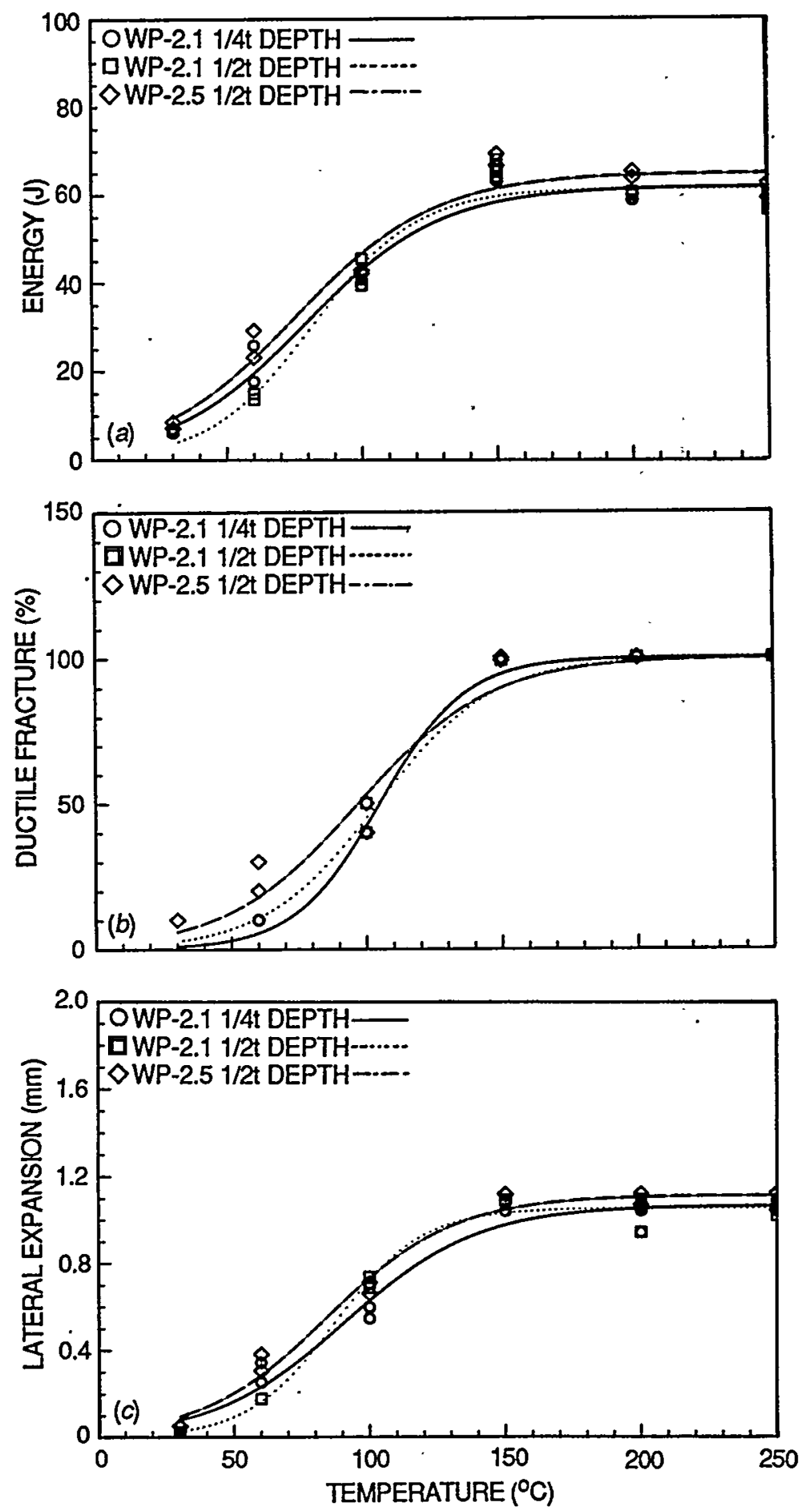

Fig. 3.2. CVN test results in $T-L$ orientation for material from halves of wide-plate specimens WP-2.1 and -2.5 . (a) CVN impact energy, (b) percent ductile fracture, and (c) lateral expansion. 
Table 3.3. Curve-fit parameters of CVN impact energy: WP-2 series material ( $T-L$ orientation)

\begin{tabular}{|c|c|c|c|c|c|c|c|}
\hline \multirow[b]{2}{*}{ Region } & \multirow{2}{*}{$\begin{array}{l}\text { Depth } \\
(t)\end{array}$} & \multicolumn{3}{|c|}{$E=(A / 2)\{1+\tanh [B(T-C)]\}^{a}$} & \multirow{2}{*}{$\begin{array}{l}\text { NDT } \\
\left({ }^{\circ} \mathrm{C}\right)\end{array}$} & \multirow{2}{*}{$\begin{array}{l}\mathrm{E} \text { at } \\
\text { NDT } \\
(\mathrm{J})\end{array}$} & \multirow{2}{*}{$\begin{array}{c}\text { Temperature } \\
\text { at } 41 \mathrm{~J} \\
\left({ }^{\circ} \mathrm{C}\right)\end{array}$} \\
\hline & & $\stackrel{A}{(J)}$ & $\left({ }^{\circ} \mathrm{C}^{-1}\right)$ & $\stackrel{\mathrm{C}}{\left({ }^{\circ} \mathrm{C}\right)}$ & & & \\
\hline $\begin{array}{l}\text { WP2.1 } \\
\text { WP2.1 } \\
\text { WP2.5 }\end{array}$ & $\begin{array}{l}1 / 4 \\
1 / 2 \\
1 / 2\end{array}$ & $\begin{array}{l}62 \\
61 \\
65\end{array}$ & $\begin{array}{l}0.01996 \\
0.02595 \\
0.01939\end{array}$ & $\begin{array}{l}79 \\
82 \\
76\end{array}$ & $\begin{array}{l}b \\
60 \\
55\end{array}$ & $\begin{array}{l}20 \\
15 \\
20\end{array}$ & $\begin{array}{l}96 \\
96 \\
90\end{array}$ \\
\hline $\begin{array}{r}a_{\mathrm{E}} \\
\mathrm{A} \\
\mathrm{B} \\
\mathrm{C} \\
b_{\mathrm{N}} \\
\text { pecime }\end{array}$ & $\begin{array}{l}=\text { CVN } \\
=\text { USE, } \\
=\text { relat } \\
=\text { tempe } \\
\text { t calcu } \\
\text { s from }\end{array}$ & $\begin{array}{l}\text { to } \\
\text { ture }\end{array}$ & $\begin{array}{l}\text { gy at te } \\
\text { e of cur } \\
\text { respondi } \\
\text { p-weight }\end{array}$ & $\begin{array}{l}\text { tran } \\
\text { ener }\end{array}$ & $\begin{array}{l}\text { tion } \\
\text { equa }\end{array}$ & $\begin{array}{l}\text { sion, } \\
\text { to one }\end{array}$ & $\begin{array}{l}\text { half USE. } \\
\text { mined with }\end{array}$ \\
\hline
\end{tabular}

Table 3.4. Curve fit parameters of CVN impact energy: PTCl characterization block ( $\mathrm{T}-\mathrm{L}$ orientation)

\begin{tabular}{|c|c|c|c|c|c|}
\hline \multirow{2}{*}{$\begin{array}{c}\text { Depth } \\
(t)\end{array}$} & \multicolumn{3}{|c|}{$E=(A / 2)\{1+\tanh [B(T-C)]\}^{a}$} & \multirow{2}{*}{$\begin{array}{c}\text { E at } \\
\text { NDT of } \\
49^{\circ} \mathrm{C} \\
(\mathrm{J})\end{array}$} & \multirow{2}{*}{$\begin{array}{c}\text { Temperature } \\
\text { at } 41 \mathrm{~J} \\
\left({ }^{\circ} \mathrm{C}\right)\end{array}$} \\
\hline & $\stackrel{A}{(J)}$ & $\begin{array}{c}B \\
\left({ }^{\circ} \mathrm{C}^{-1}\right)\end{array}$ & $\stackrel{\mathrm{C}}{\left({ }^{\circ} \mathrm{C}\right)}$ & & \\
\hline 0 & 60 & 0.02062 & 81 & $b$ & 99 \\
\hline $1 / 4$ & 59 & 0.01998 & 74 & 16 & 94 \\
\hline $1 / 2$ & 50 & 0.01675 & 76 & $b$ & 120 \\
\hline $3 / 4$ & 64 & 0.02255 & 73 & $b$ & 87 \\
\hline 1 & 63 & 0.02112 & 78 & $b$ & 92 \\
\hline
\end{tabular}

${ }^{a_{E}}=\mathrm{CVN}$ impact energy at temperature $\mathrm{T}$ in ${ }^{\circ} \mathrm{C}$,

$A=U S E$,

$B=$ related to slope of curve in transition region,

$C=$ temperature corresponding to energy equal to one-half USE.

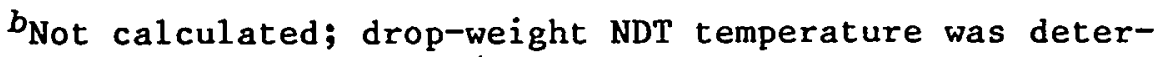
mined with specimens from $1 / 4 \mathrm{t}$. 


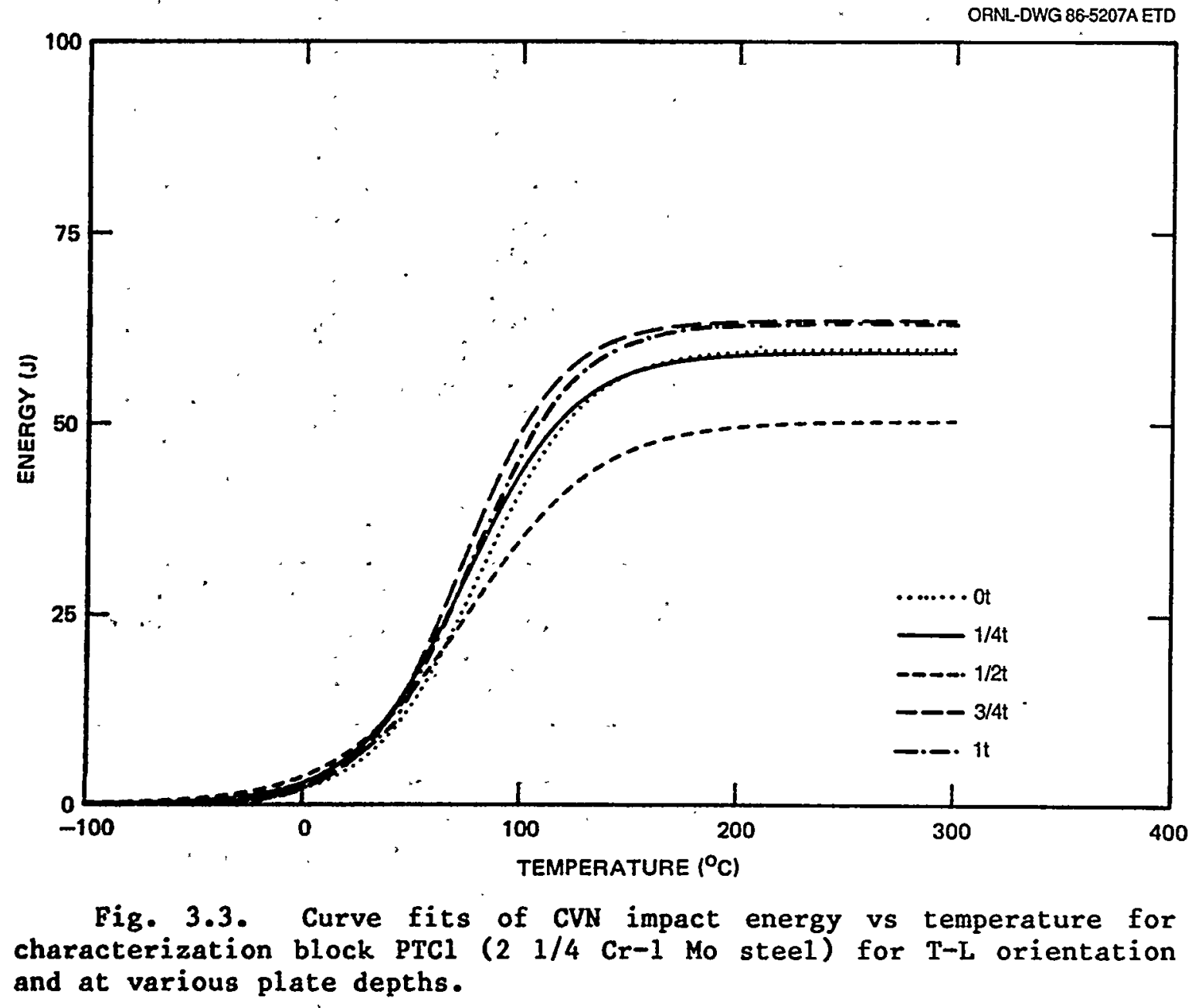

Table 3.5. Summary of results for drop-weight and CVN impact tests: broken halves of WP-2.1 and -2.5 specimens and PTC1 characterization block

\begin{tabular}{|c|c|c|}
\hline . & $\begin{array}{l}\text { Averages }^{a} \\
\text { from } W P-2.1 \\
\text { and }-2.5\end{array}$ & PTCl \\
\hline $\begin{array}{l}\text { Drop-weight NDT temperature, }{ }^{\circ} \mathrm{C} \\
\text { CVN }\end{array}$ & 60 & 49 \\
\hline $\begin{array}{l}\text { Energy at NDT temperature, } \mathrm{J} \\
\text { USE, } \mathrm{J} \\
\text { Temperature at } 41 \mathrm{~J},{ }^{\circ} \mathrm{C} \\
\text { Temperature at onset of } 100 \% \\
\text { shear, }{ }^{\circ} \mathrm{C} \\
\text { Temperature at } 50 \% \text { of USE, }{ }^{\circ} \mathrm{C}\end{array}$ & $\begin{array}{l}15-20 \\
61-65 \\
90-96 \\
150 \\
76-82\end{array}$ & $\begin{array}{l}16 \\
50-64 \\
87-120 \\
150 \\
73-81\end{array}$ \\
\hline
\end{tabular}

averages of results for material from both plates, including tests from quarter- and half-thickness depths in plate. 
Table 3.6. Tensile properties of transverse-oriented specimens machined from broken halves of specimens WP-2.1 and -2.5

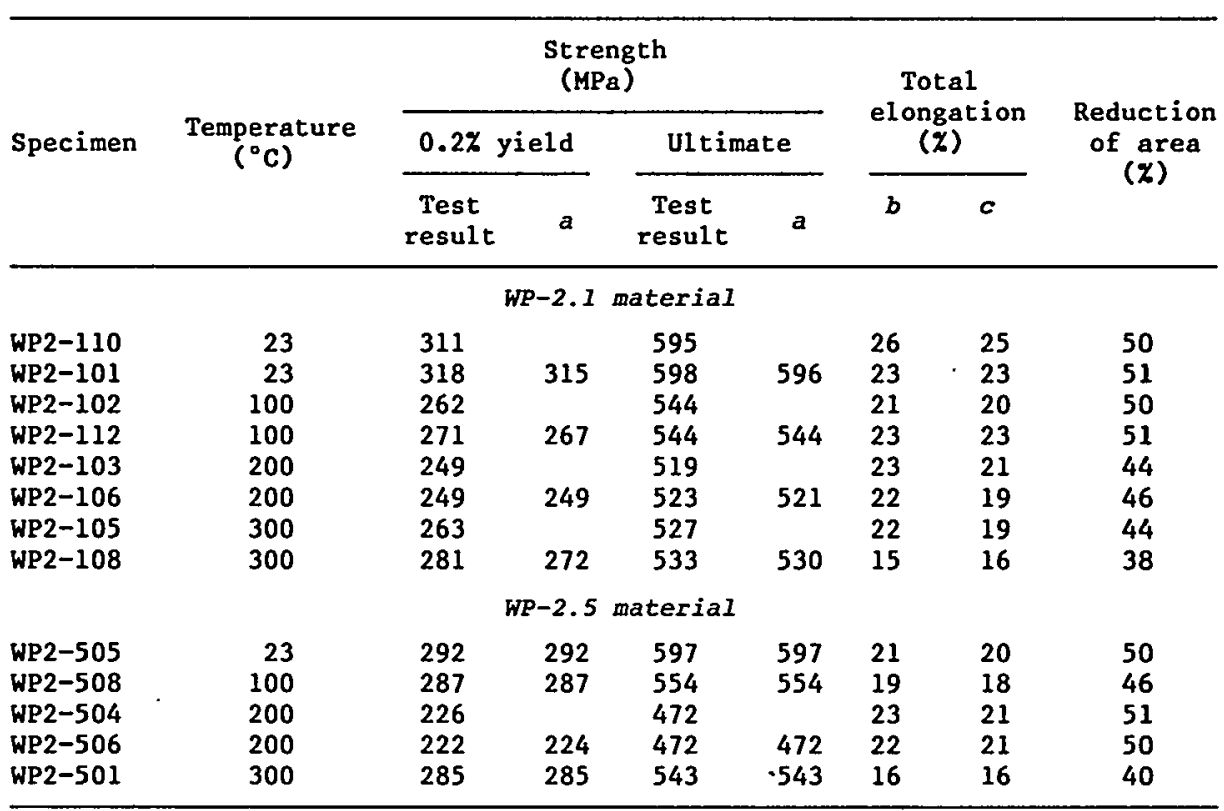

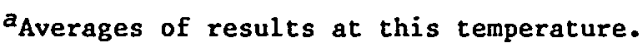

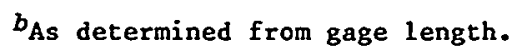

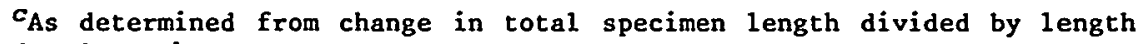
of reduced section.

ORNL-DWG 89-5008 ETD

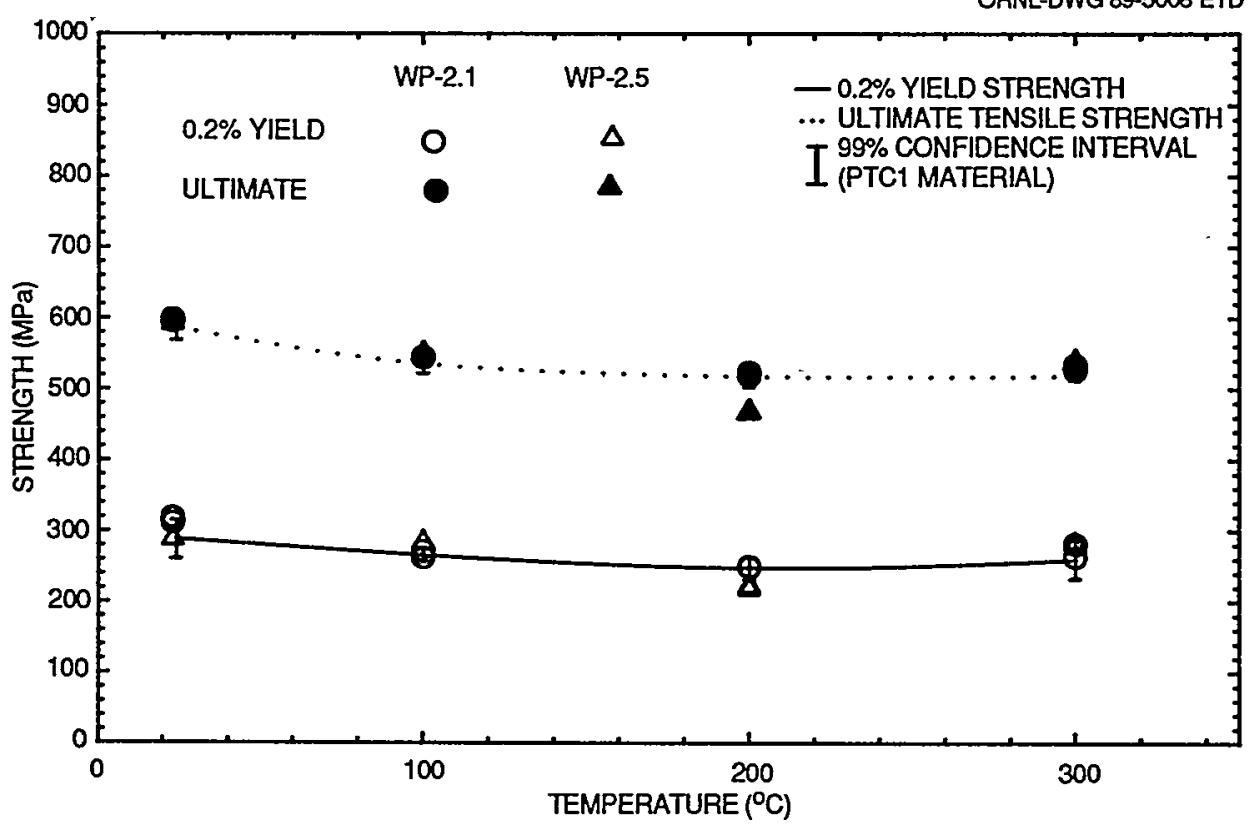

Fig. 3.4. Comparison of WP-2 material tensile strength test results with $99 \%$ confidence interval obtained from PTC1 characterization block material tests. 
Table 3.7. Tensile properties of specimens machined transverse to the rolling direction of material from characterization block PTCl

\begin{tabular}{|c|c|c|c|c|c|c|c|}
\hline \multirow{3}{*}{ Specimen ${ }^{a}$} & \multirow{3}{*}{$\begin{array}{c}\text { Temperature } \\
\left({ }^{\circ} \mathrm{C}\right)\end{array}$} & \multicolumn{3}{|c|}{$\begin{array}{c}\text { Strength } \\
(\mathrm{MPa})\end{array}$} & \multirow{3}{*}{$\begin{array}{c}\text { Fracture } \\
\text { stress } \\
\text { (MPa) }\end{array}$} & \multirow{3}{*}{$\begin{array}{c}\text { Elongation } \\
(\%)\end{array}$} & \multirow{3}{*}{$\begin{array}{c}\text { Reduction } \\
\text { of area } \\
(z)\end{array}$} \\
\hline & & \multicolumn{2}{|c|}{ Yield } & \multirow[t]{2}{*}{ Ultimate } & & & \\
\hline & & $\boldsymbol{b}$ & $c$ & & & & \\
\hline & & \multicolumn{4}{|c|}{ 4.52-mm-diam specimens } & . & \\
\hline $\begin{array}{l}\text { PI97 } \\
\text { PI93 } \\
\text { PI94 } \\
\text { PI } 127 \\
\text { PI118 } \\
\text { PII23 } \\
\text { PI98 } \\
\text { PI } 114\end{array}$ & $\begin{array}{r}-100 \\
-100 \\
-50 \\
0 \\
0 \\
100 \\
200 \\
300\end{array}$ & & $\begin{array}{l}512 \\
503 \\
348 \\
321 \\
346 \\
320 \\
269 \\
327\end{array}$ & $\begin{array}{l}715 \\
719 \\
664 \\
603 \\
599 \\
537 \\
493 \\
533\end{array}$ & $\begin{array}{l}573 \\
572 \\
470 \\
466 \\
468 \\
441 \\
411 \\
478\end{array}$ & $\begin{array}{l}35 \\
41 \\
28 \\
26 \\
25 \\
21 \\
20 \\
15\end{array}$ & $\begin{array}{l}50 \\
51 \\
51 \\
53 \\
56 \\
48 \\
50 \\
38\end{array}$ \\
\hline \multicolumn{8}{|c|}{ 6.35-mm-diam specimens } \\
\hline $\begin{array}{l}\text { PI283 } \\
\text { PI291 } \\
\text { PI285 } \\
\text { PI286 } \\
\text { PI292 } \\
\text { PI287 } \\
\text { PI288 } \\
\text { PI293 } \\
\text { PI289 } \\
\text { PI290 } \\
\text { PI294 }\end{array}$ & $\begin{array}{r}24 \\
24 \\
100 \\
100 \\
100 \\
200 \\
200 \\
200 \\
300 \\
300 \\
300\end{array}$ & $\begin{array}{l}266 \\
314 \\
265 \\
266 \\
259 \\
241 \\
248 \\
234 \\
290 \\
244 \\
248\end{array}$ & $\begin{array}{l}348 \\
314 \\
359 \\
337 \\
340 \\
315 \\
315 \\
330 \\
344 \\
325 \\
335\end{array}$ & $\begin{array}{l}574 \\
586 \\
530 \\
523 \\
530 \\
511 \\
509 \\
513 \\
520 \\
513 \\
515\end{array}$ & $\begin{array}{l}467 \\
501 \\
446 \\
432 \\
449 \\
447 \\
434 \\
442 \\
454 \\
454 \\
461\end{array}$ & $\begin{array}{l}26 \\
25 \\
22 \\
24 \\
26 \\
20 \\
19 \\
20 \\
16 \\
17 \\
16\end{array}$ & $\begin{array}{l}51 \\
44 \\
47 \\
50 \\
47 \\
46 \\
46 \\
45 \\
41 \\
43 \\
41\end{array}$ \\
\hline \multicolumn{8}{|c|}{ 12.7-mm-diam specimens } \\
\hline $\begin{array}{l}\text { PI369 } \\
\text { PI370 } \\
\text { PI371 } \\
\text { PI372 } \\
\text { PI374 } \\
\text { PI373 }\end{array}$ & $\begin{array}{r}24 \\
25 \\
100 \\
100 \\
200 \\
300\end{array}$ & $\begin{array}{l}275 \\
295 \\
256 \\
276 \\
263 \\
254\end{array}$ & 336 & $\begin{array}{l}578 \\
603 \\
536 \\
554 \\
534 \\
524\end{array}$ & & $\begin{array}{l}26 \\
27 \\
23 \\
24 \\
23 \\
21\end{array}$ & $\begin{array}{l}47 \\
50 \\
46 \\
46 \\
47 \\
42\end{array}$ \\
\hline
\end{tabular}

$a_{\text {All }}$ specimen machined from $1 / 4 t$ depth in plate with transverse orientation.

$b_{Y i e l d}$ strength obtained from $x-y$ plot of load vs strain extensometer (25.4-mm gage length).

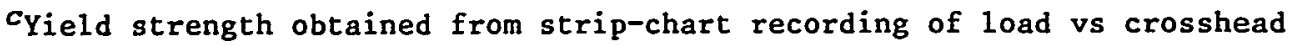
speed.

. dComputed from strip-chart readings of elongation of specimen, corrected to a gage length of four diameters when necessary. The elongations for the $12.7-\mathrm{mm}-$ diam specimens were computed from gage marks in the specimens. 


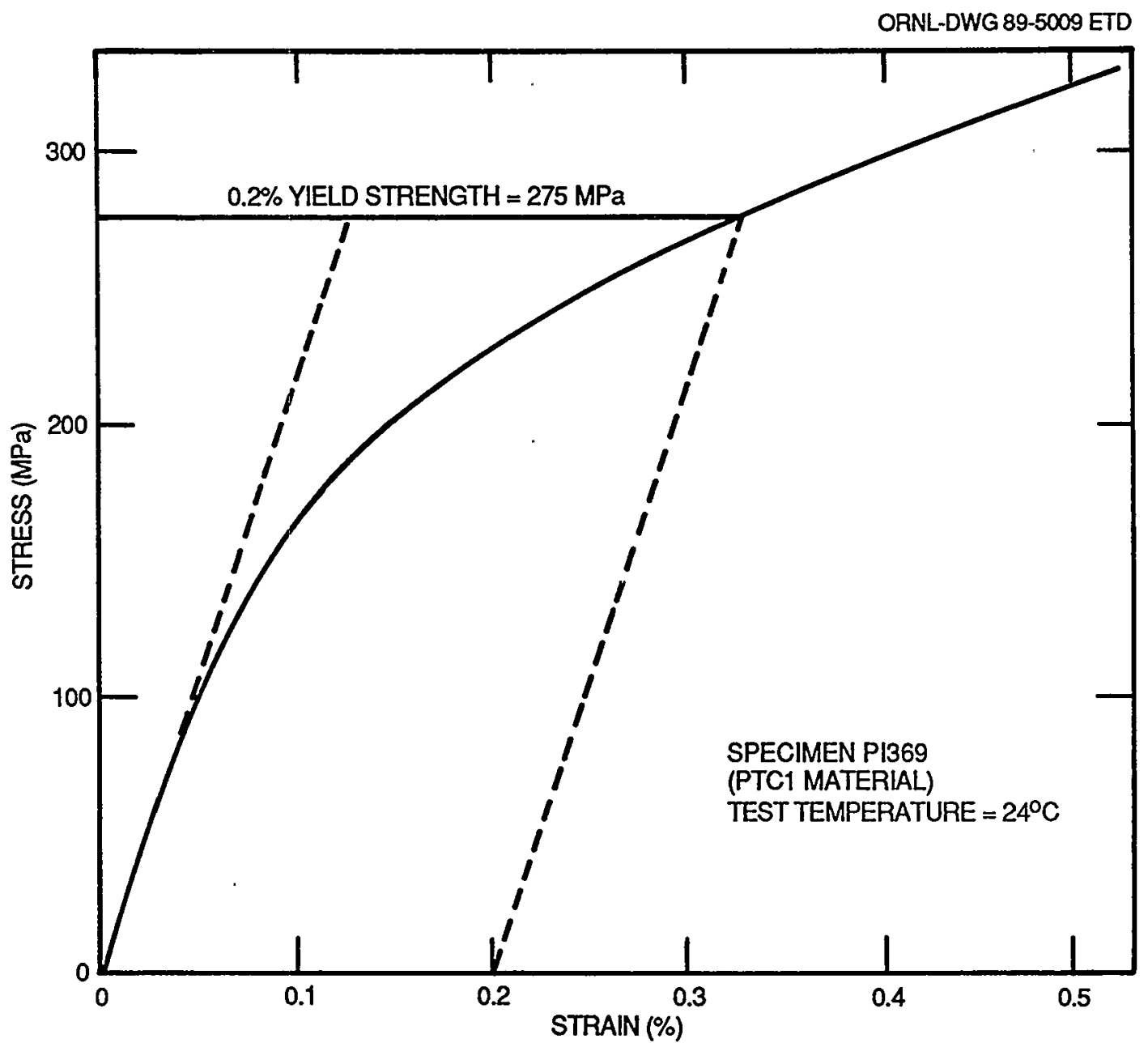

Fig. 3.5. Typical room-temperature stress-strain curve for material obtained from characterization block PTCl in direction transverse to material rolling orientation.

As may be seen from Fig. 3.4, most results from the present tests fall within the $99 \%$ confidence interval of results obtained previously from the PTCl material. The only deviations were two specimens using WP-2.5 material tested at $200^{\circ} \mathrm{C}$, in which both the yield and ultimate strength are about $10 \%$ less than the averages obtained from WP-2.1 material. Tensile properties generally do not exhibit much scatter, and it is assumed that the cause of this deviation is experimental error. Thus, it may be concluded that the posttest material from the WP-2 plates had not been subjected to any significant strain levels, either during the fabrication or testing of the large 10-m-1ong, single-edgenotch (SEN) specimens. 


\subsection{CRACK-ARREST TESTING}

Crack-arrest tests were performed according to the ASTM Test for Determining Plane-Strain Crack-Arrest Fracture Toughness, $\mathrm{K}_{\mathrm{Ia}}$, of Ferritic Steels (E 1221-88) using $33 \times 150 \times 150 \mathrm{~mm}$ specimens. From each of plates WP-2.1 and -2.5 seven specimens were fabricated; three specimens were duplex, and four were weld embrittled. The test results are given in Table 3.8 and plotted in Fig. 3.6. Also plotted in Fig. 3.6 are the results from previous T-L orientation tests on the PTCl characterization block (given in Table 3.9). Only one specimen, WP213, from the $W P-2.1$ material and tested at $70^{\circ} \mathrm{C}$ was valid in strict accordance to ASTM E 1221 and gave a $K_{\text {a }}$ of $82 \mathrm{MPa} \cdot \sqrt{\mathrm{m}}$. The ASTM E-1221 measures of validity have also been included in Table 3.8. The letters A-E refer to the corresponding criteria given in Table 2 of ASTM E 1221-88. The first row of values given for each specimen in the table are the lengths of the unbroken 1igament ( $A$ and $B$ ), specimen thickness (C), and the crack jump ( $D$ and $E$ ). The values in parentheses are the minimum ones specified in ASTM E 1221-88. Some specimens are marginally invalid, and others grossly so.

ORNL-DWG 89-5010 ETD

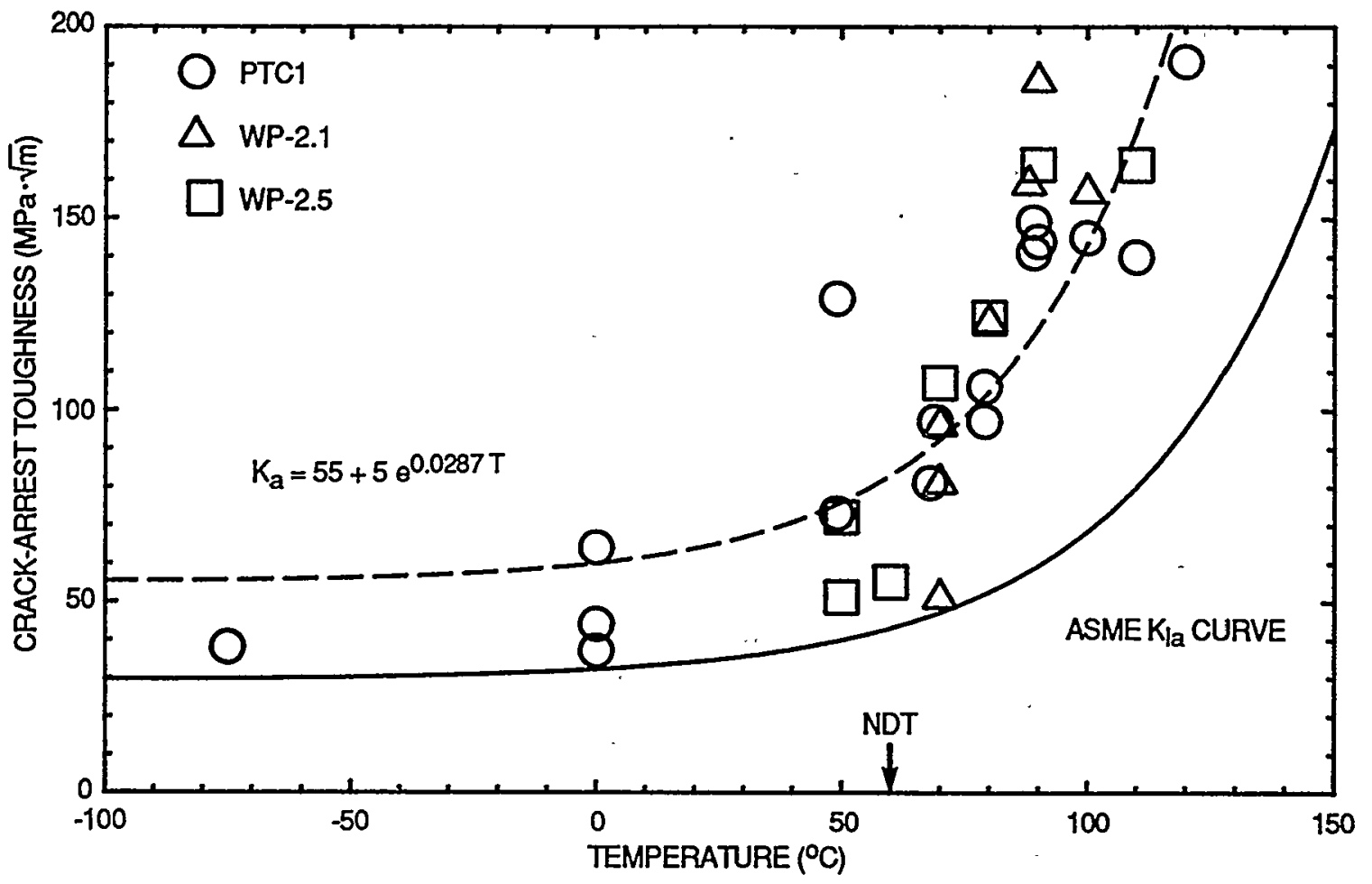

Fig. 3.6. Comparison of posttest crack-arrest toughness $\left(\mathrm{K}_{a}\right)$ values obtained for specimens fabricated from plate halves of specimens WP-2.1 and -2.5 with those obtained from PTCl material and ASME $\mathrm{K}_{\mathrm{Ia}}$ curve. 
Table 3.8. Crack-arrest toughness data from WP-2.1 and -2.5 material for both weld-embrittled and duplex specimens in the T-L orientation

\begin{tabular}{|c|c|c|c|c|c|c|c|c|}
\hline \multicolumn{2}{|c|}{ Specimen } & \multirow{3}{*}{$\begin{array}{l}\text { Temperature } \\
\left({ }^{\circ} \mathrm{C}\right)\end{array}$} & \multirow{3}{*}{$\underset{(\mathrm{MPa} \cdot \sqrt{m})}{\mathrm{K}_{a}}$} & \multirow{2}{*}{\multicolumn{5}{|c|}{$\begin{array}{c}\text { ASTM E } 1221 \text { validity criteria }{ }^{a} \\
\text { measured and minimum } \\
\text { values } b \\
(\mathrm{~mm})\end{array}$}} \\
\hline \multirow[t]{2}{*}{ ID } & \multirow[t]{2}{*}{ Type } & & & & & & & \\
\hline & & & & A & B & C & D & $\mathrm{E}$ \\
\hline \multicolumn{9}{|c|}{ WP-2.1 material } \\
\hline WP212 & WE & 70 & 97 & $\begin{array}{c}46 \\
(19)\end{array}$ & $\begin{array}{c}46 \\
(49)\end{array}$ & $\begin{array}{c}33 \\
(39)\end{array}$ & $\begin{array}{c}35 \\
(23)\end{array}$ & $\begin{array}{c}35 \\
(36)\end{array}$ \\
\hline WP213 & WE & 70 & 82 & $\begin{array}{c}37 \\
(19)\end{array}$ & $\begin{array}{c}37 \\
(35)\end{array}$ & $\begin{array}{c}33 \\
(28)\end{array}$ & $\begin{array}{c}43 \\
(23)\end{array}$ & $\begin{array}{c}43 \\
(35)\end{array}$ \\
\hline WP214A & WE & 70 & 52 & $\begin{array}{c}18 \\
(19)\end{array}$ & $\begin{array}{c}18 \\
(14)\end{array}$ & $\begin{array}{c}33 \\
(11)\end{array}$ & $\begin{array}{c}63 \\
(23)\end{array}$ & $\begin{array}{l}63 \\
(30)\end{array}$ \\
\hline WP211 & WE & 80 & 124 & $\begin{array}{c}63 \\
(19)\end{array}$ & $\begin{array}{c}63 \\
(81)\end{array}$ & $\begin{array}{c}33 \\
(65)\end{array}$ & $\begin{array}{c}18 \\
(23)\end{array}$ & $\begin{array}{c}18 \\
(35)\end{array}$ \\
\hline WP216 & DX & 88 & 160 & $\begin{array}{c}45 \\
(19)\end{array}$ & $\begin{array}{l}45 \\
(143)\end{array}$ & $\begin{array}{l}33 \\
(114)\end{array}$ & $\begin{array}{c}24 \\
(25)\end{array}$ & \\
\hline WP218 & $\mathrm{DX}$ & 90 & 187 & $\begin{array}{c}62 \\
(19)\end{array}$ & $\begin{array}{c}62 \\
(194)\end{array}$ & $\begin{array}{l}29 \\
(155)\end{array}$ & $\begin{array}{c}7 \\
(20)\end{array}$ & \\
\hline WP215 & DX & 100 & 158 & $\begin{array}{c}53 \\
(19)\end{array}$ & $\begin{array}{c}53 \\
(141)\end{array}$ & $\begin{array}{l}29 \\
(113)\end{array}$ & $\begin{array}{c}15 \\
(20)\end{array}$ & \\
\hline \multicolumn{9}{|c|}{ WP-2.5 material } \\
\hline WP252 & WE & 50 & 51 & $\begin{array}{c}7 \\
(19)\end{array}$ & $\begin{array}{c}7 \\
(13)\end{array}$ & $\begin{array}{c}33 \\
(11)\end{array}$ & $\begin{array}{c}73 \\
(23)\end{array}$ & $\begin{array}{c}73 \\
(41)\end{array}$ \\
\hline WP253 & HE & 50 & 72 & $\begin{array}{c}24 \\
(19)\end{array}$ & $\begin{array}{c}24 \\
(27)\end{array}$ & $\begin{array}{c}33 \\
(21)\end{array}$ & $\begin{array}{c}57 \\
(23)\end{array}$ & $\begin{array}{c}57 \\
(51)\end{array}$ \\
\hline WP254 & WE & 70 & 107 & $\begin{array}{c}57 \\
(19)\end{array}$ & $\begin{array}{c}57 \\
(60)\end{array}$ & $\begin{array}{c}33 \\
(48)\end{array}$ & $\begin{array}{c}24 \\
(23)\end{array}$ & $\begin{array}{c}24 \\
(33)\end{array}$ \\
\hline WP251 & WE & 60 & 55 & $\begin{array}{c}14 \\
(19)\end{array}$ & $\begin{array}{c}14 \\
(16)\end{array}$ & $\begin{array}{c}33 \\
(13)\end{array}$ & $\begin{array}{c}67 \\
(23)\end{array}$ & $\begin{array}{c}67 \\
(42)\end{array}$ \\
\hline WP256 & DX & 80 & 124 & $\begin{array}{c}43 \\
(19)\end{array}$ & $\begin{array}{c}43 \\
(86)\end{array}$ & $\begin{array}{c}33 \\
(68)\end{array}$ & $\begin{array}{c}26 \\
(24)\end{array}$ & \\
\hline WP257 & $\mathrm{DX}$ & 90 & 164 & $\begin{array}{c}56 \\
(19)\end{array}$ & $\begin{array}{l}56 \\
(148)\end{array}$ & $\begin{array}{c}33 \\
(119)\end{array}$ & $\begin{array}{c}13 \\
(24)\end{array}$ & \\
\hline WP255 & $\mathrm{DX}$ & 110 & 164 & $\begin{array}{c}59 \\
(19)\end{array}$ & $\begin{array}{l}59 \\
(156)\end{array}$ & $\begin{array}{c}33 \\
(124)\end{array}$ & $\begin{array}{c}9 \\
(24)\end{array}$ & \\
\hline
\end{tabular}

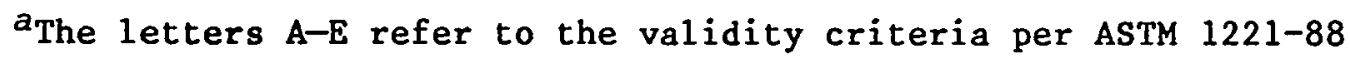
paragraph 9.3, Table 2 .

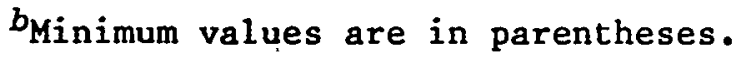

$C_{\mathrm{WE}}=$ weld-embrittled specimen; $\mathrm{DX}=$ duplex specimen . 
Table 3.9. Crack-arrest $\left(K_{a}\right)$ data for PTCl material (T-L orientation)

\begin{tabular}{lcr}
\hline Specimen & $\begin{array}{c}\text { Test } \\
\text { temperature } \\
\left({ }^{\circ} \mathrm{C}\right)\end{array}$ & $\begin{array}{c}\mathrm{K}_{\mathrm{a}} \\
(\mathrm{MPa} \cdot \sqrt{\mathrm{m}})\end{array}$ \\
\hline Weld embrittled, & $33 \times 152 \times 152 \mathrm{~mm}$ \\
P1320 & 0 & 44 \\
PI321 & 0 & 37 \\
P1313 & 49 & 73 \\
P1318 & 49 & 129 \\
P1314 & 68 & 81 \\
P1316 & 69 & 97 \\
P1317 & 79 & 106 \\
P1319 & 79 & 97 \\
P1315 & 89 & 149 \\
PI322 & 89 & 141 \\
& \\
DI308 & 33 & $152 \times 152 \mathrm{~mm}$ \\
PI310 & 90 & 144 \\
PI311 & 100 & 145 \\
PI312 & 110 & 140 \\
Precracked, & $33 \times 152 \times 152$ & $\mathrm{~mm}$ \\
PTC1A & 120 & 38 \\
PTC1C & -75 & 38 \\
PTC1B & -75 & 64 \\
\hline & 0 & \\
\hline
\end{tabular}

A11 T-L orientation data from both PTC1 and WP-2 material were used to obtain the regression fit of the curve shown dashed in Fig. 3.6. The equation was of the form $K_{a}=a+b \exp (0.0287 \mathrm{~T})$, where $T=$ temperature $\left({ }^{\circ} \mathrm{C}\right), \mathrm{K}_{\mathrm{a}}$ is the crack-arrest toughness $(\mathrm{MPa} \cdot \sqrt{\mathrm{m}})$, and $a$ and $b$ are constants to be determined by regression. The resulting equation is

$$
\mathrm{K}_{\mathrm{a}}=55+5 \exp (0.0287 \mathrm{~T}) \mathrm{MPa} \cdot \sqrt{\mathrm{m}} .
$$

The constant 0.0287 was chosen for consistency with previous wide-plate test results (see p. 37 , Ref. 6). Equation (3.1) may also be written in a form used in previous work as

$$
K_{a}=55+30 \exp [0.0287(T-N D T)] \mathrm{MPa} \cdot \sqrt{\mathrm{m}} \text {, }
$$

where NDT $=60^{\circ} \mathrm{C}$. 
In the analysis of the PTSE-2 experiment, 2 the same form of equation was regression-fit to both $T-L$ and $T-S$ small-specimen data and gave $\mathrm{K}_{\mathrm{a}}=34+11 \exp [0.02413 \mathrm{~T}]$, which can be rewritten as

$$
\mathrm{K}_{\mathrm{a}}=34+36 \exp [0.02413(\mathrm{~T}-\mathrm{NDT})] \mathrm{MPa} \cdot \sqrt{\mathrm{m}}
$$

where, for $\mathrm{PTCl}$, NDT $=49^{\circ} \mathrm{C}$. Equations (3.2) and (3.3) have been plotted together in Fig. 3.7 for comparison. Note that Eq. (3.2) is an "average" one in the least-squares sense, with the coefficient of the temperature 0.0287 chosen "a priori." The parameters in Eq. (3.3) were adjusted to give a better fit to the temperatures of interest. As may be seen from Fig. 3.7, the differences between $\mathrm{K}_{\mathrm{a}}$ calculated from either Eq. (3.2) or (3.3) for temperatures above NDT are relatively small, while there are substantial differences below NDT.

The results of the crack-arrest testing, in spite of invalidity in strict accordance with ASTM E 1221-88, appear to agree reasonably well with those of PTCl. Moreover, the trends exhibited by both valid and invalid small-specimen data from PTCl, T-L and T-S orientations,* agreed

*Incidently, there seems to be no noticeable differences between the $T-L$ and $T-S$ orientations in the small-specimen crack-arrest data from PTCl, as can be seen from Fig. 3.7.

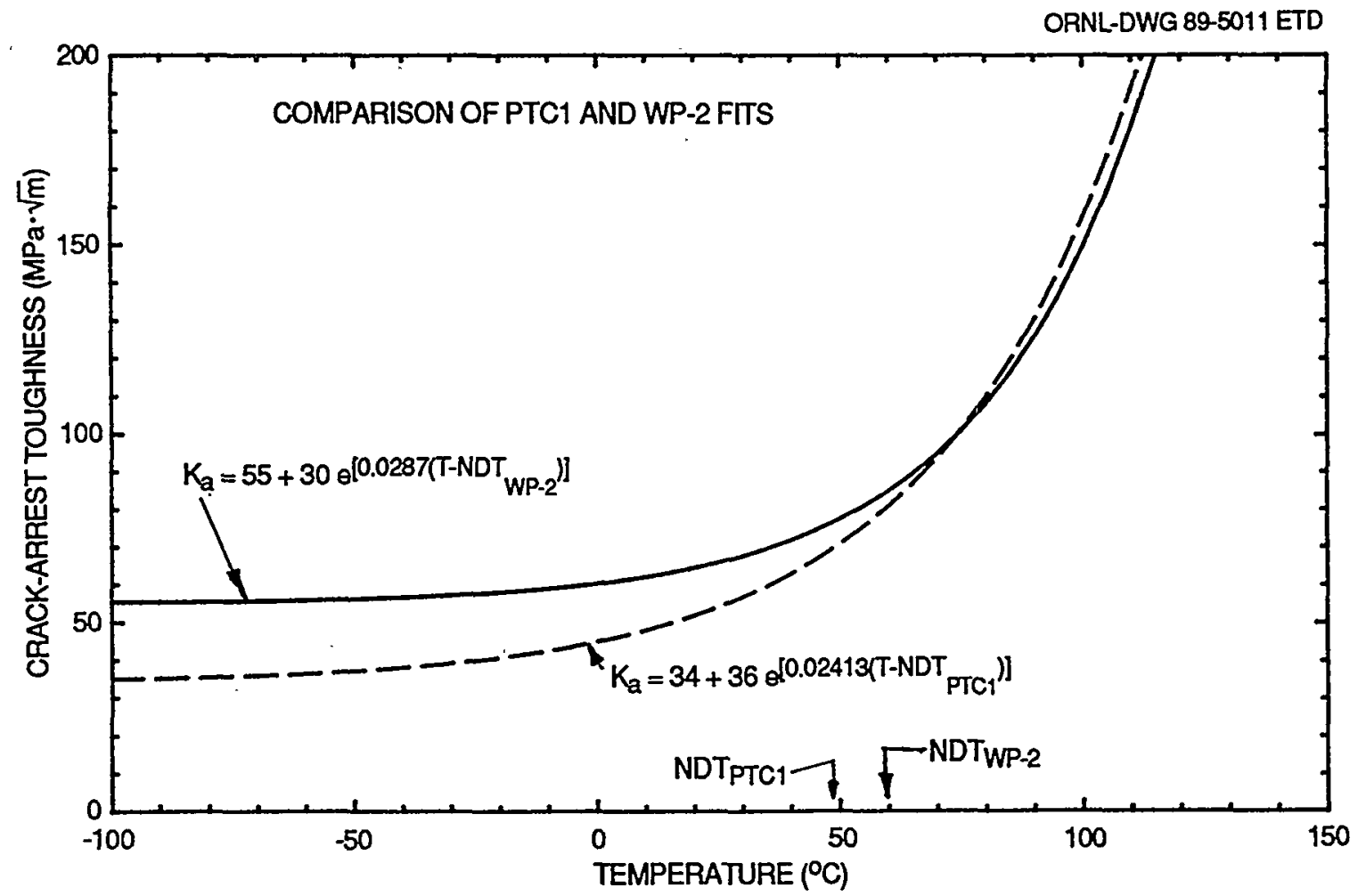

Fig. 3.7. Comparison of regression fits of crack-arrest toughness data for all PTCl ( $T-L$ and T-S orientations) material data and for WP-2 and PTCl materials ( $T-L$ orientation). 
well with the results of PTSE-2 (Fig. 3.8). This agreement tends to further reinforce the belief that the validity criteria of ASTM E 122188 may be overly restrictive.

ORNL-DWG 87-3961A ETD

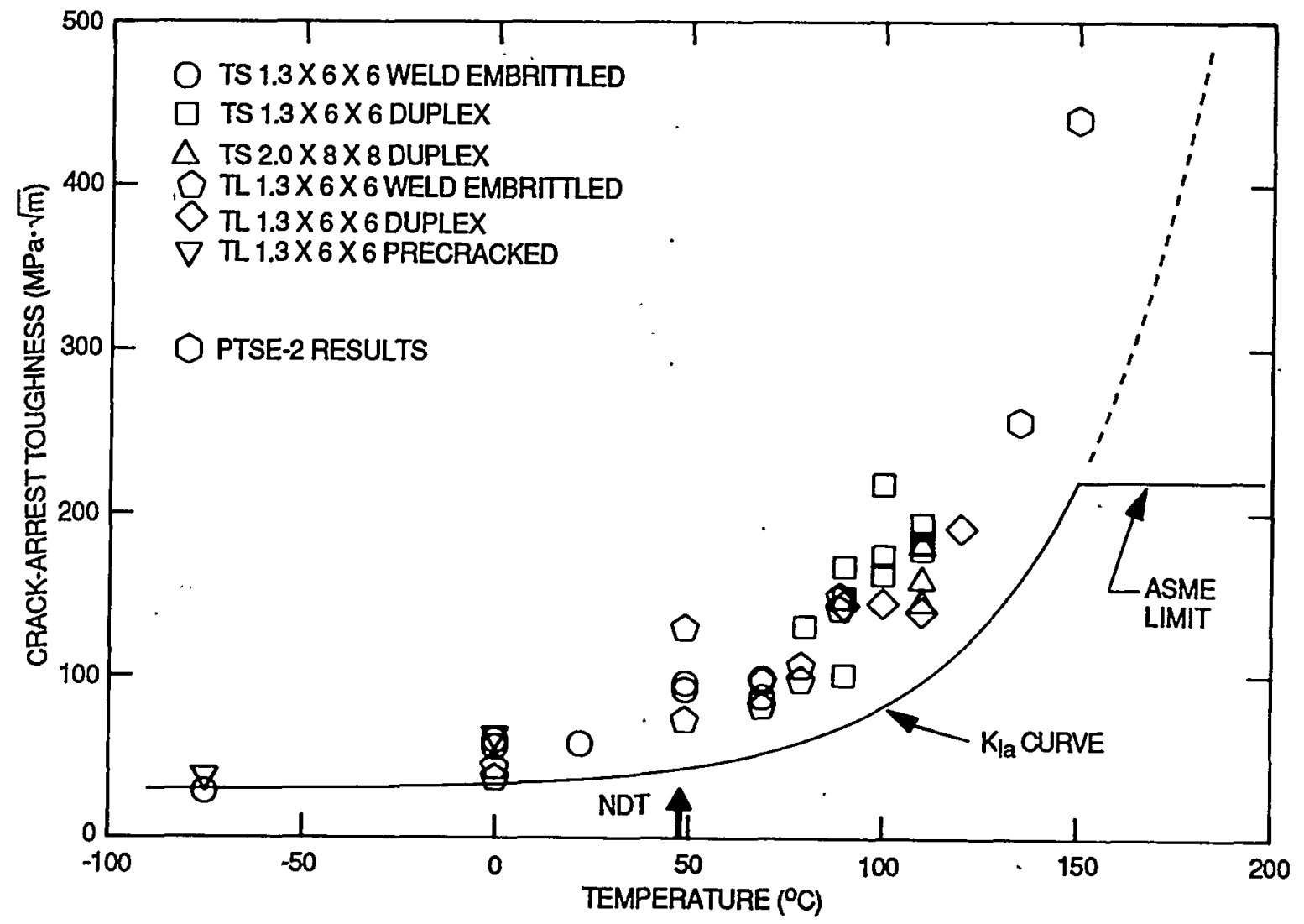

Fig. 3.8. Comparison of crack-arrest toughness test results obtained from PTCl and PTSE-2 LUS 2 1/4 $\mathrm{Cr}-1$ Mo materials.

\subsection{FRACTURE-TOUGENESS TESTING}

Fracture-toughness testing was conducted with $25-\mathrm{mm}$ compact specimens $C(T)$ machined from halves of plates WP-2.1 and -2.5 . The same procedures and methods of analysis were used as for the characterization of PTC1. The specimens were machined from midthickness $(1 / 2 t)$ in the $T-L$ orientation. In the temperature range 40 to $60^{\circ} \mathrm{C}$, where cleavage was expected, the specimens were not. side grooved. One trial specimen with no side grooves was tested at $80^{\circ} \mathrm{C}$ and did not cleave. Thus, those remaining to be tested at $80^{\circ} \mathrm{C}$ or higher were side grooved $20 \%$. Because of the limited purpose of posttest characterization, only specimens from WP-2.5 material were tested at $80^{\circ} \mathrm{C}$ or higher. 
In the 40 to $80^{\circ} \mathrm{C}$ transition range, a $\mathrm{K}_{\mathrm{Jc}}$ value was calculated by determining the modified $J$-integral 7 at the point of cleavage $\left(J_{c}\right)$ and using the relationship $\mathrm{K}^{2}=\mathrm{EJ}_{\mathrm{C}}$, where $\mathrm{E}$ is Young's modulus (a value of $205 \mathrm{GPa}$ was used). For the single specimen, WP2504, that experienced significant stable ductile tearing without final cleavage failure, a " $J c$ " was determined at the point of maximum load, resulting in a " $\mathrm{JC}_{\mathrm{Jc}}$ " of $206 \mathrm{MPa} \cdot \sqrt{\mathrm{m}}$. Specimen WP2504 also experienced a pop-in at $120 \mathrm{MPa} \cdot \sqrt{\mathrm{m}}$, and this is the value used on the plot of transition region fracture toughness given in Fig. 3.9 , and not the $206-\mathrm{MPa} \cdot \sqrt{\mathrm{m}}$ value, because no cleavage is associated with the latter. The unloading compliance method was used to estimate crack extension, but the test is conducted so as not to preclude a possible determination of $K_{I c}$ per ASTM Standard Test Method for Plane-Strain Fracture Toughness of Metallic Materials (E 399). The graphical output from the analysis of a typical test is shown in Fig. 3.10. Crack extension was determined using the nine-point averaging technique.

The results of the 40,60 , and $80^{\circ} \mathrm{C} \mathrm{K}_{\mathrm{Jc}}$ tests are shown in Table 3.10. Also given in Table 3.10 are the $K_{B C}$ values calculated using the

ORNL-DWG 89-5013 ETD

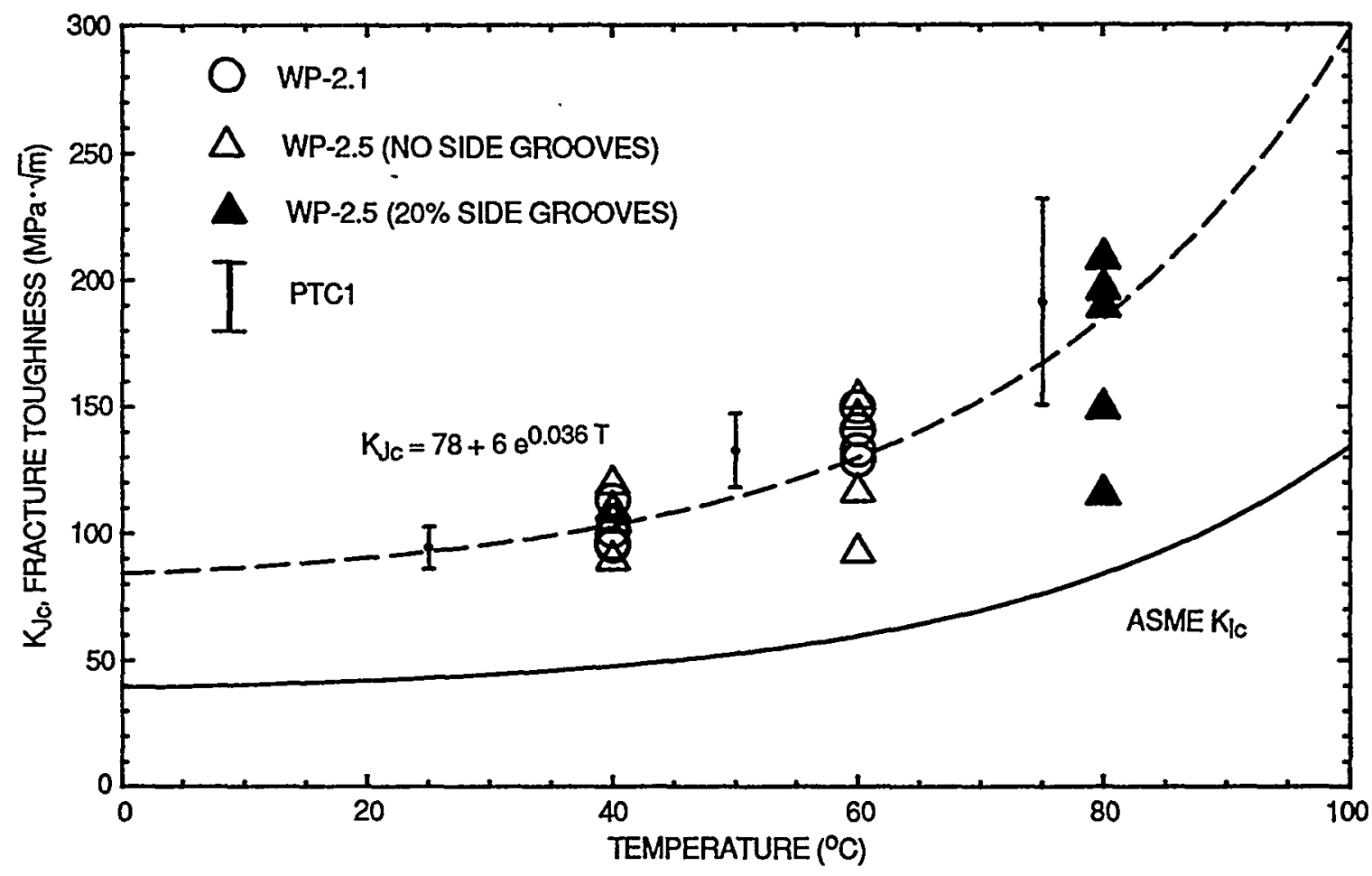

Fig. 3.9. Comparison of posttest initiation toughness $\left(\mathrm{K}_{\mathrm{JC}}\right)$ for specimens fabricated from plate halves of specimens $\mathrm{HP}-2.1$ and -2.5 with range of values exhibited for specimens fabricated from PTC1 characterization block. 
ORNL-DWG 89-5012ETD

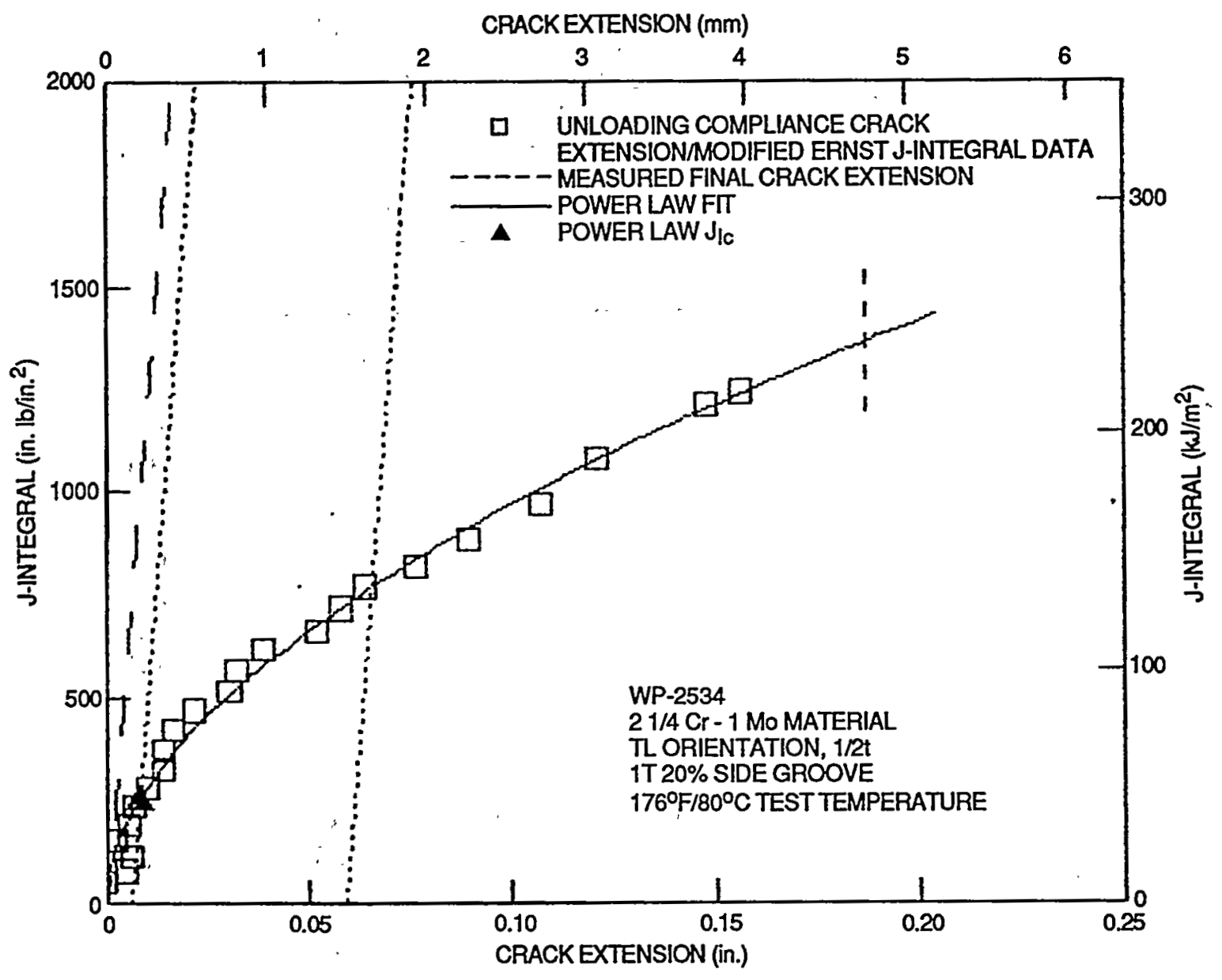

Fig. 3.10. Graphical output from analysis of a typical fracture toughness test at $80^{\circ} \mathrm{C}$ using single-specimen unloading compliance method.

method described by Merkle $e^{8}$ and the measured stable ductile crack extension (including blunting). No valid $\mathrm{K}_{\mathrm{Ic}}$ values were obtained, even at $40^{\circ} \mathrm{C}$, because of the $10 \mathrm{w}$ yield strength of this material. The scatter is typical of that exhibited in the transition range. At $80^{\circ} \mathrm{C}$, the upper value of $\mathrm{K}_{\mathrm{Jc}}$ is about twice the lowest one, but this ratio decreases to 1.3 at $40^{\circ} \mathrm{C}$. The results are also shown in Fig. 3.9, which includes the $99 \%$ confidence band of PTCl results. There is no significant difference in results between material from WP-2.1 and that from WP-2.5, but the WP-2 material overall has noticeably lower initiation toughness than PTCl, at least $>40^{\circ} \mathrm{C}$.

Data from the tests at 40 and $60^{\circ} \mathrm{C}$ were used to obtain a regression fit to an equation of the form $\mathrm{K}_{\mathrm{Jc}}=\mathrm{a}+\mathrm{b} \exp (0.036 \mathrm{~T})$, where $\mathrm{T}=\mathrm{tem}-$ perature in ${ }^{\circ} \mathrm{C}, \mathrm{K}_{\mathrm{Jc}}$ is the fracture toughness in $\mathrm{MPa} \cdot \sqrt{\mathrm{m}}$, and $\mathrm{a}$ and $\mathrm{b}$ are 
Table 3.10. Transition region fracture-toughness results from posttest characterization using $25-\mathrm{mm} C(T)$ specimens $(1 / 2 t)$ machined from broken halves of specimens WP -2.1 and -2.5 ( $T-L$ orientation)

\begin{tabular}{|c|c|c|c|c|c|}
\hline Specimen & $\begin{array}{c}\text { Test } \\
\text { temperature } \\
\left({ }^{\circ} \mathrm{C}\right)\end{array}$ & $\begin{array}{l}\text { Side } \\
\text { groove } \\
(\%)\end{array}$ & $\begin{array}{c}\mathrm{K}_{\mathrm{Jc}} \\
(\mathrm{MPa} \cdot \sqrt{\mathrm{m}})\end{array}$ & $\begin{array}{c}K_{B c} \\
(\mathrm{MPa} \cdot \sqrt{m})\end{array}$ & $\begin{array}{c}\text { Stable } \\
\text { crack } \\
\text { extension } \\
(\mathrm{mm})\end{array}$ \\
\hline \multicolumn{6}{|c|}{ WP-2.I material } \\
\hline $\begin{array}{l}\text { WP2109 } \\
\text { WP2115 } \\
\text { WP2108 } \\
\text { WP2107 }\end{array}$ & $\begin{array}{l}40 \\
40 \\
40 \\
40\end{array}$ & $\begin{array}{l}0 \\
0 \\
0 \\
0\end{array}$ & $\begin{array}{r}95 \\
113 \\
101 \\
96\end{array}$ & $\begin{array}{l}51 \\
55 \\
53 \\
52\end{array}$ & $\begin{array}{l}0.0 \\
0.0 \\
0.0 \\
0.0\end{array}$ \\
\hline $\begin{array}{l}\text { WP2104 } \\
\text { WP2118 } \\
\text { WP2106 } \\
\text { WP2101 }\end{array}$ & $\begin{array}{l}60 \\
60 \\
60 \\
60\end{array}$ & $\begin{array}{l}0 \\
0 \\
0 \\
0\end{array}$ & $\begin{array}{l}141 \\
129 \\
133 \\
150\end{array}$ & $\begin{array}{l}59 \\
57 \\
58 \\
61\end{array}$ & $\begin{array}{l}0.7 \\
0.7 \\
0.1 \\
1.0\end{array}$ \\
\hline \multicolumn{6}{|c|}{ WP-2.5 material } \\
\hline $\begin{array}{l}\text { WP } 2506 \\
\text { WP2526 } \\
\text { WP } 2503 \\
\text { WP } 2511 \\
\text { WP2521 }\end{array}$ & $\begin{array}{l}40 \\
40 \\
40 \\
40 \\
40\end{array}$ & $\begin{array}{l}0 \\
0 \\
0 \\
0 \\
0\end{array}$ & $\begin{array}{r}106 \\
121 \\
110 \\
111 \\
91\end{array}$ & $\begin{array}{l}54 \\
57 \\
55 \\
55 \\
51\end{array}$ & $\begin{array}{l}0.0 \\
0.0 \\
0.0 \\
0.0 \\
0.0\end{array}$ \\
\hline $\begin{array}{l}\text { WP2514 } \\
\text { WP2518 } \\
\text { WP2505 } \\
\text { WP2 } 2508\end{array}$ & $\begin{array}{l}60 \\
60 \\
60 \\
60\end{array}$ & $\begin{array}{l}0 \\
0 \\
0 \\
0\end{array}$ & $\begin{array}{r}94 \\
118 \\
155 \\
147\end{array}$ & $\begin{array}{l}51 \\
55 \\
62 \\
60\end{array}$ & $\begin{array}{l}0.2 \\
0.3 \\
0.9 \\
0.9\end{array}$ \\
\hline $\begin{array}{l}\text { WP2504 } \\
\text { WP2504 } \\
\text { WP2510 } \\
\text { WP2516 } \\
\text { WP2517 } \\
\text { WP2534 }\end{array}$ & $\begin{array}{l}80 \\
80 \\
80 \\
80 \\
80 \\
80\end{array}$ & $\begin{array}{l}20 \\
20 \\
20 \\
20 \\
20 \\
20\end{array}$ & $\begin{array}{l}120 \\
206 \\
198 \\
191 \\
151 \\
210\end{array}$ & $\begin{array}{l}52 \\
63 \\
63 \\
62 \\
57 \\
64 .\end{array}$ & $\begin{array}{l}0.4 \\
5.9 \\
4.5 \\
3.3 \\
2.0 \\
4.7\end{array}$ \\
\hline
\end{tabular}

${ }^{a}$ Pop-ins at 82 and $115 \mathrm{MPa} \cdot \sqrt{\mathrm{m}}$.

$b_{\mathrm{Pop}-i n}$ at cycle 13 ; values given are at maximum load of cycle 13.

$c_{\text {No }}$ cleavage; values are final ones : when test was discontinued and are not included in Fig. 3.10. 
constants to be determined by regression. The resulting equation is

$$
\mathrm{K}_{\mathrm{Jc}}=78+6 \exp (0.036 \mathrm{~T}) \mathrm{MPa} \cdot \sqrt{\mathrm{m}}
$$

The temperature coefficient 0.036 was chosen for consistency with previous work (WP-1:test series). Equation (3.4) may also be written in the form

$$
\mathrm{K}_{\mathrm{Jc}}=78+56 \exp [0.036(\mathrm{~T}-\mathrm{NDT})] \mathrm{MP}, \mathrm{a} \cdot \sqrt{\mathrm{m}}
$$

where NDT $=60^{\circ} \mathrm{C}$.

The results of toughness testing performed at 120,160 , and $200^{\circ} \mathrm{C}$ are given in Table 3.11. A power-1aw of the form $J=A(\Delta a+B)^{C}+D$ was fit to the $J_{M}$ data, with the parameters given in Table 3.11. The intersection of the power-law fit with the $0.2-\mathrm{mm}$ offset line is used to determine $\mathrm{J}_{\mathrm{Ic}}{ }^{*}$ The, table gives $\mathrm{J}$-integral values calculated by deformation theory, $J_{D}$, as recommended in the ASTM Test for $J_{I c}$, A Measure of Fracture Toughness $\left(\mathrm{E} 813-87\right.$ ), as well as modified $\mathrm{J}$-integral, $7 \mathrm{~J}_{\mathrm{M}}$. The values of $\mathrm{K}_{\mathrm{J}_{\mathrm{IC}}}$ were determined from the respective values of $\mathrm{J}$ by the expression given above. The tearing modulii were obtained from the nondimensional expression

$$
T=\left[E /\left(\sigma_{f}\right)^{2}\right](d J / d a)
$$

where

$$
\begin{aligned}
(\mathrm{dJ} / \mathrm{da})= & \text { slope of a straight line joining the intersection of the } \\
& \text { power-law fit and the } 0.15-\text { and } 1.5-\mathrm{mm} \text { exclusion lines, } \\
E= & \text { Young's modulus }(205 \mathrm{GPa}), \\
\sigma_{\mathrm{f}}= & \text { flow stress, an average of the ultimate strength and } 0.2 \% \\
& \text { offset yield strength at test temperature. }
\end{aligned}
$$

The 'power-law curve fits' to the $J_{M}$ data for all seven specimens tested $\left[120^{\circ} \mathrm{C}\right.$ (three specimens), $160^{\circ} \mathrm{C}$ (two specimens), and $200^{\circ} \mathrm{C}$ (two specimens)] have been plotted in Fig. 3.11. The number of specimens tested is too small to permit statistical analysis or firm conclusions regarding comparisons with PTC1, but the scatter of the data from WP-2.5 material seems to be smaller than that exhibited by PTCl.2 The values of $J_{M}$ for WP-2.5 material seem to fall in the scatter band exhibited by PTC1. The averaged and interpolated tearing modulii for PTCl at 120 , 160 , and $200^{\circ} \mathrm{C}$ were approximately 90,80 , and 67 , whereas for WP-2.5 material they were 71,70 , and 66 , respectively. Thus, the tearing modulii for WP-2 material at 120 and $160^{\circ} \mathrm{C}$ are $-80 \%$ of those for PTC1, but almost the same at $200^{\circ} \mathrm{C}$. The trends exhibited by the tearing 
Table 3.11. Ductile-shelf fracture-toughness results from posttest characterization using $25-\mathrm{mm} \mathrm{C}(\mathrm{T})$ specimens $(1 / 2 \mathrm{t})$ machined from broken half of specimen WP-2.5 (T-L orientation)

\begin{tabular}{|c|c|c|c|c|c|c|c|c|c|c|c|}
\hline \multirow{2}{*}{$\begin{array}{l}\text { Specimen } \\
\text { ID }\end{array}$} & \multirow{2}{*}{$\begin{array}{l}\text { Test } \\
\text { temperature } \\
\left({ }^{\circ} \mathrm{C}\right)\end{array}$} & \multicolumn{2}{|c|}{$\begin{array}{c}\mathrm{J}_{\mathrm{Ic}} \\
\left(\mathrm{kJ} / \mathrm{m}^{2}\right)\end{array}$} & \multicolumn{2}{|c|}{$(\mathrm{MPa} \cdot \sqrt{\mathrm{m}})$} & \multirow{2}{*}{$\begin{array}{l}\text { Crack }^{a} \\
\text { extension } \\
\quad(\mathrm{mm})\end{array}$} & \multirow{2}{*}{$\begin{array}{l}\text { Tearing } \\
\text { modulus } b\end{array}$} & \multicolumn{4}{|c|}{$\begin{array}{l}\text { Curve fit parameters } \\
\mathrm{J}=\mathrm{A}(\Delta \mathrm{a}+\mathrm{B})^{C}+\mathrm{D}\end{array}$} \\
\hline & & $\mathrm{J}_{\mathrm{D}}$ & $\mathrm{J}_{\mathrm{M}}$ & $\mathrm{J}_{\mathrm{D}}$ & $\mathrm{J}_{\mathrm{M}}$ & & & A & B & C & $\mathrm{D}$ \\
\hline WP2515 & 120 & 61 & 60 & 111 & 110 & 6.6 & 70 & 113 & 0.069 & 0.449 & -10 \\
\hline WP2519 & 120 & 50 & 47 & 100 & 97 & 7.5 & 70 & 101 & 0 & 0.477 & -6 \\
\hline WP2507 & 120 & 54 & 53 & 104 & 103 & 5.9 & 72 & 111 & 0 & 0.449 & -9 \\
\hline $\begin{array}{l}\text { WP2509 } \\
\text { WP2532 }\end{array}$ & $\begin{array}{l}160 \\
160\end{array}$ & $\begin{array}{l}54 \\
50\end{array}$ & $\begin{array}{l}52 \\
47\end{array}$ & $\begin{array}{r}103 \\
99\end{array}$ & $\begin{array}{r}101 \\
96\end{array}$ & $\begin{array}{l}7.6 \\
7.4\end{array}$ & $\begin{array}{l}62 \\
77\end{array}$ & $\begin{array}{r}92 \\
142\end{array}$ & $\begin{array}{l}0.035 \\
0\end{array}$ & $\begin{array}{l}0.467 \\
0.349\end{array}$ & $\begin{array}{r}-1 \\
-42\end{array}$ \\
\hline WP2523 & 200 & 49 & 48 & 98 & 97 & 7.0 & 57 & 81 & 0.037 & 0.459 & 1 \\
\hline WP2529 & 200 & 37 & 35 & 88 & 85 & 7.4 & 75 & 122 & 0 & 0.362 & -38 \\
\hline
\end{tabular}

aeasured final crack extension.

${ }^{b}$ Calculated from intersection of power-law fit and offset 1 ines.

$c_{J_{M}}$ data were used. 
ORNL-DWG 89-5014 ETD

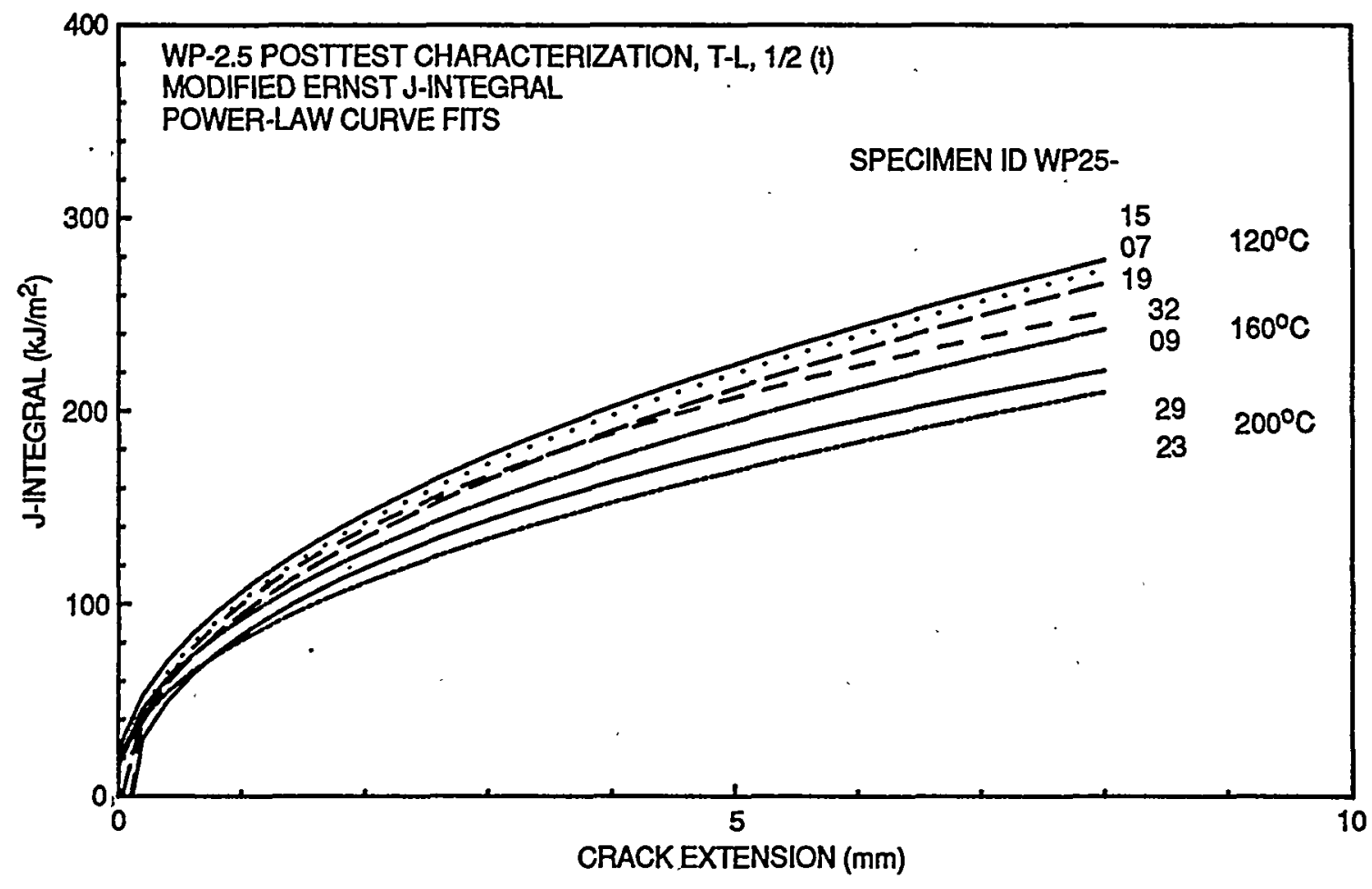

Fig. 3.11. Comparison of J-integral $\left(\mathrm{J}_{\mathrm{m}}\right)$ resistance curves at three temperatures for specimens obtained from WP-2.5 material at midthickness in $\mathrm{T}-\mathrm{L}$ orientation.

modulii for both materials are consistent because there is a decrease in modulus with increasing temperature.

The $\mathrm{K}_{\mathrm{J}_{\mathrm{Ic}}}$ values for the tests that did not undergo cleavage fracture are much lower than many of the $\mathrm{K}_{\mathrm{Jc}}$ values from specimens that did undergo mode conversion from stable tearing to cleavage fracture. Table 3.10 shows, for example, that specimen WP2534, tested at $80^{\circ} \mathrm{C}$, experienced $4.7 \mathrm{~mm}$ of stable crack extension before cleavage fracture with a $\mathrm{K}_{\mathrm{Jc}}$ value of $210 \mathrm{MPa} \cdot \sqrt{\mathrm{m}}$. The $\mathrm{J}-\mathrm{R}$ curve for that specimen is shown in Fig. 3.9. A J $\mathrm{Jc}_{\mathrm{c}}$ value (using modified J.) for that specimen is $\sim 44 \mathrm{~kJ} / \mathrm{m}^{2}$, which is lower than those shown in Table 3.11 for specimens that did not cleave at $120^{\circ} \mathrm{C}$. The resulting $\mathrm{K}_{\mathrm{J}_{\mathrm{Ic}}}$ value is $95 \mathrm{MPa} \cdot \sqrt{\mathrm{m}}$ and compares with the $\mathrm{K}_{\mathrm{Jc}}$ values at $80^{\circ} \mathrm{C}$, which ranged from 120 to $210 \mathrm{MPa} \cdot \sqrt{\mathrm{m}}$. This comparison reinforces the observation that cleavage fracture-toughness values in the mid-to-upper-transition region can be substantially greater than the toughness determined at the onset of ductile tearing.

A dynamic fracture-toughness relation (see p. 38, Ref. 6) for use in analyses of the wide-plate tests is written as

$$
K_{I D}=K_{a}+A(T) \dot{a}^{2},
$$


where $\mathrm{K}_{\mathrm{Ia}}$ is given by Eq. (3.2). For

$$
\begin{aligned}
& \mathrm{T}-\mathrm{RT}_{\mathrm{NDT}}>-13.9 \mathrm{~K}, \\
& \mathrm{~A}(\mathrm{~T})=\left[329.7+16.25\left(\mathrm{~T}-\mathrm{RT}_{\mathrm{NDT}}\right)\right] \times 10^{-6} \mathrm{MPa} \cdot \mathrm{s}^{2} \cdot \mathrm{m}^{-3} / 2
\end{aligned}
$$

and for

$$
\begin{aligned}
& \mathrm{T}-\mathrm{RT}_{\mathrm{NDT}} \leq-13.9 \mathrm{~K}, \\
& \mathrm{~A}(\mathrm{~T})=\left[121.7+1.2962\left(\mathrm{~T}-\mathrm{RT}_{\mathrm{NDT}}\right)\right] \times 10^{-6} \mathrm{MPa} \cdot \mathrm{s}^{2} \cdot \mathrm{m}^{-3} / 2 .
\end{aligned}
$$

Units for $K_{I D}$, $\dot{a}$, and $T$ are $M P a \cdot \sqrt{\mathrm{m}}, \mathrm{m} / \mathrm{s}$, and ${ }^{\circ} \mathrm{C}$, respectively. The form of the $K_{I D}$ expression in Eq. (3.6) and relations for $A(T)$ are derived from Ref. 9 by estimating that $\mathrm{RT}_{\mathrm{NDT}}=-6.1^{\circ} \mathrm{C}$ for the material used in that study. Much of the data used in Ref. 9 are presented in Ref. 10.

\section{REFERENCES}

1. H. A. Domian, Martin Marietta Energy Systems, Inc., Oak Ridge Nat1. Lab., Low Upper-Shelf Toughness, High Transition Temperature Test Insert in HSST PTSE-2 Vessel and Wide Plate Test Specimens, USNRC Report NUREG/CR-471I (ORNL/Sub/85-34128/1), February 1987.*

2. R. H. Bryan et al., Martin Marietta Energy Systems, Inc., Oak Ridge Natl. Lab., Pressurized-Thermal-Shock Test of 6-in.-Thick Pressure Vessels. PTSE-2: Investigation of Low Tearing Resistance and Warm Prestressing, USNRC Report NUREG/CR-4888 (ORNL-6377), December $1987 . *$

3. R. K. Nanstad et al., Martin Marietta Energy Systems, Inc., Oak Ridge Nat1. Lab., "Low-Upper-Shelf Material Characterization," pp. 75-114 in Heavy-Section Steel Technology Program Semiann. Prog. Rep. April-September 1987, USNRC Report NUREG/CR-4219, Vol. 4, No. 2 (ORNL/TM-9593/V4\&N2), April 1988.*

4. R. K. Nanstad et al., Martin Marietta Energy Systems, Inc., Oak Ridge Natl. Lab., "Low-Upper-Shelf Material Characterization," pp. 42-55 in Heavy-Section Steel Technology Program Semiann. Prog. Rep. October 1986-March 1987, USNRC Report NUREG/CR-4219, Vol. 4, No. 1 (ORNL/TM-9593/V4\&N1), August 1987.* 
5. R. K. Nanstad et al., Martin Marietta Energy Systems, Inc., Oak Ridge Nat1. Lab., "Pressurized-Thermal-Shock and Wide-Plate CrackArrest Characterization," pp. 55-79 in Heavy-Section Steel Technology Program Semiann. Prog. Rep. April-September 1986, USNRC Report NUREG/CR-4219, Vo1. 3, No. 2 (ORNL/TM-9593/V3\&N2), December $1986 . *$

6. D. J. Naus et al., Martin Marietta Energy Systems, Inc., Oak Ridge Nat1. Lab., Crack Arrest Behavior in SEN Wide Plates of Quenched and Tempered A 533 Grade B Steel Tested Under Nonisothermal Conditions, USNRC Report NUREG/CR-4930 (ORNL-6388), August 1987. $\star$

7. H. A. Ernst, "Material Resistance and Instability Beyond J-Controlled Crack Growth," pp. I-191-213 in Second Symposium, Volume I - Inelastic Crack Analysis, ASTM STP 803, American Society for Testing and Materials, Philadelphia, 1983.*

8. J. G. Merkle, Martin Marietta Energy Systems, Inc., Oak Ridge Nat1. Lab., An Examination of the Size Effects and Data Scatter Observed in Small Specimen Cleavage Fracture Toughness Testing, USNRC Report NUREG/CR-3672 (ORNL/TM-9088), April 1984.*

9. M. F. Kanninen et al., Batelle-Columbus Laboratories for Martin Marietta Energy Systems, Inc., Oak Ridge Natl. Lab., Preliminary Analysis of Japanese Wide-Plate Dynamic Crack Propagation Arrest Experiments, December 1983.

10. T. Kanazawa et al., "Study on Fast Fracture and Crack Arrest," Experimental Mechanics 21(2), 78-88, February 1981.t

*Available for purchase from National Technical Information Service, Springfield, VA 22161.

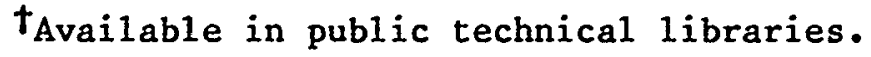




\section{SPECIMEN PREPARATION, INSTRUMENTATION, AND TESTING PROCEDURE}

\subsection{SPECIMEN PREPARATION}

The $1 \times 1 \times 0.1 \mathrm{~m}$ or $1 \times 1 \times 0.15 \mathrm{~m}$ test articles, shown schematically in Fig. 4.1, were machined and precracked by ORNL before being sent to the National Institute of Standards and Technology (NIST). The precracking was done by hydrogen charging an electron-beam (EB) weld (Fig. 4.2) located at the base of a premachined notch.1 The notch

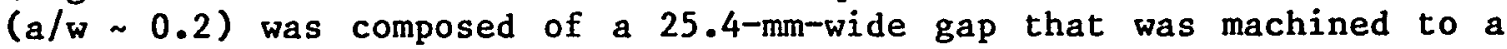
depth of $187 \mathrm{~mm}$ ( $X$ in Fig. 4.1) plus the EB weld-generated crack that had a depth of $\sim 12.7 \mathrm{~mm}$ at the end of the gap. Each face of the specimen was side-grooved to a depth equal to $12.5 \%$ of the plate thickness, and the grooves had a $0.25-\mathrm{mm}$-root radius. The initial crack was parallel to the rolling direction. With the exception of test specimens WP-2.3 and -2.6 , the crack front of each specimen was then cut into a truncated chevron configuration (Fig. 4.3) to reduce the tensile load required to achieve crack initiation. Table 4.1 presents dimensions for each test article in the WP-2 series.

ORNL-DWG 85-4318B ETD

CRACK PLANE (SIDE GROOVED) 7
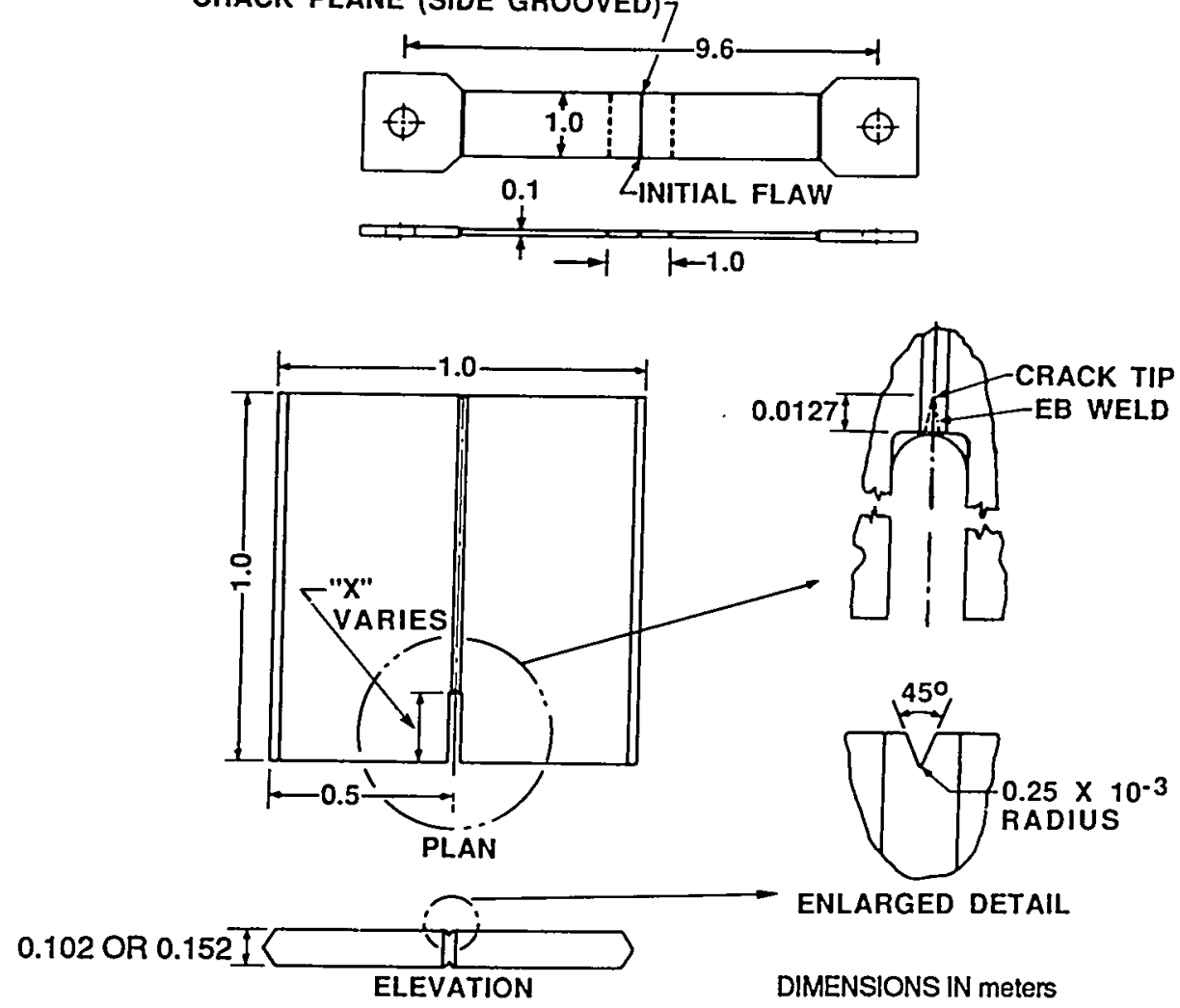

Fig. 4.1. Schematic of HSST wide-plate crack-arrest specimen. 


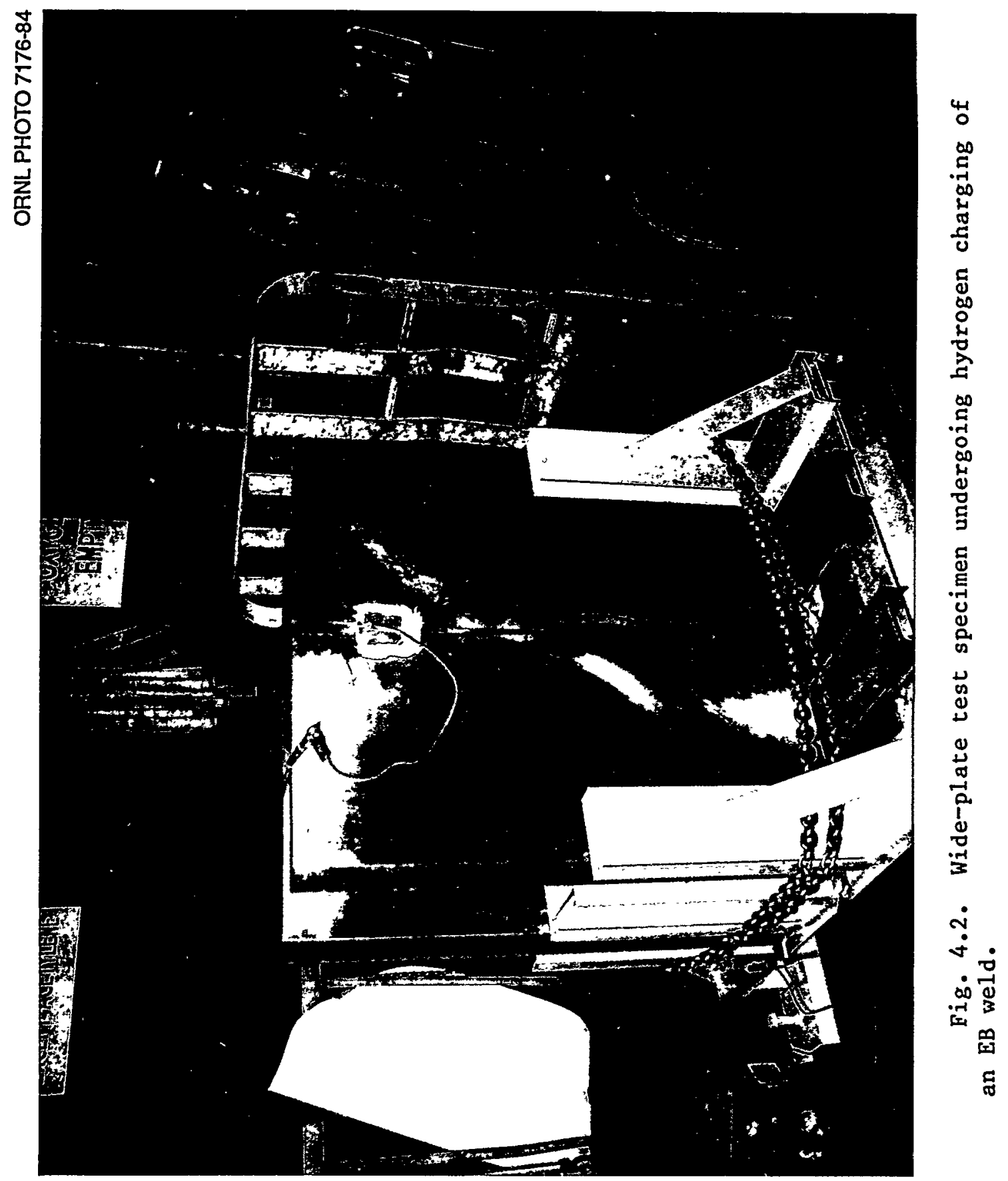


ORNL-DWG 86-4106 ETD
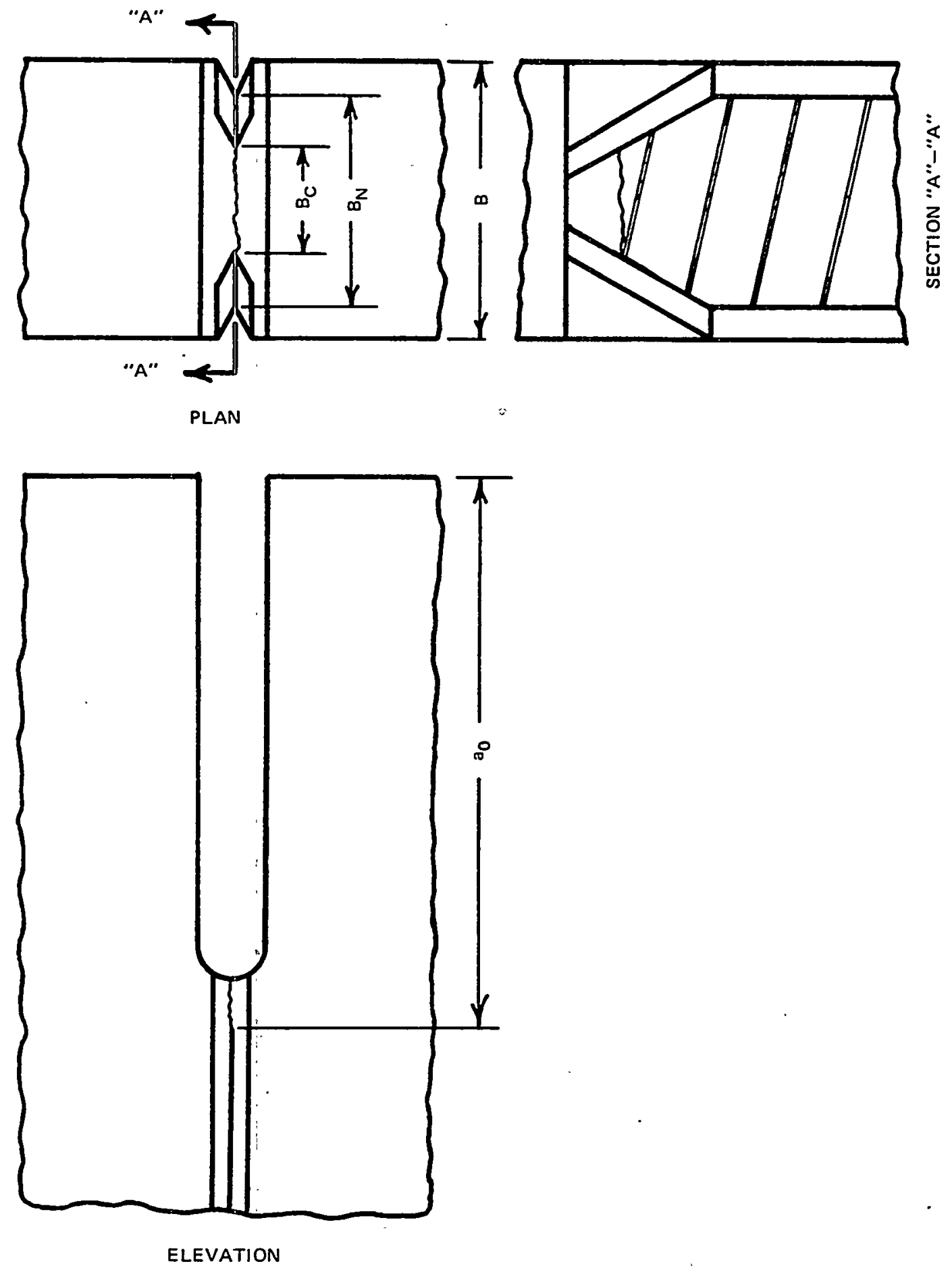

Fig. 4.3. Schematic of chevron configuration of crack front. 
Table 4.1. WP-2 series test specimen dimensions

\begin{tabular}{|c|c|c|c|c|c|c|c|}
\hline $\begin{array}{l}\text { Specimen } \\
\text { designation }\end{array}$ & $\begin{array}{c}\text { Initial } \\
\text { crack } \\
\text { length, } \\
a_{0}\end{array}$ & $\begin{array}{c}\text { Thickness, } \\
\text { B }\end{array}$ & $\begin{array}{l}\text { Notched } \\
\text { thickness, } \\
\qquad{ }_{B_{N}}\end{array}$ & $\begin{array}{c}\text { Chevron } \\
\text { thickness } \\
\text { at } a_{0}, \\
B_{c}\end{array}$ & $\begin{array}{l}\text { Width, } \\
\text { W }\end{array}$ & $\begin{array}{c}\text { Pop-in } \\
\text { crack } \\
\text { length, } \\
a_{0}^{-}\end{array}$ & $\begin{array}{c}\text { Thickness } \\
\text { at } a_{0}^{\prime}, \\
B_{c}^{-}\end{array}$ \\
\hline WP-2.1 & 199 & 152.3 & 113.9 & 61.5 & 1000 & $a$ & $a$ \\
\hline WP-2.2 & 211 & 152.4 & 113.9 & 71.9 & 1000 & $a$ & $a$ \\
\hline WP-2.3 & 200 & 152.4 & 113.8 & $a$ & 1000 & $a$ & $a$ \\
\hline WP-2.4 & 203 & 101.7 & 76.3 & 40.5 & 1000 & 251 & 75.5 \\
\hline WP-2.5 & 199 & 101.6 & 76.2 & 40.7 & 999 & 264 & $76.2^{b}$ \\
\hline WP -2.6 & 224 & 152.4 & 113.9 & $a$ & 1000 & $a$ & $a$ \\
\hline
\end{tabular}

$a_{\text {Not applicable. }}$

${ }^{b}$ Crack length after pop-in was past the region of the plate where crack front had been cut into a truncated chevron configuration. 
Upon receipt of the test article from ORNL, NIST welded it to pull plates, $*$ which were nominally $103 \mathrm{~mm}$ thick for the 102-mm-thick test articles and $153 \mathrm{~mm}$ thick for the 152-mm-thick test articles. The pul1 tabs at the end of the pull plates were strengthened by being $152 \mathrm{~mm}$ thick for the 103-mm-thick test articles and $162 \mathrm{~mm}$ thick for the 152-mm-thick test articles. (Chapter 2 of Ref. 2 presents a discussion of the development of the test specimen geometry.) Figure 4.4 gives the dimensions for each of the WP-2 test assemblies. Note that the specimen lengths changed from test to test because of removal of the test article and adjoining weldment from the pull plates after each test. Before application of axial load, the out-of-plane deviation of each of the wide-plate assemblies was determined as a function of axial position from the top load pin; the results are shown in Fig. 4.5.

\subsection{INSTRUMENTATION}

To obtain pertinent data during each test, the specimens were instrumented with five types of devices: thermocouples, strain gages, crack-opening-displacement (COD) gages, accelerometers, and a displacement transducer. Reference 3 gives more detailed information on specimen instrumentation than that presented below.

Up to 40 thermocouples were positioned on each specimen, as shown in Fig. 4.6. The thermocouples were attached by inserting and gluing them into $1.5-\mathrm{mm}$-diam by 3-mm-deep holes that had been drilled in each specimen. The hole and thermocouple were then covered with a protective silicone coating. Additional thermocouples, not indicated in Fig. 4.6, were used to control heating and cooling of the wide-plate specimen. The thermocouples were sequentially monitored on a periodic basis and corrected for room temperature, and the results were both recorded on magnetic tape and displayed on the computer screen (Fig. 4.7). During the heating and cooling processes, the thermocouples adjacent to the crack plane [Nos. 0-10 in Fig. 4.6(a) and Nos. 0-19 in Fig. 4.6(b) and (c)] were displayed graphically in real time to indicate the relationship between the actual and desired thermal gradient across the specimen width. The other thermocouples were used to indicate the temperature distribution at other positions on the specimen and pull plates during a test for use in posttest analysis.

The total number of strain gages, as well as positioning on the specimen, has varied from test to test. Up to 29 strain gages have been used in a test to provide dynamic strain-field measurments for determination of crack velocity and to provide far-field strain measurements for assessing boundary conditions. Strain gage locations used for the WP-2 series tests are presented in Figs. 4.8 and 4.9. The crack-1ine gages [gages 1-22 in Fig. 4.8(a), (c), and (d); and gages 1-20 in. Fig. $4.8(b)$ and Fig. 4.9] were two-element, $90^{\circ}$ stacked, 350- $\Omega$ Karma alloy (nickel-chromium alloy) gages on a polyimide backing. The gages had a coefficient of thermal expansion similar to that of the test specimens.

\footnotetext{
*Automated, dual-shielded metal insert gas (MIG) process used to join test articles WP-2.1, $-2.3,-2.4$, and -2.5 to pull plates. Electroslag process used to join test articles WP-2.2 and -2.6 to pull plates.
} 


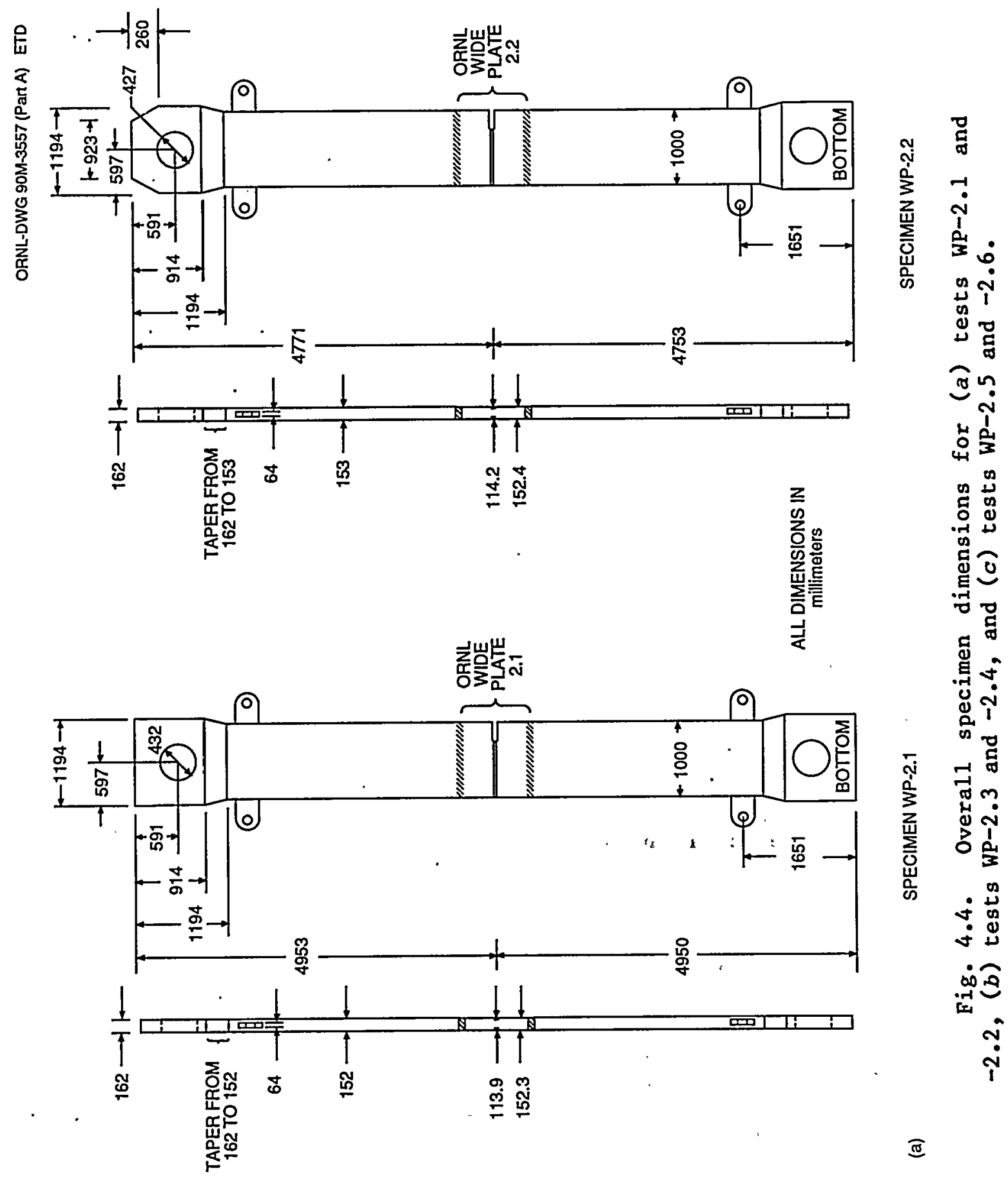



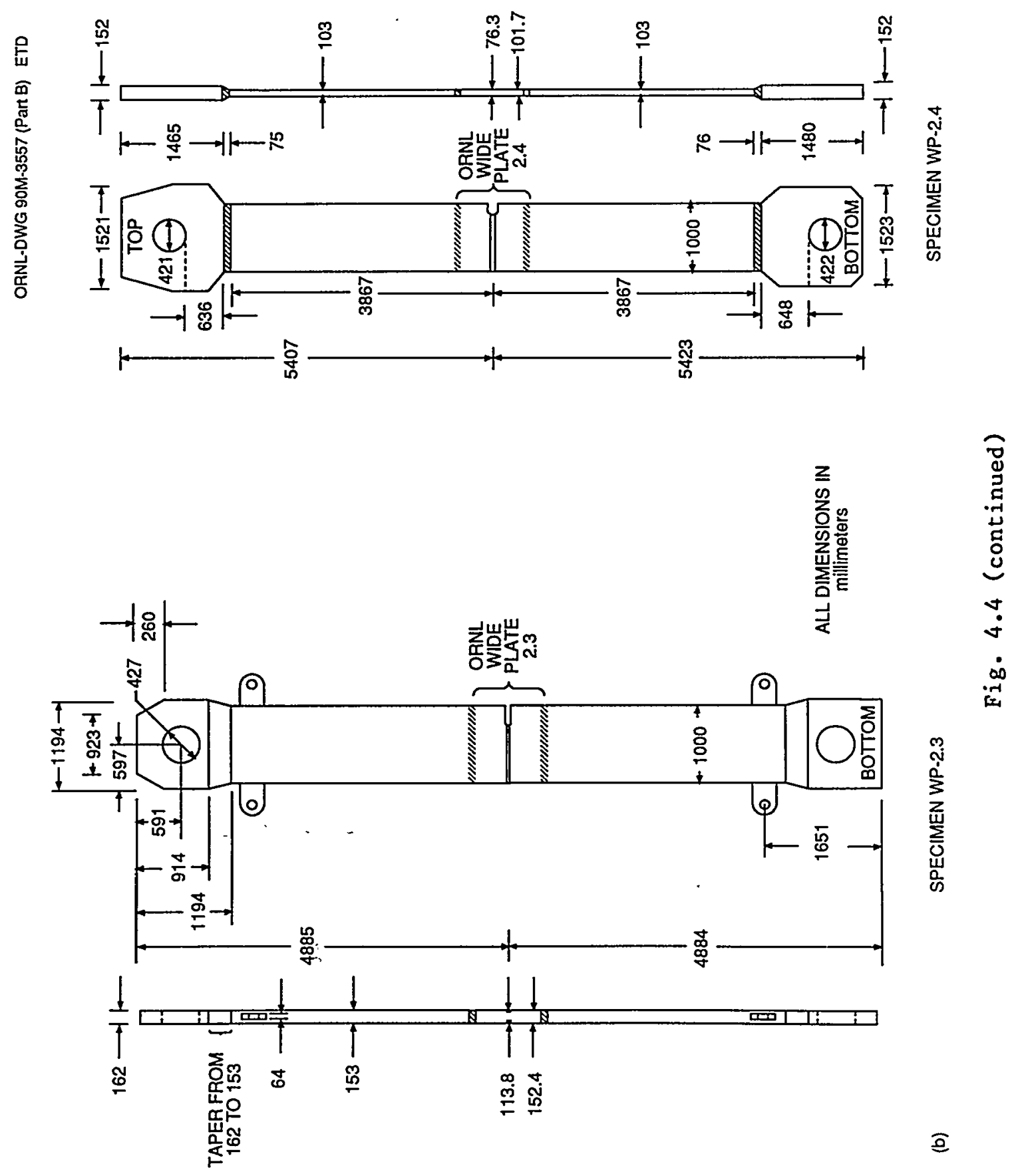


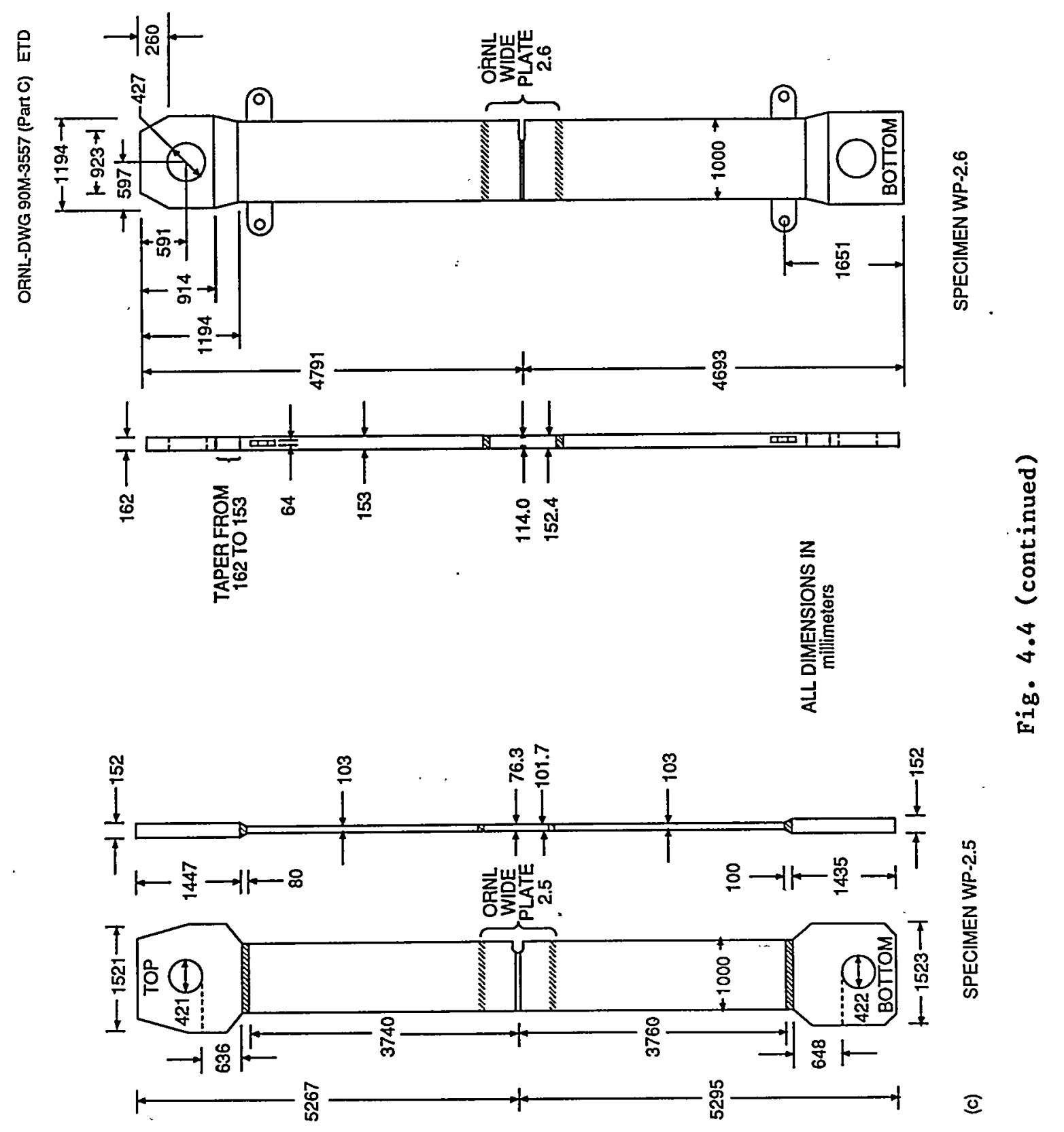




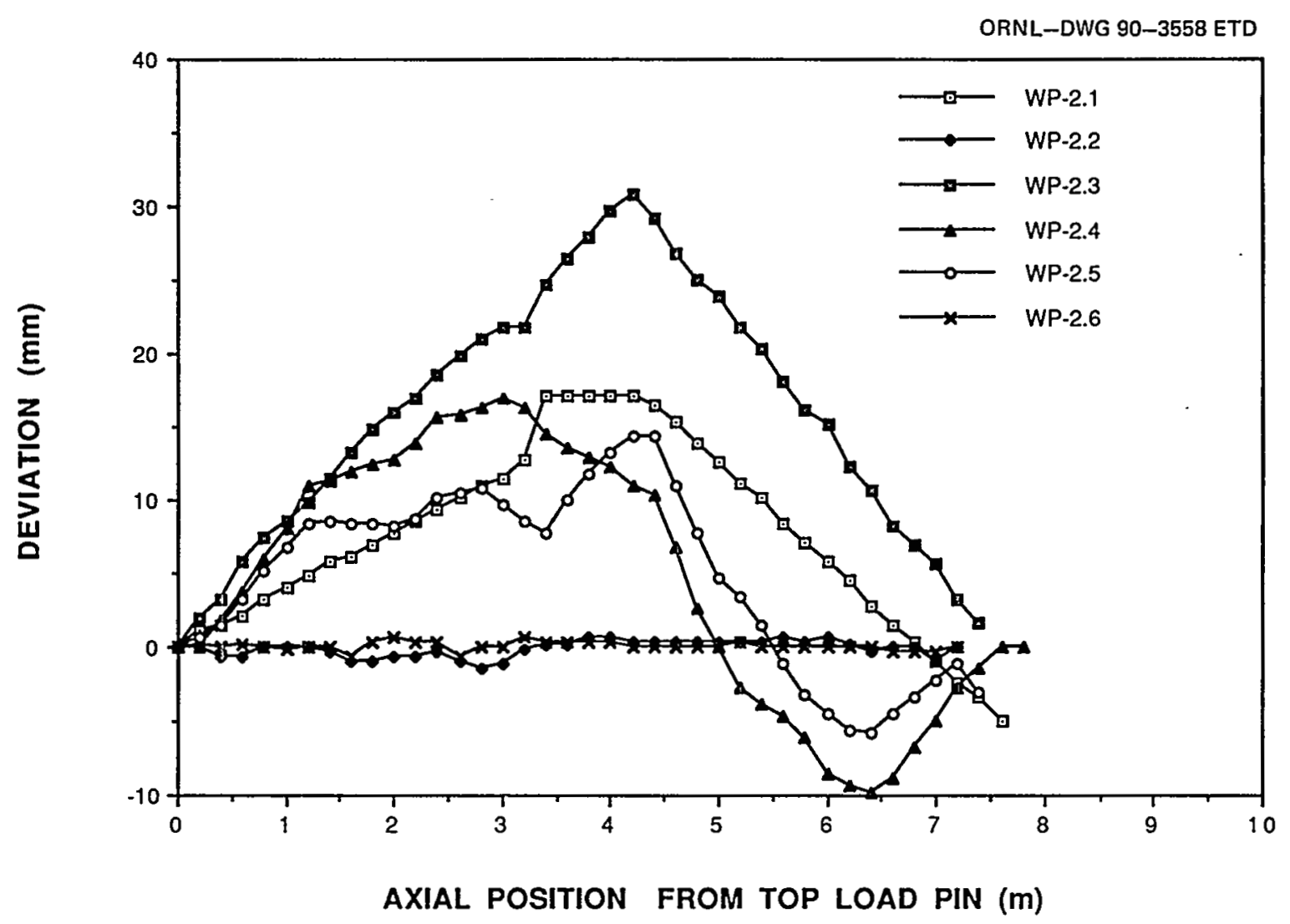

Fig. 4.5. Out-of-plane deviation vs axial position from top load pin. 


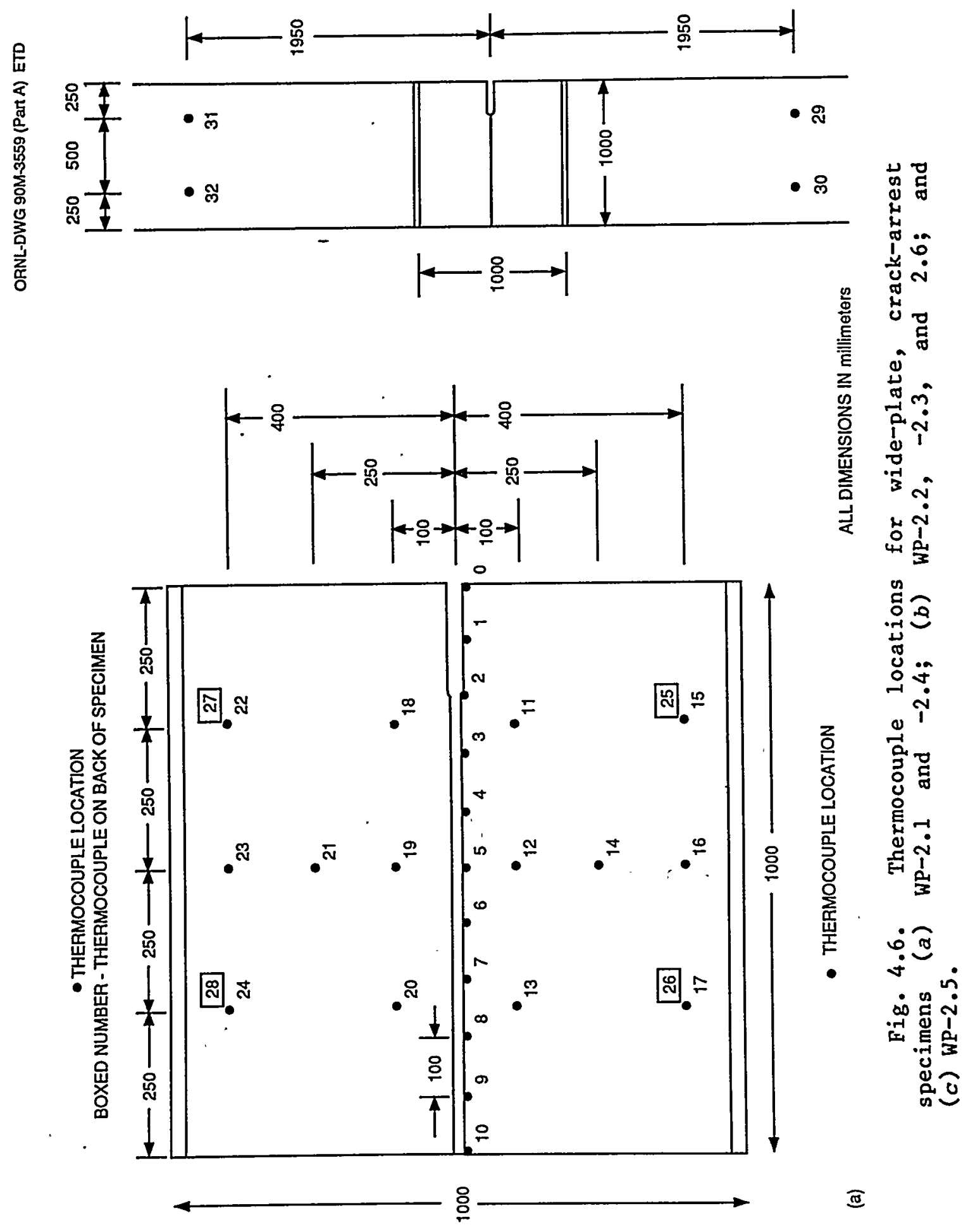


BOXED NUMBER INDICATE

NOTE: THERMOCOUPLE 5 IS LOCATED MIDTHICKNESS AT THE

BOTTOM OF THE NOTCH
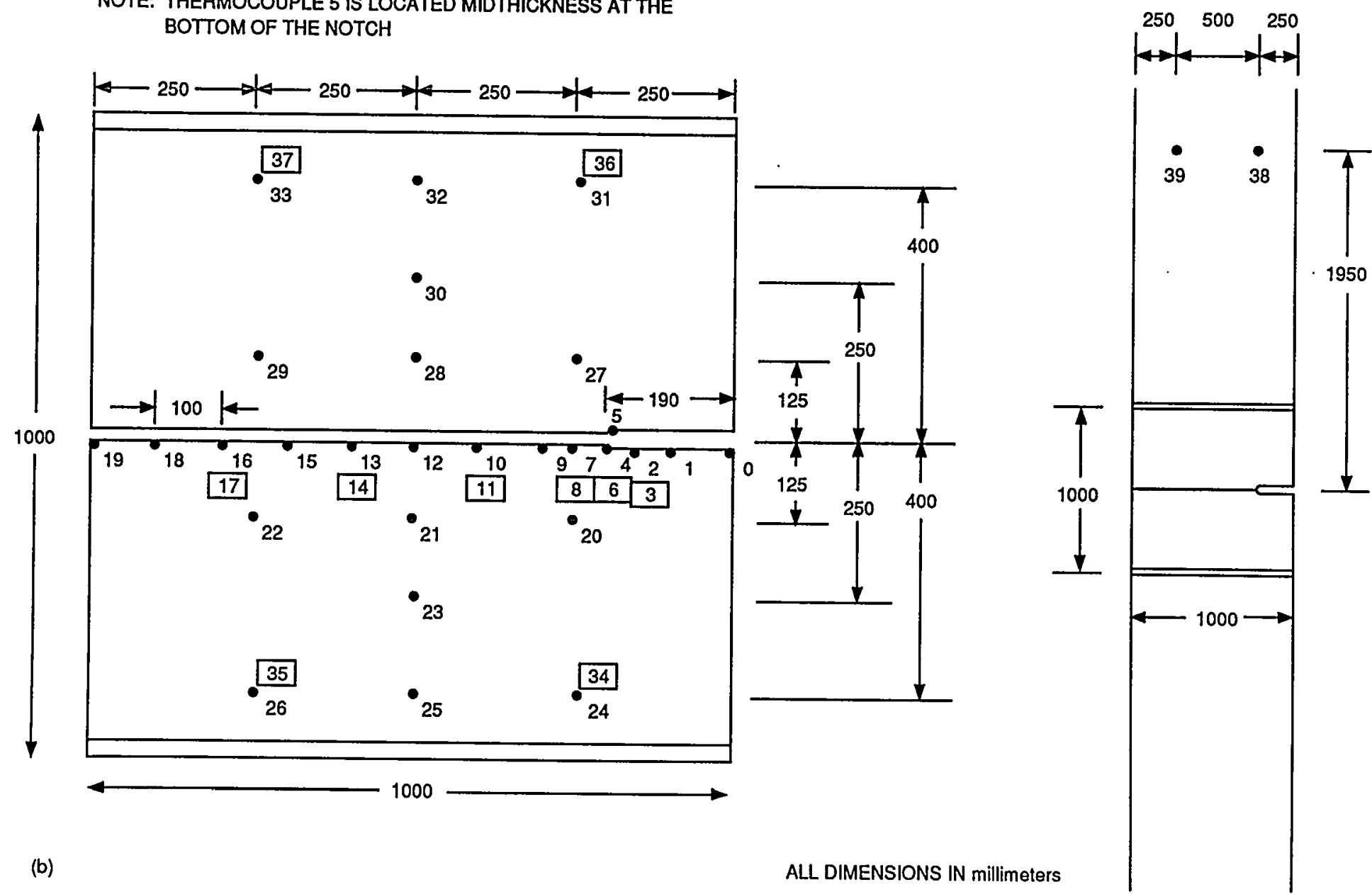

(b)

ALL DIMENSIONS IN millimeters

Fig. 4.6 (continued) 


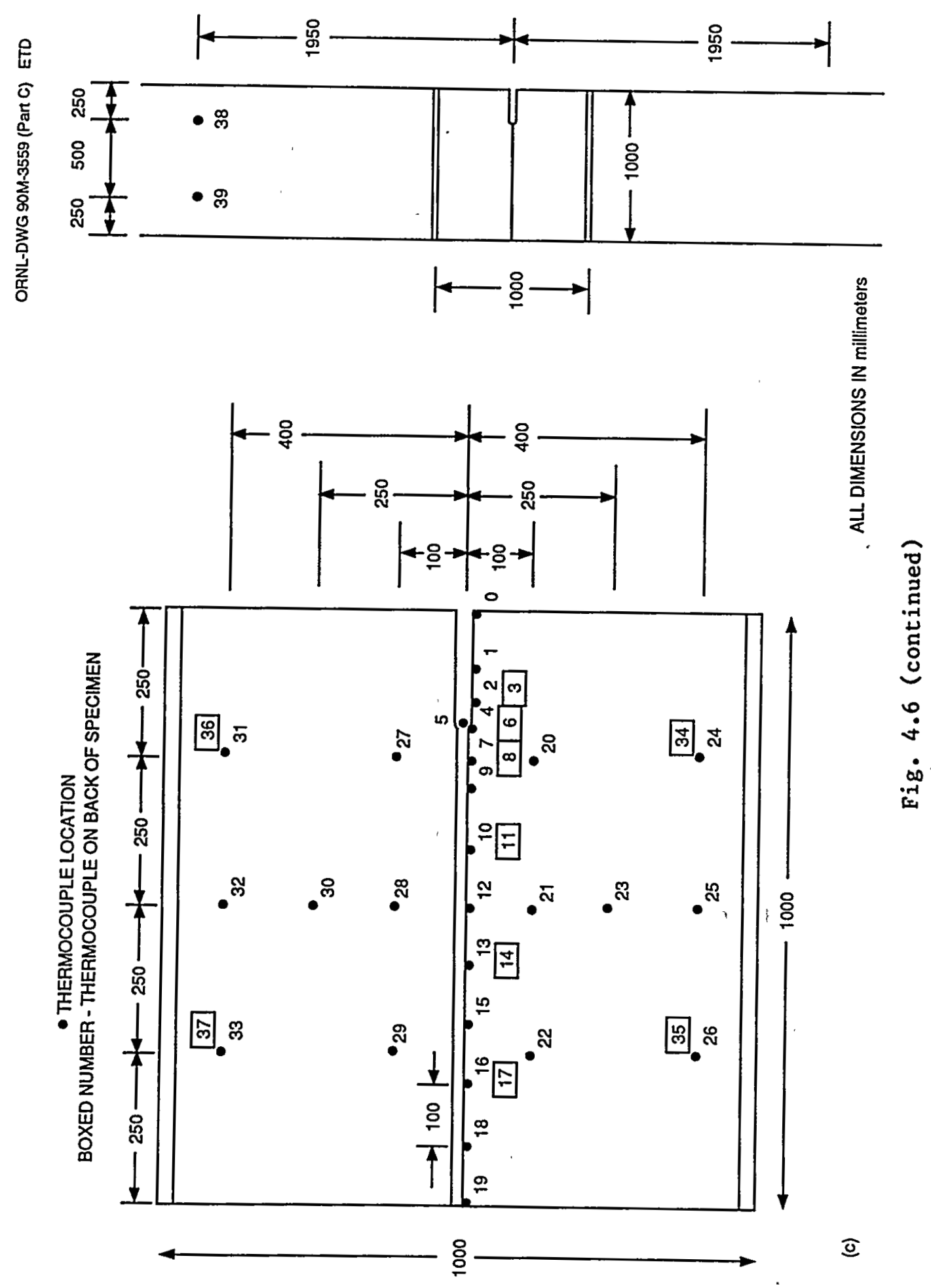


ORNL-DWG 86-5188A ETD

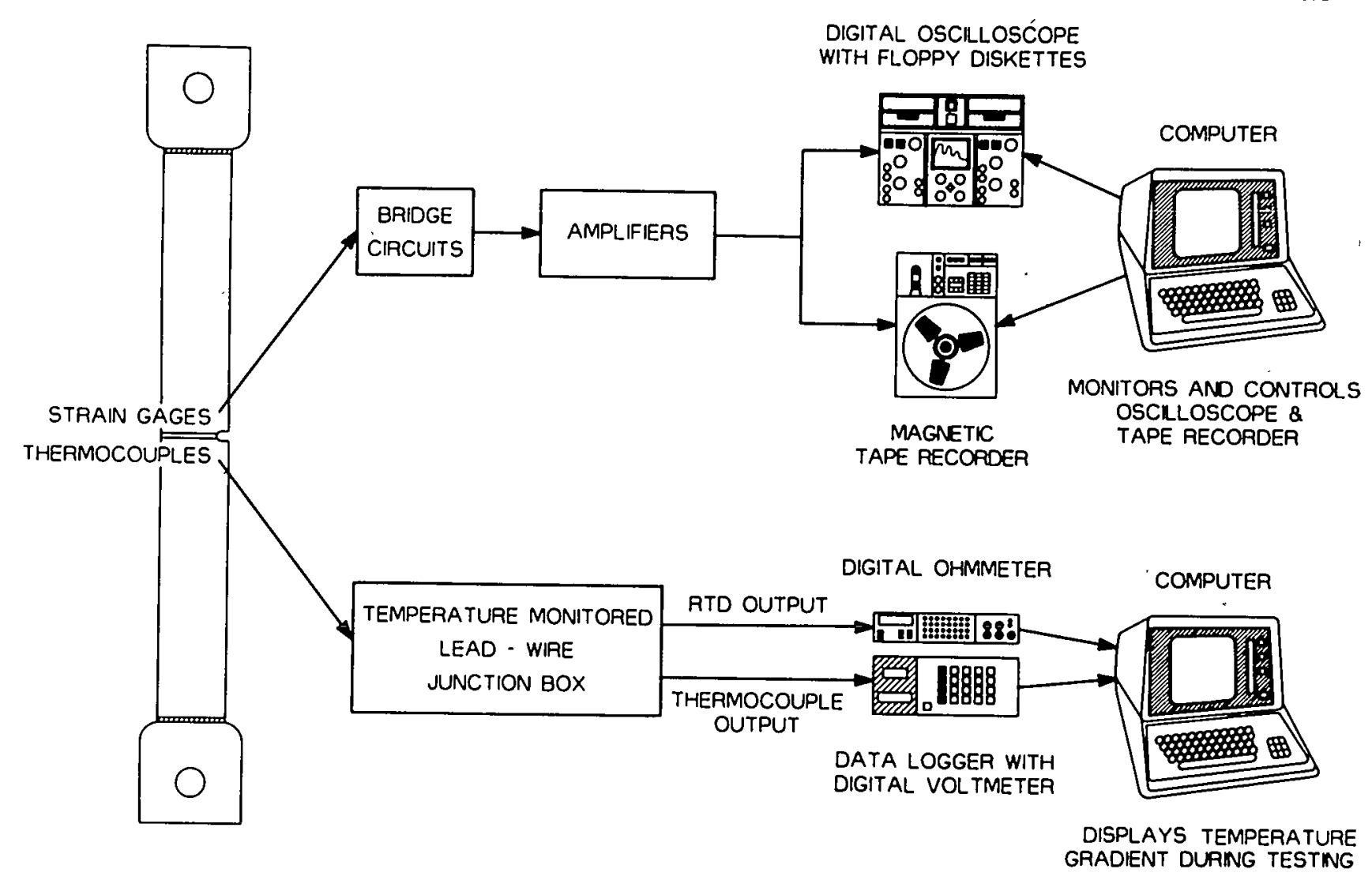

Fig. 4.7. Schematic of HSST wide-plate, crack-arrest data acquisition system. 
1 UNIAXIAL STRAIN GAGE

+ BIAXIAL STRAIN GAGE - 90 STACKED ROSETTE BOXED NUMBER INDICATES GAGE LOCATED ON BACK OF SPECIMEN

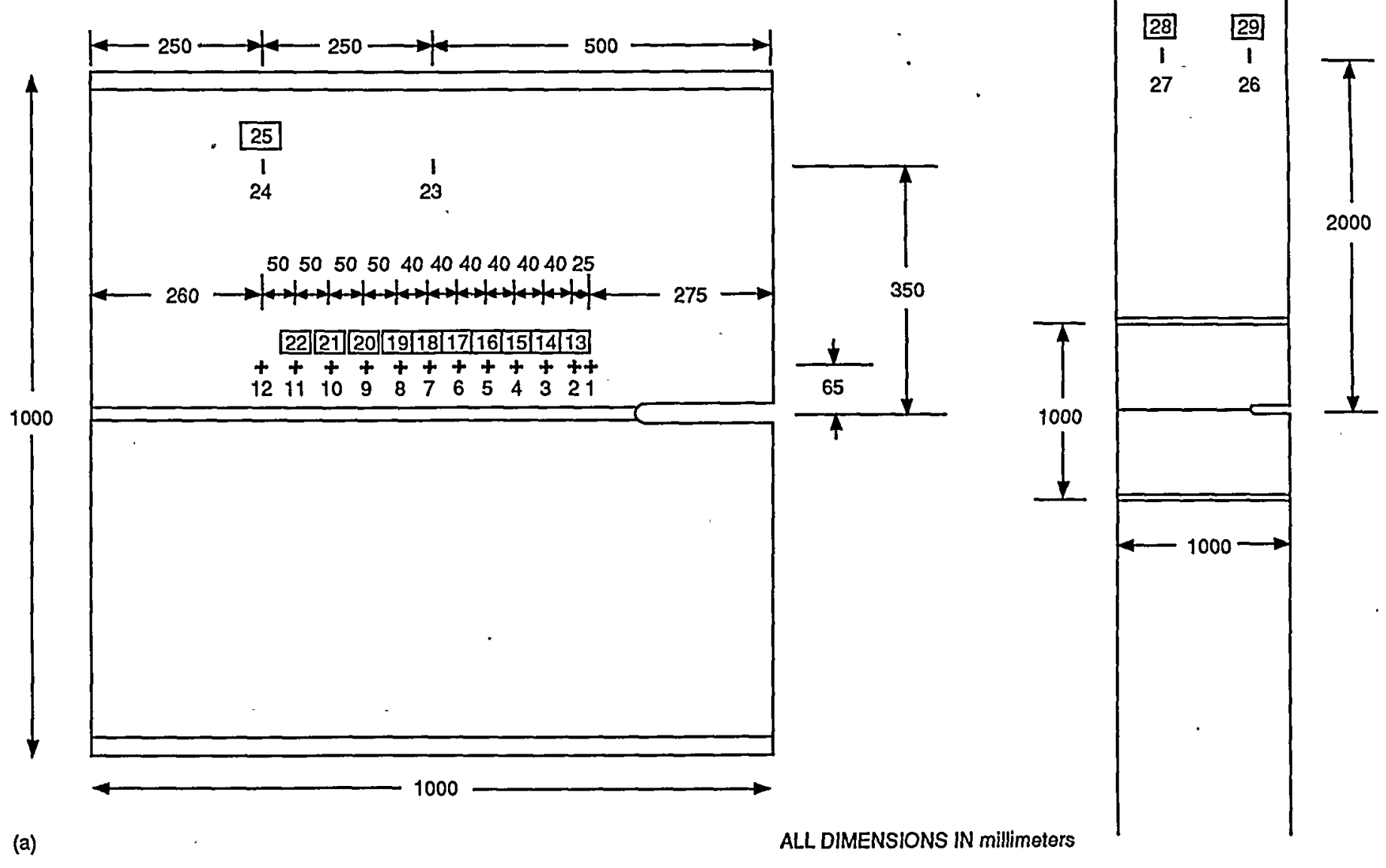

Fig. 4.8. Strain-gage locations for wide-plate, crack-arrest specimens (a) WP-2.1 and $-2.5,(b) \mathrm{WP}-2.2,(c) \mathrm{WP}-2.3$, and (d) WP-2.4. 
ORNL-DWG 90M-3600 (Part B) ETD

1 UNIAXIAL STRAIN GAGE

+ BIAXIAL STRAIN GAGE - 90 9 STACKED ROSETTE

BOXED NUMBER INDICATES GAGE LOCATED ON BACK OF SPECIMEN
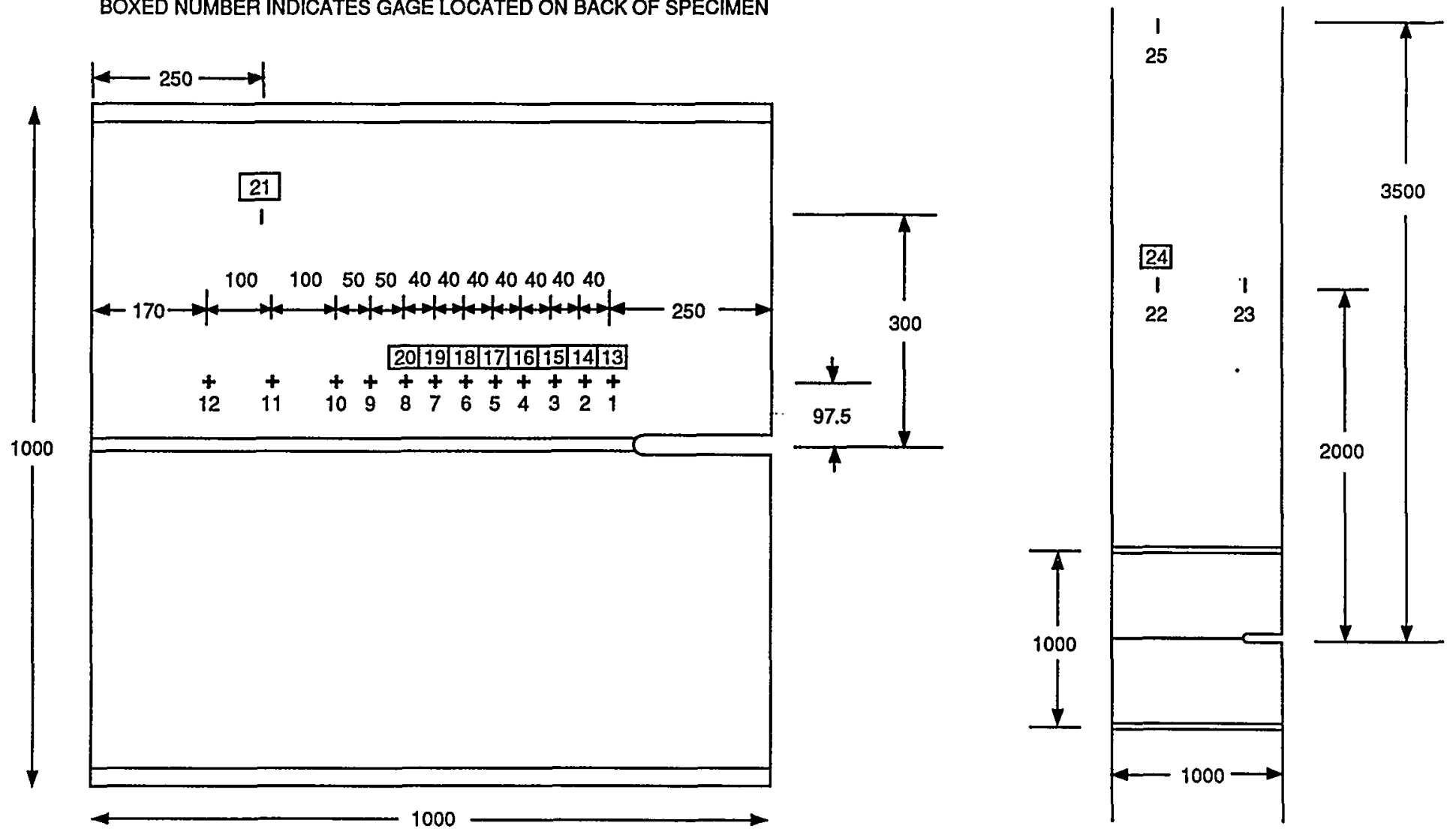

(b)

ALL DIMENSIONS IN millimeters

Fig. 4.8 (continued) 
ORNL-DWG 90M-3600 (Part C) ETD
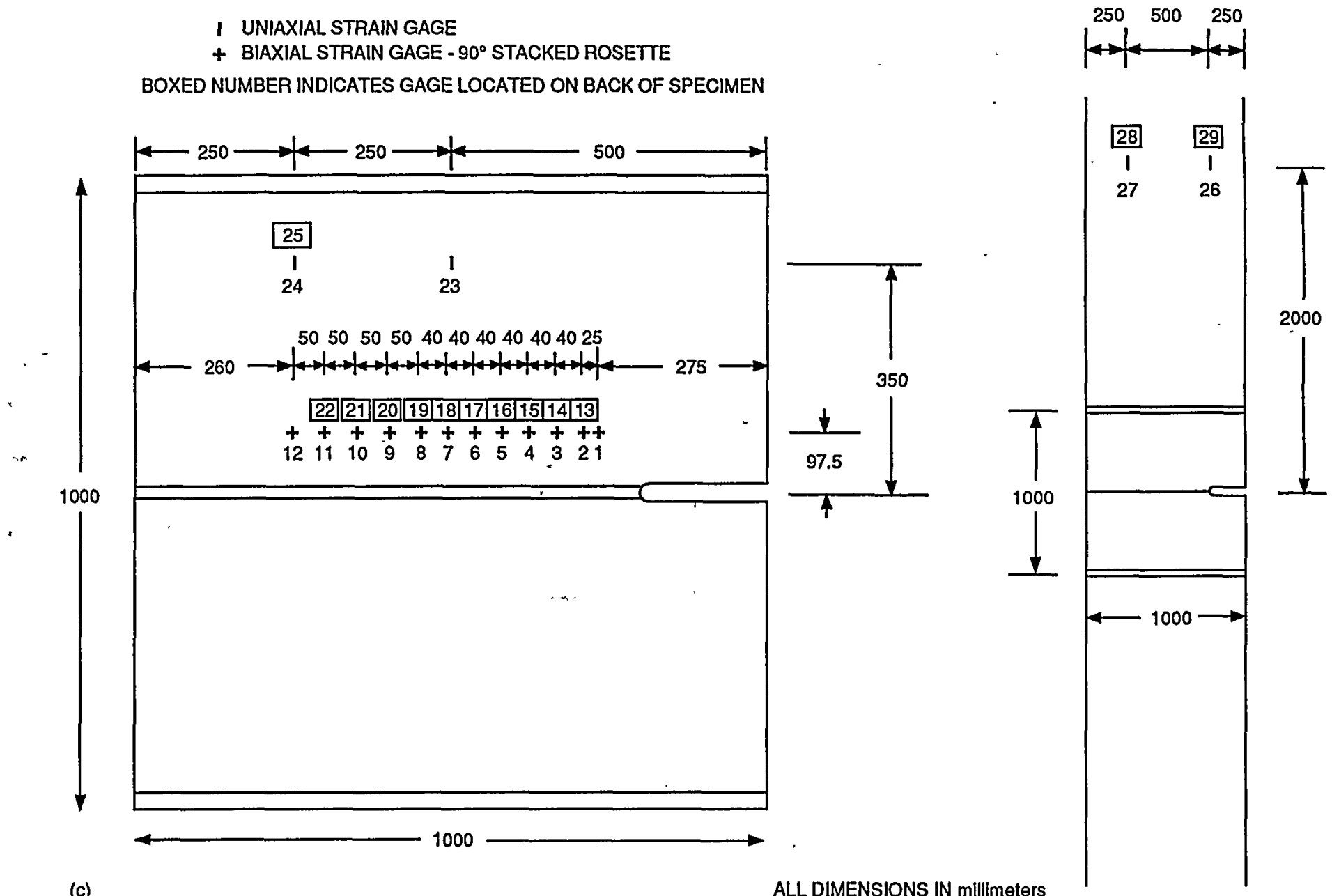

Fig. 4.8 (continued) 
ORNL-DWG $90 \mathrm{M}-3600$ (Part D) ETD

I UNIAXIAL STRAIN GAGE

+ BIAXIAL STRAIN GAGE - 90 STACKED ROSETTE

BOXED NUMBER INDICATES GAGE LOCATED ON BACK OF SPECIMEN

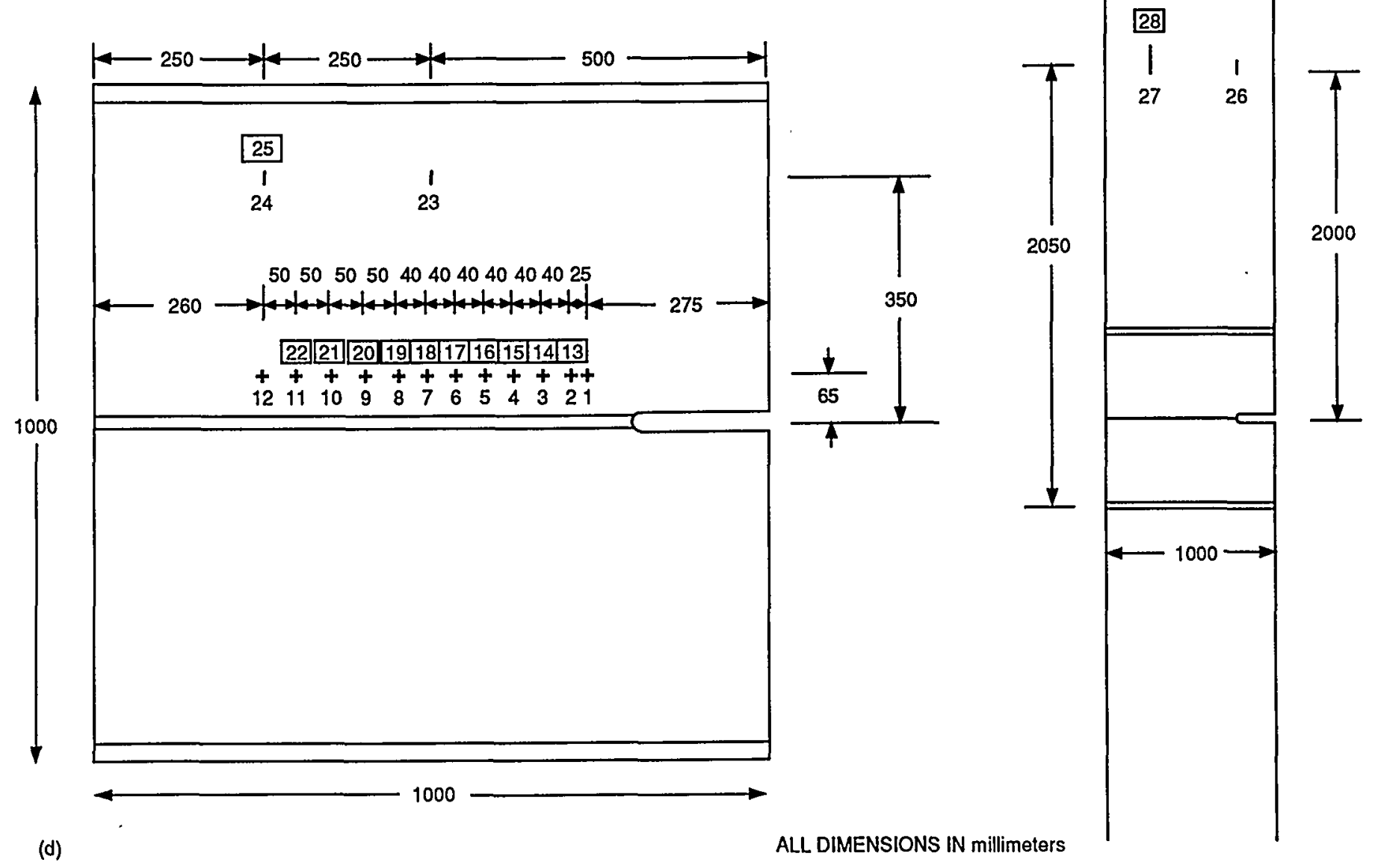

Fig. 4.8 (continued) 
I UNIAXIAL STRAIN GAGE

ORNL-DWG 90M-3600 ETD

+ BIAXIAL STRAIN GAGE - 90 STACKED ROSETTE

BOXED NUMBER INDICATES GAGE LOCATED ON BACK OF SPECIMEN
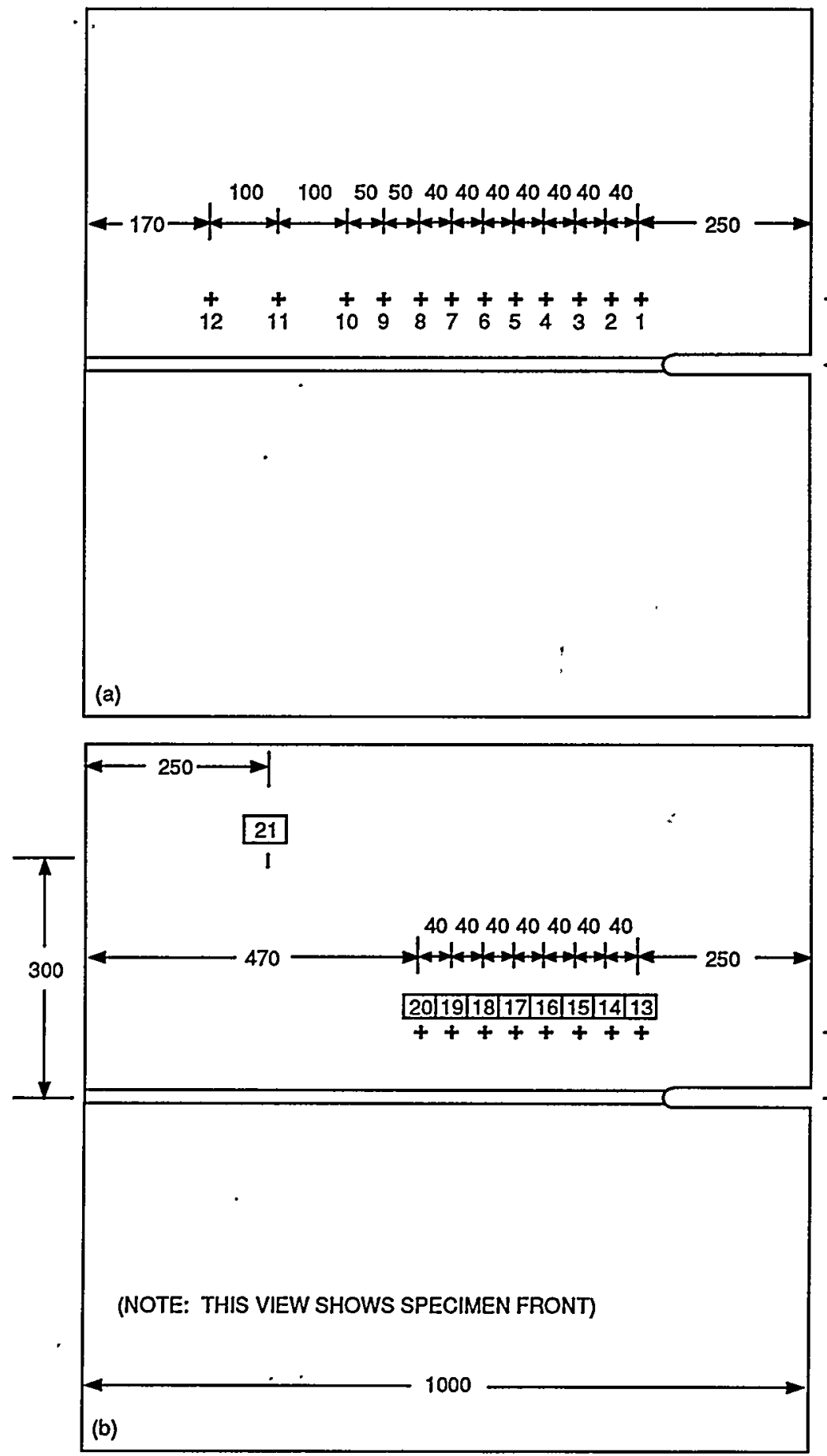

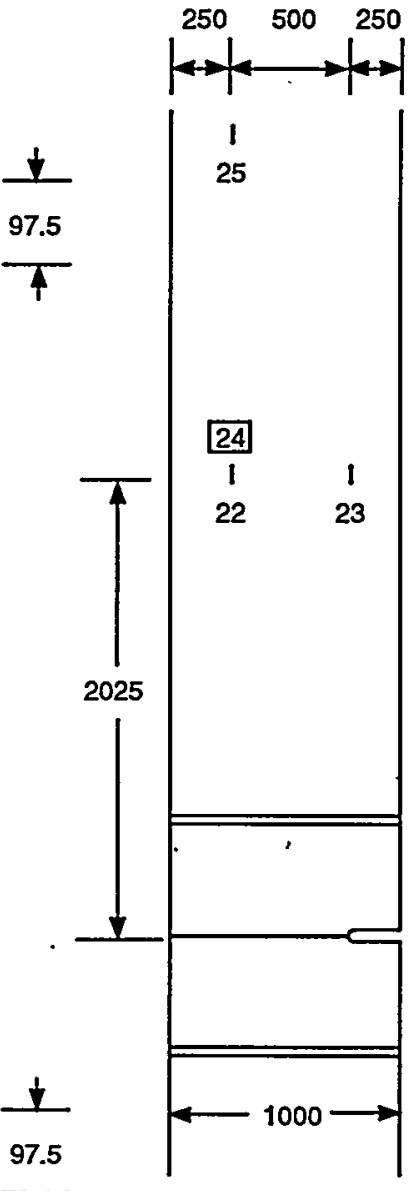

(c)

ALL DIMENSIONS IN millimeters

(e)

Fig. 4.9 Strain-gage locations for wide-plate specimen WP-2.6. (a) Plate front face, (b) plate back face viewed from front, and (c) far-field locations. 
Outputs of the crack-1ine gages for tests WP-2.1 through -2.5 were proportional to the difference between the longitudinal and transverse strains. Outputs of crack-line gages positioned on the front face of specimen WP-2.6 were also proportional to the difference between the longitudinal and transverse strains; however, crack-1ine gages 13-20 positioned on the back-face of specimen $W P-2.6$ were rotated $45^{\circ}$ relative to the orientation of that used for other crack-line gages (Fig. 4.9). This change in strain gage orientation was used to increase the sensitivity of the gages to the effects of the crack. Near- and far-field strain gages were uniaxial $350-\Omega$ Constantan alloy gages on a polyimide backing. The strain gages were attached to the plates with an elevatedtemperature cured epoxy. All gages were connected to low-reactance bridges (half-bridge configuration for crack-line gages), the imbalances of which were amplified by wide-band differential amplifiers. The strain-gage signals were recorded by a multichannel, wide-band, frequency-modulated, magnetic tape recorder, shown schematically in Fig. 4.7.

Additional instrumentation included capacitance-based COD gages mounted on the front and back faces of each specimen at $a / w=0.15$. The gages measured the displacement between points $30 \mathrm{~mm}$ above and $30 \mathrm{~mm}$ below the crack plane. Accelerometers were located on the specimen's centerline near the upper and lower pull pins. In addition, specimens WP-2.1 and -2.3 were instrumented with an acoustic emission (AE) transducer located on the specimen's lower pull plate, and specimens WP-2.2, -2.3 , and -2.6 were instrumented with a dynamic displacement transducer mounted on the specimen centerline near the bottom accelerometer. The displacement gage measured the movement of the point on the specimen where it was attached relative to that of the large columns of the testing machine. Table 4.2 indicates the presence and location of the accelerometer and dynamic displacement instrumentation for each test.

Table 4.2. Presence and location of accelerometer and dynamic displacement instrumentation used in WP-2 series tests

\begin{tabular}{|c|c|c|c|}
\hline \multirow{2}{*}{$\begin{array}{c}\text { Test } \\
\text { specimen }\end{array}$} & \multicolumn{2}{|c|}{$\begin{array}{c}\text { Accelerometer } \\
\text { location }^{a}\end{array}$} & \multirow{2}{*}{$\begin{array}{c}\text { Dynamic } \\
\text { displacement } \\
\text { gage location }\end{array}$} \\
\hline & Top & Bottom & \\
\hline$N P-2.1$ & 3.653 & 3.655 & \\
\hline NP -2.2 & & 3.458 & 3.453 \\
\hline WP- 2.3 & 3.585 & 3.589 & 3.589 \\
\hline WP-2.4 & 4.038 & 4.041 & \\
\hline WP-2.5 & 3.911 & 3.934 & \\
\hline WP-2.6 & 3.491 , & 3.398 & 3.393 \\
\hline
\end{tabular}




\subsection{HEATING-COOLING-INSULATION SYSTEMS*}

After being instrumented, the specimen was placed into the NIST testing machine (Fig. 4.10), and eight individual electric-resistance strip heaters were attached to the back edge of the plate. Each heater was $2.8 \mathrm{~cm}$ wide with a heating element $61 \mathrm{~cm}$ long and rated at $1.9 \mathrm{~W} / \mathrm{cm}^{2}$. The heaters were attached to the plate in pairs and backed with 1.3-cm-thick sheets of insulating board (Marinite I) to hold them against the plate surface and to provide insulation. The heating level during a test was controlled by two means: (1) a variac transformer, which adjusted the power level or heat output of each heater, and (2) separate on/off temperature controllers, which interacted with thermocouples at the edge of the plate to regulate two zones of heating. The primary heating zone was formed by two pairs of heaters attached to the specimen edge above and below the fracture plane. The second heating zone, consisting of two areas on either side of the first zone, was heated by two outward pairs of heaters. Temperature levels in the two zones were independently controlled to better achieve and maintain a linear thermal gradient across the specimen.

The cold edge of the specimen was cooled by spraying liquid nitrogen $\left(\mathrm{LN}_{2}\right)$ onto the notched edge of the specimen. A $2.6-\mathrm{m}-1$ ong insulated chamber was affixed to the specimen edge, equally spanning both sides of the notch. The $\mathrm{LN}_{2}$ was pumped into the chamber and sprayed directly onto the specimen surface with a copper-tube manifold consisting of sprayers at $18-\mathrm{cm}$ increments. The cooling level could be controlled by two methods. Initially, when establishing a linear thermal gradient, the temperature was controlled by adjusting the $\mathrm{LN}_{2}$ flow rate by manually setting a hand valve. When. the desired temperature was achieved, that level was maintained by controlling the $\mathrm{LN}_{2}$ flow with an on/off temperature controller interface with a thermocouple at the cold edge of the specimen. The temperature controller powered an electric solenoid gas valve that could stop or allow the flow of $\mathrm{LN}_{2}$ into the cold chamber.

Two types of thermal insulation were used to insulate the front and back faces of the specimen. (1) On the hot side of the plate, 5-cmthick by $61-\mathrm{cm}$-wide mineral wool bats were used. The bats were positioned on the specimen face at the vertical centerline of the specimen and extended beyond the heated edge and the strip heaters. (2) The cold side of the plate was insulated with $61-\mathrm{cm}$-wide by $5-\mathrm{cm}$-thick styrofoam sheets, which butt up against the mineral wool at the specimen centerline and extend beyond the cooled edge or to the cold chamber. The cold chamber was insulated with $2.5-\mathrm{cm}-$ thick styrofoam sheets. All insulation was held tight against the plate surface and, in total, covered an area $3 \mathrm{~m}$ above and $3 \mathrm{~m}$ below the fracture plane on both the front and

*Appendix B of Ref. 2 presents more details on development and checkout of the temperature gradients system and also contains a discussion of the effect of the temperature gradient on the specimen thermal strain and stress state. 


\section{ORNL PHOTO 6718-85}

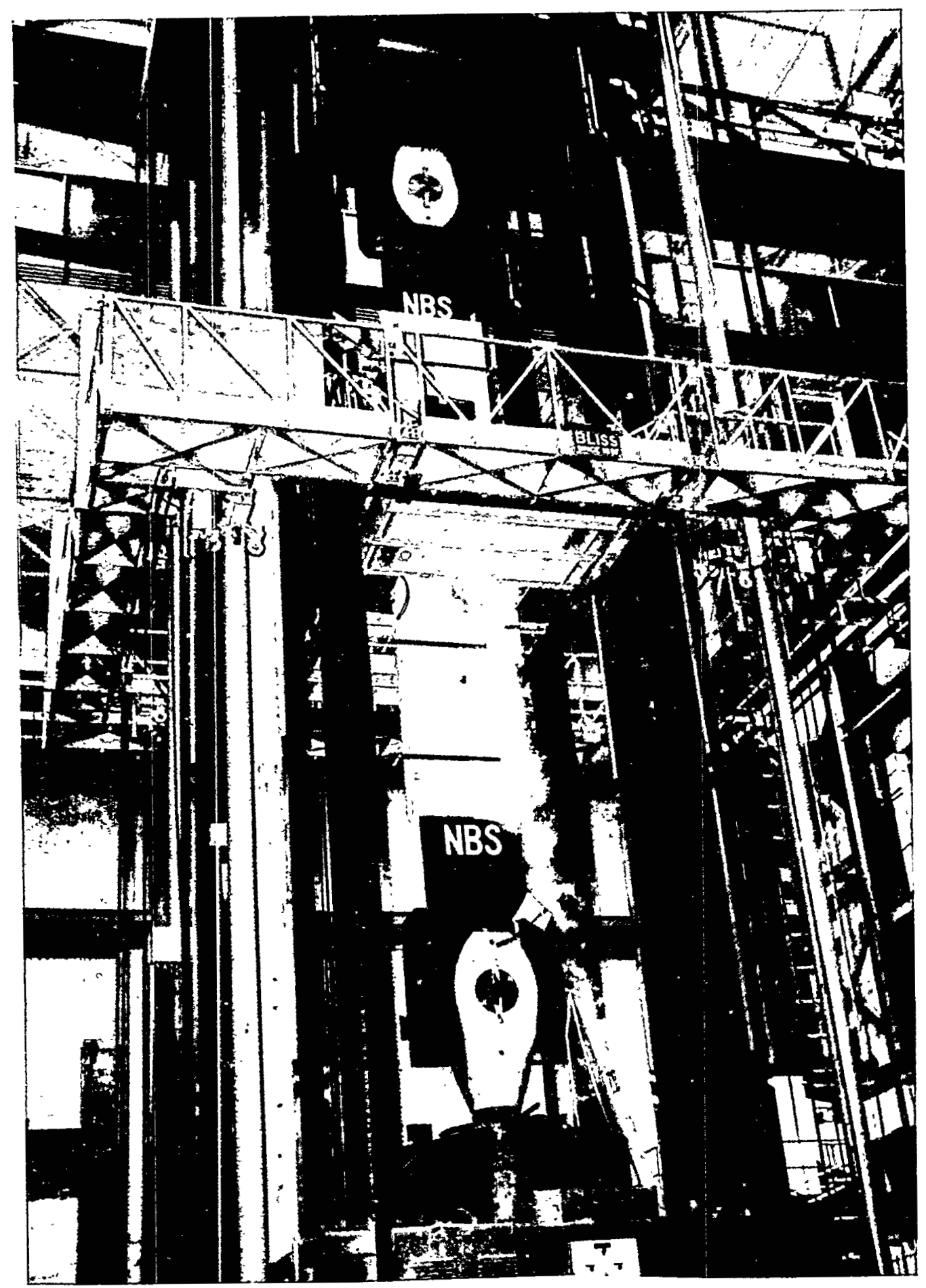

Fig. 4.10. HSST wide-plate, crack-arrest test specimen installed in NIST testing machine. 
back surfaces. Additional mineral wool and styrofoam insulation were placed on the specimen edges above and below the heaters and cold chamber to cover the same length on the specimen as the back- and front-face insulation.

\subsection{TESTING PROCEDURE}

After completion of specimen insulation, all instrumentation was attached to the data acquisition systems. Checkout was conducted to demonstrate that all instrumentation systems were operational. A temperature gradient was imposed across the plate by $\mathrm{LN}_{2}$ cooling of the notched edge while heating the other edge.* $\mathrm{LN}_{2}$ flow and power to the heaters were continuously adjusted to obtain the desired thermal gradient. Final check out of strain gages, COD gages, and the load cell were completed just before initiation of specimen testing. Tensile load was then applied to the specimen at a rate of $10-25 \mathrm{kN} / \mathrm{s}$ (range for $\mathrm{WP}-2$ test series) until fracture occurred. Details of each test are presented in Chap. 5.

*Before establishing the thermal gradient, specimens WP-2.2 and -2.6 were warm prestressed (WPS). Details of the WPS procedure used for these specimens are presented in Chap. 5.

\section{REFERENCES}

1. P. P. Holz, Union Carbide Corp. Nuclear Div., Oak Ridge Nat1. Lab., Flaw Preparations for HSST Program Vessel Fracture Mechanics Testing: Mechanical-Cycle Pumping and Electron-Beam Weld-HydrogenCharge Cracking Schemes, USNRC Report NUREG/CR-1274 (ORNL/NUREG/ TM-369), May 1980.*

2. D. J. Naus et al., Martin Marietta Energy Systems, Inc., Oak Ridge Natl. Lab., Crack-Arrest Behavior in SEN Wide Plates of Qenched and Tempered A 533 Grade B Steel Tested Under Nonisothermal Conditions, USNRC Report NUREG/CR-4930 (ORNL-6388), August 1987.*

3. G. A. Danko et al., Wide Plate Crack Arrest Tests Instrumentation for Dynamic Strain Measurements, NBSIR 85-3289, National Bureau of Standards, December 1985.†

*Available for purchase from National Technical Information Service, Springfield, VA 22161.

tAvailable from National Institute of Standards and Technology, Gaithersburg, Maryland.

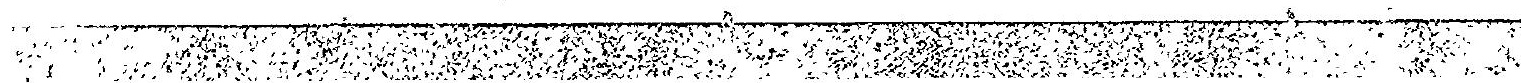




\section{SUMMARY OF WIDE-PLATE CRACK-ARREST TESTS WP-2.1 THROUGH -2.6}

Table 5.1 presents a summary of the general conditions for tests that have been conducted under the WP-2 series of wide-plate crackarrest tests. Test specimen dimensions were presented previously in Table 4.1. Transverse temperature profiles at the approximate time of the crack-initiation events are summarized in Fig. 5.1. Figure 5.2 presents the fracture surfaces of each test specimen. The remainder of this chapter contains a brief summary of each test, including presentation of pertinent results.

\subsection{TEST WP-2.1}

The purpose of test WP-2.1 was to initiate crack propagation in cleavage with arrest occurring in the central portion of the plate width at a temperature $\left(\sim 150^{\circ} \mathrm{C}\right)$ that approximates the onset of Charpy USE energy (see Sect. 3.3). After obtaining a satisfactory thermal gradient [Fig. 5.3(a)], specimen loading was initiated at a rate of $15.5 \mathrm{kN} / \mathrm{s}$. As the specimen loading increased from 9.2 to $11.4 \mathrm{MN}$, the temperature at the crack tip decreased from 59 to $55^{\circ} \mathrm{C}[20-\mathrm{cm}$ location in Fig. 5.3(b) and $(c)$ ]. The cause of this change is unknown. At a load of $11.9 \mathrm{MN}$, the fracture event initiated. The complete fracture event (cleavage and ductile tearing) lasted $\sim 100 \mathrm{~ms}$, with the cleavage runarrest events occurring over an $\sim 35-\mathrm{ms}$ interval before the onset of tearing. A small $(23-\mathrm{mm})$ ligament remained intact after fracture. Complete separation of the plate was obtained by reloading the specimen to $850 \mathrm{kN}$. Figure 5.4 shows the load vs time relationship that occurred during test WP-2.1.

The fracture surface of specimen WP-2.1 is shown in Fig. 5.5(a). Figure 5.5(b) gives a closeup of the fracture surface and shows more clearly the cleavage crack propagation-arrest events. Each cleavage arrest was delineated by a small line of fibrous fracture. The width of this line increased as the arrests occurred at higher temperatures; that is, at the first arrest the width of the fibrous fracture region was a fraction of a millimeter; however, at $a / w \sim 0.5$ the width of the fibrous fracture region had increased to several millimeters.* Small (1-mmdiam) islands of cleavage were visible at $a / w \approx 0.58$, which is beyond the final cleavage-arrest position. The fibrous fracture extending from

*The width of the fibrous fracture region increased with each subsequent arrest of cleavage crack propagation because of increasing dominance of tearing fracture. Reinitiation of cleavage crack propagation after the first crack run-arrest event resulted because of the dynamic nature of the stress-intensity factor resulting from the test setup, that is, reflected stress waves and specimen compliance. The process of tearing, reinitiation of cleavage crack propagation, and arrest continued until ductile fracture dominated and the specimen tore. 
Table 5.1. Summary of HSST wide-plate crack-arrest test conditions and results for specially heat-treated $21 / 4 \mathrm{Cr}-1$ Mo steel:

WP-2 Series

\begin{tabular}{|c|c|c|c|c|c|c|}
\hline $\begin{array}{l}\text { Test } \\
\text { No. }\end{array}$ & $\begin{array}{l}\text { Crack-tip } \\
\text { location } \\
\quad(\mathrm{cm})\end{array}$ & $\begin{array}{l}\text { Crack-tip } \\
\text { temperature } \\
\left({ }^{\circ} \mathrm{C}\right)\end{array}$ & $\begin{array}{l}\text { Initiation } \\
\text { load } \\
\text { (MN) }\end{array}$ & $\begin{array}{c}\text { Arrest } \\
\text { location } \\
(\mathrm{cm})\end{array}$ & $\begin{array}{c}\text { Arrest } \\
\text { temperature } \\
\left({ }^{\circ} \mathrm{C}\right)\end{array}$ & $\begin{array}{c}\text { Arrest } \\
\mathrm{T}-\mathrm{DW} \mathrm{NDT}_{\mathrm{NDT}} \\
\left({ }^{\circ} \mathrm{C}\right)\end{array}$ \\
\hline $\begin{array}{l}W P-2.1 A^{a} \\
W P-2.1 B \\
W P-2.1 \mathrm{D} \\
W P-2.1 \mathrm{E} \\
W P-2.1 \mathrm{~F} \\
W P-2.1 \mathrm{H} \\
W P-2.1 \mathrm{I} \\
W P-2.1 \mathrm{~J}\end{array}$ & $\begin{array}{l}19.9 \\
27.5 \\
33.5 \\
37.0 \\
40.0 \\
45.0 \\
49.0 \\
52.7\end{array}$ & $\begin{array}{r}55 \\
80 \\
96 \\
105 \\
112 \\
125 \\
135 \\
145\end{array}$ & $\begin{array}{l}11.90 \\
11.90 \\
11.90 \\
11.90 \\
11.90 \\
11.90 \\
11.90 \\
11.90\end{array}$ & $\begin{array}{l}27.5 \\
33.5 \\
37.0 \\
40.0 \\
45.0 \\
49.0 \\
52.7 \\
55.5\end{array}$ & $\begin{array}{r}80 \\
96 \\
105 \\
112 \\
125 \\
135 \\
145 \\
152\end{array}$ & $\begin{array}{l}20 \\
36 \\
45 \\
52 \\
65 \\
75 \\
85 \\
92\end{array}$ \\
\hline $\begin{array}{l}\text { WP-2.2A } a, b \\
\text { WP-2.2B } \\
\text { WP-2.2C } \\
\text { WP-2.2D } \\
\text { WP-2.2E } \\
\text { WP-2.2F } \\
\text { WP-2.2G }\end{array}$ & $\begin{array}{l}21.1 \\
43.5 \\
46.5 \\
47.8 \\
49.9 \\
51.0 \\
53.8\end{array}$ & $\begin{array}{r}58 \\
120 \\
129 \\
133 \\
139 \\
142 \\
150\end{array}$ & $\begin{array}{l}17.0 \\
17.0 \\
17.0 \\
17.0 \\
17.0 \\
17.0 \\
17.0\end{array}$ & $\begin{array}{l}43.5 \\
46.5 \\
47.8 \\
49.9 \\
51.0 \\
53.8 \\
58.2\end{array}$ & $\begin{array}{l}120 \\
129 \\
133 \\
139 \\
142 \\
150 \\
162\end{array}$ & $\begin{array}{r}60 \\
69 \\
73 \\
79 \\
82 \\
90 \\
102\end{array}$ \\
\hline $\begin{array}{l}W P-2.3 A \\
W P-2.3 B \\
W P-2.3 D \\
W P-2.3 F\end{array}$ & $\begin{array}{l}20.0 \\
34.0 \\
37.5 \\
39.7\end{array}$ & $\begin{array}{r}66 \\
97 \\
106 \\
111\end{array}$ & $\begin{array}{l}15.3 \\
15.3 \\
15.3 \\
15.3\end{array}$ & $\begin{array}{l}34.0 \\
37.5 \\
39.7 \\
45.7\end{array}$ & $\begin{array}{r}97 \\
106 \\
111 \\
126\end{array}$ & $\begin{array}{l}37 \\
46 \\
51 \\
66\end{array}$ \\
\hline $\begin{array}{l}W P-2.4 A^{a} \\
W P-2.4 B \\
W P-2.4 \mathrm{C} \\
W P-2.4 \mathrm{D} \\
W P-2.4 \mathrm{E} \\
W P-2.4 \mathrm{~F} \\
\text { WP-2.4G } \\
W P-2.4 \mathrm{H}\end{array}$ & $\begin{array}{l}20.3 \\
25.1^{c} \\
33.8 \\
39.7 \\
41.3 \\
46.2 \\
48.4 \\
51.5\end{array}$ & $\begin{array}{r}45 \\
61 \\
86 \\
102 \\
107 \\
121 \\
127 \\
137\end{array}$ & $\begin{array}{l}7.52 \\
8.85 \\
8.85 \\
8.85 \\
8.85 \\
8.85 \\
8.85 \\
8.85\end{array}$ & $\begin{array}{l}25.1 \\
33.8 \\
39.7 \\
41.3 \\
46.2 \\
48.4 \\
51.5 \\
55.5\end{array}$ & $\begin{array}{r}61 \\
86 \\
102 \\
107 \\
121 \\
127 \\
137 \\
149\end{array}$ & $\begin{array}{l}1 \\
26 \\
42 \\
47 \\
61 \\
67 \\
77 \\
89\end{array}$ \\
\hline $\begin{array}{l}W P-2.5 A^{2} \\
W P-2.5 B \\
W P-2.5 C \\
W P-2.5 D \\
W P-2.5 E \\
W P-2.5 F\end{array}$ & $\begin{array}{l}19.9 \\
27.2^{c} \\
35.0 \\
43.5 \\
47.8 \\
51.6\end{array}$ & $\begin{array}{r}66 \\
86 \\
104 \\
124 \\
135 \\
144\end{array}$ & $\begin{array}{l}7.53 \\
8.90 \\
8.90 \\
8.90 \\
8.90 \\
8.90\end{array}$ & $\begin{array}{l}27.2 \\
35.0 \\
43.5 \\
47.8 \\
51.6 \\
56.0\end{array}$ & $\begin{array}{r}86 \\
104 \\
124 \\
135 \\
144 \\
154\end{array}$ & $\begin{array}{l}26 \\
44 \\
64 \\
75 \\
84 \\
94\end{array}$ \\
\hline $\begin{array}{l}W P-2.6 A^{d} \\
W P-2.6 B \\
W P-2.6 C \\
W P-2.6 D \\
W P-2.6 \mathrm{~F} \\
W P-2.6 \mathrm{G} \\
W P-2.6 \mathrm{H}\end{array}$ & $\begin{array}{l}22.4 \\
35.7 \\
39.7 \\
41.0 \\
43.0 \\
46.0 \\
48.0\end{array}$ & $\begin{array}{r}65 \\
104 \\
115 \\
119 \\
125 \\
133 \\
139\end{array}$ & $\begin{array}{l}19.3 \\
19.3 \\
19.3 \\
19.3 \\
19.3 \\
19.3 \\
19.3\end{array}$ & $\begin{array}{l}35.7 \\
39.7 \\
41.0 \\
43.0 \\
46.0 \\
48.0 \\
54.0\end{array}$ & $\begin{array}{l}104 \\
115 \\
119 \\
125 \\
133 \\
139 \\
156\end{array}$ & $\begin{array}{l}44 \\
55 \\
59 \\
65 \\
73 \\
79 \\
96\end{array}$ \\
\hline
\end{tabular}

${ }^{a}$ Crack front cut to truncated chevron configuration.

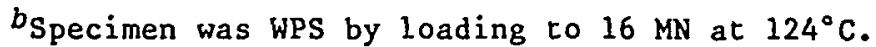

$c_{\text {After pop-in event. }}$

${ }^{d}$ Specimen was WPS by loading to $15.6 \mathrm{MN}$ at $110^{\circ} \mathrm{C}$. 


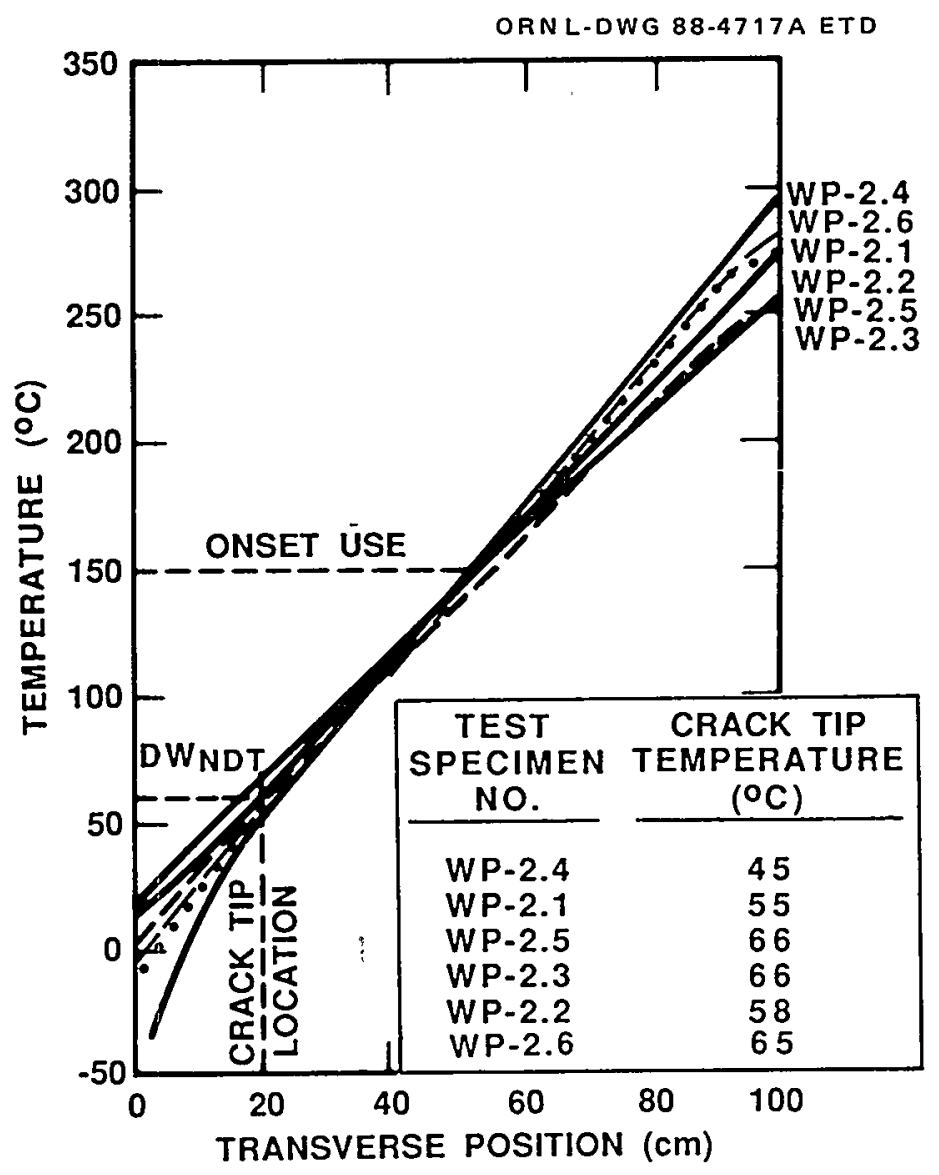

Fig. 5.1. Transverse temperature profiles at approximate time of crack initiation-arrest events: WP-2 series. 


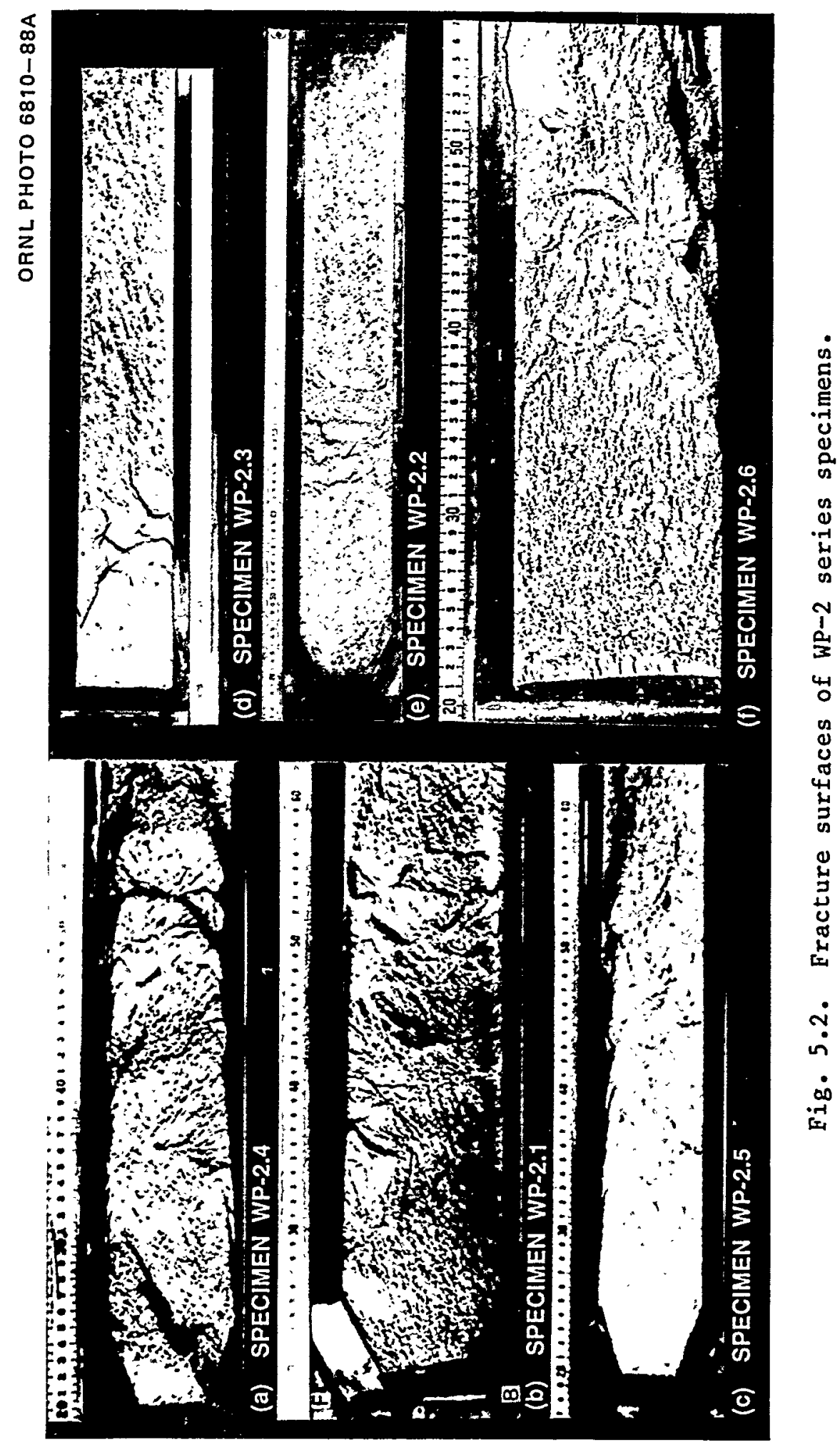


ORNL-DWG 90M-3601 ETD
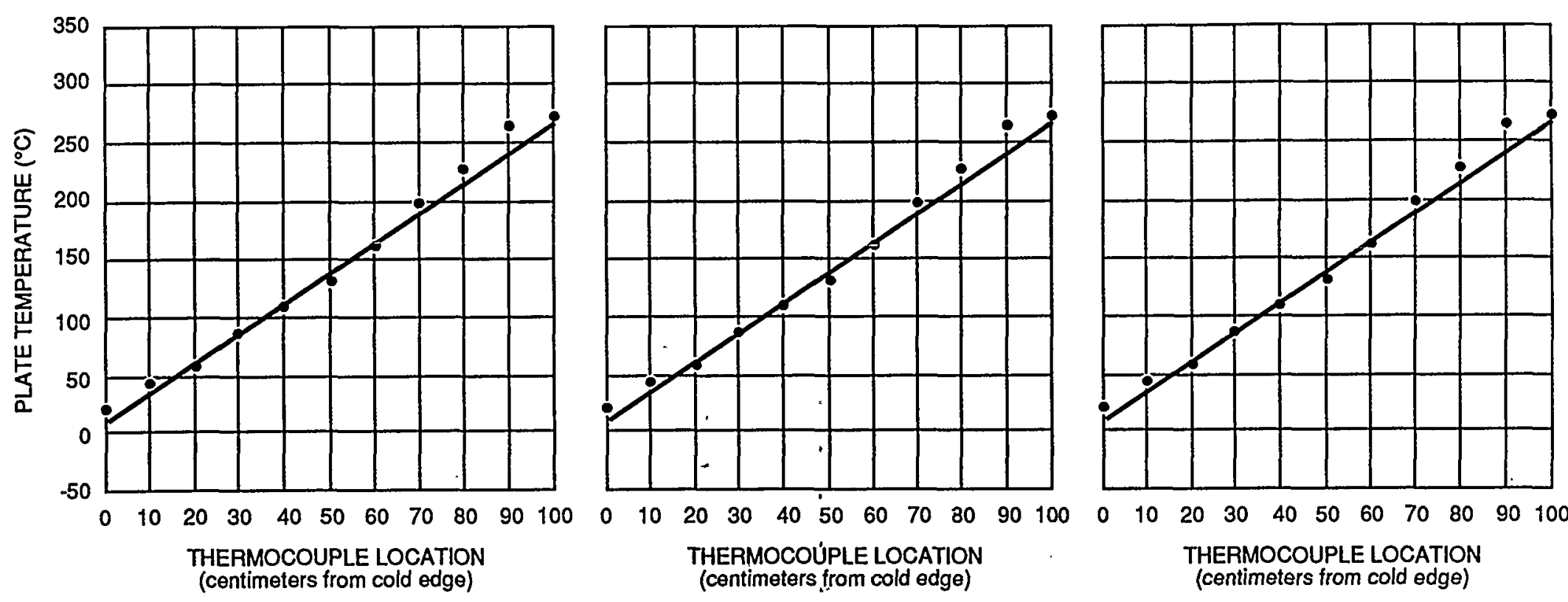

$\begin{array}{lllllllllll}0 & 10 & 20 & 30 & 40 & 50 & 60 & 70 & 80 & 90 & 100\end{array}$

(a)

\section{TEMPERATURE $\left({ }^{\circ} \mathrm{C}\right)$}

CENTIMETERS REAL IDEAL

\begin{tabular}{|c|c|c|}
\hline TIMETERS & REAL & IDEAL \\
\hline $\begin{array}{r}0 \\
10 \\
20 \\
30 \\
40 \\
50 \\
60 \\
70 \\
80 \\
90 \\
100\end{array}$ & $\begin{array}{r}14 \\
40 \\
59 \\
88 \\
111 \\
136 \\
164 \\
194 \\
226 \\
259 \\
280\end{array}$ & $\begin{array}{r}6 \\
33 \\
60 \\
86 \\
113 \\
139 \\
166 \\
193 \\
219 \\
246 \\
273\end{array}$ \\
\hline
\end{tabular}

TEMPERATURE $\left({ }^{\circ} \mathrm{C}\right)$

CENTIMETERS REAL IDEAL

$\begin{array}{rrrrr}0 & & 0 & & 6 \\ 10 & & 41 & & 33 \\ 20 & & 59 & & 60 \\ 30 & & 88 & & 86 \\ 40 & & 112 & & 113 \\ 50 & & 137 & & 139 \\ 60 & & 165 & & 166 \\ 70 & & 195 & & 193 \\ 80 & & 227 & & 219 \\ 90 & & 260 & & 246 \\ 100 & & 280 & & 273\end{array}$

THERMOCOUPLE LOCATION (centimeters from cold edge)

TEMPERATURE $\left({ }^{\circ} \mathrm{C}\right)$ CENTIMETERS REAL IDEAL

\begin{tabular}{rrr}
\hline 12 & & 6 \\
40 & & 33 \\
55 & & 60 \\
88 & & 86 \\
112 & & 113 \\
137 & & 139 \\
165 & & 166 \\
195 & & 193 \\
227 & & 219 \\
260 & & 246 \\
280 & & 273
\end{tabular}

Fig. 5.3. Actual and ideal temperature distributions across specimen width (a) at start of test, (b) at 9.2-MN 1 oad, and (c) at $\sim 10 \mathrm{~s}$ before initiation of fracture events: test WP-2.1. 


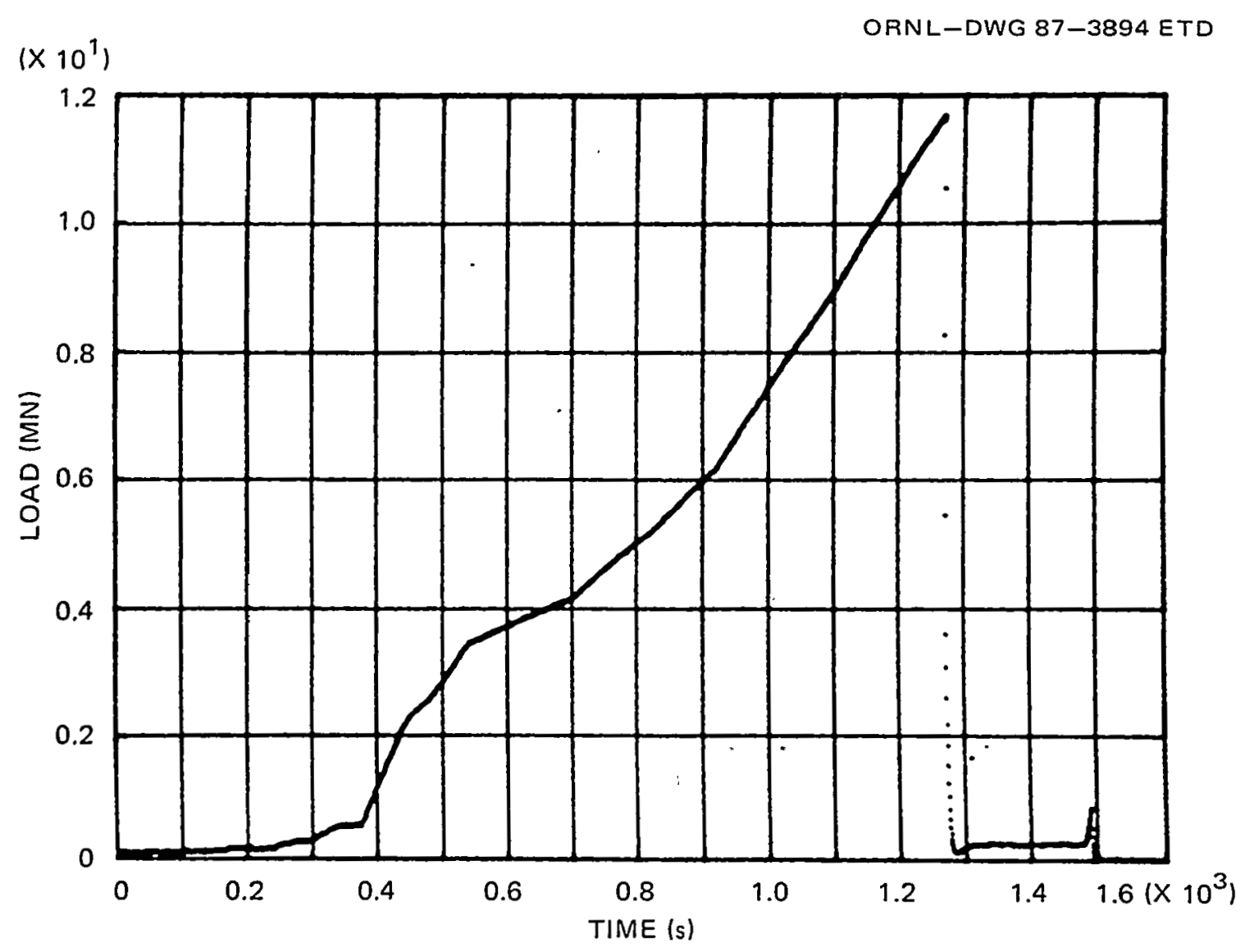

Fig. 5.4. Load history for test WP-2.1. 
ORN L-PHOTO 2013-90

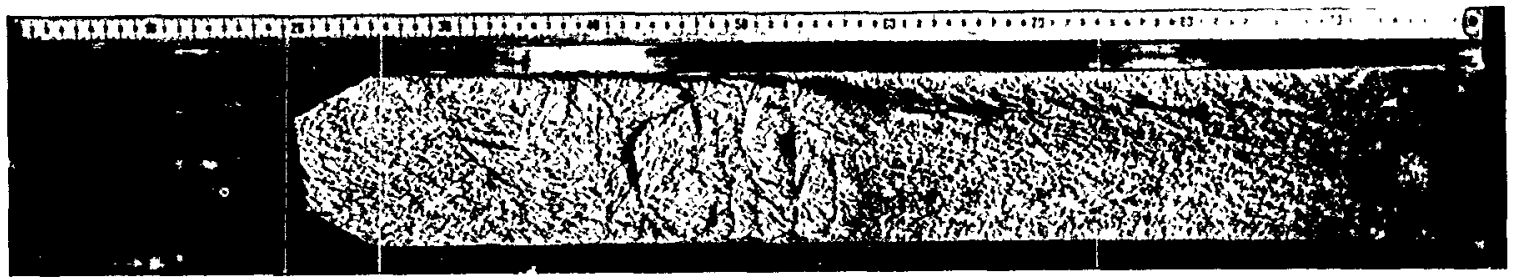

(a)

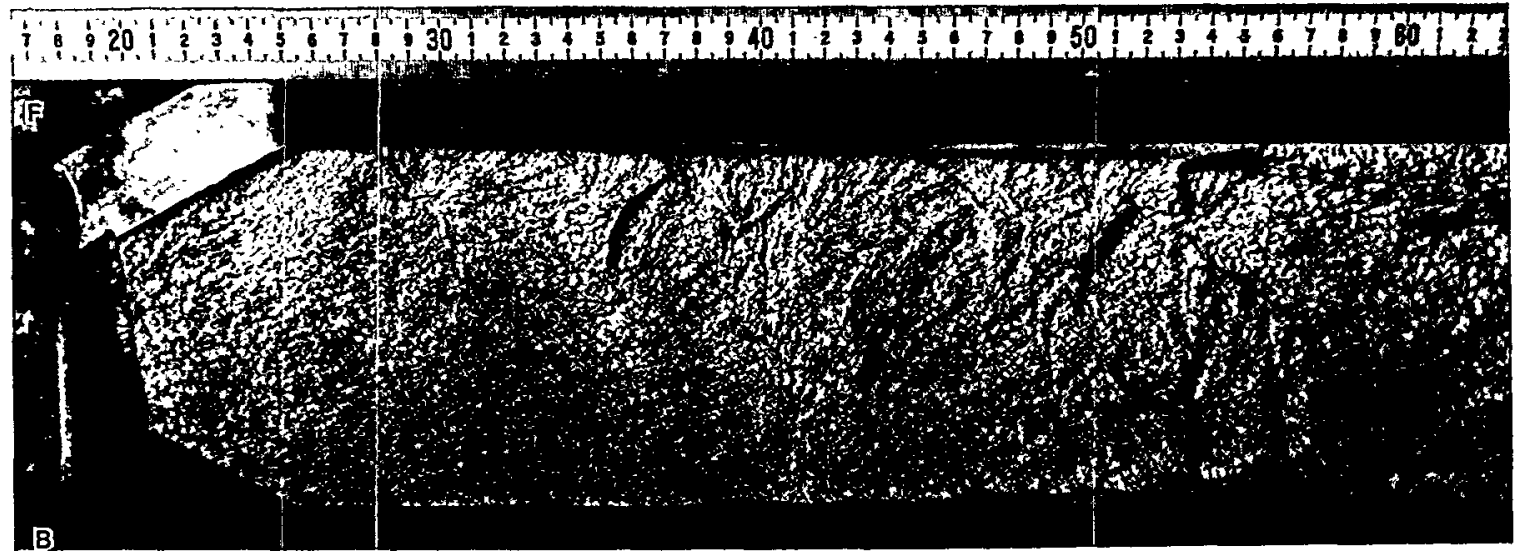

(b)

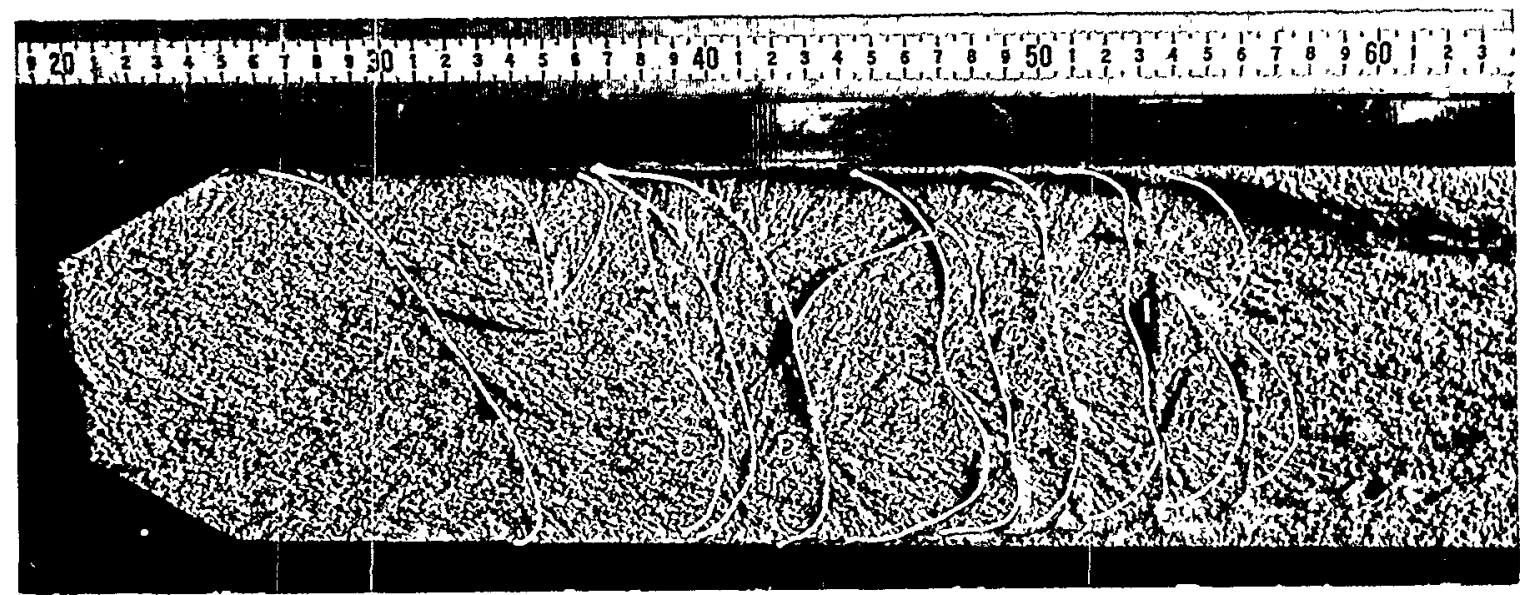

(c)

Fig. 5.5. Fracture surface of specimen WP-2.1. (a) Overall fracture surface, (b) close-up of initial crack and cleavage crack-runarrest region, and (c) close-up of initial crack and cleavage crack runarrest region with arrest location highlighted. 
$a / w=0.55$ to the end of the plate was extremely fine, or flat, compared with the fibrous fracture regions in the WP-1 test series 1 (A 533 grade B class 1 material).

Examination of the fracture surface indicates that initiation of cleavage crack growth was in the plane of the side grooves, but as the crack extended, it gradually deviated from this plane. By the loss-ofcleavage location $(\mathrm{a} / \mathrm{w} \sim 0.58)$, the crack was $14 \mathrm{~mm}$ below the plane of the side grooves. Once fibrous fracture took over, the crack returned to the side-grooved plane. Reduction-in-thickness contours surrounding the crack plane are shown in Fig. 5.6.*

Evaluations of strain-gage recordst and the fracture surface were used to deduce the crack length (position of the crack front) vs time, and the results are presented in Table 5.2. These strain-gage positions have been modified from those shown in Fig. 4.8(a) because the peak strain occurs at an angle of $72^{\circ}$ in front of the crack tip. A plot of crack-front position vs time derived from the front-face and back-face strain gage outputs is presented in Fig. 5.7. The strain-gage-derived apparent crack position as a function of time indicates that for about the first $27.5 \mathrm{~ms}$, the crack front advance was greater at the back face of the plate than at the front face. At elapsed times $>27.5 \mathrm{~ms}$, the crack front advance at comparable elapsed times was fairly consistent at the front and back faces.

\subsection{TEST WP-2.2}

Before testing, specimen WP-2.2 was WPS at a crack-tip temperature of $124^{\circ} \mathrm{C}$ (Fig. 5.8) by slowly loading it to $16 \mathrm{MN}$, holding the load constant at this value for $5 \mathrm{~min}$, and slowly reducing the load to $3 \mathrm{MN}$. The load history and load vs front-face COD results during warm prestressing are shown in Fig. 5.9. While maintaining the load constant at $3 \mathrm{MN}$, the thermal gradient was developed.

After obtaining a satisfactory temperature profile (Fig. 5.10), the specimen was loaded at an average rate of $16.2 \mathrm{kN} / \mathrm{s}$. At a load of $17 \mathrm{MN}$, cleavage crack propagation initiated, and within $\sim 9 \mathrm{~ms}$ seven crack run-arrest events occurred. After the seventh crack run-arrest event, tearing fracture reinitiated with complete separation of the plate occurring $\sim 34.5 \mathrm{~ms}$ after first initiation of cleavage crack propagation. Figure 5.11 presents the load history for test WP-2.2.

Figure 5.12 presents overall and close-up views of the fracture surface of specimen WP-2.2. The entire fracture took place. in the plane

*Reduction-in-thickness measurements are performed using a deepthroated micrometer with a resolution of $\pm 0.025 \mathrm{~mm}$. The measurements are of total thickness with no differentiation between front and back deformation.

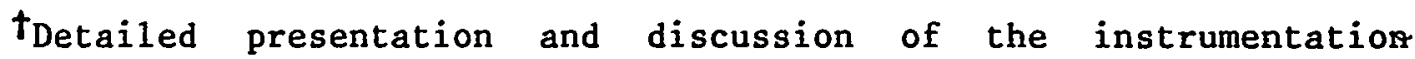
results for each test are contained in Appendix A. 


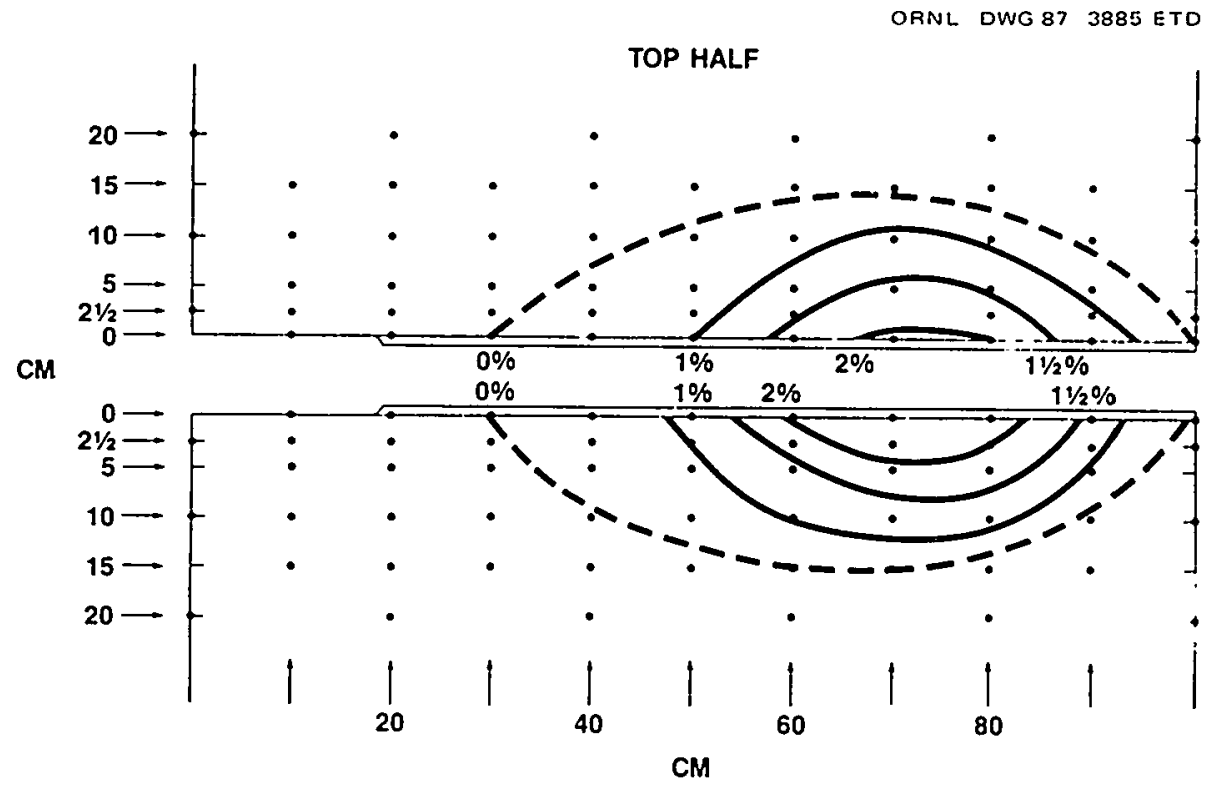

BOTTOM HALF

Fig. 5.6. Reduction-in-thickness contour map of specimen WP-2.1.

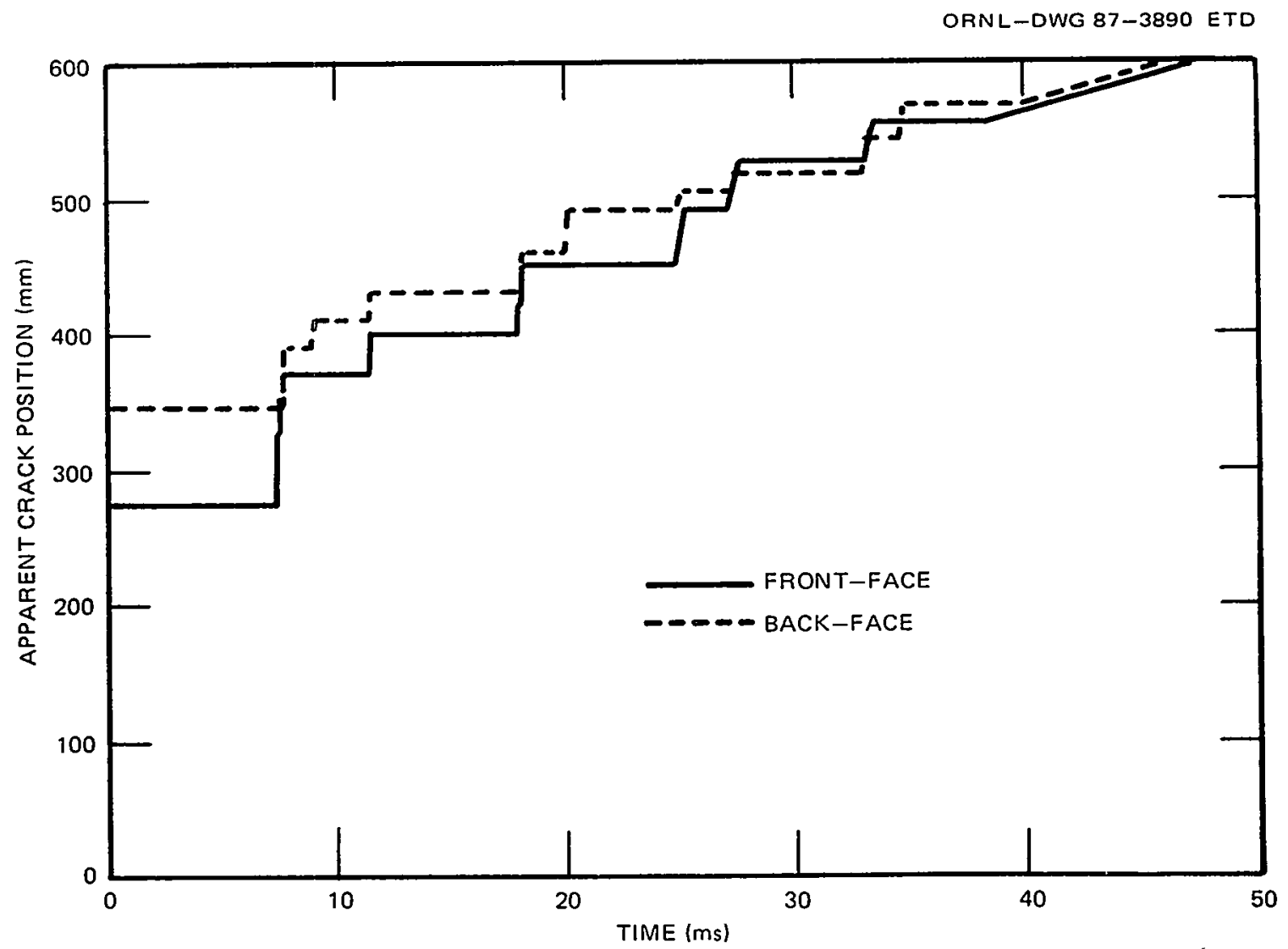
WP-2.1.

Fig. 5.7. Strain-gage-derived crack-front position vs time: test 
Table 5.2 (continued)

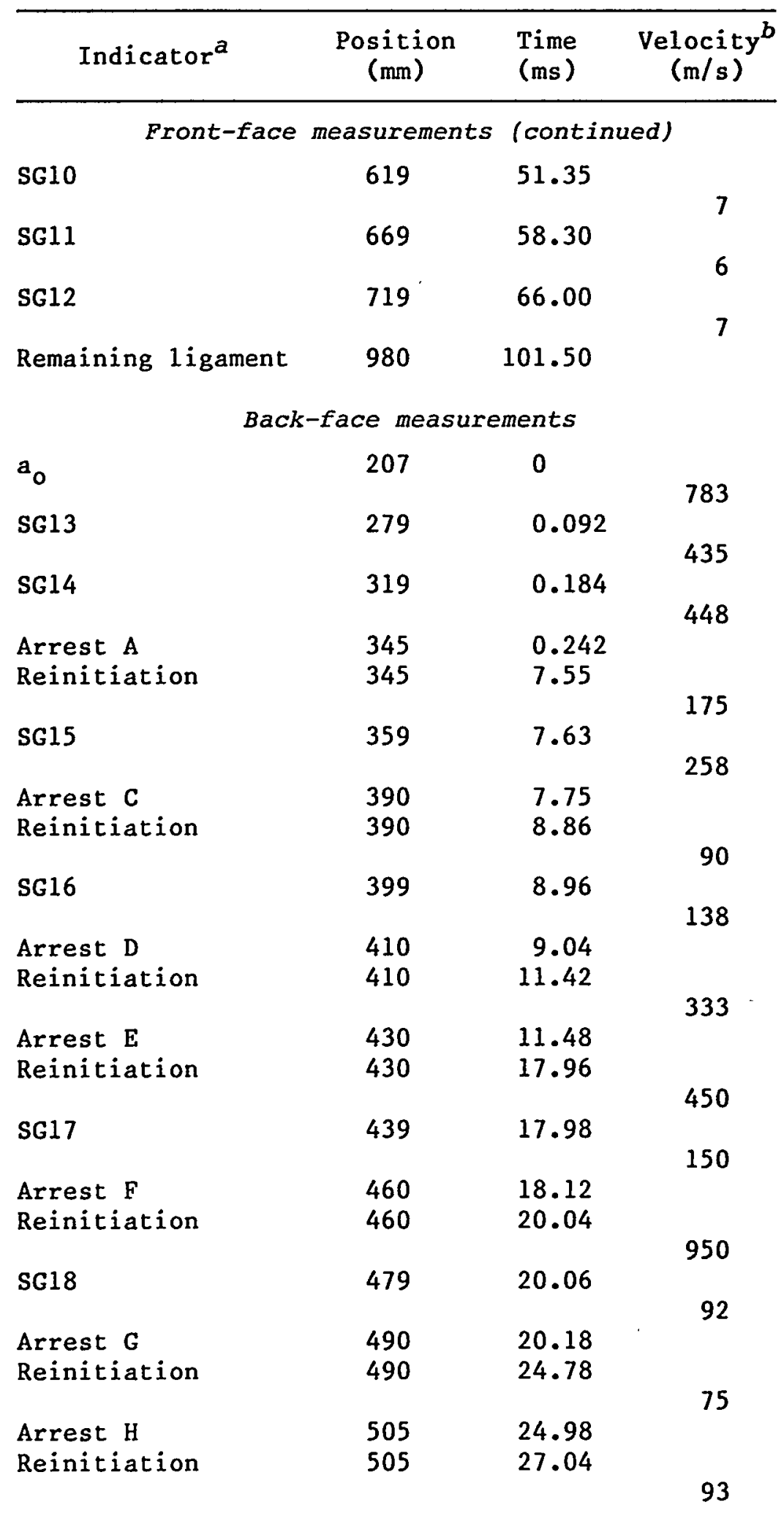


Table 5.2. Crack position vs time and velocity: test WP-2.I

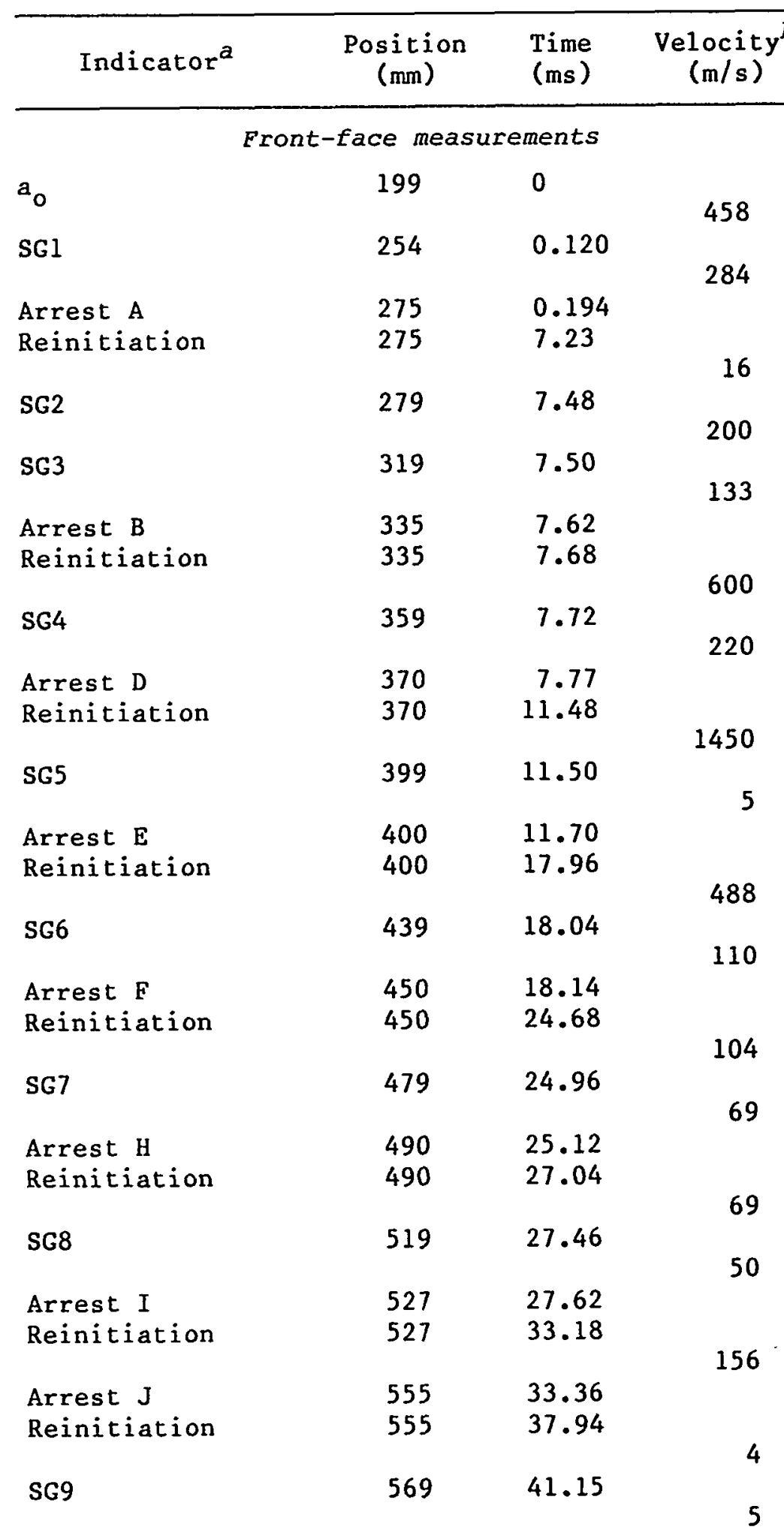


Table 5.2 (continued)

\begin{tabular}{|c|c|c|c|}
\hline Indicator ${ }^{a}$ & $\begin{array}{l}\text { Position } \\
\quad(\mathrm{mm})\end{array}$ & $\begin{array}{l}\text { Time } \\
\text { (ms) }\end{array}$ & $\begin{array}{l}\text { Velocity } \\
(\mathrm{m} / \mathrm{s})\end{array}$ \\
\hline \multicolumn{4}{|c|}{ Back-face measurements (continued) } \\
\hline $\begin{array}{l}\text { Arrest I } \\
\text { Reinitiation }\end{array}$ & $\begin{array}{l}518 \\
518\end{array}$ & $\begin{array}{l}27.18 \\
32.94\end{array}$ & \\
\hline SG19 & 519 & 33.00 & $\begin{array}{r}17 \\
433\end{array}$ \\
\hline $\begin{array}{l}\text { Arrest J } \\
\text { Reinitiation }\end{array}$ & $\begin{array}{l}545 \\
545\end{array}$ & $\begin{array}{l}33.06 \\
34.62\end{array}$ & \\
\hline $\begin{array}{l}\text { Arrest K } \\
\text { Reinitiation }\end{array}$ & $\begin{array}{l}568 \\
568\end{array}$ & $\begin{array}{l}34.76 \\
34.76\end{array}$ & 164 \\
\hline SG20 & 569 & 39.66 & 0.2 \\
\hline SG21 & 619 & 50.15 & 6 \\
\hline SG22 & 669 & 58.35 & 7 \\
\hline Remaining ligament & 974 & 101.50 & \\
\hline
\end{tabular}

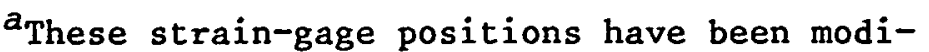
fied because the peak strain occurs at an angle of $72^{\circ}$ in front of the crack tip. Also, the crackarrest locations are averages of the quarterthickness crack length and the crack length at the side groove.

${ }^{b}$ Velocity is an average calculated velocity of crack propagation between the corresponding indicator positions. 
ORNL-DWG 89-5021 ETD

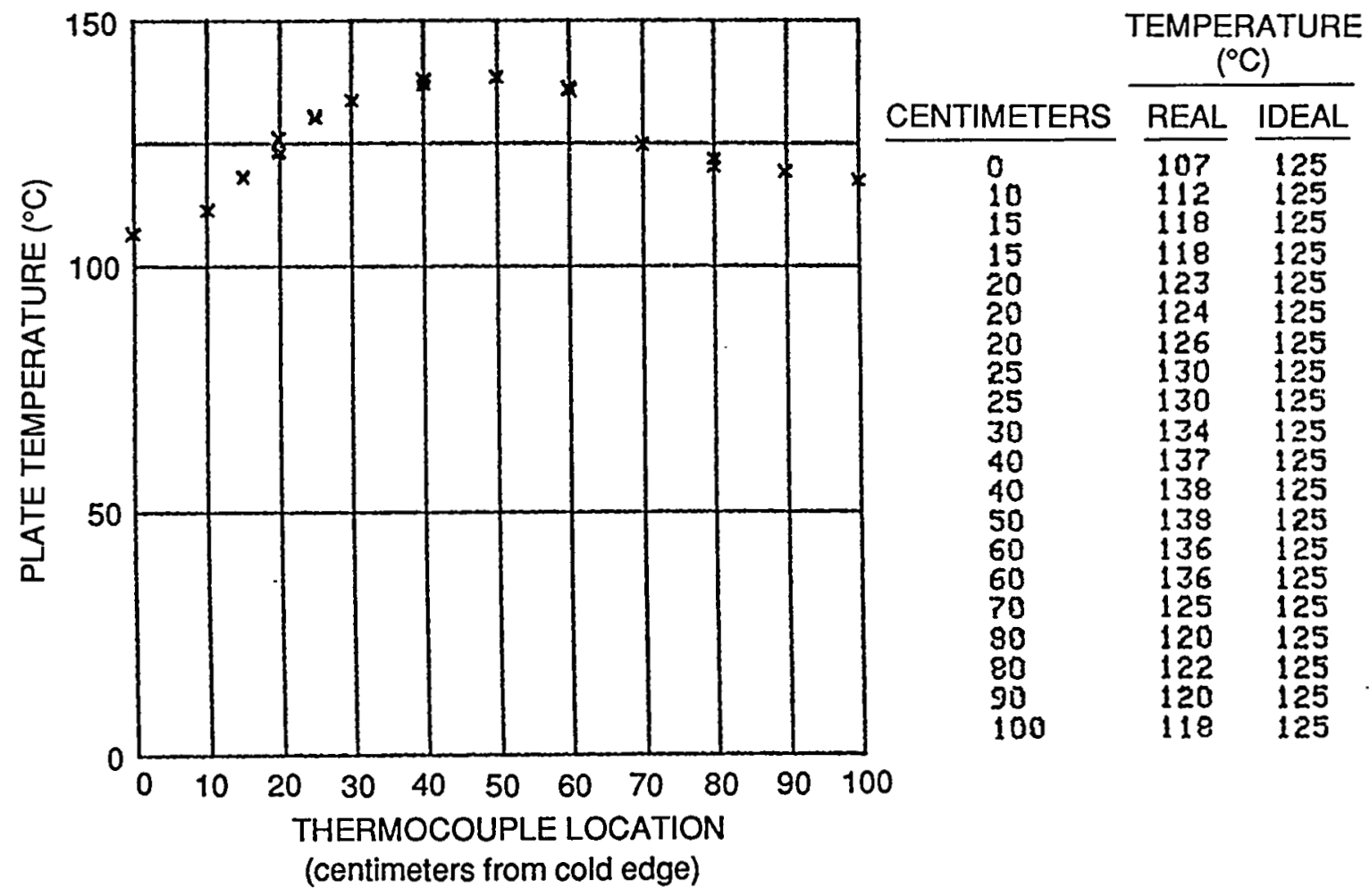

Fig. 5.8. Actual and ideal temperature distributions across specimen width during warm prestressing: test WP-2.2. 


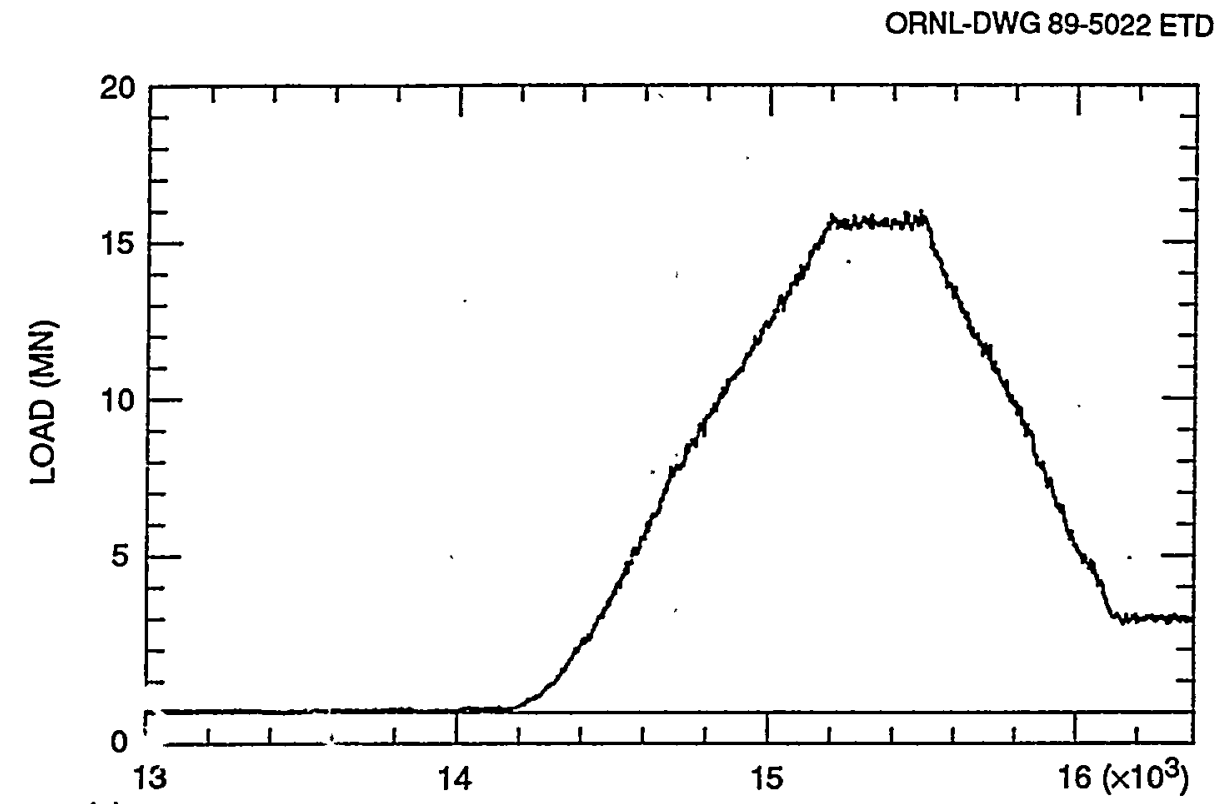

(a)

TIME (s)

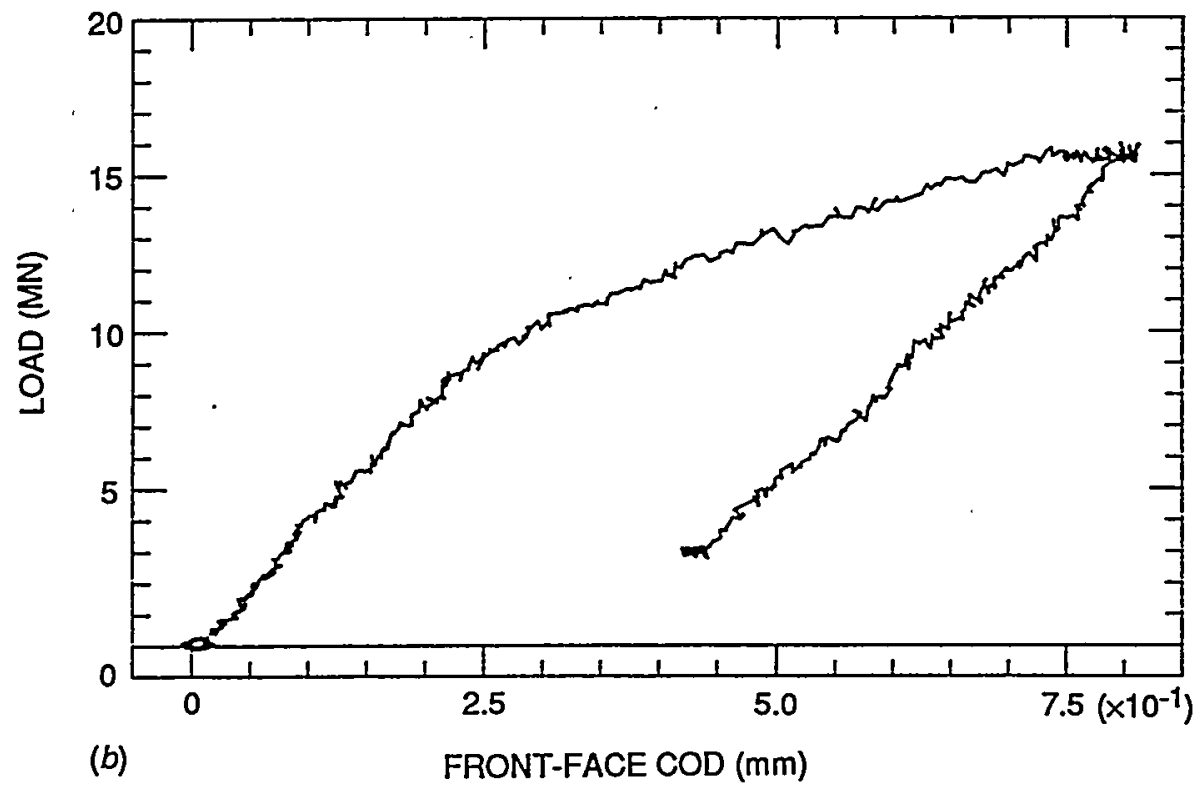

Fig. 5.9. Load vs (a) time and (b) front-face COD during warm prestressing: test WP-2.2. 
ORNL-DWG 89-5023 ETD

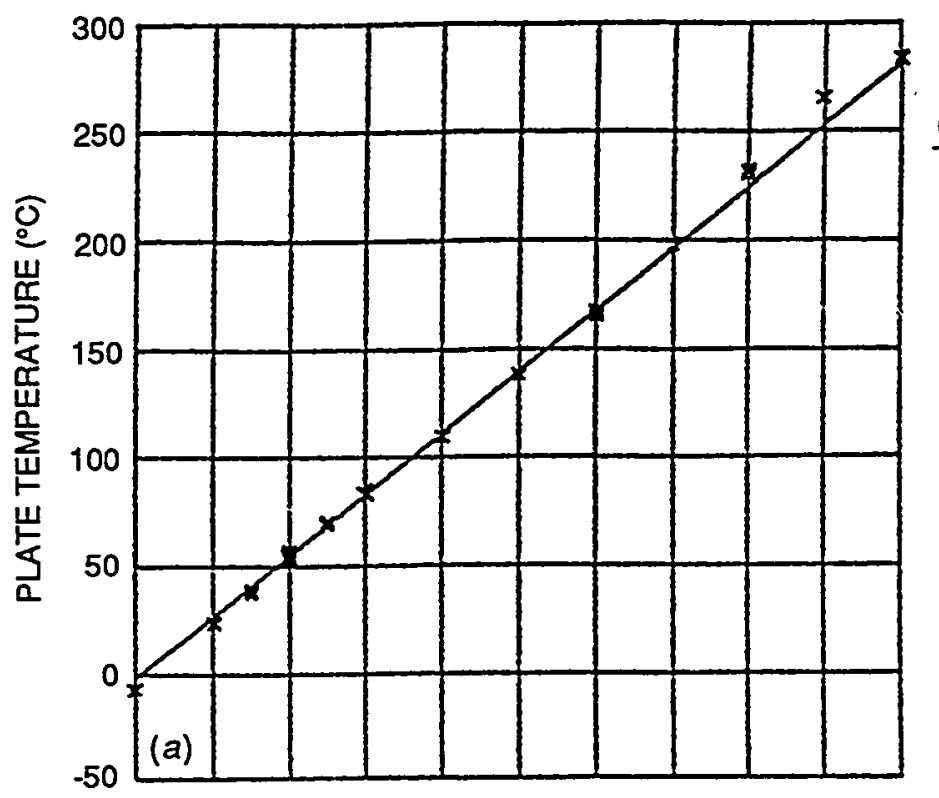

\begin{tabular}{|c|c|c|}
\hline \multirow[b]{2}{*}{ CENTIMETERS } & \multicolumn{2}{|c|}{$\begin{array}{l}\text { TEMPERATURE } \\
\left({ }^{\circ} \mathrm{C}\right)\end{array}$} \\
\hline & REAL & IDEAL \\
\hline $\begin{array}{l}0 \\
10 \\
15 \\
15 \\
20 \\
20 \\
20 \\
25 \\
25 \\
30 \\
48 \\
40 \\
50 \\
60 \\
60 \\
70 \\
80 \\
80 \\
90 \\
100\end{array}$ & $\begin{array}{l}-7 \\
24 \\
37 \\
39 \\
55 \\
57 \\
53 \\
70 \\
69 \\
83 \\
110 \\
110 \\
138 \\
167 \\
165 \\
198 \\
231 \\
232 \\
266 \\
284\end{array}$ & $\begin{array}{l}-2 \\
26 \\
40 \\
40 \\
54 \\
54 \\
54 \\
69 \\
69 \\
83 \\
111 \\
111 \\
139 \\
168 \\
168 \\
196 \\
225 \\
225 \\
253 \\
281\end{array}$ \\
\hline
\end{tabular}
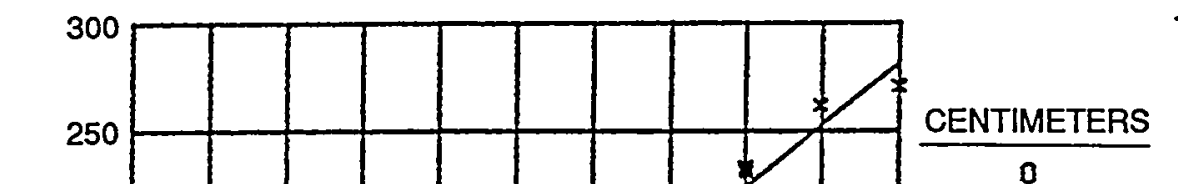

TEMPERATURE

$\left({ }^{\circ} \mathrm{C}\right)$

\begin{tabular}{|c|c|c|}
\hline & 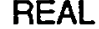 & \\
\hline $\begin{array}{l}0 \\
10 \\
15 \\
15 \\
20 \\
20 \\
20 \\
25 \\
25 \\
30 \\
40 \\
40 \\
50 \\
60 \\
60 \\
70 \\
80 \\
80 \\
90 \\
100\end{array}$ & $\begin{array}{l}-9 \\
22 \\
36 \\
37 \\
55 \\
56 \\
52 \\
70 \\
68 \\
84 \\
110 \\
110 \\
139 \\
168 \\
166 \\
200 \\
232 \\
234 \\
262 \\
271\end{array}$ & $\begin{array}{l}-2 \\
25 \\
40 \\
40 \\
54 \\
54 \\
54 \\
69 \\
69 \\
83 \\
111 \\
111 \\
139 \\
168 \\
168 \\
196 \\
225 \\
225 \\
253 \\
281\end{array}$ \\
\hline
\end{tabular}

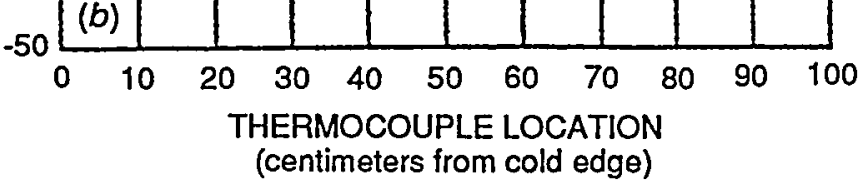

Fig. 5.10. Actual and ideal temperature distributions across specimen width (a) at start of loading and (b) just before initiation of cleavage crack run-arrest events: test WP-2.2. 
ORNL-DWG 89-5024 ETD

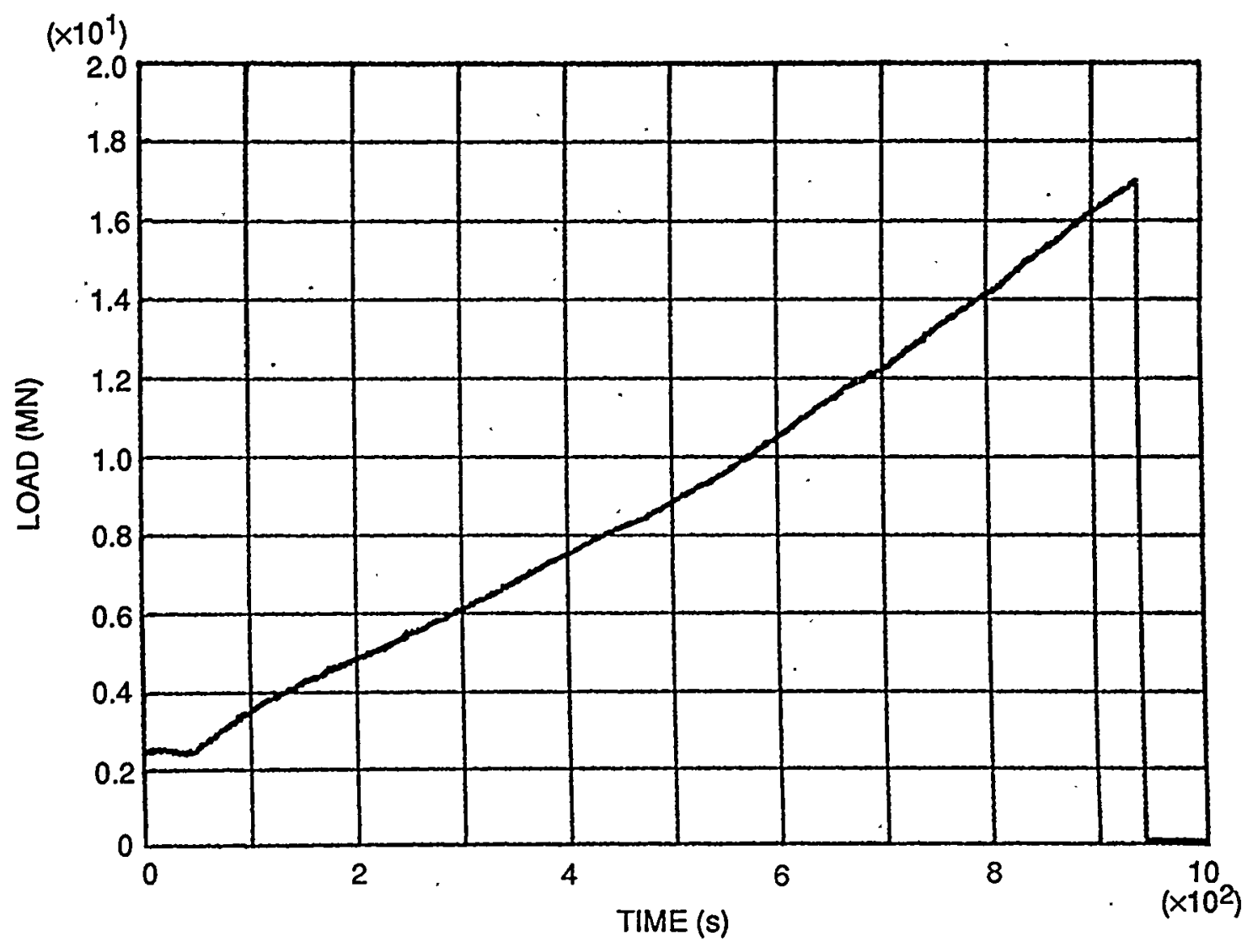

Fig. 5.11. Load history for test WP-2.2. 


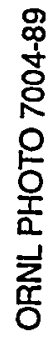
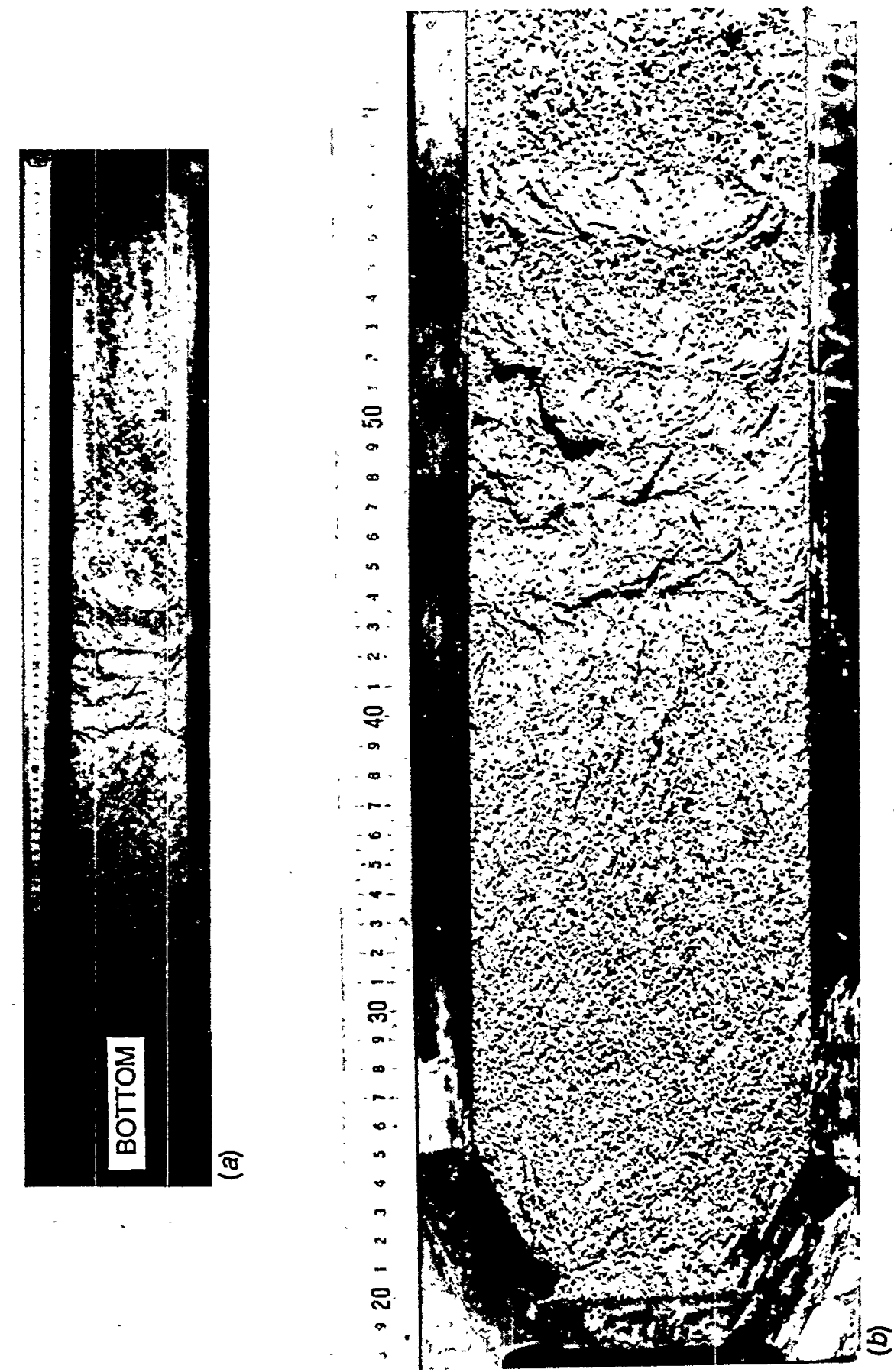

嵌

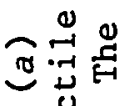

ป

ํ.

赑

出 5

럴

ये क्

की क.

$\sum_{0}^{\infty}$

○ 思口

ป

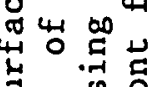

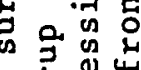

व b

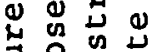

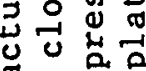

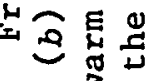

김

$\therefore$.

ำ

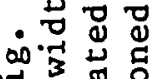

ic

0.

D 00

능 
of the side grooves. Examination of the fracture surface indicates that multiple (six to seven) crack run-arrest events occurred before the onset of ductile fracture. The reduction-in-thickness contour map for the specimen is presented in Fig. 5.13. Note that significant reductions in thickness occurred only after the location corresponding to the initial arrest; that is, a/w $\sim 0.44$.

The strain-gage records (Appendix A) and fracture surface were used to deduce the crack lengths (apparent position of the crack front) during the fracture process, and the results are summarized in Table 5.3. The crack-line strain-gage positions have been modified from those shown in Fig. 4.8(b) because the peak strain occurs at an angle of $72^{\circ}$ in front of the crack tip. Figure 5.14 presents a plot of straingage-derived crack-front position vs time from the front- and back-face strain-gage results. Crack propagation at comparable elapsed times during the test was fairly consistent at the plate front and back faces.

\subsection{TEST WP-2.3}

Test WP-2.3 was the first test in the WP-2 series that did not have the crack front cut into a truncated chevron configuration. After obtaining a satisfactory thermal gradient (Fig. 5.15), specimen loading was initiated at a rate of $14 \mathrm{kN} / \mathrm{s}$. At a load of $15.3 \mathrm{MN}$, the fracture event began and lasted about $950 \mathrm{~ms}$ (crack run-arrest events plus ductile tearing). Figure 5.16 shows the overall fracture surface for test specimen WP-2.3. A close-up of the cleavage and loss-of-cleavage regions with the cleavage run-arrest events highlighted is shown in Fig. 5.17. As noted in these figures, three cleavage run-arrest events occurred at the front face of the plate and four at the back face. The run-arrest events in Fig. $5.17(b)$ have been labeled A through F according to the apparent order in which they occurred. Examination of the fracture surface also indicates that initiation of crack growth in cleavage was in the plane of the side grooves, but as the crack extended, it deviated from this plane at several places. The maximum deviation was $6 \mathrm{~mm}$ below the plane of the side grooves on the lower half of the fracture surface. Once fibrous fracture took over, the crack returned to the plane of the side grooves. Reduction-in-thickness contours surrounding the crack plane are presented in Fig. 5.18.

Evaluation of the strain-gage records (Appendix A) and the fracture surface were used to deduce the crack length (position of the crack front) during the fracture process, and the results are summarized in Table 5.4. The strain-gage positions have been modified from those shown in Fig. 4.8(c) because the peak strain occurs at an angle of $72^{\circ}$ in front of the crack tip. A plot of the strain-gage-derived crackfront position vs time from the front-face and back-face strain gage results for the first $50 \mathrm{~ms}$ of the test is presented in Fig. 5.19(a). The crack front advance at comparable elapsed times during the cleavage crack run-arrest events was more rapid near the back face of the plate than near the front face. An expanded scale plot of the crack-front position vs time derived from the front- and back-face strain gage results over the $\approx 950-\mathrm{ms}$ duration of the test is presented in 


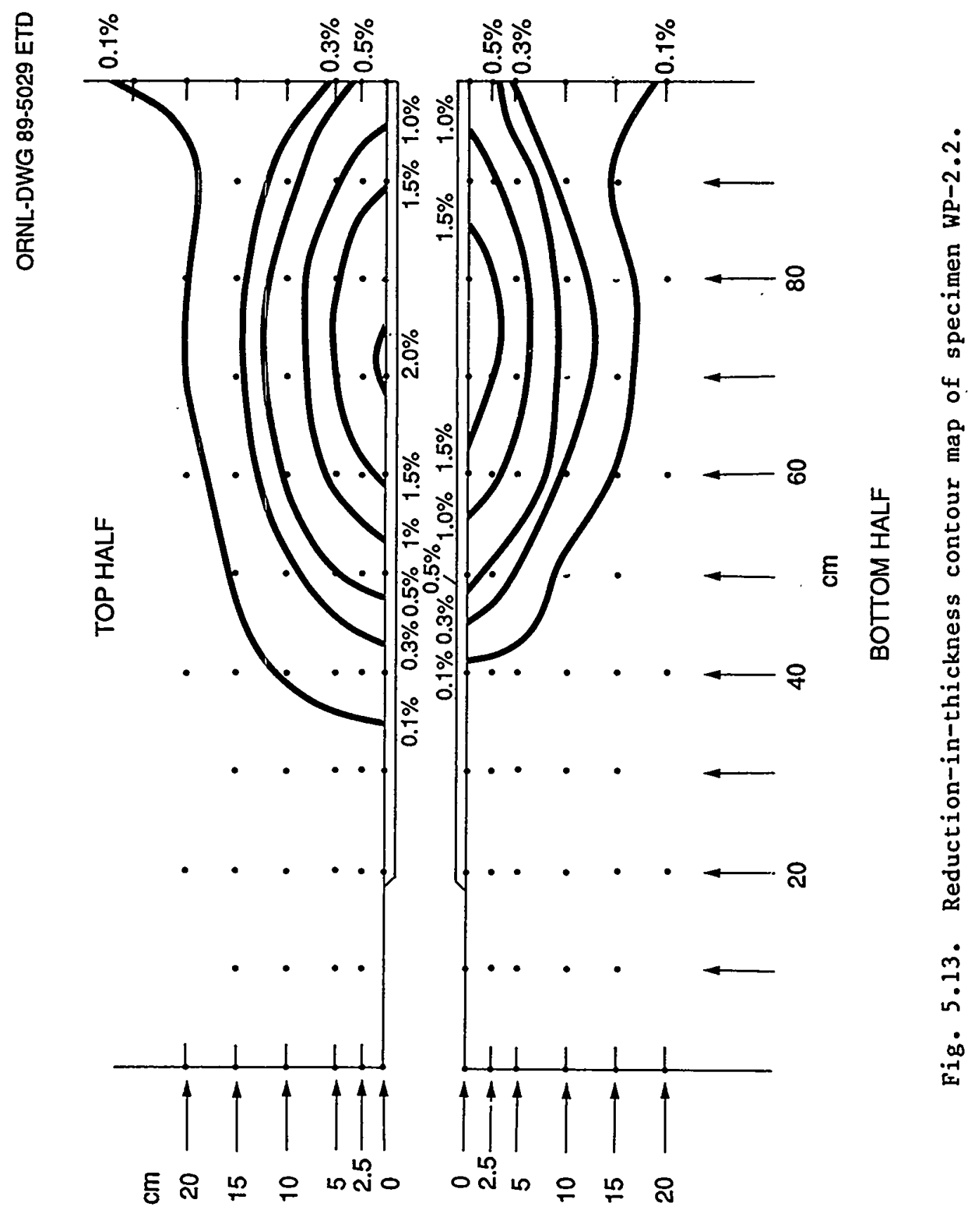


Table 5.3. Crack position vs time and velocity: test WP-2.2

\begin{tabular}{|c|c|c|c|}
\hline Indicator ${ }^{a}$ & $\begin{array}{l}\text { Position } \\
(\mathrm{mm})\end{array}$ & $\begin{array}{l}\text { Time } \\
\text { (ms) }\end{array}$ & $\begin{array}{c}\text { Velocity } \\
(\mathrm{m} / \mathrm{s})\end{array}$ \\
\hline \multicolumn{4}{|c|}{ Front-face measurements } \\
\hline Initial crack & 211 & 0 & 875 \\
\hline SG1 & 218 & 0.008 & 870 \\
\hline SG2 & 258 & 0.054 & 1538 \\
\hline SG3 & 298 & 0.080 & 541 \\
\hline SG4 & 338 & 0.154 & 500 \\
\hline SG5 & 378 & 0.234 & 476 \\
\hline SG6 & 418 & 0.318 & 213 \\
\hline $\begin{array}{l}\text { Arrest A } \\
\text { Reinitiation }\end{array}$ & $\begin{array}{l}435 \\
435\end{array}$ & $\begin{array}{l}0.398 \\
0.870\end{array}$ & 411 \\
\hline SG7 & 458 & 0.926 & 66 \\
\hline $\begin{array}{l}\text { Arrest B } \\
\text { Reinitiation }\end{array}$ & $\begin{array}{l}465 \\
465\end{array}$ & $\begin{array}{l}1.032 \\
1.546\end{array}$ & 232 \\
\hline $\begin{array}{l}\text { Arrest C } \\
\text { Reinitiation }\end{array}$ & $\begin{array}{l}478 \\
478\end{array}$ & $\begin{array}{l}1.602 \\
1.946\end{array}$ & 1111 \\
\hline SG8 & 498 & 1.964 & 500 \\
\hline $\begin{array}{l}\text { Arrest D } \\
\text { Reinitiation }\end{array}$ & $\begin{array}{l}499 \\
499\end{array}$ & $\begin{array}{l}1.966 \\
2.266\end{array}$ & 204 \\
\hline $\begin{array}{l}\text { Arrest E } \\
\text { Reinitiation }\end{array}$ & $\begin{array}{l}510 \\
510\end{array}$ & $\begin{array}{l}2.320 \\
3.628\end{array}$ & 2333 \\
\hline
\end{tabular}


Table 5.3 (continued)

\begin{tabular}{|c|c|c|c|}
\hline Indicator ${ }^{a}$ & $\begin{array}{l}\text { Position } \\
\quad(\mathrm{mm})\end{array}$ & $\begin{array}{l}\text { Time } \\
\text { (ms) }\end{array}$ & $\begin{array}{c}\text { Velocity } \\
(\mathrm{m} / \mathrm{s})\end{array}$ \\
\hline \multicolumn{4}{|c|}{ Front-face measurements } \\
\hline $\begin{array}{l}\text { Arrest F } \\
\text { Reinitiation } \\
\text { (tearing) }\end{array}$ & $\begin{array}{l}538 \\
538\end{array}$ & $\begin{array}{l}3.640 \\
7.830\end{array}$ & 11 \\
\hline SG9 & 548 & 8.77 & 317 \\
\hline $\begin{array}{l}\text { Reinitiation } \\
\text { (cleavage) }\end{array}$ & 567 & 8.83 & 188 \\
\hline $\begin{array}{l}\text { Arrest G } \\
\text { Reinitiation } \\
\text { (tearing) }\end{array}$ & $\begin{array}{l}582 \\
582\end{array}$ & $\begin{array}{l}8.91 \\
9.46\end{array}$ & 7 \\
\hline SG10 & 598 & 11.91 & 20 \\
\hline SGl1 & 698 & 16.81 & 28 \\
\hline SG12 & 798 & 20.39 & 14 \\
\hline End of plate & 1000 & 34.48 & \\
\hline \multicolumn{4}{|c|}{ Back-face measurements } \\
\hline Initial crack & 215 & 0 & 150 \\
\hline SG13 & 218 & 0.020 & 1429 \\
\hline SG14 & 258 & 0.048 & 690 \\
\hline SG15 & 298 & 0.106 & 500 \\
\hline SG16 & 338 & 0.186 & 667 \\
\hline SG17 & 378 & 0.246 & 588 \\
\hline SG18 & 418 & 0.314 & 257 \\
\hline $\begin{array}{l}\text { Arrest A } \\
\text { Reinitiation }\end{array}$ & $\begin{array}{l}436 \\
436\end{array}$ & $\begin{array}{l}0.384 \\
1.248\end{array}$ & \\
\hline & & & 239 \\
\hline
\end{tabular}


Table 5.3 (continued)

\begin{tabular}{|c|c|c|c|}
\hline Indicator ${ }^{a}$ & $\begin{array}{l}\text { Position } \\
(\mathrm{mm})\end{array}$ & $\begin{array}{l}\text { Time } \\
\text { (ms) }\end{array}$ & $\begin{array}{c}\text { Velocity } \\
(\mathrm{m} / \mathrm{s})\end{array}$ \\
\hline \multicolumn{4}{|c|}{ Back-face measurements } \\
\hline SG19 & 458 & 1.340 & 600 \\
\hline $\begin{array}{l}\text { Arrest B } \\
\text { Reinitiation }\end{array}$ & $\begin{array}{l}470 \\
470\end{array}$ & $\begin{array}{l}1.360 \\
1.934\end{array}$ & 417 \\
\hline $\begin{array}{l}\text { Arrest C } \\
\text { Reinitiation }\end{array}$ & $\begin{array}{l}490 \\
490\end{array}$ & $\begin{array}{l}1.982 \\
2.242\end{array}$ & 1000 \\
\hline $\mathrm{SG} 20$ & 498 & 2.250 & 105 \\
\hline $\begin{array}{l}\text { Arrest D } \\
\text { Reinitiation } \\
\text { (cleavage) }\end{array}$ & $\begin{array}{l}506 \\
519\end{array}$ & $\begin{array}{l}2.326 \\
3.516\end{array}$ & 159 \\
\hline $\begin{array}{l}\text { Arrest E } \\
\text { Reinitiation } \\
\text { (ductile) } \\
\text { Reinitiation } \\
\text { (cleavage) }\end{array}$ & $\begin{array}{l}532 \\
561 \\
567\end{array}$ & $\begin{array}{l}3.598 \\
7.780 \\
8.830\end{array}$ & $\begin{array}{r}6 \\
63\end{array}$ \\
\hline $\begin{array}{l}\text { Arrest F } \\
\text { Reinitiation } \\
\text { (ductile) }\end{array}$ & $\begin{array}{l}572 \\
572\end{array}$ & $\begin{array}{l}8.910 \\
9.460\end{array}$ & 17 \\
\hline End of plate & 1000 & 34.48 & \\
\hline $\begin{array}{l}{ }^{a} \text { These st } \\
\text { by } 32 \mathrm{~mm} \text { from } \\
\text { Fig. } 4.8(b) \\
\text { of } 72^{\circ} \text { in front } \\
\text { bVelocity }\end{array}$ & $\begin{array}{l}\text { gage posit } \\
\text { tual gage } \\
\text { peak stra } \\
\text { he crack } \\
\text { average }\end{array}$ & $\begin{array}{l}\text { is are a } \\
\text { osition } \\
\text { occurs } \\
\text { p. }\end{array}$ & $\begin{array}{l}1 \text { reduced } \\
\text { shown in } \\
\text { at an angle }\end{array}$ \\
\hline
\end{tabular}




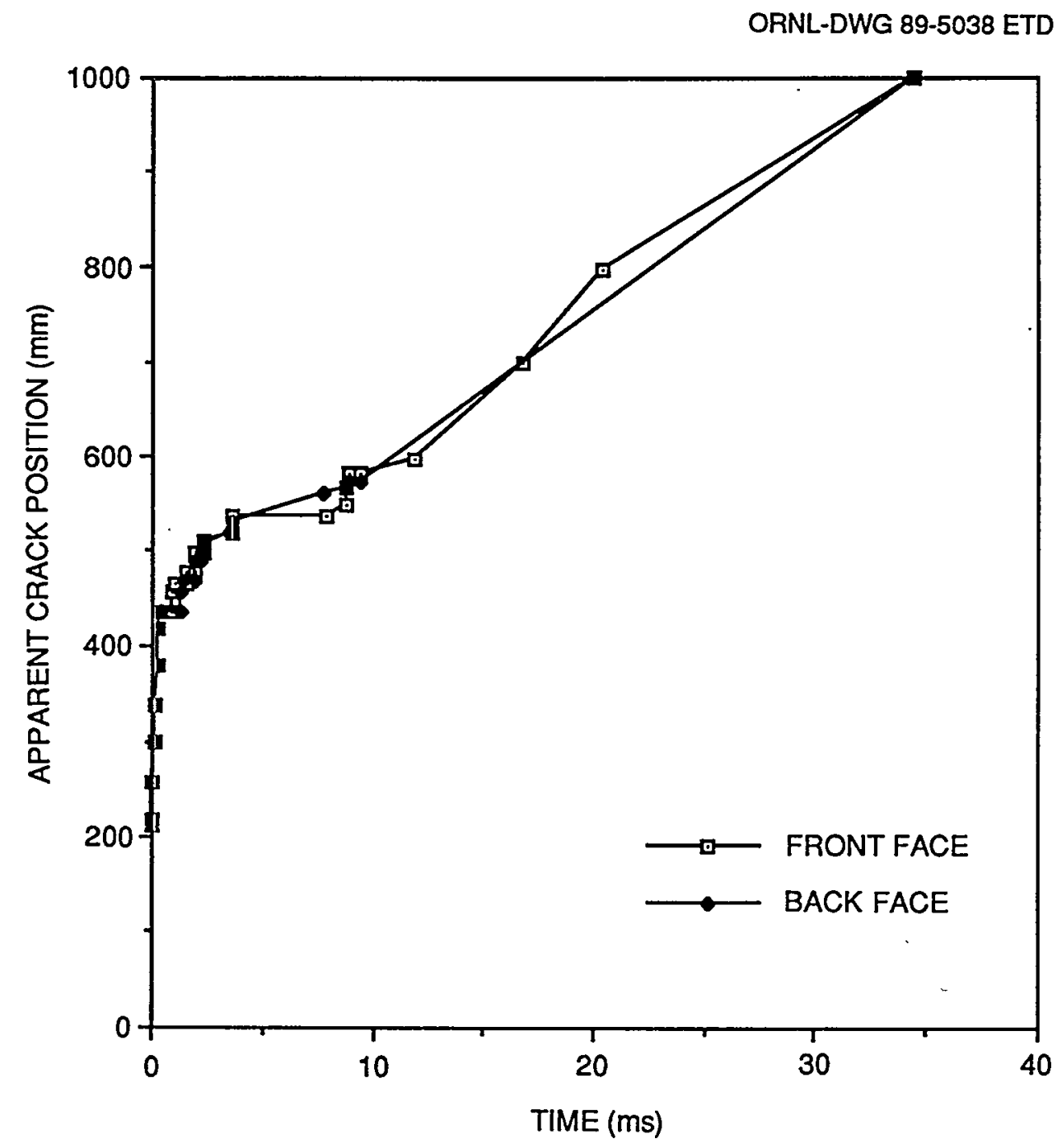

Fig. 5.14. Strain-gage-derived crack-front position vs time: test WP-2.2. 
ORNL-DWG 90M-3602 ETD

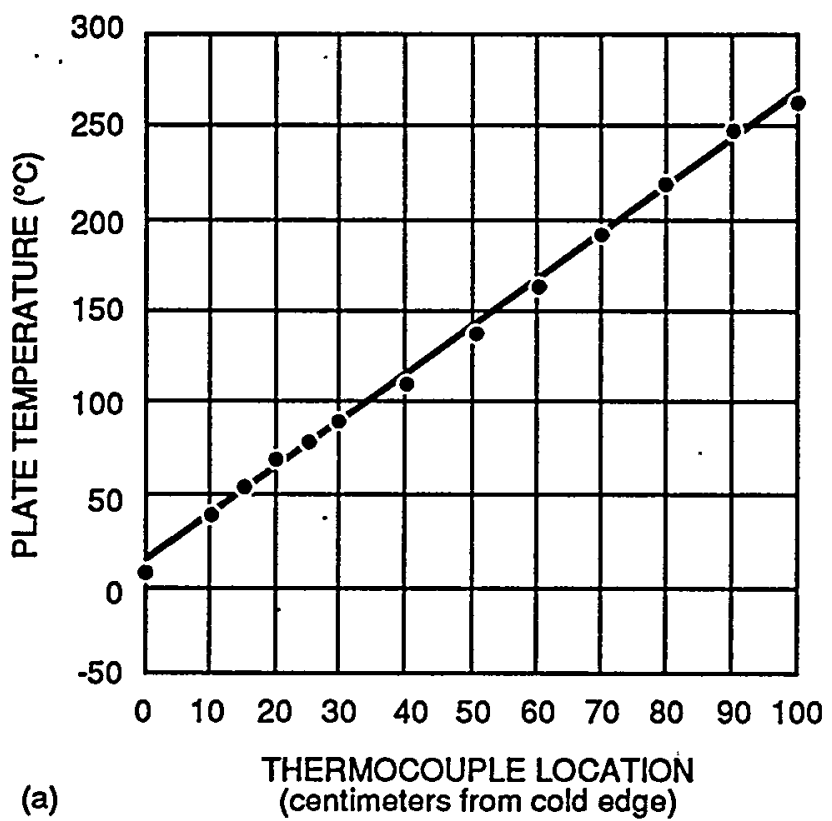

TEMPERATURE $\left({ }^{\circ} \mathrm{C}\right)$ CENTIMETERS REAL IDEAL

$\begin{array}{rrr}0 & 5 & 15 \\ 10 & 37 & 39 \\ 15 & 51 & 52 \\ 15 & 51 & 52 \\ 20 & 66 & 64 \\ 20 & 68 & 64 \\ 20 & 66 & 64 \\ 25 & 78 & 77 \\ 25 & 78 & 77 \\ 30 & 89 & 89 \\ 40 & 112 & 114 \\ 40 & 112 & 114 \\ 50 & 136 & 140 \\ 60 & 160 & 164 \\ 60 & 161 & 164 \\ 70 & 188 & 189 \\ 80 & 214 & 214 \\ 80 & 215 & 214 \\ 90 & 242 & 239 \\ 100 & 258 & 265\end{array}$

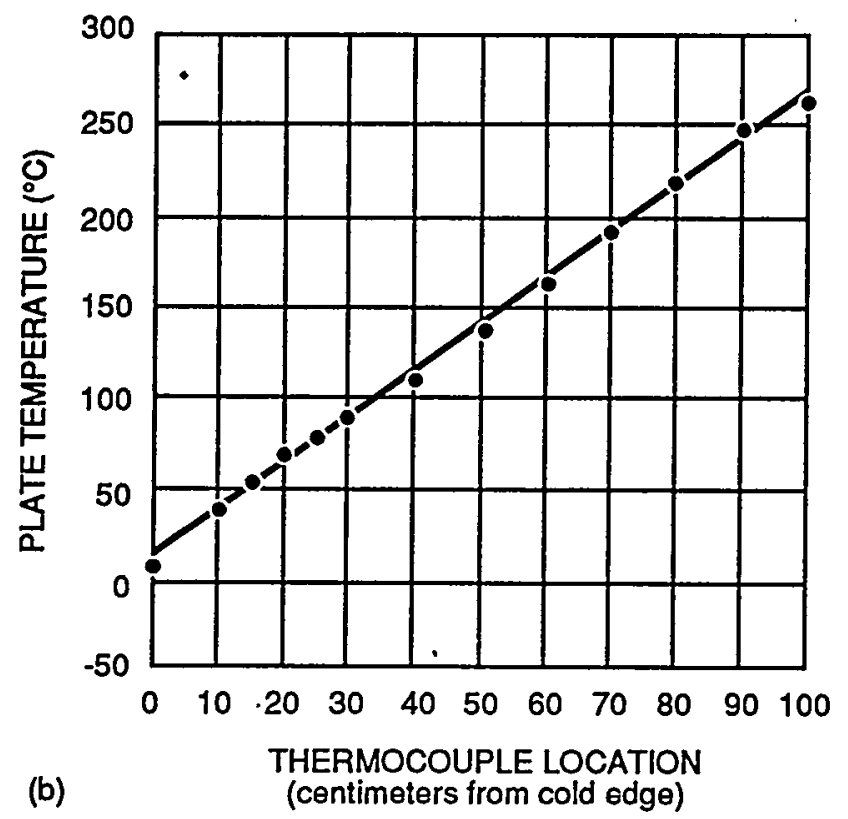

TEMPERATURE $\left({ }^{\circ} \mathrm{C}\right)$ CENTIMETERS REAL IDEAL

\begin{tabular}{|c|c|}
\hline $\begin{array}{r}0 \\
10 \\
15 \\
15 \\
20 \\
20 \\
20 \\
25 \\
25 \\
30 \\
40 \\
40 \\
50 \\
60 \\
60 \\
70 \\
80 \\
80 \\
90 \\
100\end{array}$ & $\begin{array}{r}4 \\
37 \\
51 \\
51 \\
65 \\
67 \\
66 \\
77 \\
77 \\
88 \\
111 \\
112 \\
136 \\
160 \\
160 \\
188 \\
214 \\
214 \\
242 \\
255\end{array}$ \\
\hline
\end{tabular}

Fig. 5.15. Actual and ideal temperature distributions across specimen width (a) at start of test and (b) a few seconds before fracture: test WP-2.3. 


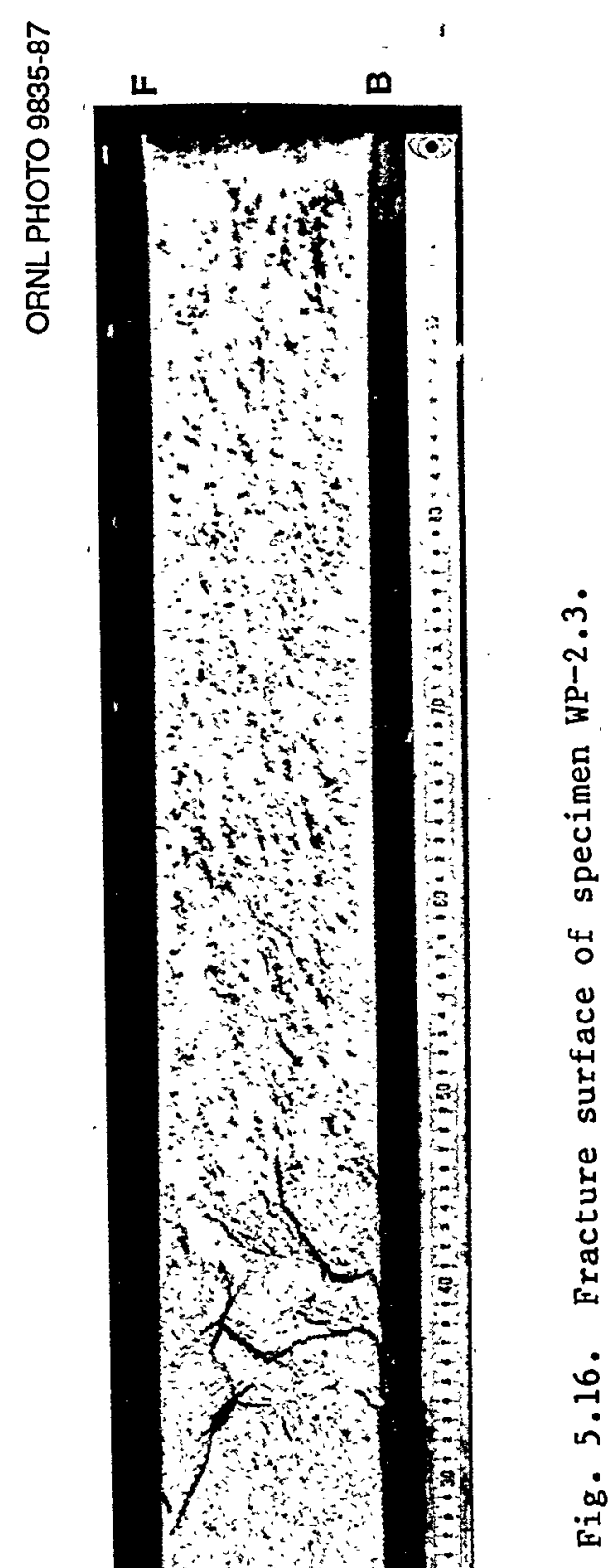


ORNL-PHOTO $9836-87$

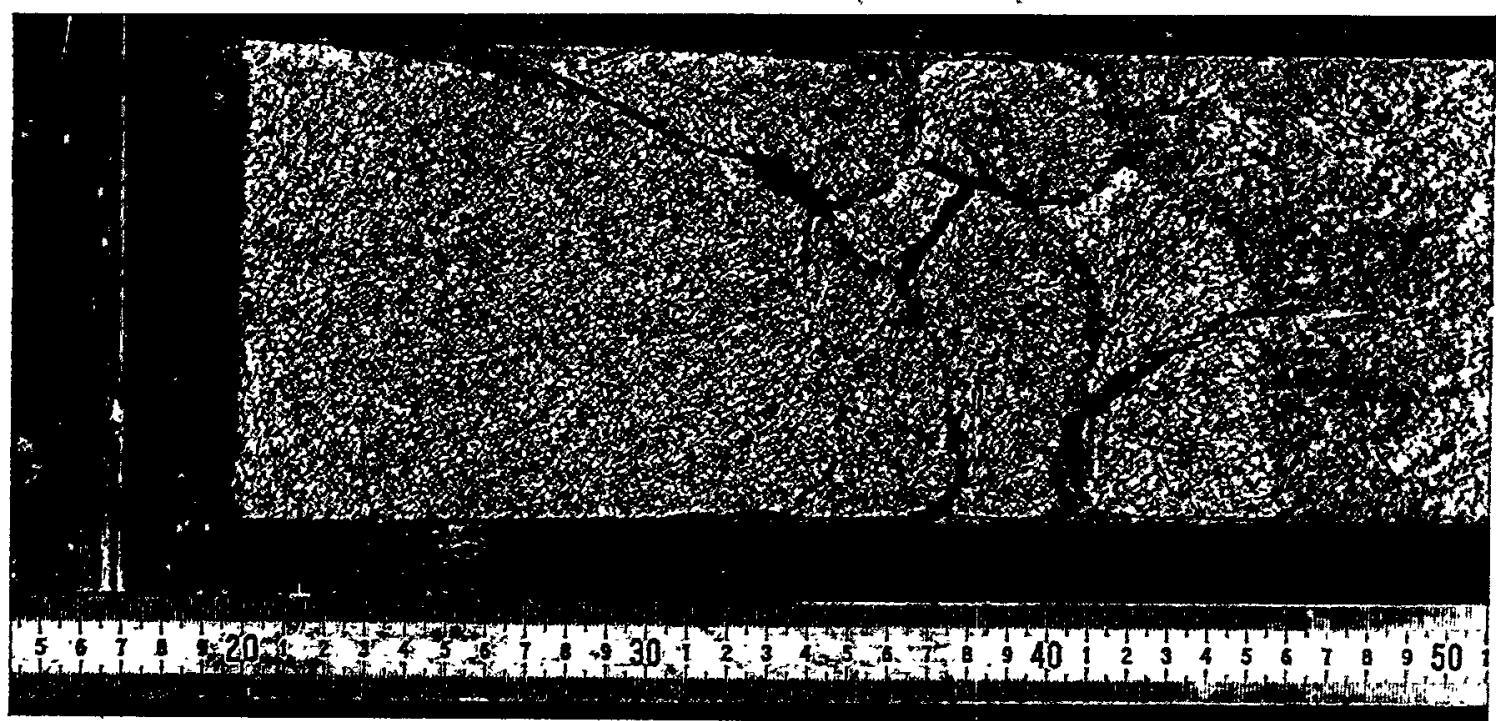

(a)

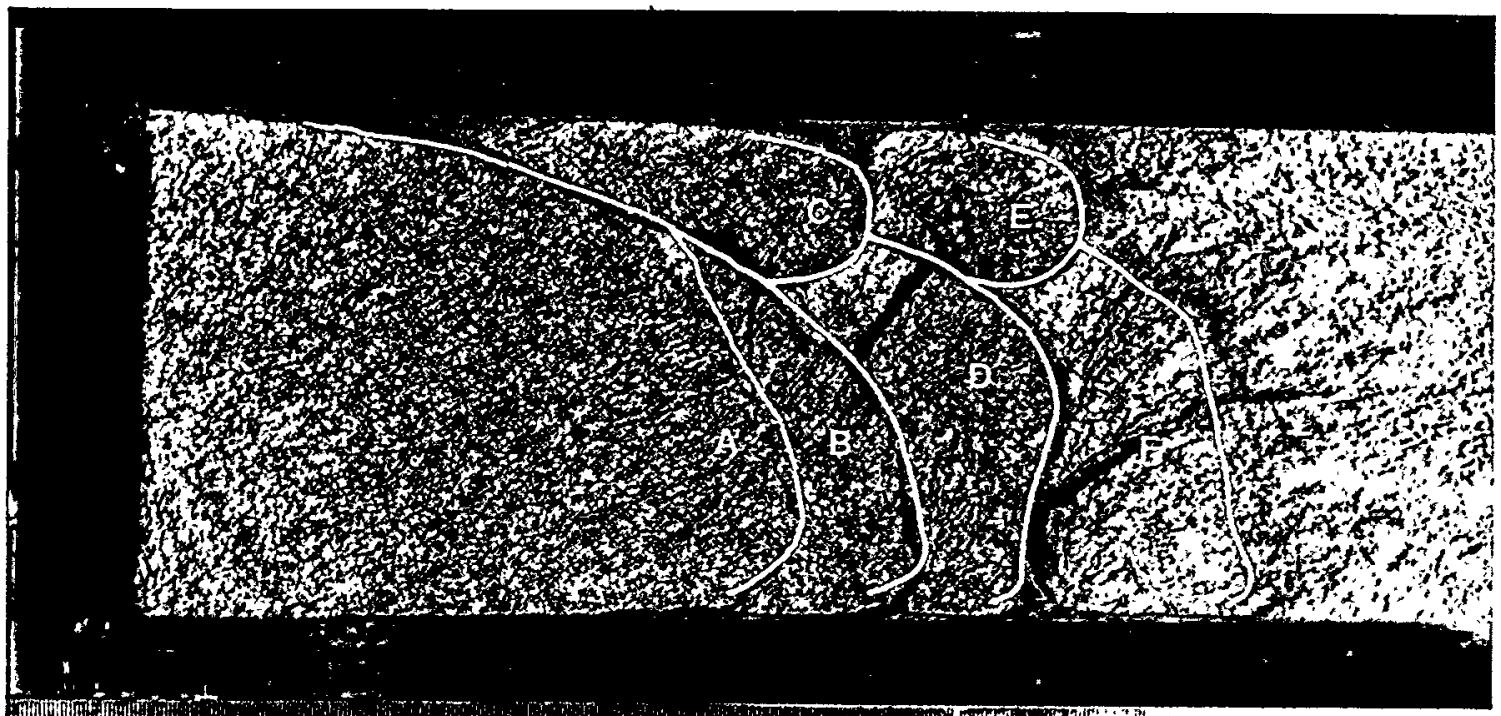

(5)

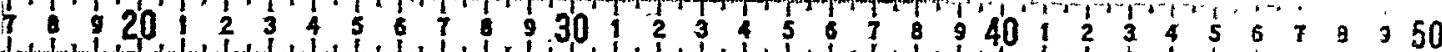

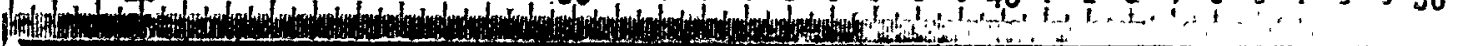

(b)

Fig. 5.17. Close-up of cleavage and loss-of-cleavage regions (a) without cleavage run-arrest events highlighted, and (b) with cleavage run-arrest events highlighted: test WP-2.3. 


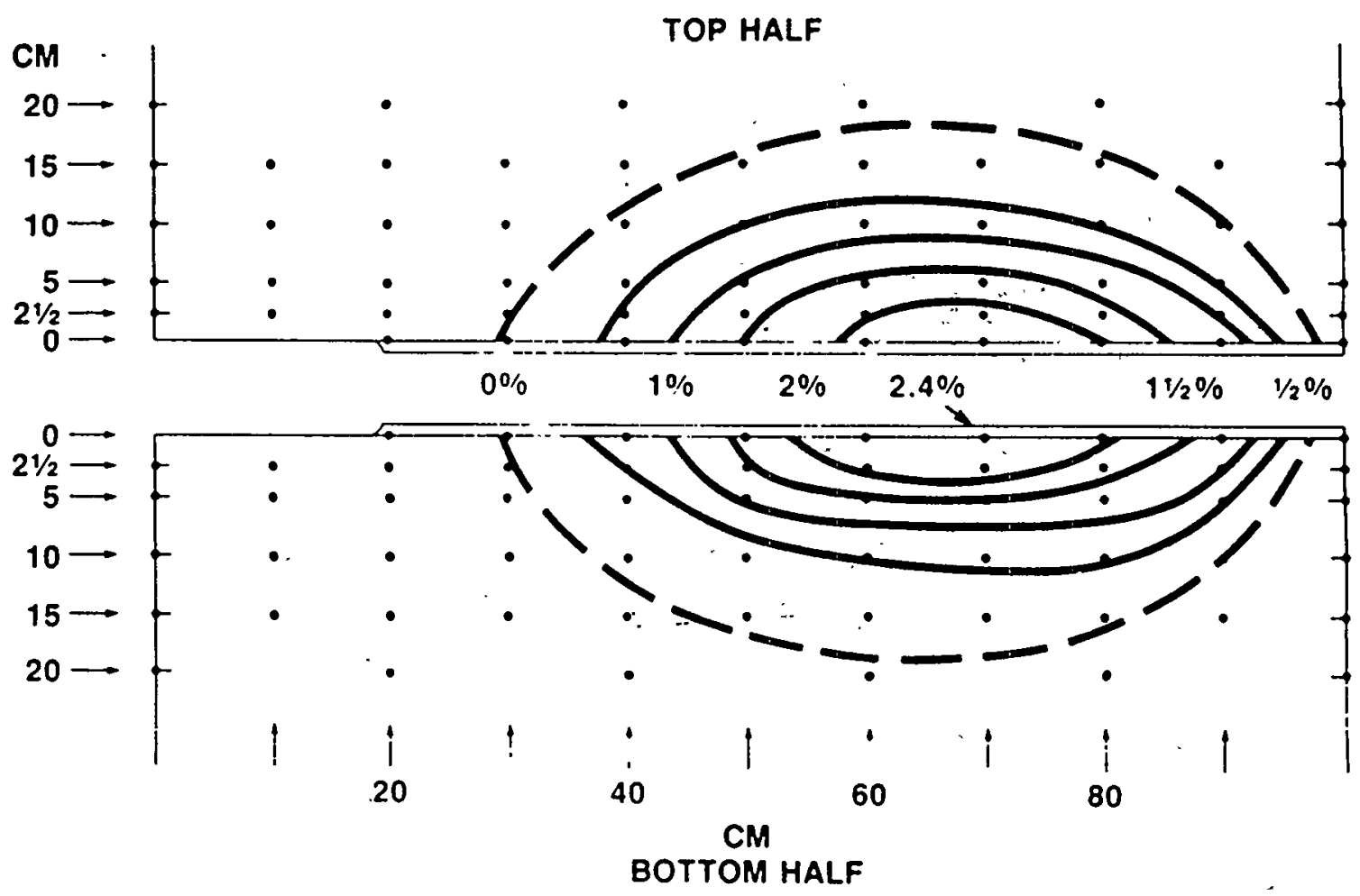

Fig. 5.18. Reduction-in-thickness contour map of specimen WP-2.3. 
Table 5.4. Crack position vs time and velocity: test WP-2.3

\begin{tabular}{|c|c|c|c|}
\hline Indicator ${ }^{a}$ & $\begin{array}{l}\text { Position } \\
\quad(\mathrm{mm})\end{array}$ & $\begin{array}{l}\text { Time } \\
\text { (ms) }\end{array}$ & $\begin{array}{l}\text { Velocityb } \\
(\mathrm{m} / \mathrm{s})\end{array}$ \\
\hline \multicolumn{4}{|c|}{ Front-face measurements } \\
\hline$a_{0}$ & 200 & 0 & \\
\hline SG1 & 243 & 0.059 & 729 \\
\hline SG2 & 268 & 0.074 & 1667 \\
\hline $\begin{array}{l}\text { Arrest A } \\
\text { Reinitiation }\end{array}$ & $\begin{array}{l}275 \\
275\end{array}$ & $\begin{array}{r}0.222 \\
12.489\end{array}$ & 47 \\
\hline SG3 & $\quad 308$ & 12.574 & 388 \\
\hline $\begin{array}{l}\text { Arrest } \mathrm{C} \\
\text { Reinitiation }\end{array}$ & $\begin{array}{l}345 \\
345\end{array}$ & $\begin{array}{l}12.749 \\
37.344\end{array}$ & 211 \\
\hline SG4 & 348 & 37.364 & 150 \\
\hline SG5 & 388 & 37.384 & 2000 \\
\hline $\begin{array}{l}\text { Arrest E } \\
\text { Reinitiation }\end{array}$ & $\begin{array}{l}400 \\
400\end{array}$ & $\begin{array}{l}37.524 \\
43.324\end{array}$ & 86 \\
\hline SG6 & 428 & 136 & 0.3 \\
\hline SG7 & 468 & 812 & 0.06 \\
\hline SG8 & 508 & 856 & 0.9 \\
\hline SG9 & 558 & 875 & 2.6 \\
\hline SG10 & 608 & 882.5 & 6.7 \\
\hline $\mathrm{SGl1}$ & 658 & $(888.5)$ & $(8.3)$ \\
\hline $\mathrm{SG} 12^{\mathrm{C}}$ & 708 & $(892)$ & $(14.3)$ \\
\hline Ligament & (993) & 917.0 & $(11.4)$ \\
\hline End of plate & 1000 & 942.5 & 0.3 \\
\hline
\end{tabular}


Table 5.4 (continued)

\begin{tabular}{|c|c|c|c|}
\hline Indicator ${ }^{a}$ & $\begin{array}{l}\text { Position } \\
\quad(\mathrm{mm})\end{array}$ & $\begin{array}{l}\text { Time } \\
\text { (ms) }\end{array}$ & $\begin{array}{l}\text { Velocity } \\
(\mathrm{m} / \mathrm{s})\end{array}$ \\
\hline \multicolumn{4}{|c|}{ Back-face measurements } \\
\hline$a_{0}$ & 200 & 0 & 1700 \\
\hline SG13 & 268 & 0.040 & 541 \\
\hline SG14 & 308 & 0.114 & 327 \\
\hline $\begin{array}{l}\text { Arrest A } \\
\text { Reinitiation }\end{array}$ & $\begin{array}{l}340 \\
340\end{array}$ & $\begin{array}{l}0.212 \\
3.160\end{array}$ & \\
\hline SG15 & 348 & 3.242 & $\begin{array}{r}98 \\
338\end{array}$ \\
\hline $\begin{array}{l}\text { Arrest B } \\
\text { Reinitiation }\end{array}$ & $\begin{array}{l}375 \\
375\end{array}$ & $\begin{array}{r}3.322 \\
13.004\end{array}$ & \\
\hline SG16 & 388 & $\begin{array}{l}\text { Not } \\
\text { working }\end{array}$ & 314 \\
\hline $\begin{array}{l}\text { Arrest D } \\
\text { Reinitiation }\end{array}$ & $\begin{array}{l}397 \\
397\end{array}$ & $\begin{array}{l}13.074 \\
38.464\end{array}$ & \\
\hline SG17 & 428 & $\begin{array}{l}\text { Too } \\
\text { noisy }\end{array}$ & 500 \\
\hline $\begin{array}{l}\text { Arrest } F \\
\text { Reinitiation }\end{array}$ & $\begin{array}{l}457 \\
457\end{array}$ & $\begin{array}{l}38.584 \\
44.304\end{array}$ & 0.02 \\
\hline SG18 & 468 & 688 & 0.26 \\
\hline SG19 & 508 & 842 & 2.17 \\
\hline SG20 & 558 & 865 & 2.94 \\
\hline SG21 & 608 & 882 & 6 \\
\hline SG22 & 650 & 889 & 12 \\
\hline Ligament & 993 & 917 & 0.27 \\
\hline End of plate & 1000 & 942.5 & \\
\hline
\end{tabular}

$a_{\text {These }}$ strain-gage positions are all reduced by $32 \mathrm{~mm}$ from the actual gage position because the peak strain occurs at an angle of $72^{\circ}$ in front of the crack tip.

$b_{\text {Velocity }}$ is an average calculated velocity for crack propagation.

${ }^{c}$ Gage broke before peak formed. 

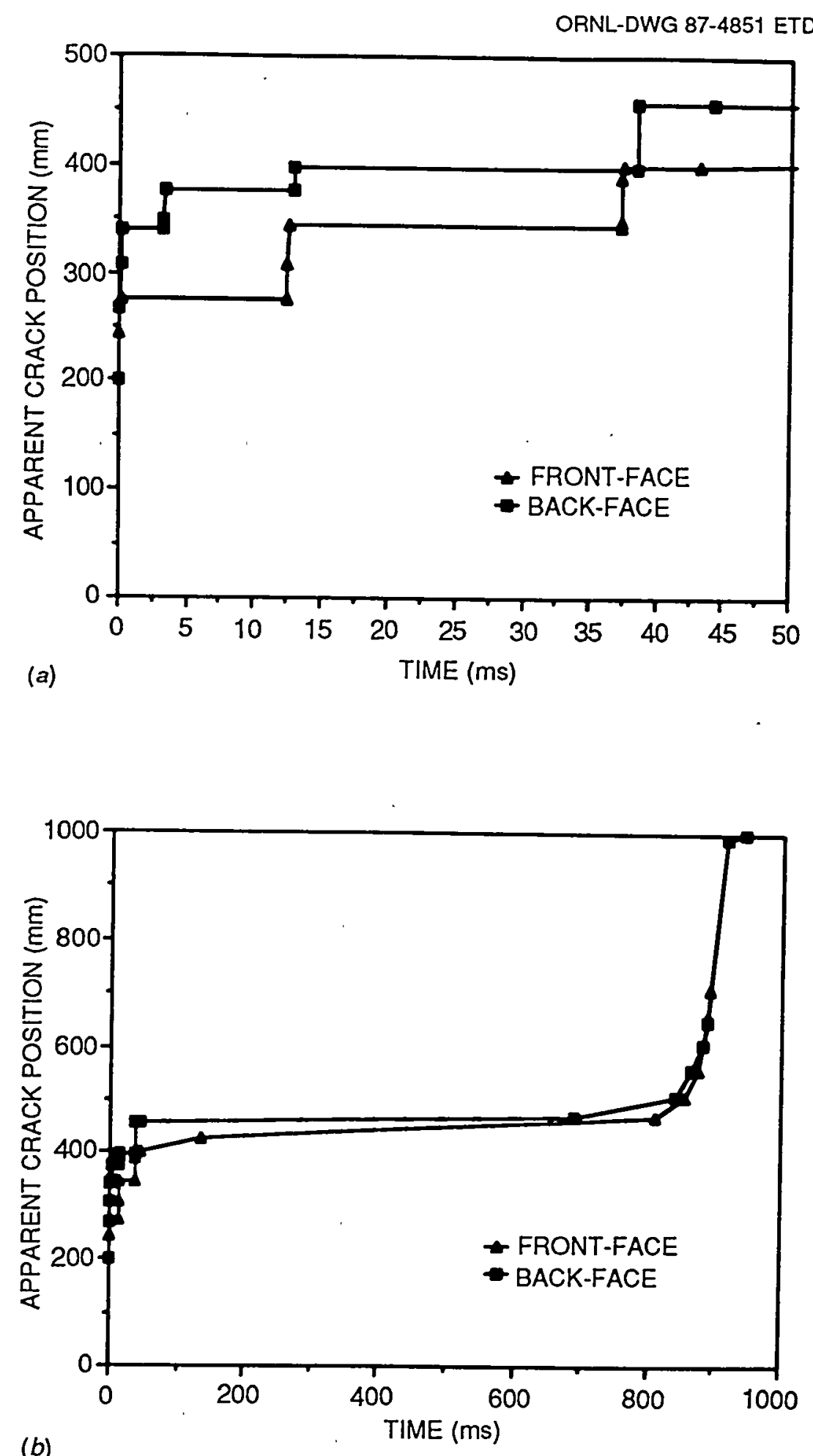

Fig. 5.19. Strain-gage-derived crack-front position vs time for (a) results for first $50 \mathrm{~ms}$ of test and (b) results for entire $\sim 950 \mathrm{~ms}$ of test: test WP-2.3. 
Fig. 5.19(b). As presented in this plot, the crack-front advance across the plate width did not become fairly uniform until the crack advance had reached an $a / w \sim 0.6$, while ductile tearing was occurring.

\subsection{TEST WP-2.4}

Loading of test specimen WP-2.4 at $11 \mathrm{kN} / \mathrm{s}$ was initiated after obtaining a satisfactory thermal gradient (Fig. 5.20). At $7.52 \mathrm{MN}$, or $\sim 85 \%$ of the final peak load, a pop-in event occurred. When the load reached $8.85 \mathrm{MN}$ (Fig. 5.21), the fracture event began and lasted about $90 \mathrm{~ms}$ (crack run-arrest events plus ductile tearing). The strain-gage records and fracture surface indicated that up to seven crack run-arrest events had occurred over an $\approx 29-\mathrm{ms}$ interval before the onset of tearing. A smal1 (7-mm) ligament remained intact after the main fracture events. Complete separation of the plate was achieved by applying a $254-\mathrm{kN}$ load. With the exception of strain gage 6 and the top accelerometer, all gages functioned during the test. Some data, however, from strain gages 19-22, were lost late in the test because of saturation of amplifiers.

An overall view and a close-up of the fracture surface of specimen WP-2.4 is shown in Fig. 5.22. Examination of the fracture surface in the chevron region (Fig. 5.23) revealed that a crack pop-in had occurred to a crack depth of $\sim 251 \mathrm{~mm}$ before initiation of the main crack runarrest events. This pop-in is substantiated by examining records for strain gages 1-3 on the front face of the specimen and strain gages 13 and 14 on the back face of the specimen, which all show a sudden increase in strain at $\sim 500 \mathrm{~s}$ into the test (Fig. 5.24). Following the sudden increase in strain, each of these gages exhibited an increase in strain rate even though no change in loading rate had occurred. (This suggests that the crack had suddenly advanced or popped-in.) As noted in Fig. 5.24, the strain and strain rate increases were less pronounced for the front-face gages than for the back-face gages, suggesting that the crack advance was less at the front-face than at the back-face of the specimen.

Examination of the fracture surface indicates that initiation of crack growth in cleavage was in the plane of the side grooves, but as it extended, it gradually deviated from this plane. By the time the crack had reached the depth at which tearing instability initiated, the crack was $8 \mathrm{~mm}$ below the plane of the side grooves. Once fibrous fracture took over, the crack returned to the side-grooved plane. Reduction-inthickness contours surrounding the crack plane are shown in Fig. 5.25.

Examination of the strain-gage records (Appendix A) and the fracture surface were also used to deduce the crack length (position of the crack front) during the fracture process, and the results are presented in Table 5.5. In the table the strain gage positions have been modified from those shown in Fig. 4.8(d) to account for the fact that the peak strain occurs at an angle of $72^{\circ}$ in front of the crack tip. Also, the crack lengths listed in the table are averages of the quarterthickness crack lengths and the crack lengths at the side groove. Plots of the crack-front position vs time, derived from the front-face and back-face strain-gage results, are presented in Fig. 5.26. 


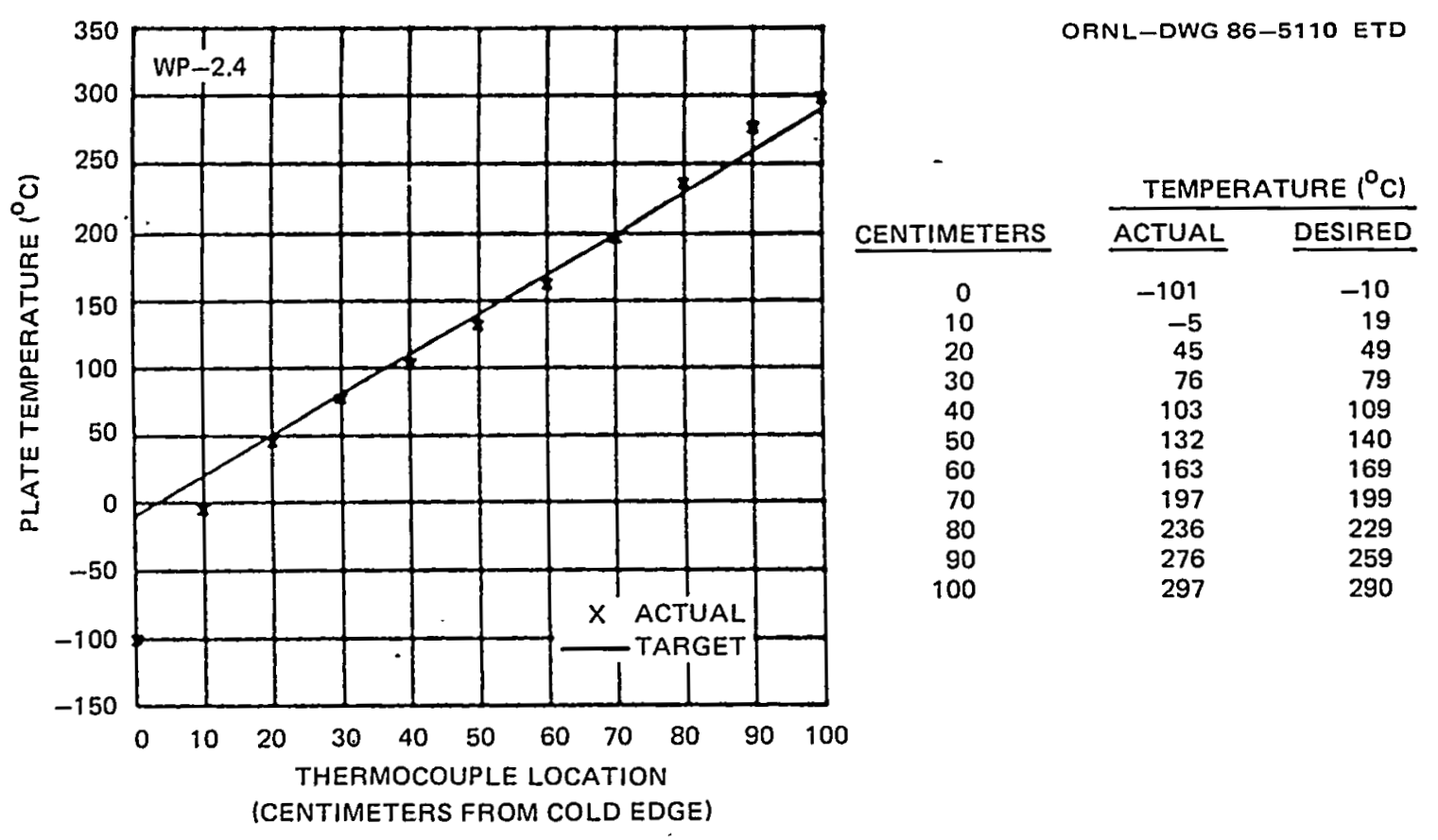

Fig. 5.20. Actual and ideal temperature distributions across specimen width at approximate time of specimen fracture: test WP-2.4.

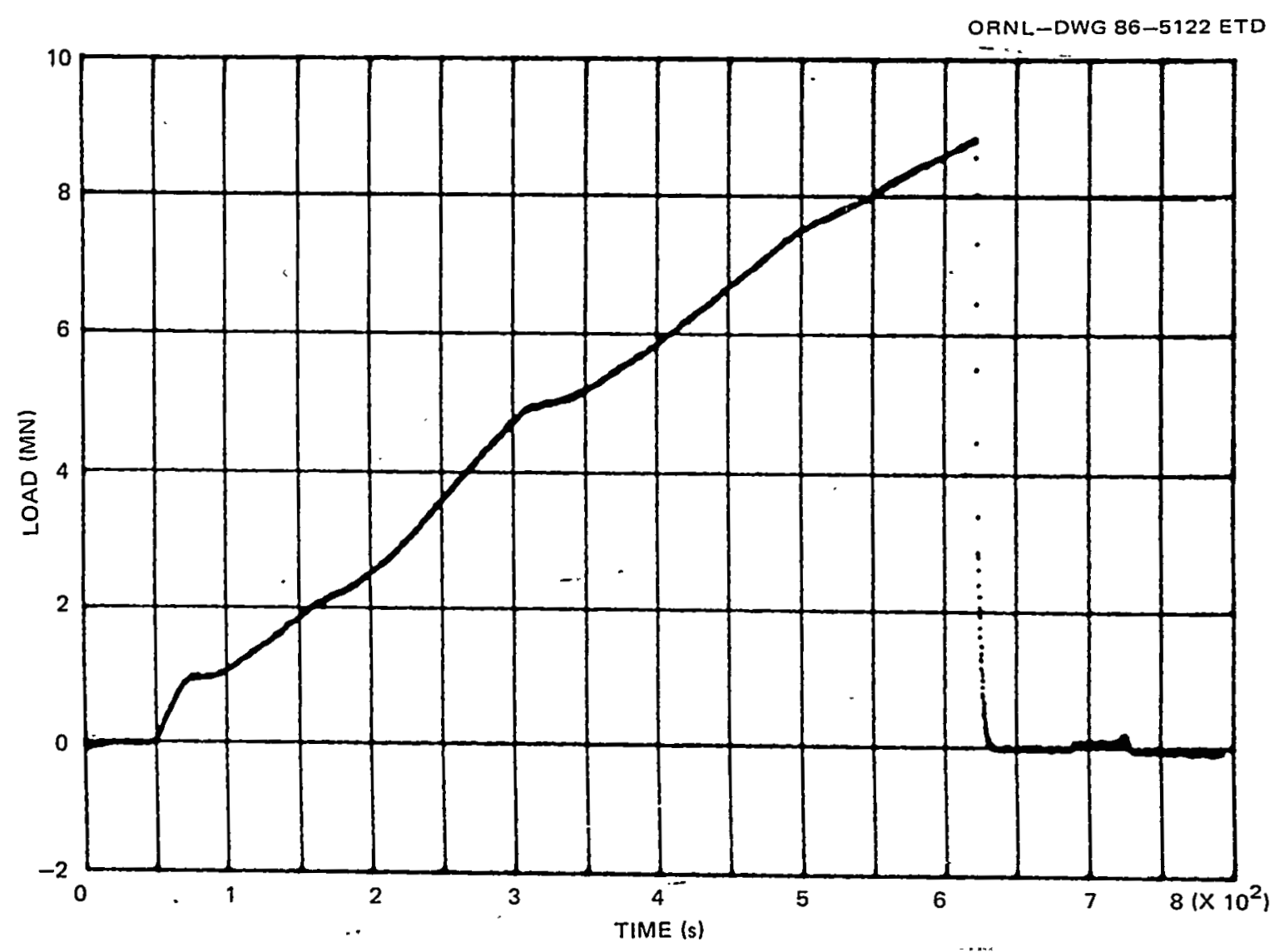

Fig. 5.21. Load history for test WP-2.4. 
0
0
1
$\frac{1}{0}$
N
0
$\frac{1}{5}$
$\frac{1}{1}$
$\frac{1}{0}$
1
$\frac{1}{2}$
0
0

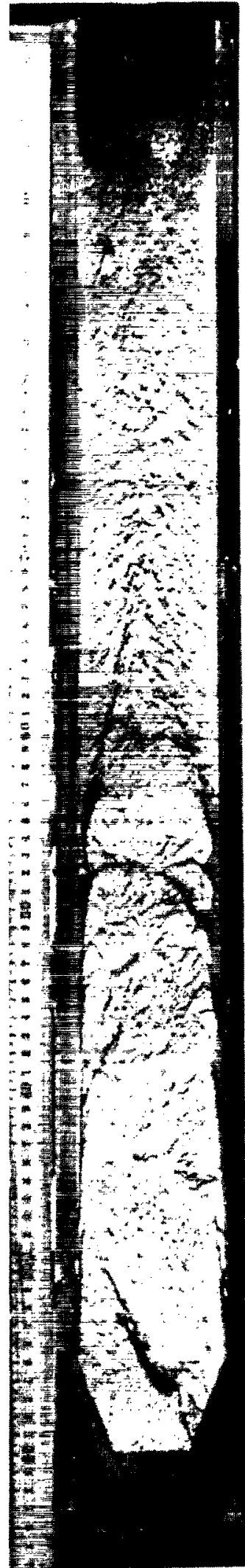

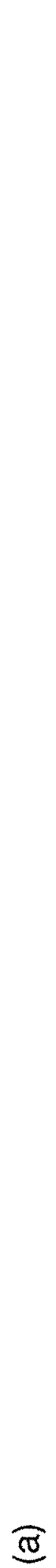

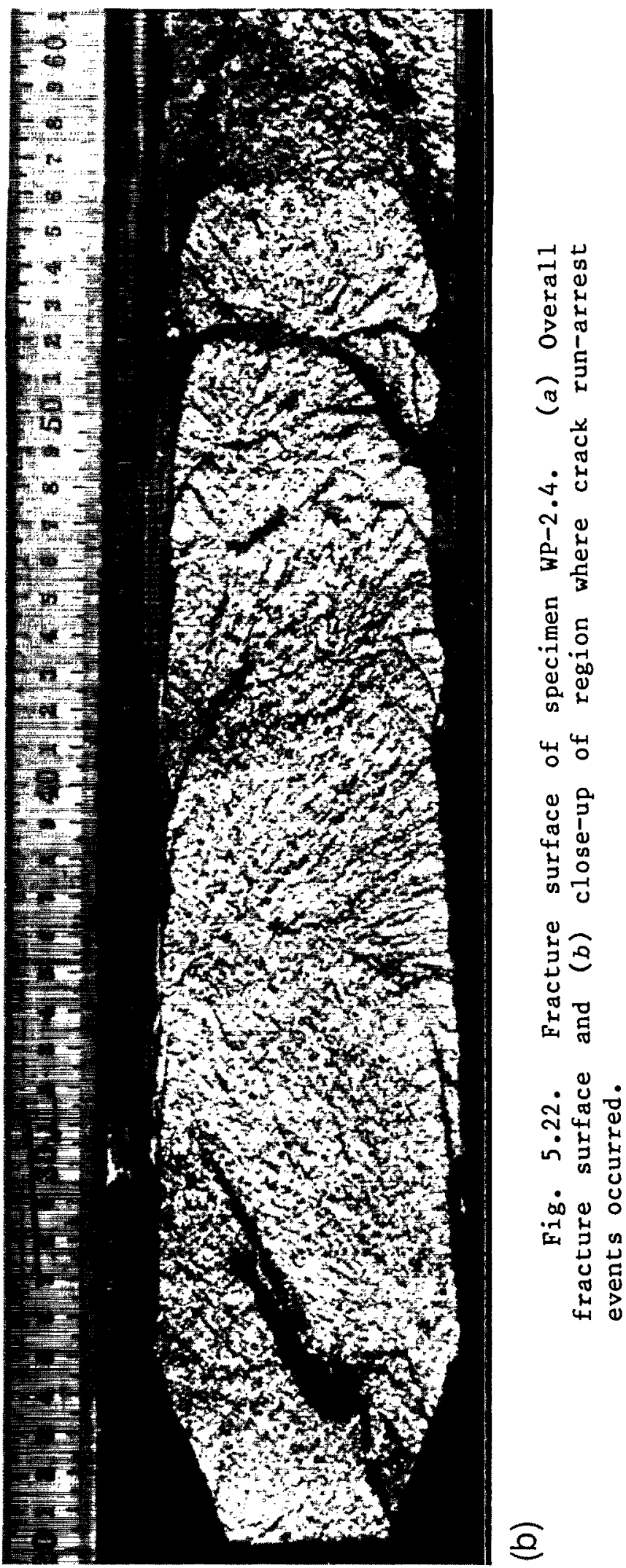




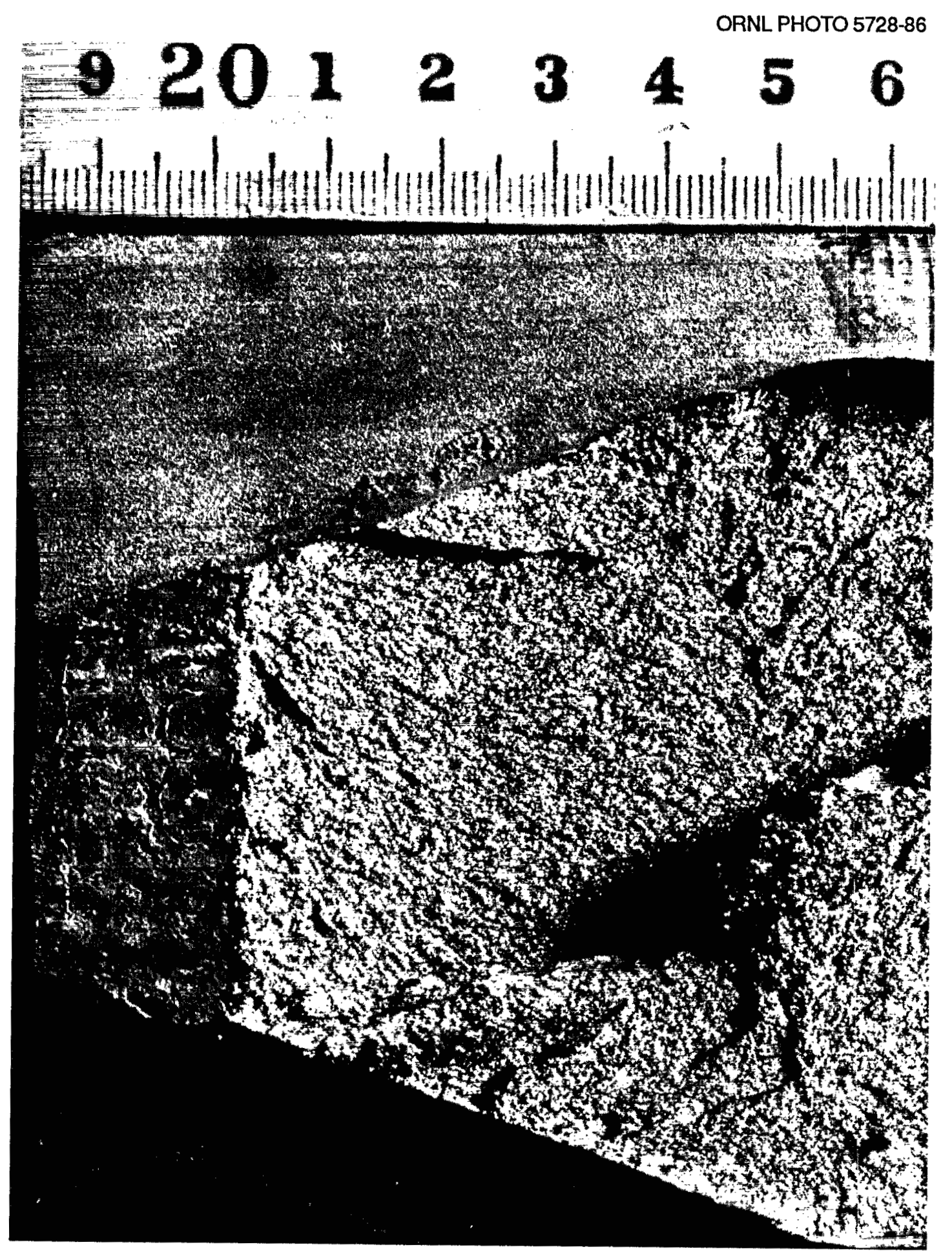

Fig. 5.23. Close-up of initial flaw and region of pop-in: test WP-2.4. 
ORNL-DWG 86-5112A ETD

$\left(\times 10^{-3}\right)$
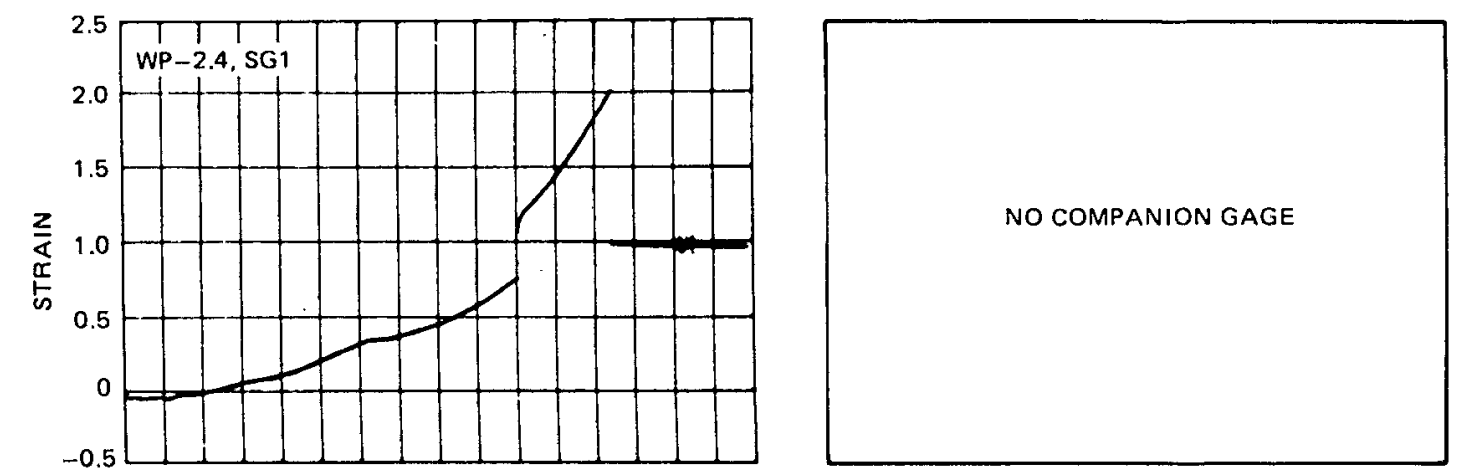

$\left(\times 10^{-3}\right)$
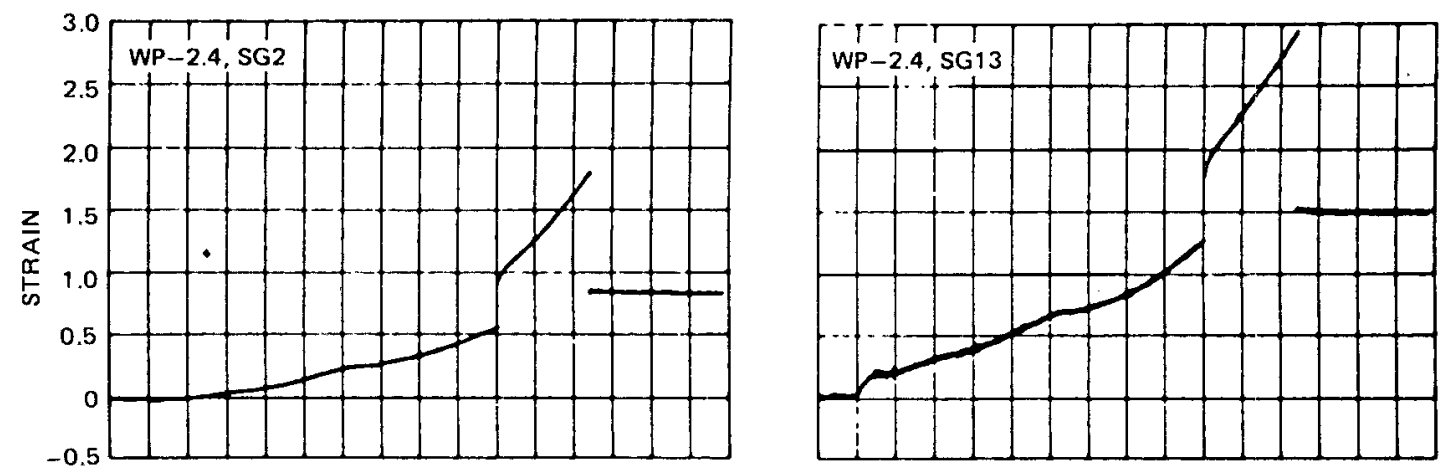

$\left(\times 10^{-3}\right)$
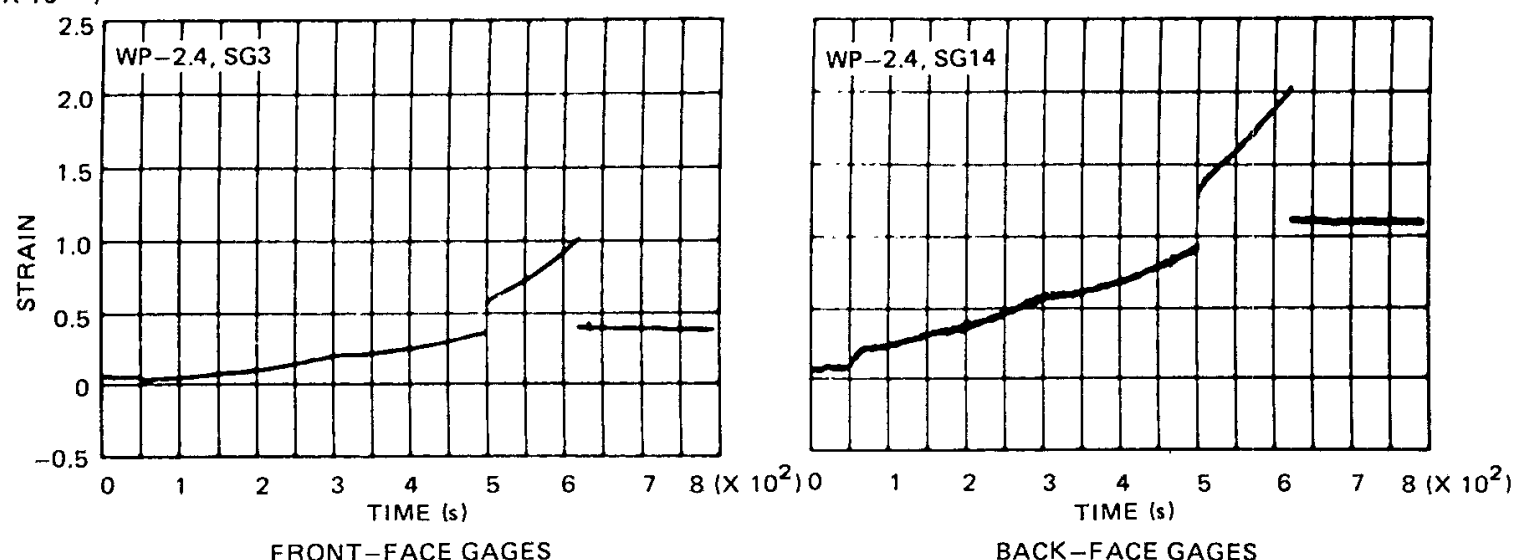

Fig. 5.24. Pop-in detected by strain gages $1-3$ on plate front face and 13 and 14 on plate back face: test WP-2.4. 


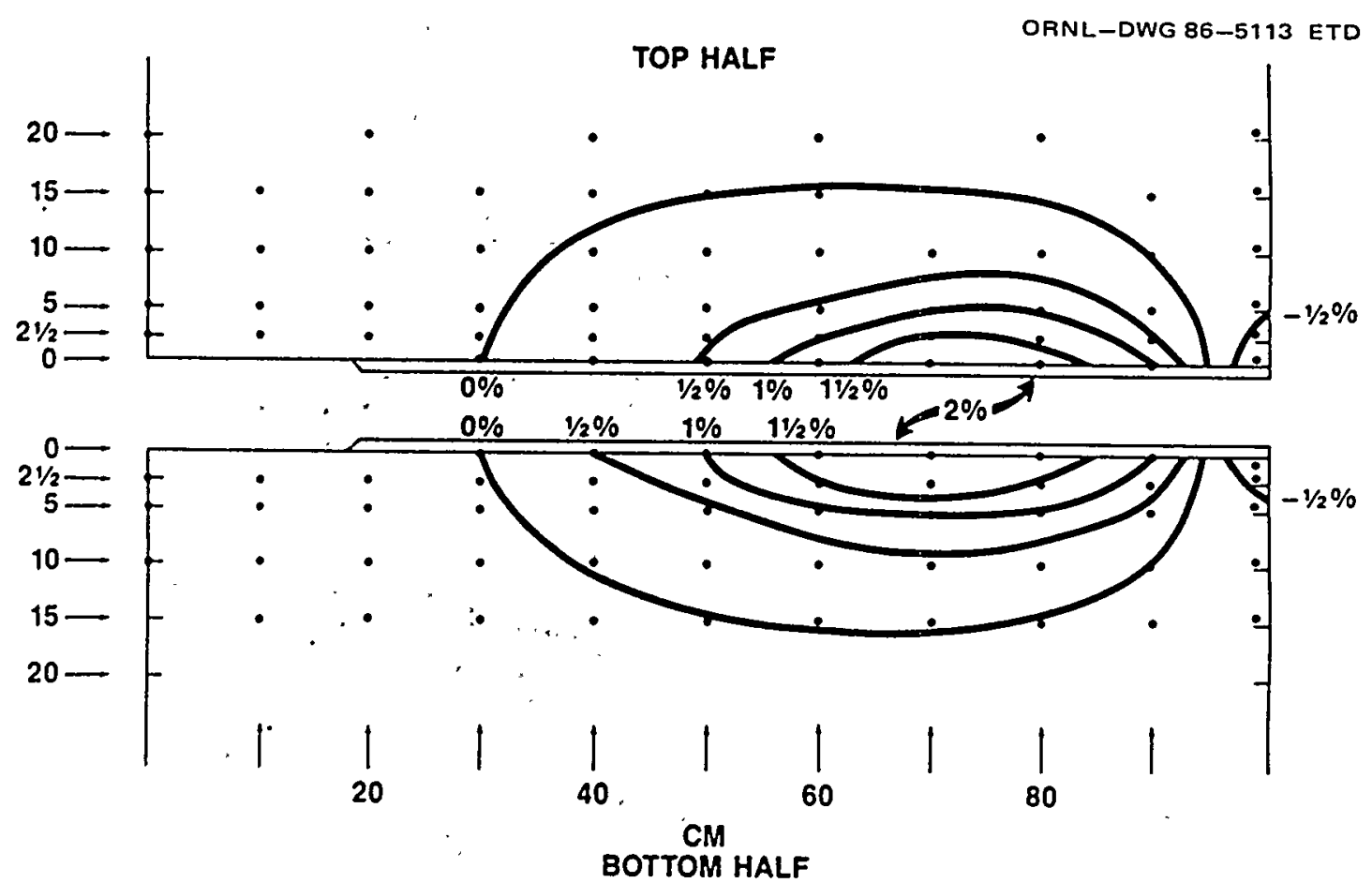

Fig. 5.25. Reduction-in-thickness contour map of specimen WP-2.4.

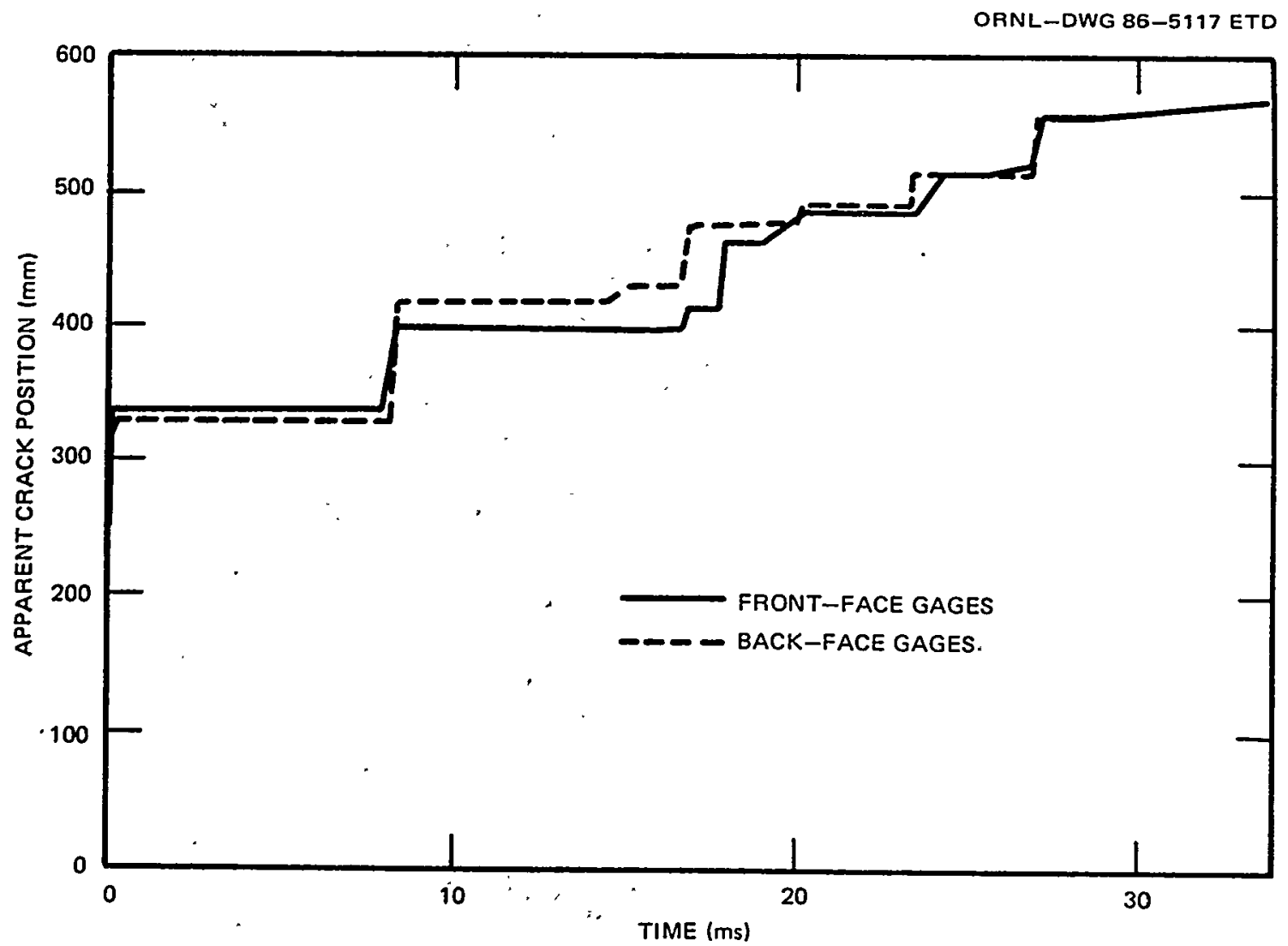

Fig. 5.26. Strain-gage-derived crack-front position vs time: test WP-2.4. 
Table 5.5. Crack position vs time and velocity: test WP-2.4

\begin{tabular}{|c|c|c|c|}
\hline Indicator ${ }^{a}$ & $\begin{array}{l}\text { Position } \\
\quad(\mathrm{mm})\end{array}$ & $\begin{array}{l}\text { Time } \\
\text { (ms) }\end{array}$ & $\begin{array}{c}\text { Velocity } \\
(\mathrm{m} / \mathrm{s})\end{array}$ \\
\hline \multicolumn{4}{|c|}{ Front-face measurements } \\
\hline Pop-in (Arrest A) & 251 & 0 & \\
\hline SGI & 254 & 0 & 1250 \\
\hline SG2 & 279 & 0.02 & 667 \\
\hline SG3 & 319 & 0.08 & 950 \\
\hline $\begin{array}{l}\text { Arrest B } \\
\text { Reinitiation }\end{array}$ & $\begin{array}{l}338 \\
338\end{array}$ & $\begin{array}{l}0.10 \\
8.00\end{array}$ & \\
\hline 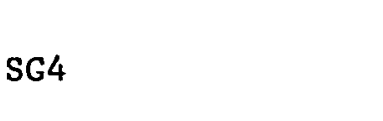 & 359 & 8.23 & $\begin{array}{r}91 \\
422\end{array}$ \\
\hline $\begin{array}{l}\text { Arrest C } \\
\text { Reinitiation }\end{array}$ & $\begin{array}{l}397 \\
397\end{array}$ & $\begin{array}{r}8.32 \\
15.82\end{array}$ & \\
\hline 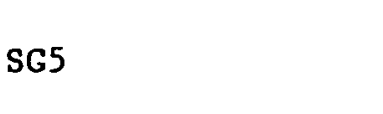 & 399 & 16.70 & 2 \\
\hline $\begin{array}{l}\text { Arrest D } \\
\text { Reinitiation }\end{array}$ & $\begin{array}{l}413 \\
413\end{array}$ & $\begin{array}{l}16.86 \\
17.80\end{array}$ & \\
\hline $\begin{array}{l}\text { Arrest E } \\
\text { Reinitiation }\end{array}$ & $\begin{array}{l}462 \\
462\end{array}$ & $\begin{array}{l}17.96 \\
19.08\end{array}$ & 306 \\
\hline SG7 & 479 & 20.12 & 16 \\
\hline $\begin{array}{l}\text { Arrest F } \\
\text { Reinitiation }\end{array}$ & $\begin{array}{l}484 \\
484\end{array}$ & $\begin{array}{l}20.40 \\
23.46\end{array}$ & 18 \\
\hline & & & 33 \\
\hline $\begin{array}{l}\text { Arrest G } \\
\text { Reinitiation }\end{array}$ & $\begin{array}{l}515 \\
515\end{array}$ & $\begin{array}{l}24.40 \\
25.46\end{array}$ & \\
\hline SG8 & 519 & 26.88 & 3 \\
\hline $\begin{array}{l}\text { Arrest } \mathrm{H} \\
\text { Reinitiation }\end{array}$ & $\begin{array}{l}555 \\
555\end{array}$ & $\begin{array}{l}27.32 \\
28.86\end{array}$ & 82 \\
\hline SG9 & 569 & 33.98 & 3 \\
\hline SG10 & 619 & 43.16 & 5 \\
\hline SGll & 669 & 48.62 & 9 \\
\hline $\mathrm{SG} 12$ & 719 & 52.90 & 12 \\
\hline Remaining 1 igament & 993 & 90.46 & 7 \\
\hline
\end{tabular}


Table 5.5 (continued)

\begin{tabular}{|c|c|c|c|}
\hline Indicator ${ }^{a}$ & $\begin{array}{l}\text { Position } \\
\text { (mm) }\end{array}$ & $\begin{array}{l}\text { Time } \\
\text { (ms) }\end{array}$ & $\begin{array}{l}\text { Velocity } \\
(\mathrm{m} / \mathrm{s})\end{array}$ \\
\hline \multicolumn{4}{|c|}{ Back-face measurements } \\
\hline Pop-in (Arrest A) & 251 & 0 & 833 \\
\hline sG13 & 276 & 0.03 & 860 \\
\hline SG14 & 319 & 0.08 & 50 \\
\hline $\begin{array}{l}\text { Arrest B } \\
\text { Reinitiation }\end{array}$ & $\begin{array}{l}329 \\
329\end{array}$ & $\begin{array}{l}0.28 \\
8.24\end{array}$ & \\
\hline SG15 & 359 & 8.28 & 750 \\
\hline SG16 & 399 & 8.33 & 800 \\
\hline $\begin{array}{l}\text { Arrest C } \\
\text { Reinitiation }\end{array}$ & $\begin{array}{l}418 \\
418\end{array}$ & $\begin{array}{r}8.38 \\
14.50\end{array}$ & 380 \\
\hline $\begin{array}{l}\text { Arrest D } \\
\text { Reinitiation }\end{array}$ & $\begin{array}{l}429 \\
429\end{array}$ & $\begin{array}{l}15.12 \\
16.56\end{array}$ & 18 \\
\hline sG17 & 439 & 16.74 & 56 \\
\hline $\begin{array}{l}\text { Arrest E } \\
\text { Reinitiation }\end{array}$ & $\begin{array}{l}474 \\
474\end{array}$ & $\begin{array}{l}16.87 \\
18.02\end{array}$ & 269 \\
\hline $\mathrm{SG} 18$ & 479 & 20.20 & 2 \\
\hline $\begin{array}{l}\text { Arrest F } \\
\text { Reinitiation }\end{array}$ & $\begin{array}{l}490 \\
490\end{array}$ & $\begin{array}{l}20.38 \\
23.43\end{array}$ & 01 \\
\hline $\begin{array}{l}\text { Arrest G } \\
\text { Reinitiation }\end{array}$ & $\begin{array}{l}514 \\
514\end{array}$ & $\begin{array}{l}23.47 \\
27.00\end{array}$ & 600 \\
\hline Arrest $\mathrm{H}$ & 556 & 27.20 & 210 \\
\hline
\end{tabular}

${ }^{2}$ These strain-gage positions have been modified because the peak strain occurs at an angle of $72^{\circ}$ in front of the crack tip. Also, the crack lengths 1 isted are averages of the quarter-thickness crack lengths and the crack lengths at the side groove.

${ }^{b}$ Velocity is an average calculated velocity for crack propagation. 
After examination of the strain-gage records and fracture surfaces to deduce the apparent crack-front position as a function of time, fractographic analyses of specimen WP- 2.4 were conducted. After careful visual examination, the specimen fracture surface was cut into small pieces to allow them to be inserted into a scanning electron microscope (SEM). Figure 5.27 shows the fracture surface and indicates how it was sectioned. Section 1 in the figure was examined to determine if initial loading produced any ductile tearing from the sharp precrack produced by the EB-weld procedure. Figure 5.28 shows a portion of the fracture surface at the end of the EB-weld-generated precrack. The EB weld is on the right in the figure, and the cleavage fracture of the first crack run-arrest event is on the left. Ductile tearing was observed at the end of the welded region, and its width is given on the figure. The average width of the tearing region was $\sim 800 \mu \mathrm{m}$. Figure 5.29 shows a detail of the ductile tearing from the end of the tearing strip, as indicated by the box marked on the bottom of Fig. 5.28. The EB-weld structure can be seen in the upper-right corner of Fig. 5.29(a), and a detail of the tearing is shown in Fig. 5.29(b). The apparent initiation site for the first crack run-arrest event is shown in Fig. 5.30. Figure $5.30(a)$ shows the area marked in the upper box in Fig. 5.28. Visual examination of the ridges on the fracture surface indicate that the fracture initiated in this region. Figure $5.30(b)$ presents a detail from the center of Fig. $5.30(a)$, which shows the ductile tearing that preceeded the cleavage fracture of the crack run-arrest event. Figure $5.30(c)$ presents a detail from the center of Fig. $5.30(b)$, which shows the apparent initiation site from a clump of particles at the center of the figure. Figure $5.30(d)$ presents a detail of the clump of particles.

A section was taken through section 1 in Fig. 5.27, and a surface perpendicular to the fracture was polished and examined metallographically. The heat-affected zone associated with the EB weld was noted, and from the length of this zone, it was determined that the initiation site was located in the base metal rather than in either the weld or its heat-affected zone.

Visual examination of section 2 in Fig. 5.27 suggests that an arrest event had occurred on at least part of the fracture surface of that section. Figure 5.31 shows a view of this fracture surface and reveals that an arrest event did occur. The strip of ductile tearing that is associated with the arrest event and subsequent reloading following arrest, is indicated on the figure. The width of the ductile tearing strip varies, with an average value being $\sim 700 \mu \mathrm{m}$ and a maximum width of $\sim 1000 \mu \mathrm{m}$. The tearing strip bowed out across the surface, was not continuous across the entire specimen width, and was apparent on only about one-third the specimen width. This tearing is believed to reflect reinitiation of crack growth, before cleavage occurs, rather than the arrest process. The apparent cleavage initiation site for the second crack run-arrest event is shown in Fig. 5.32. The initiation site area, shown in Fig. 5.32(a), is located near the bottom of Fig. 5.31 at one end of the strip of ductile tearing. Figure $5.32(b)$ shows a view of the initiation area, located at the center top of Fig. $5.32(a)$. The apparent initiation site is shown in Fig. 5.32(c) and in greater detail in Fig. $5.32(d)$. The cleavage fracture appears to have initiated at a small particle near the center of Fig. $5.32(d)$. 


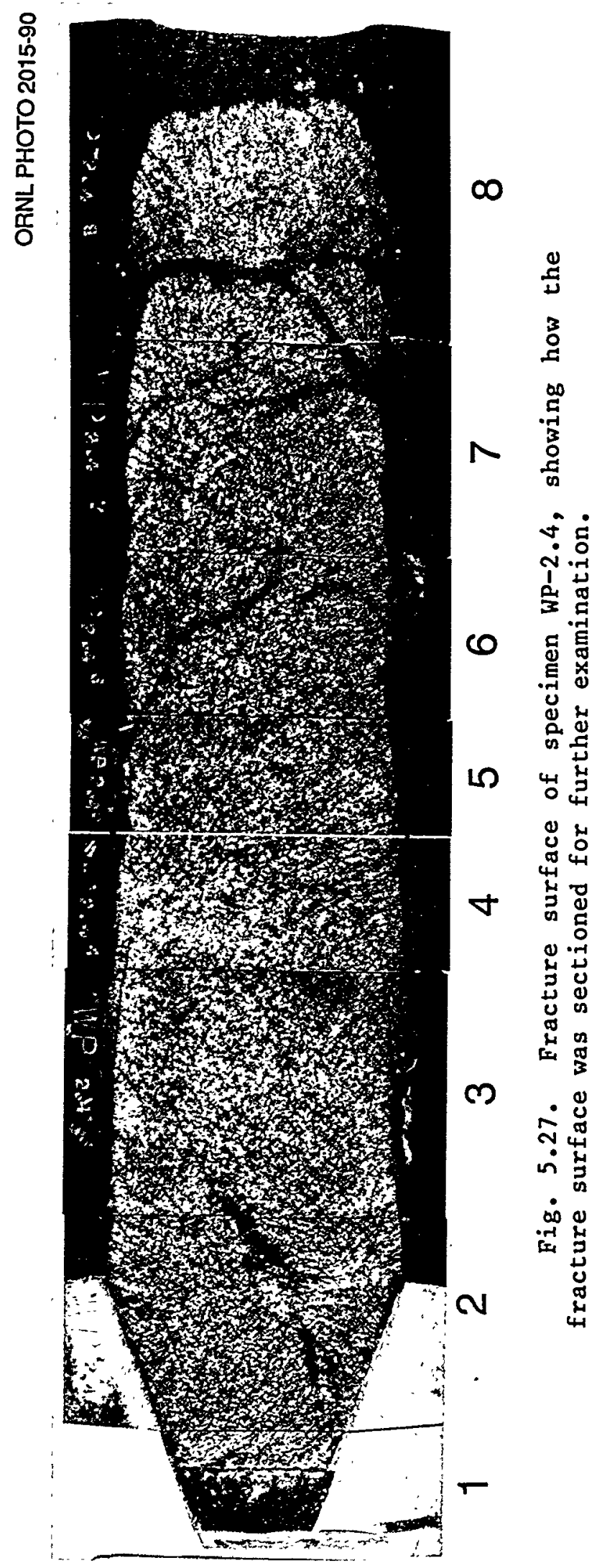


ORNL PHOTO 2016-90

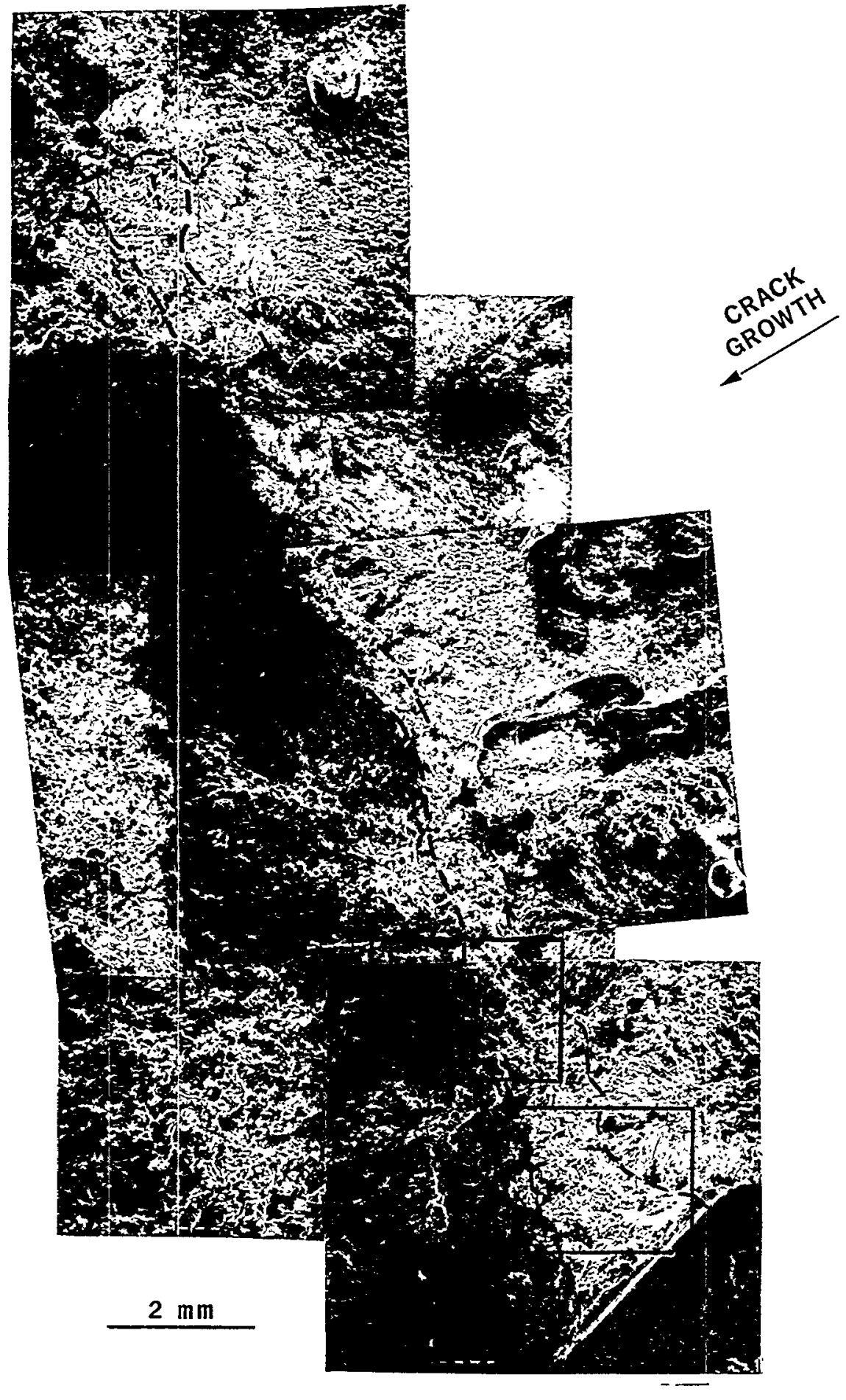

Fig. 5.28. A view of a portion of tip of precrack for specimen WP-2.4, Sect. 1 (Fig. 5.27). 
ORNL PHOTO 2017-90
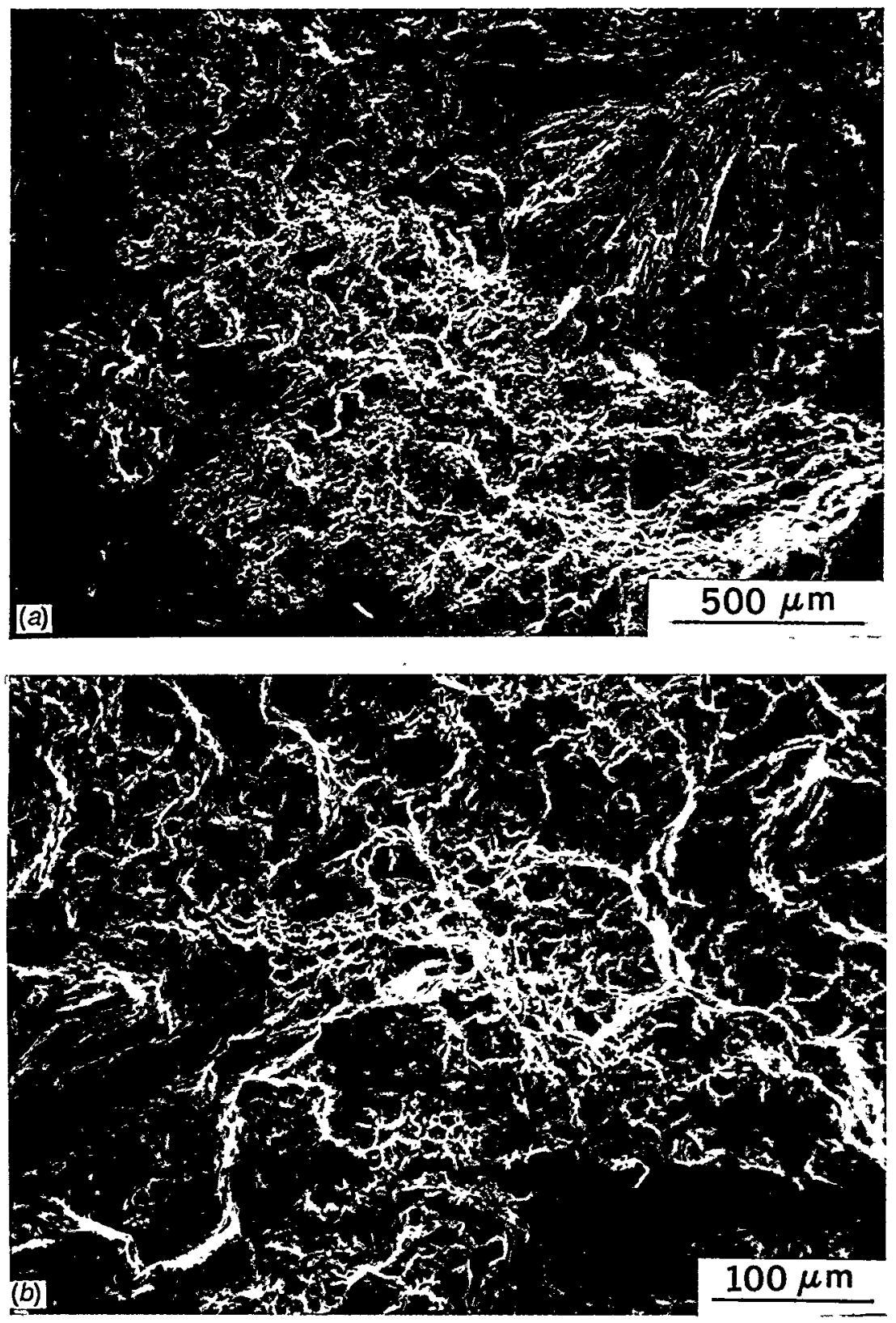

Fig. 5.29. Detail of ductile tearing from EB weld flaw, Sect. 1 (Fig. 5.27). (a) EB-weld structure and (b) detail of tearing. 
ORNL PHOTO 2018-90


Fig. 5.30. Apparent initiation site for first crack run-arrest event, Sect. 1 (Fig. 5.27). (a) Low magnification view of tearing zone shown in upper box in Fig. 5.28 with apparent initiation site indicated by arrow, (b) detail from (a) showing ductile tearing and cleavage fracture, (c) detail of (b) showing initiation at a particle clump, and (d) detail of (c). 
ORNL PHOTO 2019-90

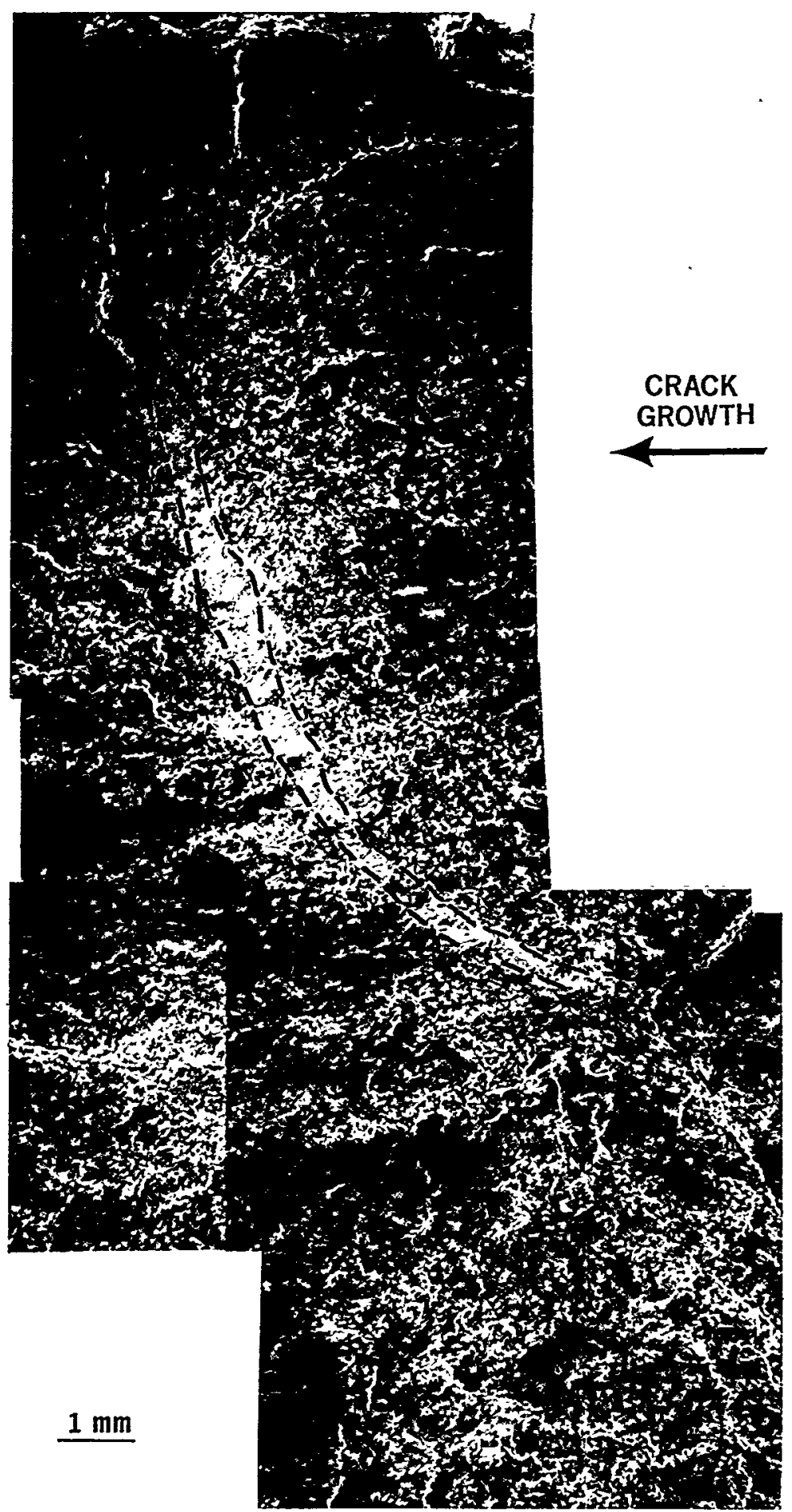

Fig. 5.31. Section 2 (Fig...5.27) showing first arrest event on part of fracture surface. 

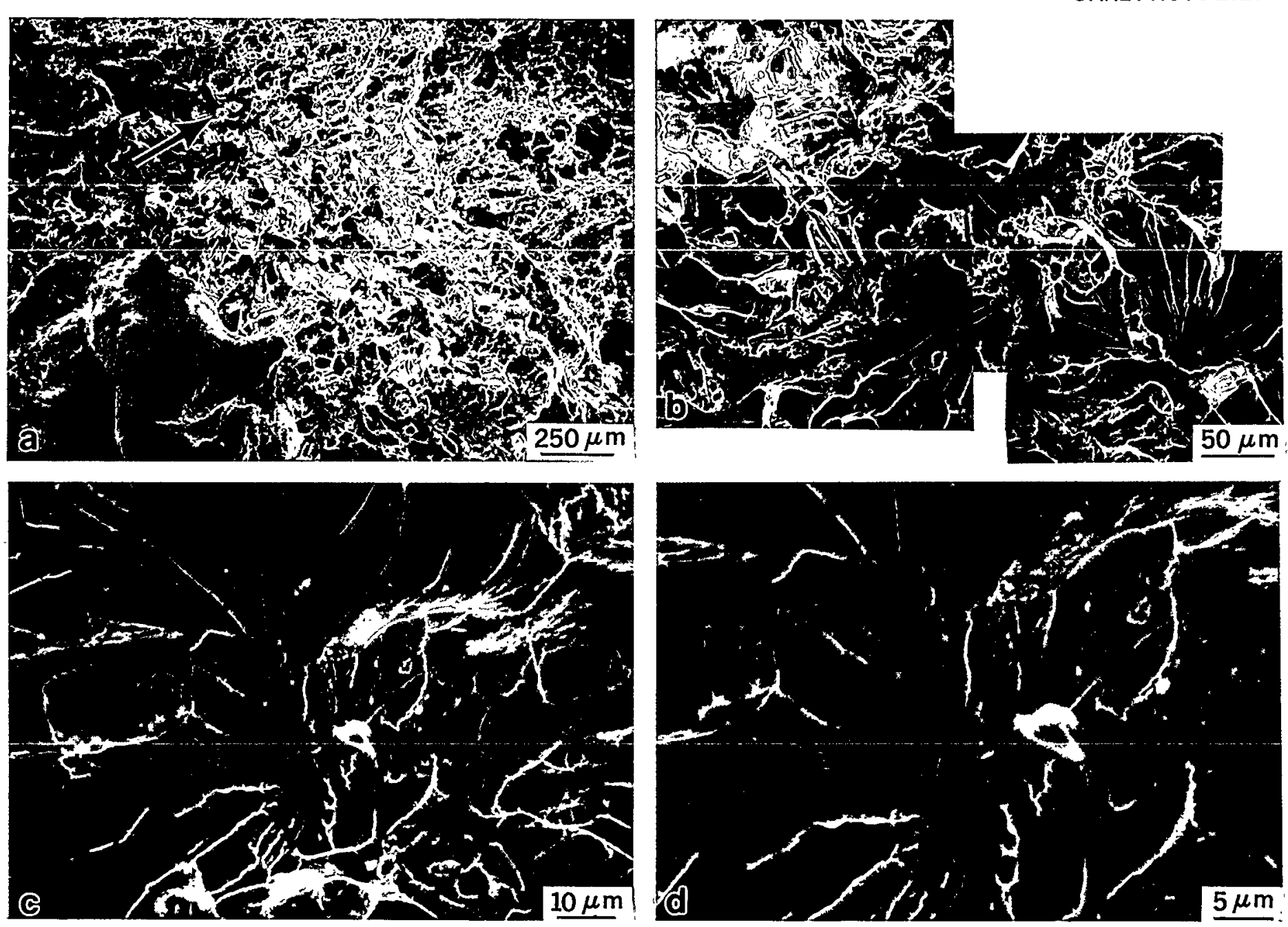

Fig. 5.32. Apparent initiation site for second crack run-arrest event, Sect. 2 (Fig. 5.27). (a) View of initiation area from bottom of tearing strip in Fig. 5.31 with apparent initiation site indicated by arrow, (b) higher magnification view of initiation region, (c) detail of initiation site showing initiation from a particle, and $(d)$ detail of $(c)$. 
It is interesting to compare the extent of stable crack growth and the stress-intensity values at the initiation of cleavage fracture with fracture-toughness tests performed on material from the broken halves of specimen WP-2.5 (see Sect. 3.6). As noted in Table 3.10, tests of 25.4-mm-thick compact specimens of the TL orientation were performed at 40 and $60^{\circ} \mathrm{C}$. Tests at $40^{\circ} \mathrm{C}$ showed no stable tearing and $\mathrm{K}_{\mathrm{Jc}}$ values from 91 to $121 \mathrm{MPa} \cdot \sqrt{\mathrm{m}}$. Crack initiation for test WP -2.4 occurred at $45^{\circ} \mathrm{C}$ at a stress-intensity factor of $143 \mathrm{MPa} \cdot \sqrt{\mathrm{m}}$ (see Table 6.3 ), which is $\approx 18 \%$ higher than the largest value observed with the 1T compact specimens, but after $\sim 800 \mu \mathrm{m}$ of stable tearing. This amount of stable tearing is quite different than that observed in the $1 T$ specimens, where no stable tearing occurred at $40^{\circ} \mathrm{C}$. The second initiation for specimen WP-2.4 occurred at a location where the temperature was estimated to be $61^{\circ} \mathrm{C}$. Compact specimen tests at $60^{\circ} \mathrm{C}$ gave final $\mathrm{K}_{\mathrm{Jc}}$ values from 94 to 155 $\mathrm{MPa} \cdot \sqrt{\mathrm{m}}$ with stable tearing from 200 to $900 \mu \mathrm{m}$. The estimated $\mathrm{K}$ value of $178 \mathrm{MPa} \cdot \sqrt{\mathrm{m}}$ (Table 6.3) after $700 \mu \mathrm{m}$ of stable tearing for the second initiation event for test WP-2.4 is again $\sim 15 \%$ greater than the highest value observed in the compact specimen tests.

\subsection{TEST WP-2.5}

After obtaining a satisfactory thermal gradient (Fig. 5.33), loading of test specimen WP-2.5 was initiated at $25 \mathrm{kN} / \mathrm{s}$. At $7.53 \mathrm{MN}$, or $86 \%$ of peak load, a pop-in event was heard and was later supported by the strain-gage outputs, accelerometer readings, and examination of the fracture surface.* Specimen loading was continued, and at a load of 8.9 MN (Fig. 5.34), the fracture event began and lasted $\sim 90 \mathrm{~ms}$ (cleavage fracture plus ductile tearing). A small $8.5-\mathrm{mm}$ plate 1 igament remained intact after the fracture event. While all instrumentation was functional at the start of the test, the COD gage's responses, which for this test were recorded on a transient oscilloscope, were not complete. Because of an improper selection of triggering parameters, the first few milliseconds of COD data were not recorded (see Appendix A, Fig. A.69). In addition, strain gages $4,7,8,11$, and 12 became inoperative during the test.

The entire fracture surface of specimen WP-2.5 is shown in Fig. 5.35(a). Figure $5.35(b)$ shows the entire fracture surface with the cleavage run-arrest events highlighted. Similarly, close-ups of the cleavage and loss-of-cleavage regions without and with the cleavage runarrest events highlighted are shown in Fig. 5.36(a) and (b), respectively. Examination of a close-up of the fracture surface in the region of the chevron (Fig. 5.37) confirmed that a pop-in event had occurred to

*As noted previously, specimen WP-2.4 also experienced a pop-in event before the main crack run-arrest events. Both tests WP-2.4 and -2.5 used specimens that were $102 \mathrm{~mm}$ thick. The remainder of the $\mathrm{WP}-2$ series tests that used 152-mm-thick specimens did not experience a popin event. 
ORNL-DWG 9OM-3603 ETD

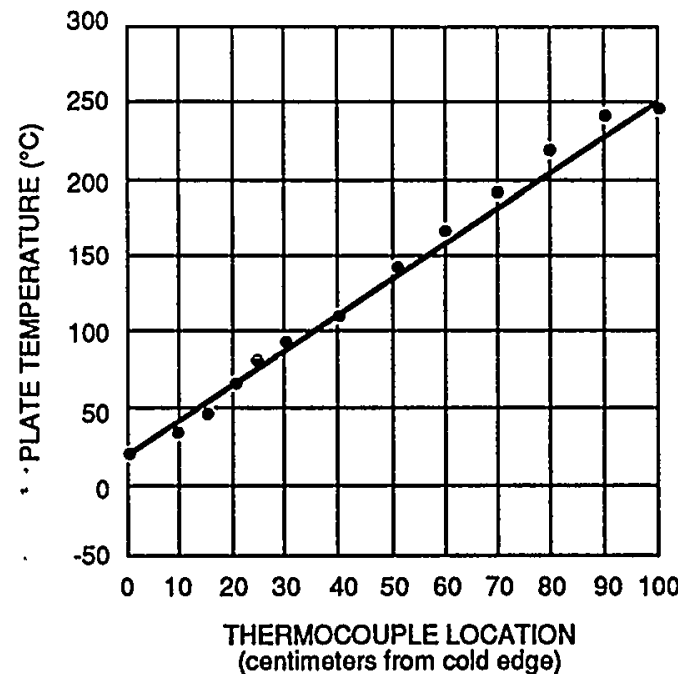

(centimeters from cold edge)

TEMPERATURE $\left({ }^{\circ} \mathrm{C}\right)$

\begin{tabular}{c} 
CENTIMET \\
\hline 0 \\
10 \\
15 \\
15 \\
20 \\
20 \\
20 \\
25 \\
25 \\
30 \\
40 \\
40 \\
50 \\
60 \\
60 \\
70 \\
80 \\
80 \\
90 \\
100
\end{tabular}

(a)

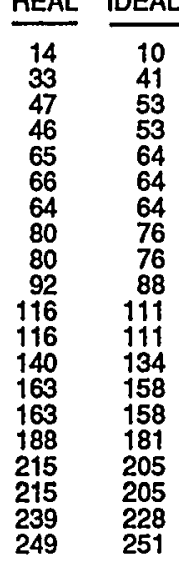

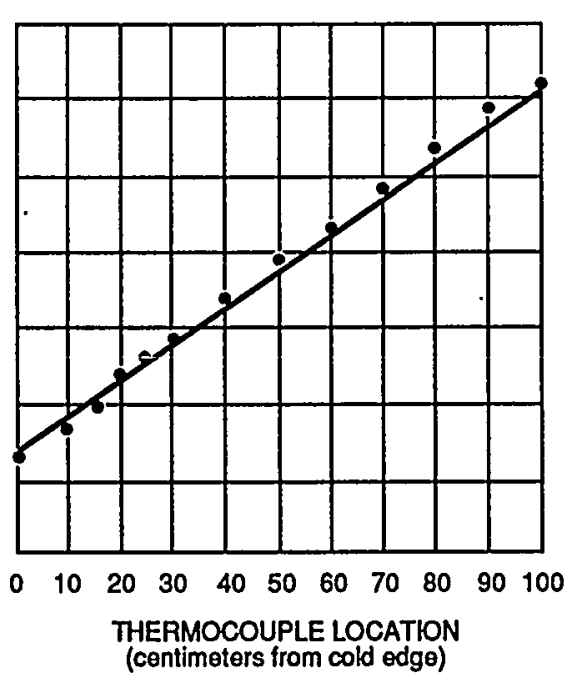

TEMPERATURE $\left({ }^{\circ} \mathrm{C}\right)$

CENTIMETERS REAL IDEAL

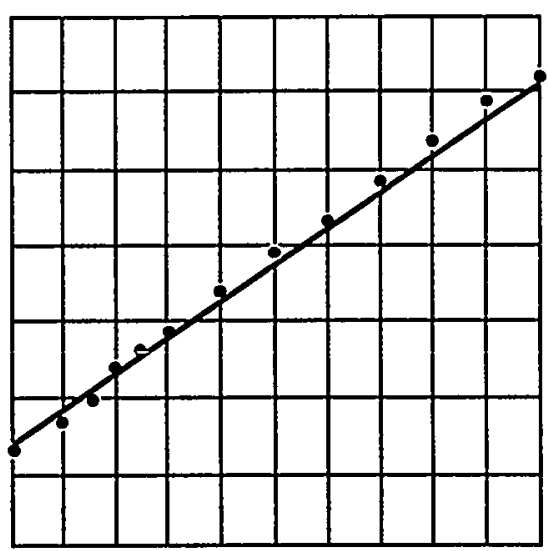

$\begin{array}{lllllllllll}0 & 10 & 20 & 30 & 40 & 50 & 60 & 70 & 80 & 90 & 100\end{array}$ THERMOCOUPLE LOCATION (centimeters from cold odge)

TEMPERATURE $\left({ }^{\circ} \mathrm{C}\right)$

CENTIMETERS REAL IDEAL

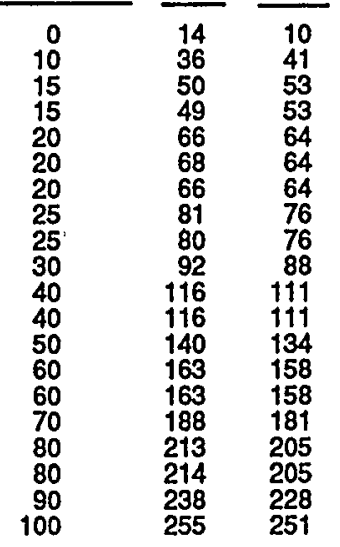

0
10
15
15
20
20
20
25
25
30
40
40
50
60
60
70
80
80
90
100

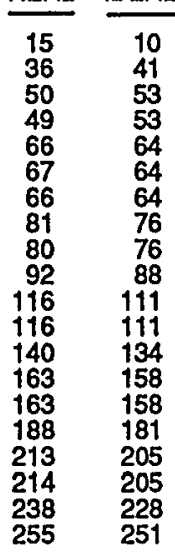

Fig. 5.33. Actual and ideal temperature distributions across specimen width (a) at start of test, (b) at crack pop-in event, and (c) at approximate time of fracture events: test WP -2.5 . 


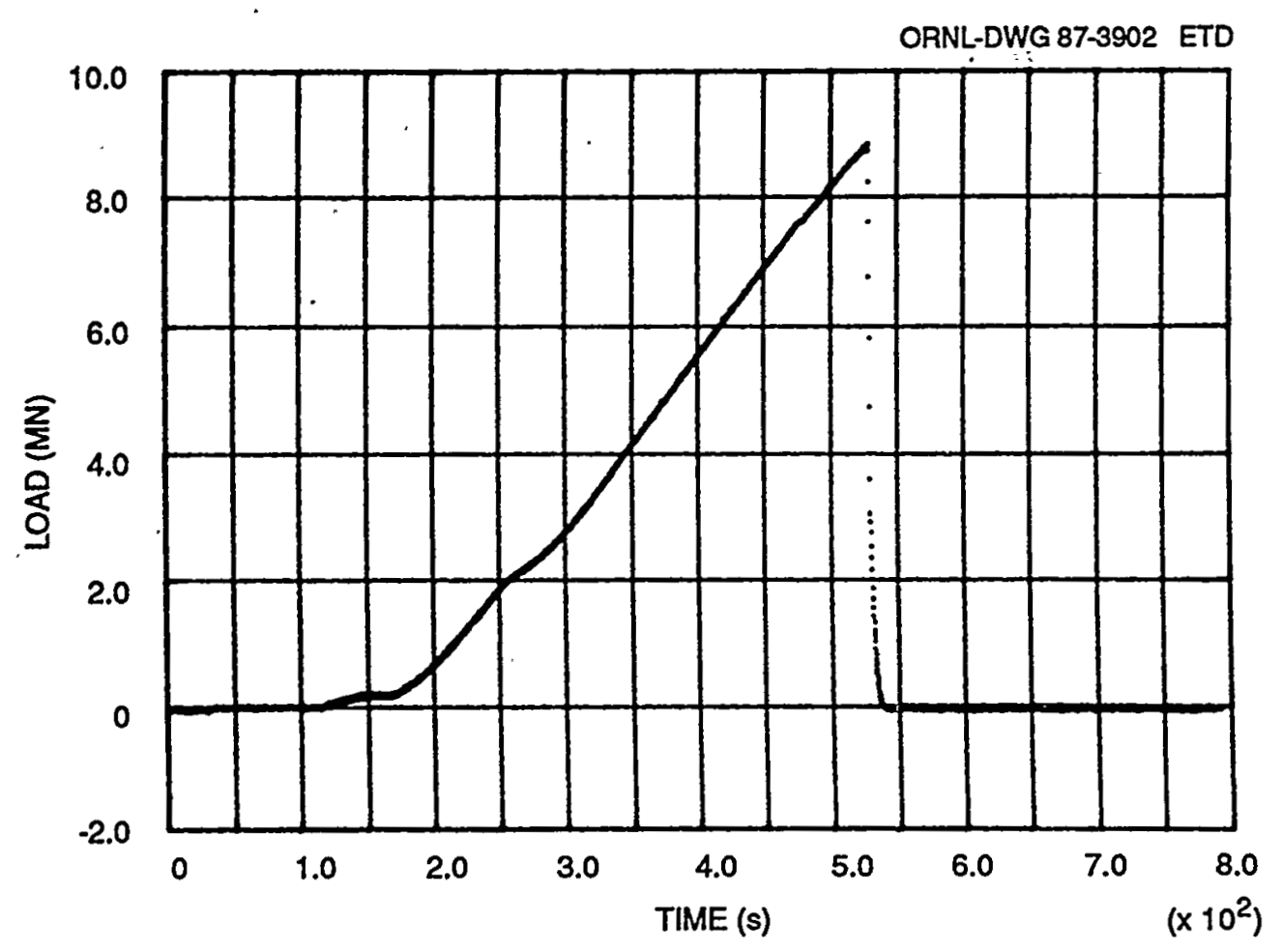

Fig. 5.34. Load history for test WP-2.5. 


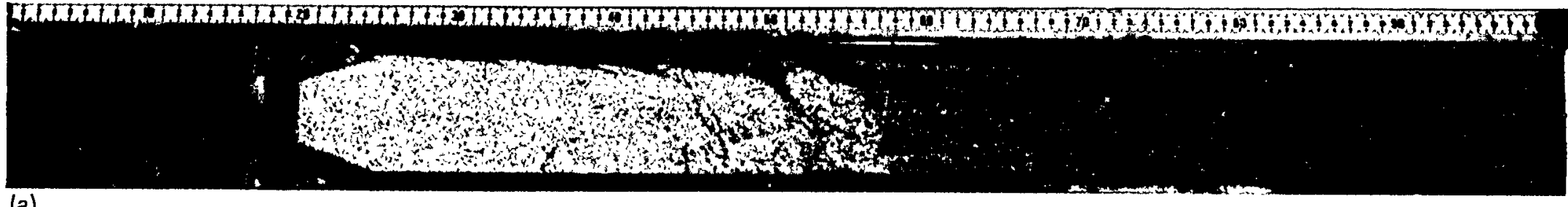

(a)

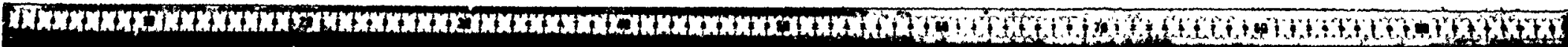
of

(b)

Fig. 5.35. Fracture surface for specimen WP-2.5. (a) Entire fracture surface, and (b) entire fracture surface with cleavage runarrest events highlighted. 

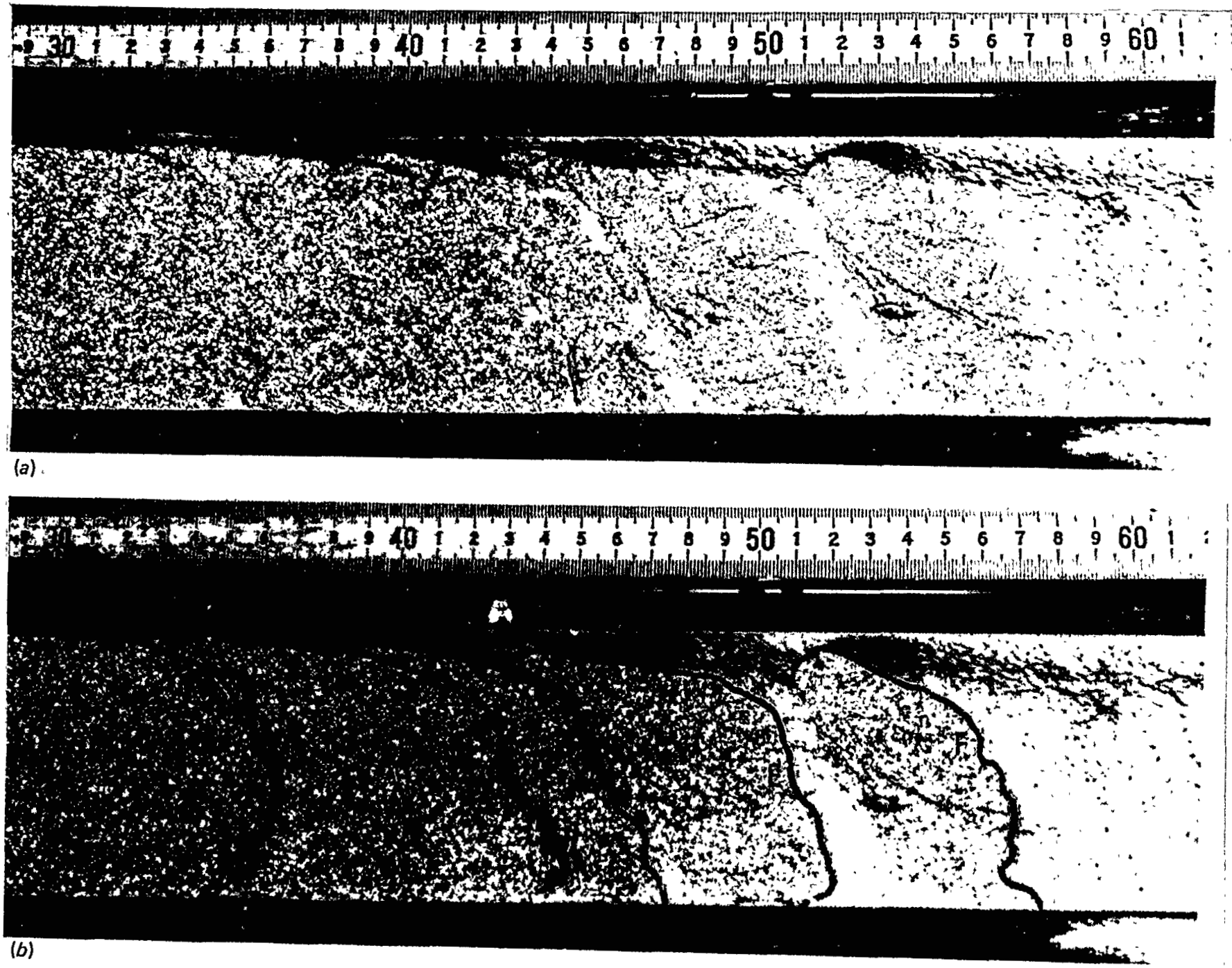

Fig. 5.36. Close-up of fracture surface for specimen WP-2.5. (a) Cleavage and loss-of-cleavage regions, and $(b)$ cleavage and loss-of-cleavage regions with cleavage run-arrest events highlighted: test WP-2.5. 


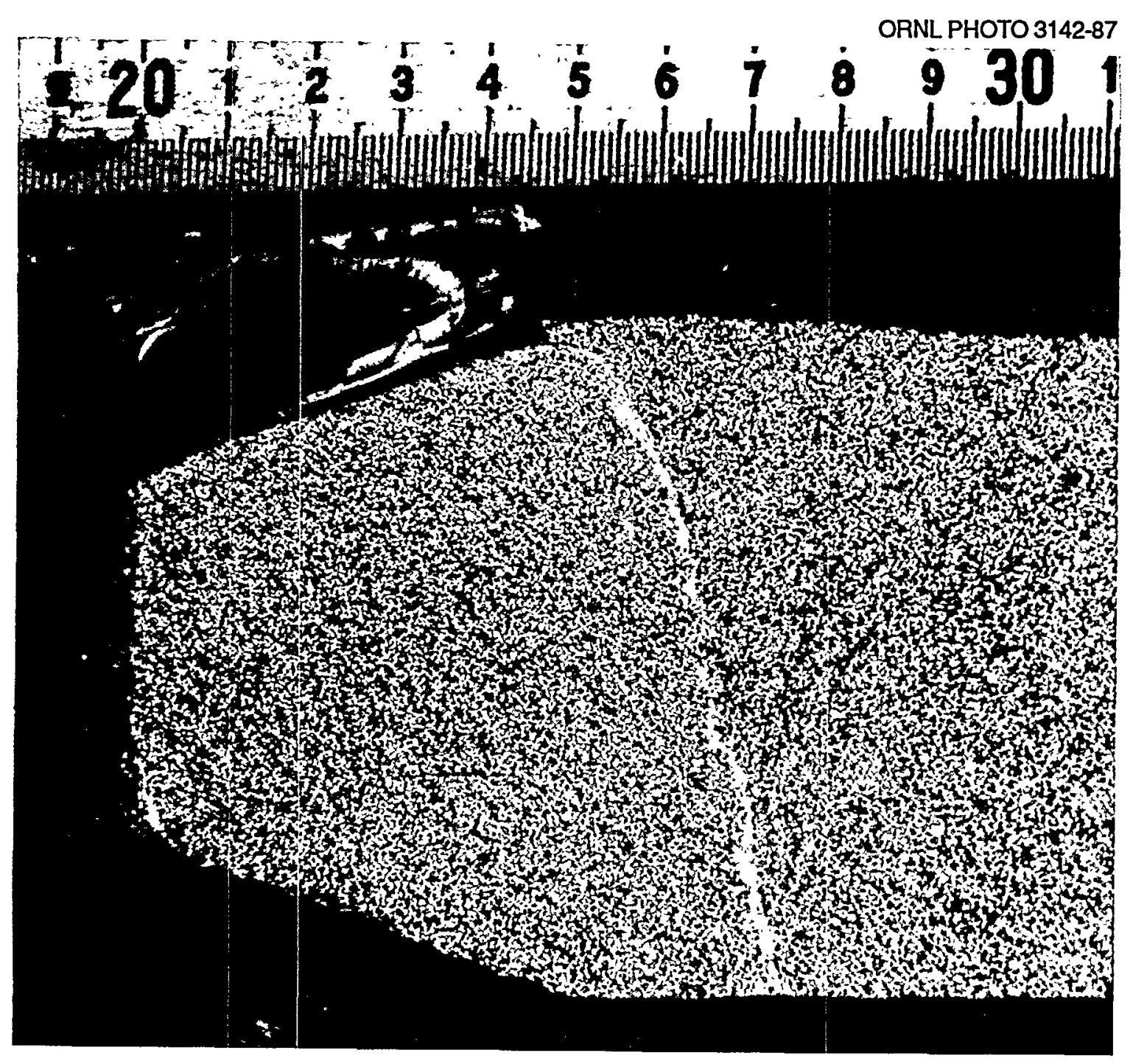

Fig. 5.37. Close-up of initial EB weld-generated crack and region of pop-in: test WP-2.5. 
an estimated average crack depth of $264 \mathrm{~mm}$ before initiation of the main fracture event. This is further substantiated in Fig. 5.38, which presents strain-gage records for strain gages 1-3 on the front face of the specimen and strain gages 13 and 14 on the back face of the specimen; each record shows a sudden increase in strain at $\sim 480 \mathrm{~s}$ into the test, followed by a sudden increase in strain and strain rate even though no change in loading rate was made by the operator. As noted in Fig. 5.38, the strain and strain rate increases were more pronounced for back-face gage 14 than its companion front-face gage 3, indicating that the crack had advanced more near the back-plate surface than the frontplate surface. A selection of high-resoluticn strain gage and accelerometer records during the crack pop-in are presented in Figs. 5.39 and 5.40, respectively.

Examination of the fracture surface indicates that initiation of crack growth in cleavage was in the plane of the side grooves, but as it extended, it gradually deviated from this plane. By the time the crack had reached the final cleavage-arrest location $(a / w \approx 0.56$ at plate back face) it was $8 \mathrm{~mm}$ below the plane of the side grooves.

Evaluation of the strain-gage records (Appendix A) and the fracture surface were also used to deduce the crack length (position of the crack front) during the fracture process, and the results are presented in Table 5.6. The strain-gage positions have been modified from those shown in Fig. 4.8(a) because the peak strain occurs at an angle of $72^{\circ}$ in front of the crack tip. Also, the crack-arrest locations 1 isted are averages of the quarter-thickness crack lengths and the crack lengths at the side groove. A plot of the strain-gage-derived crack-front position vs time using the front-face and back-face strain-gage results is presented in Fig. 5.41. Results in this figure indicate that the crack front advance at comparable elapsed times during the cleavage crack runarrest events was more rapid near the plate back face than near the plate front face. As noted in Table 5.6, it was not until the crack advance had reached an $a / w \sim 0.669$ (while ductile tearing was occurring) that the crack front advance was fairly uniform across the plate width (as indicated by the strain gages).

After examination of the strain-gage records and fracture surfaces to deduce the apparent crack-front position as a function of time, fractographic analyses of specimen WP-2.5 were conducted. As was done for specimen WP-2.4, the fracture surface of specimen WP-2.5 was cut into smaller pieces for insertion into the SEM. Figure 5.42 shows the fracture surface and indicates how it was sectioned. Because the fracture surface of specimen WP-2.5 had not been as well preserved as that of specimen WP-2.4, which was discussed earlier, it was somewhat difficult to identify features of interest. Investigation of section $A$ in Fig. 5.42 revealed ductile tearing at the tip of the EB weld that was followed by the cleavage area associated with the first crack run-arrest event. Figure 5.43 shows the tearing strip at the tip of the EB weld. The apparent initiation site is presented in Fig. 5.44. Figure 5.44(a) shows the ductile tearing strip and cleavage in the initiation area shown in the dashed box in Fig. 5.43. The average width of the tearing strip was $\sim 1200 \mu \mathrm{m}$. Details of the initiation site are presented in Figs. $5.44(b)$ and $(c)$. As noted earlier, damage to the fracture surface is evident in Fig. $5.44(c)$ and made it impossible to identify the exact 


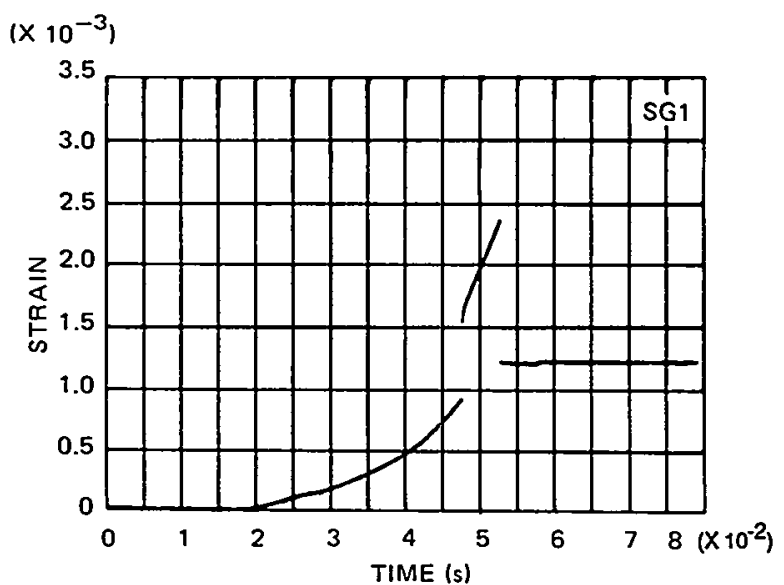

ORNL-DWG 87-3895A ETD
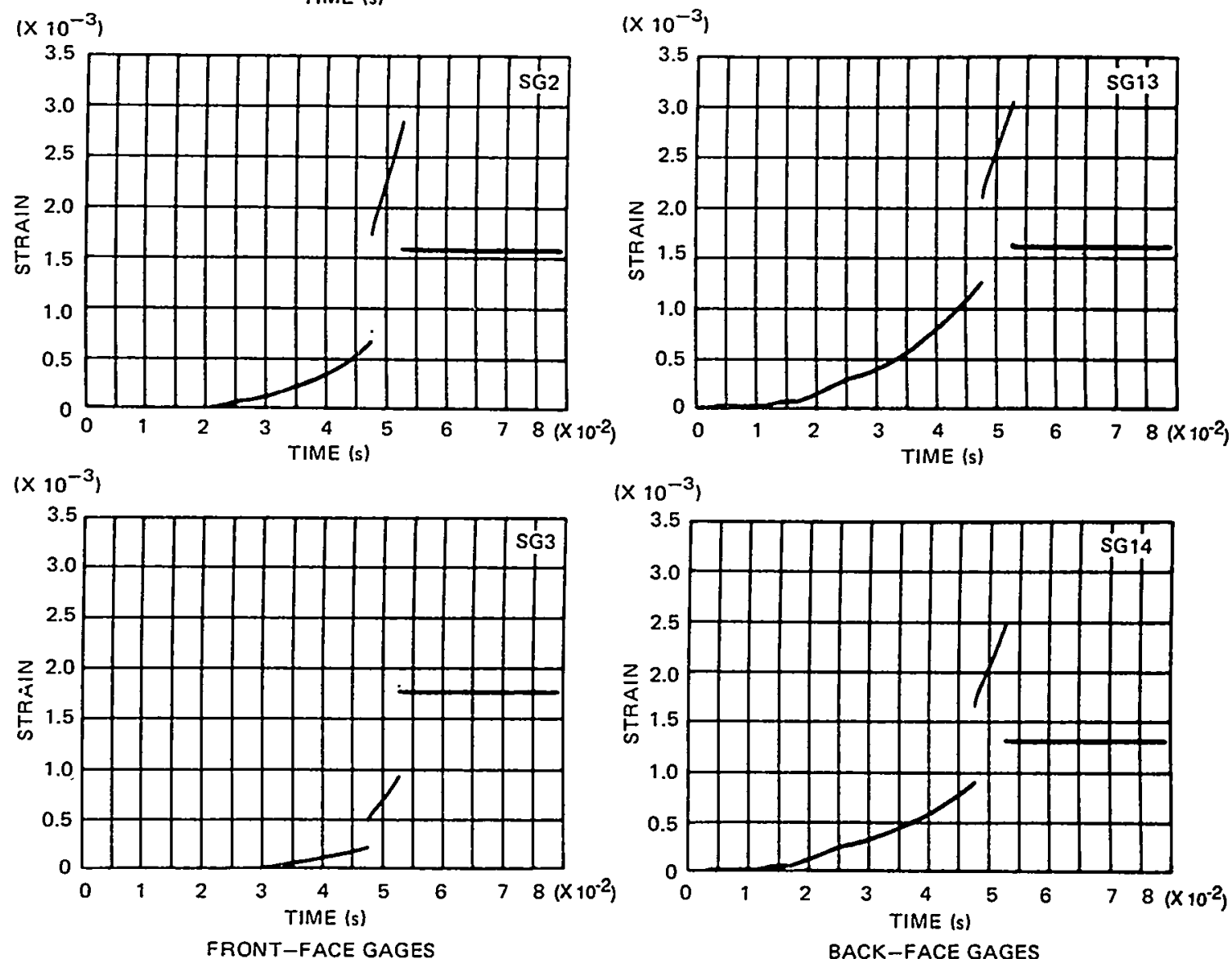

Fig. 5.38. Pop-in as detected by strain gages $1-3$ on plate front face and 13 and 14 on plate back face: test WP-2.5. 


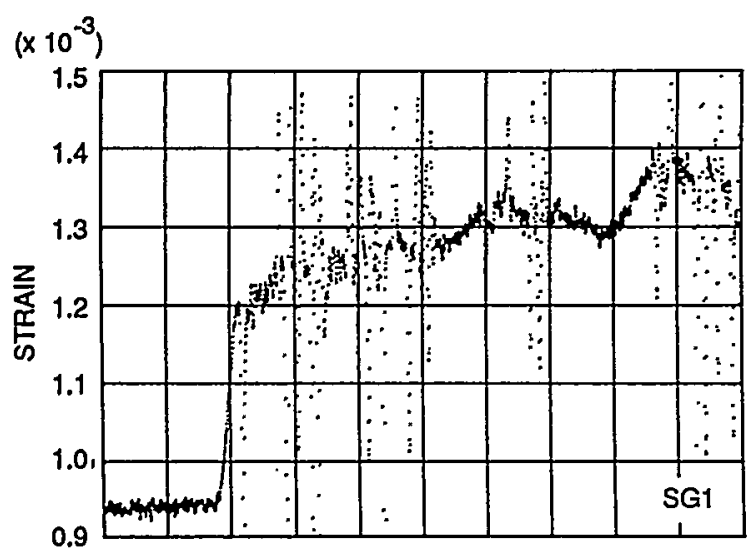

ORNL-DWG 90-3684 ETD

$\left(\times 10^{-3}\right)$
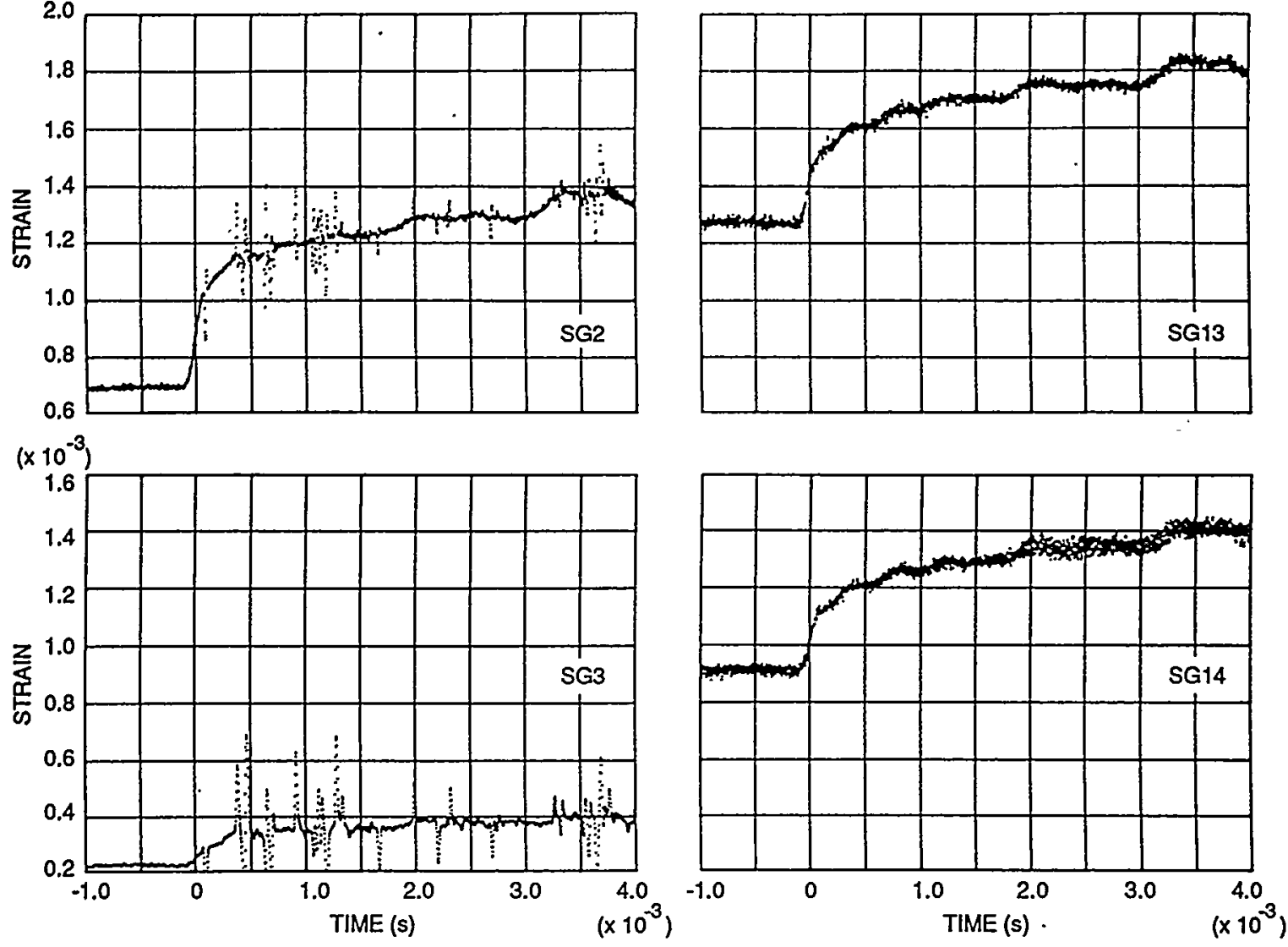

Fig. 5.39. High-resolution strain-gage records for companion crack-1ine gages during pop-in event: test WP-2.5. 

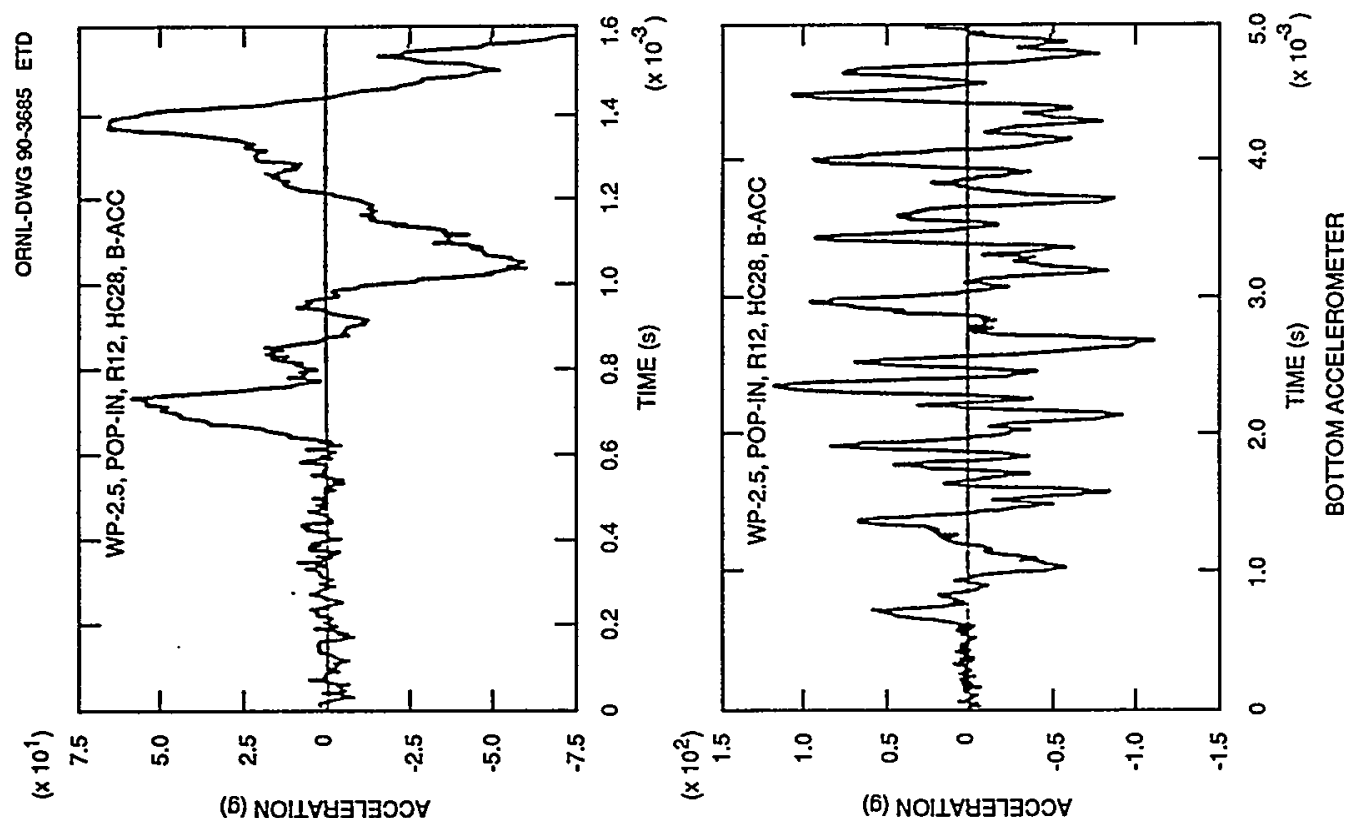

.
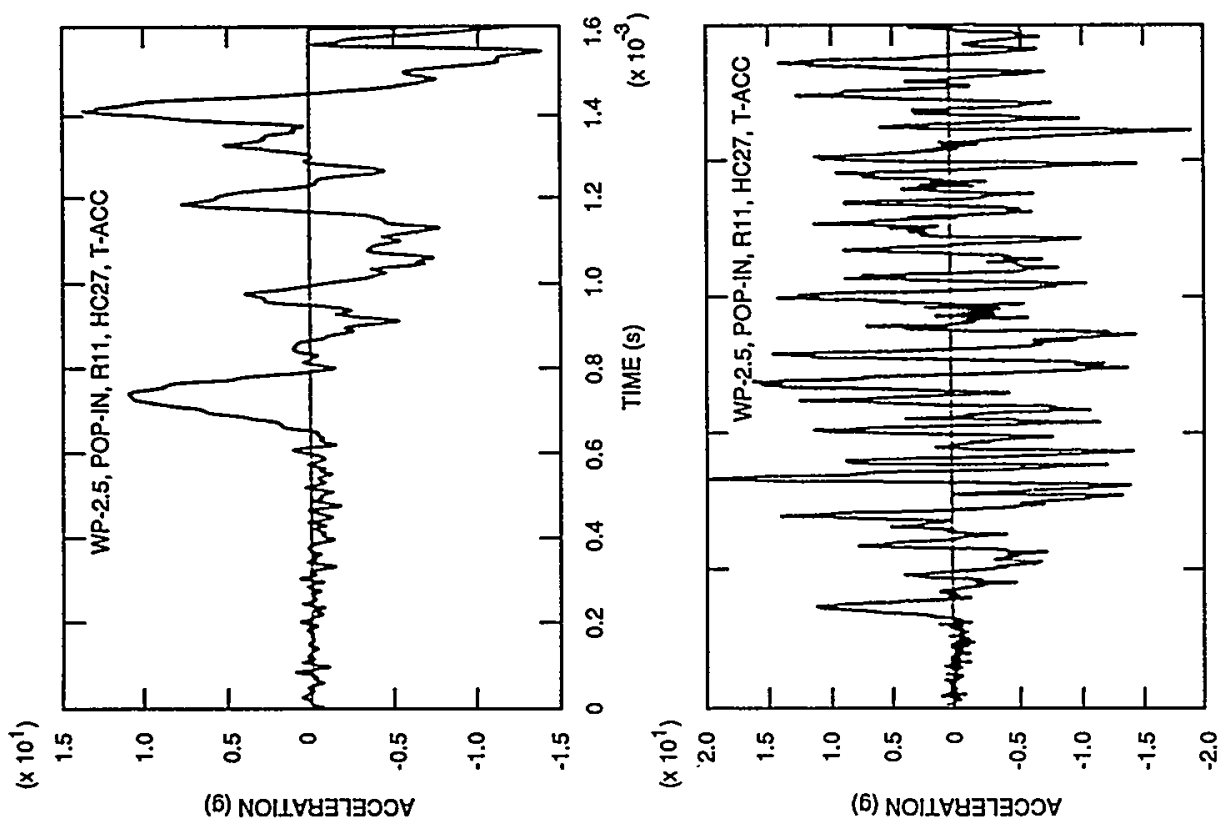

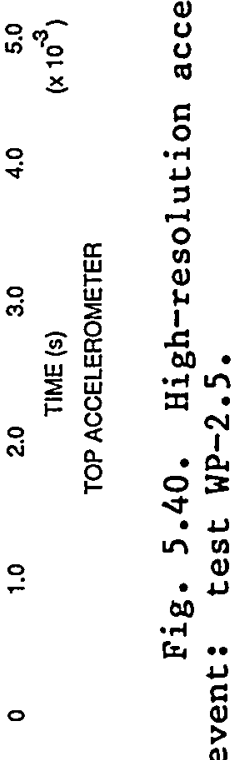

\section{(6) NOILYษ $37300 \%$}

(6) NOIL $487900 \%$ 
Table 5.6. Crack position vs time and velocity: test WP-2.5

\begin{tabular}{|c|c|c|c|}
\hline Indicator ${ }^{a}$ & $\begin{array}{l}\text { Position } \\
\quad(\mathrm{mm})\end{array}$ & $\begin{array}{l}\text { Time } \\
\text { (ms) }\end{array}$ & $\begin{array}{l}\text { Velocity } \\
(\mathrm{m} / \mathrm{s})\end{array}$ \\
\hline \multicolumn{4}{|c|}{ Front-face measurements } \\
\hline Pop-in (Arrest A) & 250 & 0 & 133 \\
\hline SG1 & 254 & 0.03 & 1250 \\
\hline SG2 & 279 & 0.05 & 71 \\
\hline $\begin{array}{l}\text { Arrest B } \\
\text { Reinitiation }\end{array}$ & $\begin{array}{l}300 \\
300\end{array}$ & $\begin{array}{l}0.344 \\
7.87\end{array}$ & \\
\hline SG3 . & 319 & 7.88 & 1900 \\
\hline $\begin{array}{l}\text { Arrest C } \\
\text { Reinitiation }\end{array}$ & $\begin{array}{l}385 \\
385\end{array}$ & $\begin{array}{r}8.45 \\
11.33\end{array}$ & \\
\hline SG5 & 399 & 11.43 & 140 \\
\hline $\begin{array}{l}\text { Arrest D } \\
\text { Reinitiation }\end{array}$ & $\begin{array}{l}400 \\
400\end{array}$ & $\begin{array}{l}11.58 \\
18.39\end{array}$ & \\
\hline SG6 & 439 & 19.15 & 51 \\
\hline $\begin{array}{l}\text { Arrest E } \\
\text { Reinitiation }\end{array}$ & $\begin{array}{l}450 \\
450\end{array}$ & $\begin{array}{l}19.31 \\
27.79\end{array}$ & 69 \\
\hline & & & 183 \\
\hline $\begin{array}{l}\text { Arrest F } \\
\text { Reinitiation }\end{array}$ & $\begin{array}{l}523 \\
523\end{array}$ & $\begin{array}{l}28.19 \\
33.11\end{array}$ & \\
\hline SG9 & 569 & 35.67 & 18 \\
\hline SG10 & 619 & 43.89 & 6 \\
\hline SG11 & 669 & 47.85 & 13 \\
\hline Remaining 1 igament & 990.5 & 84 & \\
\hline Bac & face measu & nents & \\
\hline Pop-in (Arrest A) & 272 & 0 & \\
\hline SG13 & 276 & 0 & 614 \\
\hline SG14 & 319 & 0.07 & 66 \\
\hline
\end{tabular}


Table 5.6 (continued)

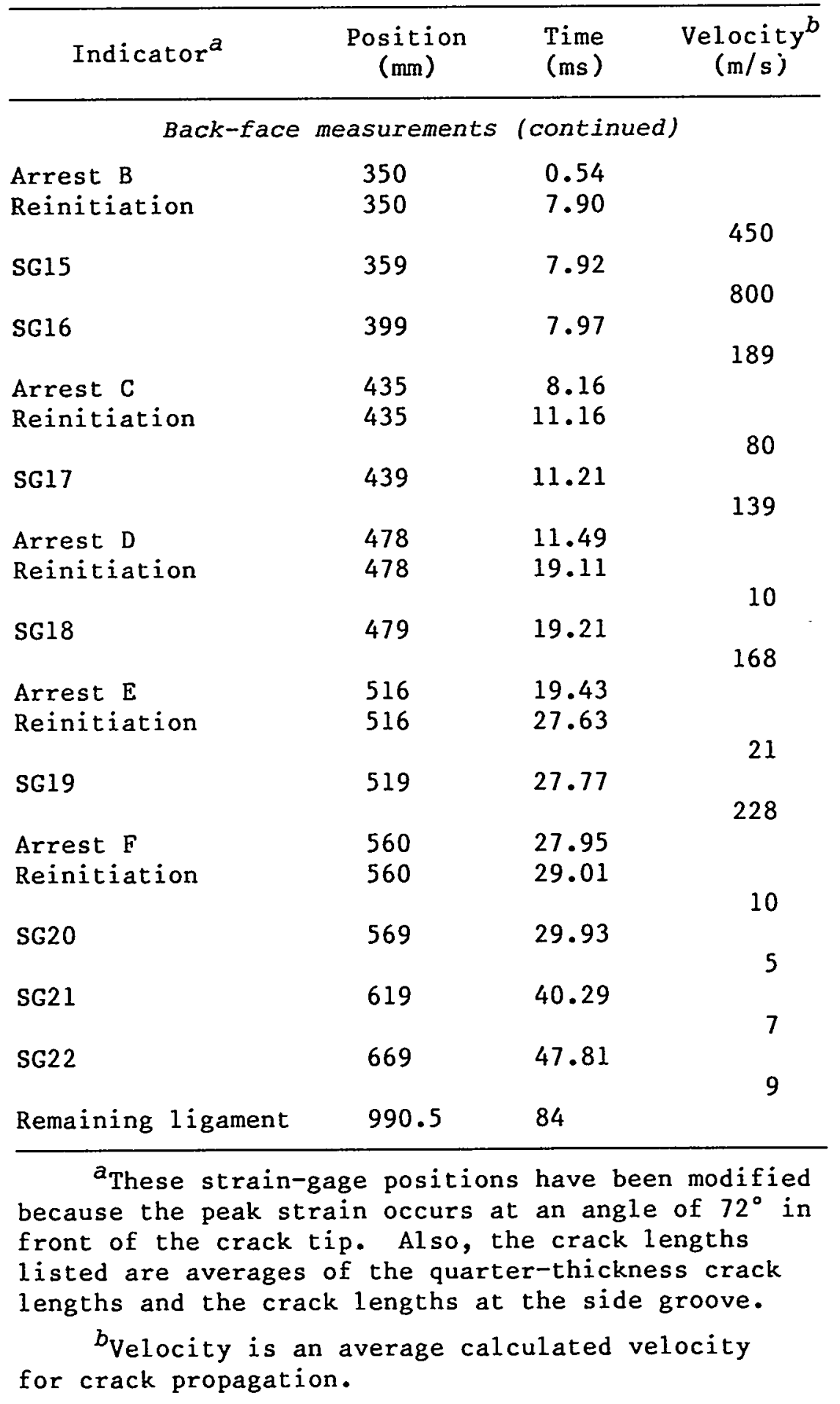




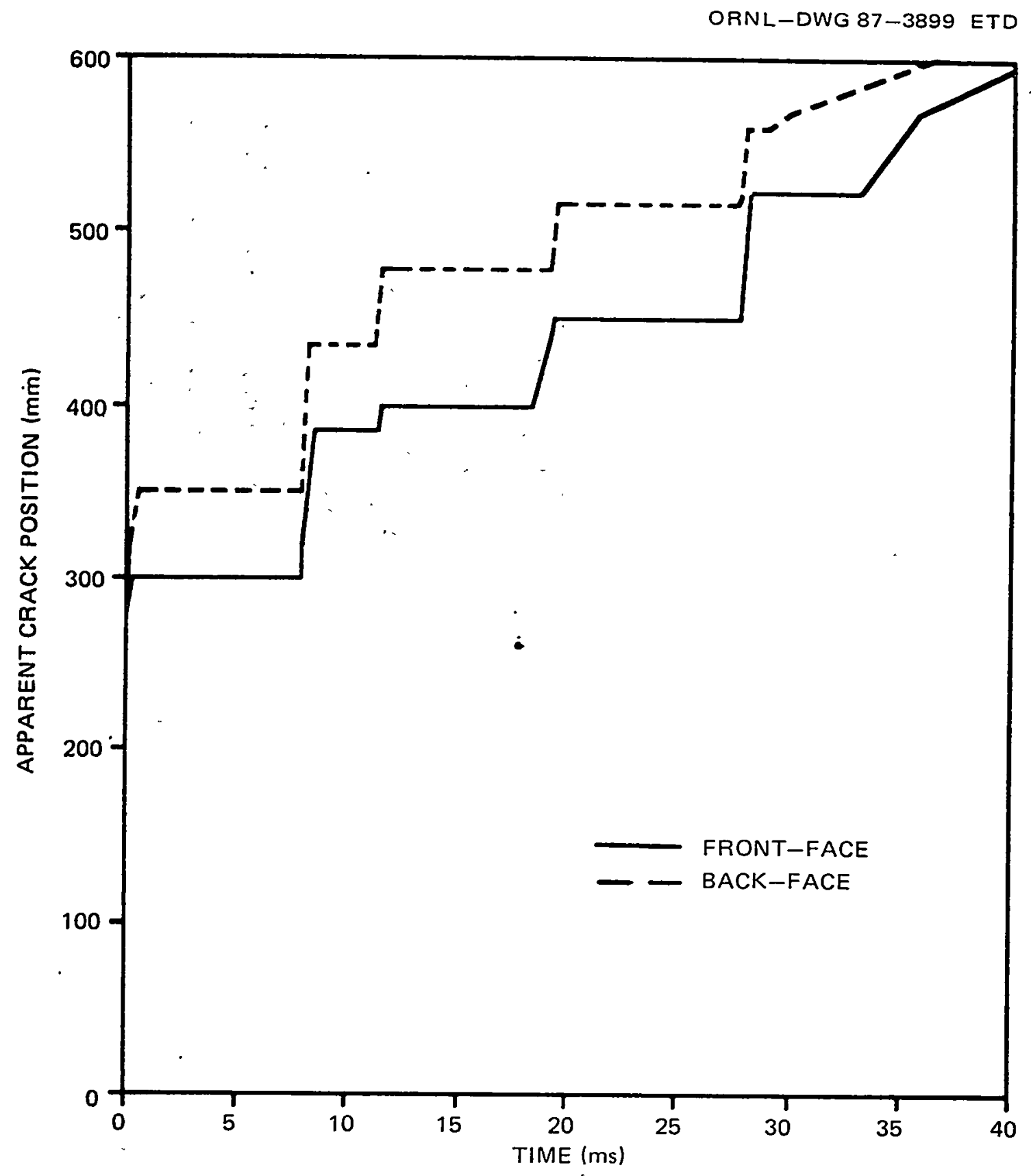

Fig. 5.41. Strain-gage-derived crack-front position vs time: test WP-2.5. 


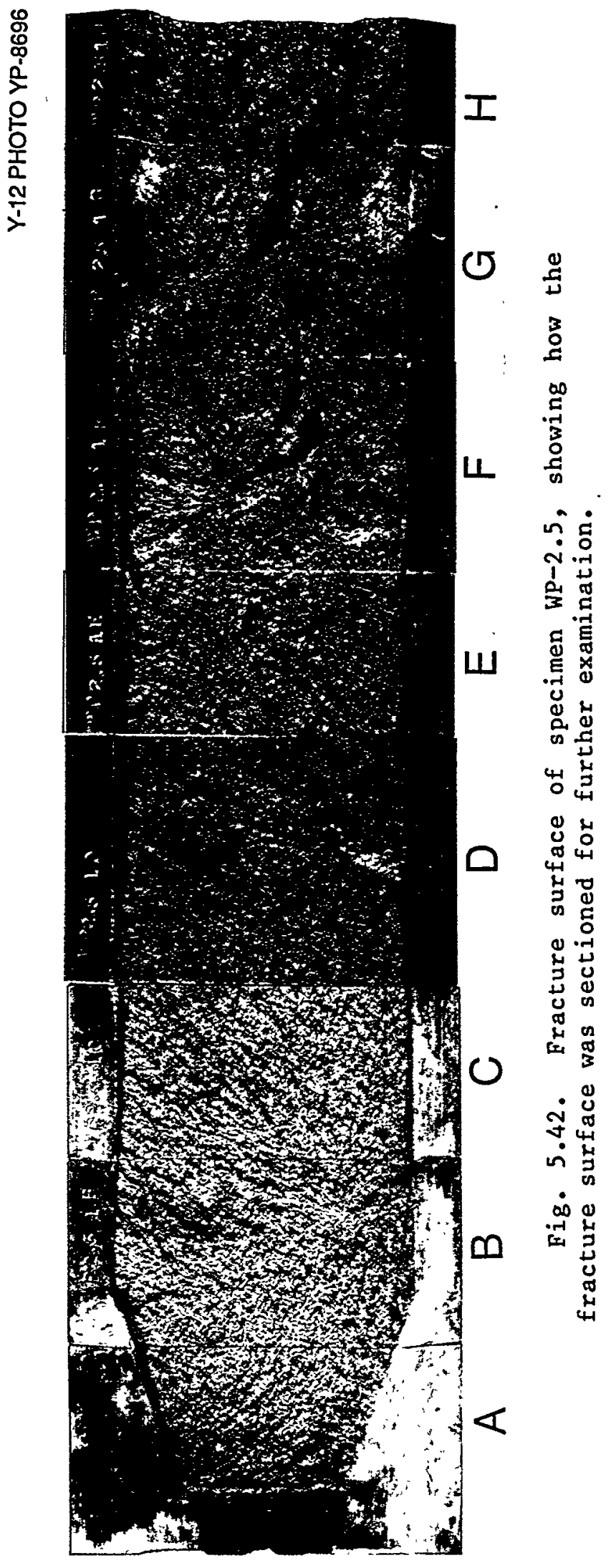




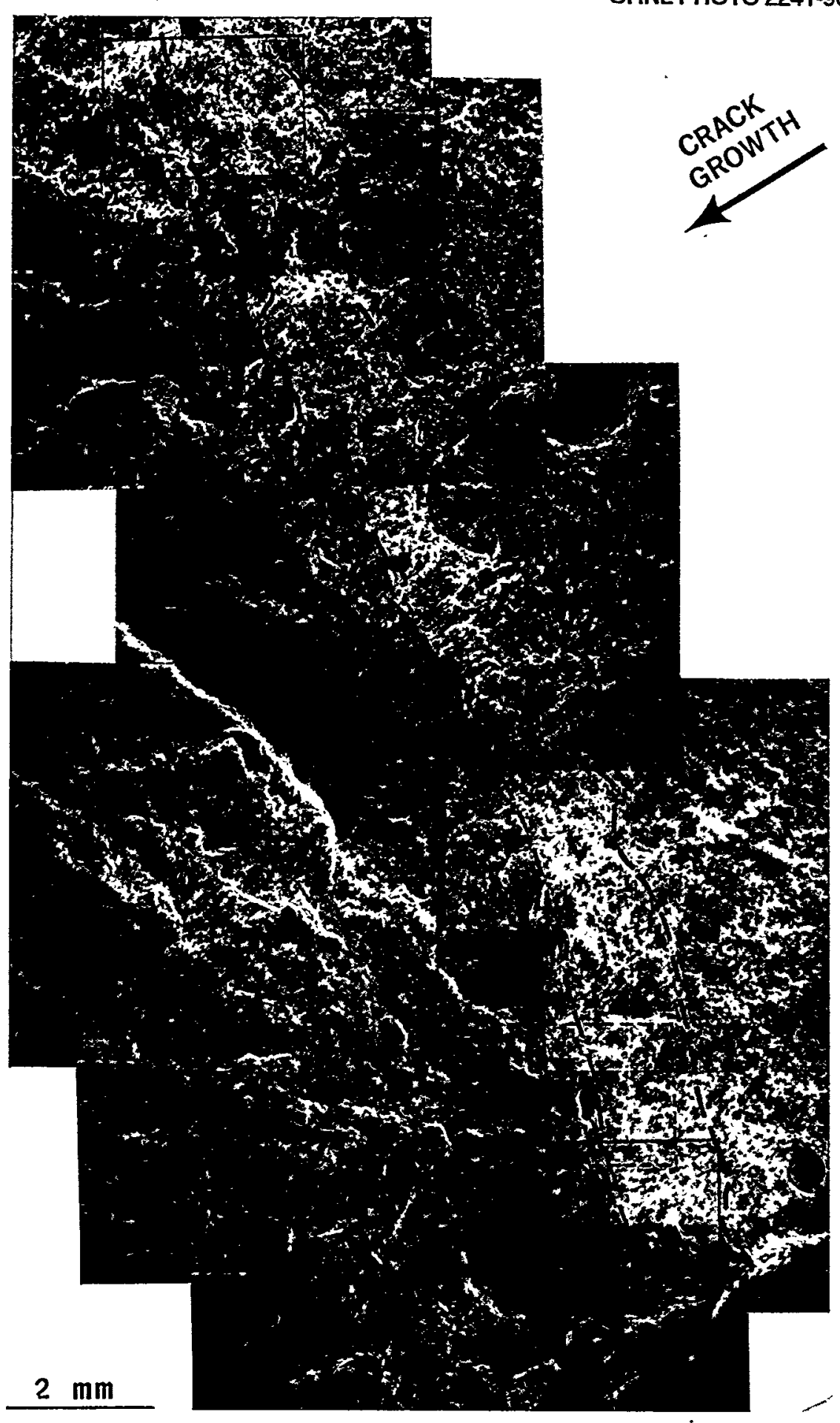

Fig. 5.43. Precrack and initial tearing from specimen WP 2.5, Sect. A (Fig. 5.42). The tearing strip from the initial loading is marked. The $\mathrm{EB}$ weld is to the right and the first crack-run=arrest event to the left. 

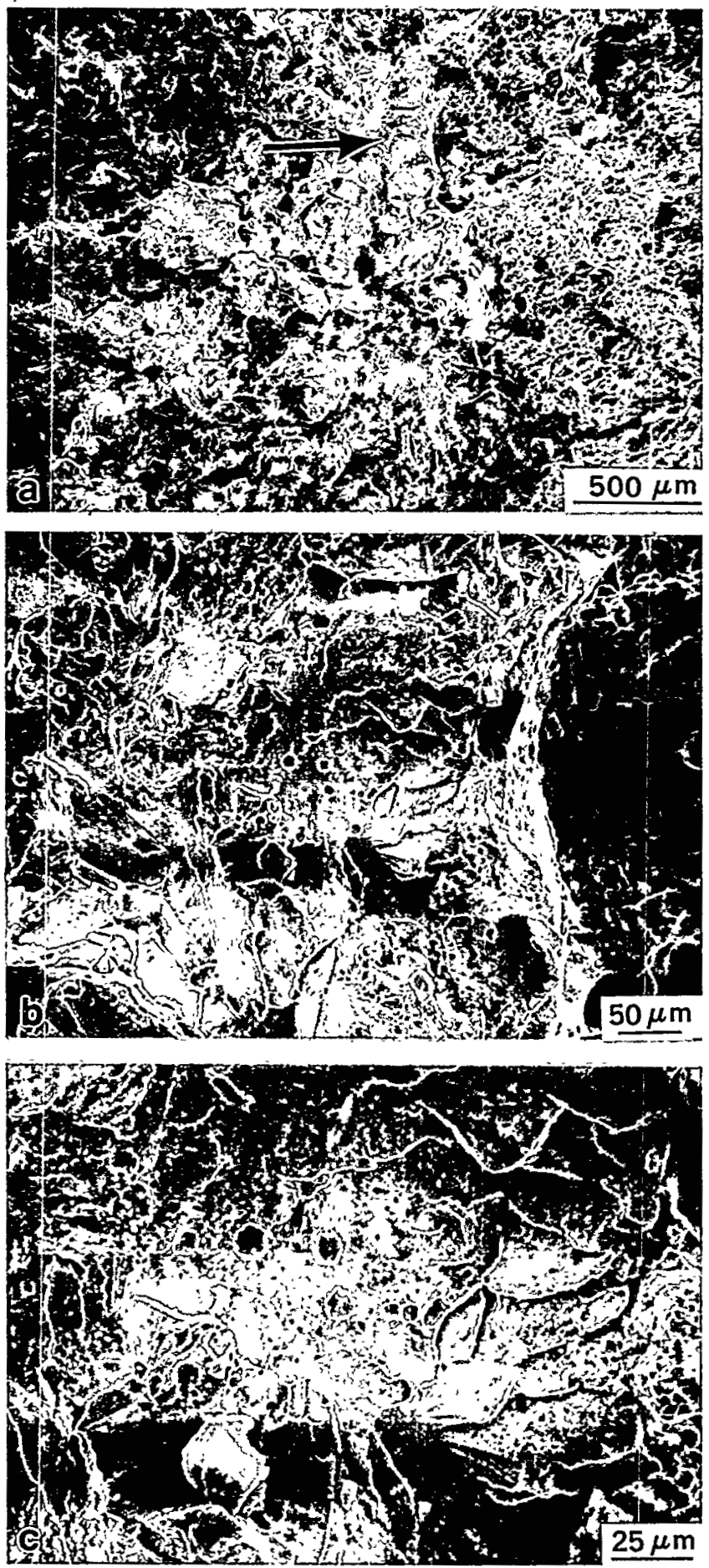

Fig. 5.44. View of apparent initiation site for first crack runarrest event, Sect. A (Fig. 5.42). (a) View of ductile tearing zone and cleavage fracture from dashed box in Fig. 5.43 with apparent initiation site indicated by arrow, (b) detail of apparent initiation site, and (c) detail of (b). 
feature associated with the initiation event. Section B of Fig. 5.42 contains the first arrest front and the second crack run-arrest event. The arrest front is marked by a band of ductile tearing, $1500 \mu \mathrm{m}$ wide and is shown in Fig. 5.45. The ductile tearing from a region in the center of the specimen, as indicated by a box in Fig. 5.45 , is shown in greater detail in Fig. 5.46. The initiation site for the next crack run-arrest event could not be identified because of the damage noted earlier to the fracture surface.

\subsection{TEST WP-2.6}

Specimen WP-2.6 was the second specimen in WP-2 series to not have its crack front cut into a truncated chevron configuration. It was also the second WPS specimen in this series. The warm prestressing procedure consisted of slowly loading the specimen to $15.56 \mathrm{MN}$ while maintaining the crack tip temperature at $110^{\circ} \mathrm{C}$ (Fig. 5.47), holding the load constant at this value for $5 \mathrm{~min}$, and slowly reducing the load to 3.25 MN. The load history and load vs front- and back-face coD results during warm prestressing are shown in Fig. 5.48. While maintaining the load at $3.25 \mathrm{MN}$, the thermal gradient was developed.

After obtaining a satisfactory temperature profile (Fig. 5.49), the specimen was loaded at an average rate of $9.6 \mathrm{kN} / \mathrm{s}$. At a load of 19.33 MN, cleavage crack propagation initiated, and within an $\sim 10.5-\mathrm{ms}$ interval seven crack run-arrest events occurred. After the seventh crack run-arrest event, tearing fracture reinitiated with complete separation of the plate occurring $\sim 34.5 \mathrm{~ms}$ after first initiation of cleavage crack propagation. Figure 5.50 presents the load history for test WP-2.6.

Figure 5.51 shows the fracture surface of specimen WP-2.6. As noted in Fig. 5.52, which presents a close-up of the region where the crack run-arrest events occurred, there were numerous crack run-arrest events during this test. As the crack propagated, it deviated from the plane of the side grooves, reaching $\sim 10 \mathrm{~mm}$ above the plane at the furthest extent of cleavage crack propagation. Reduction-in-thickness contours surrounding the crack plane are shown in Fig. 5.53.

The strain-gage records (Appendix A) and fracture surface were used to deduce the crack length (apparent position of the crack front) during the fracture process, and the results are summarized in Table 5.7. In the table, the strain-gage positions have been modified from those shown in Fig. 4.8(e) to account for the fact that the peak strain occurs at an angle of $72^{\circ}$ in front of the crack tip. Figure 5.54 is a plot of strain-gage-derived crack-front position vs time from the front-face and back-face strain gage results during the entire fracture process. 
ORNL PHOTO 2243-90

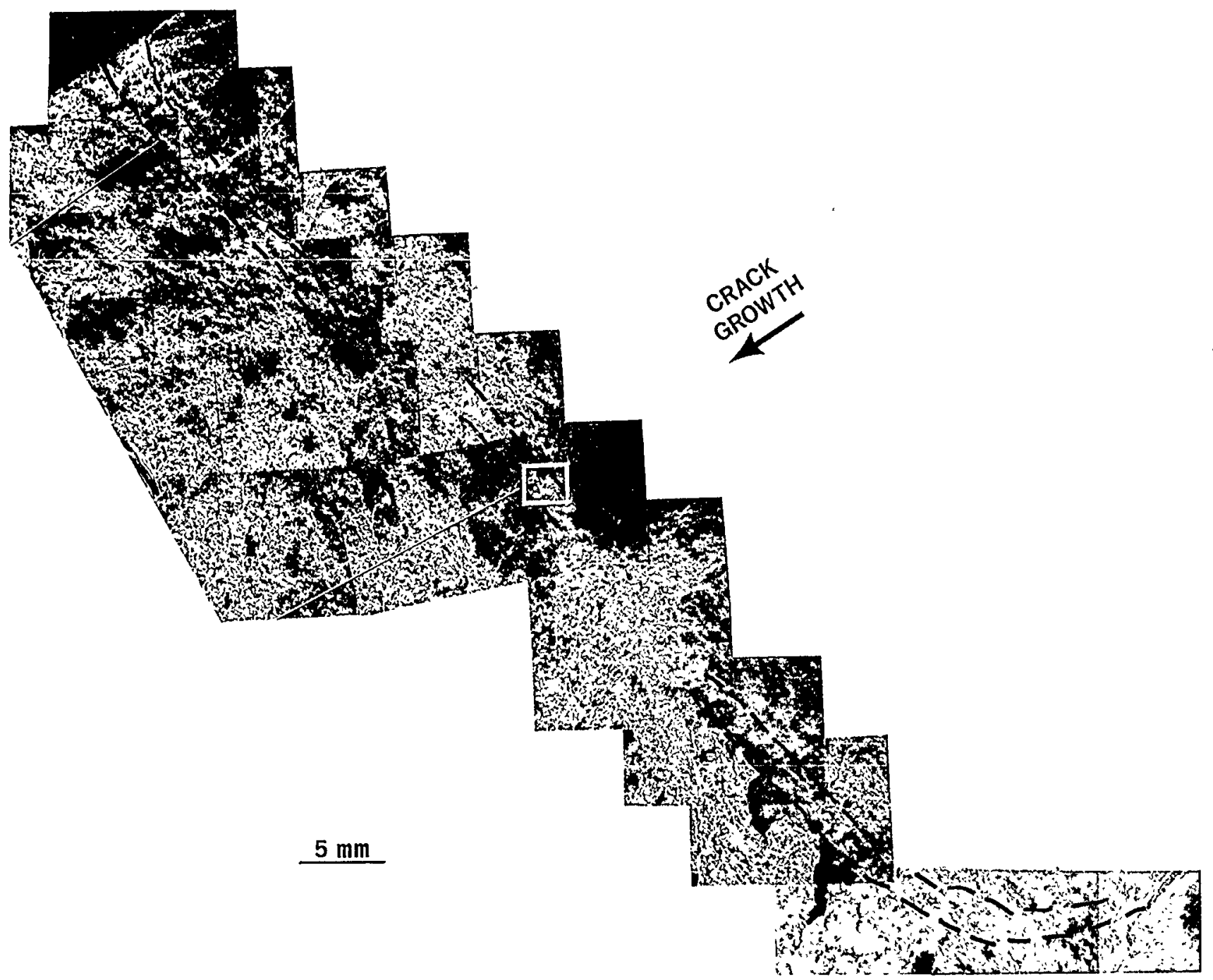

Fig. 5.45. First arrest location from Sect. B (Fig. 5.42). The tearing strip is shown by the dashed lines. 
ORNL PHOTO 2244-90
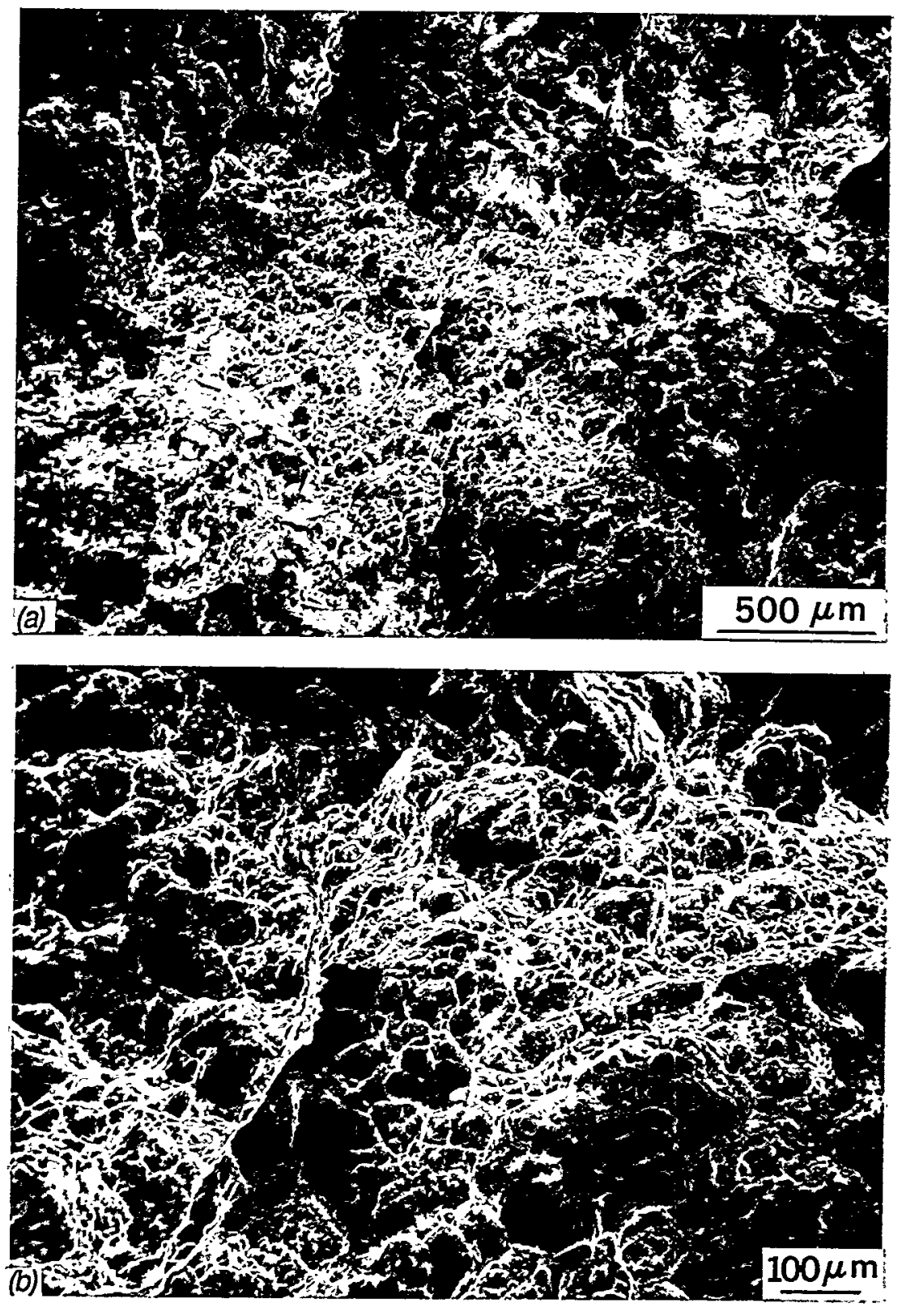

Fig. 5.46. Ductile tearing strip from Sect. B (Fig. 5.42) after first crack run-arrest event. (a) Detail of ductile tearing from box shown in center of Fig. 5.45, and (b) detail of ductile tearing. 
ORNL-DWG 89-5025 ETD

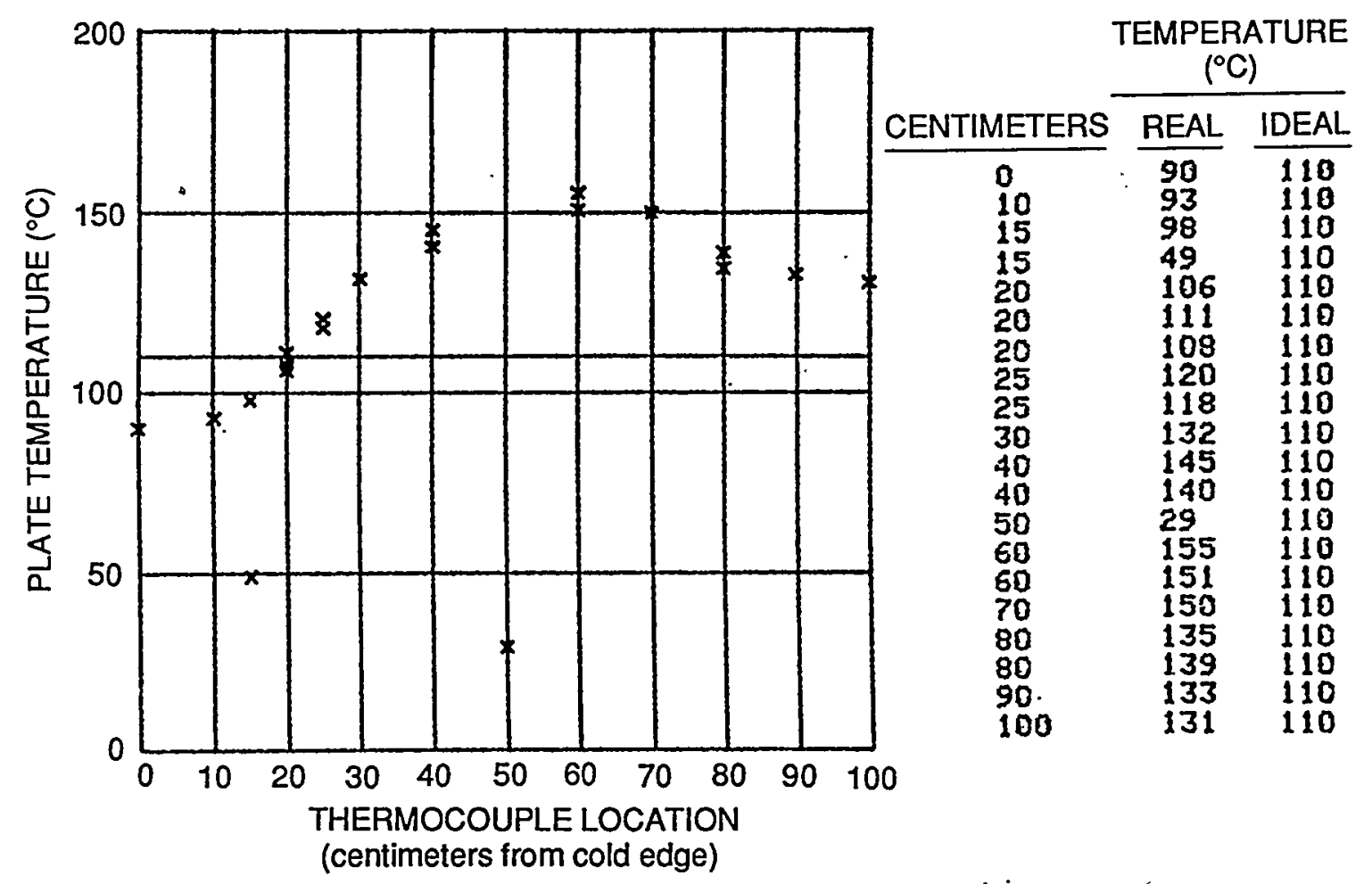

Fig. 5.47. Actual and ideal temperature distribution across specimen width during warm prestressing: test WP-2.6. 
ORNL-DWG 89-5026 ETD
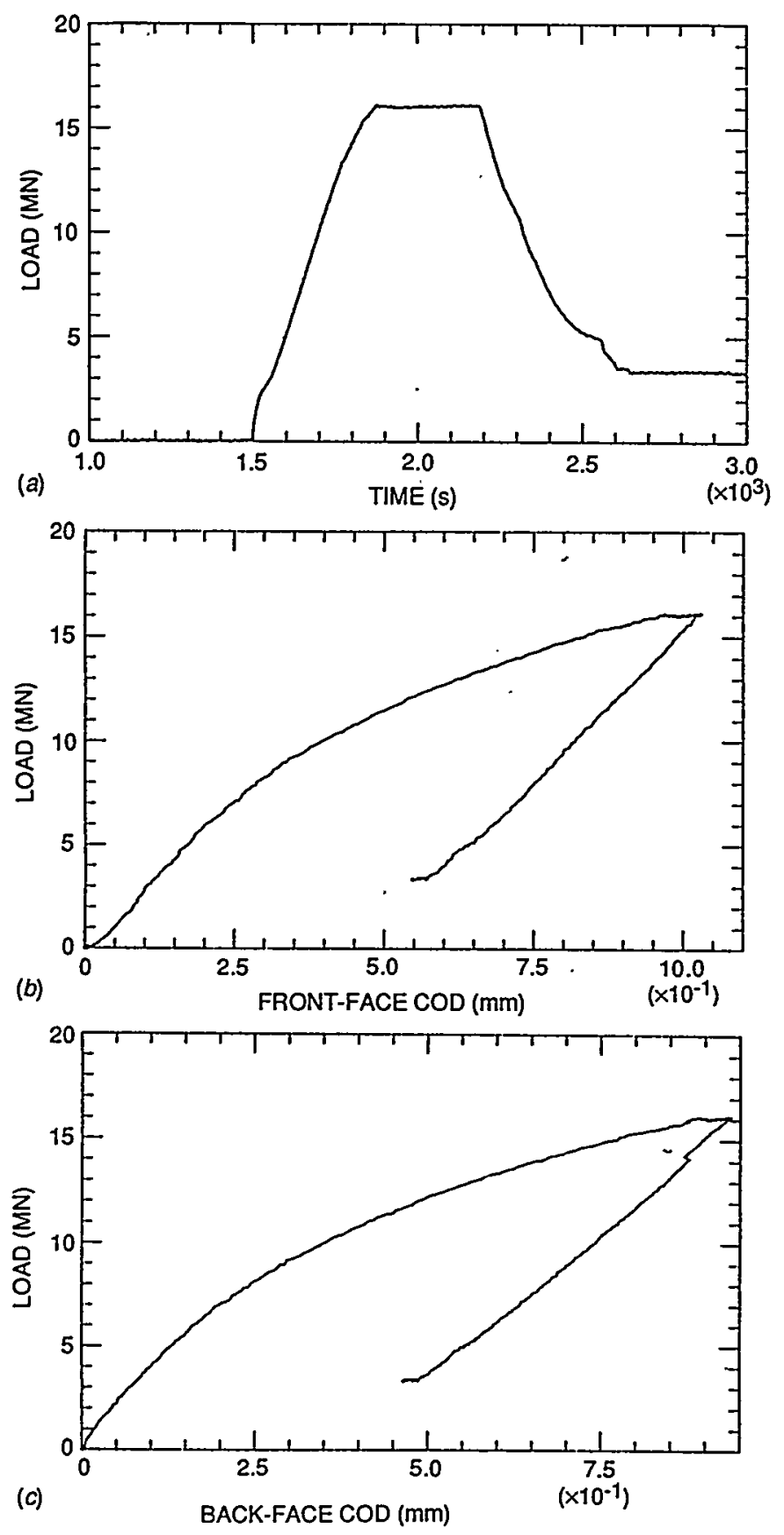

Fig. 5.48. Load vs (a) time, (b) front-face COD, and (c) back-face COD during warm prestressing: test WP-2.6. 
ORNL-DWG 89-5027 ETD

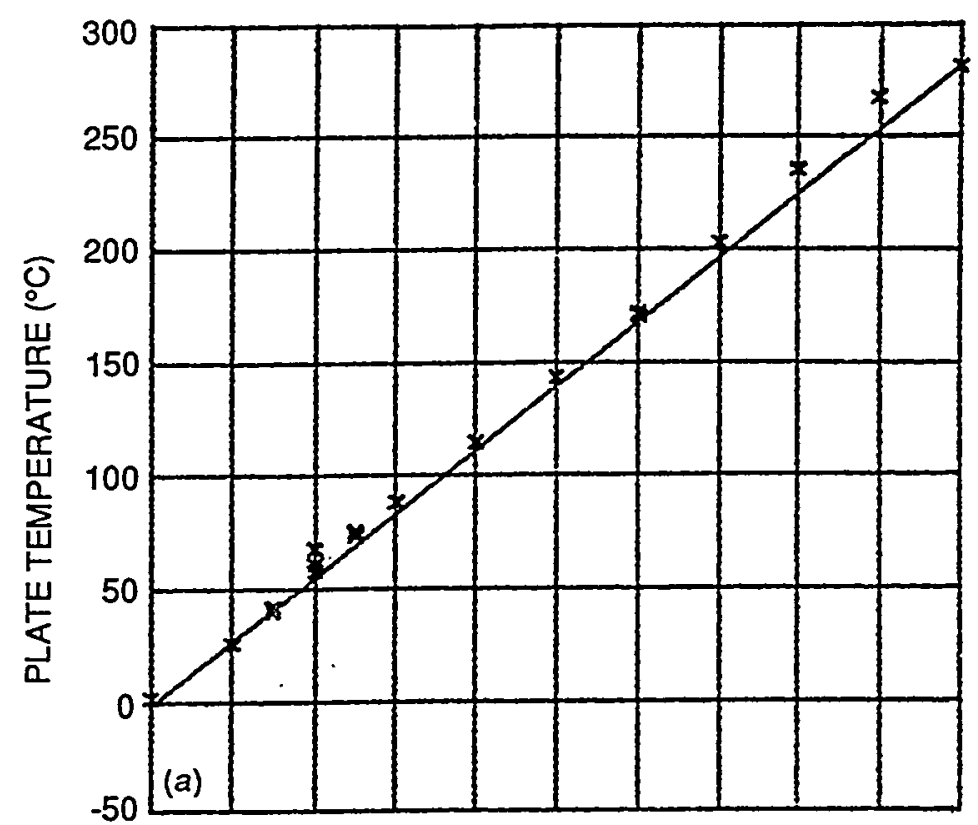

\begin{tabular}{|c|c|c|}
\hline \multirow[b]{2}{*}{ CENTIMETERS } & \multicolumn{2}{|c|}{$\begin{array}{l}\text { TEMPERATURE } \\
\left({ }^{\circ} \mathrm{C}\right)\end{array}$} \\
\hline & REAL & IDEAL \\
\hline $\begin{array}{l}0 \\
10 \\
15 \\
15 \\
20 \\
20 \\
20 \\
25 \\
25 \\
30 \\
40 \\
40 \\
50 \\
60 \\
60 \\
70 \\
80 \\
80 \\
90 \\
100\end{array}$ & $\begin{array}{l}2 \\
26 \\
42 \\
40 \\
61 \\
67 \\
57 \\
75 \\
73 \\
88 \\
114 \\
115 \\
143 \\
172 \\
171 \\
203 \\
235 \\
236 \\
257 \\
282\end{array}$ & $\begin{array}{l}-2 \\
26 \\
40 \\
40 \\
54 \\
54 \\
54 \\
69 \\
69 \\
83 \\
111 \\
111 \\
139 \\
168 \\
168 \\
196 \\
225 \\
225 \\
253 \\
281\end{array}$ \\
\hline
\end{tabular}

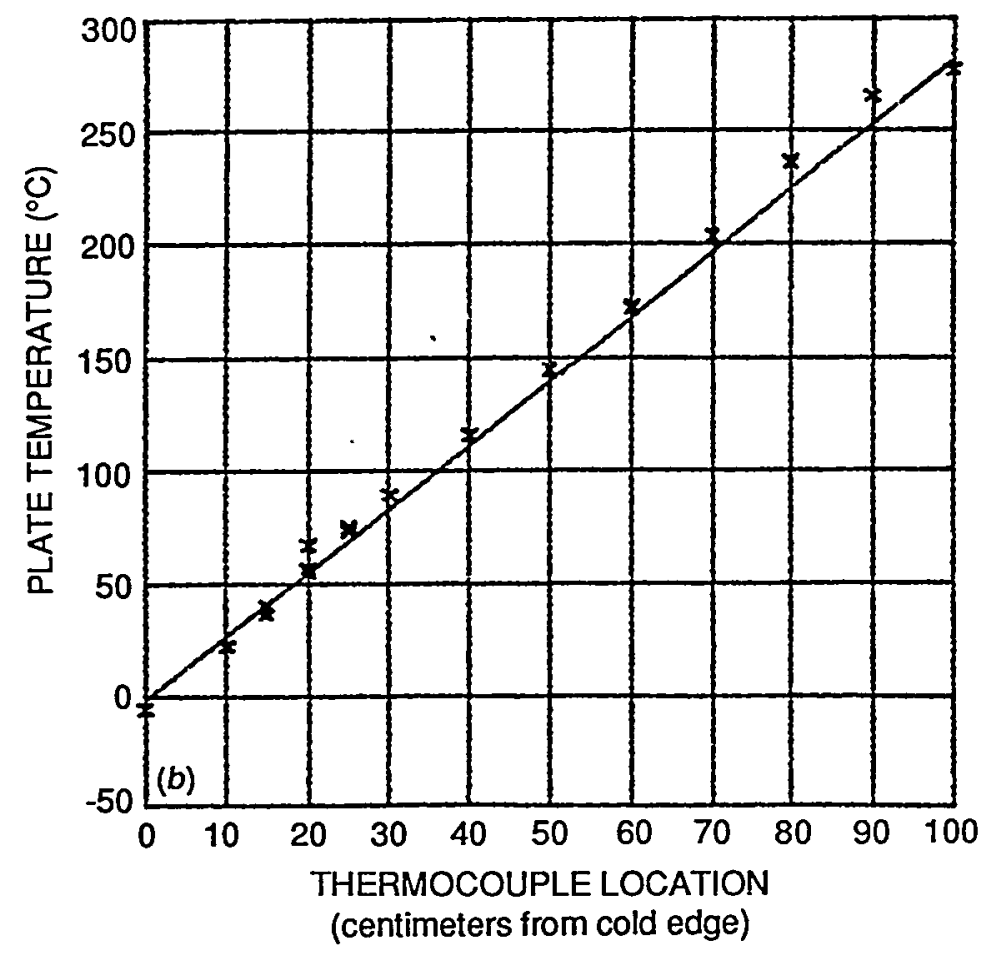

TEMPERATURE ('C)

\section{CENTIMETERS}

REAL

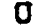 \\ 0
10 \\ 15}

15

20

20

25

25

30

40

40

50

60

60

80

80

90
100

$\begin{array}{ll}-6 & -2 \\ 22 & 26\end{array}$

$40 \quad 40$

$37 \quad 40$

$57 \quad 54$

$67 \quad 54$

$55 \quad 54$

7569

7369

$89 \quad 83$

$116 \quad 112$

$116 \quad 111$

$145 \quad 139$

$172 \quad 168$

$172 \quad 168$

$204 \quad 196$

$236 \quad 225$

236. 225

$277 \quad 281$

Fig. 5.49. Actual and ideal temperature distributions across specimen width (a) at start of loading and (b) just before initiation of cleavage crack run-arrest events: test WP-2.6. 


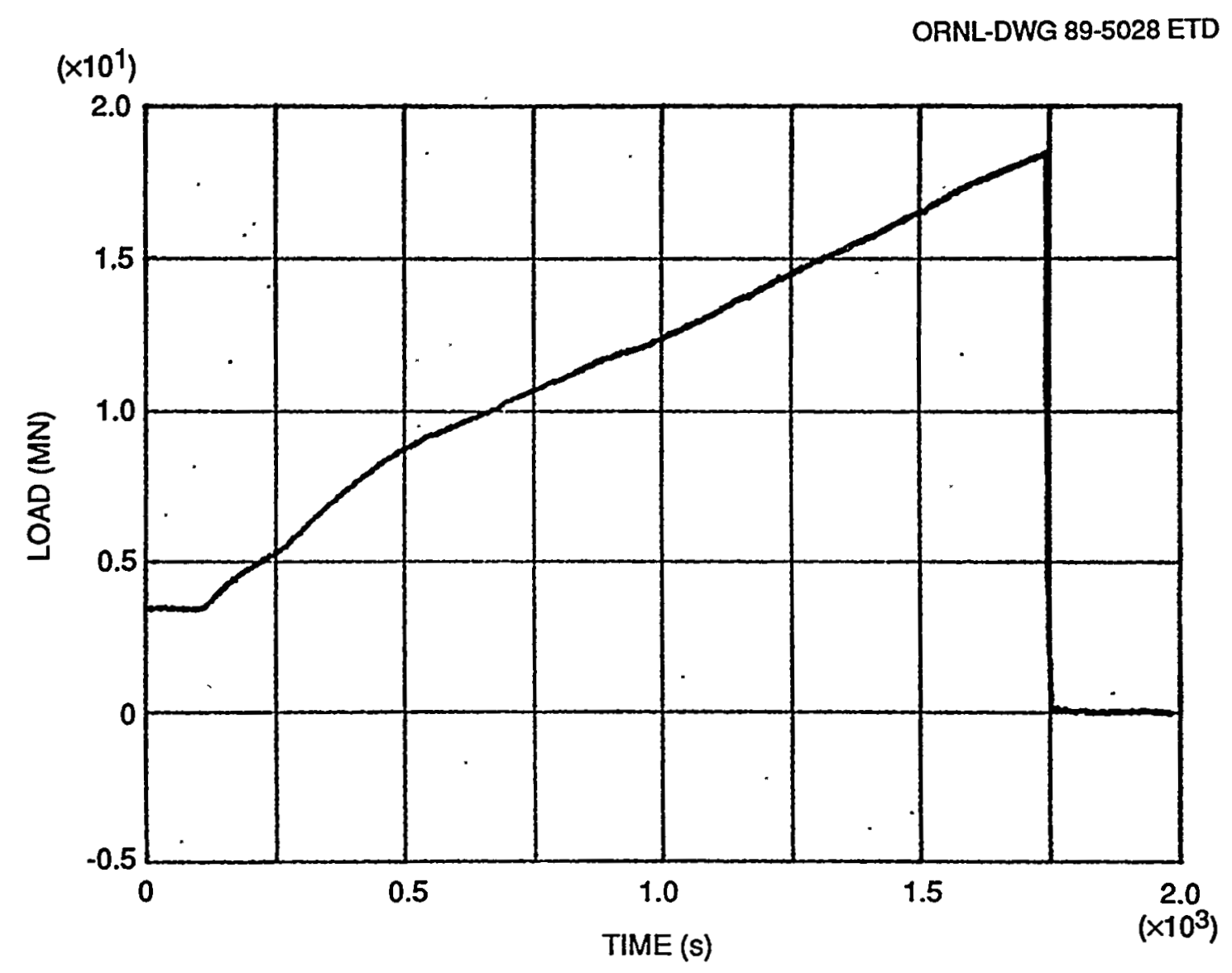

Fig. 5.50. Load history for test WP-2.6. 
ORNL PHOTO 7005-89R

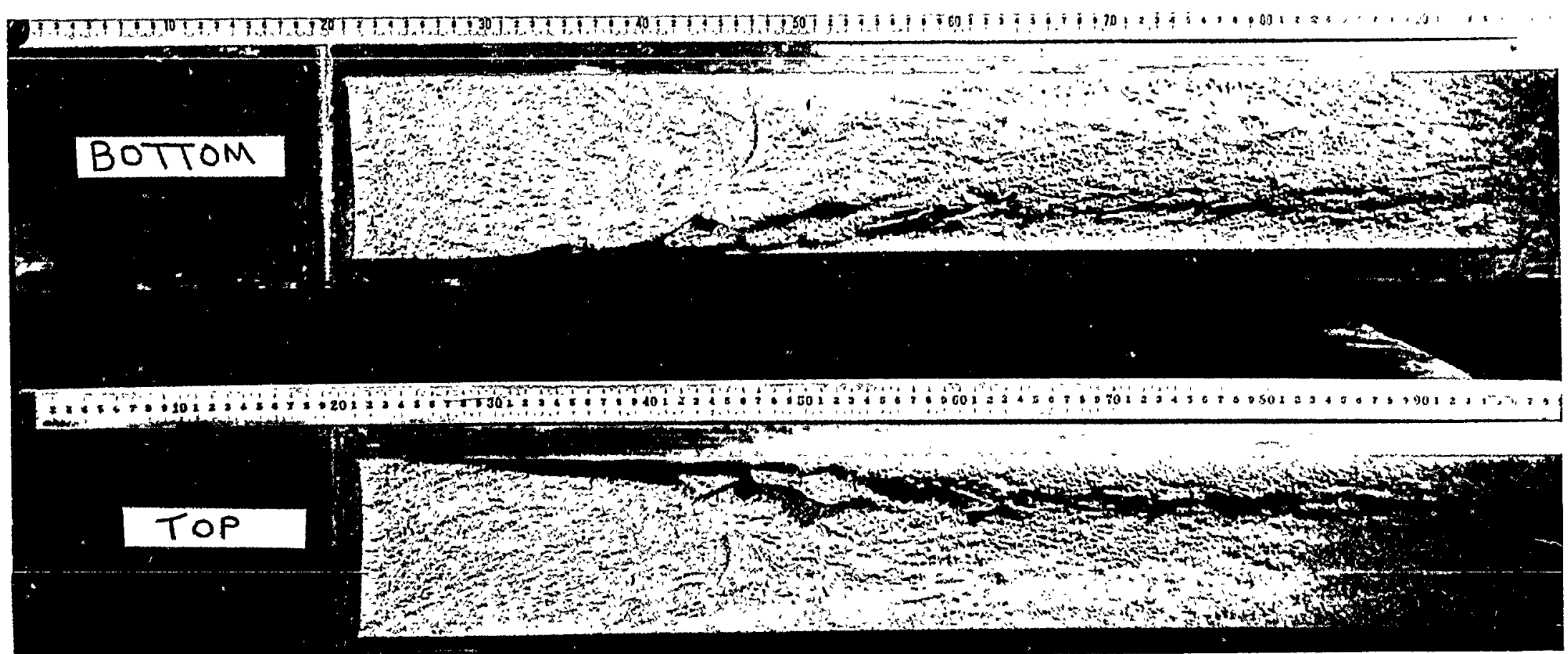

Fig. 5.51. Fracture surfaces of bottom and top plate halves of specimen WP-2.6. 

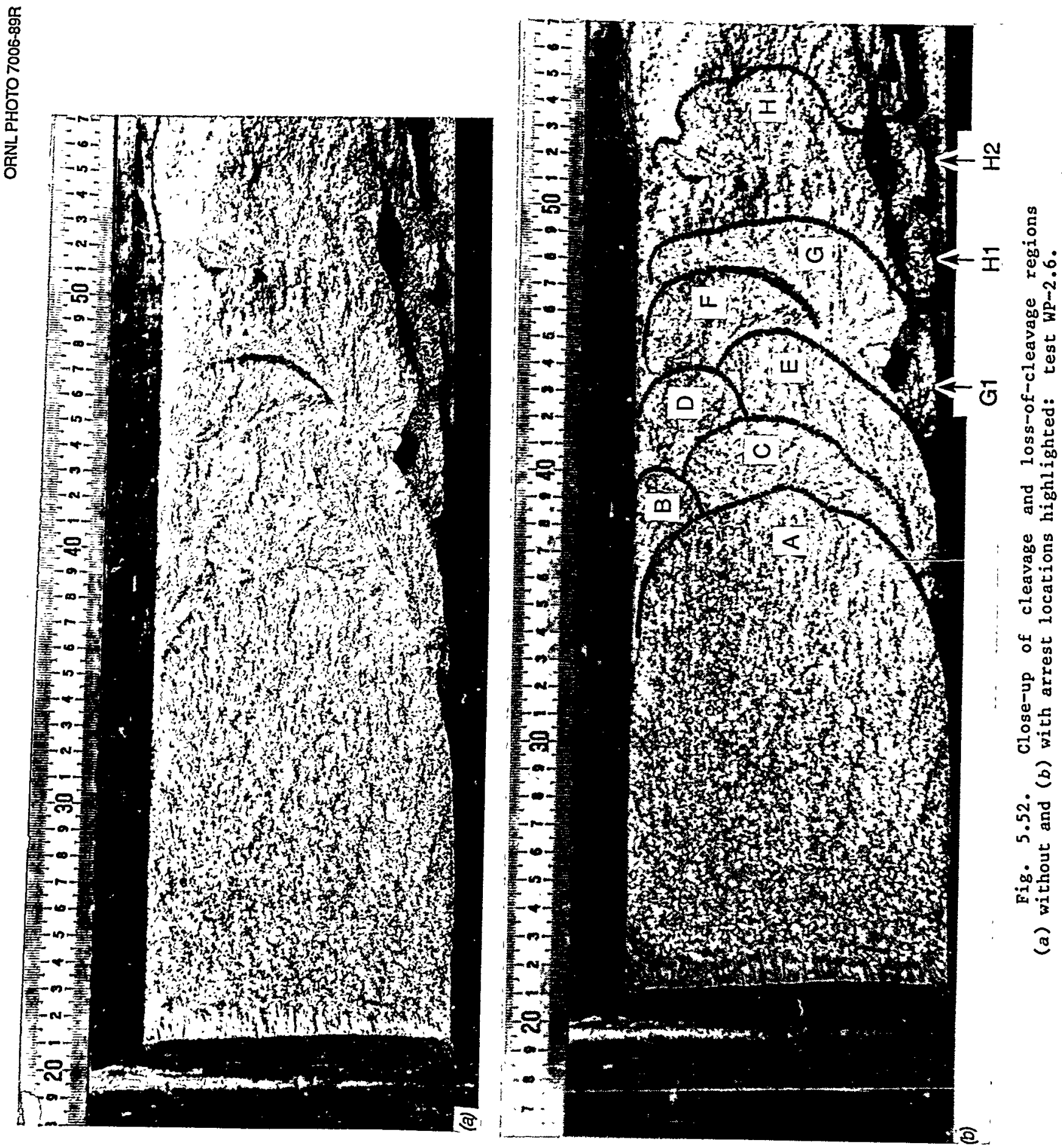
ORNL-DWG 89-5041 ETD

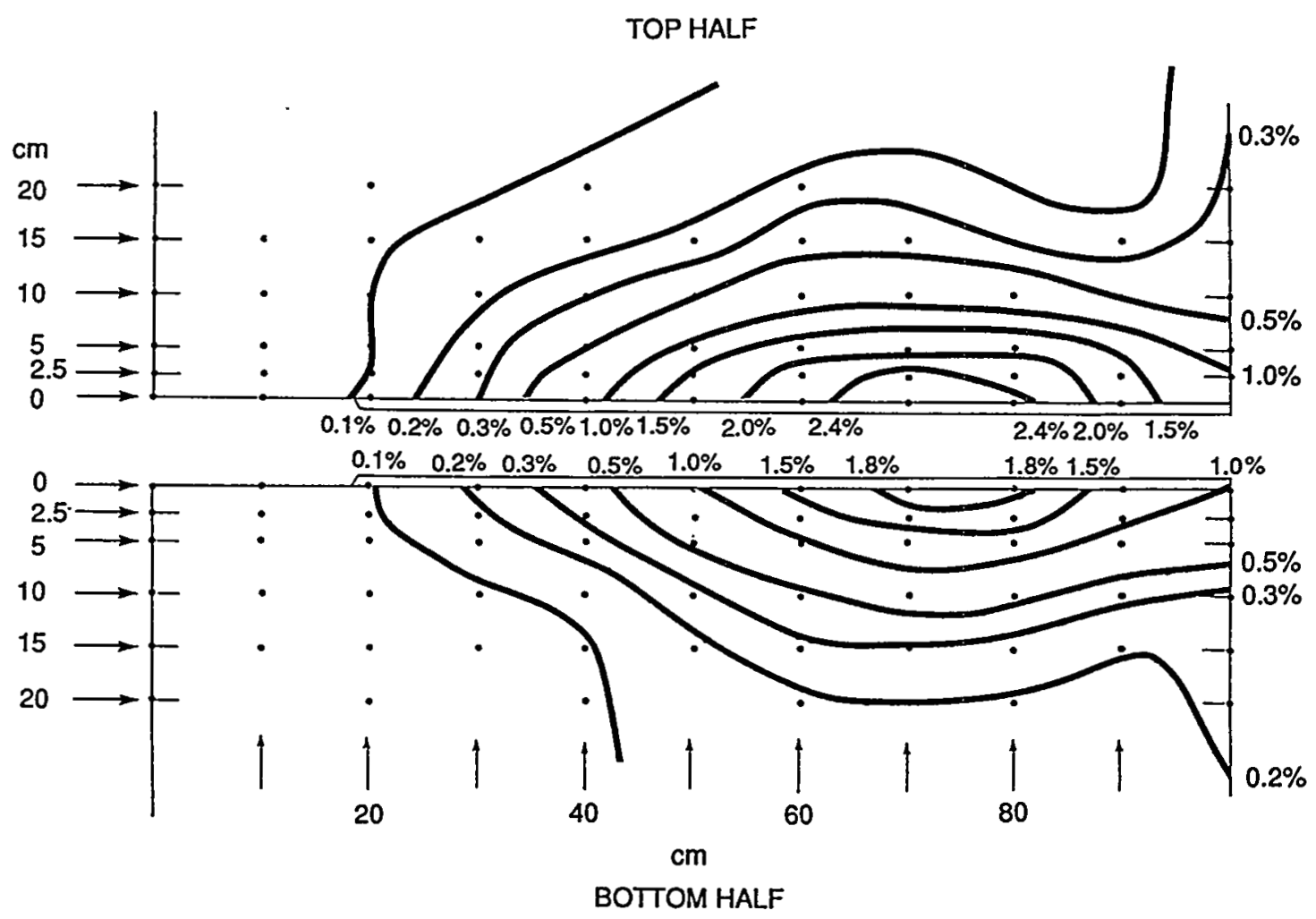

Fig. 5.53. Reduction-in-thickness contour map of specimen WP-2.6. 
Table 5.7. Crack position vs time and velocity: test WP-2.6

\begin{tabular}{|c|c|c|c|}
\hline Indicator ${ }^{a}$ & $\begin{array}{l}\text { Position } \\
\quad(\mathrm{mm})\end{array}$ & $\begin{array}{l}\text { Time } \\
\text { (ms) }\end{array}$ & $\begin{array}{l}\text { Velocity } \\
(\mathrm{m} / \mathrm{s})\end{array}$ \\
\hline \multicolumn{4}{|c|}{ Front-face measurements } \\
\hline SG1 & 218 & 0 & \\
\hline Initial crack $^{c}$ & 225 & 0 & 971 \\
\hline SG2 & 258 & 0.034 & 625 \\
\hline SG3 & 298 & 0.098 & 435 \\
\hline SG4 & 338 & 0.190 & 232 \\
\hline $\begin{array}{l}\text { Arrest A } \\
\text { Reinitiation A }\end{array}$ & $\begin{array}{l}357 \\
357\end{array}$ & $\begin{array}{l}0.272 \\
1.000\end{array}$ & 467 \\
\hline SG5 & 378 & 1.045 & 317 \\
\hline $\begin{array}{l}\text { Arrest B } \\
\text { Reinitiation B }\end{array}$ & $\begin{array}{l}397 \\
397\end{array}$ & $\begin{array}{l}1.105 \\
1.405\end{array}$ & 108 \\
\hline $\begin{array}{l}\text { Arrest C } \\
\text { Reinitiation C }\end{array}$ & $\begin{array}{l}410 \\
410\end{array}$ & $\begin{array}{l}1.525 \\
1.945\end{array}$ & 27 \\
\hline SG6 & 418 & 2.237 & 145 \\
\hline $\begin{array}{l}\text { Arrest D } \\
\text { Reinitiation D }\end{array}$ & $\begin{array}{l}430 \\
430\end{array}$ & $\begin{array}{l}2.320 \\
3.255\end{array}$ & 49 \\
\hline SG7 & 458 & 3.830 & 8 \\
\hline $\begin{array}{l}\text { Arrest F } \\
\text { Reinitiation F }\end{array}$ & $\begin{array}{l}460 \\
460\end{array}$ & $\begin{array}{l}4.090 \\
7.165\end{array}$ & 73 \\
\hline $\begin{array}{l}\text { Arrest G } \\
\text { Reinitiation G }\end{array}$ & $\begin{array}{l}480 \\
480\end{array}$ & $\begin{array}{r}7.440 \\
10.380\end{array}$ & 1064 \\
\hline
\end{tabular}


Table 5.7 (continued)

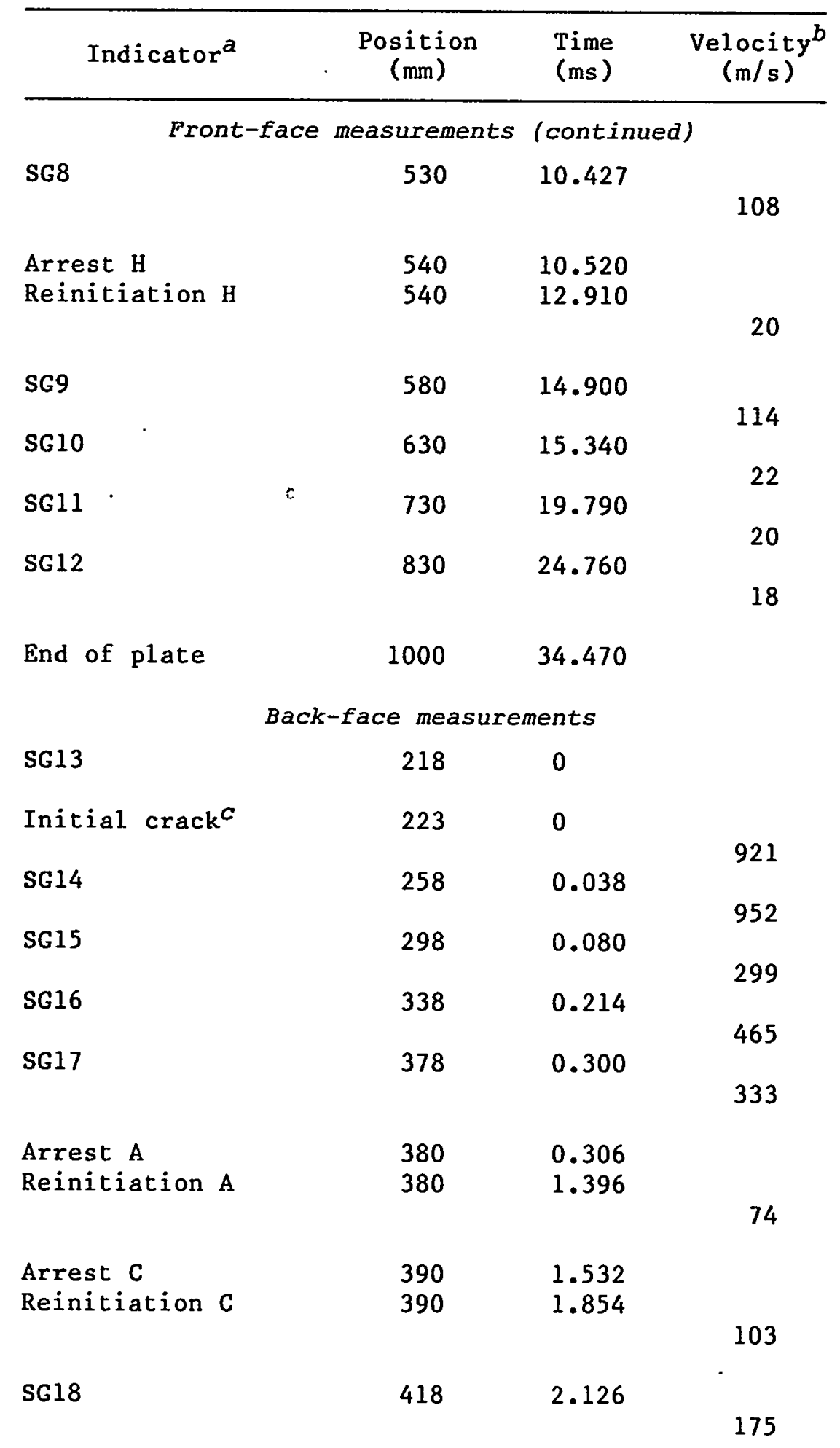


Table 5.7 (continued)

\begin{tabular}{|c|c|c|c|}
\hline Indicator ${ }^{a}$ & $\begin{array}{l}\text { Position } \\
\quad(\mathrm{mm})\end{array}$ & $\begin{array}{l}\text { Time } \\
\text { (ms) }\end{array}$ & $\begin{array}{l}\text { Velocity } \\
(\mathrm{m} / \mathrm{s})\end{array}$ \\
\hline \multicolumn{4}{|c|}{ Back-face measurements (continued) } \\
\hline $\begin{array}{l}\text { Arrest E } \\
\text { Reinitiation E }\end{array}$ & $\begin{array}{l}425 \\
425\end{array}$ & $\begin{array}{l}2.166 \\
3.152\end{array}$ & 198 \\
\hline $\begin{array}{l}\text { Arrest G1 } \\
\text { Reinitiation } \mathbf{G l}\end{array}$ & $\begin{array}{l}480 \\
480\end{array}$ & $\begin{array}{l}3.430 \\
7.160\end{array}$ & 71 \\
\hline SG19 & 490 & 7.300 & 167 \\
\hline $\begin{array}{l}\text { Arrest } \mathrm{H} 1 \\
\text { Reinitiation } \mathrm{H} 1 \\
\text { (ductile) }\end{array}$ & $\begin{array}{l}520 \\
520\end{array}$ & $\begin{array}{l}7.480 \\
7.480\end{array}$ & 6 \\
\hline $\begin{array}{l}\text { SG20 } \\
\text { (ductile tearing } \\
\text { past) }\end{array}$ & 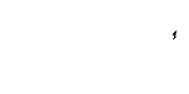 & 9.190 & 5 \\
\hline $\begin{array}{l}\text { Reinitiation } \mathrm{Hl} \\
\text { (cleavage) }\end{array}$ & 535 & 10.250 & 20 \\
\hline $\begin{array}{l}\text { Arrest } \mathrm{H} 2 \\
\text { Reinitiation } \mathrm{H} 2 \\
\text { (ductile) }\end{array}$ & $\begin{array}{l}540 \\
540\end{array}$ & $\begin{array}{l}10.500 \\
10.500\end{array}$ & \multirow[t]{2}{*}{19} \\
\hline End of plate & 1000 & 34.47 & \\
\hline \multicolumn{4}{|c|}{$\begin{array}{l}\text { These strain-gage positions are all reduced } \\
\text { by } 32 \mathrm{~mm} \text { from the actual gage position shown in } \\
\text { Fig. } 4.8(e) \text { because the peak strain occurs at an } \\
\text { angle of } 72^{\circ} \text { in front of the crack tip. Also note } \\
\text { that back-face gages } 13-20 \text { have been rotated } 45^{\circ} \\
\text { relative to companion front-face gages. }\end{array}$} \\
\hline $\begin{array}{r}b \text { Velocity is } \\
\text { crack propagation }\end{array}$ & $\begin{array}{l}\text { average ca } \\
\text { tween indic }\end{array}$ & $\begin{array}{l}\text { ulated } \\
\text { or point }\end{array}$ & ocity for \\
\hline
\end{tabular}




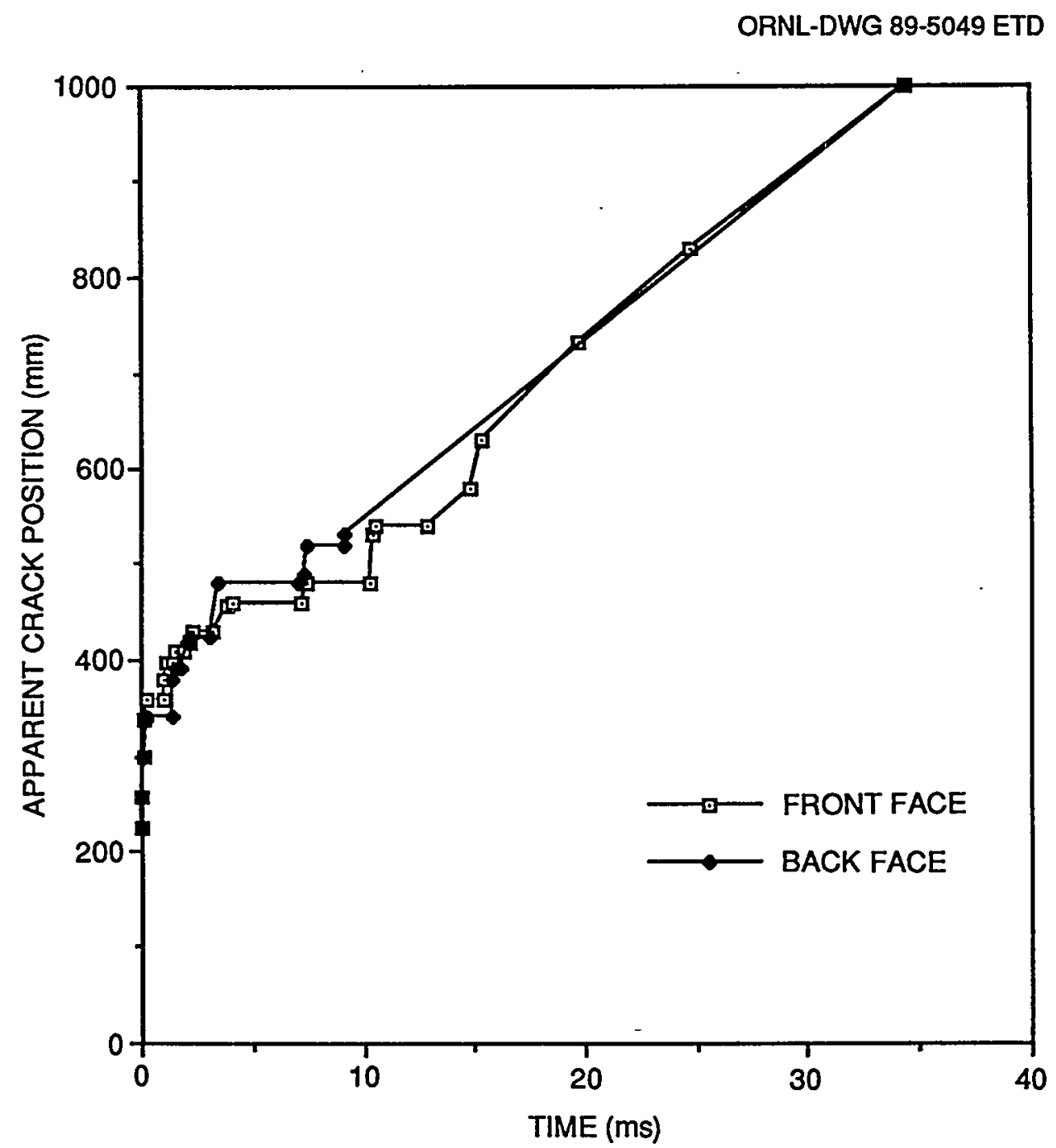

Fig. 5.54. Strain-gage-derived crack-front position vs time: test WP-2.6. 


\section{REFERENCE}

1. D. J. Naus et al., Martin Marietta Energy Systems, Inc., Oak Ridge Nat1. Lab., Crack-Arrest Behavior in SEN Wide Plates of Quenched and Tempered A 533 Grade B Steel Tested Under Nonisothermal Conditions, USNRC Report NUREG/CR-4930 (ORNL-6388), August 1987.*

*Available for purchase from National Technical Information Service, Springfield, VA 22161. 


\section{POSTTEST ANALYSES, CRACK-ARREST TOUGHNESS RESULTS, AND COMPARISON OF DATA WITH OTHER \\ LARGE-SCALE TEST RESULTS}

\subsection{POSTTEST ANALYSES}

Posttest analyses were conducted for each of the wide-plate, crackarrest tests in the WP-2 series to investigate the interaction of parameters (plate geometry, material properties, temperature profile, and mechanical loading) that affect the crack run-arrest events. Threedimensional (3-D), static, finite-element analyses were performed to determine the static stress-intensity factor at the time of crack initiation. These analyses were conducted using the ORMGEN/ORVIRT fracture analysis system 1,2 in conjunction with the ADINA-84 finiteelement code. ${ }^{3}$ Quasi-static analyses use the ORNL computer code WPSTAT 4 to evaluate static stress-intensity factors as a function of crack length and temperature differential across the plate. WPSTAT also categorizes arrested crack lengths in terms of three types of instability limits: reinitiation, tearing instability, and tensile instability.

Two-dimensional (2-D) elastodynamic analyses* were carried out using the ADINA/VPF dynamic crack analysis code ${ }^{5}$ that is capable of performing both application- and generation-mode analyses. In the application-mode analysis, the crack tip is propagated incrementally when $K_{I}$, the dynamically computed stress-intensity factor, equals the specified dynamic fracture-toughness value $K_{I D}$, which depends on the crack velocity $\dot{a}$ and the temperature $T$ [Eq. (3.6)]. In the generation-mode analysis, the crack tip is propagated incrementally according to a prescribed crack-position-vs-time relationship, and values of fracture toughness are determined from the dynamically computed $\mathrm{K}_{\mathrm{I}}$. For both modes of analysis, the dynamic stress-intensity factor is determined in each time step from the dynamic J-integral containing the appropriate inertial and thermal terms.

\subsubsection{Posttest 3-D Static Analyses}

The 3-D finite-element model used for the wide-plate analyses incorporated a segment of the plate assembly measured from the crack plane to the top of the load-pin holet (Fig. 6.1). The crack-tip region

*The development and use of dynamic analysis methods was required to incorporate the significant dynamic effects exhibited by the wideplate tests, that is, multiple crack-run-arrest events.

The length of the segment modeled varied from test to test as a result of the cutting procedure used to remove a test article before welding the next test article to the pull plates. For wide-plate specimens WP-2.1 through -2.6 the segments modeled (dimension $Y$ in Fig. 6.1) were $4.58,4.38,4.62,5.00,4.90$, and $4.36 \mathrm{~m}$, respectively. 


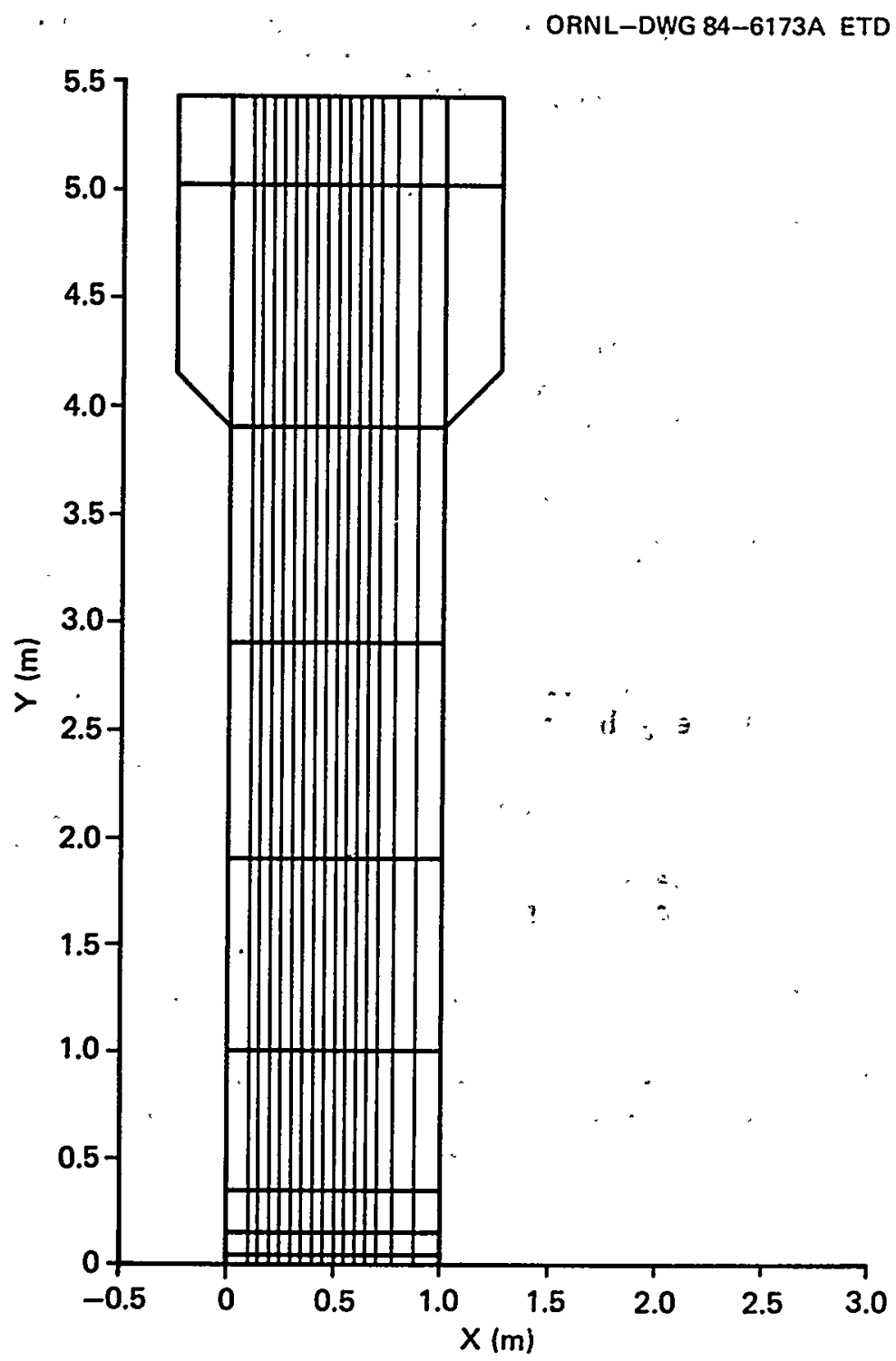

Fig. 6.1. Example of finite-element model used for dynamic analysis of wide-plate crack-arrest tests.

of the model included the chevron cutout (if present), $*$ the side grooving, and the edge notch (Fig. 6.2). Table 4.1 and Figs. 4.1 and 4.3 present specimen dimensions. From symmetry conditions that neglected out-of-plane eccentricity, one-quarter of the partial pul1-plate assembly was modeled using 3751 nodes and 720 20-noded isoparametric elements.

The thermal deformations computed from a posttest 2-D analysis were superimposed on a 3-D finite-element model to account for the in-plane

*Specimens WP-2.3 and -2.6 did not have their crack front cut into a truncated chevron configuration. 


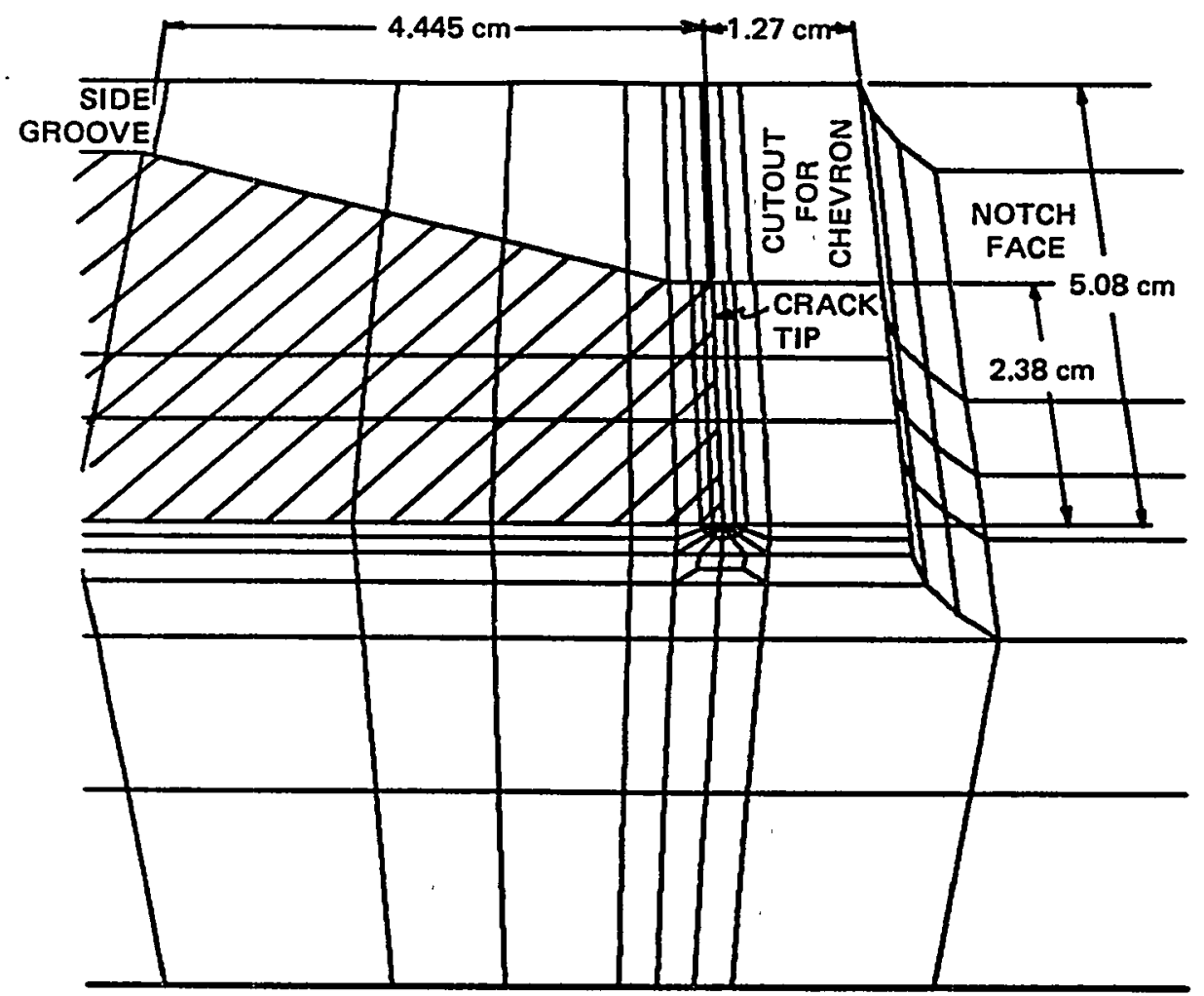

Fig. 6.2. Detail of crack-tip region from 3-D finite-element model of 102-mm-thick wide-plate specimen.

thermal bending effect in the 3-D analyses. The 2-D thermoelastic analysis used a temperature distribution from a heat-conduction analysis based on assumptions that the heated and cooled edges of the plate were fixed at $T_{\max }$ and $T_{\min }$, respectively, along a 2.4-m length (centered relative to the crack plane) and that the pul1-tab edges were maintained at $\mathrm{T}=20.0^{\circ} \mathrm{C} . *$ The edge temperatures were selected to yield a temperature distribution in the crack plane $(0.2 \leq \mathrm{a} / \mathrm{w} \leq 0.6)$ that agreed with the measured values presented in Chap. 5 for each specimen, for example, Fig. 5.20 for test WP-2.4. Computed load-1ine (through the top of the load-pin hole) eccentricities produced by the in-plane thermal bending in tests WP-2.1 through -2.6 were $2.01,1.96,1.74,2.37,1.97$, and 2.02 $\mathrm{cm}$, respectively, relative to the geometric center of the plates.

In the 3-D analysis a uniform line load, statically equivalent to the initiation load, was applied at the location corresponding to the top of the load-pin hole. The results of this analysis yielded a static stress-intensity factor $\left(K_{I}\right)$ at the center of the plate. Values of $k_{I}$

*Values of $T_{\min }$ and $T_{\max }$ for wide-plate tests WP-2.1 through -2.6 were 0 and $274^{\circ} \mathrm{C},-2$ and $280^{\circ} \mathrm{C}, 19$ and $253^{\circ} \mathrm{C},-11$ and $275^{\circ} \mathrm{C}, 17$ and $263^{\circ} \mathrm{C}$, and 0 and $290^{\circ} \mathrm{C}$, respectively. 
that were obtained for tests WP-2.1 through -2.6 were $126,183,136$, 143,141 , and $174 \mathrm{MPa} \cdot \sqrt{\mathrm{m}}$, respectively. Comparison of these computed $\mathrm{K}_{\mathrm{T}}$ values with the small-specimen static initiation values, $\mathrm{K}_{\mathrm{Jc}}$, evaluated from Eq. (3.5) using the appropriate specimen crack-tip temperature (Table 5.1) and a $\mathrm{DW}_{\mathrm{NDT}}=60^{\circ} \mathrm{C}$, yields $\mathrm{K}_{\mathrm{I}} / \mathrm{K}_{\mathrm{Jc}}$ ratios of $1.01,1.4,0.92$, $1.07,0.72$, and 1.2 , for tests WP-2.1 through -2.6 , respectively.

\subsubsection{Posttest 2-D Static and Dynamic Analyses}

\subsubsection{Static and Stability Analyses}

Posttest quasistatic 2-D analyses for both crack arrest and crack stability were done using the ORNL computer code WPSTAT. ${ }^{4}$ As described in Ref. 4, the WPSTAT code evaluates static stress-intensity factors as a function of crack length a and temperature differential $\Delta T=T_{\max }$ $T_{\min }$ across the plate. These factors are computed for fixed-force conditions $K_{I}^{F}(a, \Delta T)$ and for fixed load-pin displacement conditions $\mathrm{K}_{\mathrm{I}}^{\mathrm{DSP}}(\mathrm{a}, \Delta \mathrm{T})$ by superposing contributións from tension and bending finite-element and handbook solutions. Also, WPSTAT categorizes arrested crack lengths in terms of the three types of instability limits described below.

For the WP-2 series wide-plate tests the posttest WPSTAT calculations of the static factors $\mathrm{K}_{I}^{\mathrm{F}}(\mathrm{a}, \Delta \mathrm{T})$ and $\mathrm{K}_{\mathrm{I}}^{\mathrm{DSP}}(\mathrm{a}, \Delta \mathrm{T})$ used the actual temperature profiles at the approximate time of initiation of the crack run-arrest events shown in Fig. 5.1. For these specified temperature profiles, the dependence of the arrested crack lengths and crack stabilities upon the applied initiation load $F_{\text {in }}$ (Table 5.1) was investigated with WPSTAT, and the results are presented in Fig. 6.3 for test WP-2.4.* Figure 6.3 includes the statically calculated final crack length $a_{f c}$ and the instability crack lengths for reinitiation a rein, for tensile instability $a_{I 1}$, and for tearing instability $a_{I 2}$. The tensile instability calculation is based on the average stress in the remaining ligament equal to an ultimate stress $\sigma_{\mathrm{u}}=500 \mathrm{MPa}$, which represents the lowest value for the temperature range of interest. For the tearing instability calculation, the material tearing resistance is assumed to be represented by a power-1aw J-resistance curve of the following form $\mathrm{J}_{\mathrm{R}}=\mathrm{c}(\Delta \mathrm{a})^{\mathrm{m}}$, where $\mathrm{c}=0.1114, \mathrm{~m}=0.3832$, and the units of $\mathrm{J}_{\mathrm{R}}$ and $\Delta \mathrm{a}$ are $\mathrm{kJ} / \mathrm{m}^{2}$ and $\mathrm{mm}$, respectively. In Fig. 6.3 , the statically computed arrest length corresponding to the measured initiation load $F_{\text {in }}=8.85$ $M N$ is $a_{f c}=0.432 \mathrm{~m}$. This computed arrest point is between the tensile instability curve $a_{I 1}$ and the tearing instability curve $a_{I 2}$, implying an unstable condition. The measured initial arrest point $a_{f_{1}}=0.338 \mathrm{~m}$ is below the tearing instability curve.

*only the results for test WP-2.4 are presented in the remainder of this section. Posttest static and stability analyses for tests WP-2.1, $-2.2,-2.3,-2.5$, and -2.6 are contained in Refs. $6,7,8,8$, and 7 , respectively. 
ORNL-DWG 9OM-3634 ETD

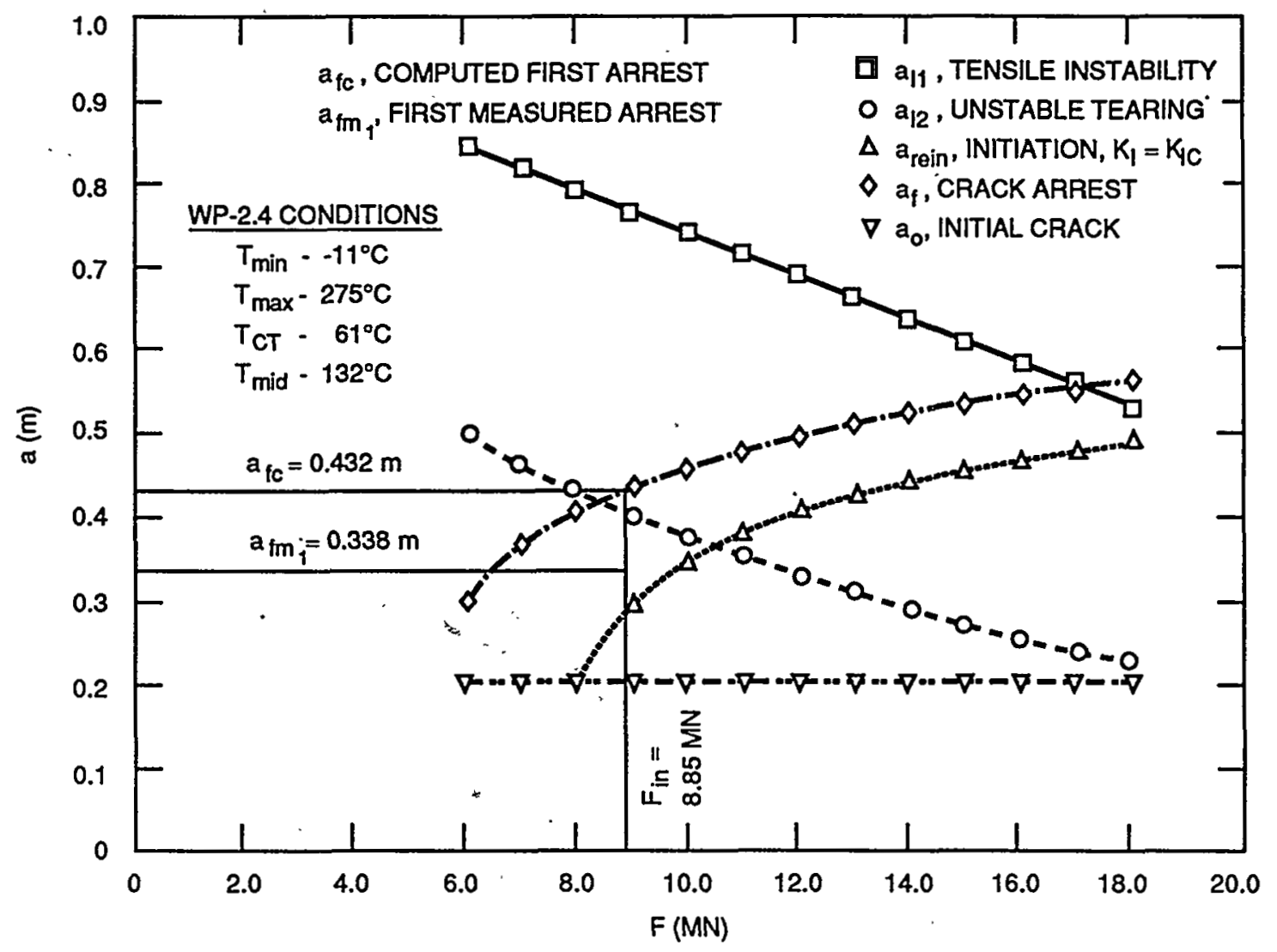

Fig. 6.3. Statically calculated crack lengths: test WP-2.4.

In Fig. 6.4, the $\mathrm{K}_{\mathrm{Ia}}$ function presented in Eq. (3.2) is evaluated on the arrest crack-length curve $a_{f}$, on the incipient tearing-instability curve $a_{I 2}$, and on the cleavage-reinitiation curve $a_{r e i n}$. The $K_{I c}$ function presented in Eq: (3.5) is evaluated on the curve arein $(F)$. Evaluation of the $K_{\mathrm{Ia}}$ curve at the initiation load $\mathrm{F}_{\text {in }}=8.85 \mathrm{MN}$ yields an arrest toughness of $\mathrm{K}_{\mathrm{Ia}}=190 \mathrm{MPa} \cdot \sqrt{\mathrm{m}}$ at the computed arrest point $a_{f c}=0.432 \mathrm{~m}$ where the crack-tip temperature would be $112^{\circ} \mathrm{C}$ (see Table $6.1 *)$.

The complete static fracture-mechanics and stability analyses are depicted in Fig. 6.5 for the initiation $10 \mathrm{ad} \mathrm{F}_{\text {in }}=8.85 \mathrm{MN}$. Included in the figure are curves for initiation toughness $K_{I c}$, arrest toughness $\mathrm{K}_{\mathrm{Ia}}$, displacement-controlled stress-intensity factor $\mathrm{K}_{\mathrm{I}}^{\mathrm{DISP}}$, and forcecontrolled stress-intensity factor $k_{I}^{F}$. The regions of tearing and

*Although only the results for test WP-2.4 are discussed in this section, Table 6.1 presents a summary of WPSTAT results for each of the tests in the WP-2 series. More detailed information on the analyses for each test can be obtained from the references noted previously. 


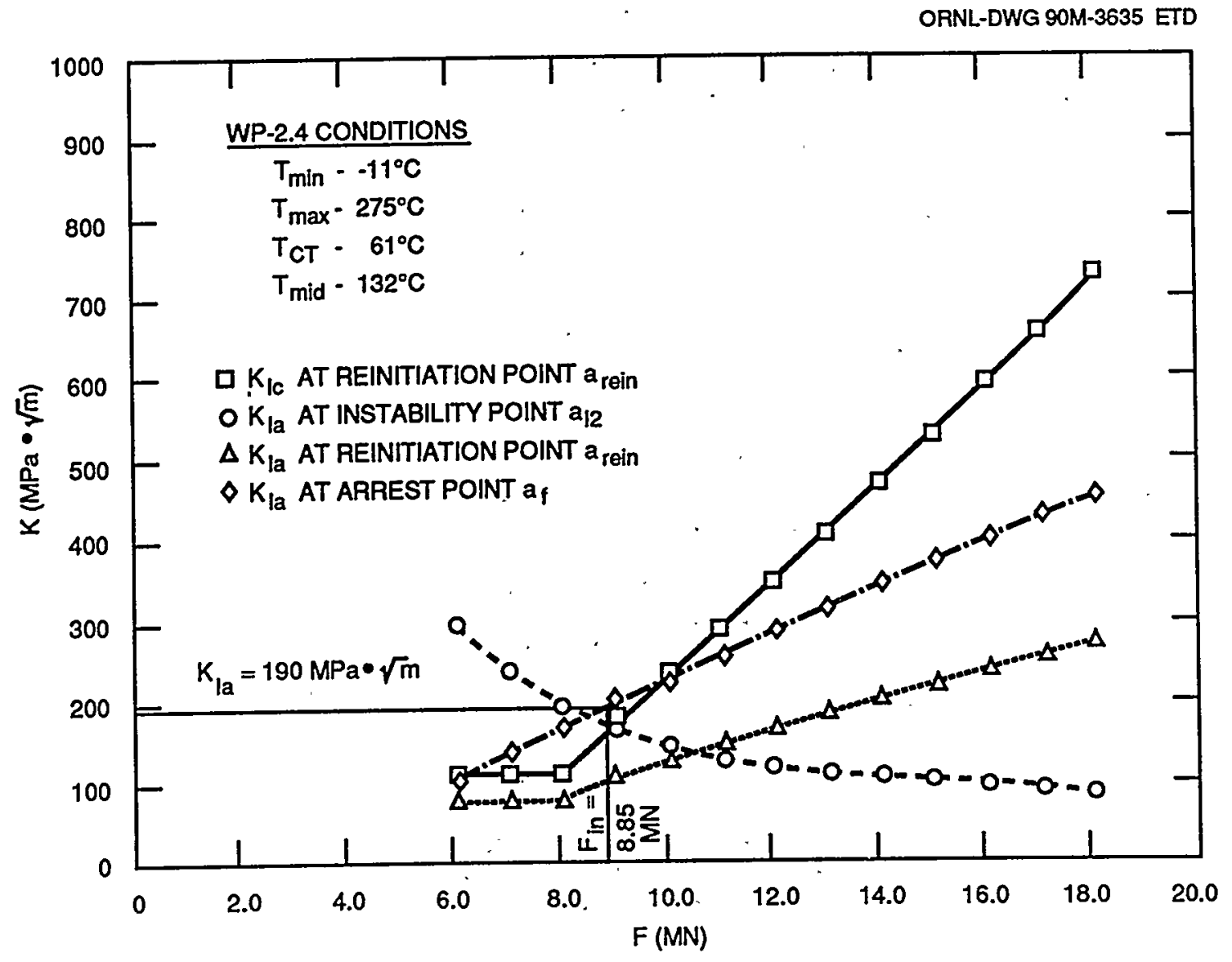

Fig. 6.4. Determination of arrest toughness at initiation load of 8.85 MN: test WP-2.4.

Table 6.1. Summary of WPSTAT results for $W P-2$ series tests

\begin{tabular}{lcccc}
\hline $\begin{array}{c}\text { Test } \\
\text { specimen }\end{array}$ & $\begin{array}{c}\text { Initiation } \\
\text { load, } \\
F_{\text {in }}\end{array}$ & $\begin{array}{c}\text { Predicted } \\
\text { arrest crack } \\
\text { (MNgth, } a_{f} \\
(\mathrm{~m})\end{array}$ & $\begin{array}{c}\text { Temperature } \\
\text { at arrest } \\
\text { point, } \\
\left({ }^{\circ} \mathrm{C}\right)\end{array}$ & $\begin{array}{c}\text { Crack-arrest } \\
\text { toughness, } \\
(\mathrm{MPa} \cdot \sqrt{\mathrm{m}})\end{array}$ \\
\hline WP-2.1 & 11.9 & 0.347 & 99 & 148 \\
WP-2.2 & 17.0 & 0.452 & 125 & 250 \\
WP-2.3 & 15.3 & 0.427 & 118 & 215 \\
WP-2.4 & 8.9 & 0.432 & 112 & 190 \\
WP-2.5 & 8.9 & 0.358 & 106 & 167 \\
WP-2.6 & 19.3 & 0.451 & 131 & 284 \\
\hline
\end{tabular}


ORNL-DWG 90M-3636 ETD

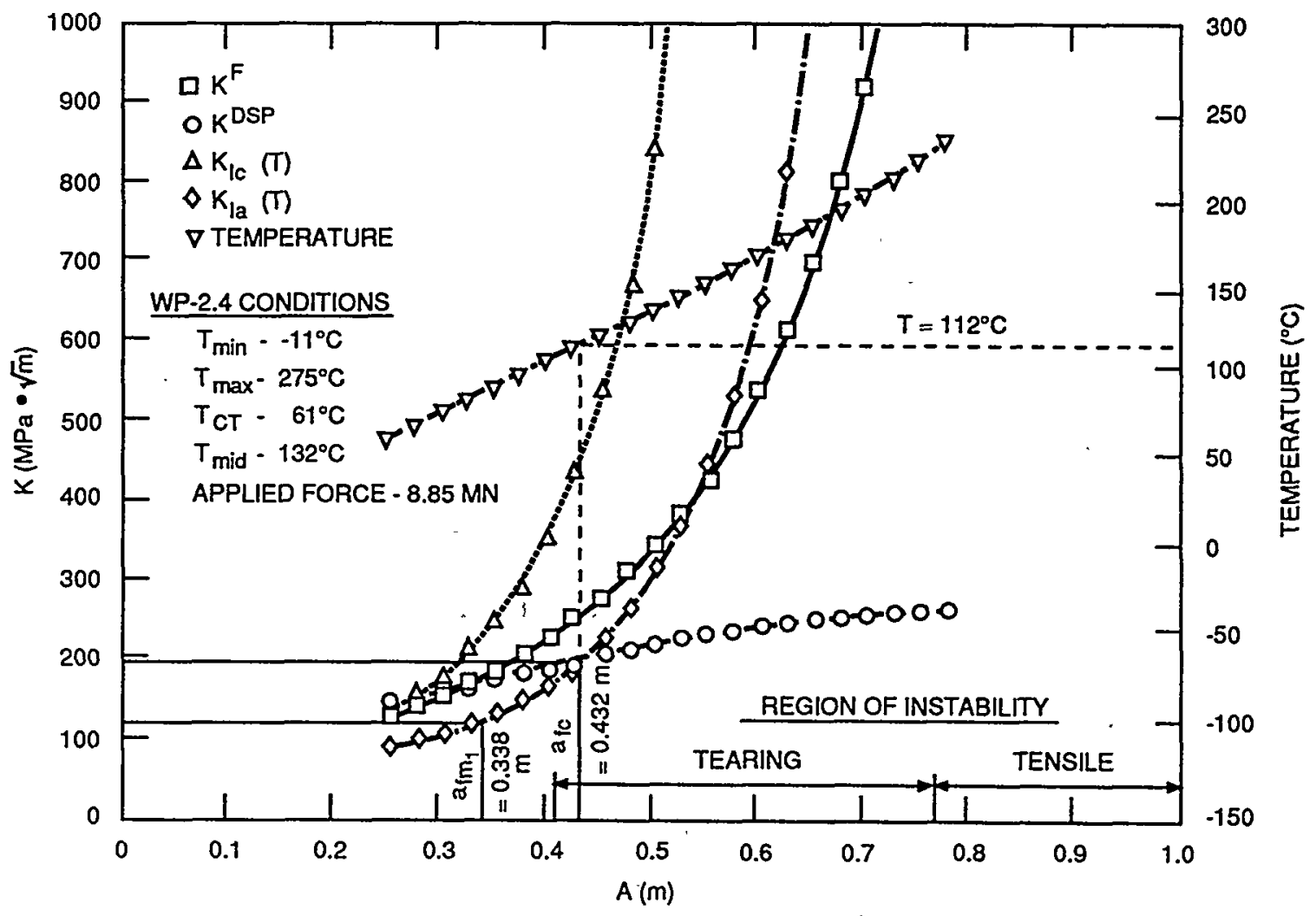

Fig. 6.5. Complete static and stability analyses for initiation load of $8.85 \mathrm{MN}$ : test WP-2.4.

tensile instability and the computed initial arrest point $a_{\text {fc }}$ are also identified in Fig. 6.5.

\subsubsection{Application-Mode Dynamic Analysis (Fired-Load Boundary Condition)}

Elastodynamic fracture analysis was performed using the finiteelement method and the implicit Newmark-Beta scheme for the time integration. The dynamic stress-intensity factor $K_{I}$ is determined in each time step from the dynamic J-integral containing the appropriate inertial and thermal terms. The crack-growth modeling technique of these codes uses a scheme in which crack-plane nodes, initially restrained normal to the crack plane by stiff springs, are released incrementally according to the selected analysis mode.

Elastodynamic analyses of wide-plate test WP-2.4 were carried out with the ADINA/VPF (Ref. 5) dynamic crack analysis code. The 2-D planestress finite-element model of the wide-plate configuration used in the analyses consists of 894 nodes and 264 eight-noded isoparametric elements. Thirty-one spring elements are used in the crack plane to model 
propagation of the crack tip. Side grooves are taken into account by adjusting the resulting stress-intensity factor calculated in each time step of the analysis, that is, multiplying by $\sqrt{\mathrm{B} / \mathrm{B}_{\mathrm{N}}}$.

A posttest application-mode analysis of wide-plate test WP-2.4 was performed using the material properties given in Chap. 3. The global deformation of the assembly caused by thermal strains was incorporated into the analyses. For finite-element applications, static thermoelastic analyses were performed with the ADINA/ADINAT finite-element codes $^{3}$ to determine the thermal deformation of the plate assembly. The thermal displacements were added to the nodal coordinates. The temperature distribution for the analyses was interpolated from the data measured along the crack plane (Fig. 5.20) and used only for determination of dynamic fracture toughness. For the dynamic analysis, the load was fixed at the value of the measured fracture load, $8.85 \mathrm{MN}$, as a prescribed concentrated load. The time step was set at $\Delta t=5 \mu s$.

The calculated crack-depth history (plate front face) from this analysis is presented in Fig. 6.6. Figure 6.7 shows the dynamic stressintensity factor $\mathrm{K}_{\mathrm{I}}^{\mathrm{DYN}}$, the static toughness $\mathrm{K}_{\mathrm{Ia}}$, and the crack velocity $\dot{a}$ as a function of instantaneous crack depth. In Fig. 6.7, the crack velocity decreases smoothly, and crack propagation continues at

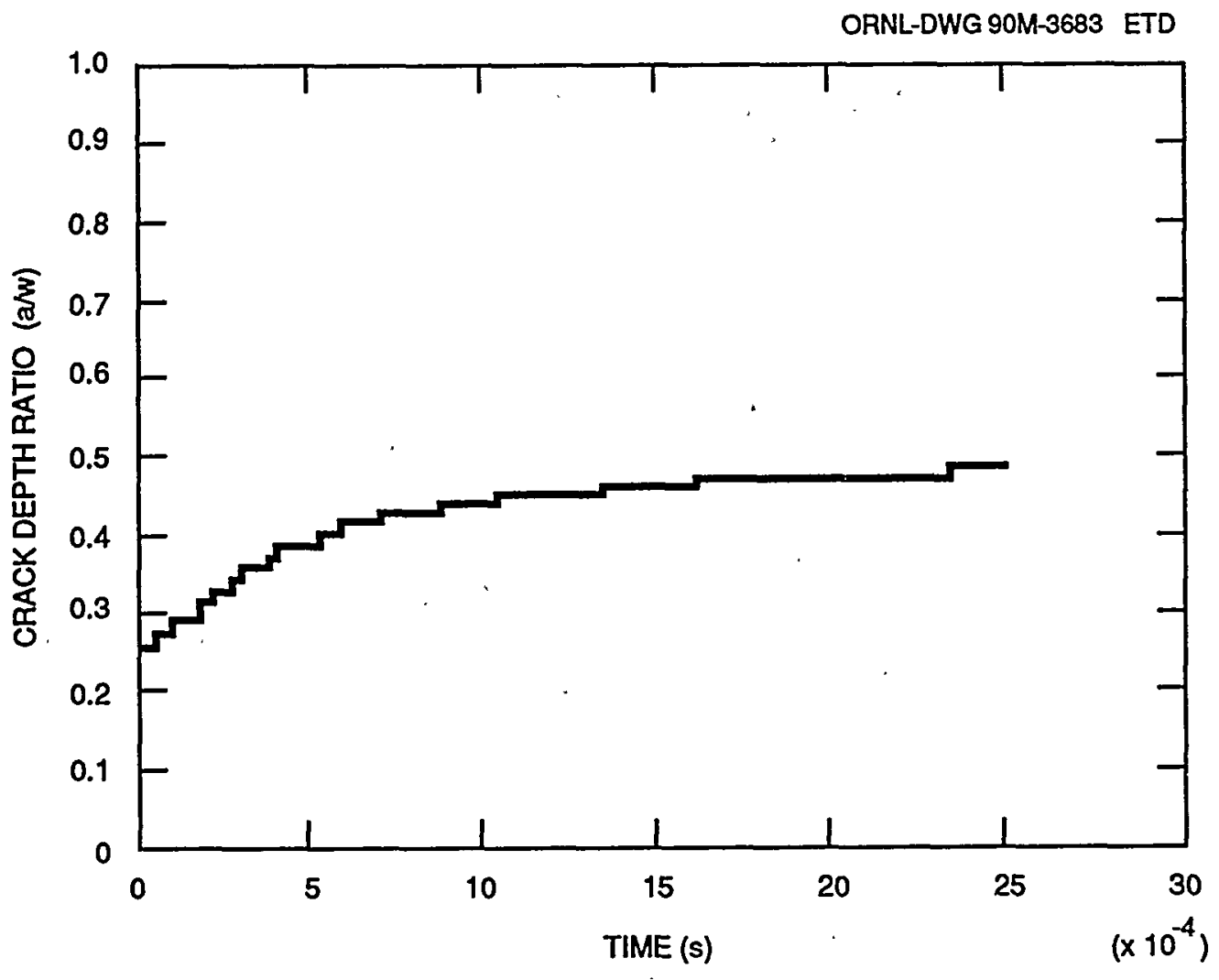

Fig. 6.6. Dynamic-analysis, crack-depth history: test WP-2.4. 
ORNL-DWG 90M-3637 ETD

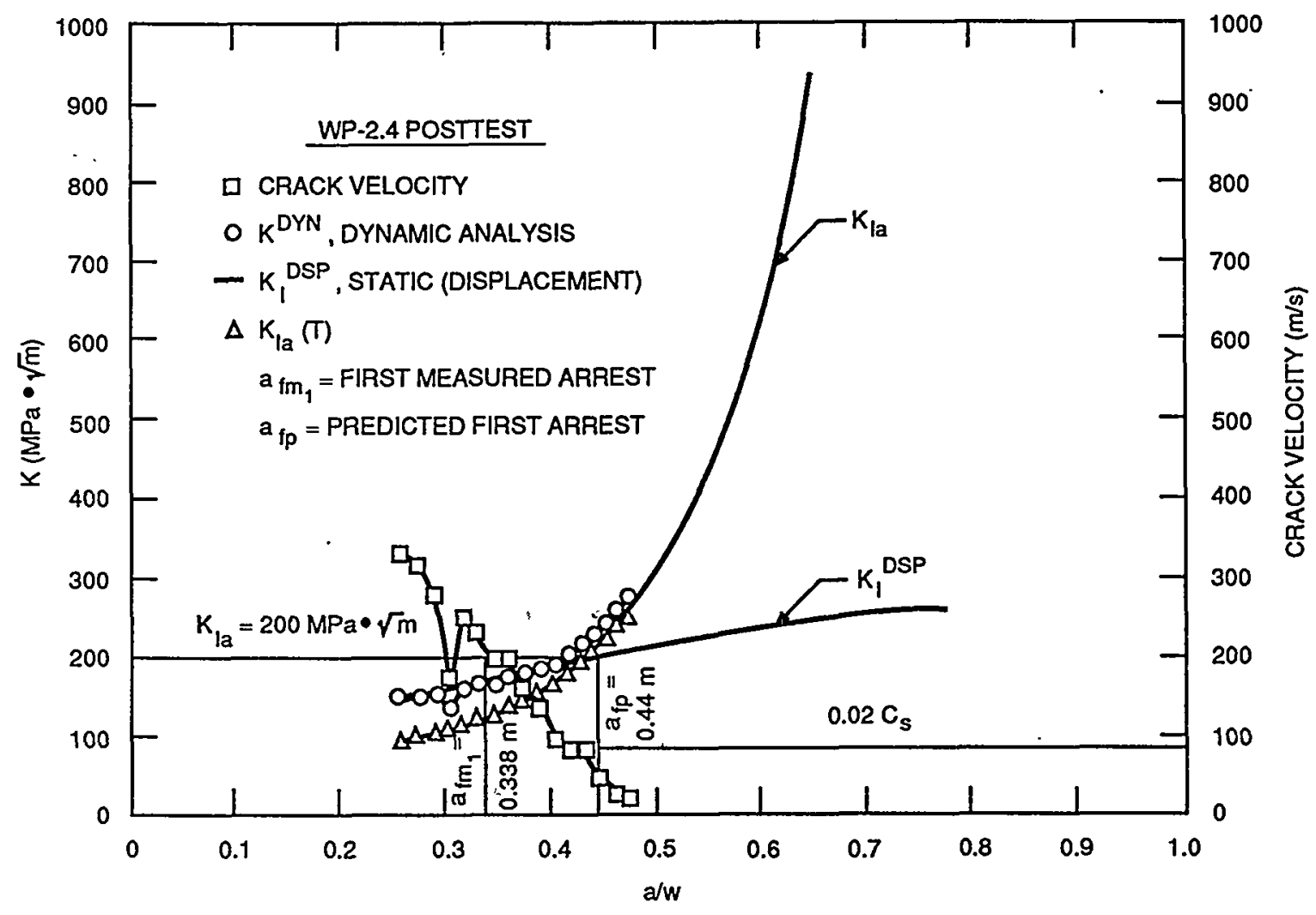

Fig. 6.7. Dynamic factor, static toughness, quasi-static displacement-controlled factor, and crack velocity vs instantaneous crack length: test WP-2.4.

small velocities for values of $a / w>\sim 0.43$. Because it is unlikely that a real crack would propagate at these low velocities for an extended period of time, arrest has been arbitrarily defined to occur when the crack velocity drops below a threshold velocity of $2 \%$ of the shear wave velocity $\left(C_{s}\right)$; that is, $0.02 C_{s}=64 \mathrm{~m} / \mathrm{s}$. Based on this assumption, an arrest is predicted from the application-mode analysis at $a_{f_{p}}=0.44 \mathrm{~m}$, where the crack-tip temperature would be $\mathrm{T}=118^{\circ} \mathrm{C}$ and the arrest toughness would be $\mathrm{K}_{\mathrm{Ia}}=200 \mathrm{MPa} \cdot \sqrt{\mathrm{m}}$. The predicted arrest point exceeds the first measured arrest point, $a_{f_{m_{1}}}=0.338 \mathrm{~m}$, where $\mathrm{T}=86.3^{\circ} \mathrm{C}$ and $\mathrm{K}_{\mathrm{Ia}_{\mathrm{a}}}=$ $122 \mathrm{MPa} \cdot \sqrt{\mathrm{m}}$. The analyses were terminated at time $t=3 \mathrm{~ms}$ (see Table $6.2 *)$.

*Table 6.2 presents a summary of application-mode dynamic analysis results for each of the tests in the WP-2 series. More detailed information on the analyses for each test can be obtained from the references noted previously. 
Table 6.2. Summary of application-mode dynamic analyses for,WP-2 series tests

\begin{tabular}{lcccc}
\hline $\begin{array}{c}\text { Test } \\
\text { specimen }\end{array}$ & $\begin{array}{c}\text { Initiation } \\
\text { load, } \\
\text { Fin } \\
(\mathrm{MN})\end{array}$ & $\begin{array}{c}\text { Predicted } \\
\text { arrest crack } \\
\text { length, } \mathrm{a}_{\mathrm{fp}} \mathrm{a}^{\mathrm{(m})}\end{array}$ & $\begin{array}{c}\text { Temperature } \\
\text { at arrest } \\
\text { point, } \\
\left({ }^{\circ} \mathrm{C}\right)\end{array}$ & $\begin{array}{c}\text { Track-arrest } \\
\text { toughness, K } \\
(\mathrm{MPa} \cdot \sqrt{\mathrm{m}})\end{array}$ \\
\hline WP-2.1 & 11.9 & 0.371 & 102 & 143 \\
WP-2.2 & 17.0 & 0.452 & 124 & 251 \\
WP-2.3 & 15.3 & 0.429 & 118 & 220 \\
WP-2.4 & 8.9 & 0.439 & 118 & 200 \\
WP-2.5 & 8.9 & 0.371 & 109 & 181 \\
WP-2.6 & 19.3 & 0.430 & 125 & 253 \\
\hline
\end{tabular}

${ }^{a}$ Arrest has been defined to occur when the crack velocity drops below a threshold velocity of $2 \%$ of the shear wave velocity $\left(c_{s}\right)$; that is, $0.02 C_{s}=64 \mathrm{~m} / \mathrm{s}$. The value given is for the first crack run-arrest event.

\subsubsection{Generation-Mode Dynamic Analysis, (Fixed Load Boundary Condition}

From the output of the crack-line gages and from an inspection of the fracture surface, estimates of the crack position as a function of time were constructed and listed in Table 5.5 for the plate front and back faces for test WP-2.4.* Figure 6.8 depicts the apparent crack position vs time that was derived from Table 5.5 and used as input for the posttest generation-mode elastodynamic analysis of test WP-2.4. For these analyses, the load point was fixed at the value of the initiation load, $8.85 \mathrm{MN}$, as a prescribed concentrated 1oad, and the time step was set at $\Delta t=10 \mu \mathrm{s}$. From these calculations, the stress-intensity factor as a function of time is given in Fig: 6.9. The generation-mode analysis (fixed-load-point boundary condition)t results for the seven crack run-arrest events (plate front face) of test WP-2.4 are given in Table 6.3.

The computed strain histories corresponding to selected points close to the front-side gage 1-12 7 [see Fig. 4.8(d) for gage locations]

*only the results for test WP-2.4 are presented in this section. Generation-mode dynamic results for the other tests in the WP-2 series are summarized in Sect. 6.2. More details on each test can be obtained by consulting the appropriate references noted earlier.

$t_{\text {Appendix }} \mathrm{B}$ discusses the importance of the analysis method (static vs dynamic) and boundary condition (fixed-load or fixed-load-pin displacement) used to interpret the wide-plate crack-arrest tests.

¥Note that because strain gage 6 did not function during the test, computed and actual strain histories for its companion back-face gage (17) are presented. 


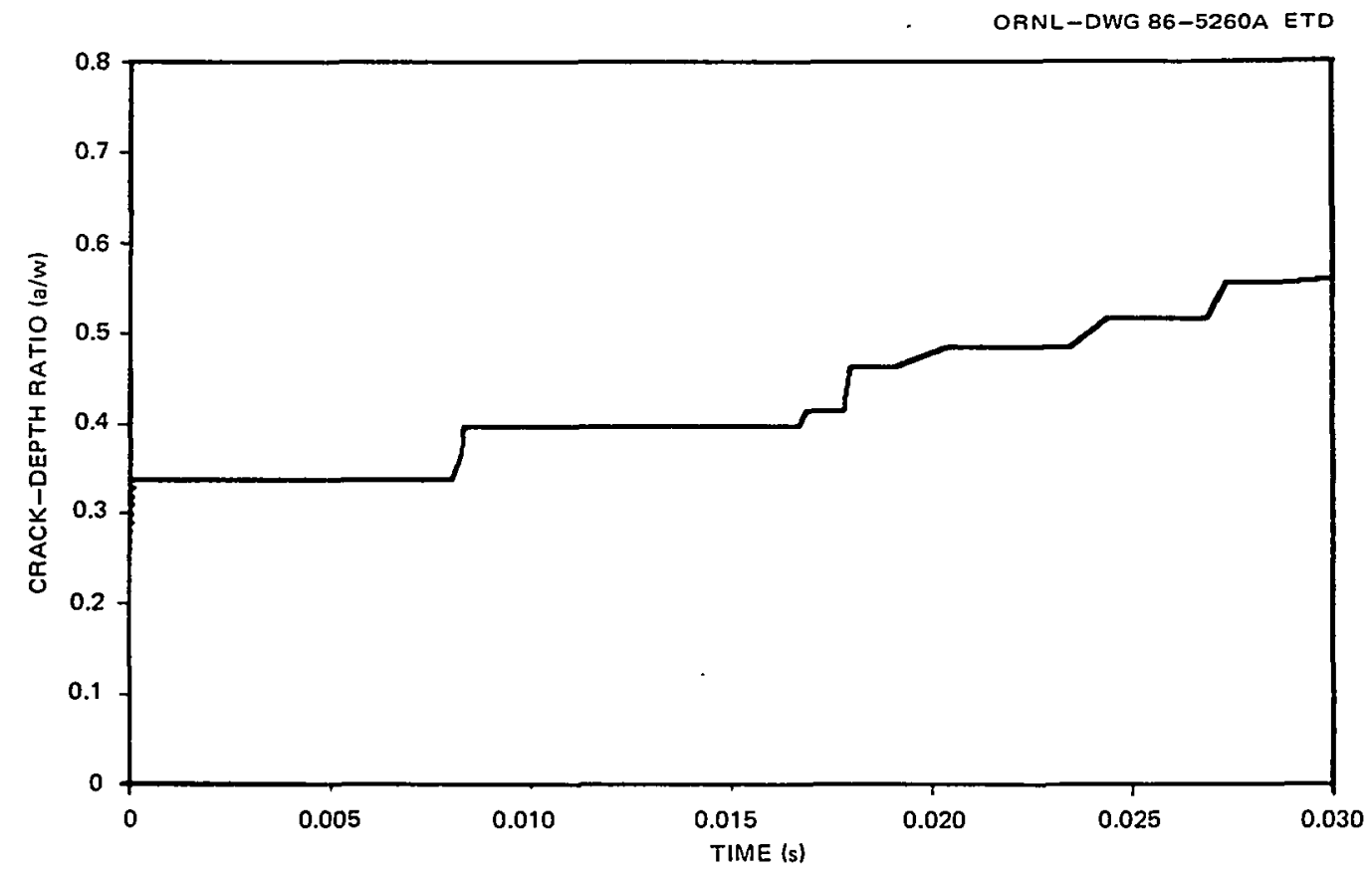
WP-2.4.

Fig. 6.8. Crack-depth history from front-face strain gages: test

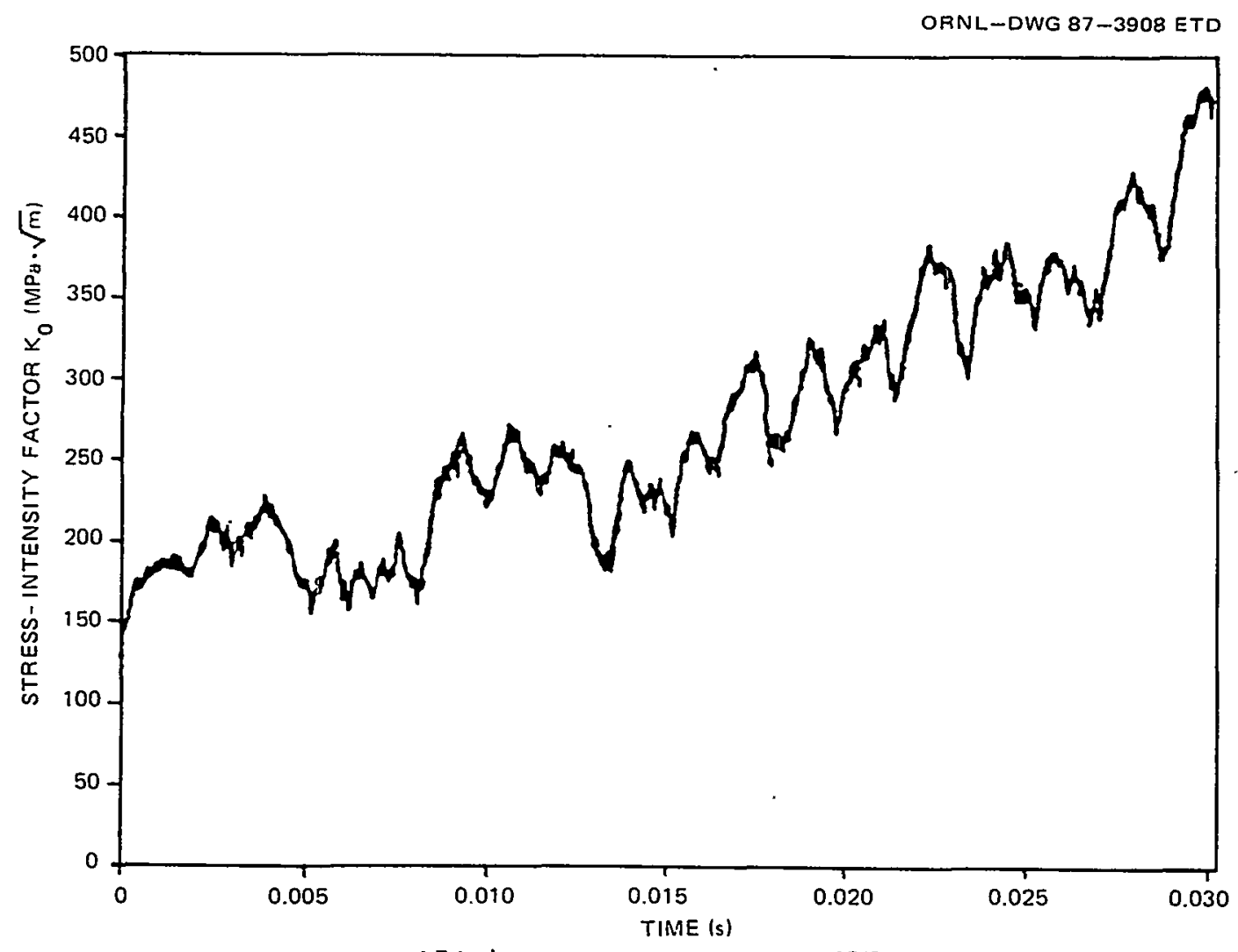

Fig. 6.9. Calculated stress-intensity factor vs time from generation-mode dynamic analysis (fixed-load case): test WP-2.4. 
Table 6.3. Summary of generation-mode

(fixed-load) dynamic analysis results for test WP- 2.4

\begin{tabular}{lccc}
\hline \multicolumn{1}{c}{ Event } & $\begin{array}{c}\text { Time } \\
(\mathrm{ms})\end{array}$ & $\begin{array}{c}\mathrm{A} \\
(\mathrm{m})\end{array}$ & $\begin{array}{c}\mathrm{K} \\
(\mathrm{MPa} \cdot \sqrt{\mathrm{m}})\end{array}$ \\
\hline Initiation & 0.0 & 0.251 & 143 \\
First arrest & 0.10 & 0.338 & 137 \\
Reinitiation & 8.00 & 0.338 & 178 \\
& & & \\
Second arrest & 8.32 & 0.397 & 188 \\
Reinitiation & 15.82 & 0.397 & 281 \\
& & & \\
Third arrest & 16.86 & 0.413 & 281 \\
Reinitiation & 17.80 & 0.413 & 281 \\
& & & \\
Fourth arrest & 17.96 & 0.462 & 249 \\
Reinitiation & 19.08 & 0.462 & 318 \\
Fifth arrest & 20.40 & 0.484 & 307 \\
Reinitiation & 23.46 & 0.484 & 322 \\
Sixth arrest & 24.40 & 0.515 & 381 \\
Reinitiation & 25.46 & 0.515 & 355 \\
Seventh arrest & 27.32 & 0.555 & 397 \\
Reinitiation & 28.86 & 0.555 & 389 \\
\hline
\end{tabular}

are depicted in Figs. 6.10 to 6.12 for test WP-2.4. Also shown in the figures are the actual strain histories derived from the gages. The sharply defined strain peaks in the figures correspond to the point in time when the fast-running crack passes under a gage point. As crack propagation slows, the peaks are transformed into more blunted curves. Pertinent events during a test (arrests, reinitiations, etc.), as detected by the strain gages, are noted on selected strain histories in Appendix A.

In Fig. 6.13 the COD calculated at $a / w=0.15$ (from the plate cold edge) using the generation-mode analysis is compared with measured data from the front-face gage. 

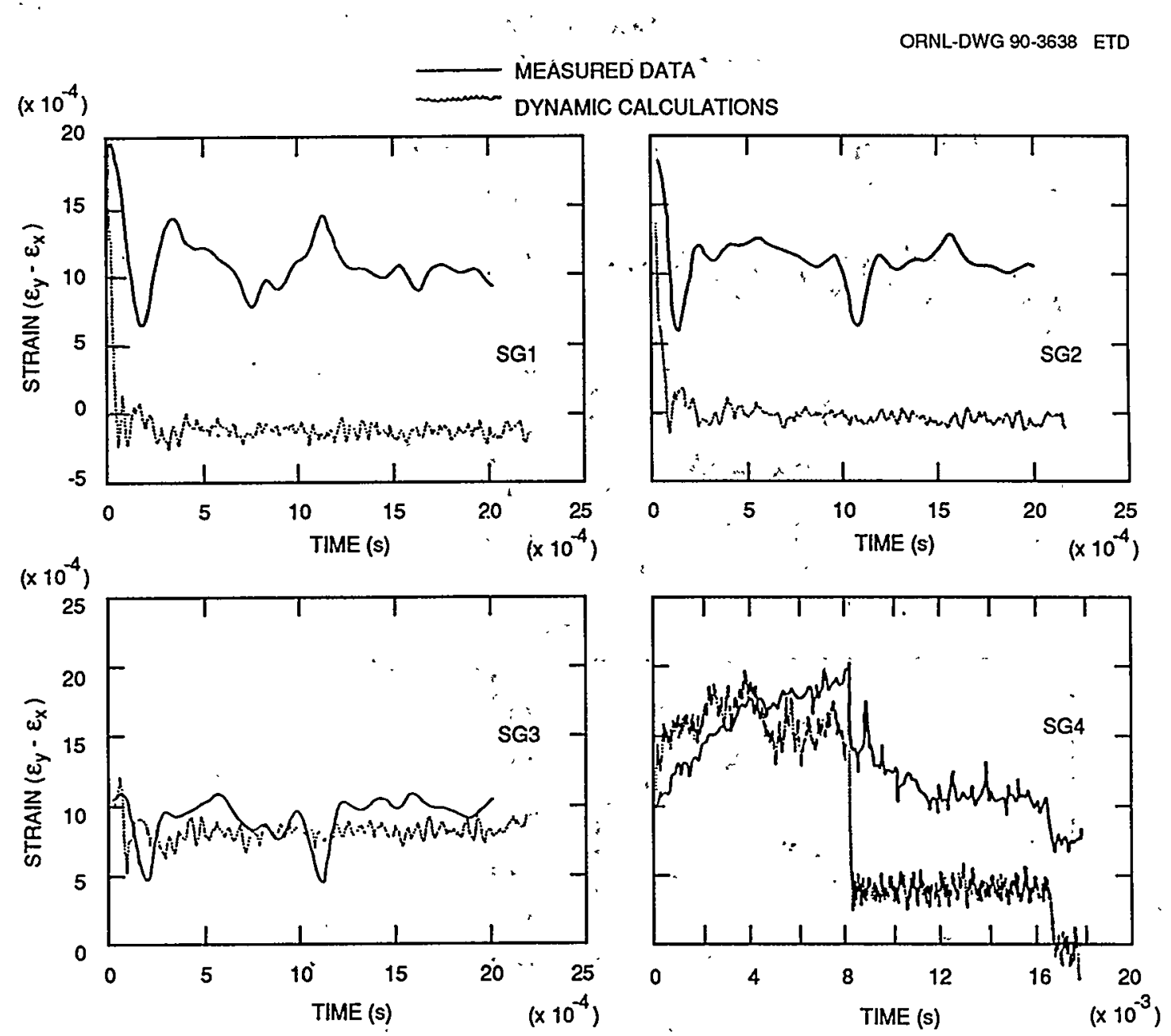

Fig. 6.10. Actual and computed strain histories for front-face crack-line gages 1-4: test WP-2.4. 


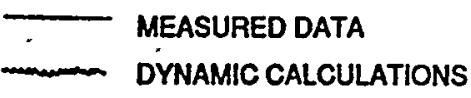

ORNL-DWG 90.3639 ETD
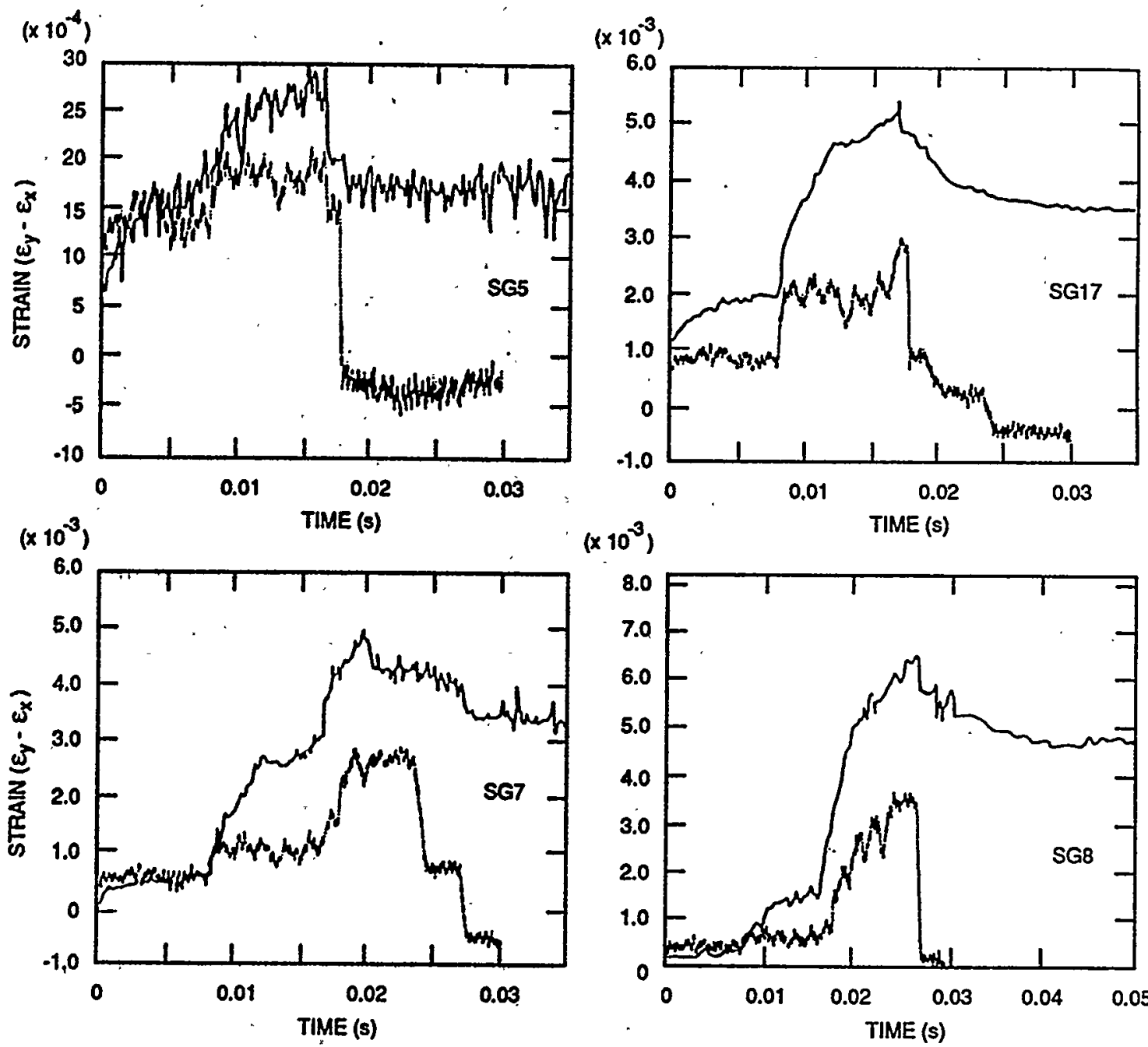

$\left(\times 10^{-3}\right)$

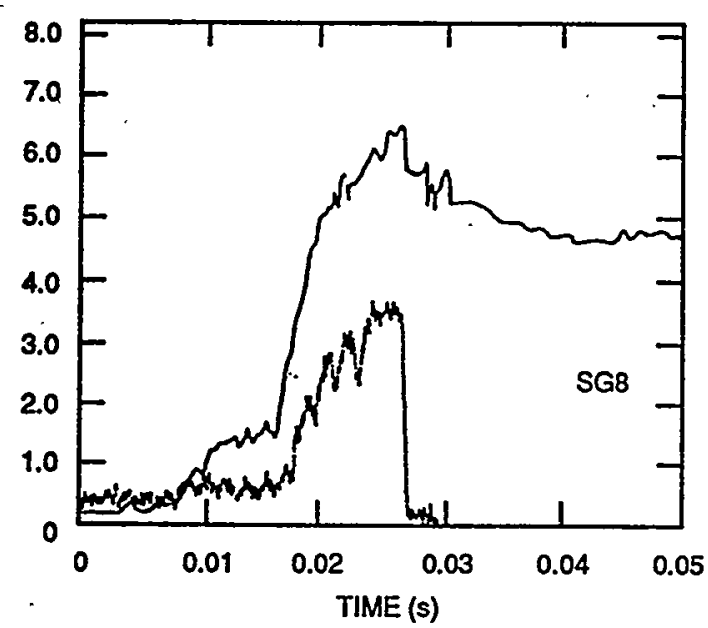

Fig. 6.11. Actual and computed strain histories for crack-1ine gages 5, 17, 7, and 8: test WP-2.4. 
MEASURED DATA

DYMaMIC CALCULATIONS
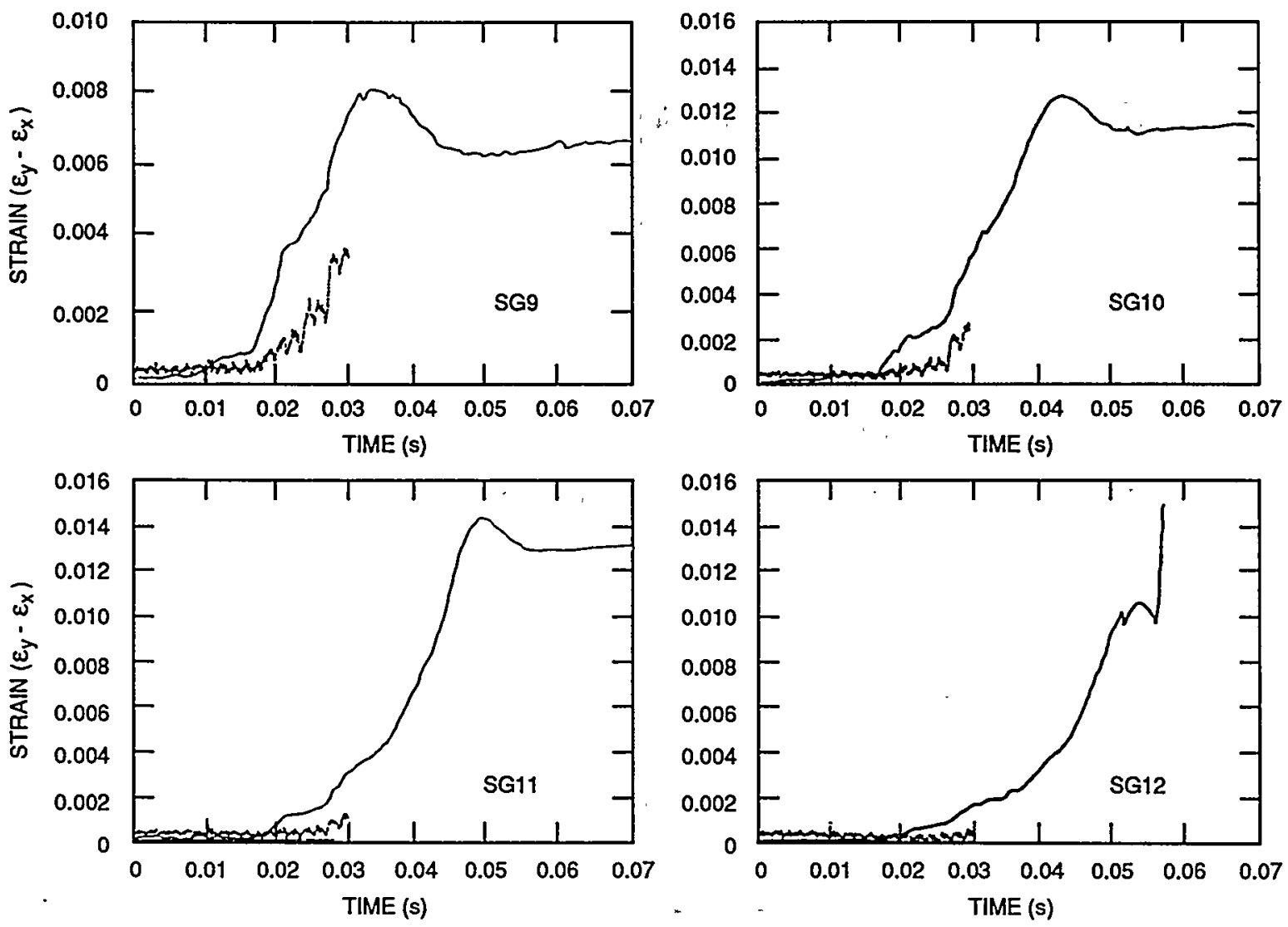

Fig. 6.12. Actual and computed strain histories for front-face crack-1ine gages 9-12: test WP-2.4. 


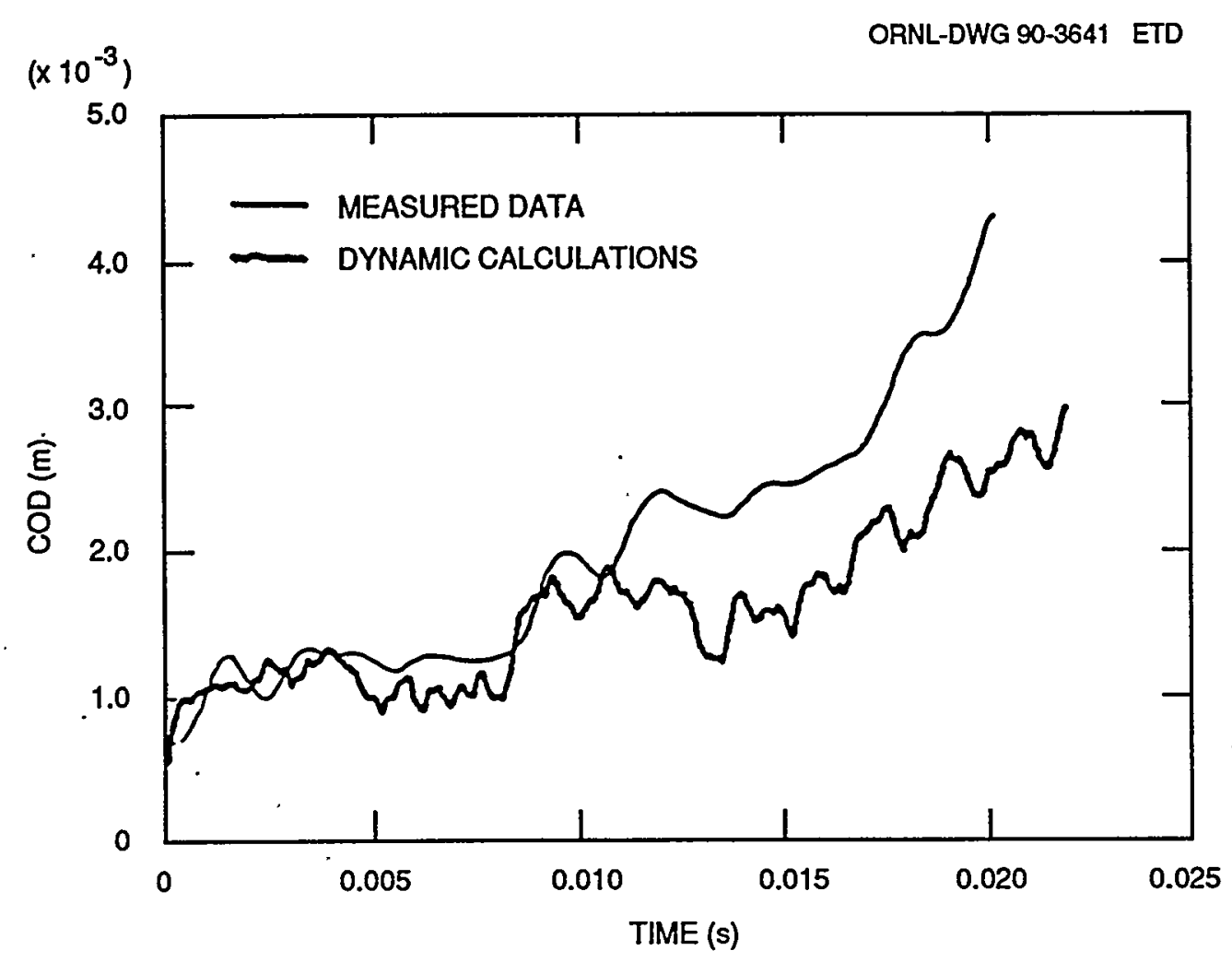

Fig. 6.13. Actual and generation-mode dynamic analysis computed COD at $a / w=0.15$ for front-face gage (fixed-load case): test WP-2.4.

\subsection{CRACK-ARREST TOUGHNESS RESULTS}

Crack-arrest toughness values for the WP-2 series wide-plate tests have been determined by static and dynamic analyses, as well as by handbook techniques. Appendix $B$ presents a discussion of the importance of the analysis method (static vs dynamic) and boundary conditions (fixedload or fixed-load-pin displacement) used to interpret the wide-plate crack-arrest tests. For reasons discussed in Appendix $B$ and because of the long durations of the crack run-arrest events ( $t>9 \mathrm{~ms}$ ) observed for the LUS WP-2 series materials, considerable load adjustment can take place as a result of specimen/pull-plate compliance. Therefore, the most meaningful calculations of crack-arrest toughness values for such conditions should take these factors into account through the use of a dynamic finite-element analysis. As shown in Appendix B, the long fracture durations of these tests lead to dynamic results that approach those predicted by load-controlled static conditions. Fixed-1oad, generation-mode, dynamic finite-element determinations of crack-arrest toughness values as well as test conditions for the WP-2 series tests are summarized in Table 6.4. Figure 6.14 presents a plot of crackarrest toughness values against the arrest-toughness temperature minus $\mathrm{DW}_{\mathrm{NDT}}\left(60^{\circ} \mathrm{C}\right)$ for the WP-2 series tests. Also included in the figure are previous wide-plate crack-arrest tests that used A 533 grade B class 1 
Table 6.4. Summary of HSST wide-plate crack-arrest test conditions and crack-arrest toughness values for specially heat-treated

2 1/4 $\mathrm{Cr}^{-1}$ Mo steel: WP-2 Series

\begin{tabular}{|c|c|c|c|c|c|c|c|}
\hline Test & $\begin{array}{c}\text { Crack } \\
\text { location } \\
(\mathrm{cm})\end{array}$ & $\begin{array}{c}\text { Crack } \\
\text { temperature } \\
\left({ }^{\circ} \mathrm{C}\right)\end{array}$ & $\begin{array}{c}\text { Initiation } \\
\text { load } \\
\text { (MN) }\end{array}$ & $\begin{array}{l}\text { Arrest } \\
\text { location } \\
(\mathrm{cm})\end{array}$ & $\begin{array}{c}\text { Arrest } \\
\text { temperature } \\
\left({ }^{\circ} \mathrm{C}\right)\end{array}$ & $\begin{array}{l}\text { Arrest } \\
\mathrm{T}-\mathrm{DW}_{\mathrm{NDT}} \\
\left({ }^{\circ} \mathrm{C}\right)^{\mathrm{N}}\end{array}$ & $\begin{array}{c}\text { Crack-arrest } \\
\text { toughness } \\
(\mathrm{MPa} \cdot \sqrt{\mathrm{m}})\end{array}$ \\
\hline $\begin{array}{l}\text { WP-2.1A } \\
\text { WP-2.1B } \\
\text { WP-2.1D } \\
\text { WP-2.1E } \\
\text { WP-2.1F } \\
\text { WP-2.1H } \\
\text { WP-2.1I } \\
\text { WP-2.1J }\end{array}$ & $\begin{array}{l}19.9 \\
27.5 \\
33.5 \\
37.0 \\
40.0 \\
45.0 \\
49.0 \\
52.7\end{array}$ & $\begin{array}{r}55 \\
80 \\
96 \\
105 \\
112 \\
125 \\
135 \\
145\end{array}$ & $\begin{array}{l}11.90 \\
11.90 \\
11.90 \\
11.90 \\
11.90 \\
11.90 \\
11.90 \\
11.90\end{array}$ & $\begin{array}{l}27.5 \\
33.5 \\
37.0 \\
40.0 \\
45.0 \\
49.0 \\
52.7 \\
55.5\end{array}$ & $\begin{array}{r}80 \\
96 \\
105 \\
112 \\
125 \\
135 \\
145 \\
152\end{array}$ & $\begin{array}{l}20 \\
36 \\
45 \\
52 \\
65 \\
75 \\
85 \\
92\end{array}$ & $\begin{array}{l}106 \\
153 \\
158 \\
170 \\
201 \\
293 \\
371 \\
406\end{array}$ \\
\hline $\begin{array}{l}W P-2.2 A^{b}, c \\
W P-2.2 B \\
W P-2.2 C \\
W P-2.2 D \\
W P-2.2 E \\
W P-2.2 F \\
W P-2.2 G\end{array}$ & $\begin{array}{l}21.1 \\
43.5 \\
46.5 \\
47.8 \\
49.9 \\
51.0 \\
53.8\end{array}$ & $\begin{array}{r}58 \\
120 \\
129 \\
133 \\
139 \\
142 \\
150\end{array}$ & $\begin{array}{l}17.0 \\
17.0 \\
17.0 \\
17.0 \\
17.0 \\
17.0 \\
17.0\end{array}$ & $\begin{array}{l}43.5 \\
46.5 \\
47.8 \\
49.9 \\
51.0 \\
53.8 \\
58.2\end{array}$ & $\begin{array}{l}120 \\
129 \\
133 \\
139 \\
142 \\
150 \\
162\end{array}$ & $\begin{array}{r}60 \\
69 \\
73 \\
79 \\
82 \\
90 \\
102\end{array}$ & $\begin{array}{l}201 \\
259 \\
281 \\
277 \\
380 \\
364 \\
446\end{array}$ \\
\hline $\begin{array}{l}W P-2.3 A \\
W P-2.3 B \\
W P-2.3 D \\
W P-2.3 F\end{array}$ & $\begin{array}{l}20.0 \\
34.0 \\
37.5 \\
39.7\end{array}$ & $\begin{array}{r}66 \\
97 \\
106 \\
111\end{array}$ & $\begin{array}{l}15.3 \\
15.3 \\
15.3 \\
15.3\end{array}$ & $\begin{array}{l}34.0 \\
37.5 \\
39.7 \\
45.7\end{array}$ & $\begin{array}{r}97 \\
106 \\
111 \\
126\end{array}$ & $\begin{array}{l}37 \\
46 \\
51 \\
66\end{array}$ & $\begin{array}{l}144 \\
232 \\
255 \\
258\end{array}$ \\
\hline $\begin{array}{l}W P-2.4 A^{b} \\
W P-2.4 B \\
W P-2.4 \mathrm{C} \\
W P-2.4 \mathrm{D} \\
W P-2.4 \mathrm{E} \\
W P-2.4 \mathrm{~F} \\
W P-2.4 \mathrm{G} \\
W P-2.4 \mathrm{H}\end{array}$ & $\begin{array}{l}20.3 \\
25.1^{d} \\
33.8 \\
39.7 \\
41.3 \\
46.2 \\
48.4 \\
51.5\end{array}$ & $\begin{array}{r}45 \\
61 \\
86 \\
102 \\
107 \\
121 \\
127 \\
137\end{array}$ & $\begin{array}{l}7.52 \\
8.85 \\
8.85 \\
8.85 \\
8.85 \\
8.85 \\
8.85 \\
8.85\end{array}$ & $\begin{array}{l}25.1 \\
33.8 \\
39.7 \\
41.3 \\
46.2 \\
48.4 \\
51.5 \\
55.5\end{array}$ & $\begin{array}{r}61 \\
86 \\
102 \\
107 \\
121 \\
127 \\
137 \\
149\end{array}$ & $\begin{array}{l}1 \\
26 \\
42 \\
47 \\
61 \\
67 \\
77 \\
89\end{array}$ & $\begin{array}{l}137 \\
188 \\
281 \\
249 \\
307 \\
381 \\
397\end{array}$ \\
\hline
\end{tabular}


Table 6.4 (continued)

\begin{tabular}{|c|c|c|c|c|c|c|c|}
\hline Test & $\begin{array}{c}\text { Crack } \\
\text { location } \\
(\mathrm{cm})\end{array}$ & $\begin{array}{l}\text { Crack } \\
\text { temperature } \\
\left({ }^{\circ} \mathrm{C}\right)\end{array}$ & $\begin{array}{l}\text { Initiation } \\
\text { load } \\
\text { (MN) }\end{array}$ & $\begin{array}{c}\text { Arrest } \\
\text { location } \\
(\mathrm{cm})\end{array}$ & $\begin{array}{l}\text { Arrest } \\
\text { temperature } \\
\left({ }^{\circ} \mathrm{C}\right)\end{array}$ & $\begin{array}{l}\text { Arrest } \\
\mathrm{T}-\mathrm{DW}_{\mathrm{NDT}} \\
\left({ }^{\circ} \mathrm{C}\right)^{\mathrm{N}}\end{array}$ & $\begin{array}{c}\text { Crack-arrest } \\
\text { toughness } \\
(\mathrm{MPa} \cdot \sqrt{\mathrm{m}})\end{array}$ \\
\hline $\begin{array}{l}W P-2.5 A^{b} \\
W P-2.5 B \\
W P-2.5 C \\
W P-2.5 D \\
W P-2.5 E \\
W P-2.5 F\end{array}$ & $\begin{array}{l}19.9 \\
27.2^{d} \\
35.0 \\
43.5 \\
47.8 \\
51.6\end{array}$ & $\begin{array}{r}66 \\
86 \\
104 \\
124 \\
135 \\
144\end{array}$ & $\begin{array}{l}7.53 \\
8.90 \\
8.90 \\
8.90 \\
8.90 \\
8.90\end{array}$ & $\begin{array}{l}27.2 \\
35.0 \\
43.5 \\
47.8 \\
51.6 \\
56.0\end{array}$ & $\begin{array}{r}86 \\
104 \\
124 \\
135 \\
144 \\
154\end{array}$ & $\begin{array}{l}26 \\
44 \\
64 \\
75 \\
84 \\
94\end{array}$ & $\begin{array}{l}171 \\
190 \\
268 \\
306 \\
366\end{array}$ \\
\hline $\begin{array}{l}W P-2.6 A^{e} \\
W P-2.6 B \\
W P-2.6 C \\
W P-2.6 D \\
W P-2.6 F \\
W P-2.6 G \\
W P-2.6 H\end{array}$ & $\begin{array}{l}22.4 \\
35.7 \\
39.7 \\
41.0 \\
43.0 \\
46.0 \\
48.0\end{array}$ & $\begin{array}{l}65 \\
104 \\
115 \\
119 \\
125 \\
133 \\
139\end{array}$ & $\begin{array}{l}19.3 \\
19.3 \\
19.3 \\
19.3 \\
19.3 \\
19.3 \\
19.3\end{array}$ & $\begin{array}{l}35.7 \\
39.7 \\
41.0 \\
43.0 \\
46.0 \\
48.0 \\
54.0\end{array}$ & $\begin{array}{l}104 \\
115 \\
119 \\
125 \\
133 \\
139 \\
156\end{array}$ & $\begin{array}{l}44 \\
55 \\
59 \\
65 \\
73 \\
79 \\
96\end{array}$ & $\begin{array}{l}204 \\
259 \\
286 \\
350 \\
328 \\
411 \\
413\end{array}$ \\
\hline
\end{tabular}

a Dynamic finite-element analyses (fixed load) using ORNL program ADINA/VPF (Ref. 5). $K_{I_{a}}$ values are presently being reassessed to incorporate tunneling effects and should therefore not be considered as final. Incorporation of tunneling effects will result in a slight reduction in $\mathrm{K}_{\mathrm{Ia}}$ valves presented ( $i . e ., \leq 10-20 \%$ ) as noted in Appendix $C$.

${ }^{b}$ Crack front cut to truncated chevron configuration.

${ }^{c}$ Specimen was warm prestressed by loading to $16 \mathrm{MN}$ at $124^{\circ} \mathrm{C}$.

$d_{\text {After pop-in event. }}$

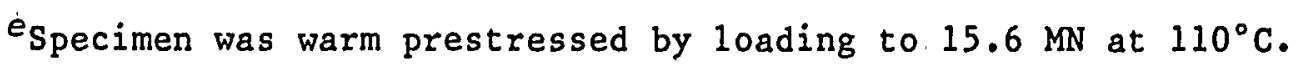




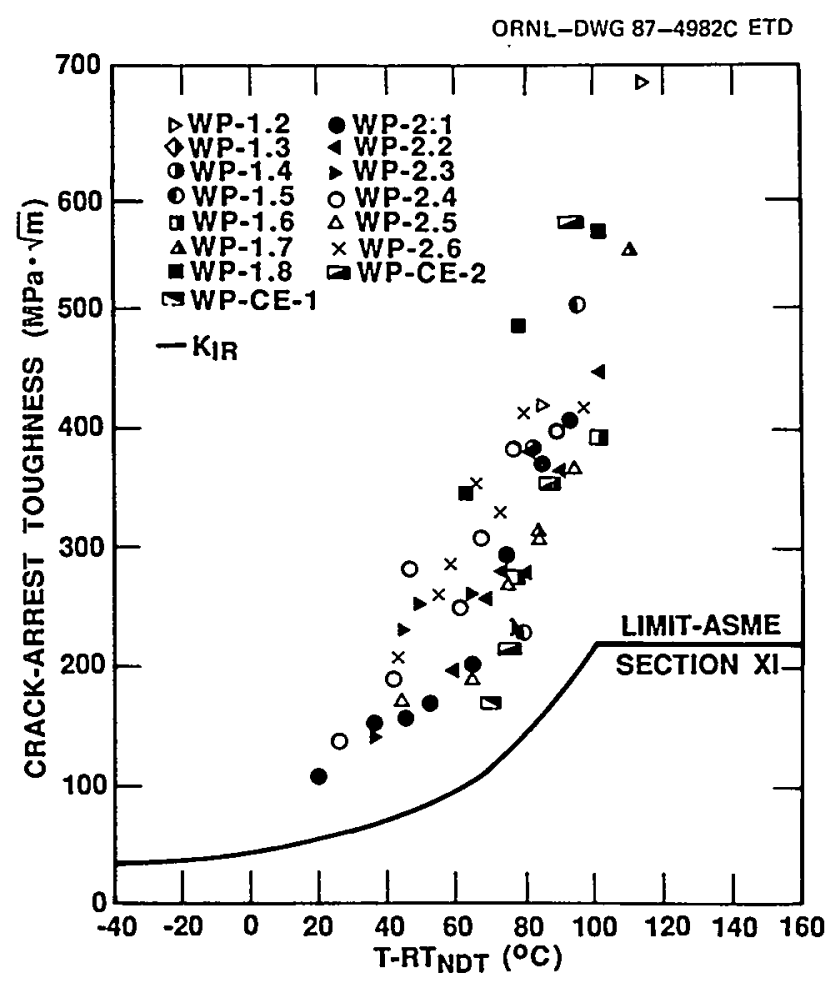

Fig. 6.14. Fixed-load, generation-mode, dynamic finite-element crack-arrest toughness results for HSST wide-plate tests.

materials (WP-I and WP-CE series)9-11 and the $K_{I R}$ curve from Sect. XI of the ASME B\&PVC. The crack-arrest toughness results obtained from the HSST wide-plate crack-arrest tests consistently extend above the reference fracture-toughness curve. At temperatures near and above the onset of Charpy USE ( $\mathrm{T}-\mathrm{RT}_{\mathrm{NDT}}=78,85$, and $90^{\circ} \mathrm{C} *$ for the WP-1, WP-CE, and WP-2 series materials, respectively), the $\mathrm{K}_{\mathrm{Ia}}$ values increase with temperature at an accelerating rate. Also, as noted in Fig. 6.15, crack arrests in the WP-2 test series have occurred at temperatures up to $102^{\circ} \mathrm{C}$ above the $\mathrm{DW}_{\mathrm{NDT}}\left(60^{\circ} \mathrm{C}\right)$ and up to $12^{\circ} \mathrm{C}$ above the temperature corresponding to the onset of Charpy USE $\left(150^{\circ} \mathrm{C}\right)$.

\subsection{COMPARISON OF WIDE-PLATE CRACK-ARREST TOUGHNESS DATA WITH OTHER LARGE-SCALE TEST RESULTS}

The trend for $\mathrm{K}_{\mathrm{Ia}}$ values to extend above the 1 imit proposed in $A S M E$ $B \& P V C$ Sect. XI, as shown in Fig. 6.14, is further substantiated in Fig. 6.16. Included in the figure are $\mathrm{K}_{\mathrm{Ia}}$ data from several large-scale tests 12-23 plus the wide-plate results. The rate of $\mathrm{K}_{\mathrm{Ia}}$ increase in these tests appears to increase significantly at $\mathrm{T}-\mathrm{RT}_{\mathrm{NDT}}{ }^{*}$ above $\sim 90^{\circ} \mathrm{C}$.

$* T-D W_{N D T}$ value for WP-2 series material. 


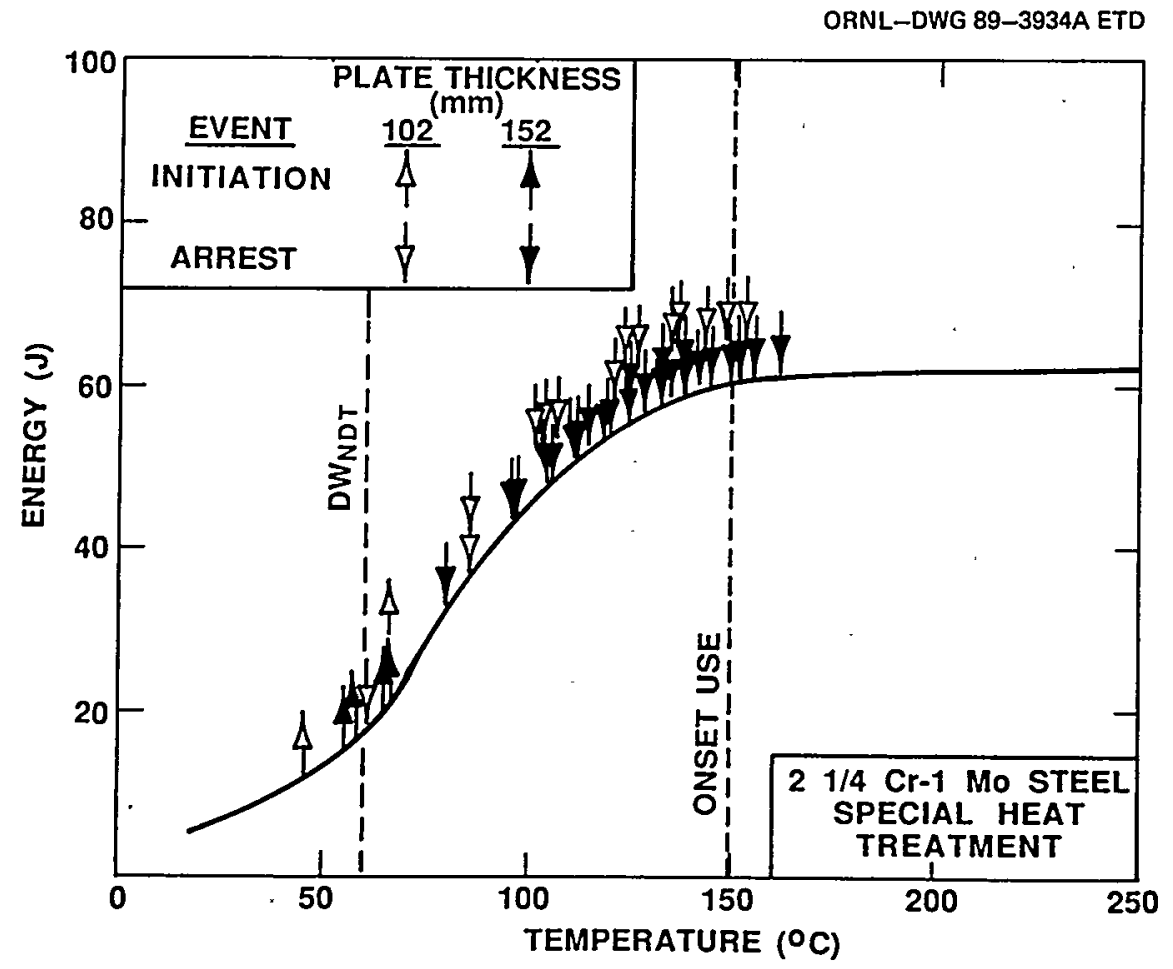

Fig. 6.15. Relationship of WP-2 series initiation and arrest events to CVN energy vs temperature curve.

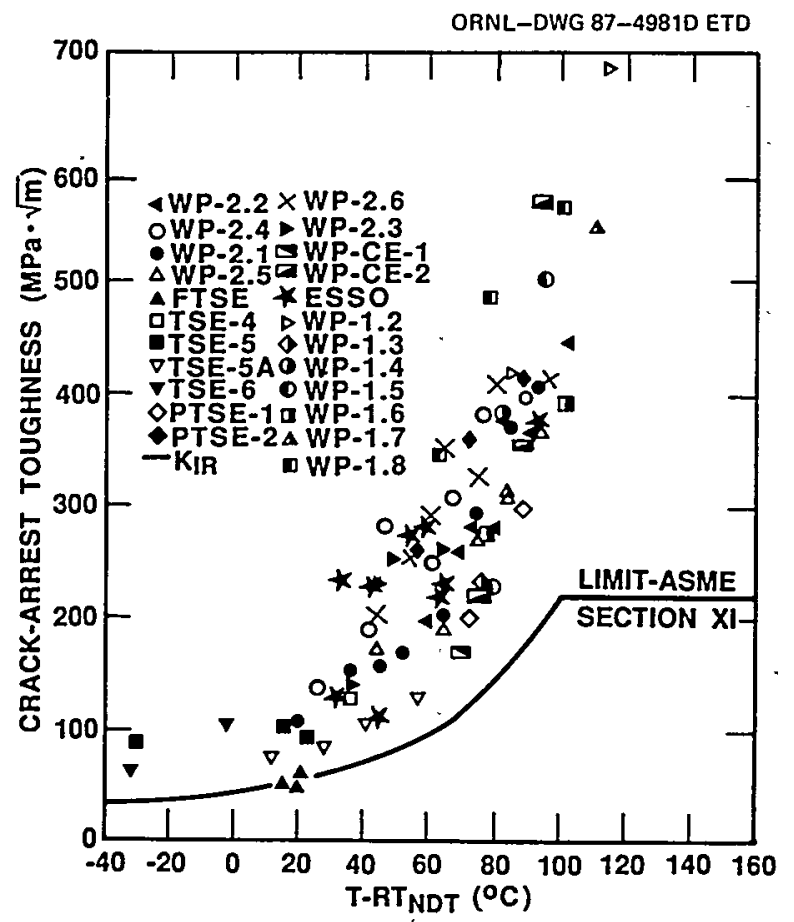

Fig. 6.16. HSST wide-plate crack-arrest data (fixed-1oad, generation-mode dynamic finite-element calculations) show trend consistent with other large-specimen crack-arrest test results. 


\section{REFERENCES}

1. B. R. Bass and J. W. Bryson, Union Carbide Corp. Nuclear Div., Oak Ridge Nat1. Lab., Application of Energy Release Rate Technique to Part-Through Cracks in Plates and Cylinders, Volume 1, ORMGEN-3D: A Finite Element Mesh Generator for 3-Dimensional Crack Geometries, USNRC Report NUREG/CR-2997/VI (ORNL/TM-8527/V1), December 1982.*

2. B. R. Bass and J. W. Bryson, Union Carbide Corp. Nuclear Div., Oak Ridge Nat1. Lab., Applications of Energy Release Rate Technique to Part-Through Cracks in Plates and Cylinders, Volume 2, ORVIRT: A Finite Element Program for Energy Release Rate Calculations for 2-D and 3-D Crack Models, USNRC Report NUREG/CR-2997/V2 (ORNL/TM$8527 /$ V2), February 1983."

3. K. J. Bathe; ADINA - A Finite Element Program and Automatic Dynamic Incremental Nonlinear Analysis, Report A-1, Massachusetts Institute of Technology, Cambridge, Mass., 1984.

4. B. R. Bass, C. E. Pugh, and H. K. Stamm, "Dynamic Analyses of a Crack Run-Arrest Experiment in a Nonisothermal Plate," in Pressure Vessel Components Design and Analysis, Vol. 4, ASME Publication PVP, Vol. 98.2, pp. 175-84, 1985.†

5. B. R. Bass and J. Keeney-Walker, Martin Marietta Energy Systems, Inc., Oak Ridge Natl. Lab., "Computer Program Development for Dynamic Fracture Analysis," in Heavy-Section Steel Technology Program Semiann. Prog. Rep. April-September 1985, USNRC Report NUREG/CR-4219/V2 (ORNL/TM-9593/V2), January 1986.*

6. B. R. Bass and J. Keeney-Walker, Martin Marietta Energy Systems, Inc., Oak Ridge Natl. Lab., "Wide-Plate Analyses at ORNL," pp. 111-31 in Heavy-Section Steel Technology Program Semiann. Prog. Rep. October 1986-March 1987, USNRC Report NUREG/CR-4219, Vo1. 4, No. 1 (ORNL/TM-9593/V4\&N1), August 1987.:

7. D. J. Naus et al., Martin Marietta Energy Systems, Inc., Oak Ridge Nat1. Lab., "High-Temperature Crack Arrest Tests Using 152-mm-Thick SEN Wide Plates of Low-Upper-Shelf Base Material: Test WP-2.2 and WP-2.6," USNRC Report NUREG/CR-5450 (ORNL/TM-11352), February $1990 . *$

8. B. R. Bass and J. Keeney-Walker, Martin Marietta Energy Systems, Inc., Oak Ridge Nat1. Lab., "Wide-Plate Analyses at ORNL," pp. 156-91 in Heavy-Section Steel Technology Program Semiann. Prog. Rep. April-September 1987, USNRC Report NUREG/CR-4219, Vol. 4, No. 2 (ORNL/TM-9593/V4\&N2), April 1988.*

9. D. J. Naus et al., Martin Marietta Energy Systems, Inc., Oak Ridge Nat1. Lab., Crack-Arrest Behavior in SEN Wide Plates of Quenched and Tempered $A 533$ Grade $B$ Steel Tested Under Nonisothermal Conditions, USNRC Report NUREG/CR-4930 (ORNL-6388), August 1987.* 
10. D. J. Naus et a1., Martin Marietta Energy Systems, Inc., Oak Ridge Nat1. Lab., High-Temperature Crack-Arrest Behavior in 152-mm-Thick SEN Wide Plates of Quenched and Tempered A 533 Grade B Class 1 Steel, USNRC Report NUREG/CR-5330 (ORNL/TM-11083), Apri1 1989.*

11. D. J. Naus et al., Martin Marietta Energy Systems, Inc., Oak Ridge Nat1. Lab., SEN Wide-Plate Crack-Arrest Tests Utilizing A 533 Grade $B$ Class 1 Material: WP-CE Test Series, USNRC Report NUREG/CR-5408 (ORNL/TM-11269), November 1989.*

12. R. D. Cheverton et a1., Martin Marietta Energy Systems, Inc., Oak Ridge Nat1. Lab., Pressure Vessel Fracture Studies Pertaining to the PWR Thermal-Shock Issue: Experiments TSE-5, TSE-5A, and TSE-6, USNRC Report NUREG/CR-4249 (ORNL-6163), June 1985.*

13. R. D. Cheverton et al., Martin Marietta Energy Systems, Inc., Oak Ridge Nat1. Lab., Pressure Vessel Fracture Studies Pertaining to. the PWR Thermal-Shock Issue: Experiment TSE-7, USNRC Report NUREG/CR-4304 (ORNL-6177), August 1985.*

14. R. H. Bryan et a1., Martin Marietta Energy Systems, Inc., Oak Ridge Nat1. Lab., Pressurized-Thermal-Shock.Test of 6-in.-Thick Pressure Vessels. PTSE-1: Investigation of Warm Prestressing and UpperShelf Arrest, USNRC Report NUREG/CR-4106 (ORNL-6135), Apri1 1985.*

15. R. H. Bryan et al., Martin Marietta Energy Systems, Inc., Oak Ridge Nat1. Lab., Pressurized-Thermal-Shock Test of 6-in.-Thick Pressure Vessels. PTSE-2: Investigation of Low Tearing Resistance and Warm Prestressing, USNRC Report NUREG/CR-4888 (ORNL-6377), December $1987 . *$

16. Japan Welding Council, Structural Integrity of Very Thick Steel Plate for Nuclear Reactor Pressure Vessels, JWES-AE-7806, 1977 (in Japanese).

17. T. Kanazawa, S. Machida, and T. Teramoto, "Preliminary Approaches to Experimental and Numerical Study of Fast Crack Propagation and Crack Arrest," in Fast Fracture and Crack Arrest, ASTM STP 627, American Society for Testing and Materials, Philadelphia, Pa., 1977 , pp. 39-58.t

18. N. Ohashi et a1., "Fracture Toughness of Heavy Section LWR Pressure Vessel Steel Plate Produced by Basic Oxygen Furnace and Ladle Refining Process," Vol. 1, Pp. 391-96 in Proceedings of the Fourth International Conference on Pressure Vessel Technology, I. Mech. E. , $1980 .{ }^{\dagger}$

19. T. Kanazawa et al., "Study on Fast Fracture and Crack Arrest," Experimental Mechanics 21(2), 77-88, February 1981. ${ }^{\dagger}$ 
20. S. Machida, Y. Kawaguchi, and M. Tsukamoto, "An Evaluation of the Crack Arrestability of $9 \% \mathrm{Ni}$ Steel Plate to an Extremely Long Brittle Crack," Journal of the Society of Naval Architect of Japan $150,511-17$ (1981), translation ORNL-tr-5052.

21. T. Kanazawa, S. Machida, and H. Yajima, "Recent Studies on Brittle Crack Propagation and Arrest in Japan," in Fracture Mechanics Technology Applied to Material and Structure Design, G. C. Sih, N. E. Ryan, and R. Jones, Eds. (Martinua Ni jhoff, The Hague, 1983), pp. $81-100$.

22. Y. Nakano, "Stress Intensity Factor During Brittle Crack Propagation and Arrest in ESSO Specimens," in Proceedings of the 18th National Symposium on $X$-Ray Study on Deformation and Fracture Solids, The Society of Materials Science, Japan, July 13-14, 1981.

23. A. Pellissier-Tanon, P. Sollogoub, and B. Houssin, "Crack Initiation and Arrest in an SA 508 Class-3 Cylinder Under Liquid Nitrogen Thermal-Shock," Paper G/F 1/8, Vol. G/H, pp. 137-42 in Transactions of the 7 th International Conference on Structural Mechanics in Reactor Technology, August 22-26, 1983, Chicago, Illinois, Elsevier Science Publishing Co., Inc., New York, 1983.t

*Available for purchase from National Technical Information Service, Springfield, VA 22161

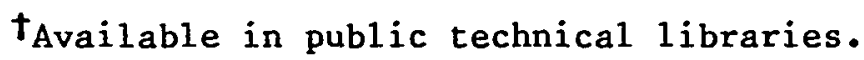




\section{CONCLUSIONS}

The HSST Program has an integrated effort under way to extend the range of applicability of current state-of-the-art crack-arrest practices and to develop alternatives where improvements are needed. A consistent trend is formed when the crack-arrest data now available from the three types of HSST large-specimen tests are combined on a plot of $\mathrm{K}_{\mathrm{Ia}}$ vs $\mathrm{T}-\mathrm{RT}_{\mathrm{NDT}}$. Collectively, these data, along with other largespecimen test results, show that arrest can and does occur at temperatures up to and above those that correspond to the onset of Charpy upper-shelf behavior, and the measured $K_{I a}$ values extend above the limit included in Sect. XI of the ASME B\&PVC. Results obtained from the present study further substantiate this trend and indicate that even a degraded (simulated) material (Charpy USE $\sim 65 \mathrm{~J}, \mathrm{DW}_{\mathrm{NDT}}=60^{\circ} \mathrm{C}$ ) will exhibit high crack-arrest toughness $\left(\mathrm{K}_{\mathrm{Ia}}\right.$ values $\left.>400 \mathrm{MPa} \cdot \sqrt{\mathrm{m}}\right)$. Furthermore, cleavage crack propagation and arrests for this material have occurred at temperatures up to and slightly above that corresponding to the onset of its Charpy USE $\left(150^{\circ} \mathrm{C}\right)$. Although some tearing fracture followed arrest events in each test, the results indicate that arrest occurred before conversion to ductility tearing and that these fracture modes can be treated analytically as independent events.

In summary, the results obtained from the three series of wideplate crack-arrest tests support (1) the use of fracture-mechanics concepts to analyze cleavage run-arrest events, (2) the treatment of cleavage- and ductile-fracture modes as separate events, and (3) the fact that cleavage arrest can occur. at toughness levels well above the ASME Iimit and at temperatures above those that correspond to the onset of CVN USE for good-quality A 533 grade B class 1 material (WP-1 and WPCE test series) as well as for a degraded (simulated) material (WP-2 test series). 
$\therefore$

.

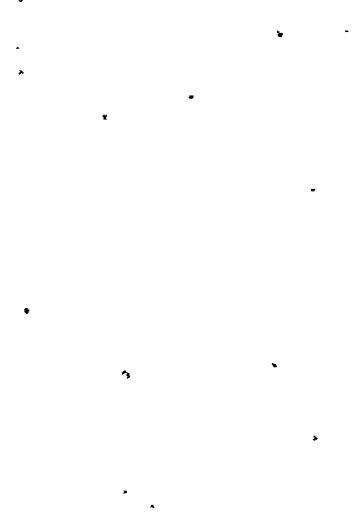




\section{Appendix A}

\section{SUMMARY OF INSTRUMENTATION RESULTS}

\section{A.1 TEST WP-2.1}

\section{A.1.1 Strain Gages}

Strain-gage records [see Fig. $4.8(a)$ for strain-gage locations] for companion front- and back-face gages adjacent to the crack propagation plane are shown in Figs. A.1 to A.3. Available near- and far-field strain-gage results are presented in Fig. A.4. Evaluation of the strain-gage records and examination of the fracture surface indicate that multiple (eight to ten) crack run-arrest events occurred during the test. More details of these crack run-arrest events followed by fibrous tearing are presented in Figs. A.5 to A.13. Figure A.5 shows the crack passing under strain gage 1 and arresting $(t=0.194 \mathrm{~ms})$ before reaching strain gages 2-4. The crack passing under strain gages 2 and 3 , momentarily arresting $(t=7.62 \mathrm{~ms})$ before passing under strain gage 4 , and a major arrest ( $t=7.77 \mathrm{~ms}$ ) occurring before reaching strain gage 5 are illustrated in Fig. A.6. The momentary crack arrest $(t=7.62-7.68 \mathrm{~ms})$ that occurred between strain gages 3 and 4 is depicted in Fig. A.7. The 20-ms records for strain gages $4-7$ are shown in Fig. A.8 and reveal that the crack passed under strain gage 5 and arrested again $(t=11.70 \mathrm{~ms})$ before reaching strain gages 6 and 7 . The 50-ms records of strain gages 5-8 are shown in Fig. A.9 and cover the period for the cleavage arrest $(t=11.70 \mathrm{~ms})$ just past strain gage 5 and subsequent arrests that occurred between strain gages 6 and $7(t=18.14 \mathrm{~ms})$, strain gages 7 and $8(t=25.12 \mathrm{~ms})$, and after strain gage $8(t=27.62$ and $33.76 \mathrm{~ms})$. Fibrous tearing occurred as the crack passed strain gages 9-12 (Fig. A.10). Outputs for strain gages 13-16, located on the back face of the plate adjacent to the crack propagation plane, are presented in Fig. A.11 and show the crack running past strain gages 13 and 14 prior to arresting ( $t=0.242 \mathrm{~ms}$ ) before strain gage 15. Thirty-five- to fiftymillisecond records of strain gages 15-18 (Fig. A.12) cover the period for the arrest $(t=7.75 \mathrm{~ms})$ just past strain gage 15 and subsequent crack run-arrest events, with arrests occurring between strain gages 16 and $17(t=9.04$ and $11.48 \mathrm{~ms})$ and strain gages 17 and $18(t=18.12)$. Outputs of strain gages 19-22 for an $80-\mathrm{ms}$ period are presented in Fig. A.13, which covers the time interval in which the arrest events occurred between gages 18 and $19(t=20.18,24.98$, and $27.18 \mathrm{~ms})$ and gages 19 and $20(t=33.06$ and $34.76 \mathrm{~ms})$, followed by fibrous tearing.

\section{A.1.2 Additional Instrumentation}

Output from the AE transducer mounted on the lower pull plate $3.6 \mathrm{~m}$ below the crack plane is presented in Fig. A.14. Longitudinal accelerations recorded by "damped" accelerometers mounted $3.653 \mathrm{~m}$ above (top accelerometer) and $3.655 \mathrm{~m}$ below (bottom accelerometer) the crack plane 


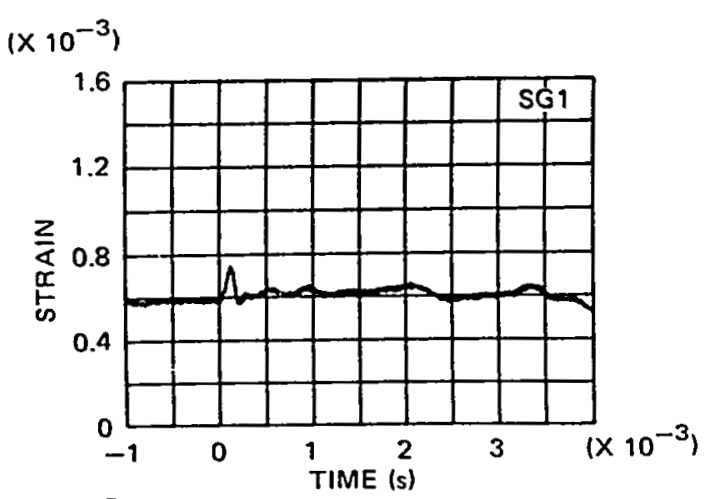

ORNL-DWG 87-3886A ETD

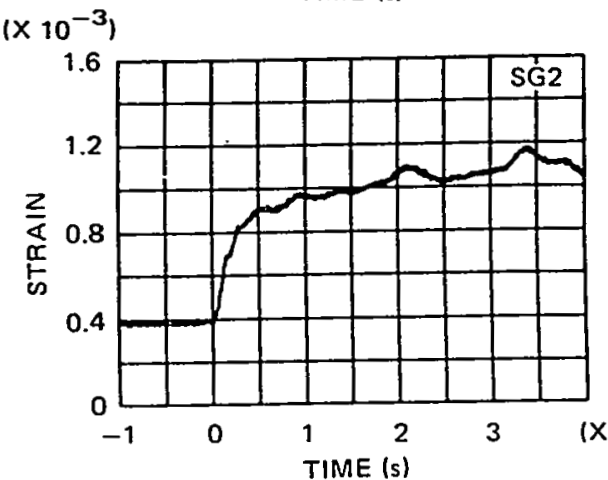

$\left(\times 10^{-3}\right)$

NO COMPANION GAGE
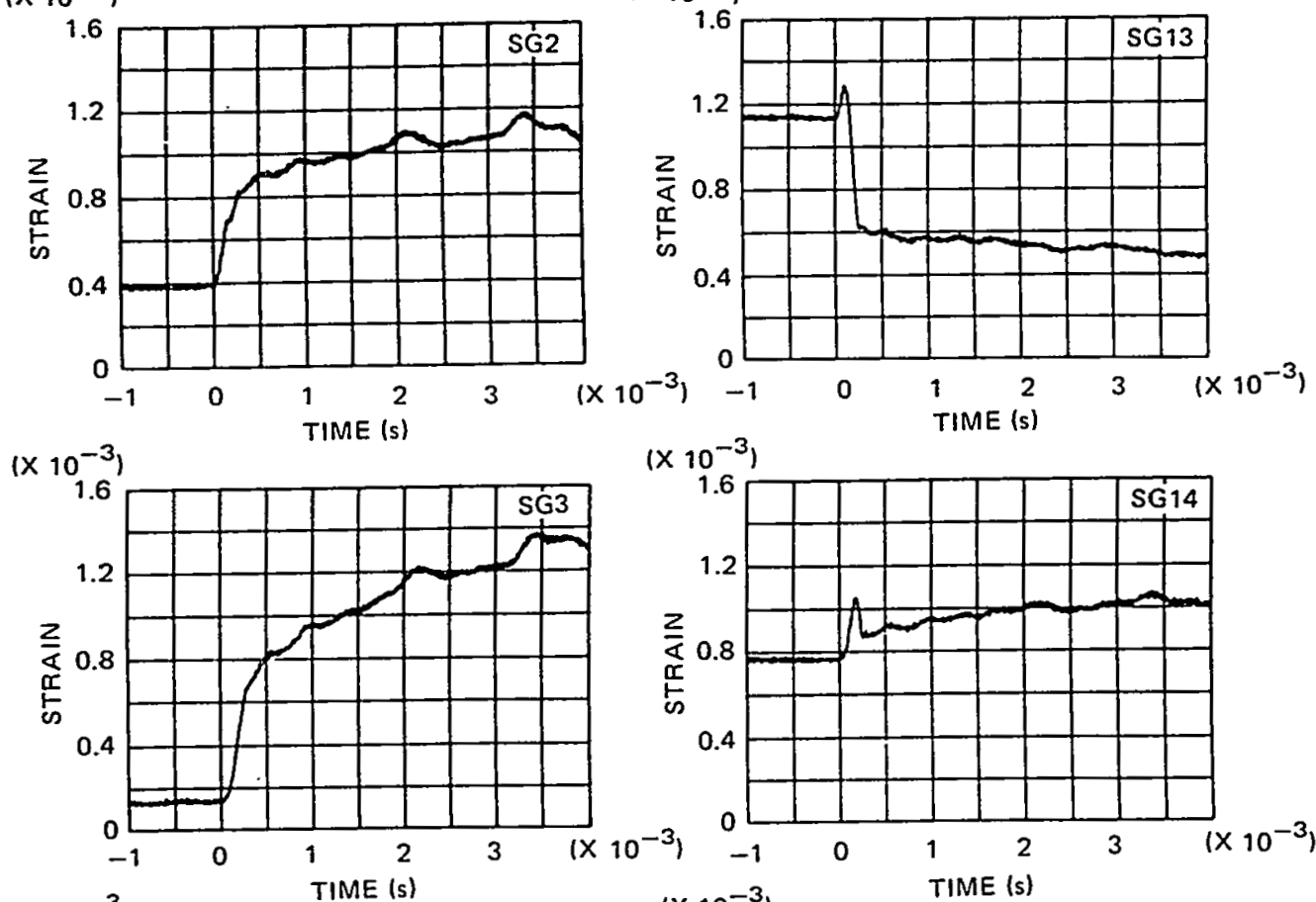

$\left(\times 10^{-3}\right)$
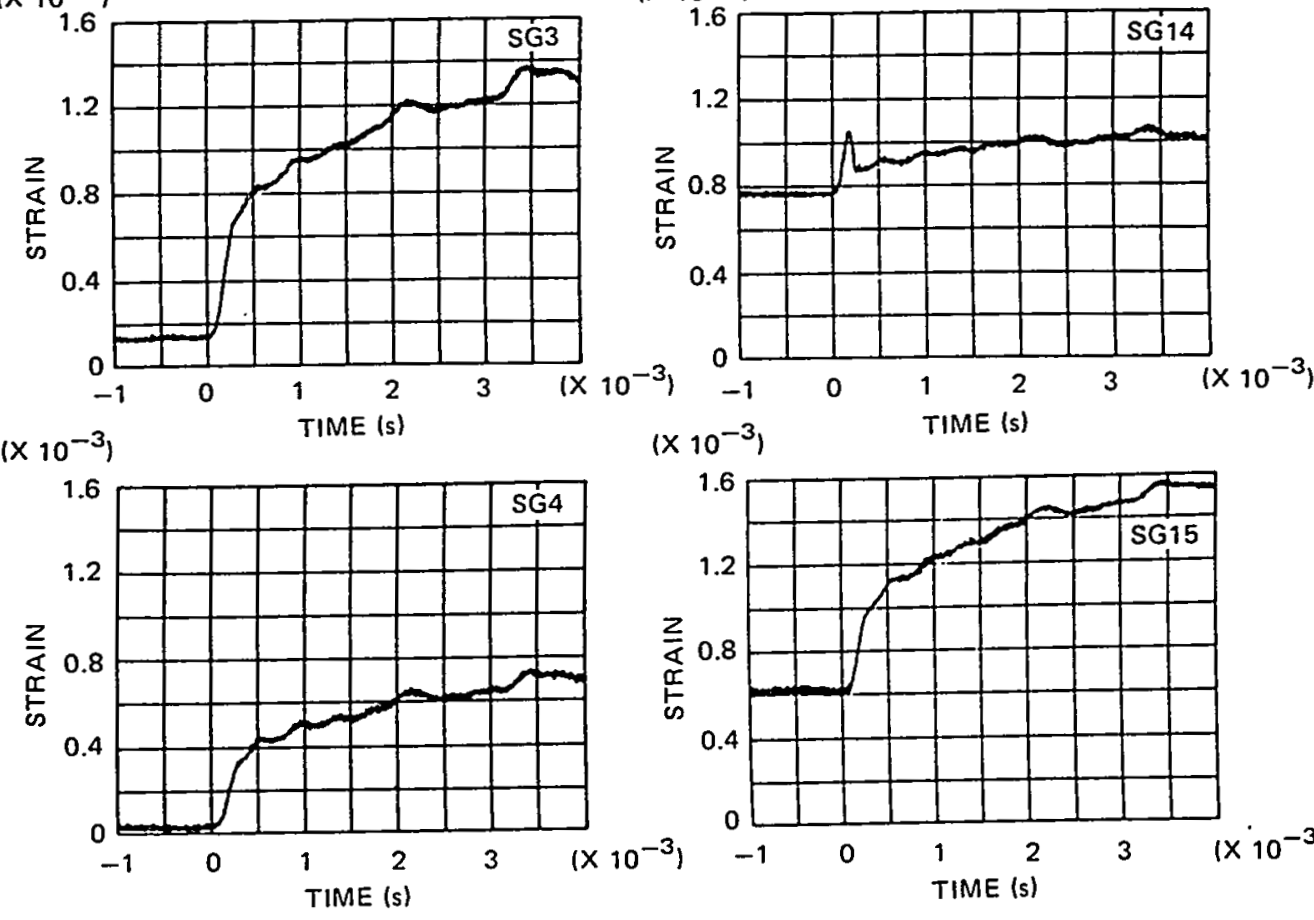

$\left(\times 10^{-3}\right)$

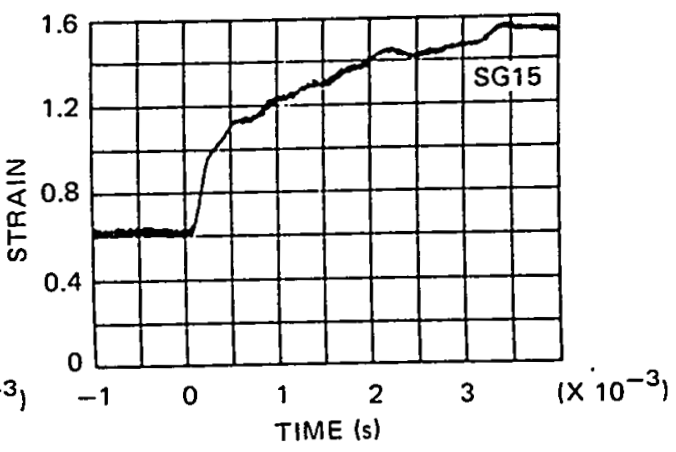

FRONT-FACE GAGES

BACK-FACE GAGES

Fig. A.1. Strain histories for companion crack-line gages: test WP-2.1 (gages $1-4$ and 13-15). 

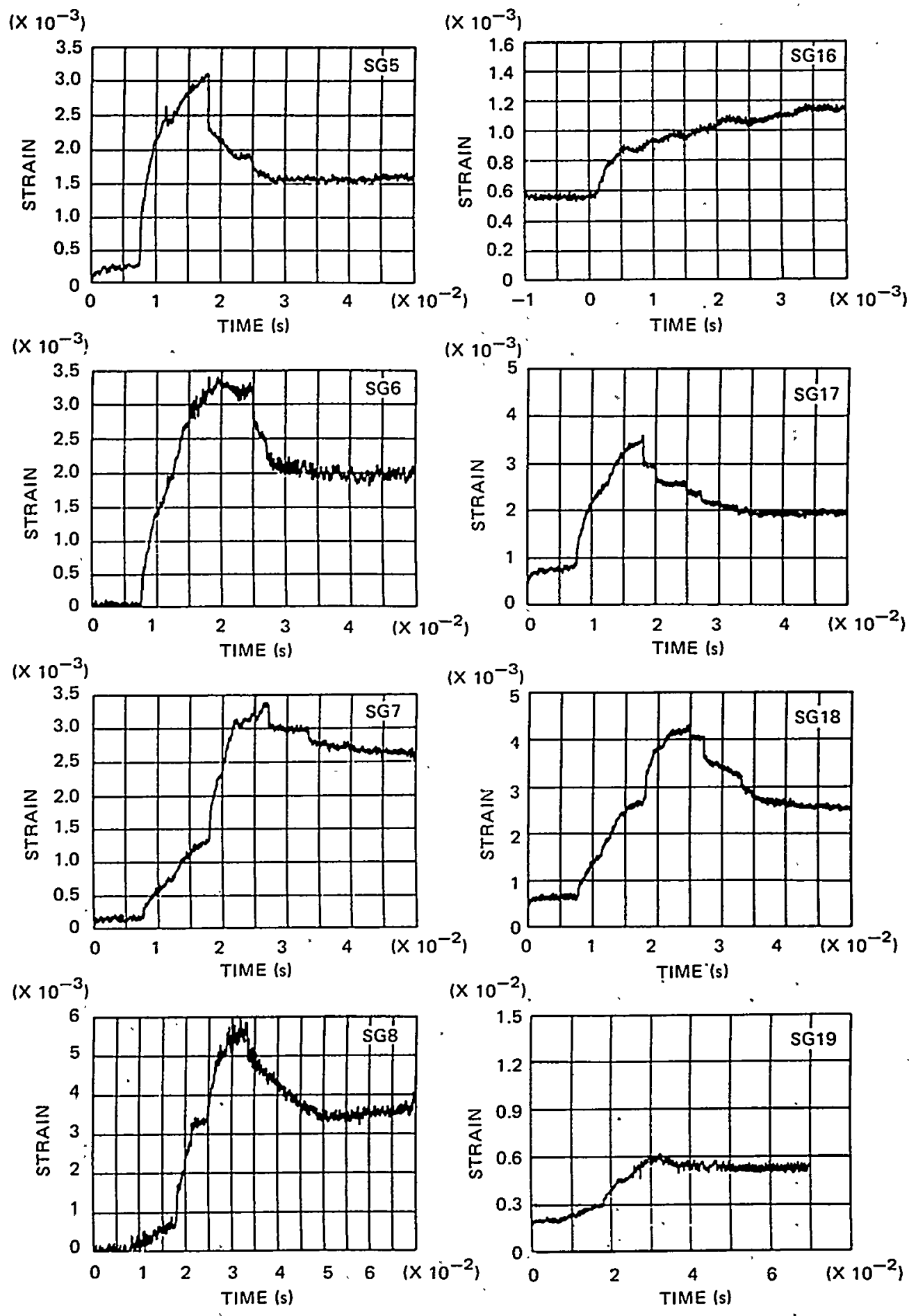

$\left(\times 10^{-2}\right)$

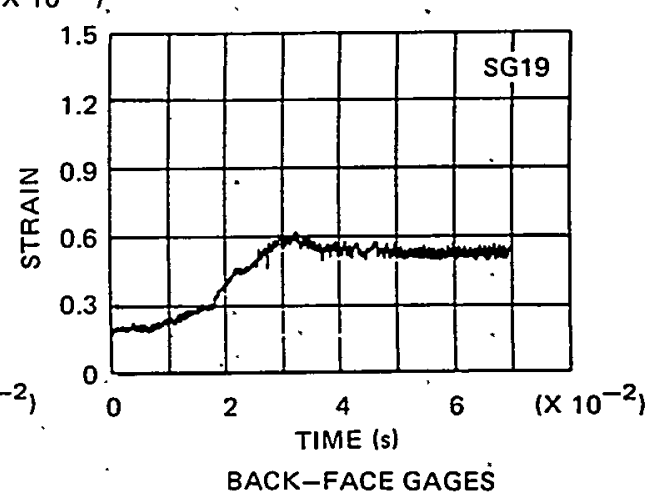

Fig. A.2. Strain histories for companion crack-1ine gages: test WP-2.1 (gages 5-8 and 16-19). 

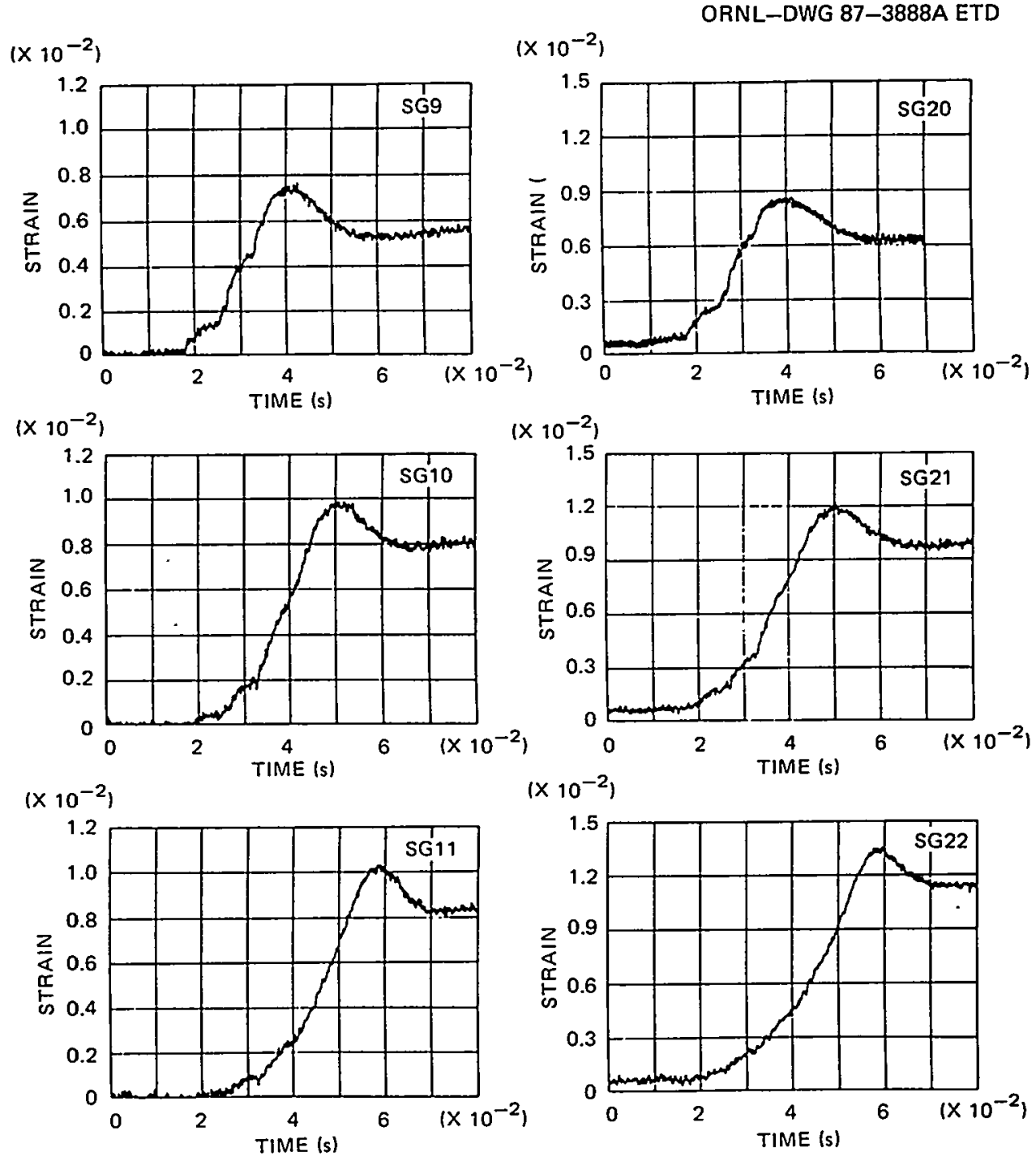
$\left(\times 10^{-2}\right)$
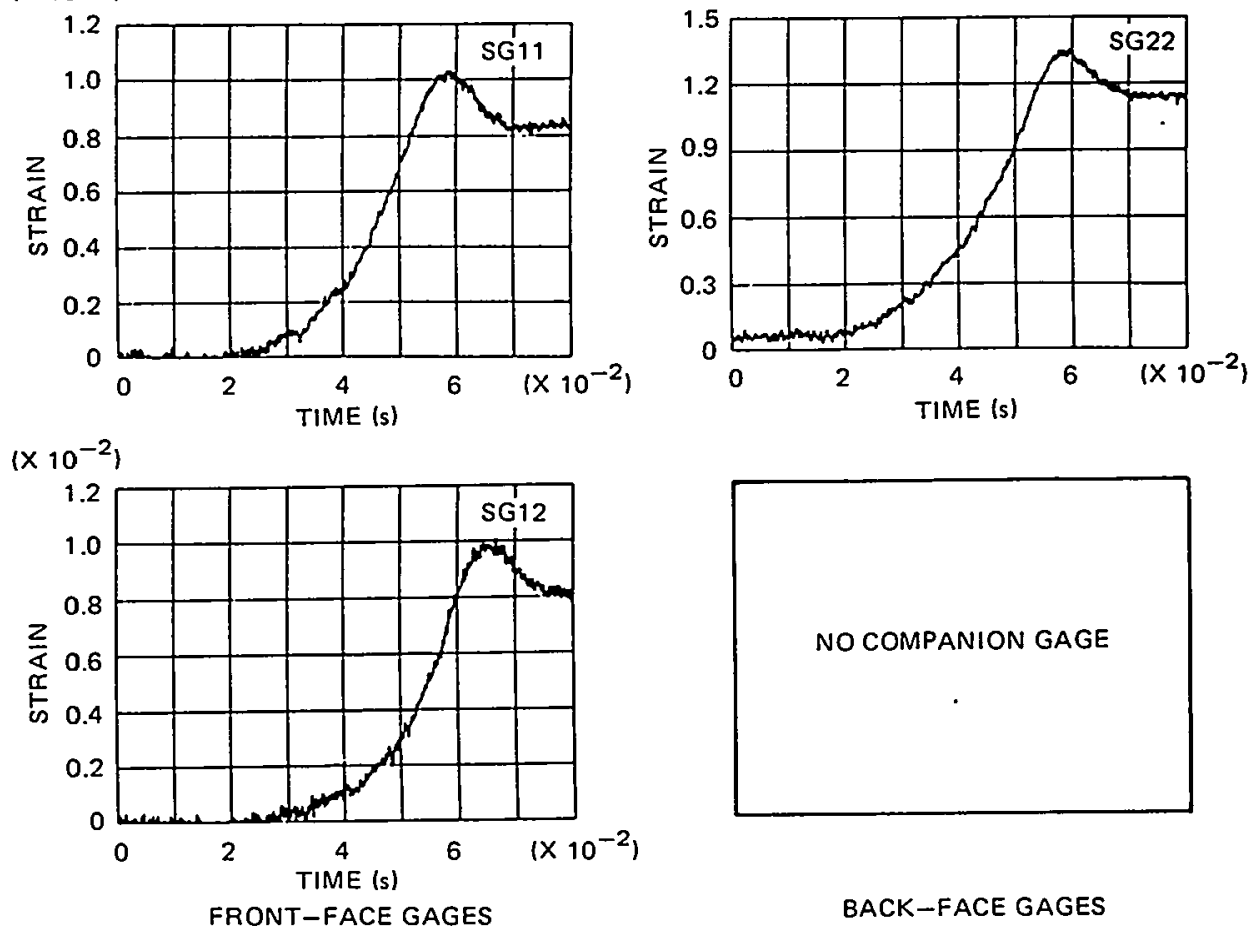

Fig. A.3. Strain histories for companion crack-1ine gages: test WP-2.1 (gages $9-12$ and 20-22). 

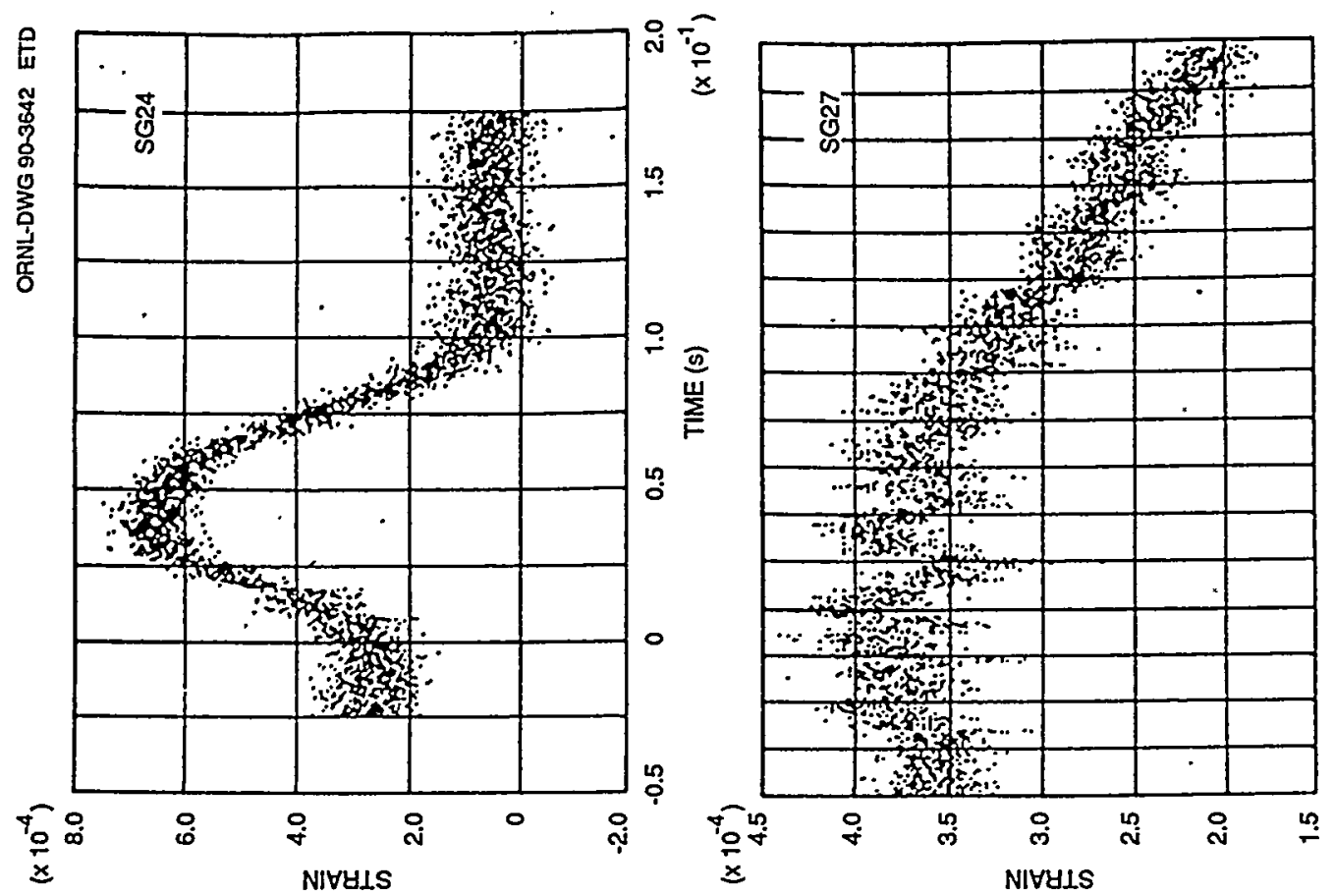

$\frac{0}{0}$

is

-1
0

일
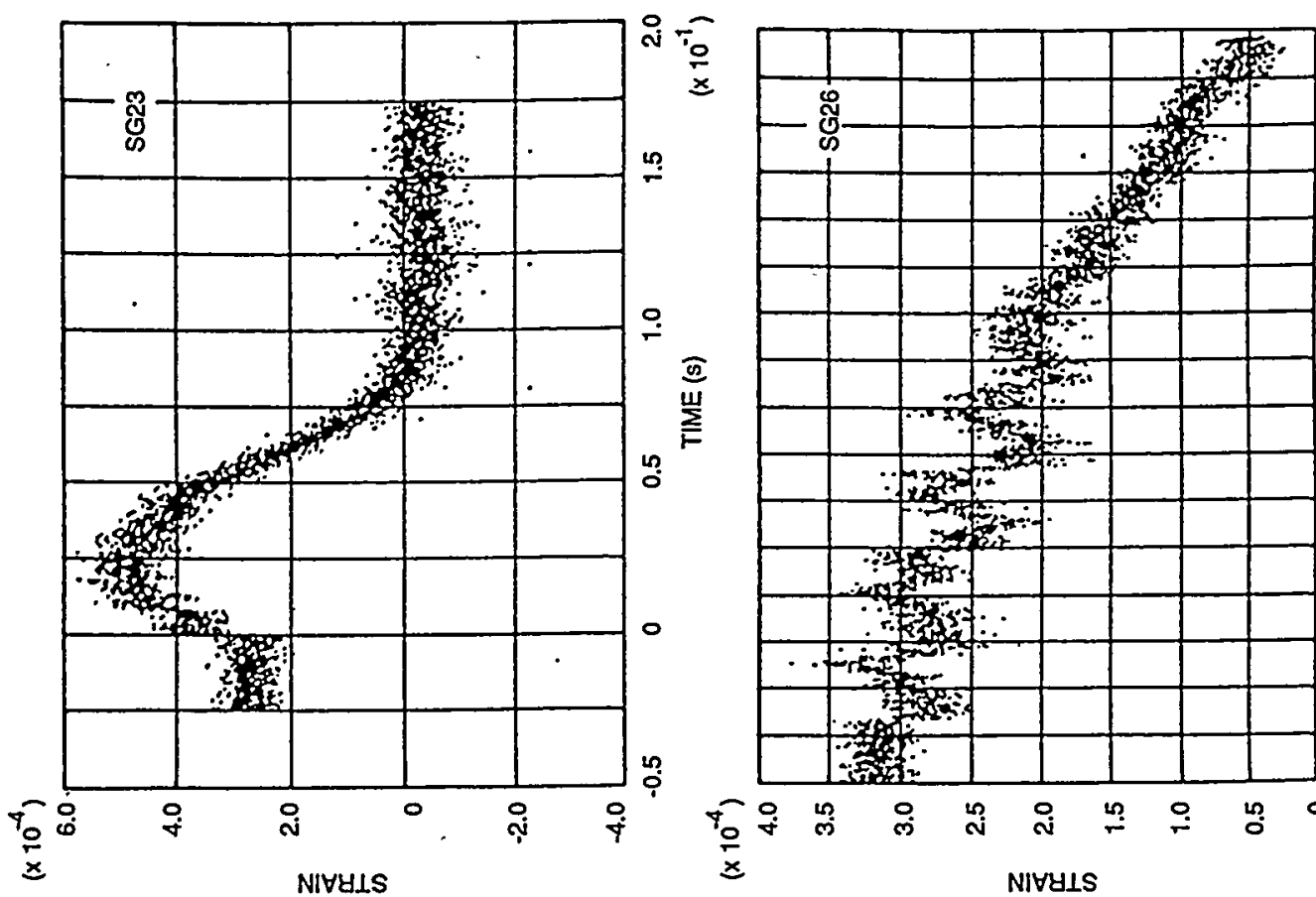

일

움

ल

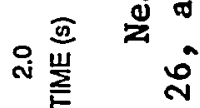

$\because \quad \dot{4}$

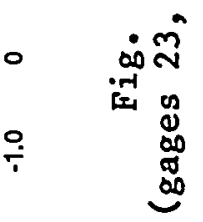

ช0ำ

NIVUIS 

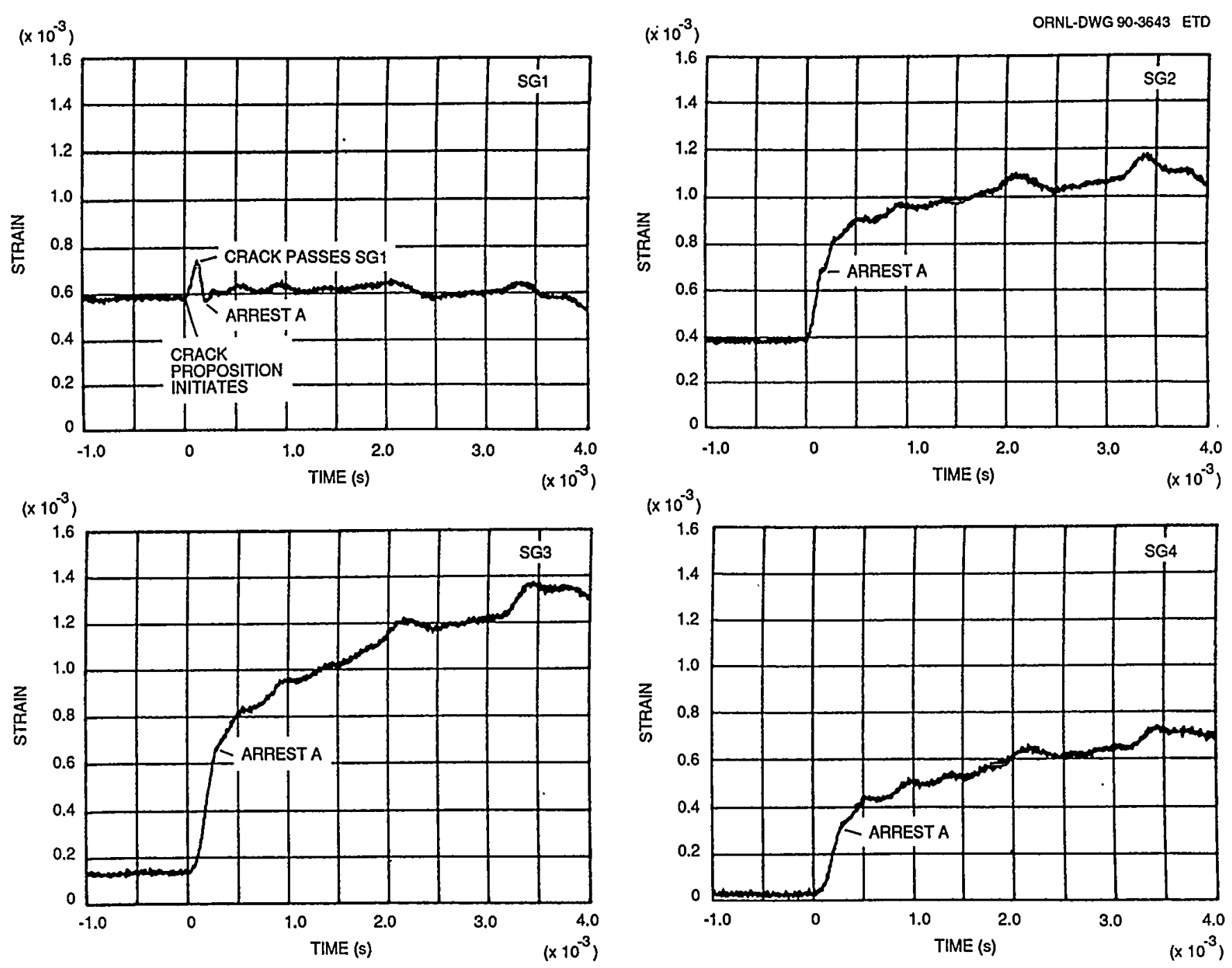

Fig. A.5. Strain histories for gages 1-4 showing crack passing under strain gage 1 and arresting before reaching strain gage 2: test WP-2.1. 



$\left(\times 10^{-3}\right)$

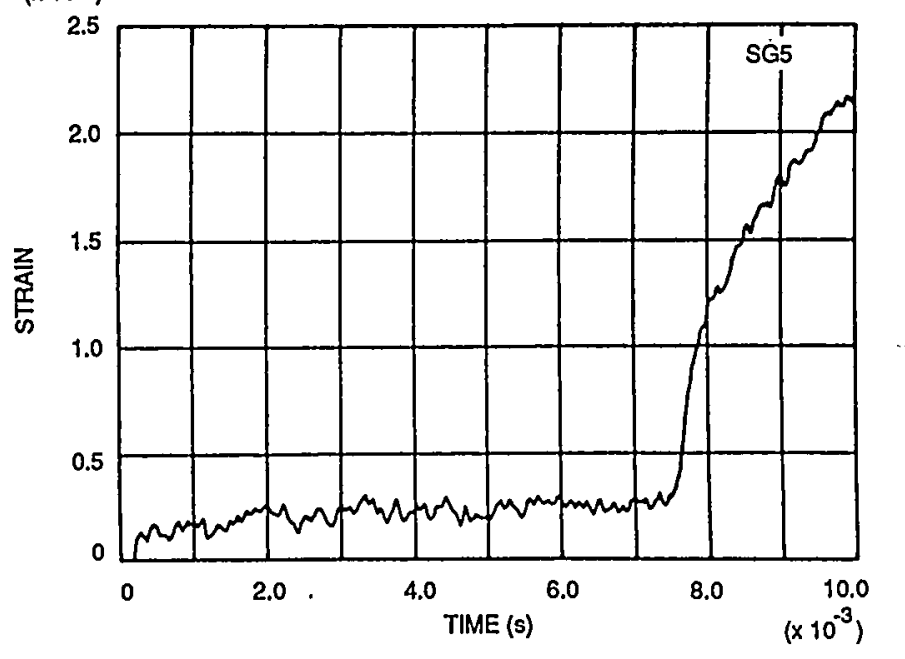

Fig. A.6. Strain histories for gages 2-5 showing crack passing under strain gages 2 and 3 , arresting momentarily before passing under strain gage 4, and arresting before passing under gage 5: test WP-2.1. 

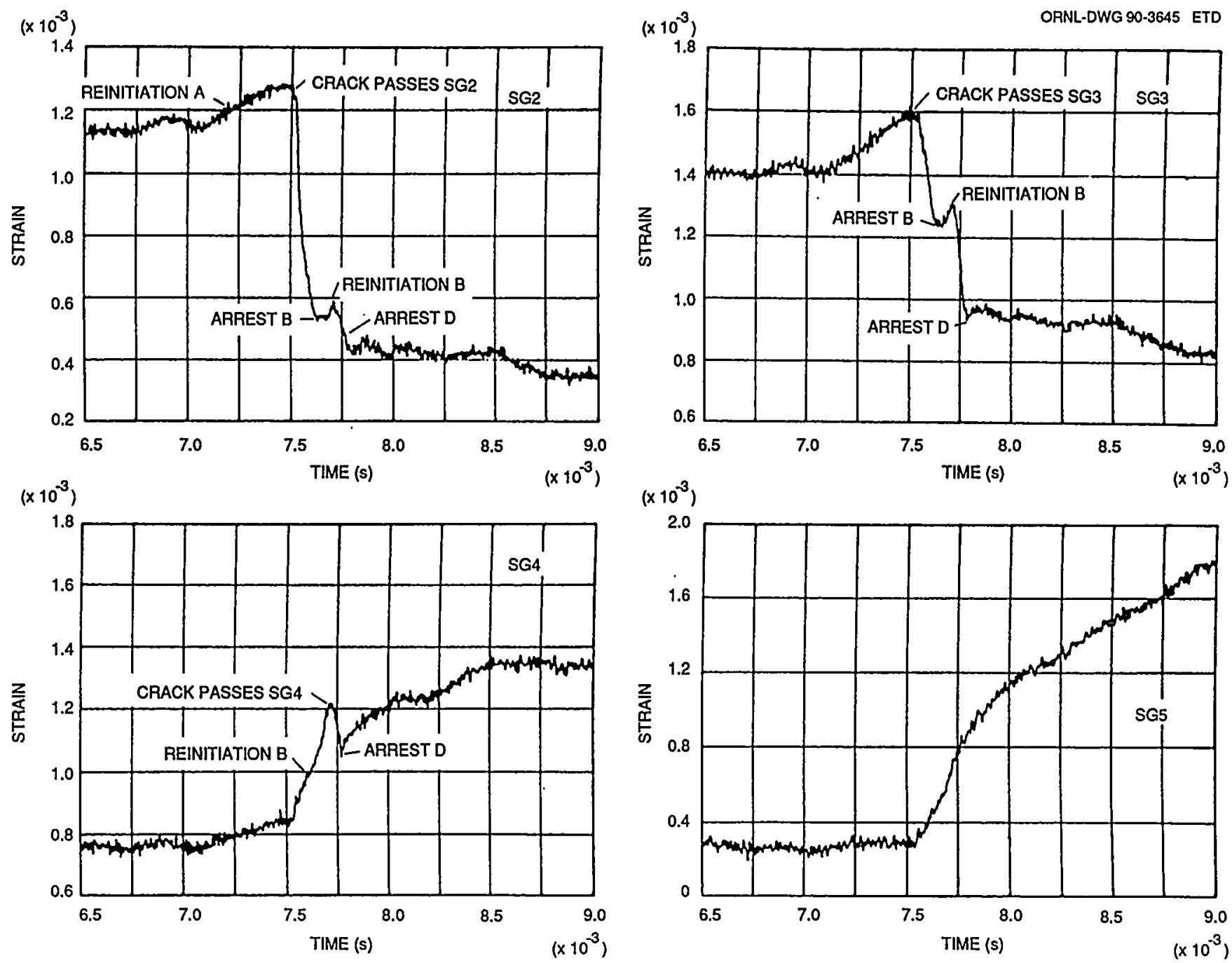

Fig. A.7. Strain histories for gages 2-5 showing momentary arrest between gages 3 and 4 : test WP-2.1. 
$\left(\times 10^{-3}\right)$

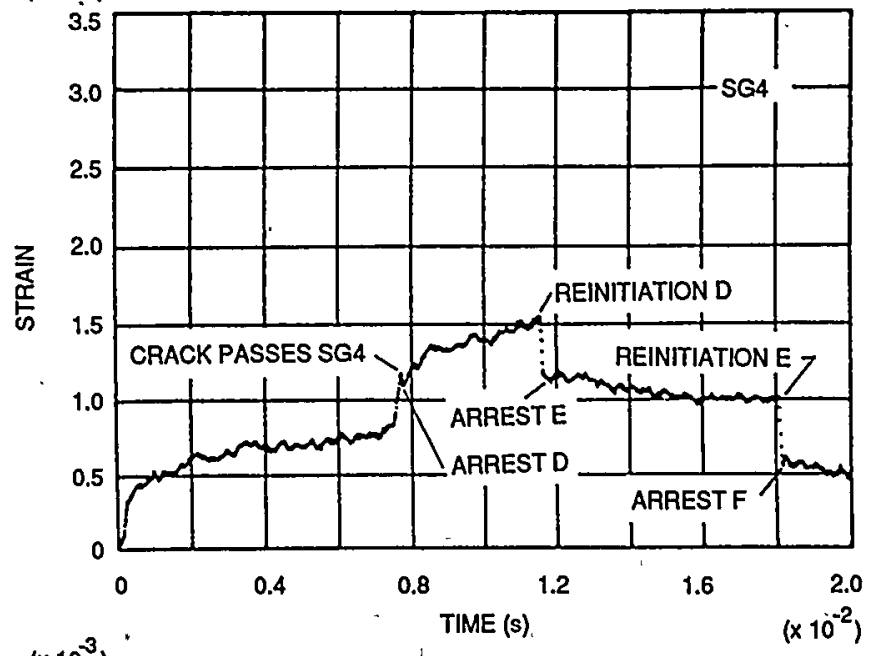

$\left(\times 10^{-3}\right)$

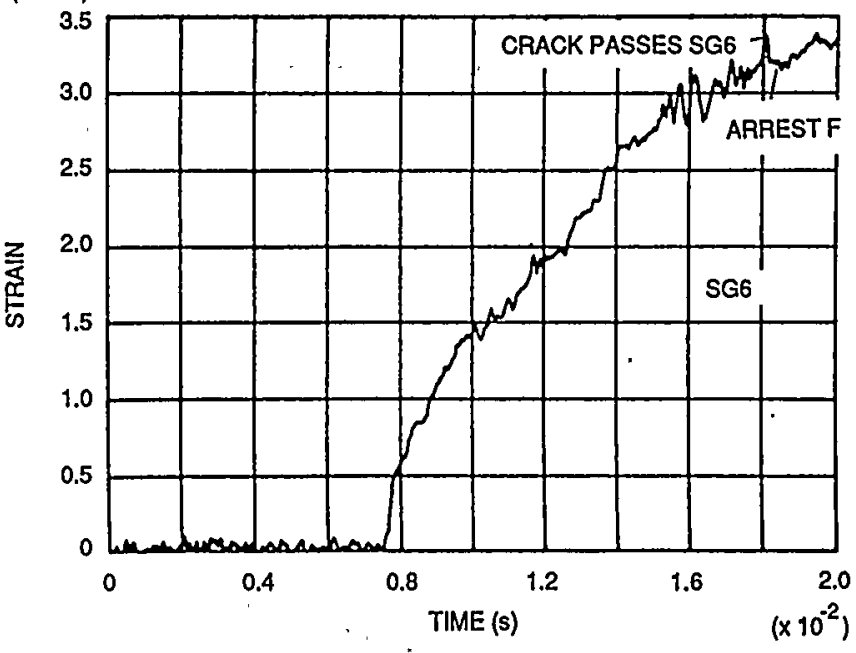

$\left(\times 10^{-3}\right)$

ORNL-DWG 90-3646 ETD

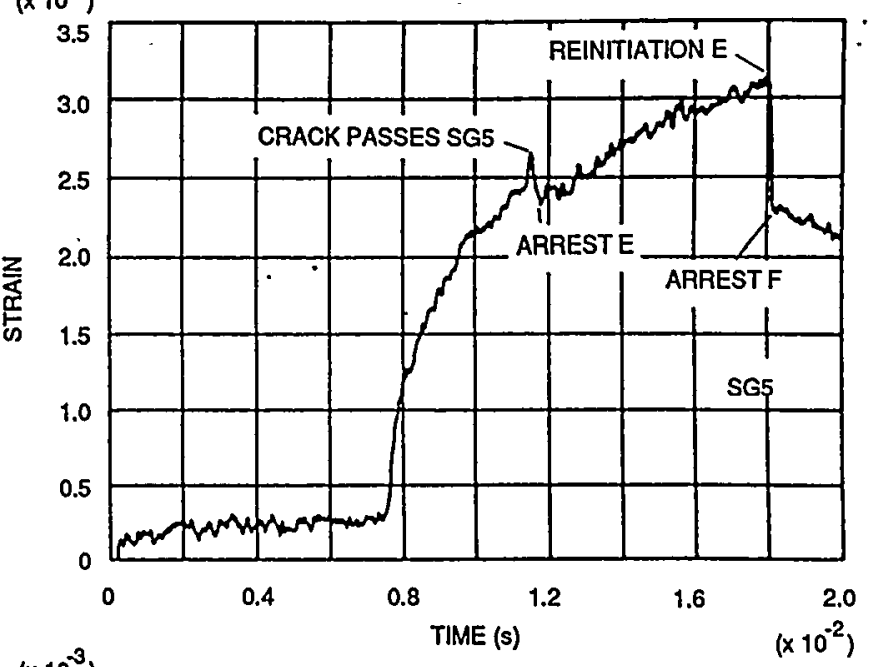

$\left(\times 10^{-3}\right)$

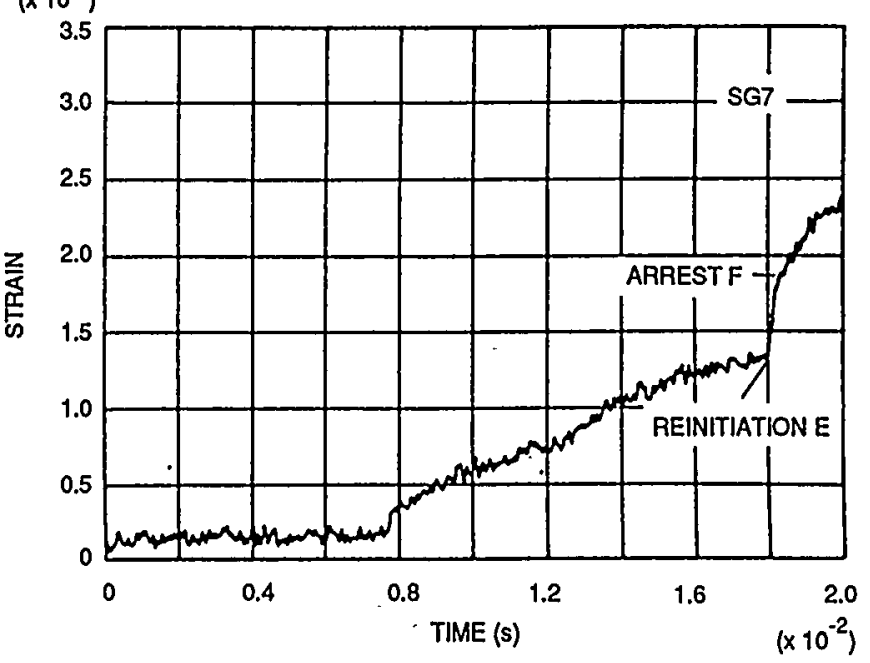

Fig. A.8. Twenty-millisecond records of strain gages 4-7 showing previous crack run-arrest events and crack passing under gage 5 and arresting before reaching gages 6 and 7: test WP-2.1. 


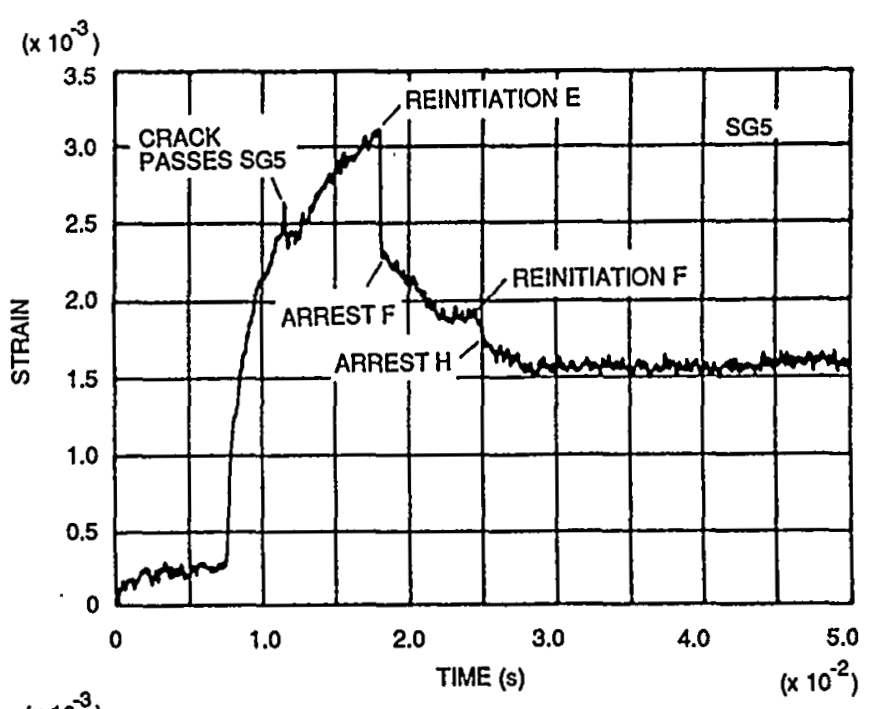

$\left(\times 10^{-3}\right)$

ORNL-DWG 90-3647 ETD
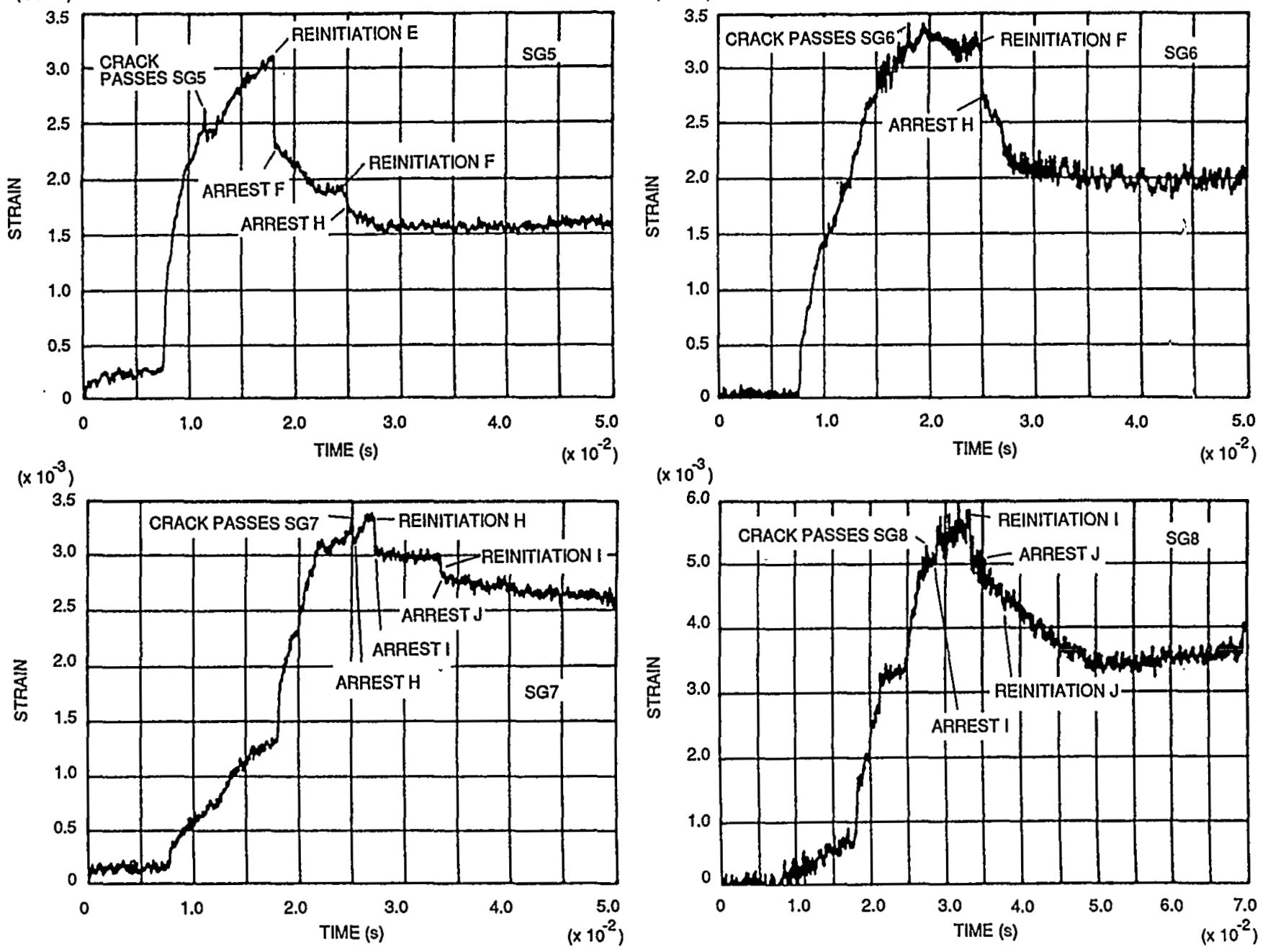

$\left(\times 10^{3}\right)$

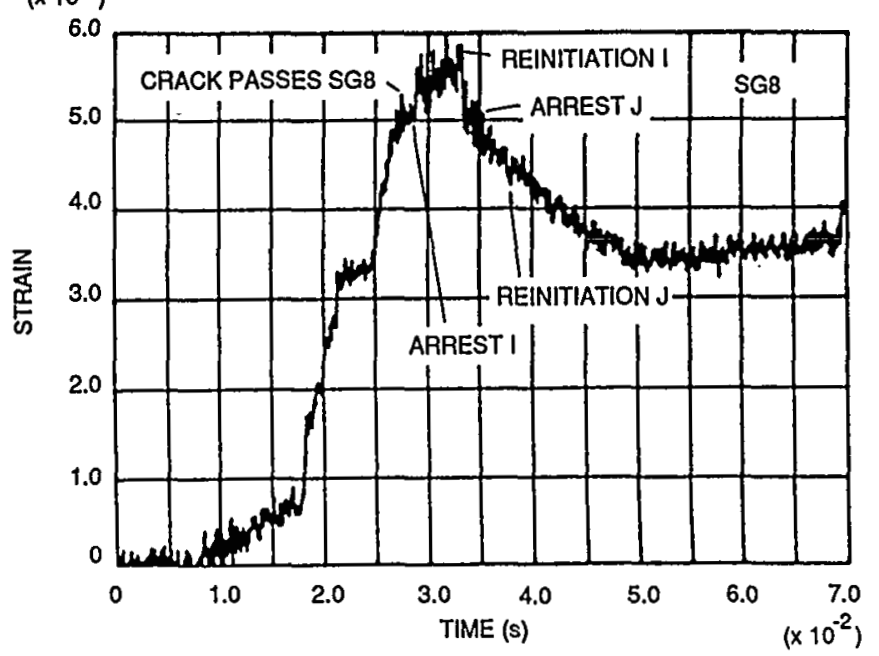

Fig. A.9. Fifty-millisecond records of strain gages 5-8 showing fibrous tearing after a cleavage arrest just past gage 5 , followed by cleavage fracture, reinitiation just past gage 6 , another arrest, and cleavage fracture reinitiation that passes under gage 8 and arrests: test WP-2.1. 

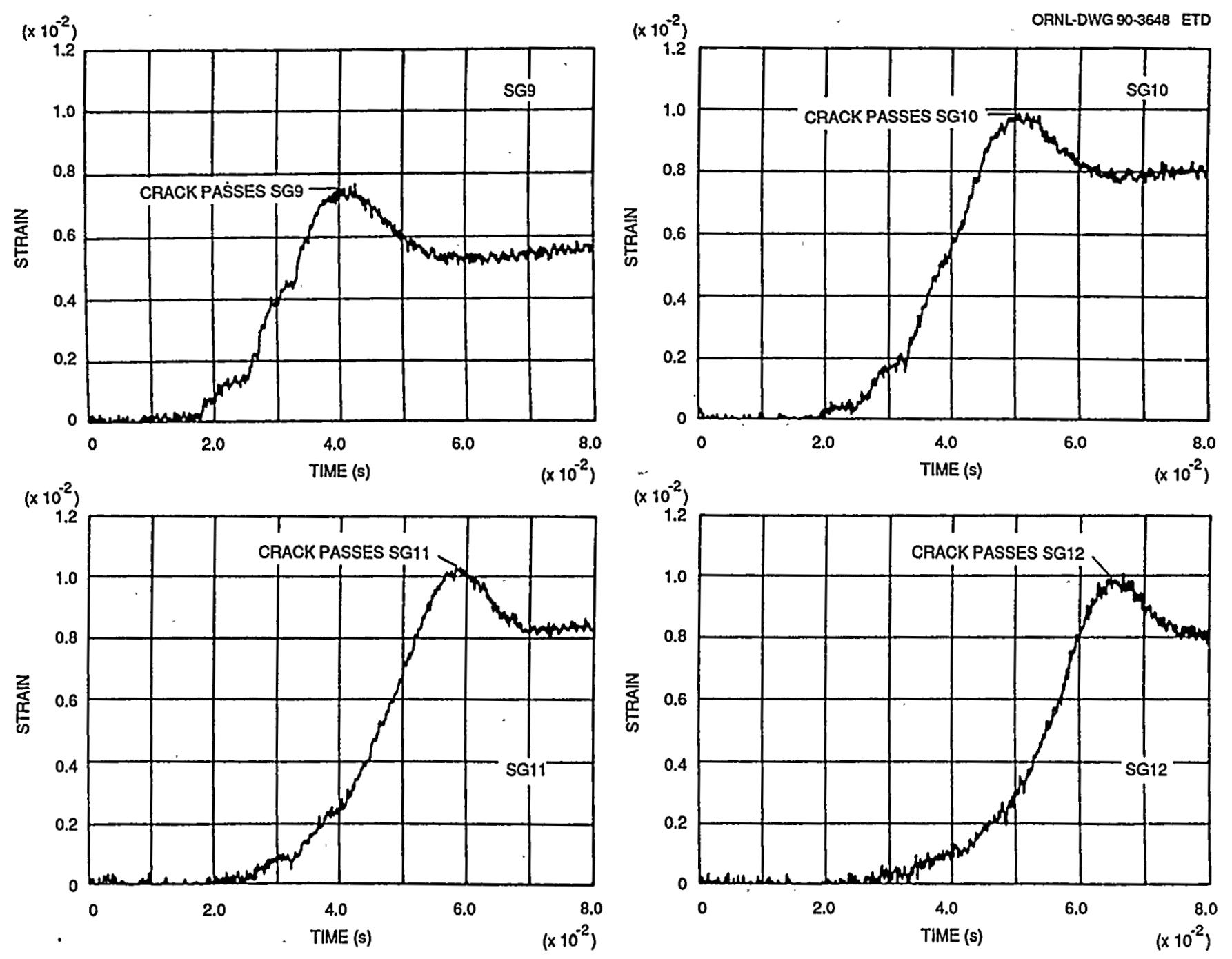

Fig. A.10. Strain. histories of gages 9-12 showing fibrous tearing past these gages: test WP-2.1. 

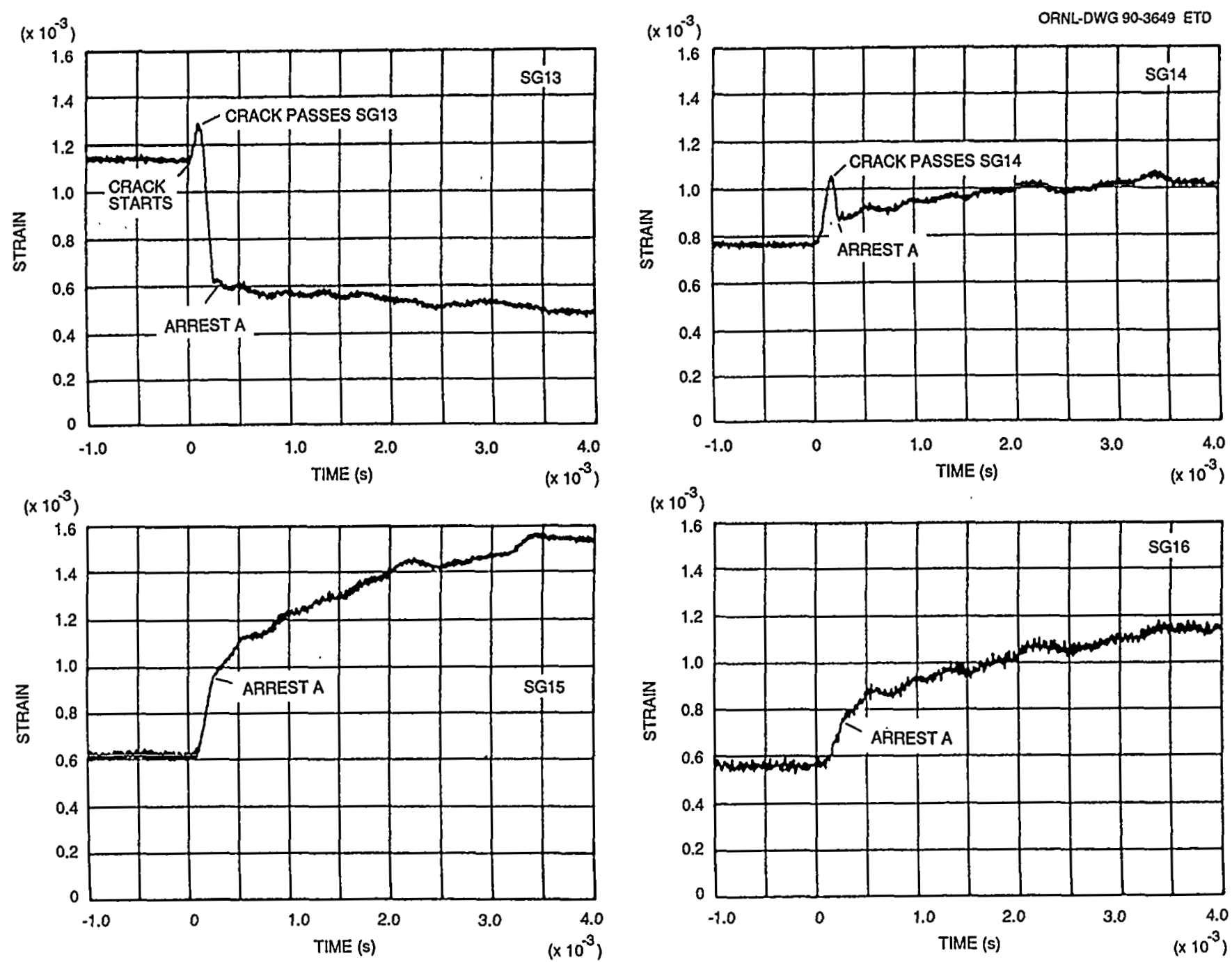

Fig. A.11. Strain histories for gages 13-16 showing crack passing under gages 13 and 14 before arresting before gage 15: test WP-2.1. 

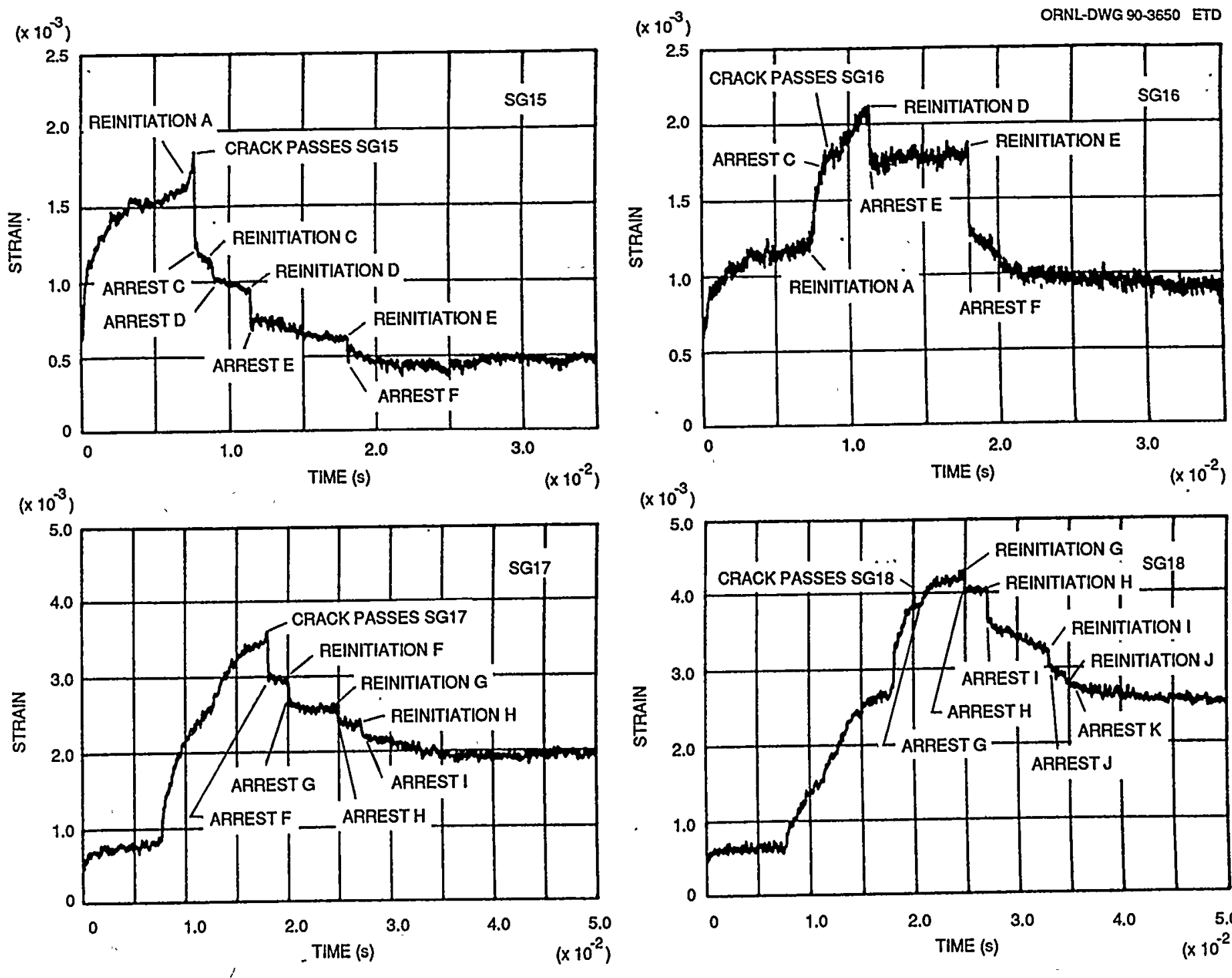

$\left(\times 10^{-3}\right)$

Fig. A.12. Strain histories for gages 15-18. showing crack passing under gage 15 , reinitiating, passing under gage 16 , arresting, reinitiating, passing under gage 17, arresting, reinitiating, and passing under gage 18: test WP-2.1. 

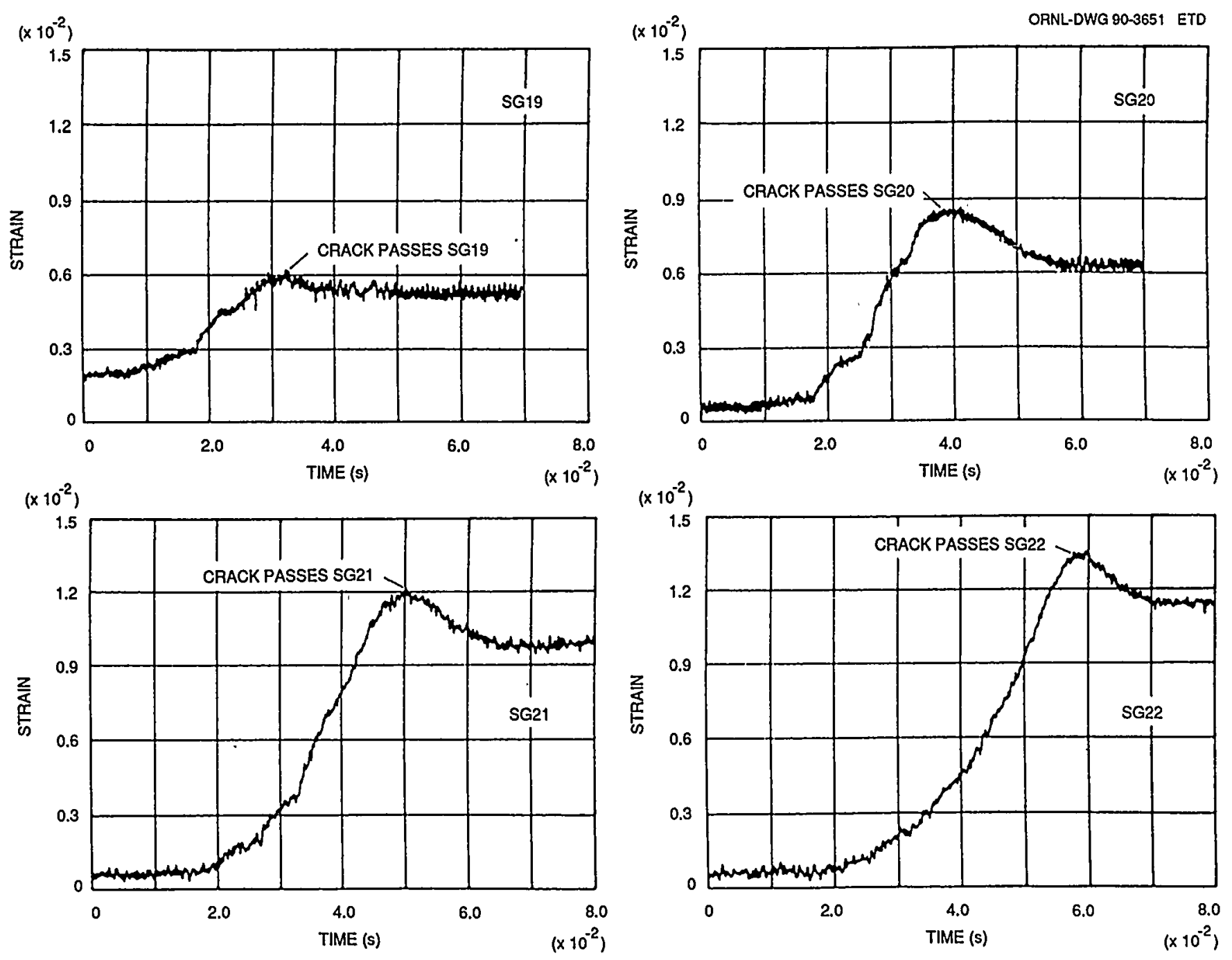

Fig. A.13. Strain histories for gages 19-22 showing fibrous tearing past these gages: test WP-2.1. 


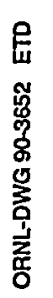

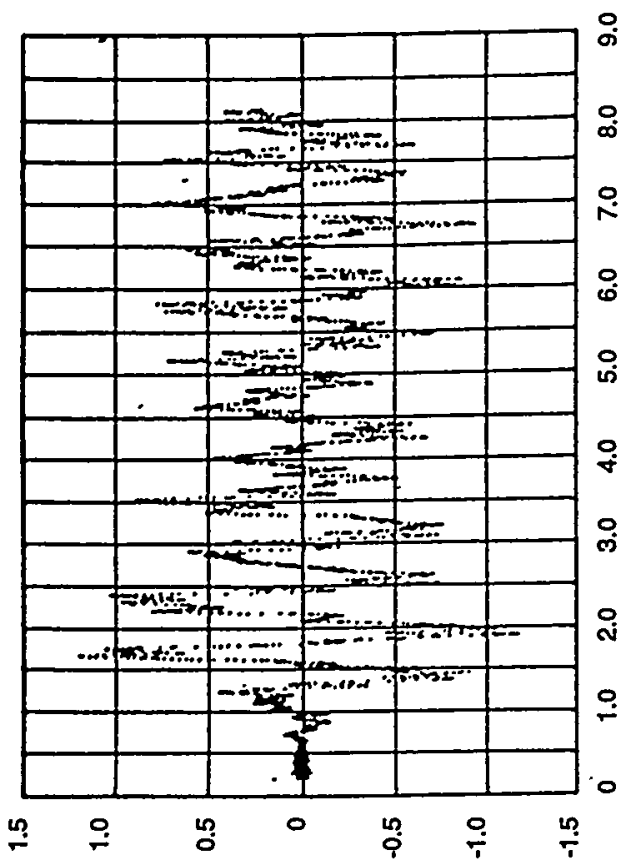

(N) $\perp$ ก)

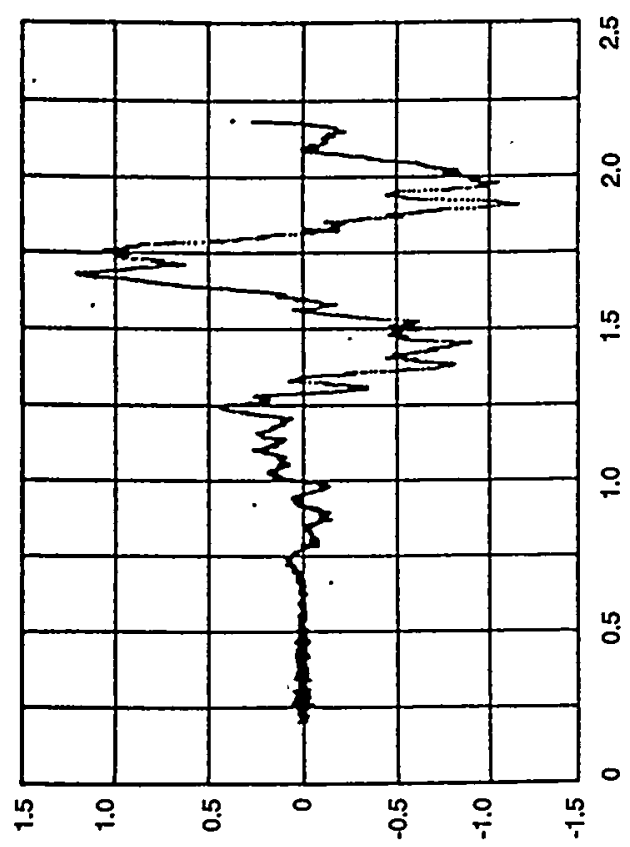

(N) LndIno $\exists y$

iั
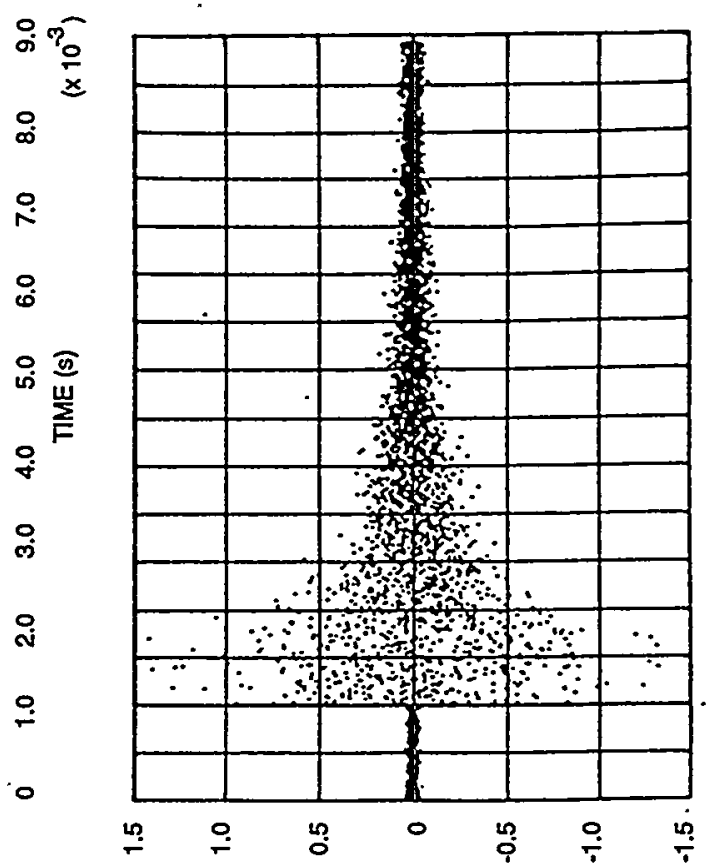

in

웅

$\stackrel{\circ}{\mathrm{i}}$

-1

(n) $\perp$ AIno $\exists y$

요
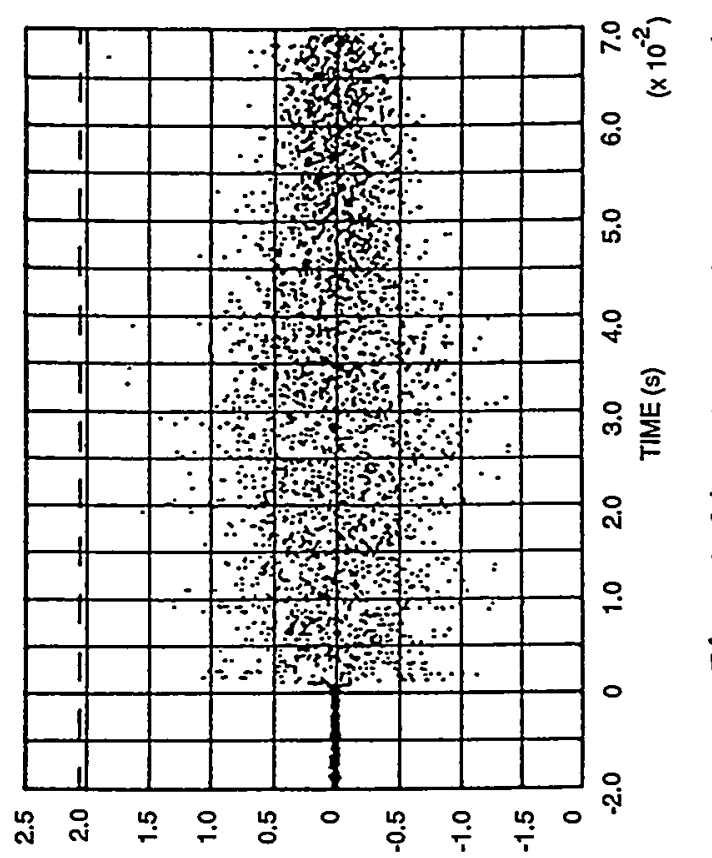

(A) Lndino $\exists \forall$ 
are shown in Fig. A.15. Front- and back-face COD results for gages located at $a / w=0.150$ are presented in Fig. A.16. COD values obtained from the back-face COD gage, at comparable times during the fracture event, were consistently higher than values obtained from the front-face COD gage. This correlates with the results presented previously in Fig. 5.7, which indicated that for the time period monitored by the COD gages, the apparent crack front advance was more rapid at the back-face of the plate. As shown in Fig. A.16, the measurement capacities of the front- and back-face COD gages were exceeded $\sim 36$ and $31 \mathrm{~ms}$, respectively, into the fracture event.

\section{A.2 TEST WP-2.2}

\section{A.2.1 Strain Gages}

Figures A.17 to A.20 present strain histories [see Fig. $4.8(b)$ for strain-gage locations] for companion front- and back-face crack-1ine gages. Figure A.17 shows the cleavage crack propagating past gages 1 and 2 on the plate front face and gage 13 on the plate back face (strain gage 14 did not operate correctly). Propagation of the cleavage crack past gages 3 and 4 on the plate front face and gages 15 and 16 on the plate back face is shown in Fig. A.18. Continued propagation of the cleavage crack past gages 5 and 6 on the plate front face and gages 17 and 18 on the plate back face is presented in Fig. A.19. Also shown in Fig. A.19 are arrest of cleavage crack propagation just past strain gages 6 (plate front face) and 18 (plate back face) and multiple reinitiations and arrests of cleavage crack propagation. Cleavage crack propagation past gages 7 and 8 on the plate front face and gages 19 and 20 on the plate back face, with subsequent arrests and reinitiations of cleavage crack propagation, are shown in Fig. A.20. Strain histories for front-face crack-1ine gages 9-12 (Fig. A.21) show arrest of cleavage crack propagation just past gage 9 with subsequent fibrous crack propagation past gages 10-12. Figure A.22 presents the strain history for near-field gage 21 (a) during the cleavage crack run-arrest events and (b) during the entire fracture process. Far-field strain histories for gages 22-25 during the cleavage crack run-arrest events are presented in Fig. A.23. Strain histories during the entire fracture process for farfield gages $22-25$ are presented in Fig. A.24.

\section{A.2.2 Additional Instrumentation}

Front- and back-face COD histories at two time resolutions are presented in Fig. A.25. Longitudinal accelerations recorded by a "damped" accelerometer mounted on the specimen's centerline at $3.458 \mathrm{~m}$ below the crack plane are presented in Fig. A.26 at two time resolutions. A1so presented in Fig. A.26 are dynamic displacements of the specimen, relative to that of the large columns of the testing machine, as measured $3.453 \mathrm{~m}$ below the crack plane. The dynamic displacement results cover the same time intervals as the accelerometer data. 

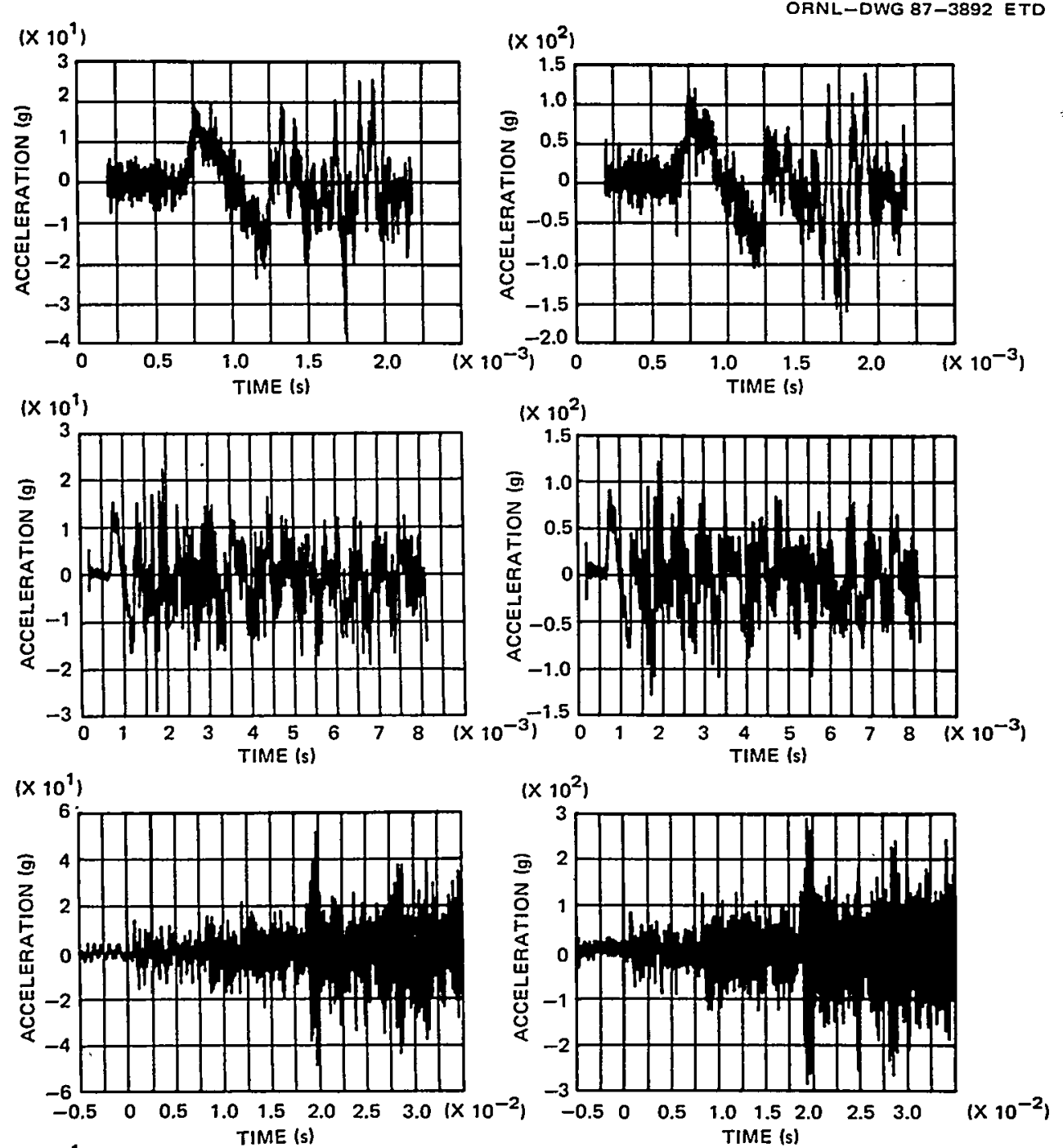

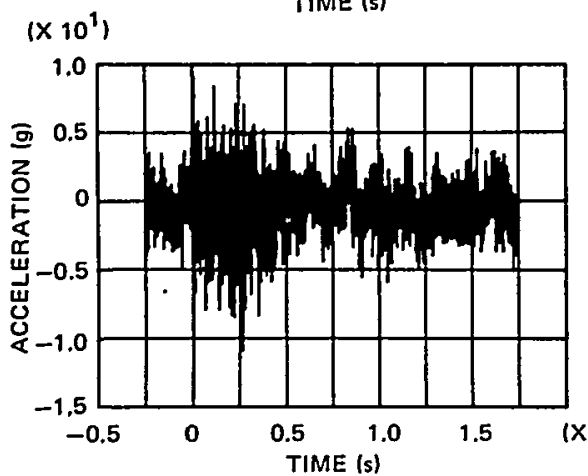

(a) TOP ACCELEROMETER

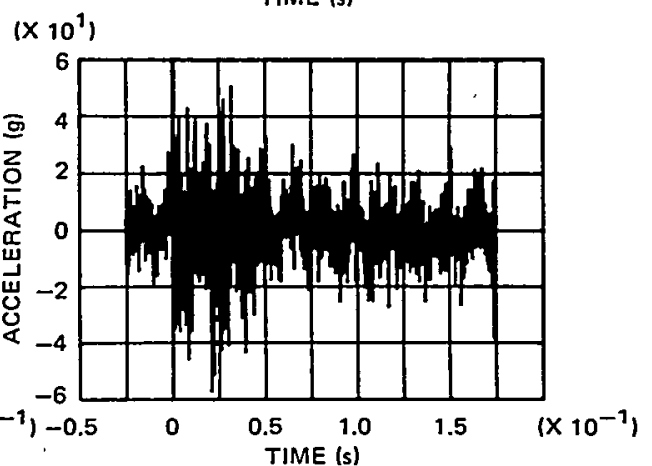

(b) BOTTOM ACCELEROMETER

Fig. A.15. Longitudinal acceleration results at various time resolutions measured by top and bottom "damped" accelerometers mounted $3.653 \mathrm{~m}$ above and $3.655 \mathrm{~m}$ below crack plane, respectively: test WP- 2.1 . 

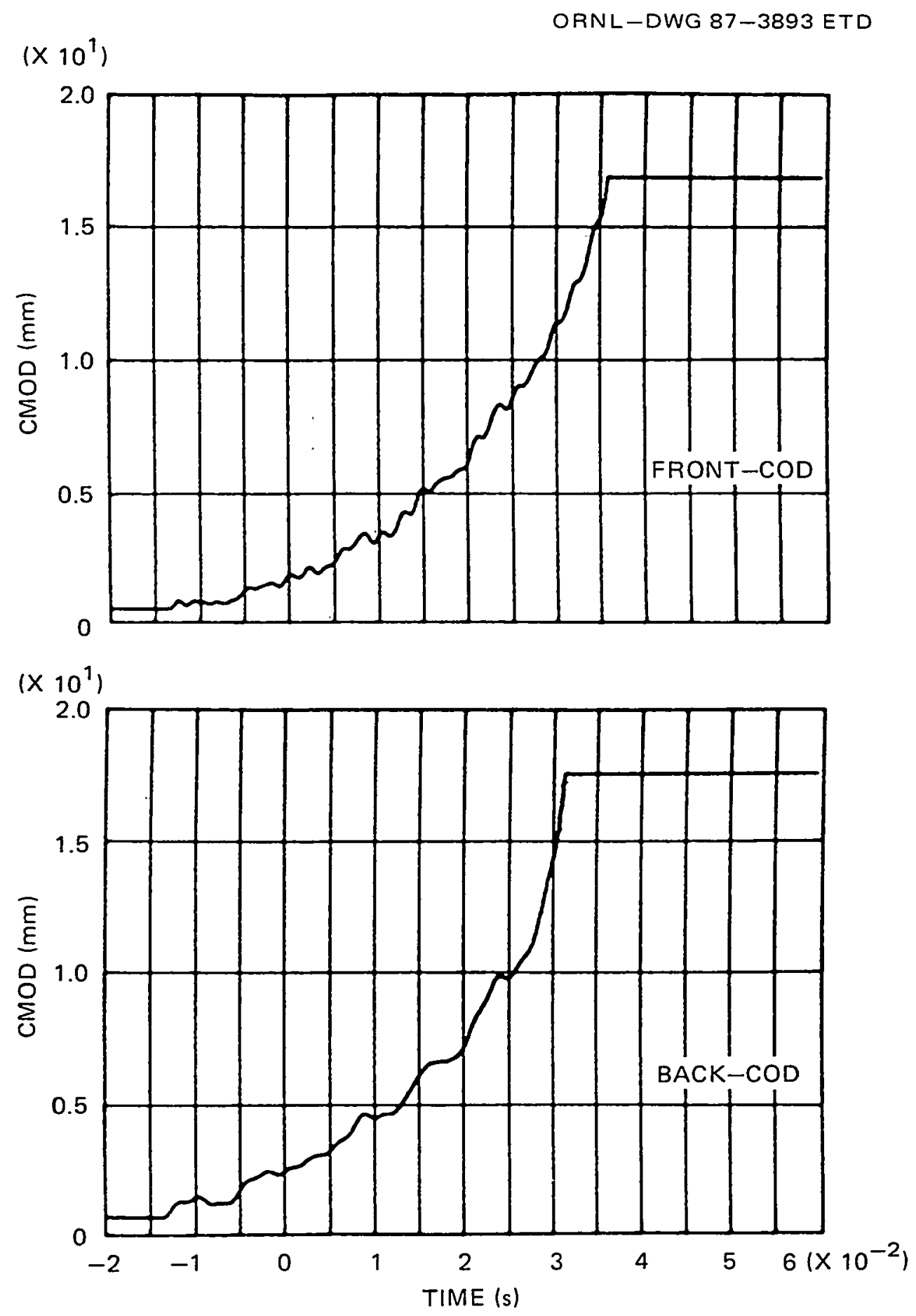

Fig. A.16. Front and back COD histories obtained from gages mounted at $a / w=0.15$ : test $W P-2.1$. 
ORNL-DWG 89-5030 ETD
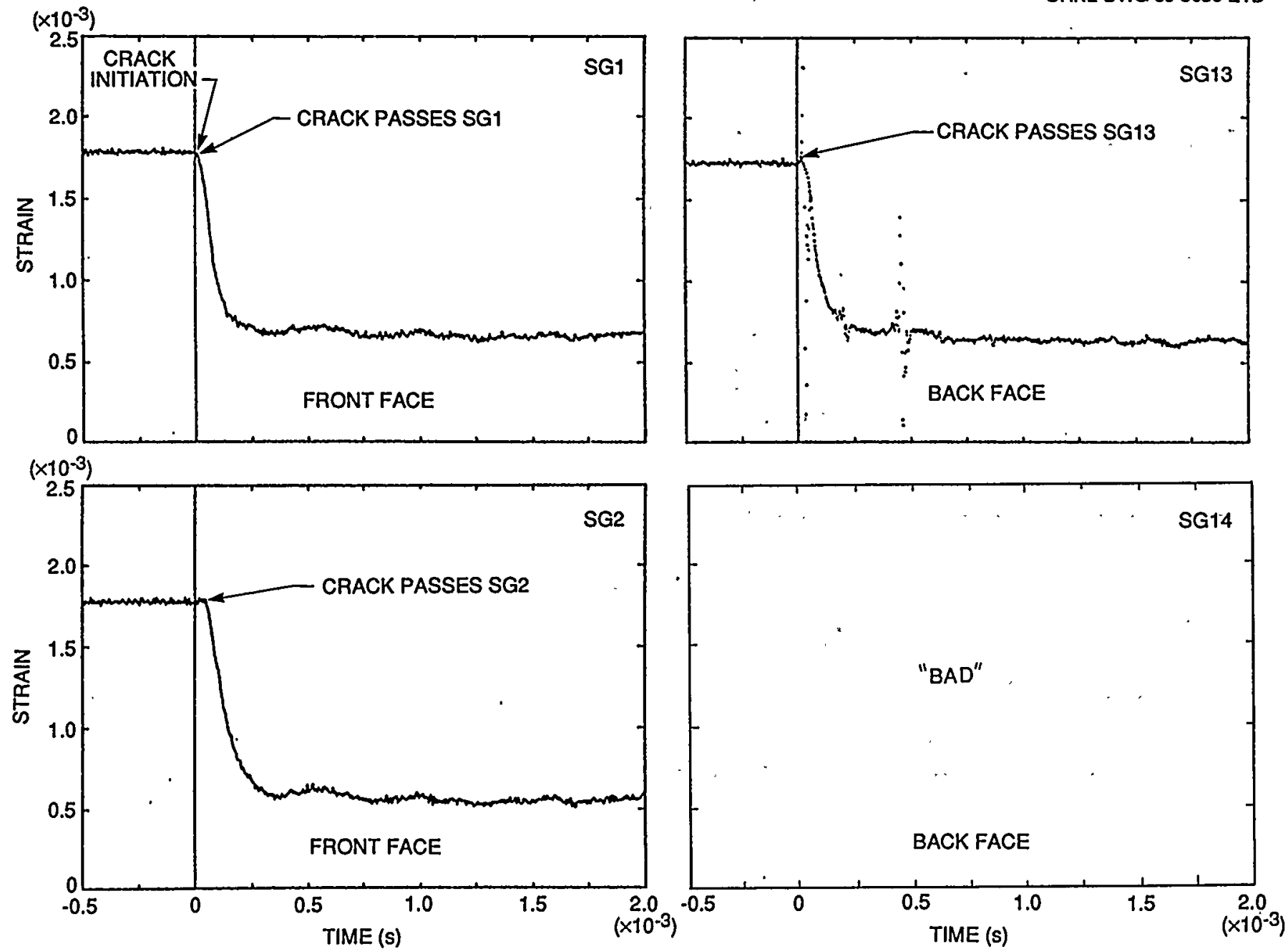

Fig. A.17. Strain histories for companion crack-line gages showing cleavage crack passing these gages: test WP-2.2 (gages 1, 2, and 13). 
ORNL-DWG 89-5031 ETD
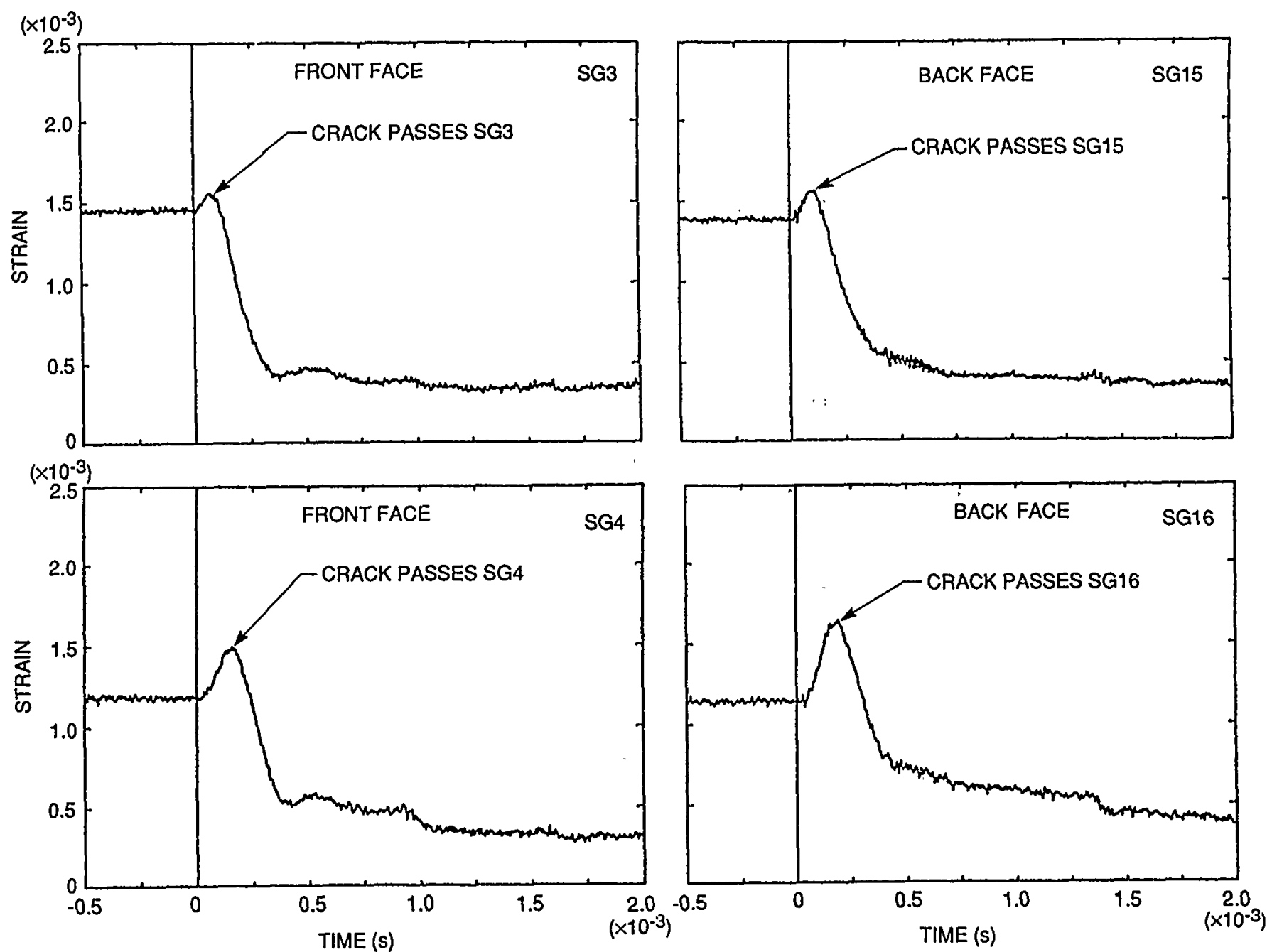

Fig. A.18. Strain histories for companion crack-line gages showing cleavage crack passing these gages: test WP-2.2 (gages 3, 4, 15, and 16). 

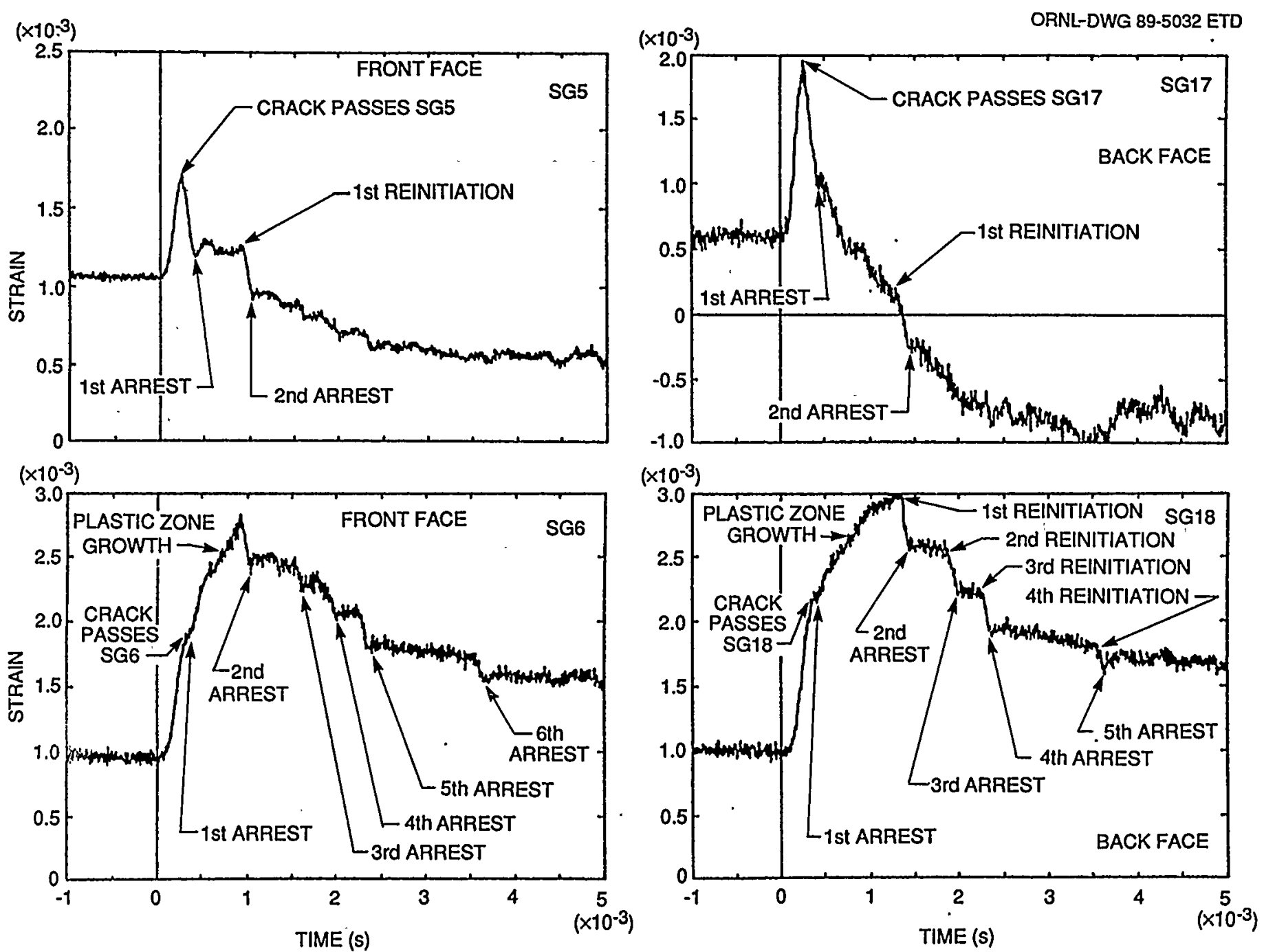

Fig. A.19. Strain histories for companion crack-line gages showing cleavage crack propagating past gages 5 and 17 and arresting just past gages 6 and 18: test WP-2.2. 
ORNL-DWG 89-5033 ETD
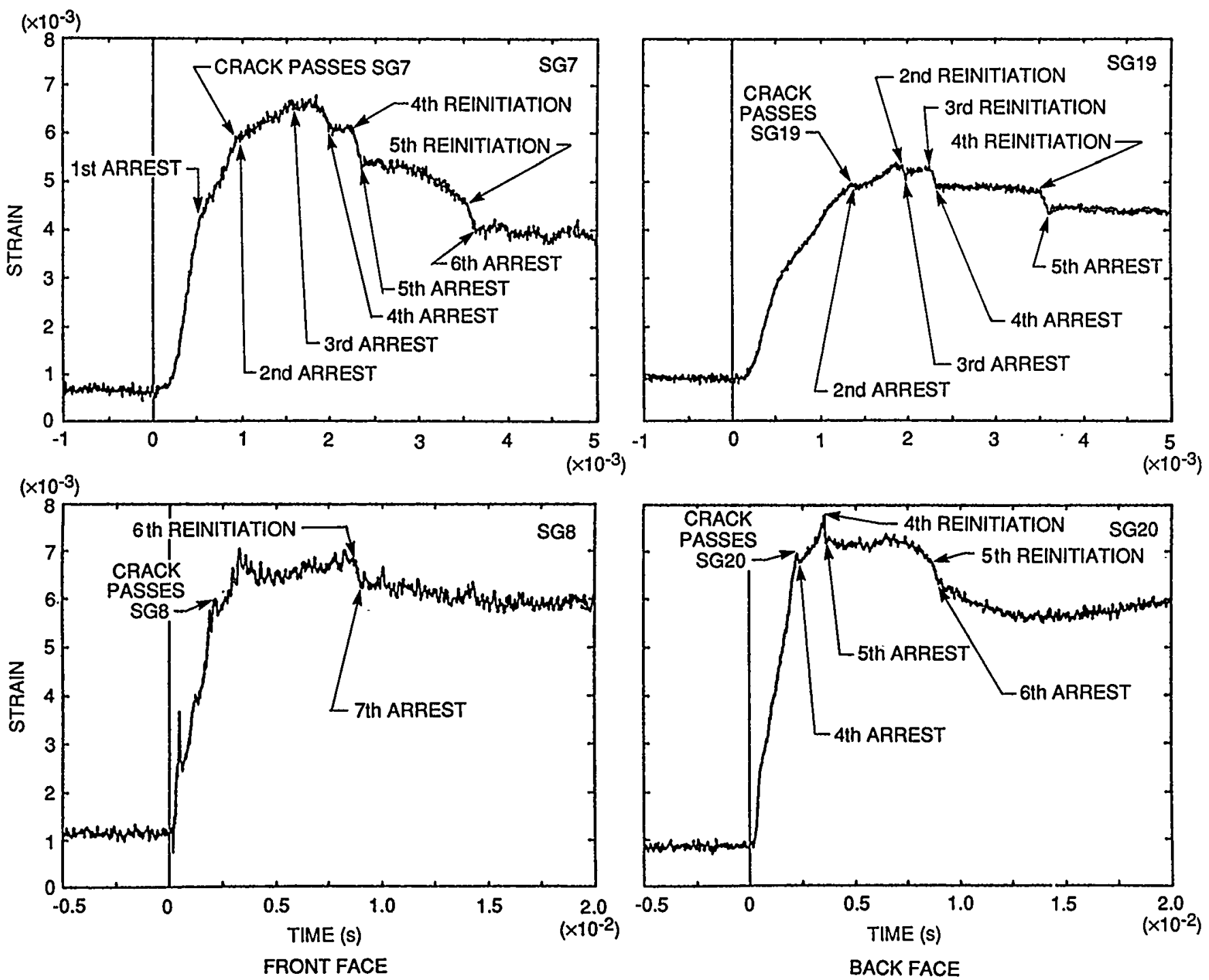

Fig. A.20. Strain histories for companion crack-1ine gages showing cleavage crack passing these gages followed by cleavage crack run-arrest events: test WP-2.2 (gages $7,8,19$, and 20). 
ORNL-DWG 89-5034 ETD
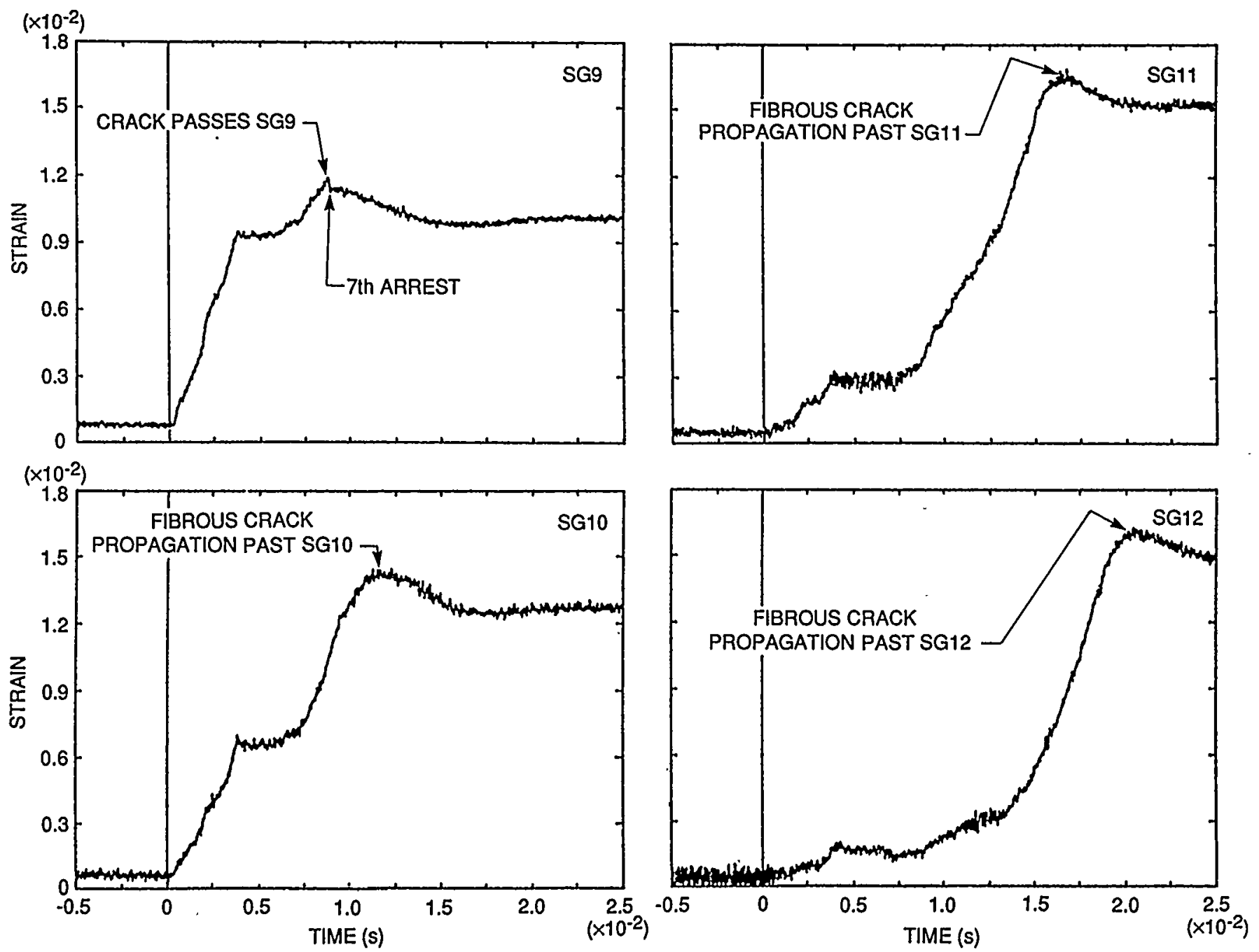

Fig. A.21. Strain histories for front-face crack-line gages showing arrest of cleavage crack propagation past gage 9 with subsequent fibrous crack propagation past gages 10-12: test WP-2.2. 

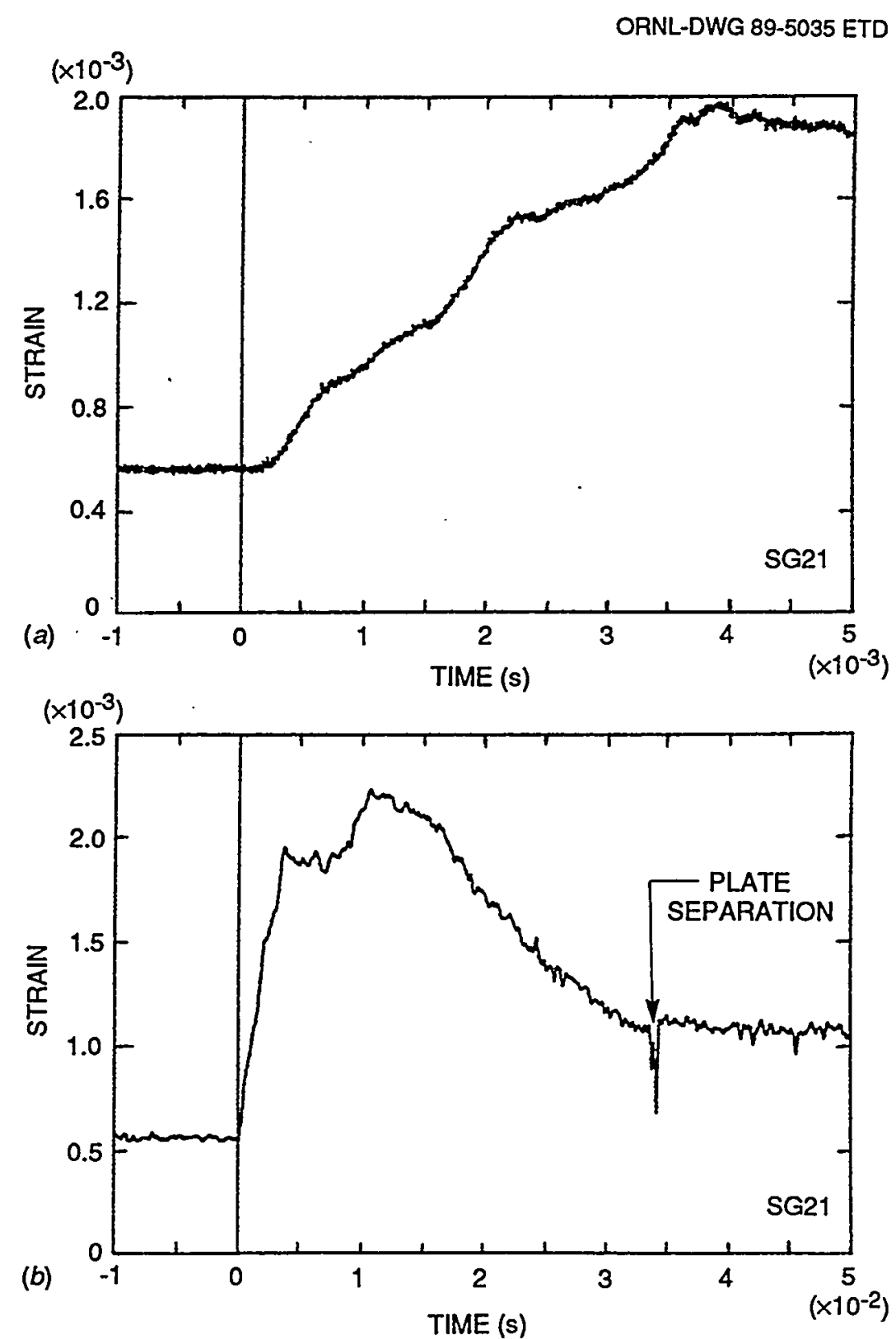

Fig. A.22. Strain history for near-field gage 21 (a) during cleavage run-arrest events and $(b)$ during entire fracture process: test WP-2.2. 

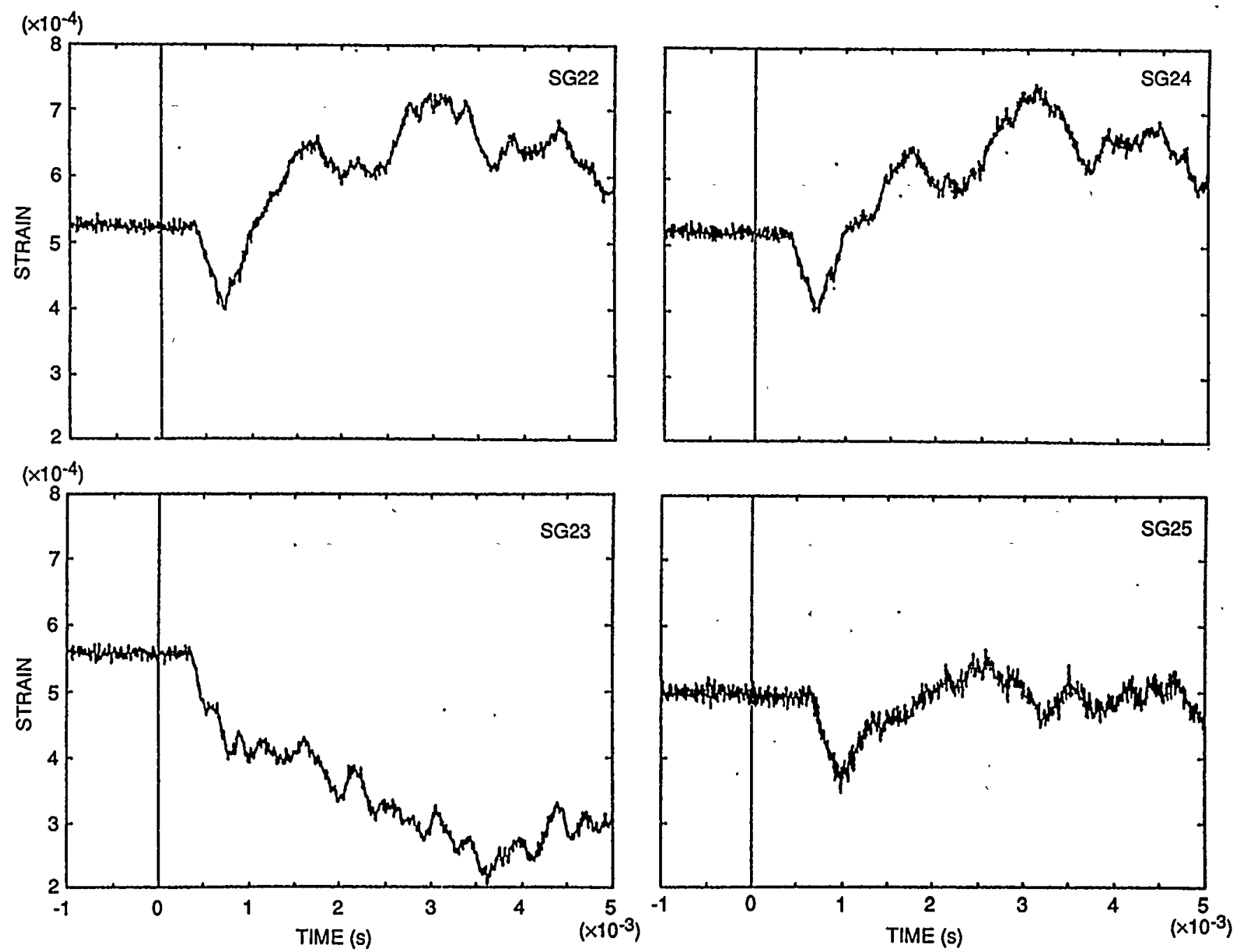

Fig. A.23. Strain histories for far-field gages 22-25 during cleavage run-arrest events: test WP-2.2. 

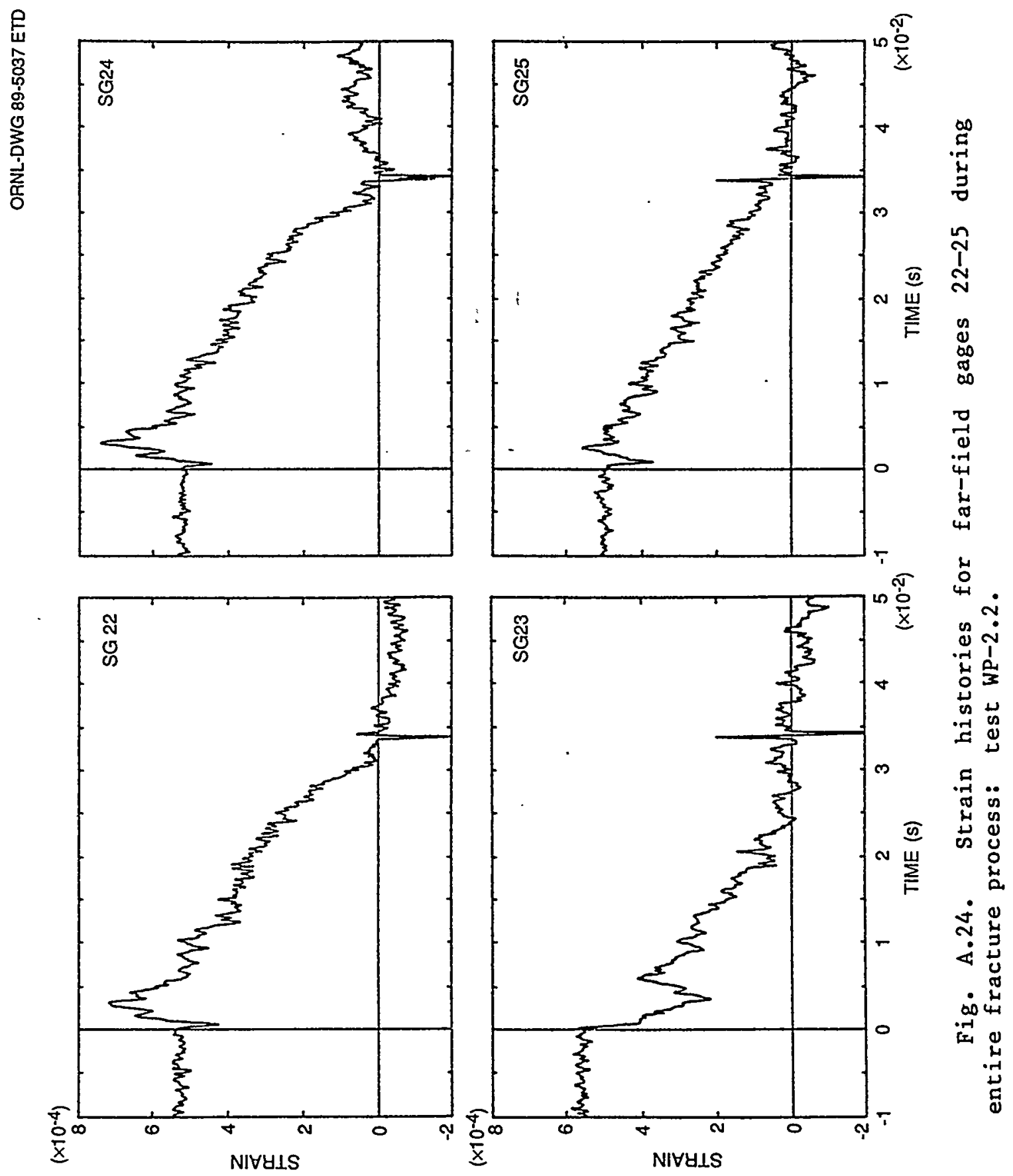

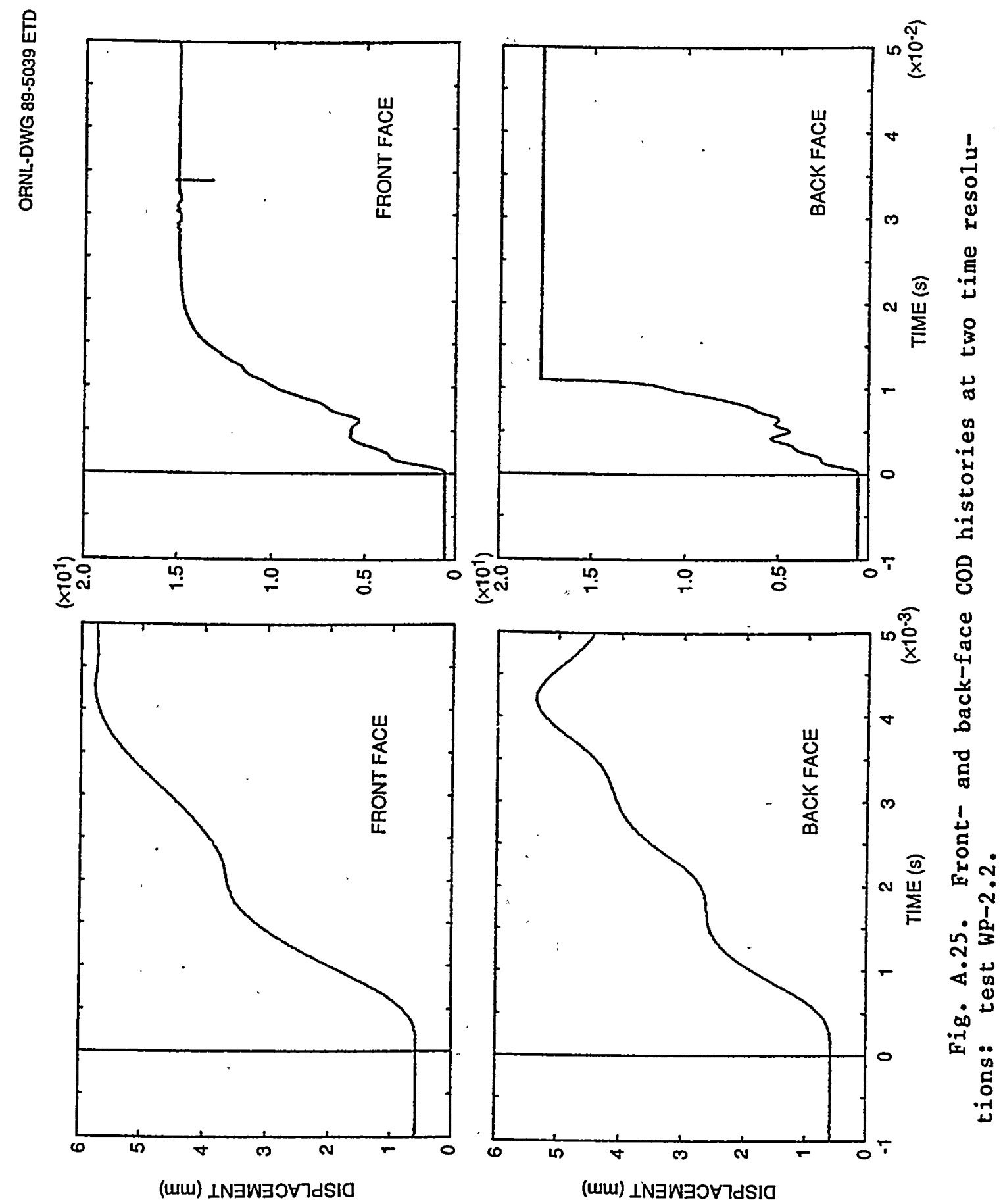

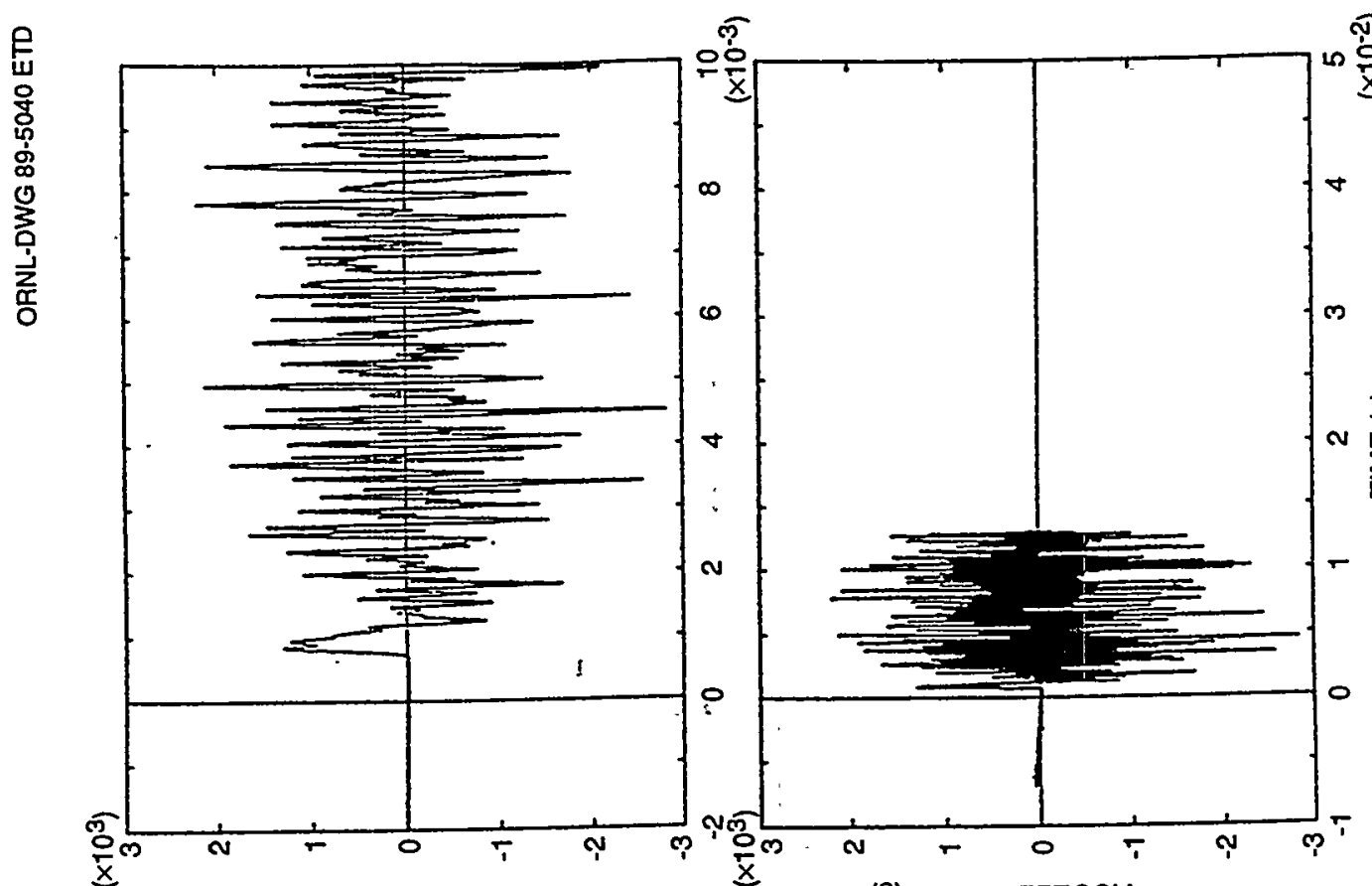

(6) NOIL $8437 \exists O O Y$

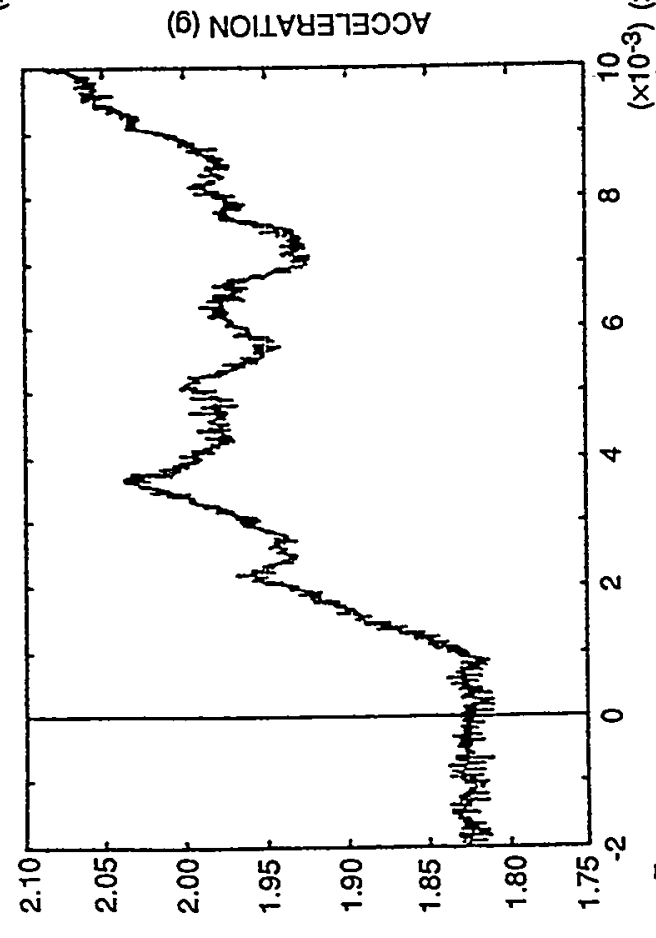

(6) NOIIVY
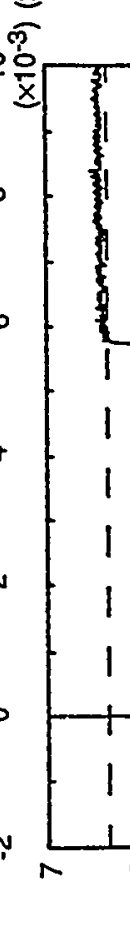

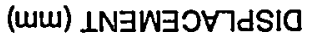

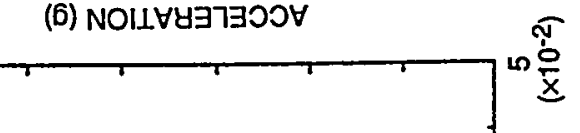

芹岁

ब

E

㟧.

a

on

㕝

0

당요

$\infty$ 苟

它先

ง

울

บับ

$\varangle$

os

$\infty$

的出 


\section{A.3 TEST WP-2.3}

\section{A.3.1 Strain Gages}

Strain-gage records, shown in Figs. A.27 to A.29 for companion crack-line gages [see Fig. $4.8(\mathrm{c})$ for strain-gage locations], indicate that four major cleavage crack run-arrest events occurred during the test. Near- and far-field strain-gage results are presented in Fig. A.30. More detailed information on the cleavage crack run-arrest events followed by fibrous tearing is presented in Figs. A.31 to A.39. Figure A.31 shows the crack passing under strain gages 1 and 2 and arresting $(t=0.222 \mathrm{~ms})$ before reaching strain gages 3 and 4 . Reinitiation of crack propagation at $t=12.489 \mathrm{~ms}$, as detected by strain gages 1 and 2 , and the crack passing strain gage $3(t=12.574)$ with a subsequent arrest ( $t=12.749 \mathrm{~ms}$ ) before reaching, strain gage 4 are shown in Fig. A.32. Strain histories for gages 3 and 4 in the figure also show reinitiation of crack propagation at $t=37.344 \mathrm{~ms}$. Propagation of the crack past strain gage 5 , a subsequent arrest ( $t=37.524 \mathrm{~ms}$ ) before reaching strain gage 6 , and reinitiation ( $=43.324 \mathrm{~ms})$ with propagation past strain gages 6-8 are shown in Fig. A.33. An expanded time scale in Fig. A.34 for strain gages 5-8 "shows the crack (now converted to fibrous tearing) passing strain gages 6-8. Propagation of the crack (fibrous tearing) past strain gages $9-12$ is presented in Fig. A.35. Strain histories presented in Fig. A.36 for back-face gages 13-15 show the crack passing gages $13(t=0.040 \mathrm{~ms})$ and $14(t=0.114 \mathrm{~ms})$ and then arresting ( $t=0.212 \mathrm{~ms}$ ) before reaching gage 15 . Multiple crack runarrest events, as detected by strain gages 13-15, are presented in Fig. A.37. In particular, reinitiations at $t=3.160,13.004$, and $38.464 \mathrm{~ms}$ are evident. Although detailed interpretation of the strain output for gage 17 is not possible because of signal noise, results for strain gage 18 in Fig. A.38 indicate the early crack run-arrest events followed much later by the crack passing ( $t=688 \mathrm{~ms}$ ) the gage. Propagation of the crack (fibrous tearing) past strain gages 19-22 is shown in Fig. A.39.

\section{A.3.2 Additional Instrumentation}

Longitudinal accelerations recorded by "damped" accelerometers mounted on the specimen's centerline at $3.585 \mathrm{~m}$ above (top) and $3.589 \mathrm{~m}$ below (bottom) the crack plane are presented in Fig. A.40. Results obtained from the displacement gage mounted at the same location as the bottom accelerometer are presented in Fig. A.41. Front- and back-faceCOD results obtained from gages located at $a / w=0.150$ are presented in Fig. A.42. AE results obtained from a transducer mounted on the lower pull tab are presented for four levels of time resolution in Fig. A.43. 
ORNL-DWG 87-4847A ETD
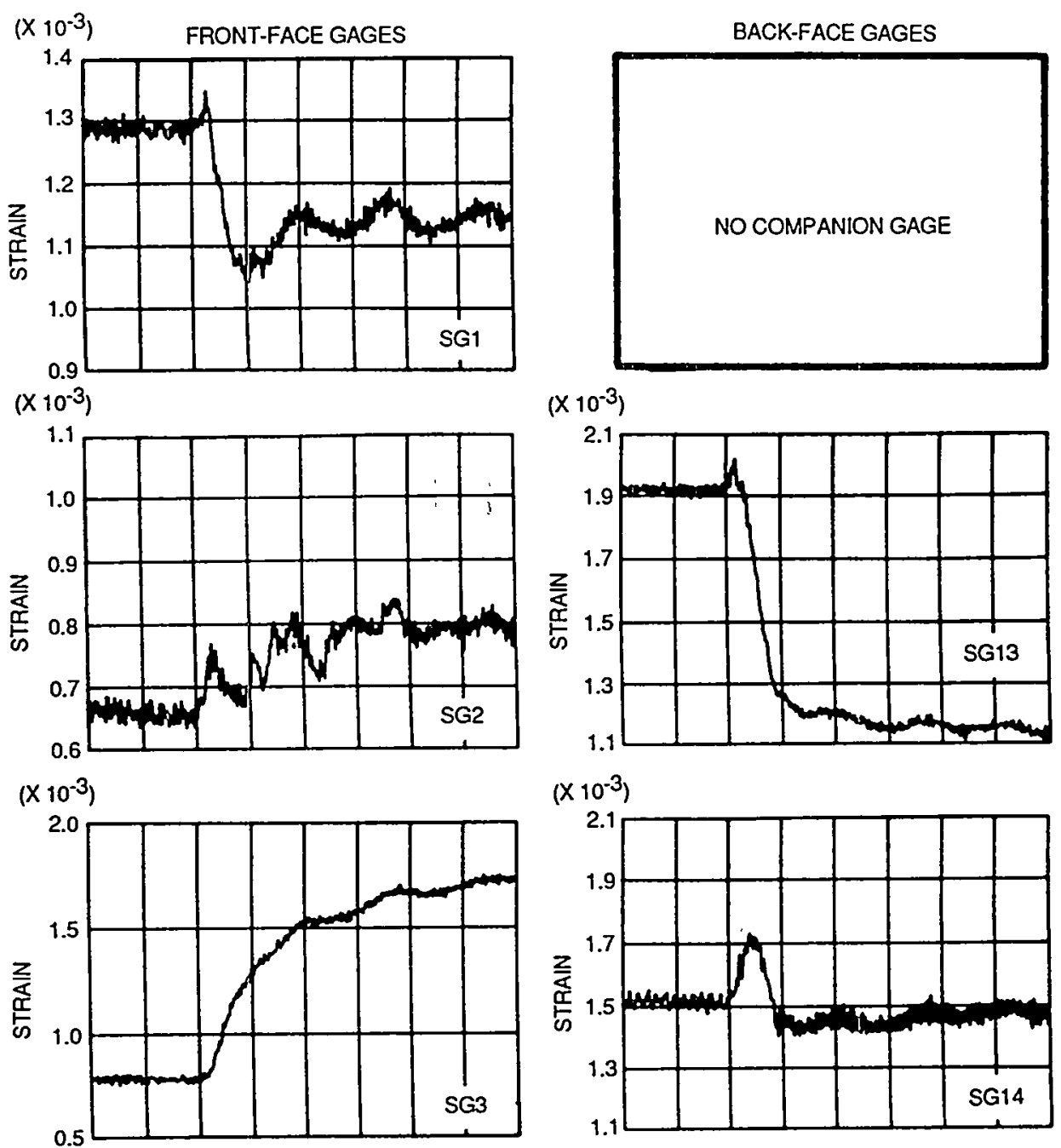

$\left(\times 10^{-3}\right)$

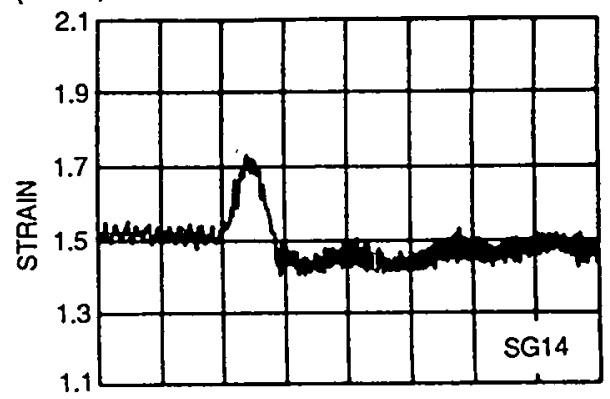

$\left(\times 10^{-3}\right)$

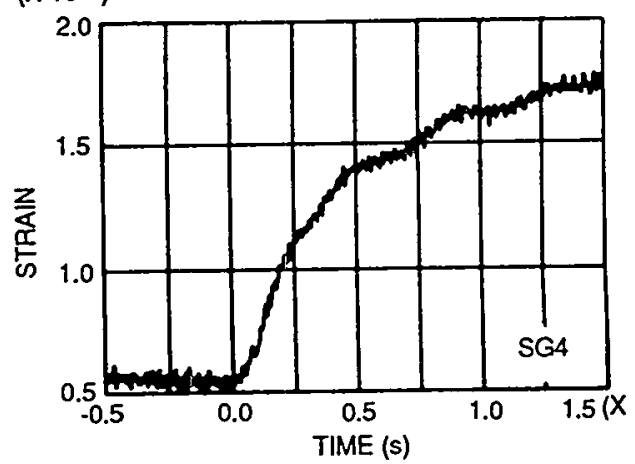

$\left(\times 10^{-3}\right)$

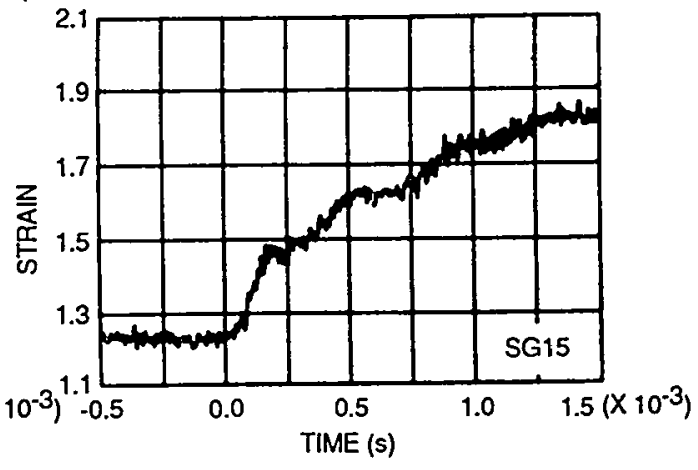

Fig. A.27. Strain histories for companion crack-line gages: test wP-2.3 (gages 1-4 and 13-15). 

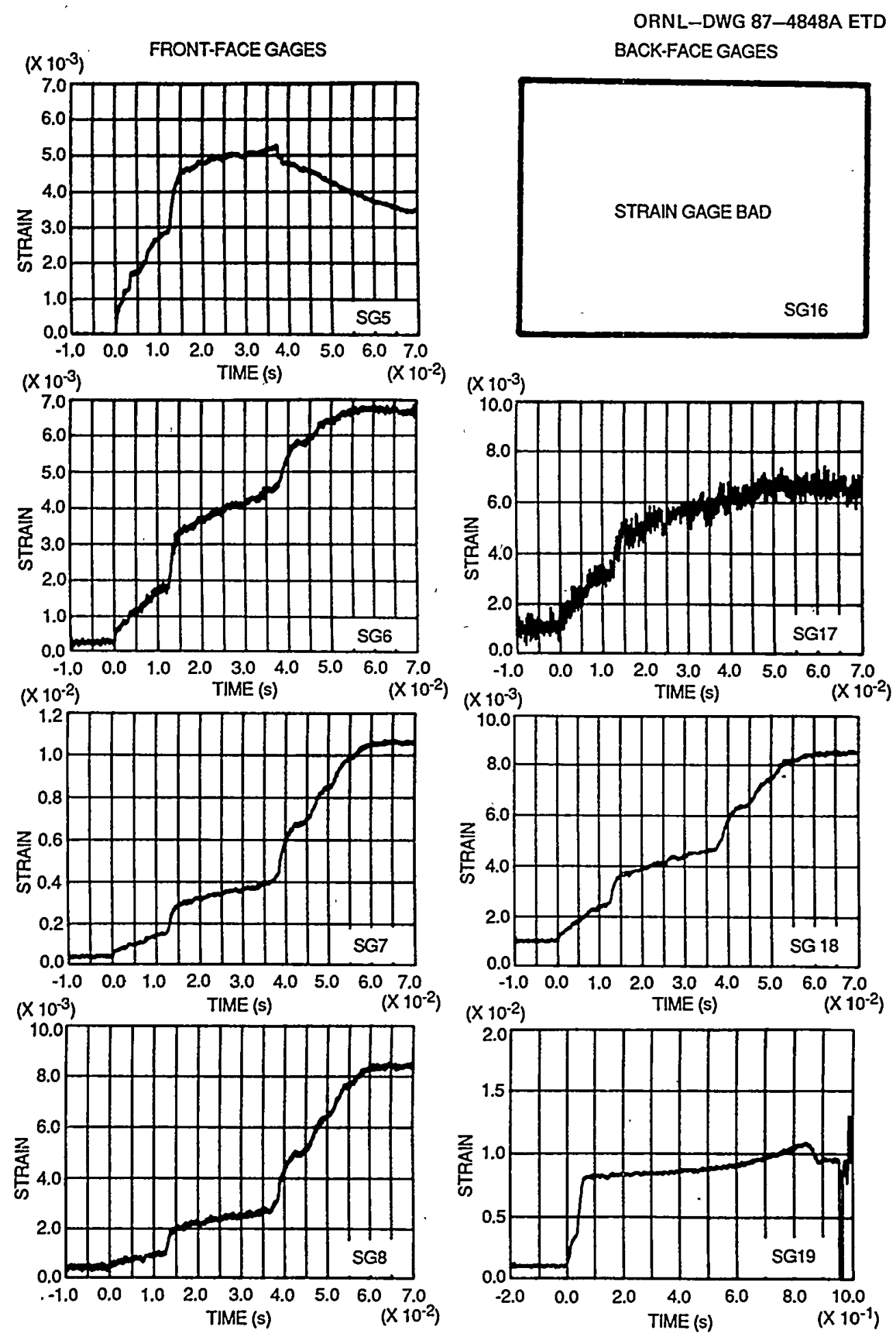

Fig. A.28. Strain histories for companion crack-line gages: test WP -2.3 (gages 5-8 and 16-19). 

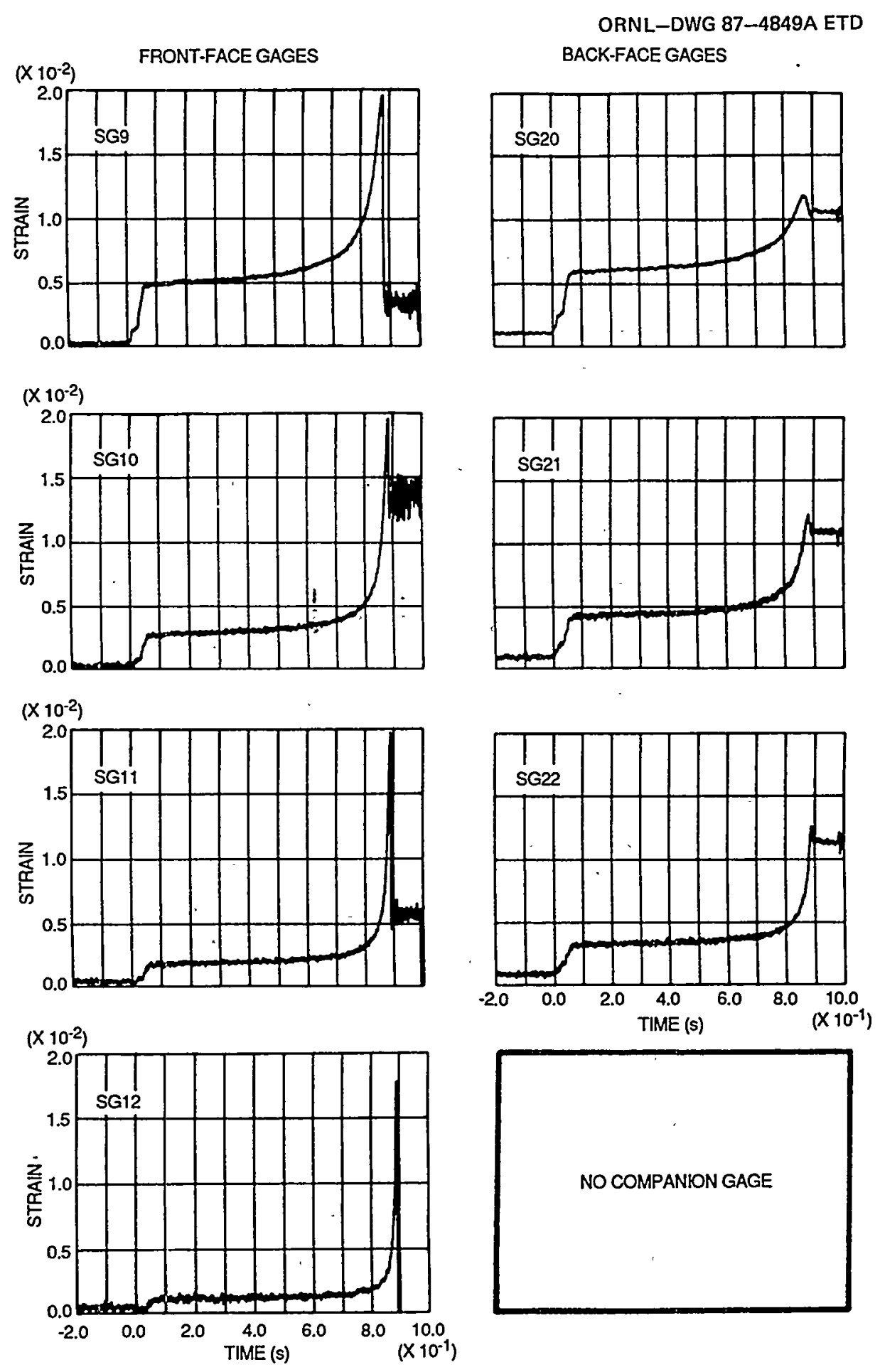

Fig. A.29. Strain histories for companion crack-line gages: test WP-2.3 (gages $9-12$ and 20-22). 

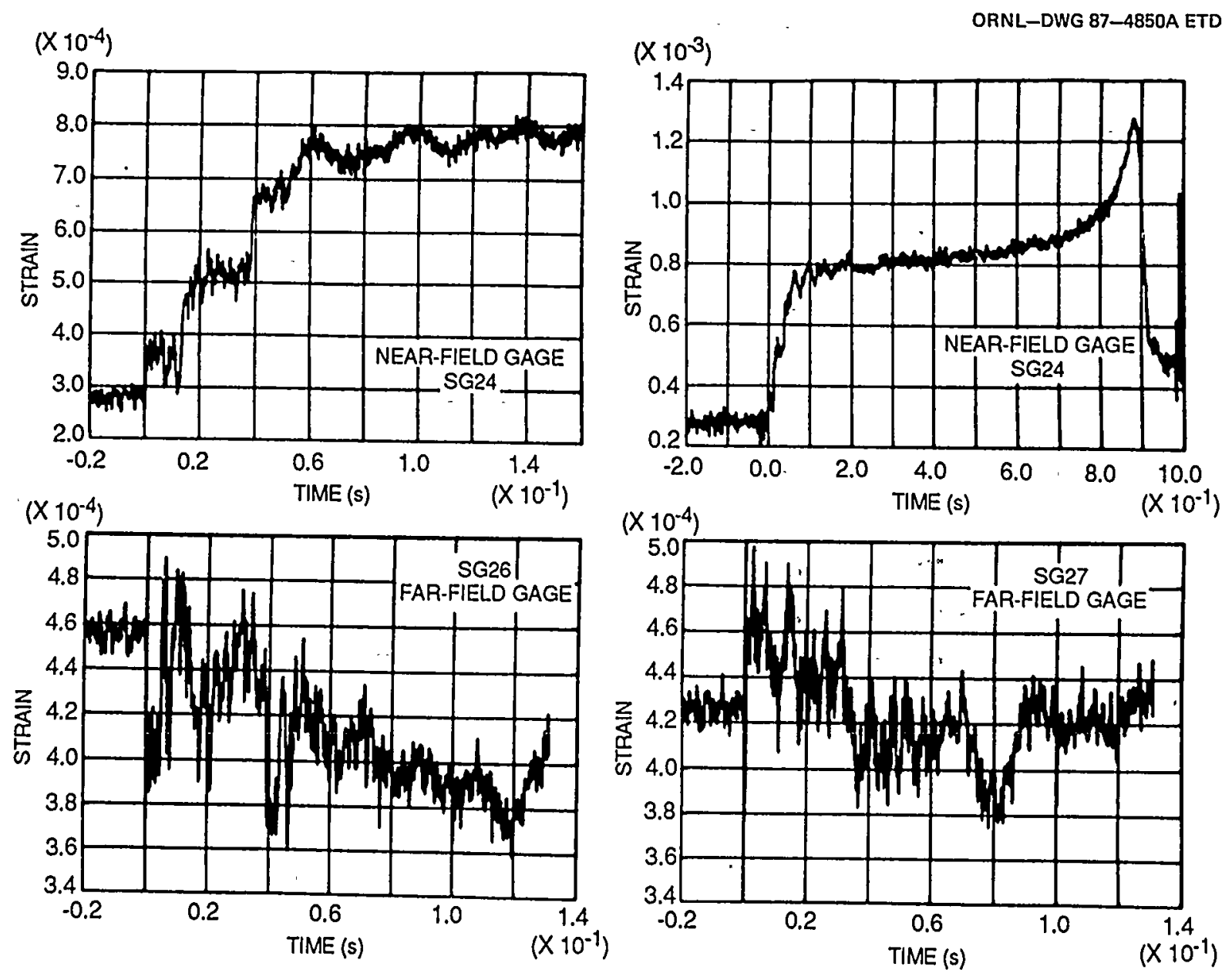

Fig. A.30. Crack run-arrest events as detected by near- and farfield strain gages: test WP-2.3 (gages 24,26 , and 27). 

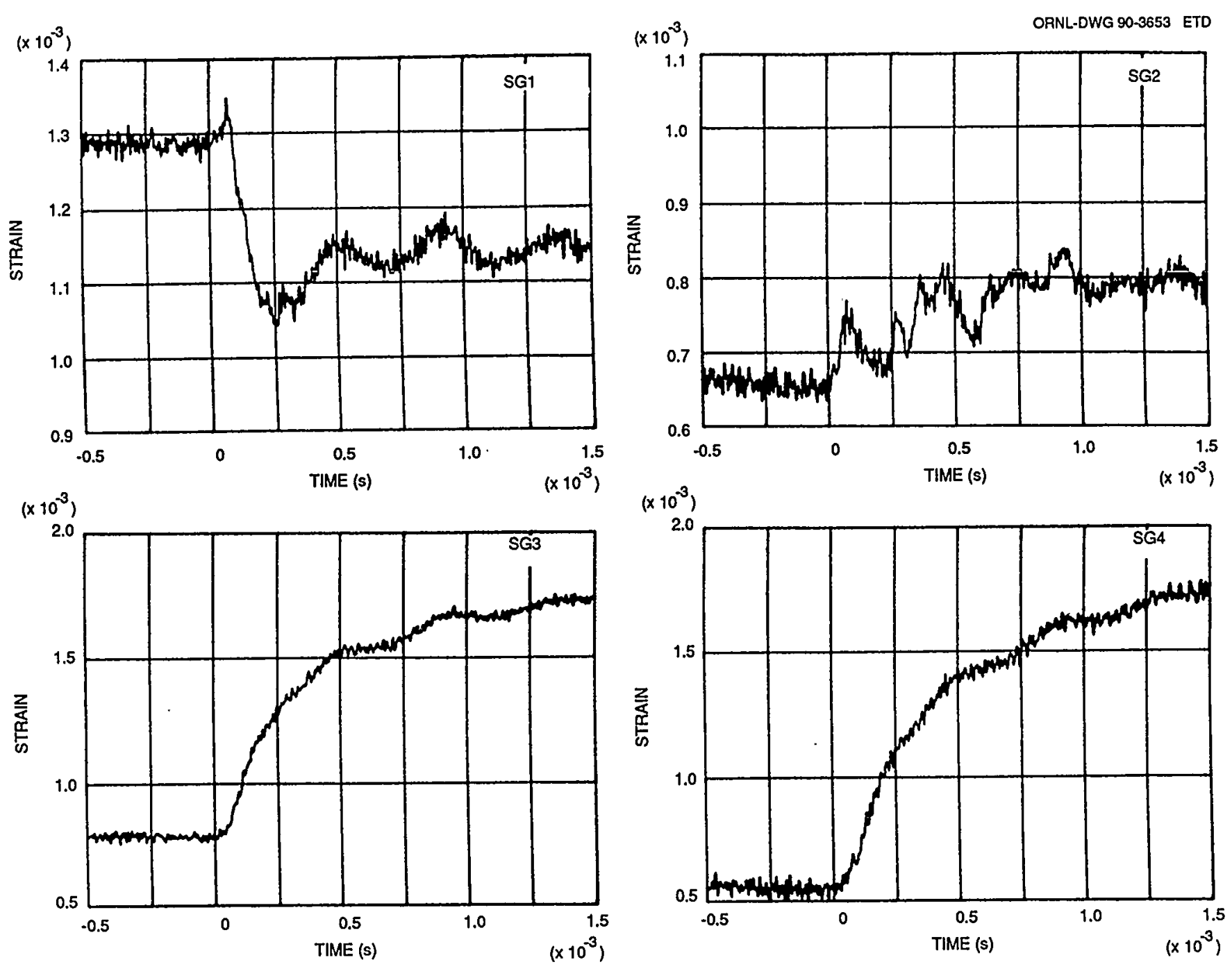

Fig. A.31. Strain histories for gages $1-4$ showing crack passing under gages 1 and 2 and arresting before reaching gages 3 and 4: test WP-2.3. 

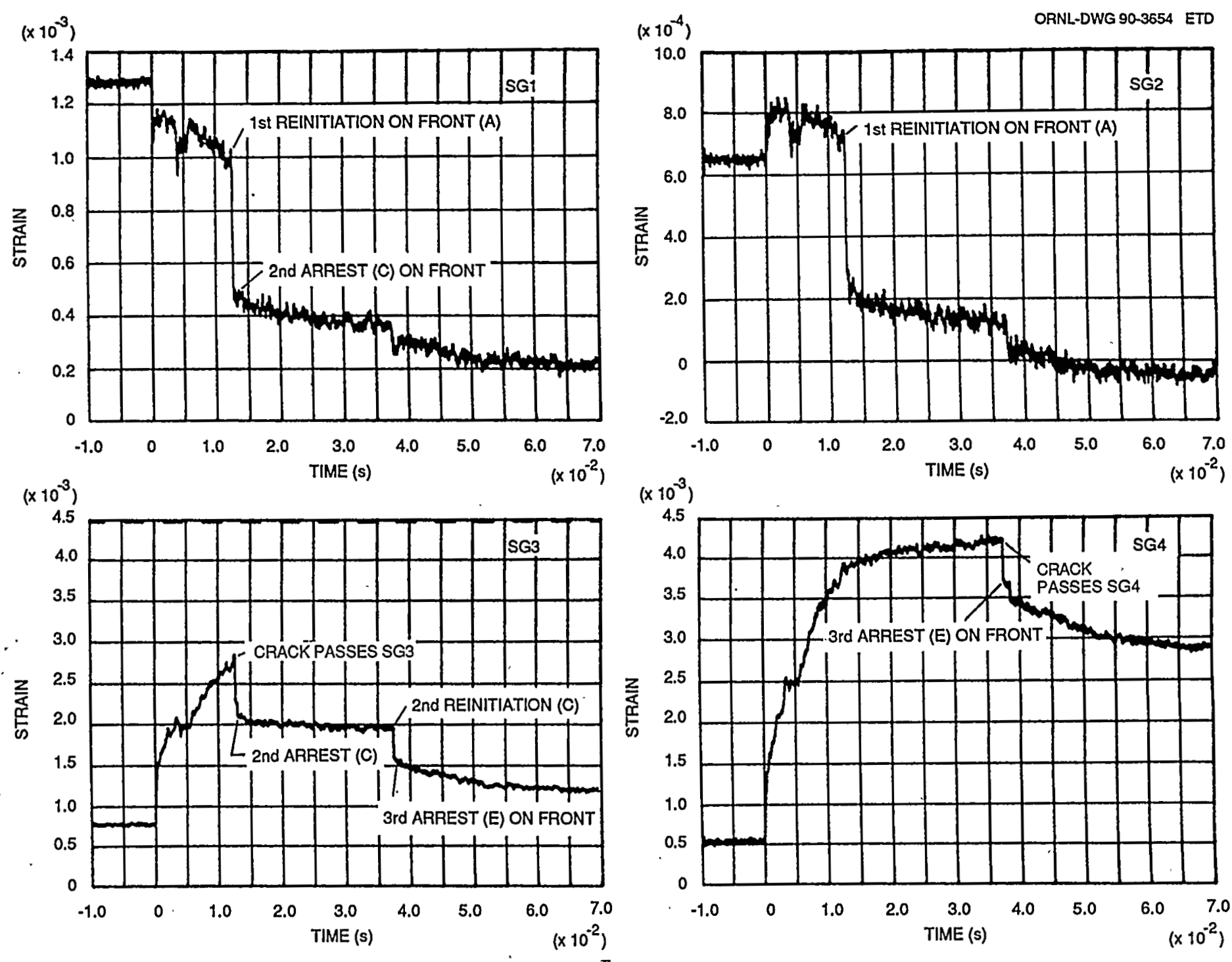

Fig. A.32. Strain histories for gages 1-4 showing reinitiation of crack propagation as detected by gages 1 and 2 and crack passing gage 3 with a subsequent arrest before reaching gage 4: test WP-2.3. 

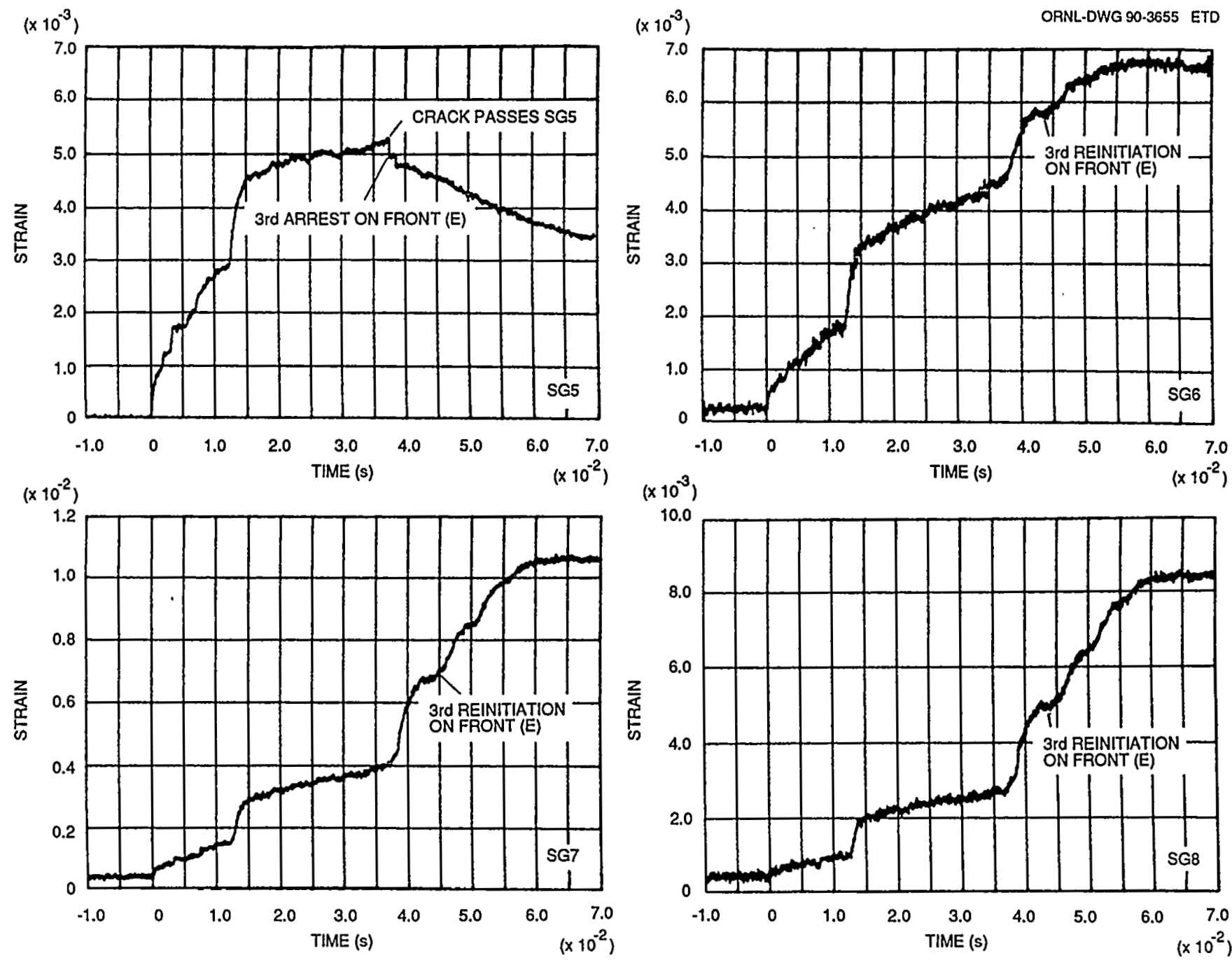

Fig. A.33. Strain histories for gages 5-8 showing propagation of the crack past gage 5 , a subsequent arrest before reaching gage 6 , and reinitiation with the crack propagating past gages 6-8: test WP-2.3. 

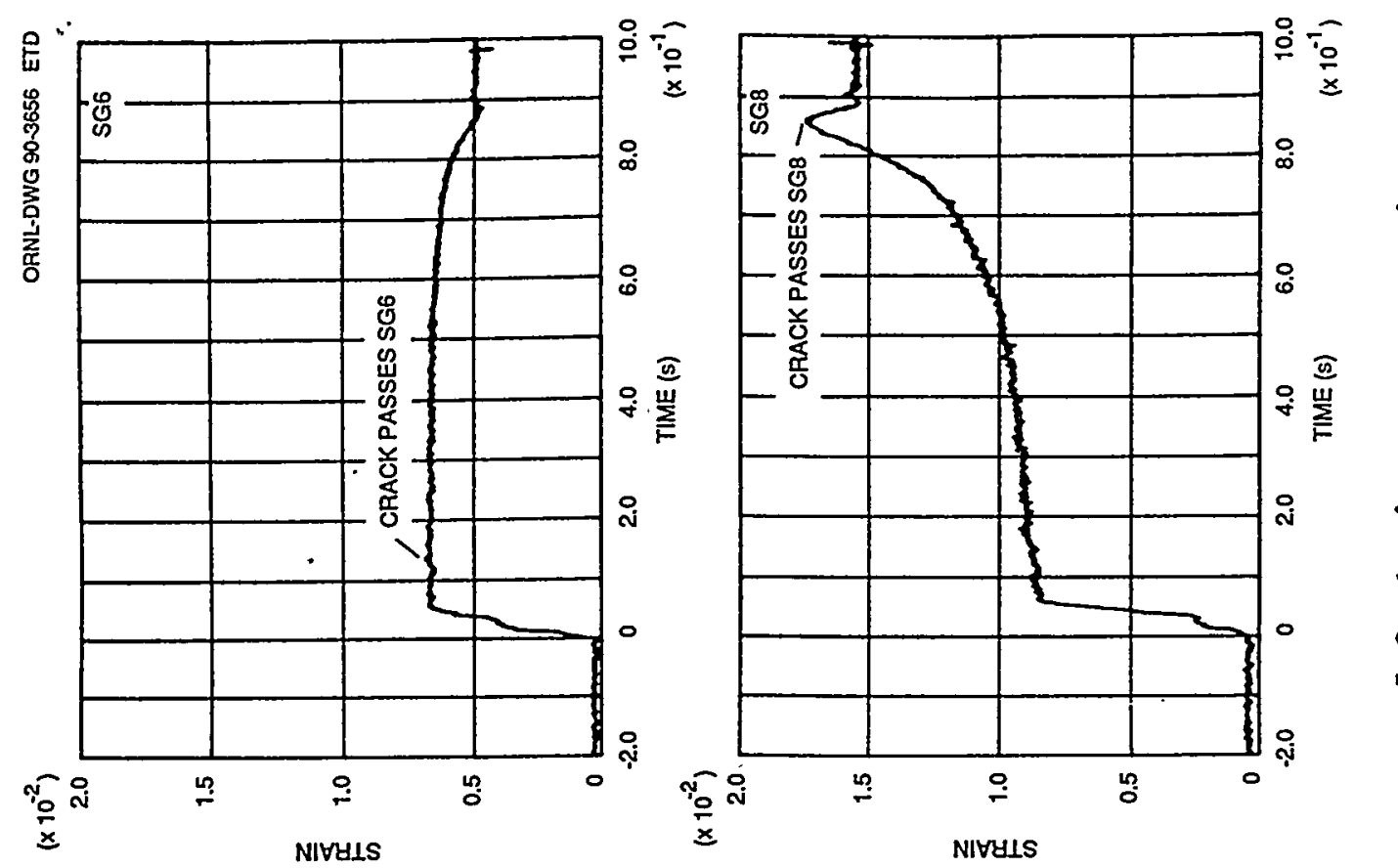

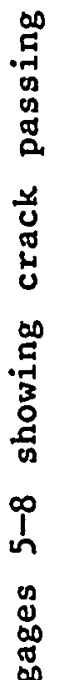
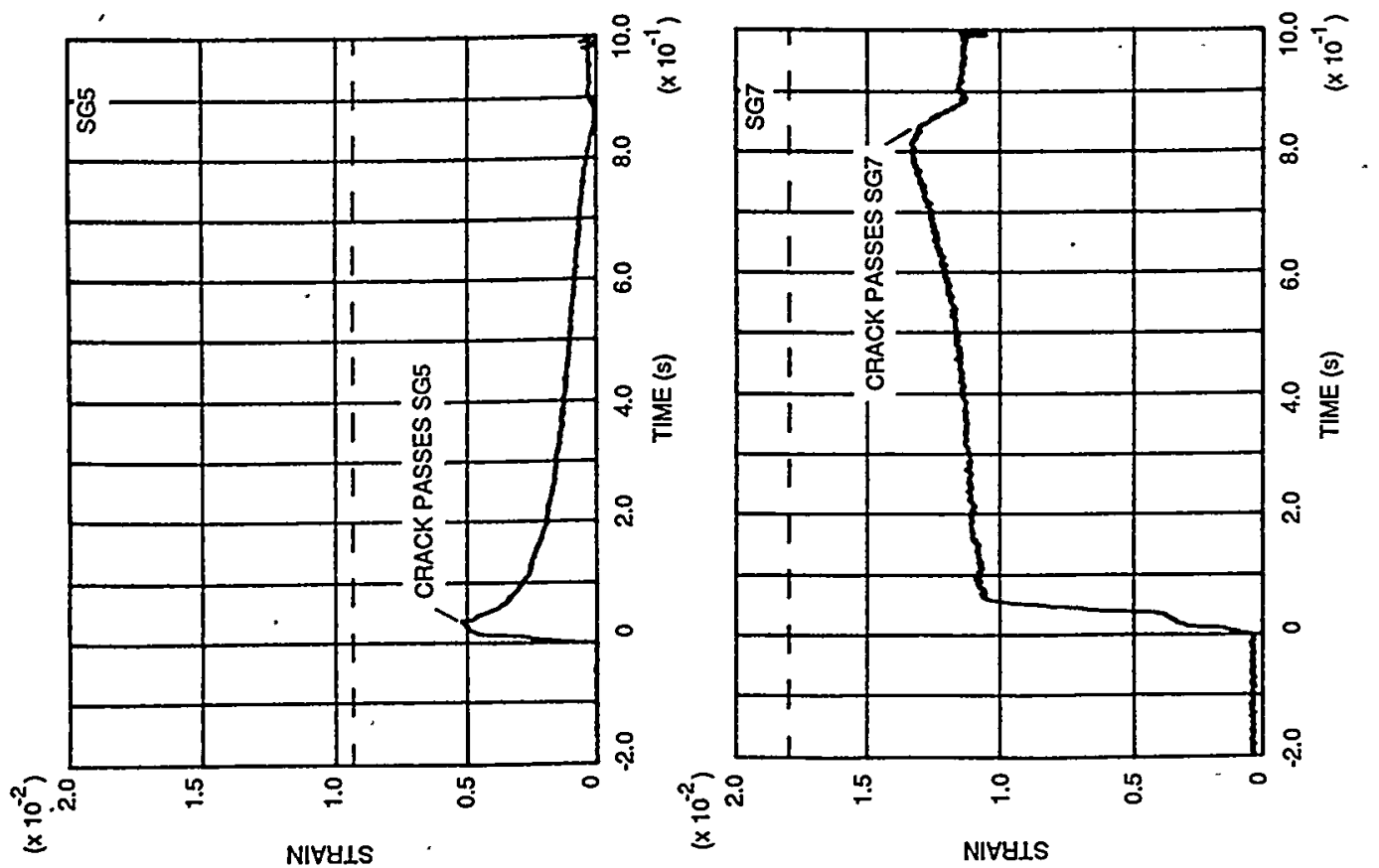

感

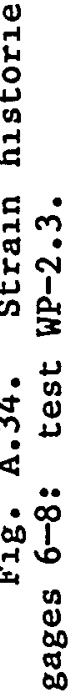

NIVUIS

$x$
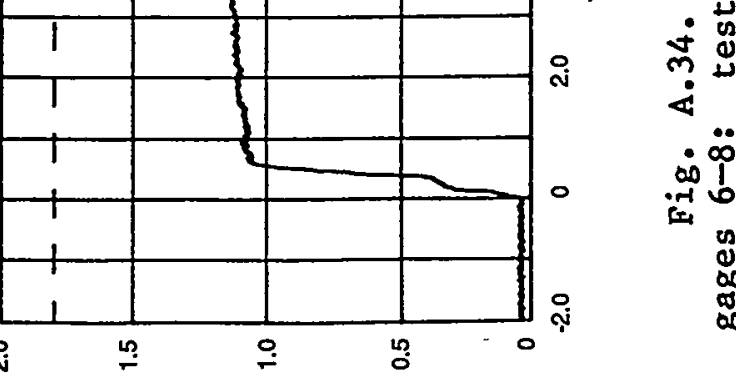

NItULIS 

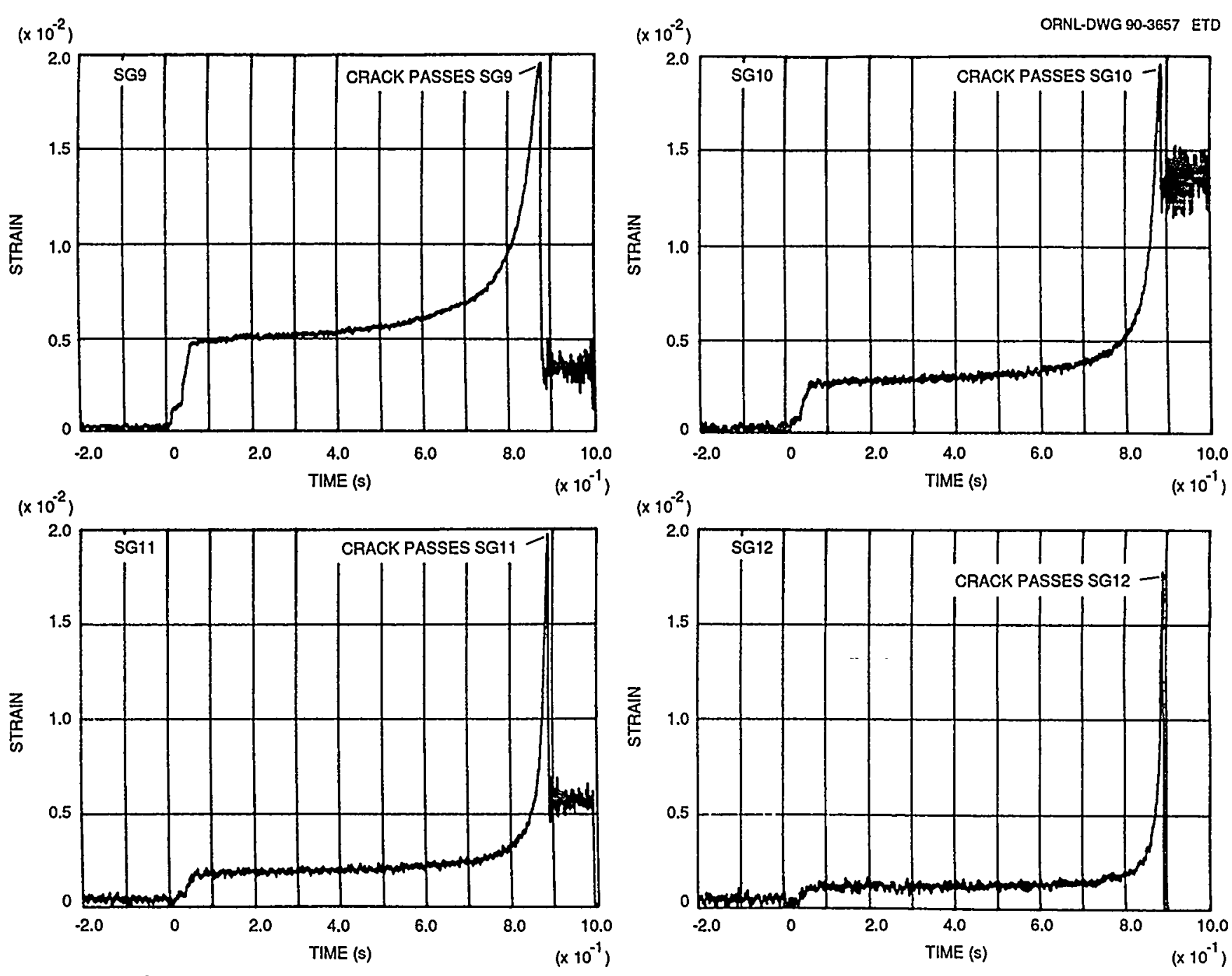

Fig. A.35. Strain histories for gages 9-12 showing crack passing these gages: test WP-2.3. 

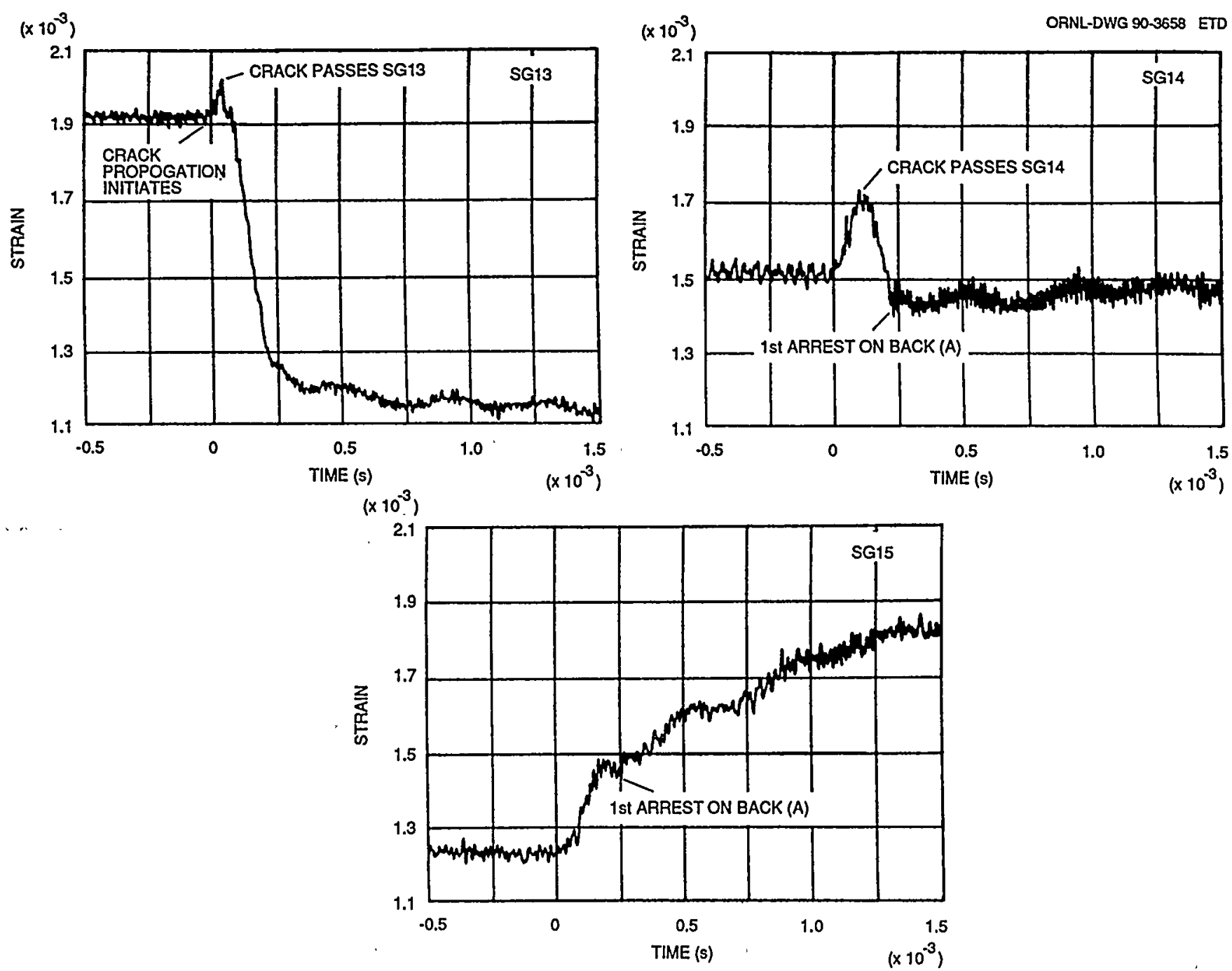

Fig. A.36. Strain histories for back-face gages 13-15 showing crack passing gages 13 and 14 and then arresting before reaching gage 15: test WP-2.3. 
$\left(\times 10^{-3}\right)$

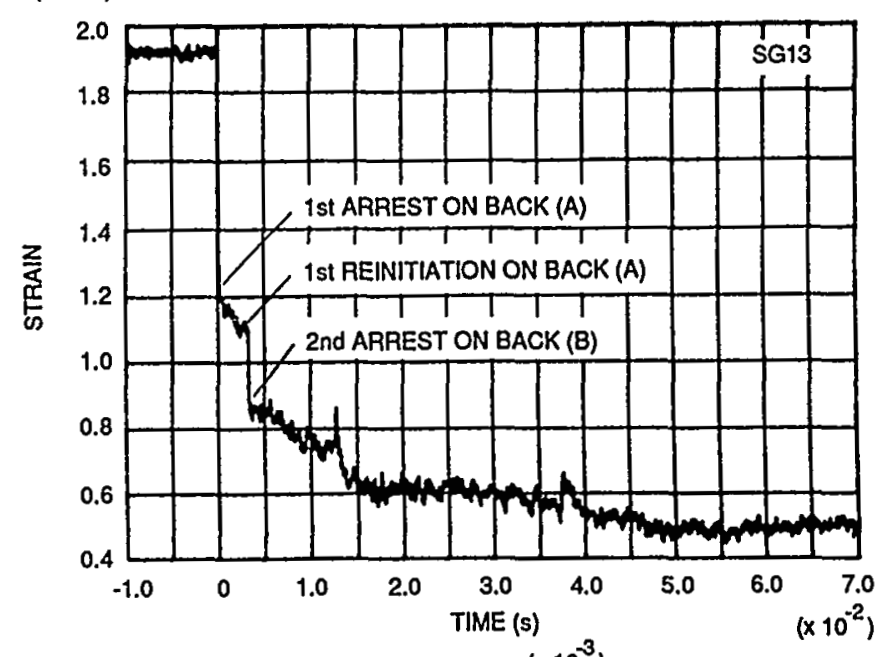

$\left(\times 10^{-3}\right)$

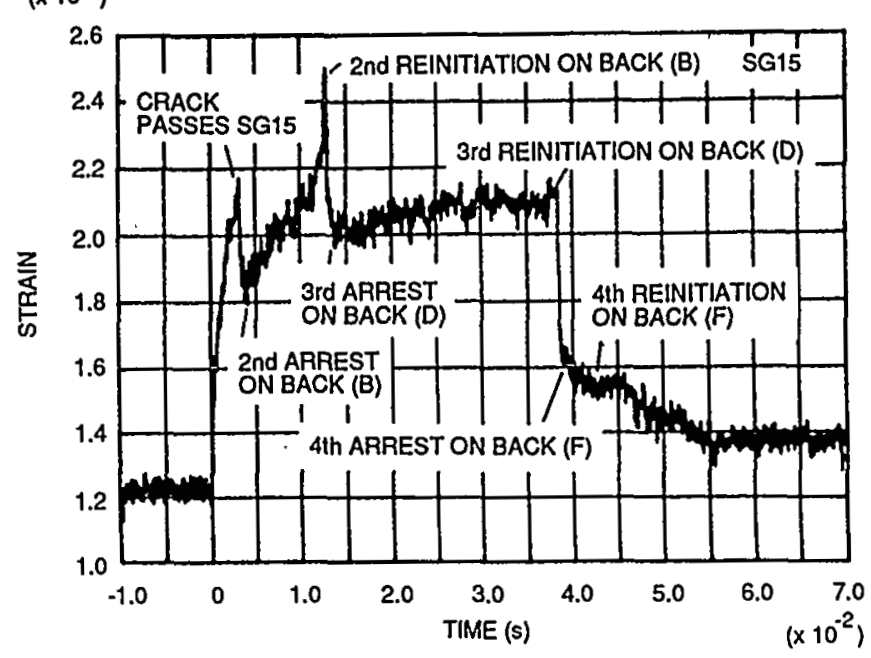

ORNL-DWG 90-3659 ETD

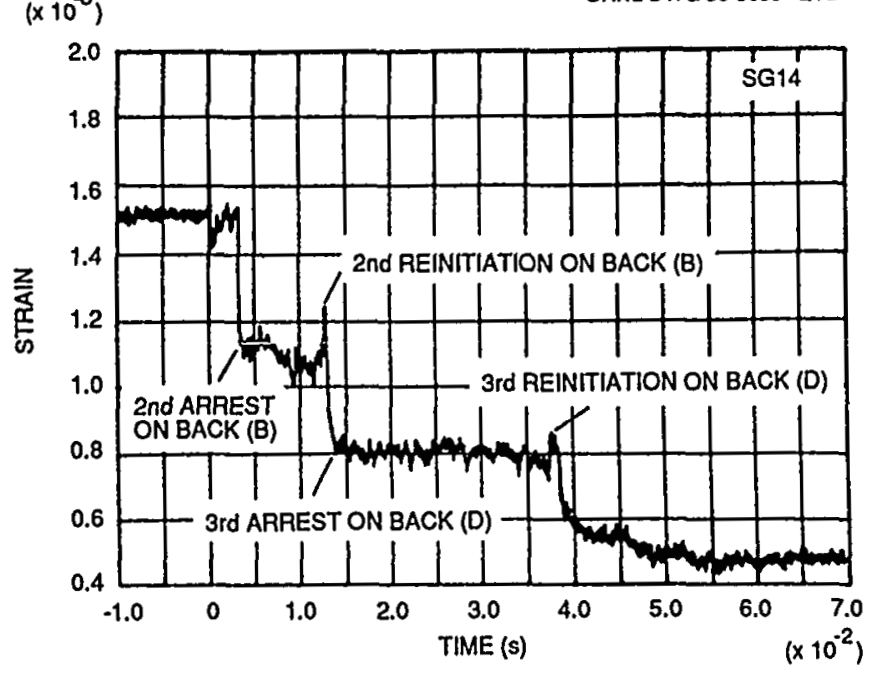

Fig. A.37. Strain histories for back-face gages 13-15 showing multiple crack run-arrest events: test WP-2.3. 

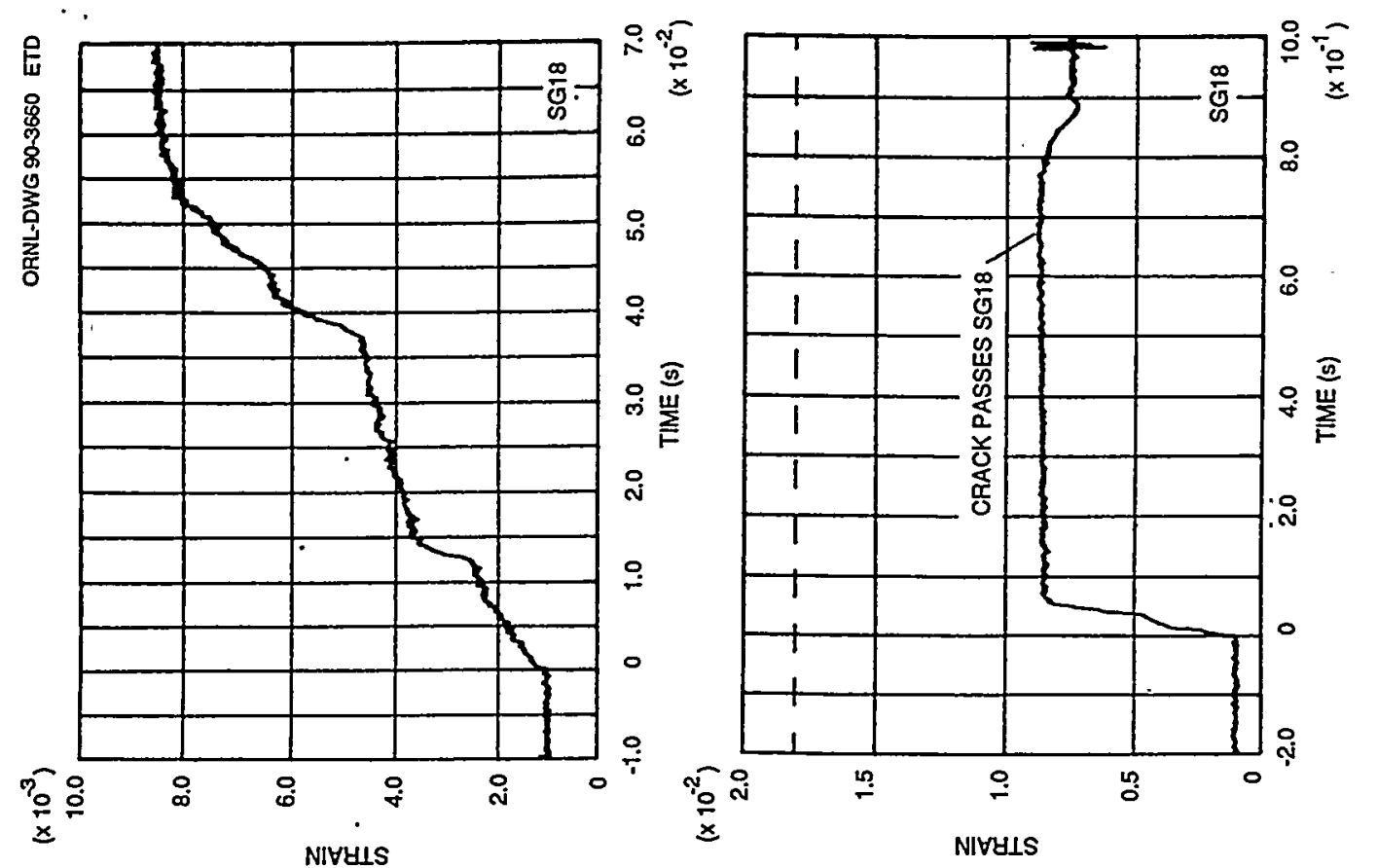

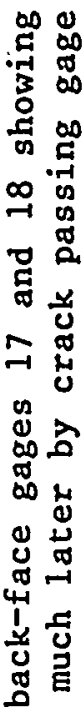
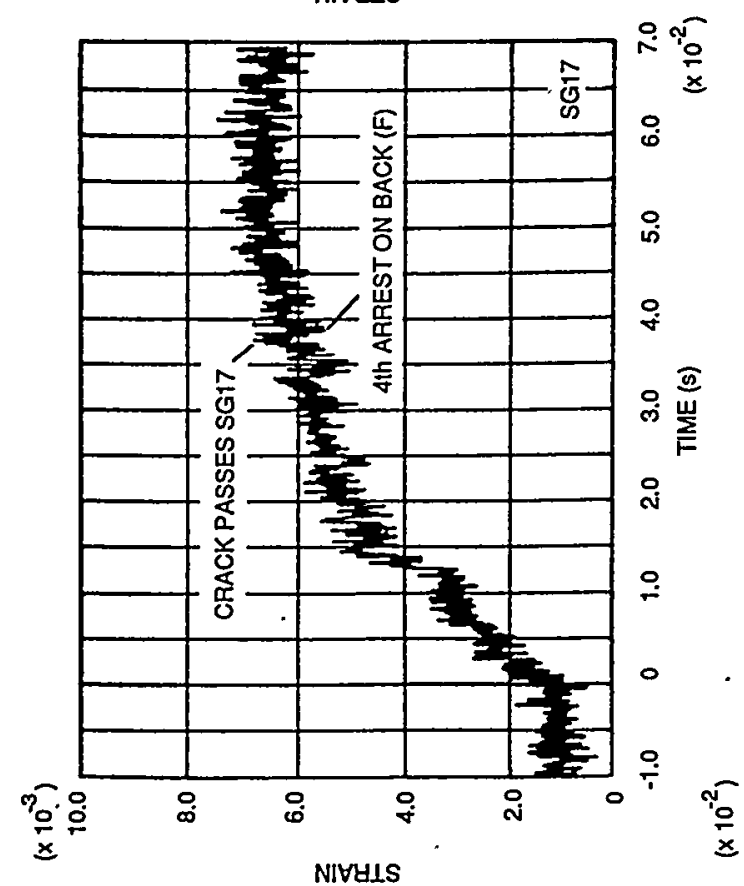

NIVUIS

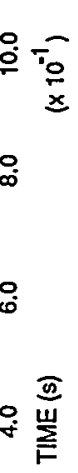

H

क 둥

雚出

.7

5

告

क

$1 m$

$\infty \dot{j}$

ก 41

को मू

in

苫

NIVUIS

뭉

5 

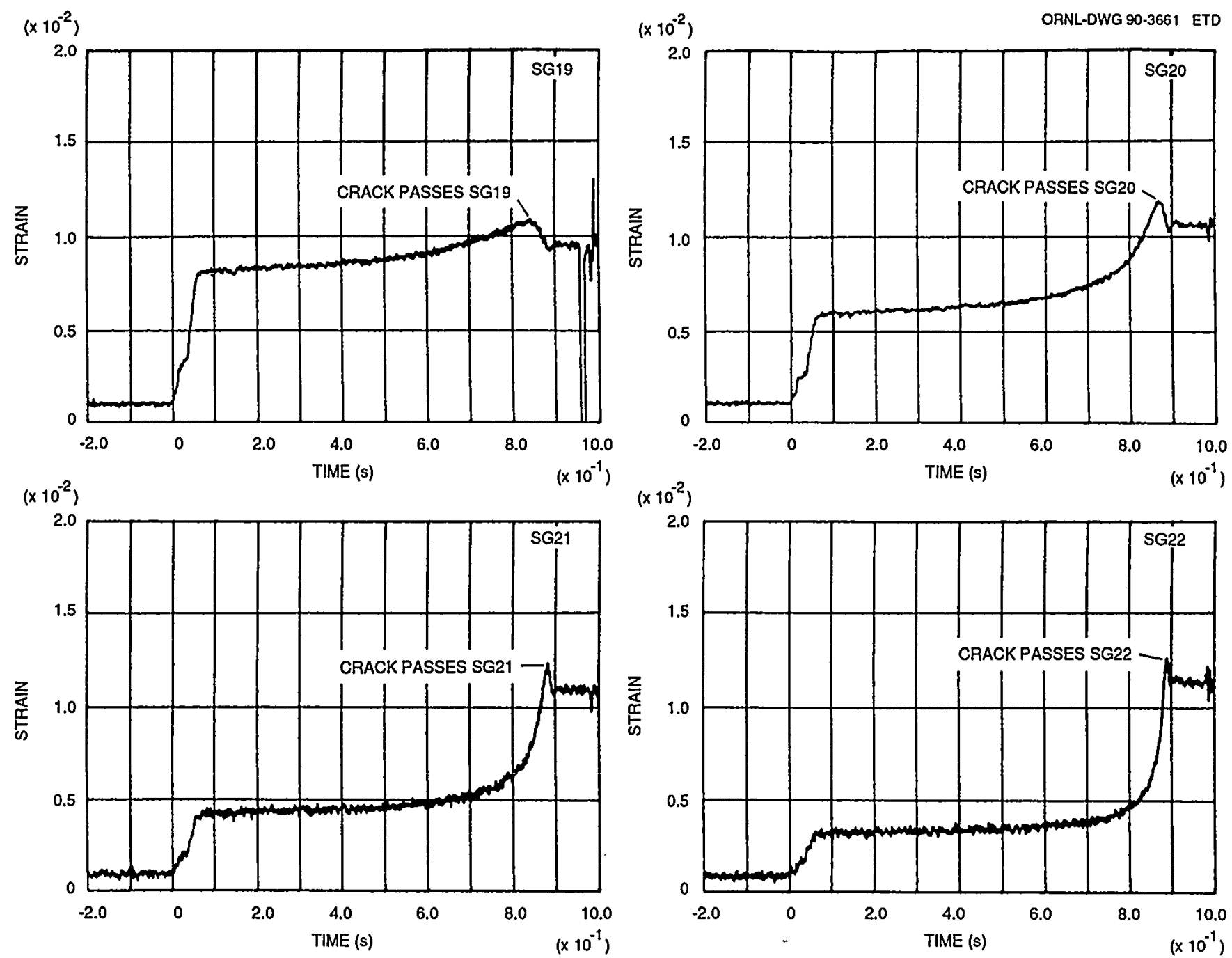

Fig: A.39. Strain histories for back-face gages 19-22 showing propagation of crack past these gages: test WP-2.3. 

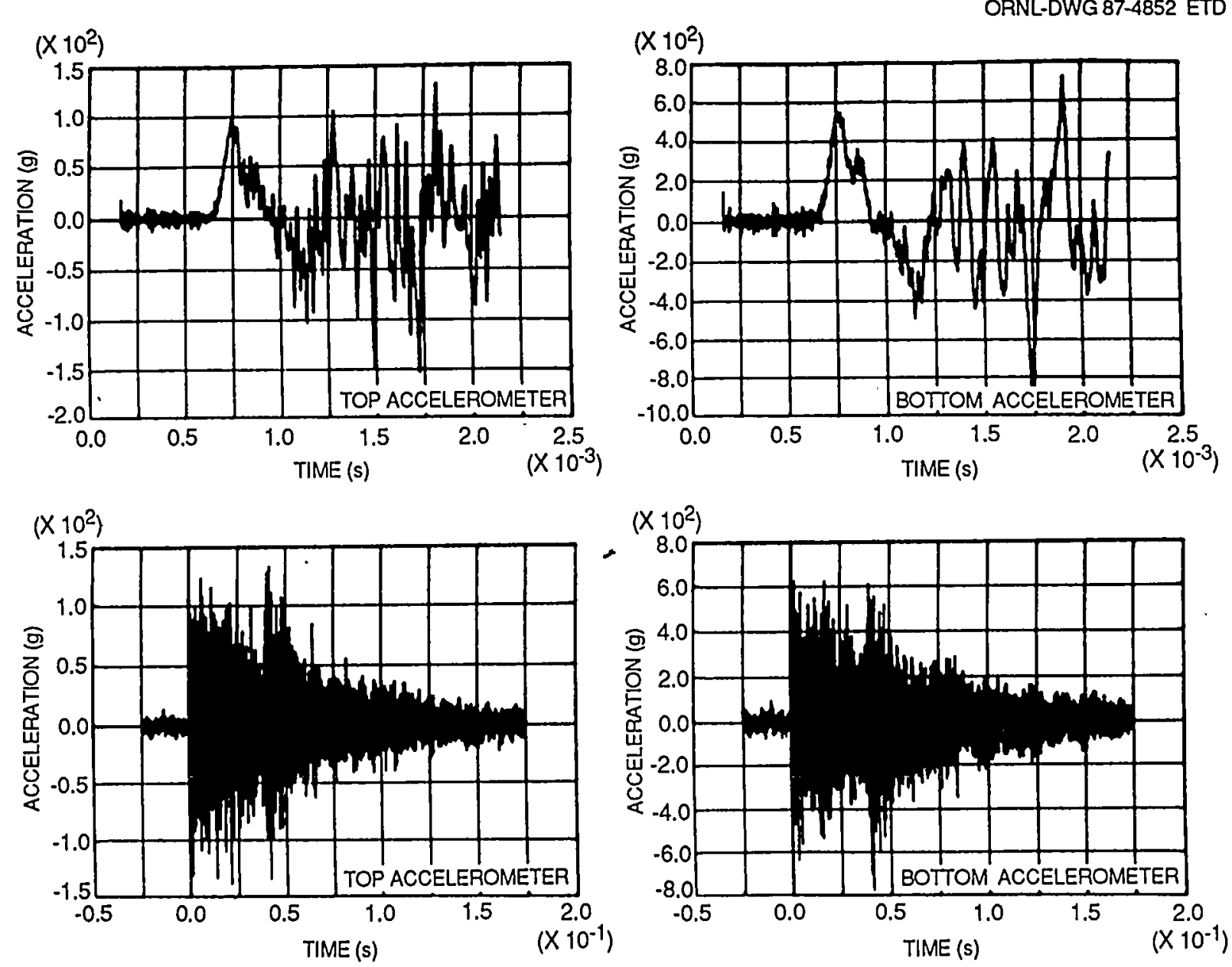

Fig. A.40. Longitudinal acceleration results at two levels of time resolution measured by top and bottom "damped" accelerometers mounted $3.585 \mathrm{~m}$ above and $3.589 \mathrm{~m}$ below the crack plane, respectively: test WP-2.3. 


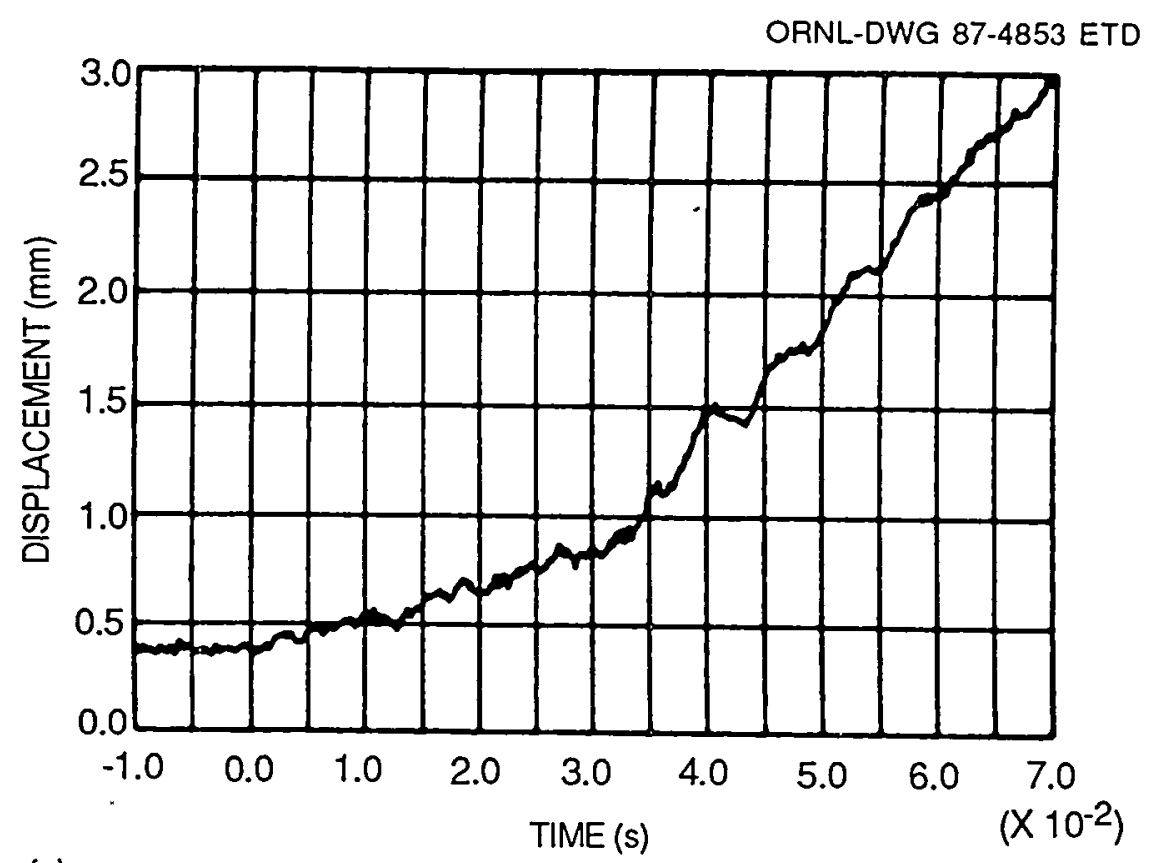

(a)

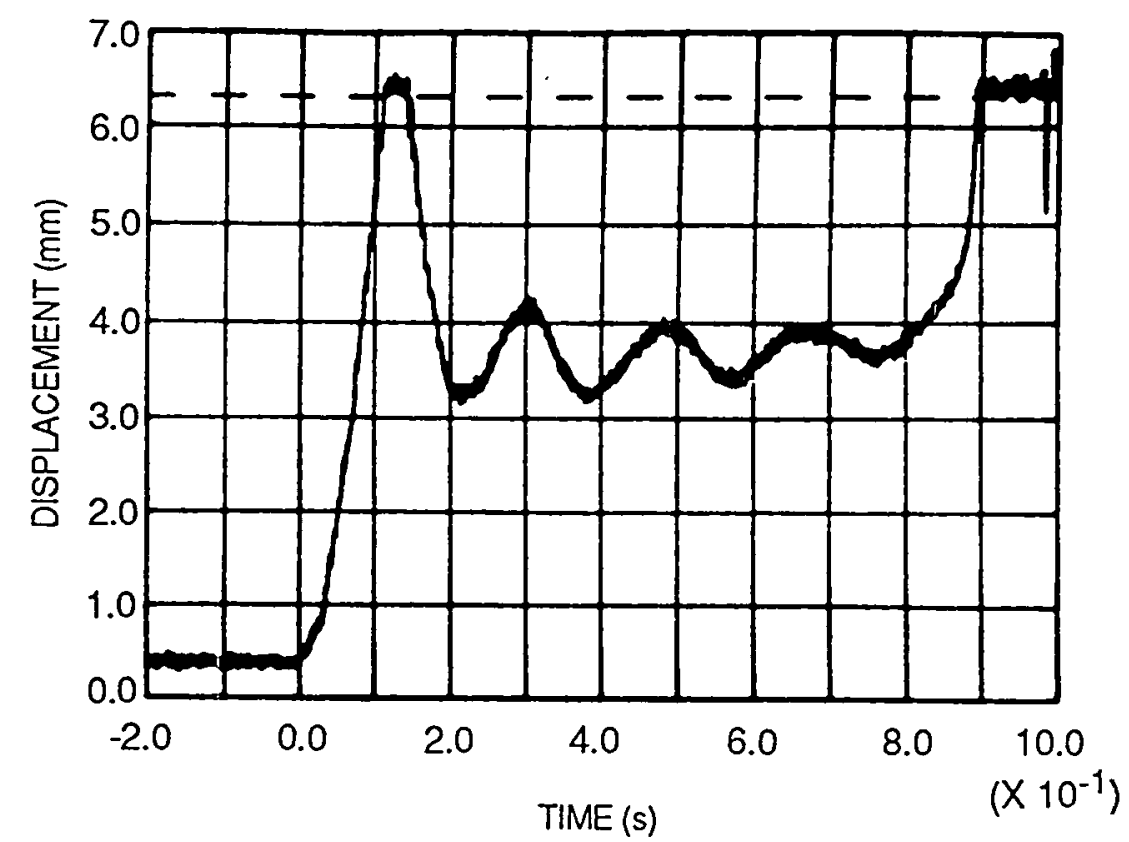

(b)

Fig. A.41. Bottom displacement gage results (a) during initial crack run-arrest events and $(b)$ during entire test: test WP-2.3. 


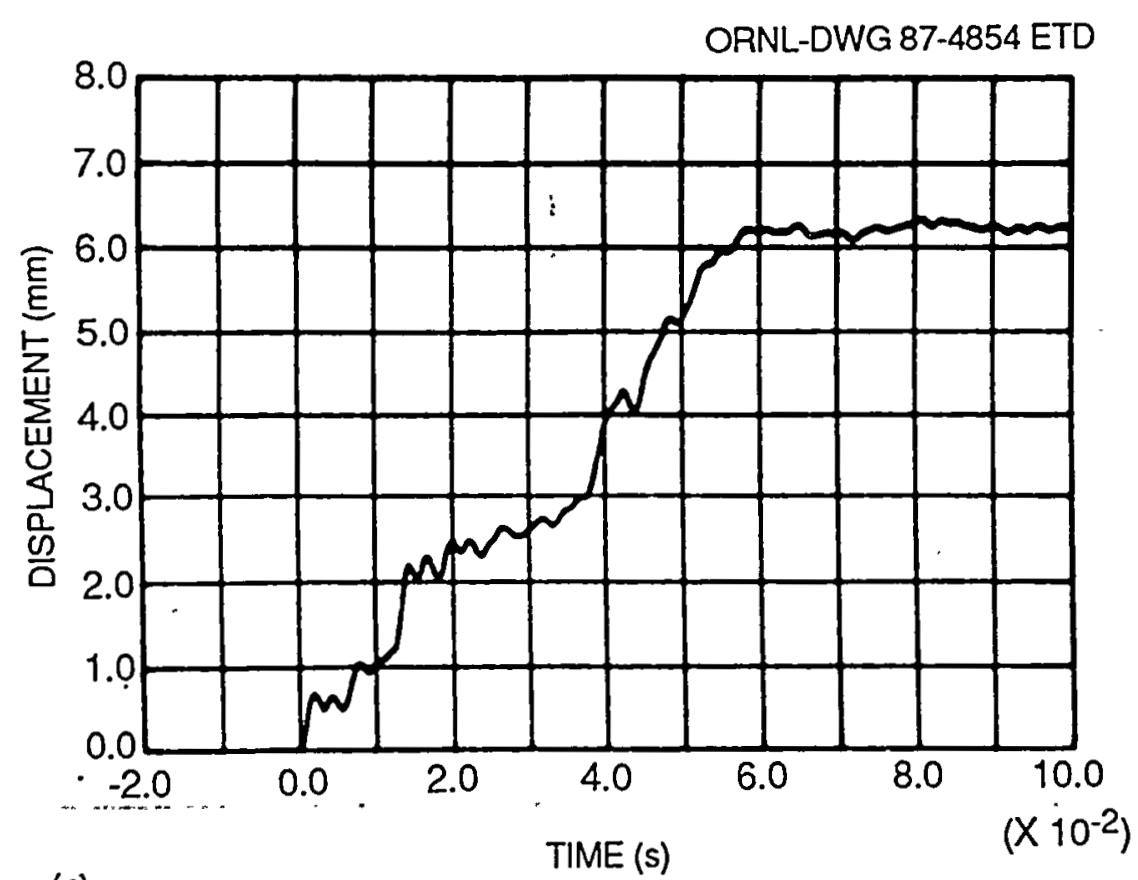

(a)

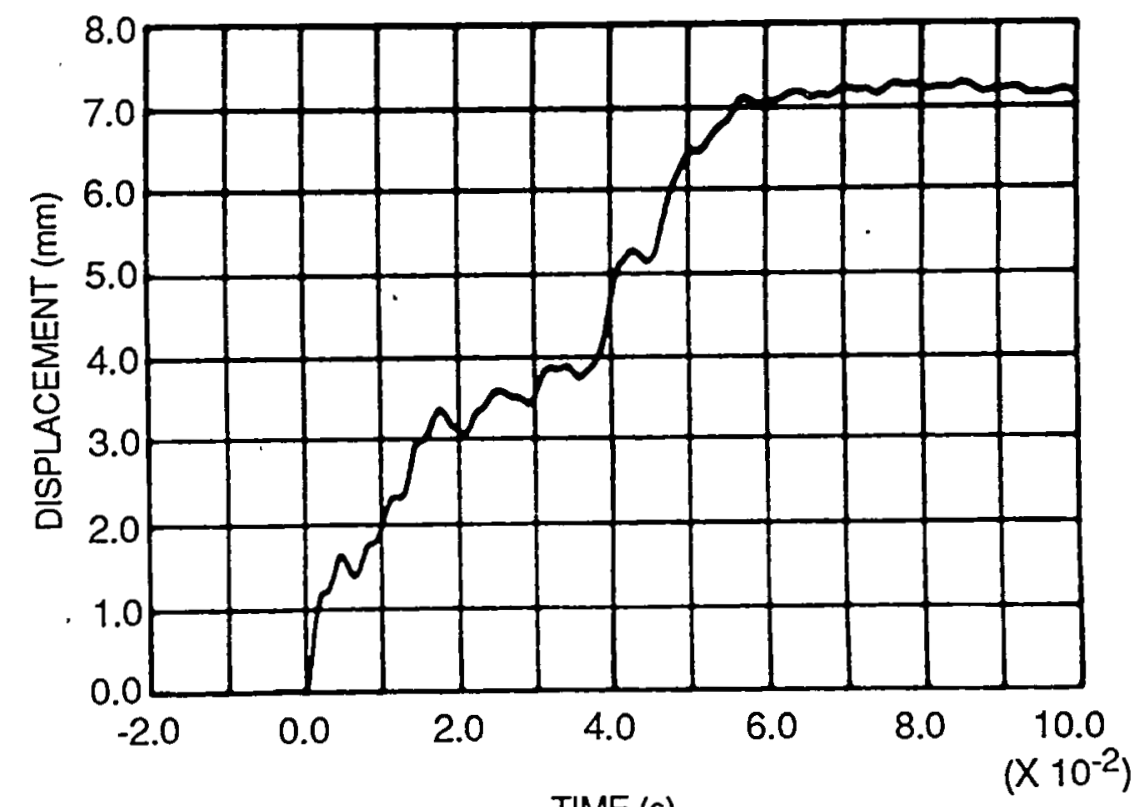

(b)

Fig. A.42. COD gage results during initial crack run-arrest events: test WP-2.3. (a) Front face and (b) back-face. 

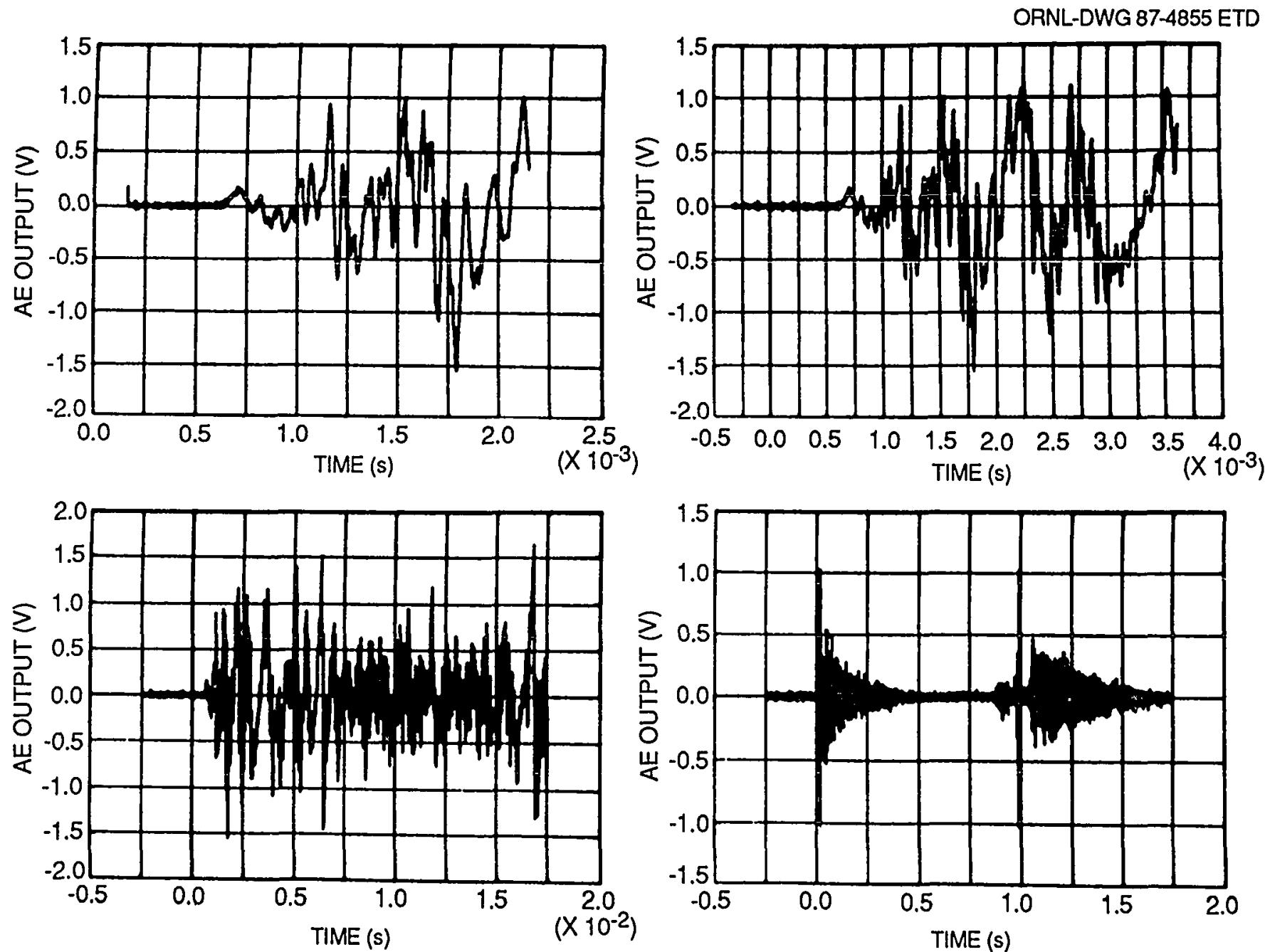

Fig. A.43. AE results for various time resolutions: test WP-2.3. 


\section{A.4 TEST WP-2.4}

\section{A.4.1 Strain Gages}

Strain-gage records for companion crack-1ine gages [see Fig. 4.8(d) for strain-gage locations] are presented in Fig. A.44 to A.46. Figure A.47 shows initiation of the first crack run-arrest event as detected by strain gage 1 . Propagation of the crack during the first crack run-arrest event, as detected by companion crack-1ine gages 2 and 3 and 13 and 14, is presented in Fig. A.48. Arrest and reinitiation of crack propagation as detected by companion crack-1ine gages 4 and 15 at two levels of time resolution are shown in Fig. A.49. Figure A.50 presents additional crack run-arrest events as detected by companion crack-line gages 5 and 6 and 16 and 17. Additional crack run-arrest events as detected by companion crack-1ine gages 7 and 8 and 18 and 19 are presented in Fig. A.51. Figure A.52 shows ductile tearing as detected by companion crack-1ine gages 9 and 10 and 20 and 21 . Figure A.53 presents ductile tearing as detected by crack-line gages 11,12 , and 22. The fracture event, as monitored by near-field strain gages 23 and 25 and far-field strain gages 26 and 27 , is shown in Fig. A.54.

\section{A.4.2 Additional Instrumentation}

Output from the $A E$ transducer mounted on the specimen lower pull tab is presented in Fig. A.55. Longitudinal acceleration recorded by a "damped" accelerometer located $4.041 \mathrm{~m}$ below the crack plane is shown in Fig. A.56. Longitudinal acceleration recorded by a "shock" accelerometer located $4.038 \mathrm{~m}$ above the crack plane is presented in Fig. A.57. Front- and back-face COD results at various times after fracture initiation are shown in Fig. A.58.

\section{A.5 TEST WP-2.5}

\section{A.5.1 Strain Gages}

Strain records, shown in Figs. A.59 to A.61 for companion crackline gages, indicate that six cleavage crack run-arrest events occurred during the test [gage locations are presented in Fig. 4.8(a)]. Nearand far-field strain-gage results are presented in Fig. A.62. More details on the crack run-arrest events followed by fibrous tearing are presented in Figs. A.63 to A.67. Figure A.63 shows the crack passing under strain gages 1 and 2 and arresting ( $t=0.344 \mathrm{~ms})$ before reaching strain gage 3. The longer strain history for gage 3 in Fig. A.63 shows reinitiation of crack propagation at $t=7.87 \mathrm{~ms}$ and the crack passing under gage 3 at $t=7.88 \mathrm{~ms}$. Strain histories for gages $5,6,9$, and 10 (Fig. A.64) show multiple crack run-arrest events. Figure A.65 presents strain histories for gages 13-15, indicating that the crack passes gages 13 and 14 with a subsequent arrest at $t=0.54 \mathrm{~ms}$ before reaching gage 15. The longer strain history shown in Fig. A.65 for gage 14 shows 


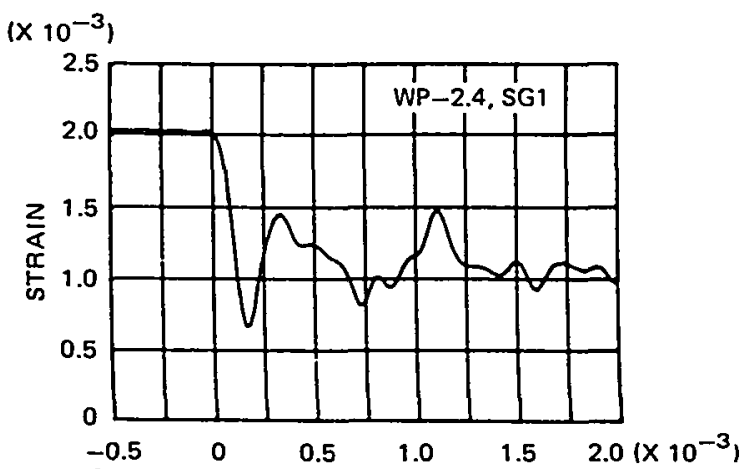

ORNL-DWG 86-5114A ETD
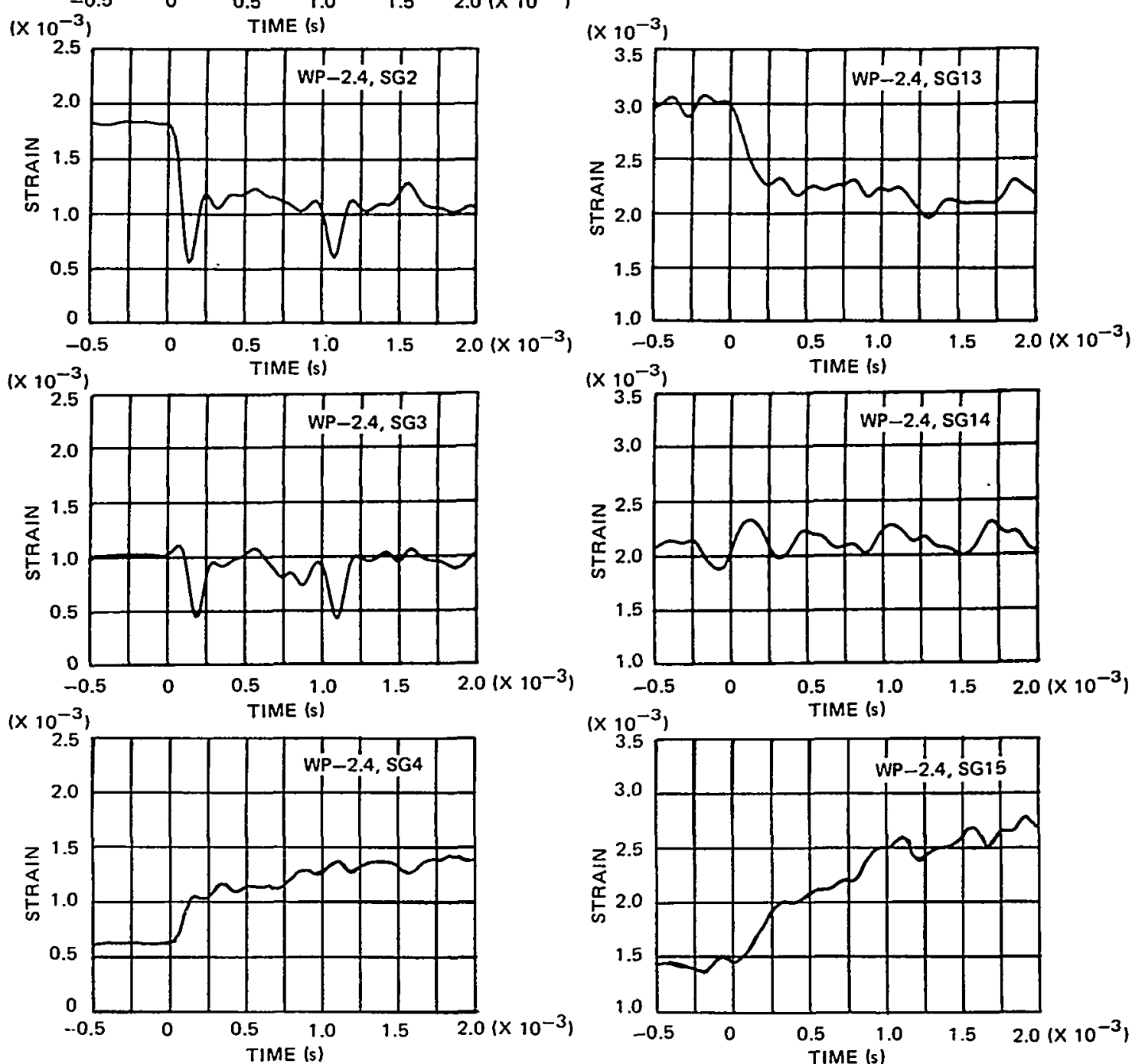

FRONT-FACE GAGES

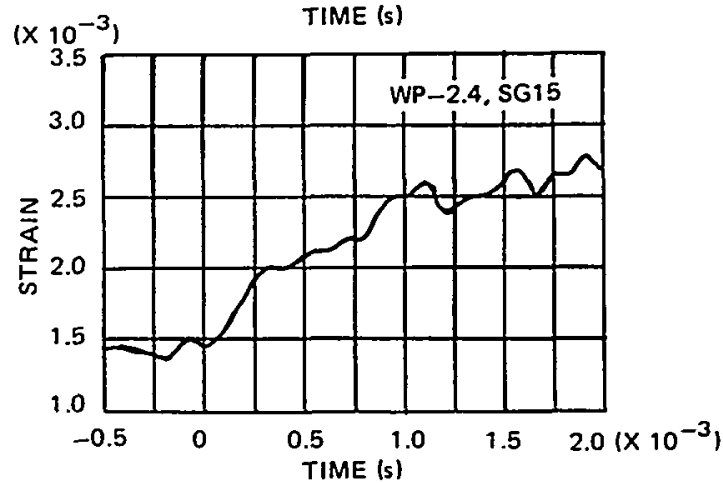

BACK-FACE GAGES

Fig. A.44. Strain histories for companion crack-line gages: test WP-2.4 (gages 1-4 and 13-15). 
ORNL-DWG 86-5115A ETD
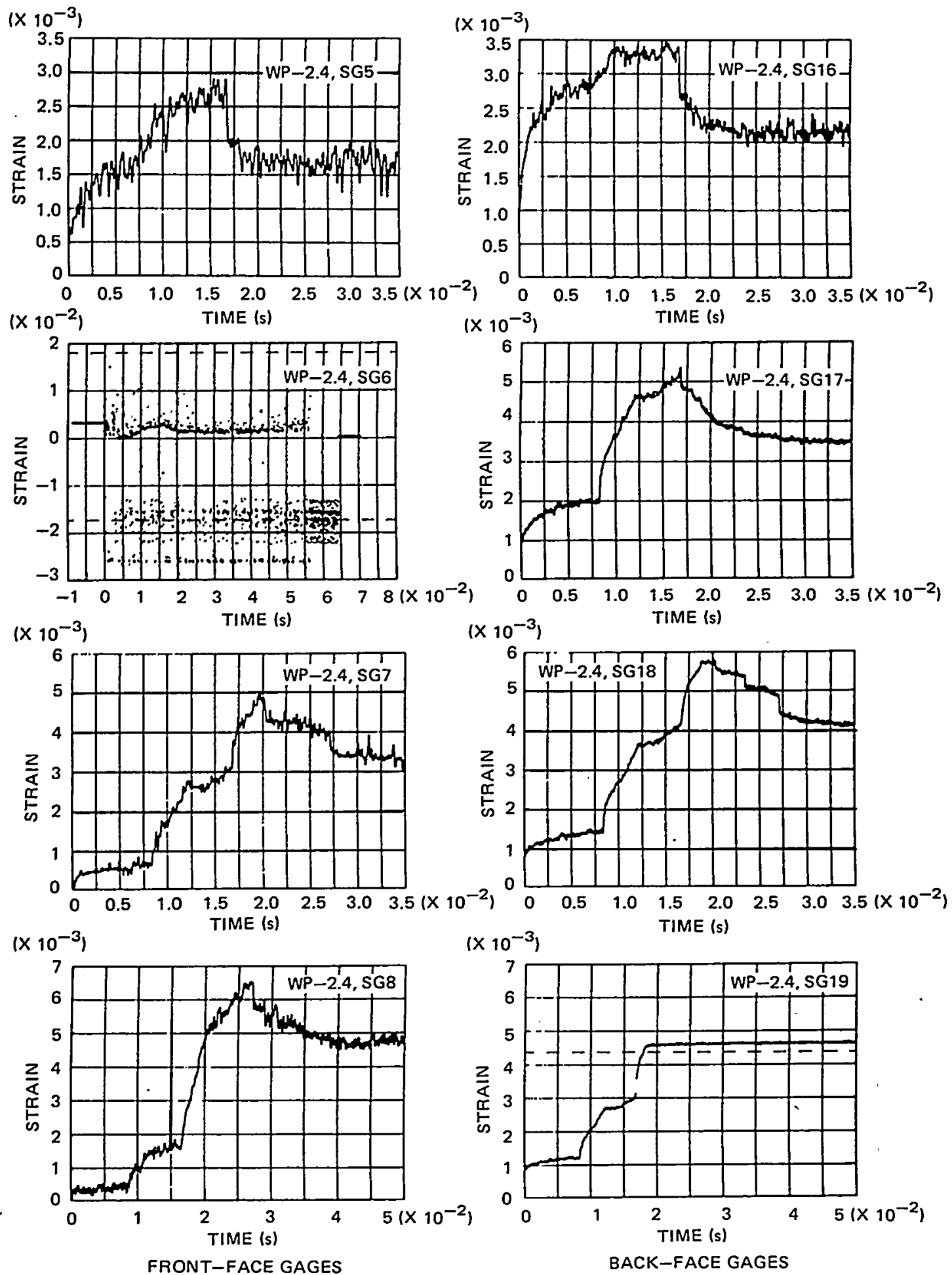

Fig. A.45. Strain histories for companion crack-line gages: test WP-2.4 (gages 5-8 and 16-19). 


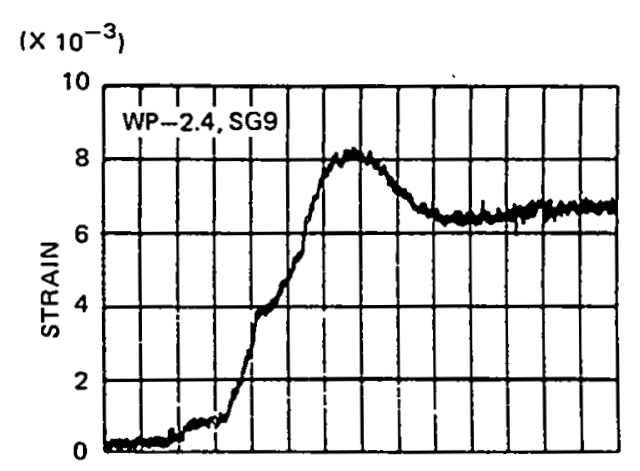

ORNL-DWG 86-5116A ETD
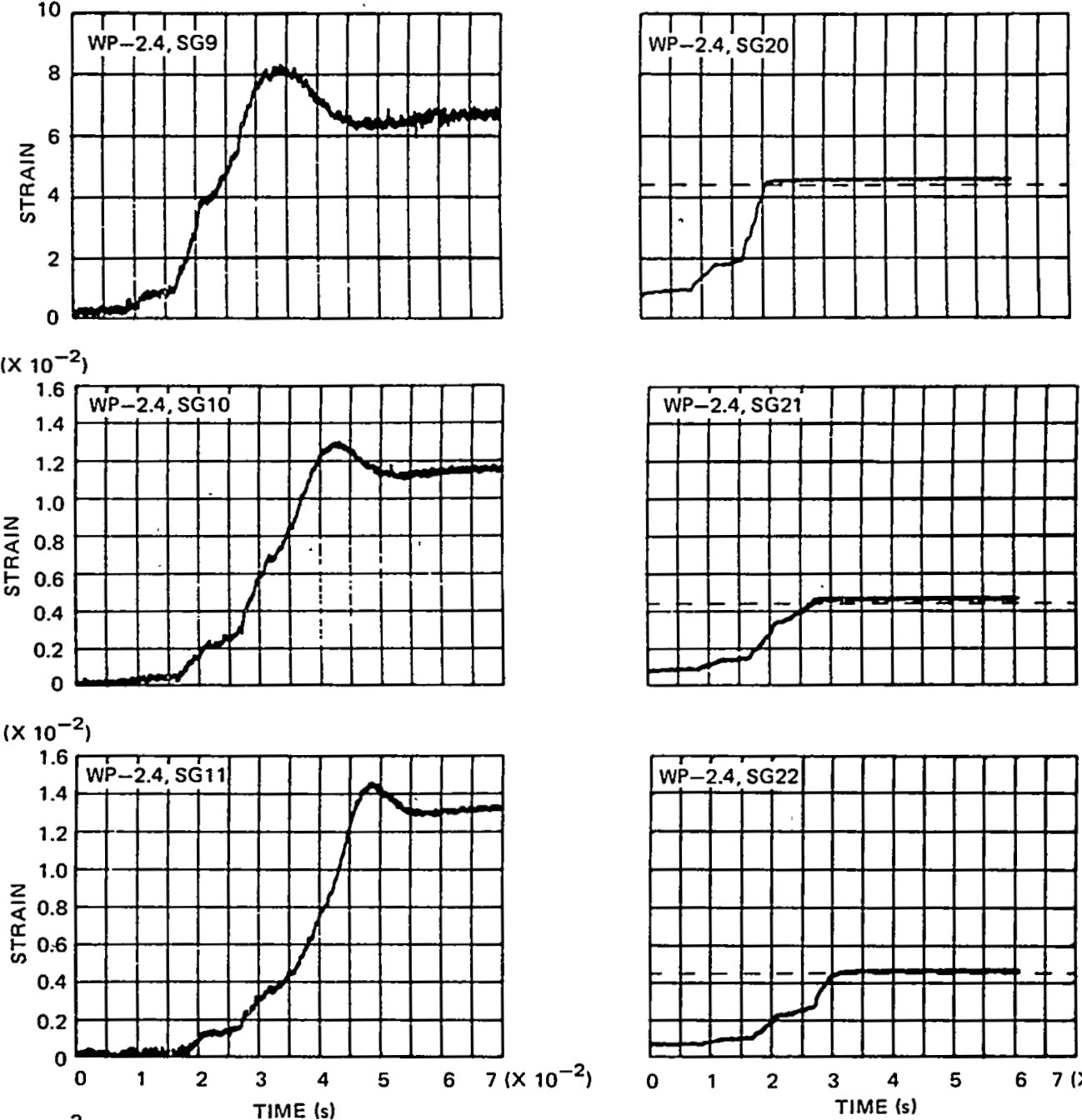

$\left(\times 10^{-2}\right)$ TIME (s)
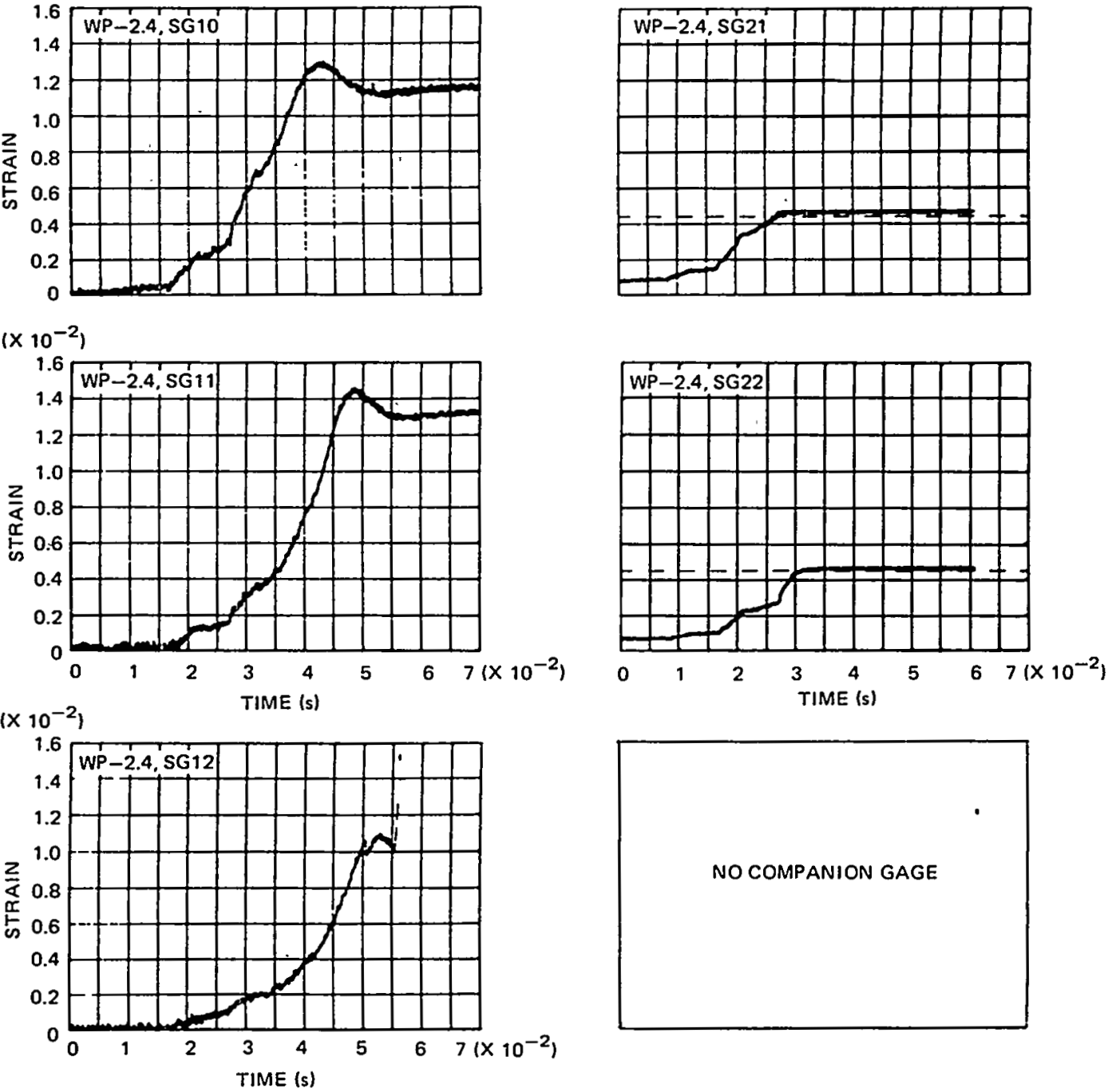

FRONT-FACE GAGES

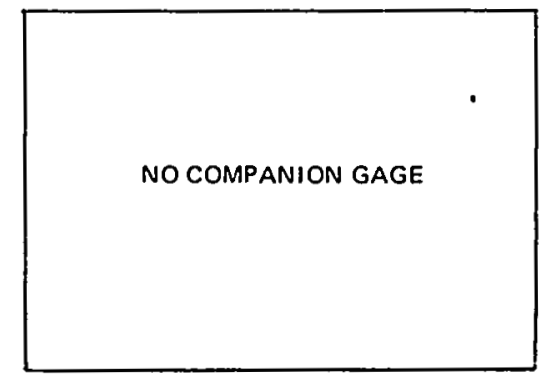

BACK-FACE GAGES

Fig. A.46. Strain histories for companion crack-1ine gages: test WP-2.4 (gages 9-12 and 20-22). 

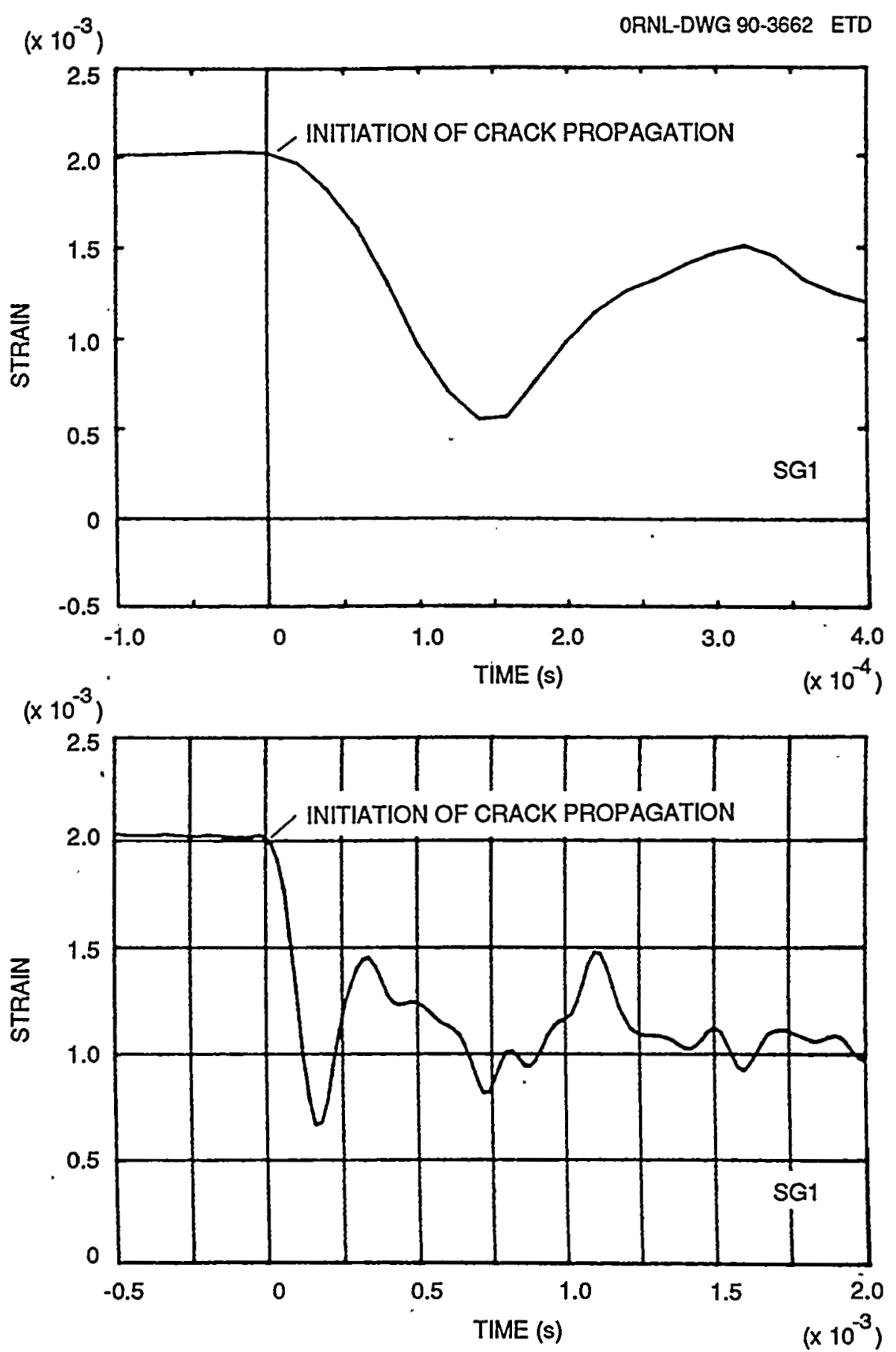

Fig. A.47. Initiation of first crack run-arrest event as detected by strain gage 1 for two time resolutions: test WP-2.4. 


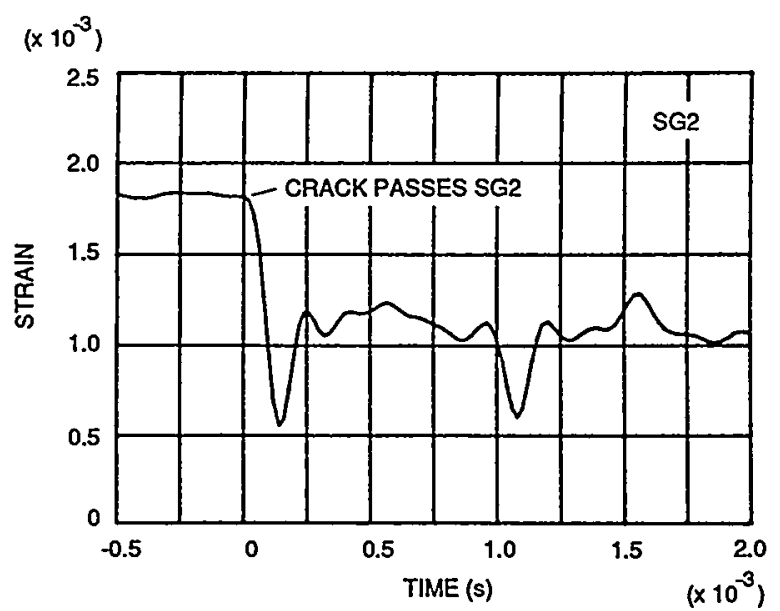

$\left(\times 10^{-3}\right)$

ORNL-DWG 90-3663 ETD
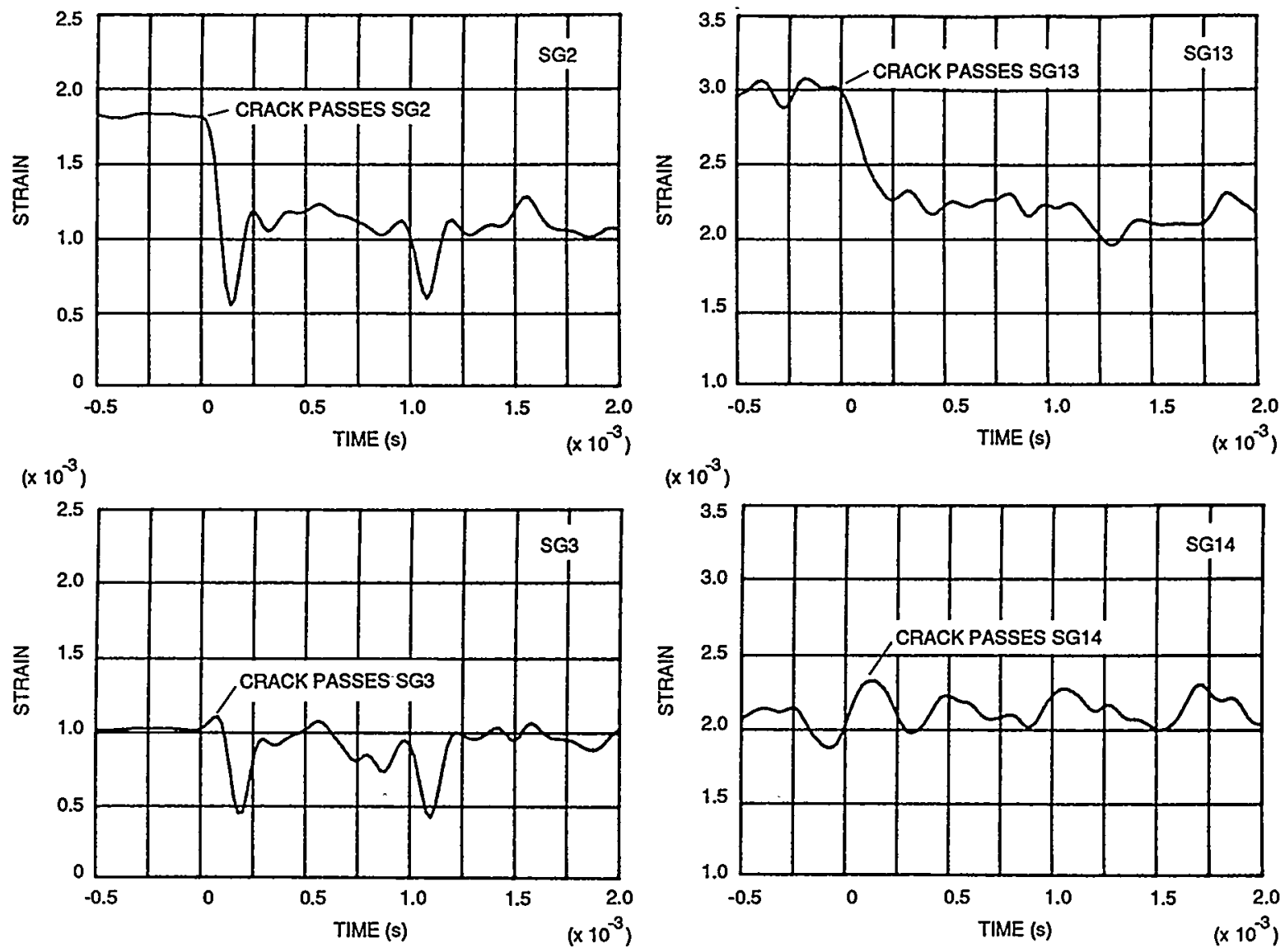

Fig. A.48. Propagation of crack during first crack run-arrest event as detected by companion crack-1ine gages 2 and 3 and 13 and 14: test WP-2.4. 

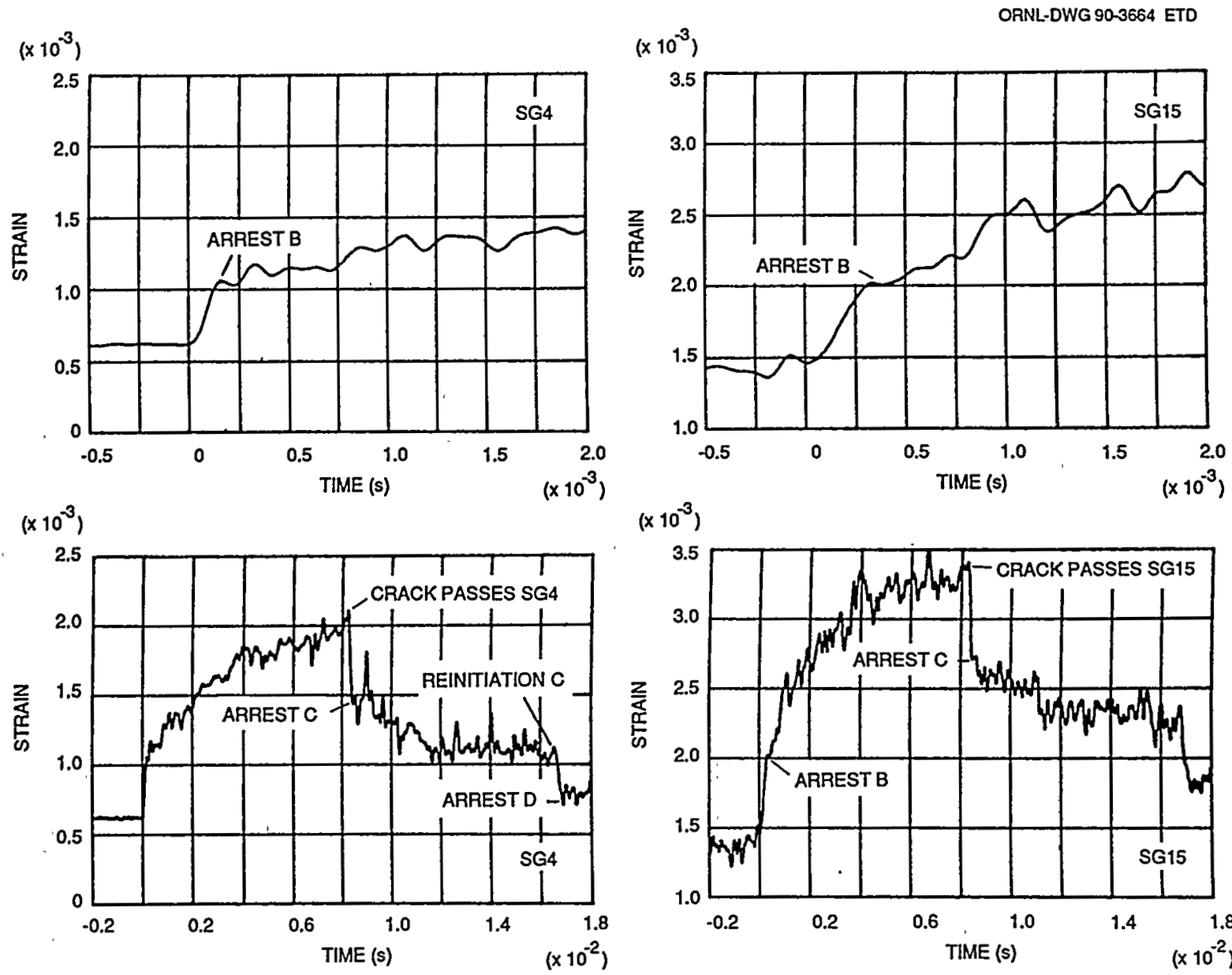
$\left(\times 10^{-3}\right)$

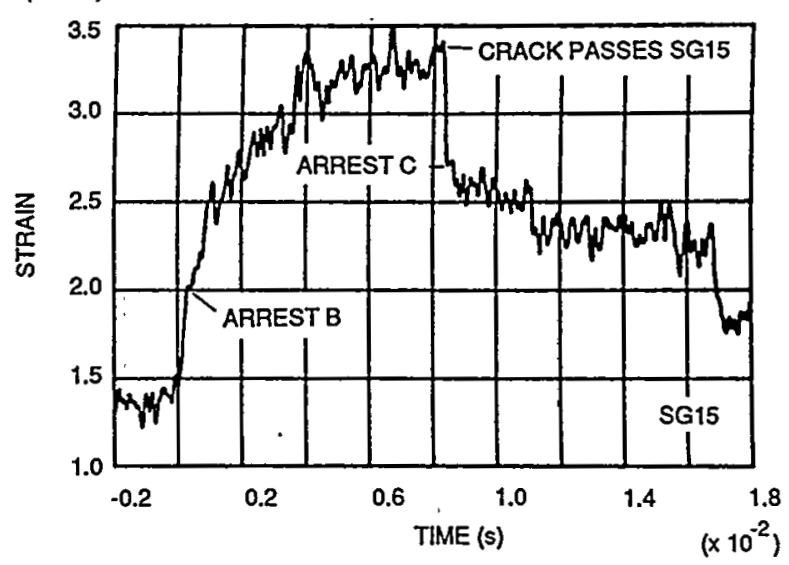

Fig. A.49. Arrest and reinitiation of crack propagation as detected by companion crack-line gages 4 and 15 at two levels of time resolution: test WP-2.4. 

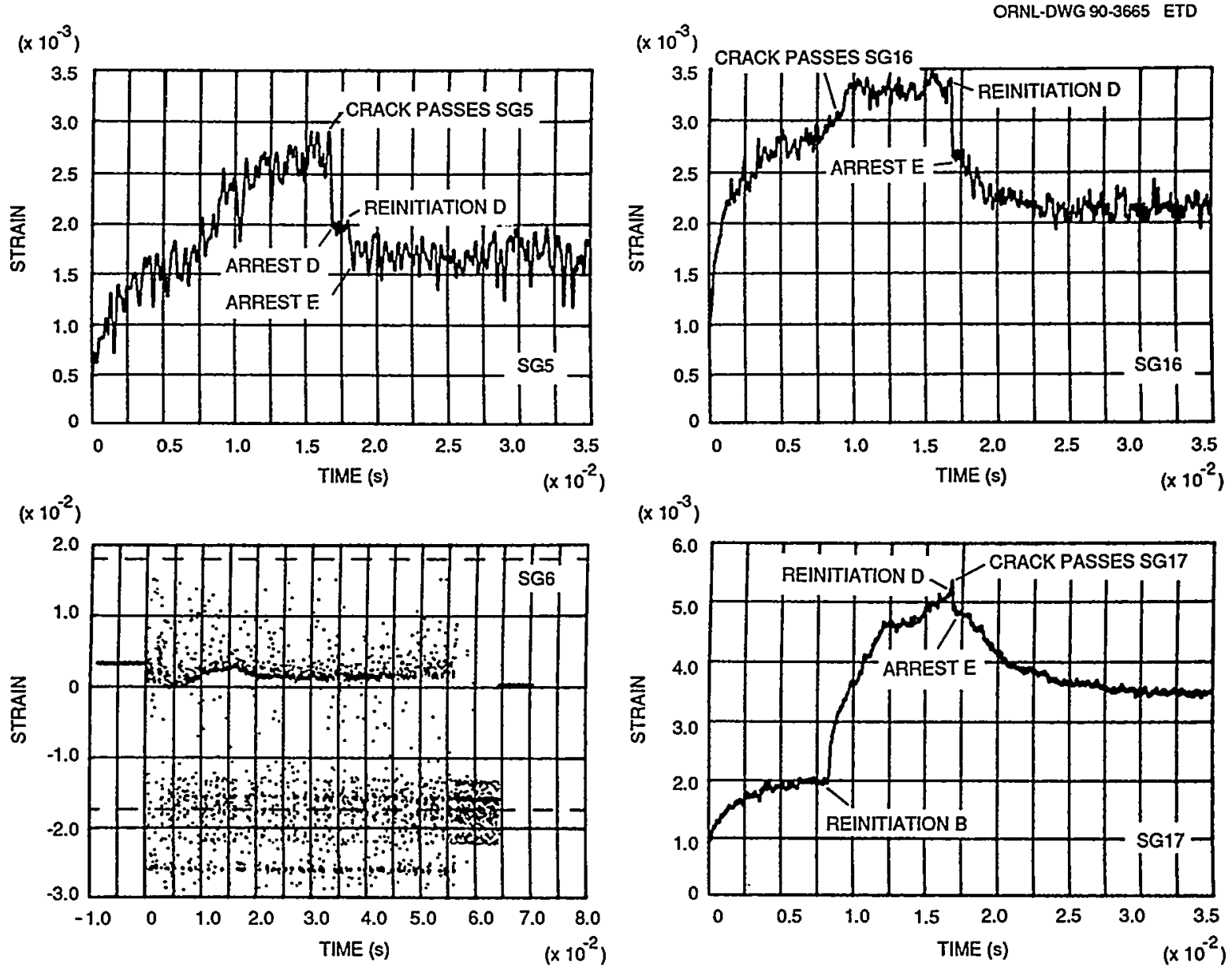

Fig. A.50. Additional crack run-arrest events as detected by companion crack-line gages 5 and 6 and 16 and 17: test WP-2.4. 

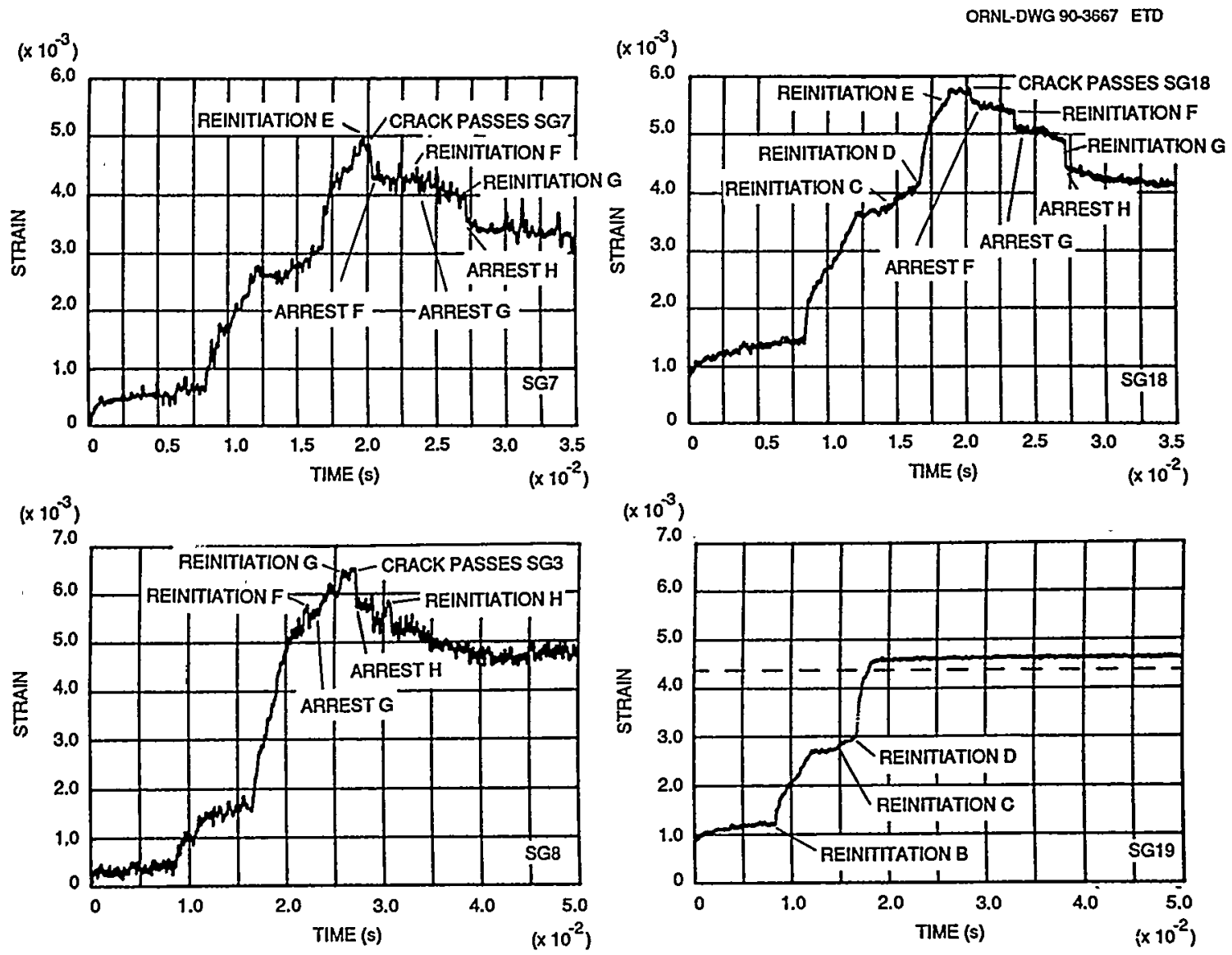

Fig. A.51. Additional crack run-arrest events as detected by companion crack-1ine gages 7 and 8 and 18 and 19: test WP-2.4. 

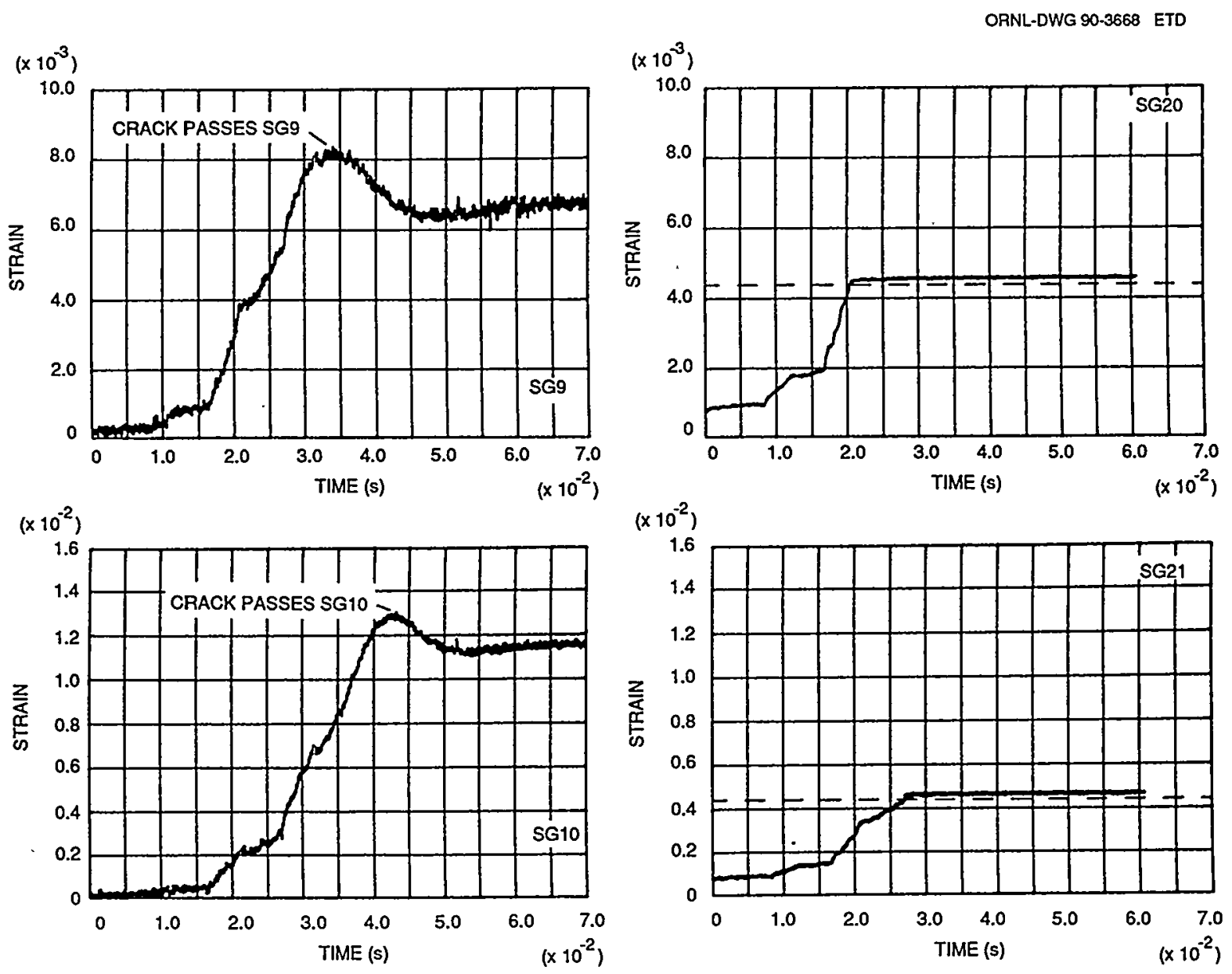

Fig. A.52. Ductile tearing as detected by companion crack-line gages 9 and 10 and 20 and 21 : test WP-2.4. 

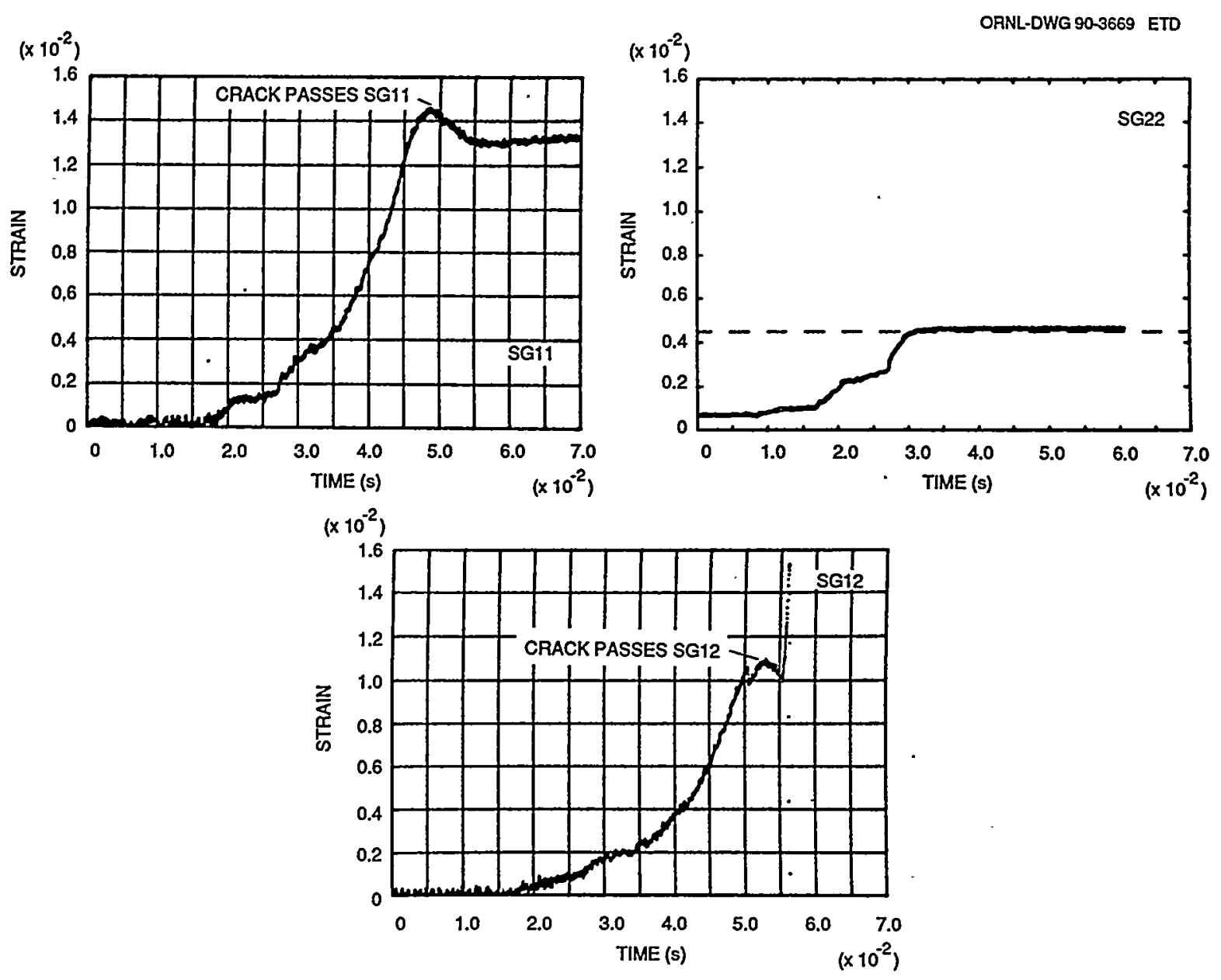

Fig. A.53. Ductile tearing as detected by crack-1ine gages 11,12 , and 22: test WP-2.4. 

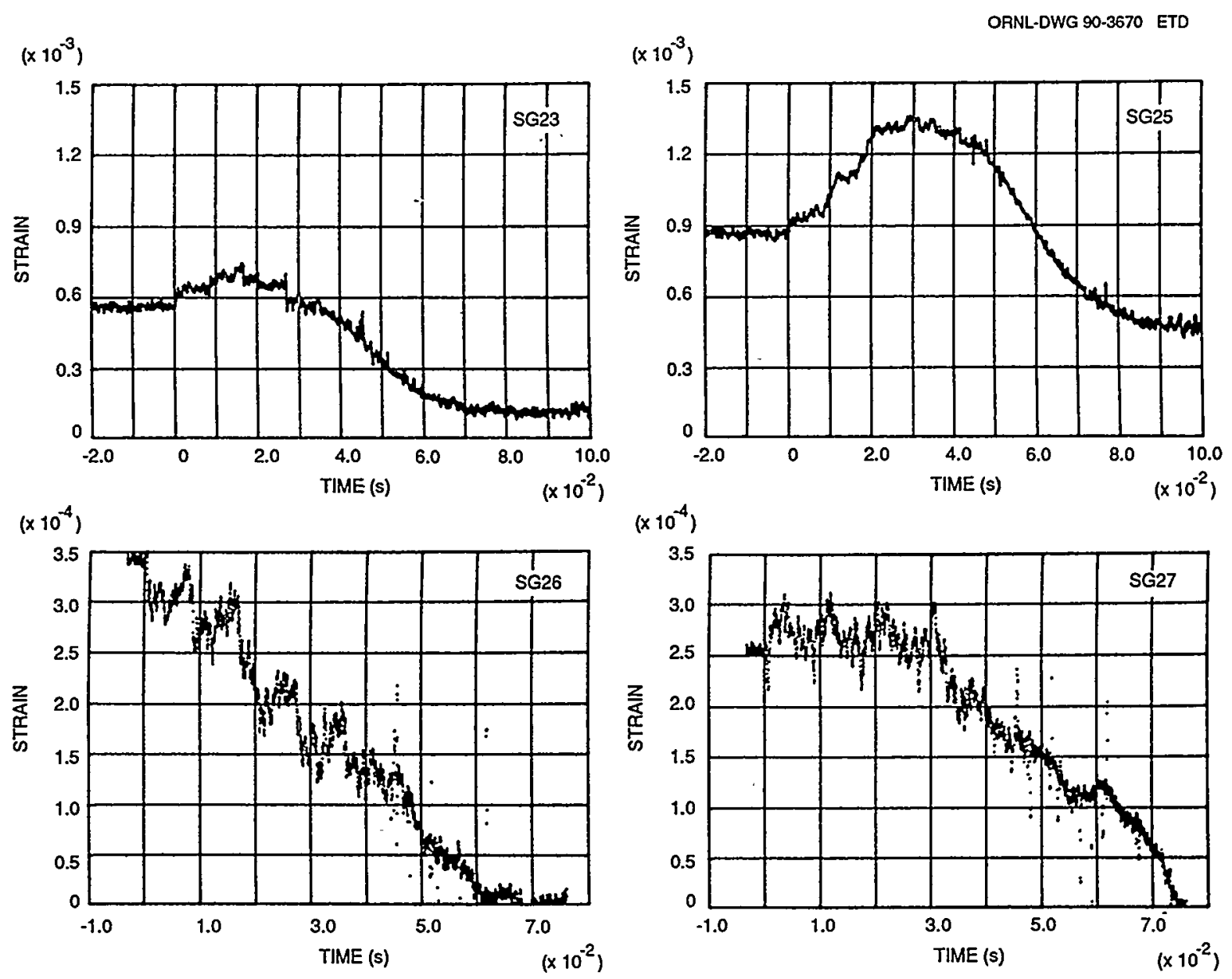

Fig. A.54. Crack run-arrest events as monitored by near-field strain gages 23 and 25 and far-field strain gages 26 and 27 : test WP-2.4. 


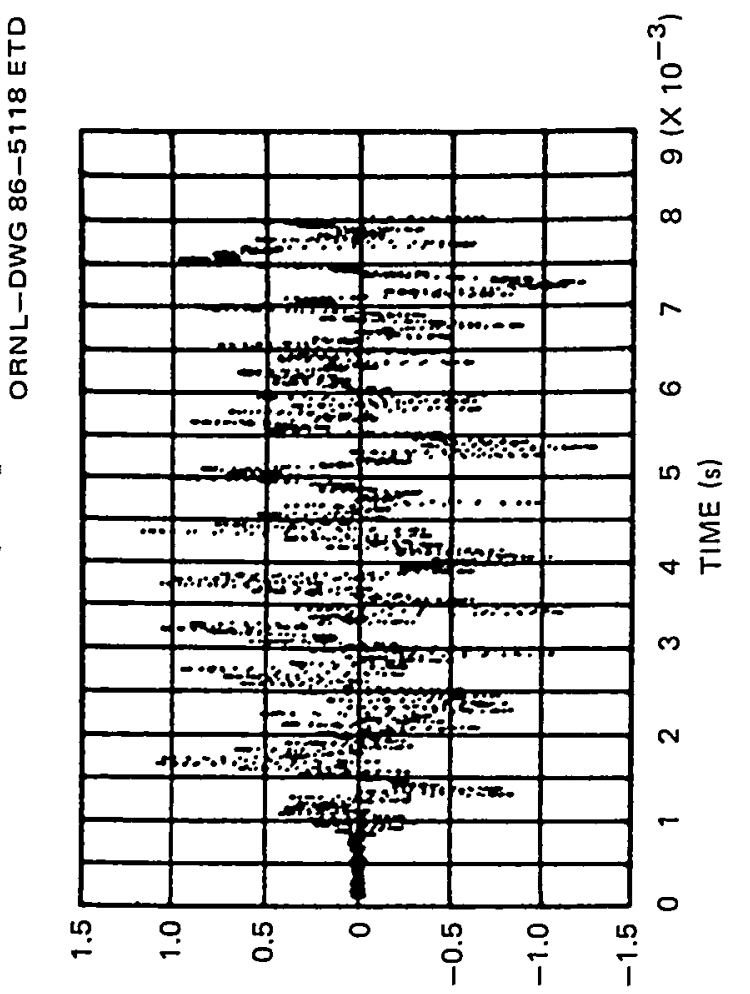

( $)$ Lnd Lno $\exists \forall$

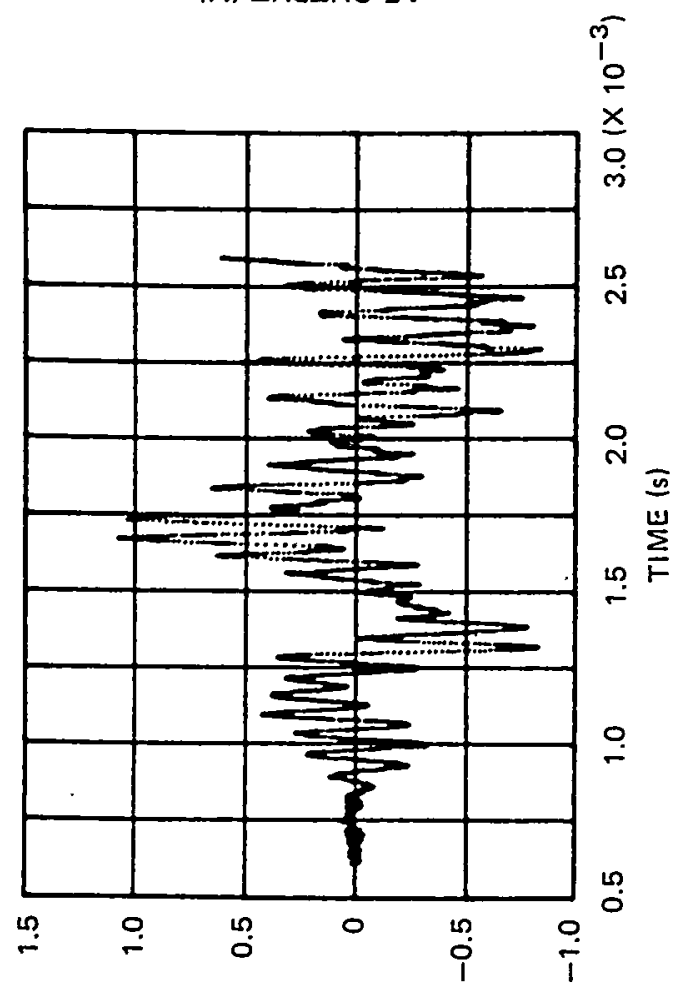

( $) \perp \cap \perp \perp \cap \circ \exists \forall$
ติ

음

$\underline{x}$

$\stackrel{n}{i}$

우

离

$\because F$

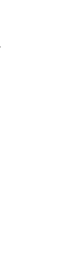

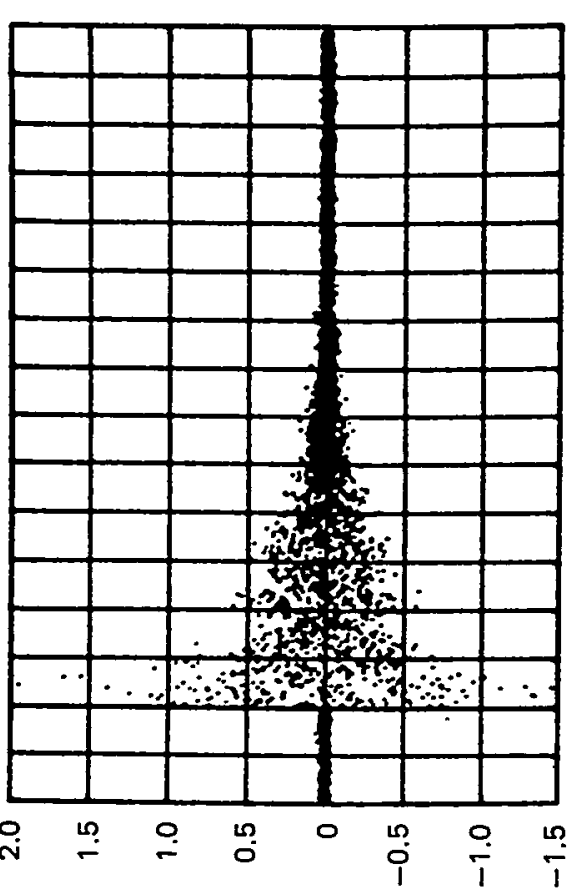

( $) \perp \cap d \perp \cap 0 \exists \forall$

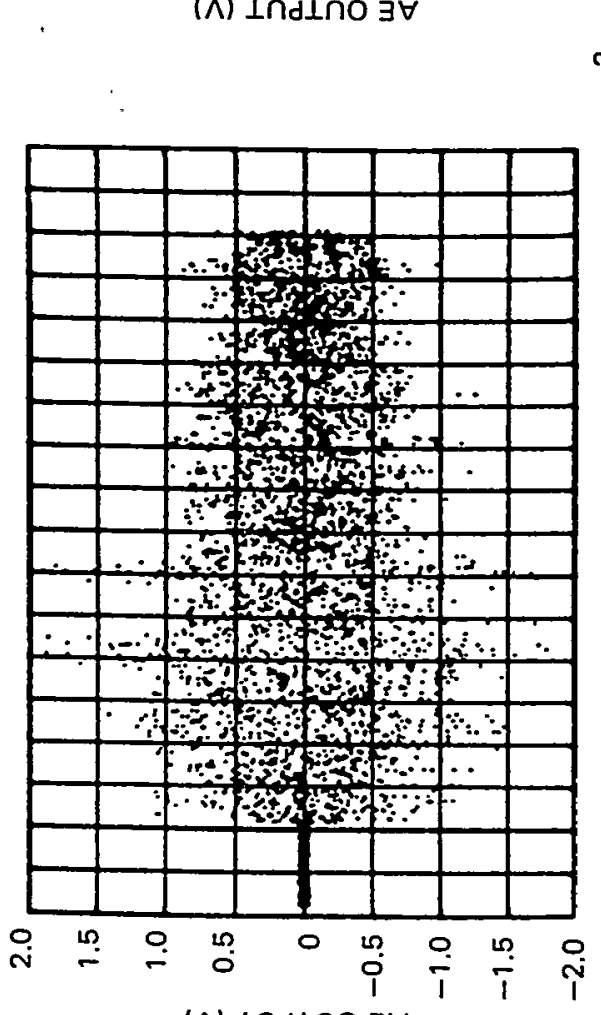

(N) $\perp \cap d \perp \cap 0 \exists \forall$ 
ORNL-OWG 86-5119 ETD
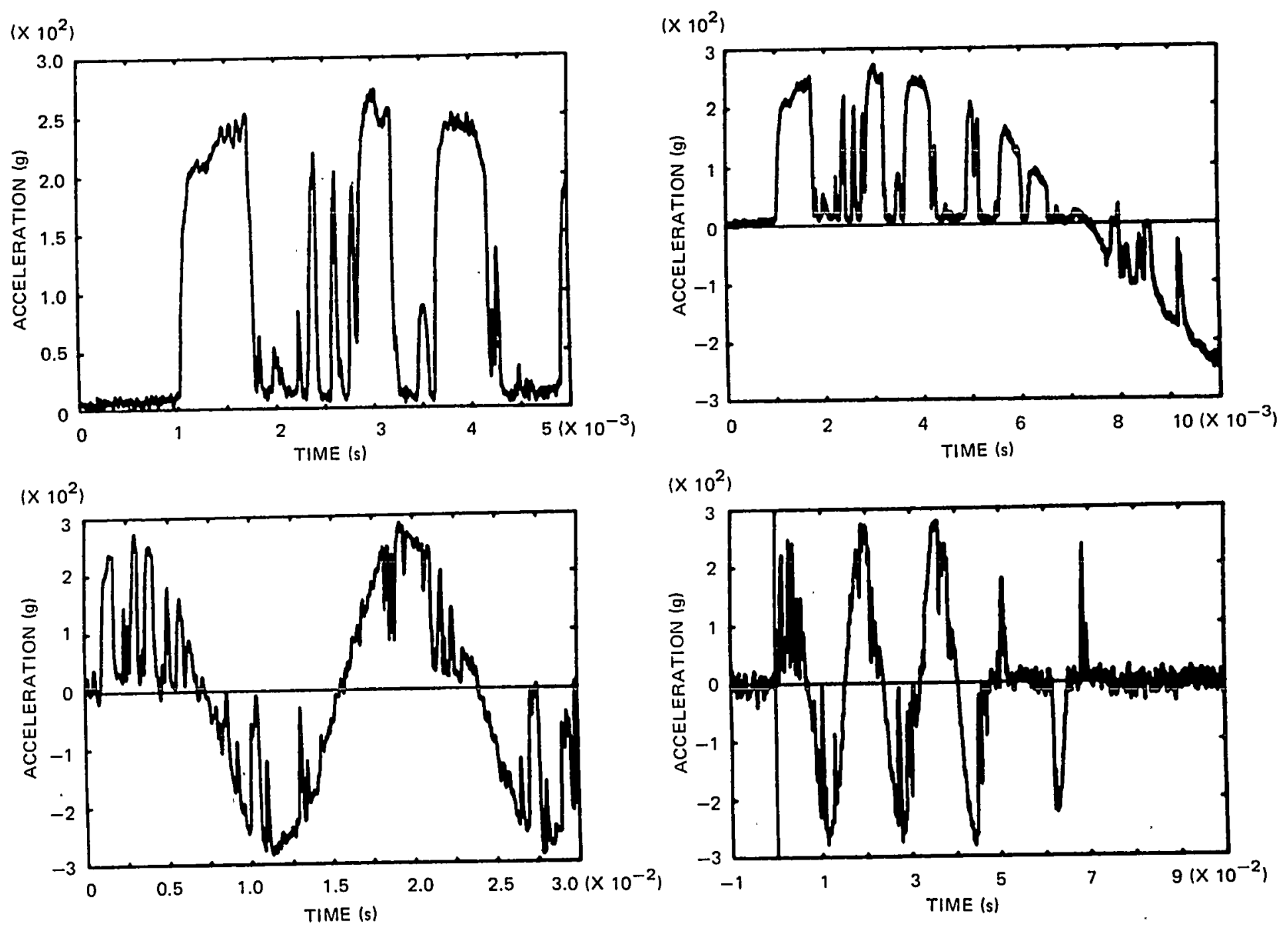

$\left(\times 10^{2}\right)$

Fig. A.56. Longitidual acceleration during test measured by

"damped" accelerometer mounted $4.041 \mathrm{~m}$ below crack plane: test WP-2.4. 


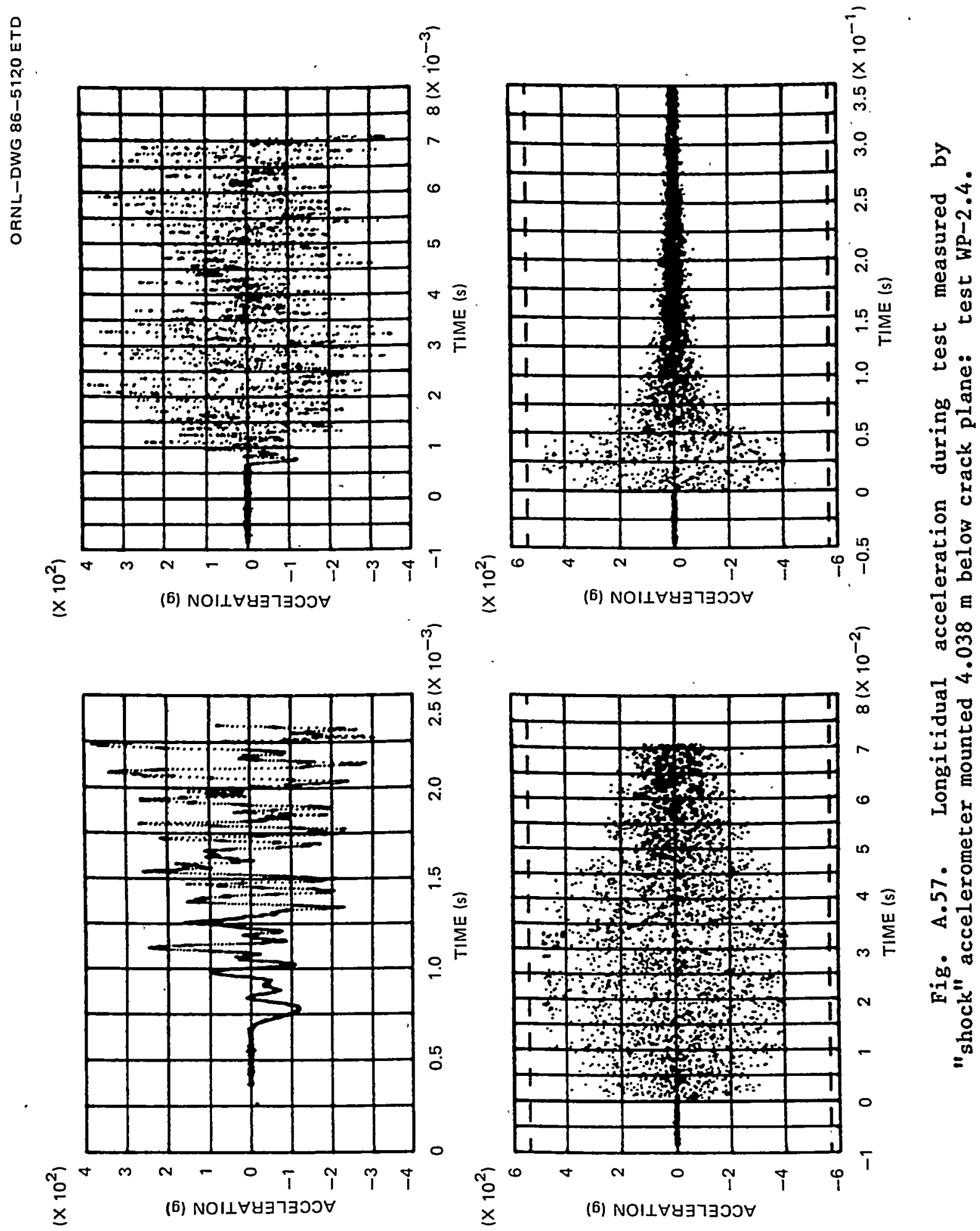



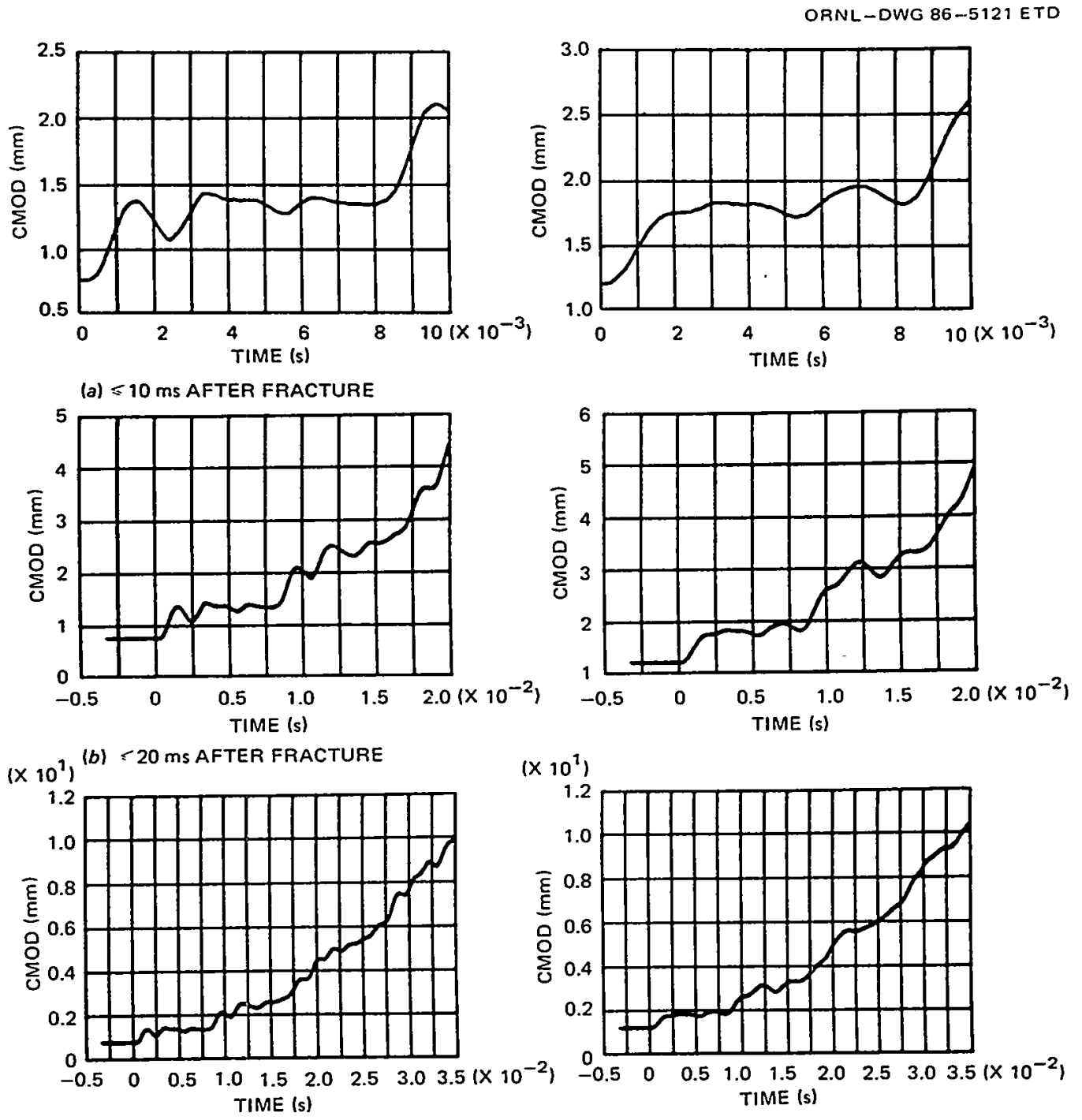

(c) $\leqslant 35 \mathrm{~ms}$ AFTER FRACTURE
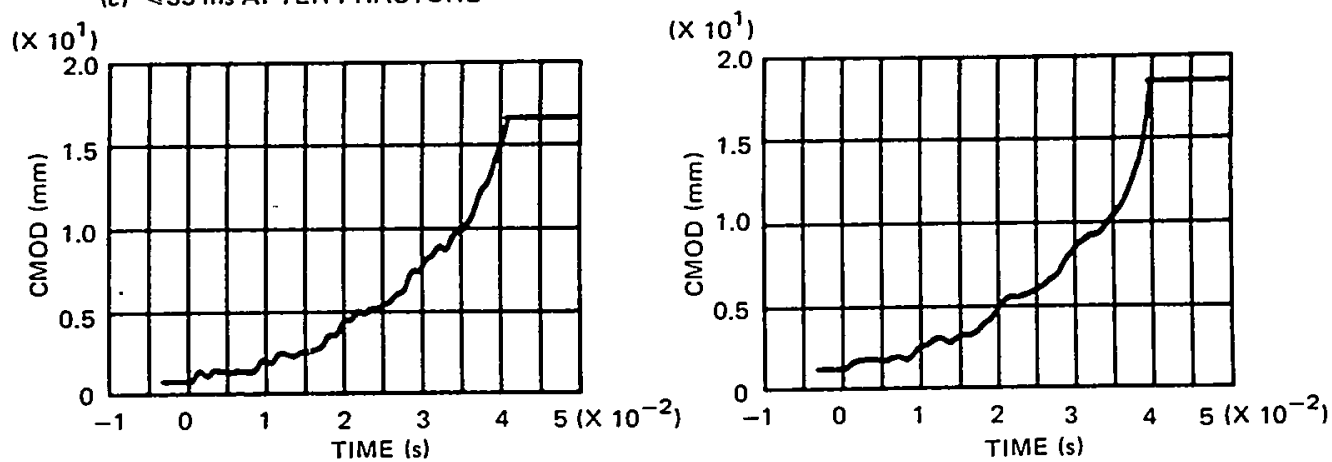

(d) $\cdot 50 \mathrm{~ms}$ AFTER FRACTURE

FRONT-COD

BACK-COD

Fig. A.58. Front- and back-face COD at various time spans after fracture initiation: test WP-2.4. 


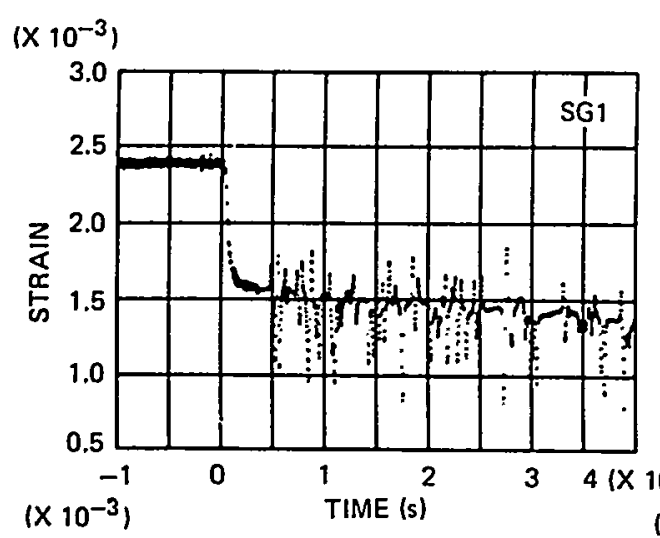

ORNL-DWG 87-3896A ETD

$\left(X 10^{-3}\right)$

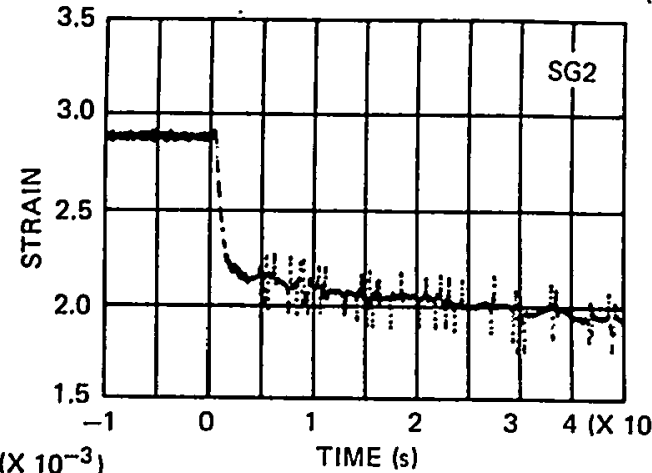

$\left(\times 10^{-3}\right)$

NO COMPANION GAGE
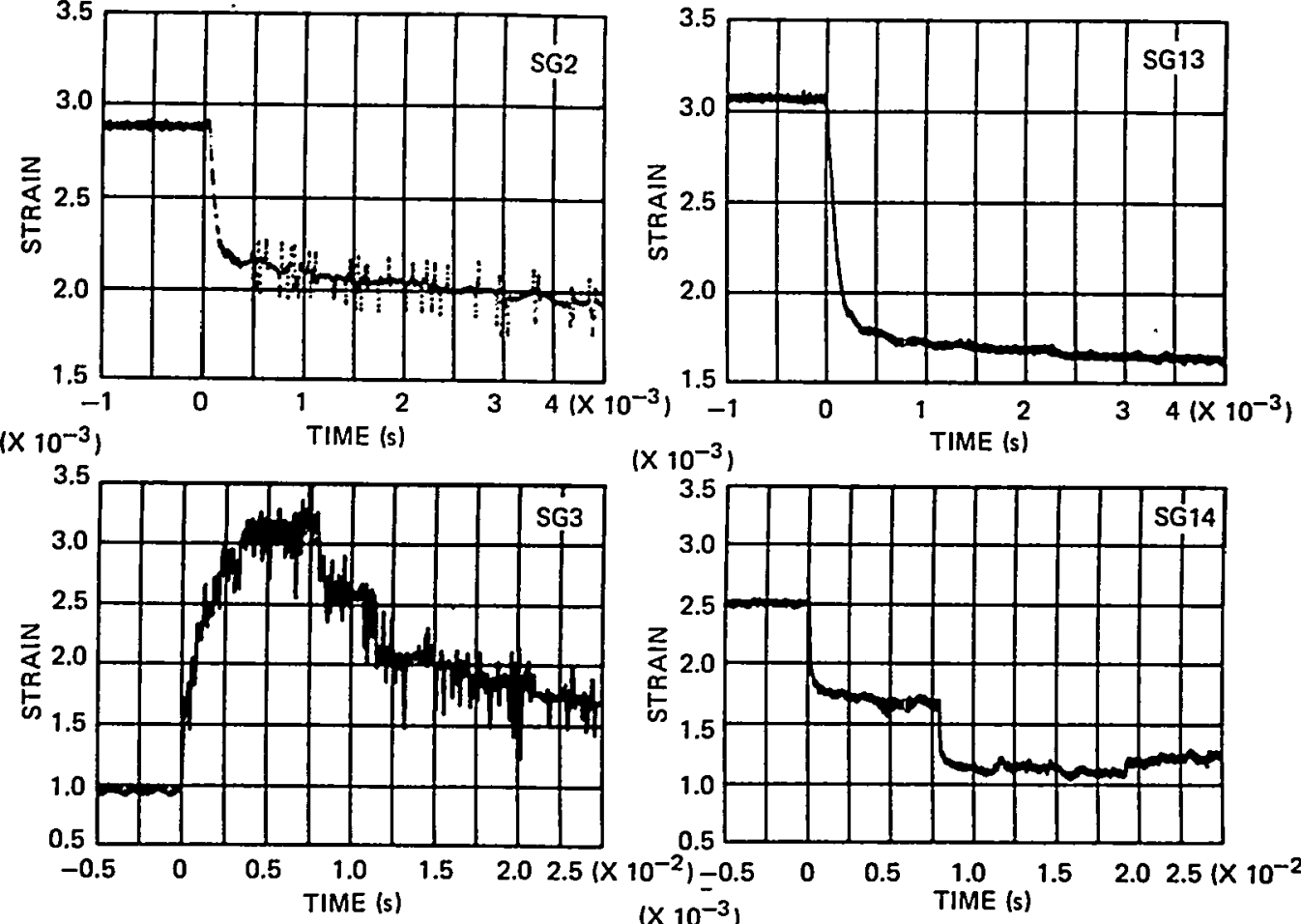

$\left(\times 10^{-3}\right)$
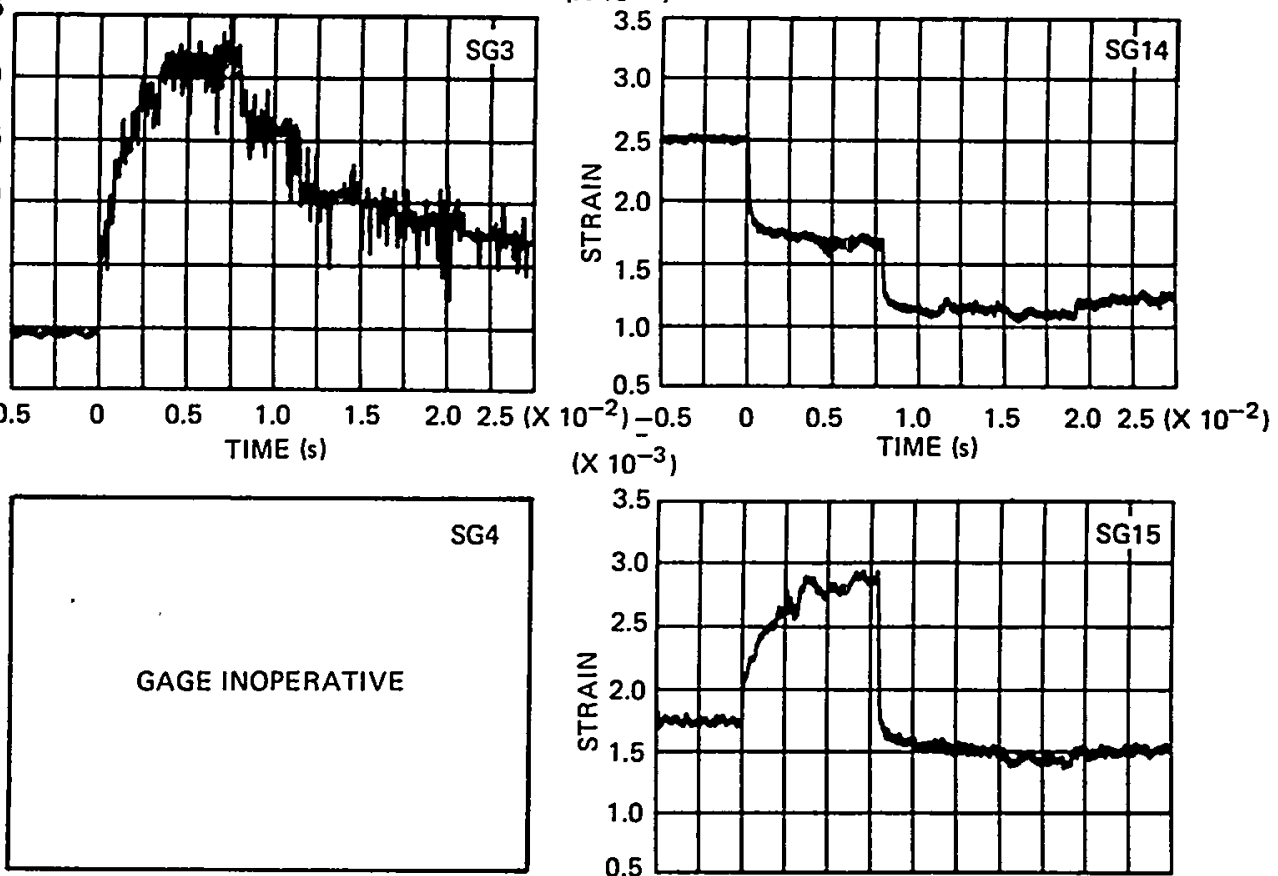

FRONT-FACE GAGES

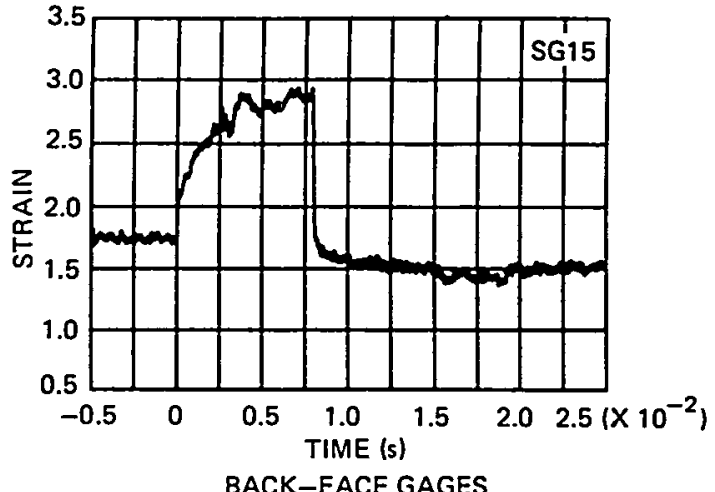

Fig. A.59. Strain histories for companion crack-line gages: test WP-2.5 (gages $1-4$ and 13-15). 


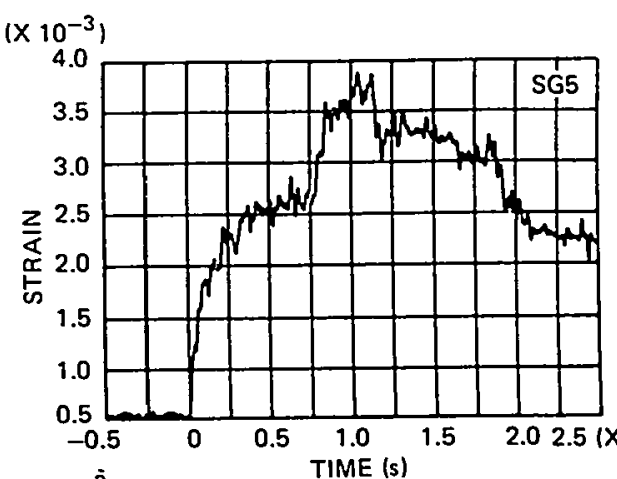

$\left(\times 10^{-3}\right)$

ORNL-DWG 87-3897A ETD
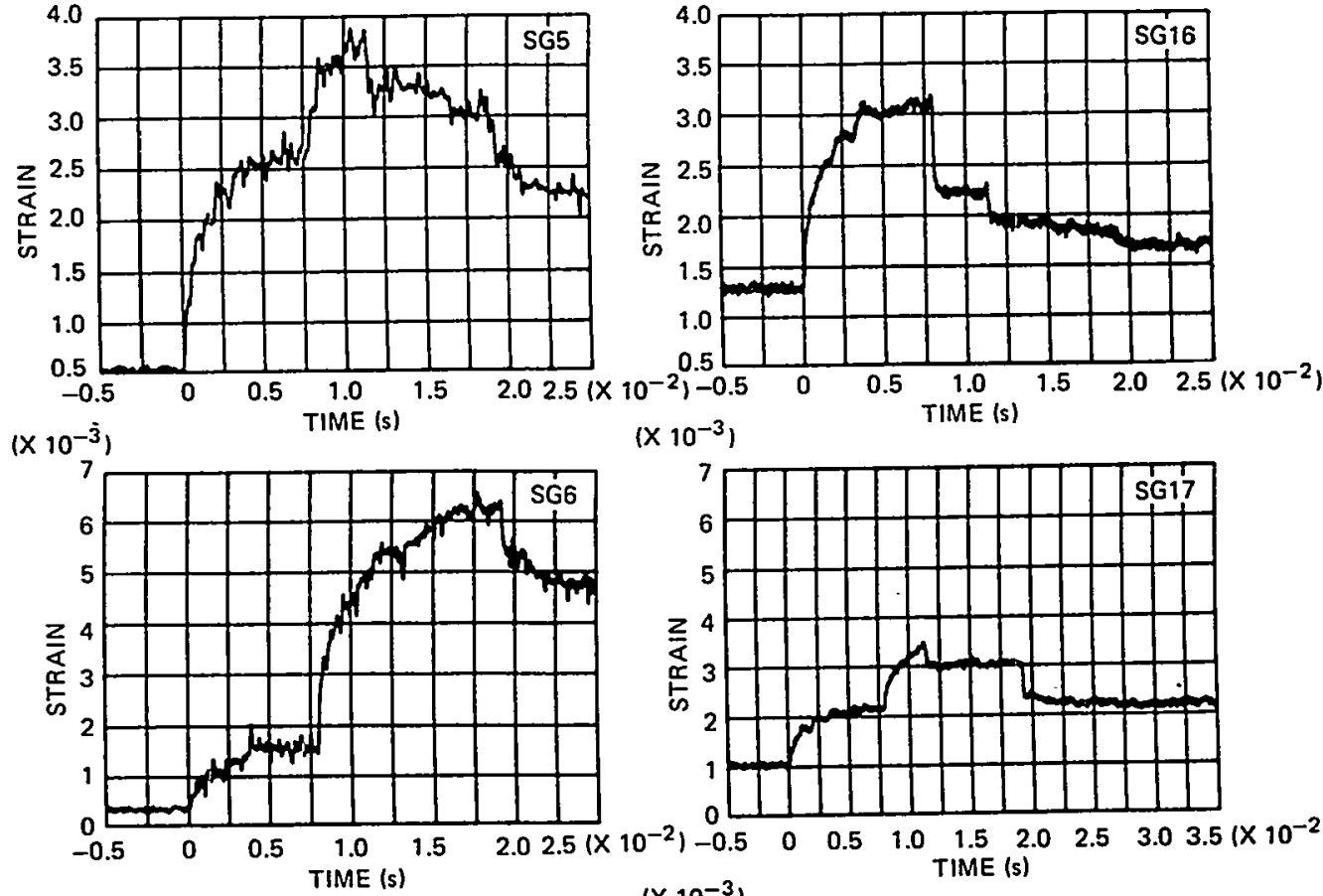

$\left(\times 10^{-3}\right)$

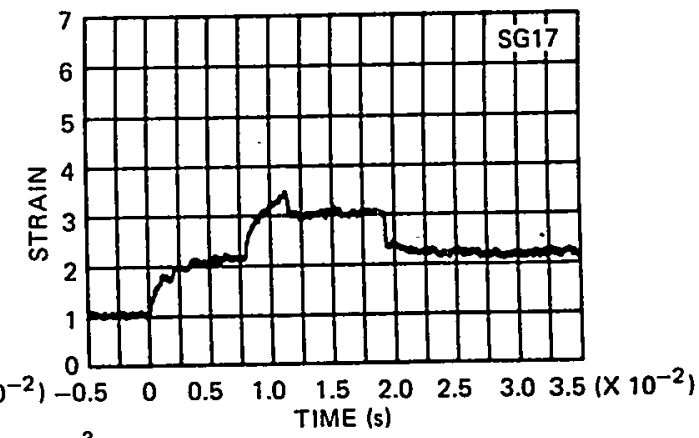
$\left(\times 10^{-3}\right)$
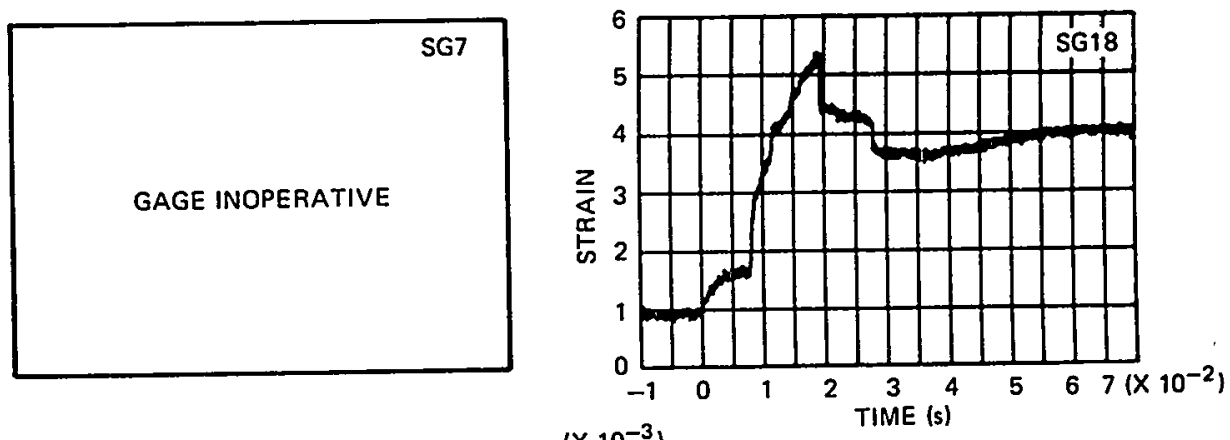

$\left(\times 10^{-3}\right)$
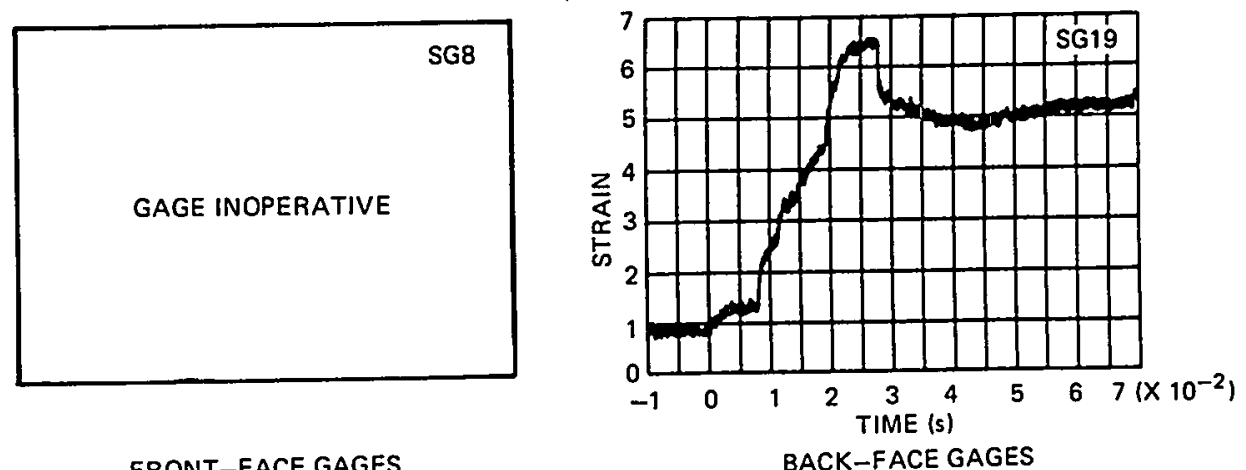

FRONT-FACE GAGES

Fig. A.60. Strain histories for companion crack-1ine gages: test WP-2.5 (gages 5-8 and 16-19). 
$\left(\times 10^{-2}\right)$

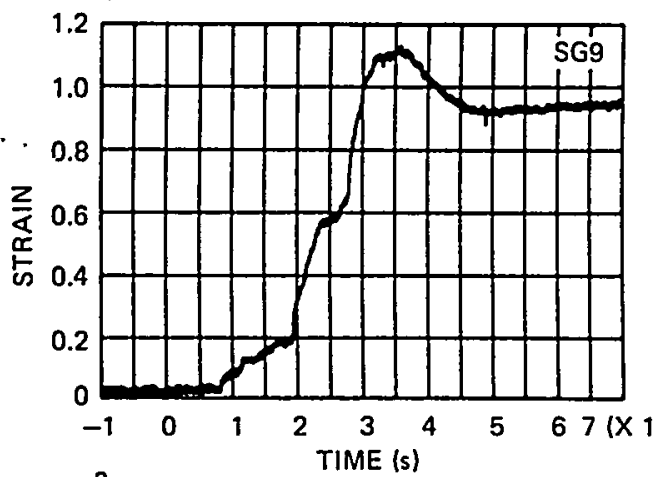

$\left(\times 10^{-2}\right)$

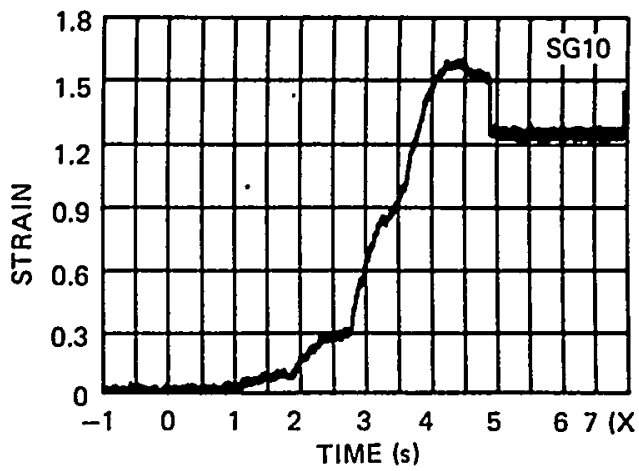

SG11

GAGE INOPERATIVE
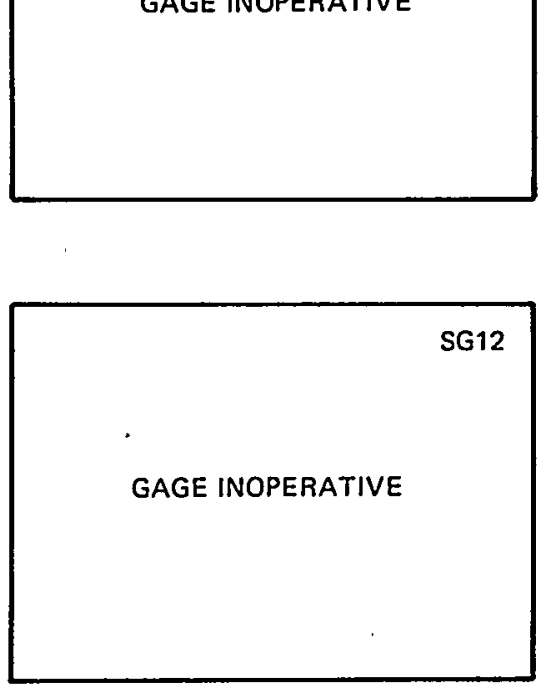

FRONT-FACE GAGES

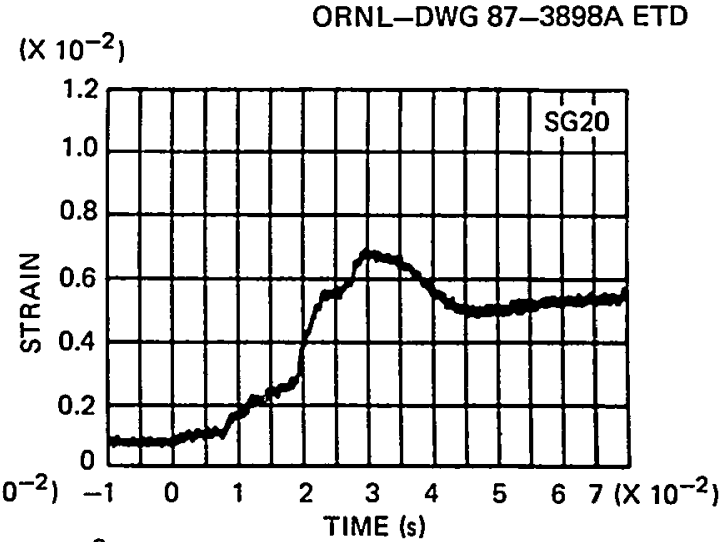

$\left(\times 10^{-2}\right)$

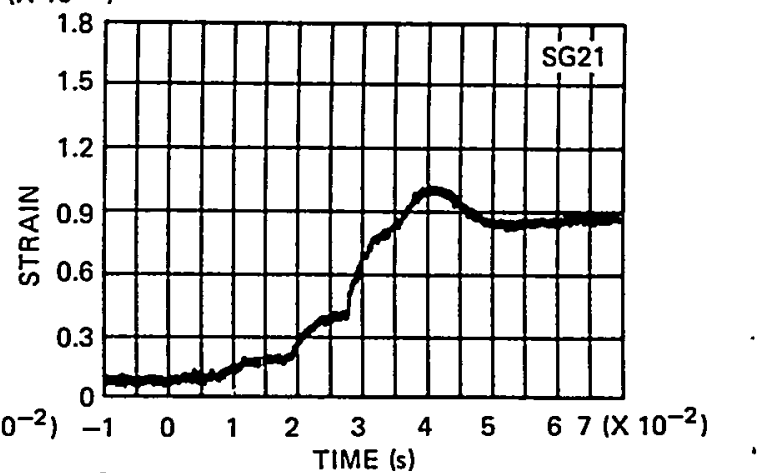

$\left(\times 10^{-2}\right)$

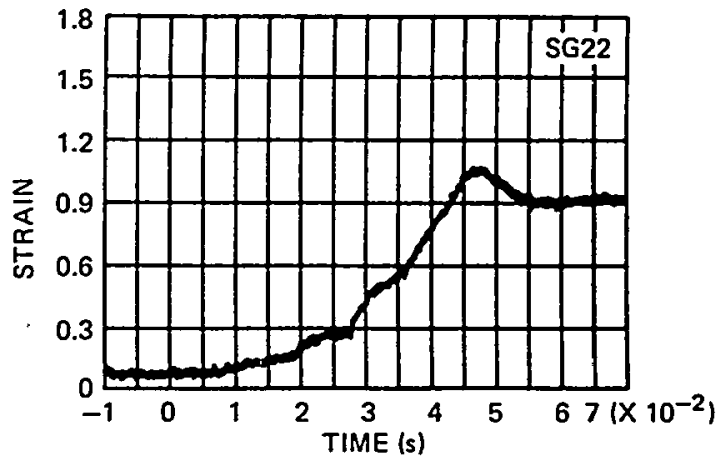

NO COMPANION GAGE

BACK-FACE GAGES

Fig. A.61. Strain histories for companion crack-1ine gages: test WP-2.5 (gages 9-12 and 20-22). 


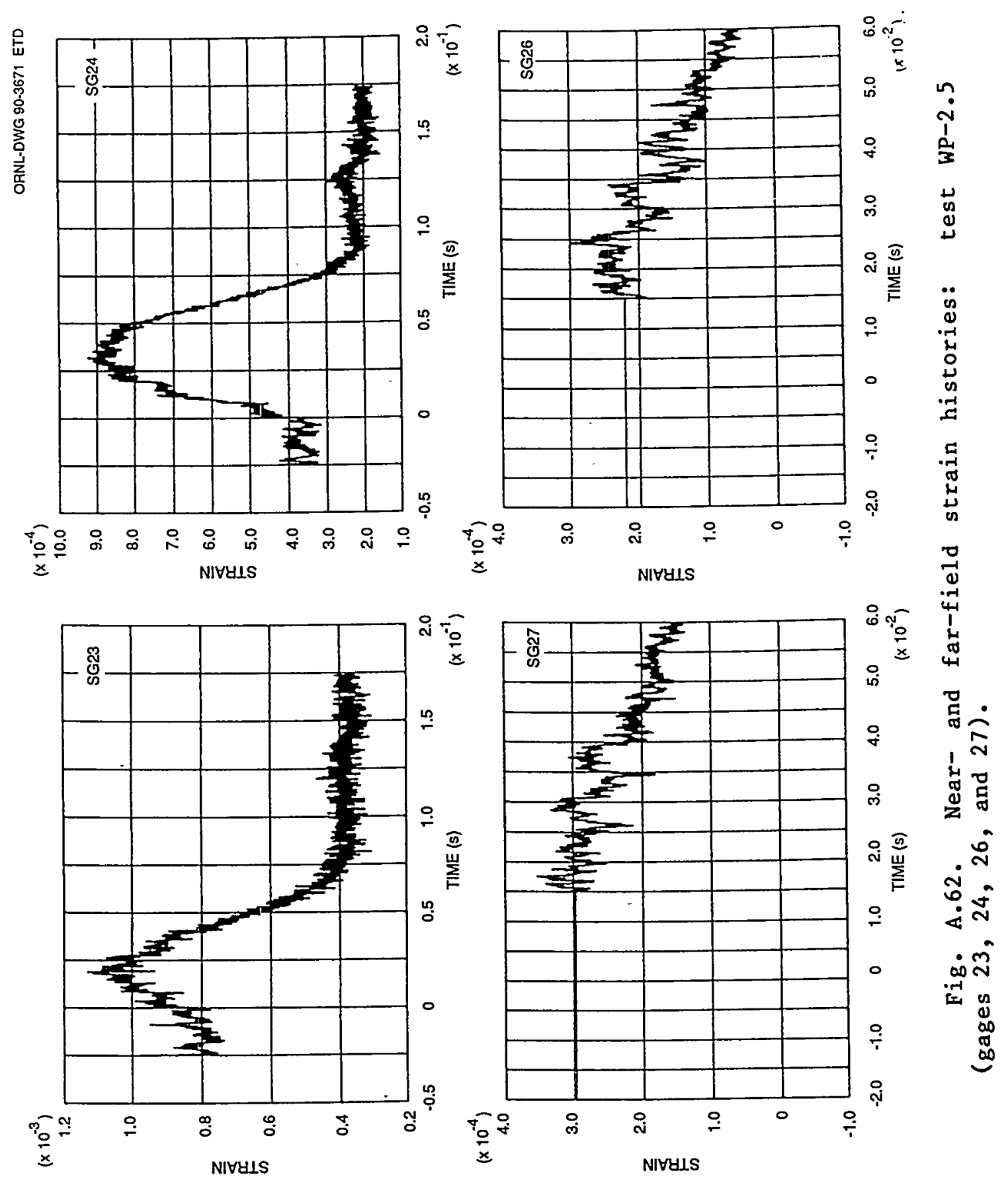


$\left(\times 10^{-3}\right)$

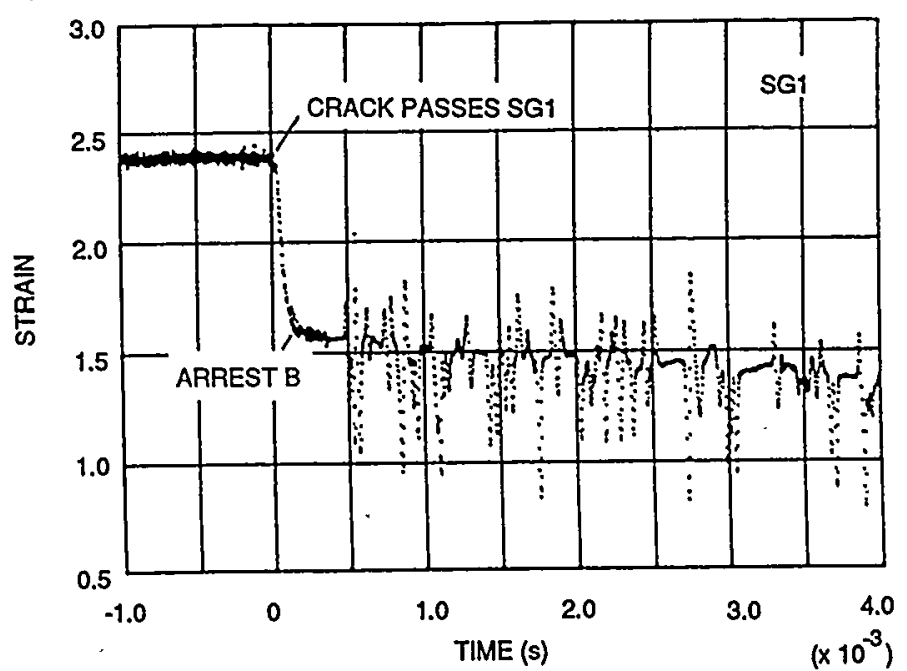

$\left(\times 10^{-3}\right)$

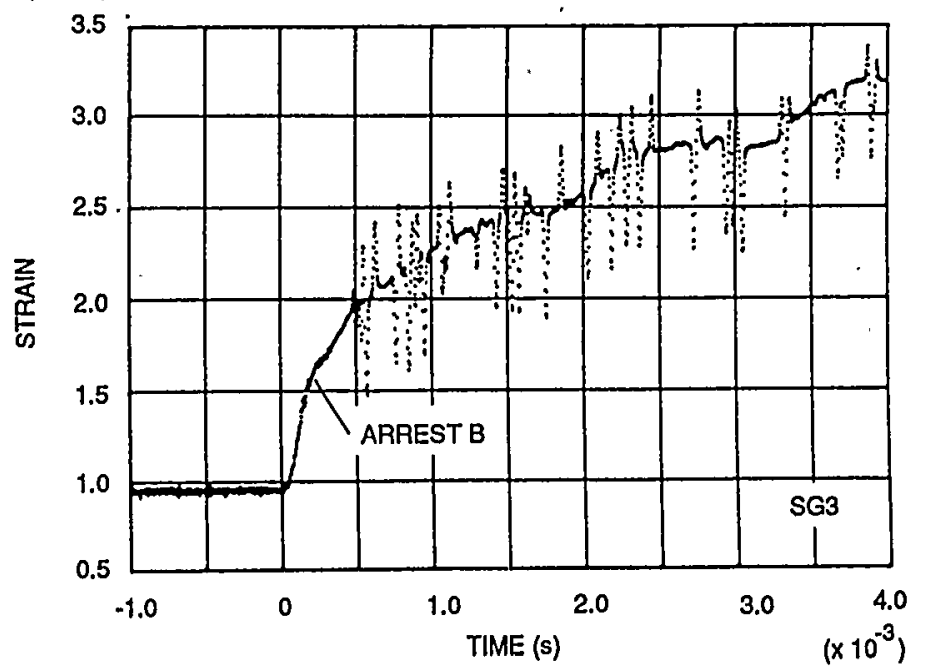

$\left(\times 10^{-3}\right)$

ORNL-DWG 90-3672 ETD

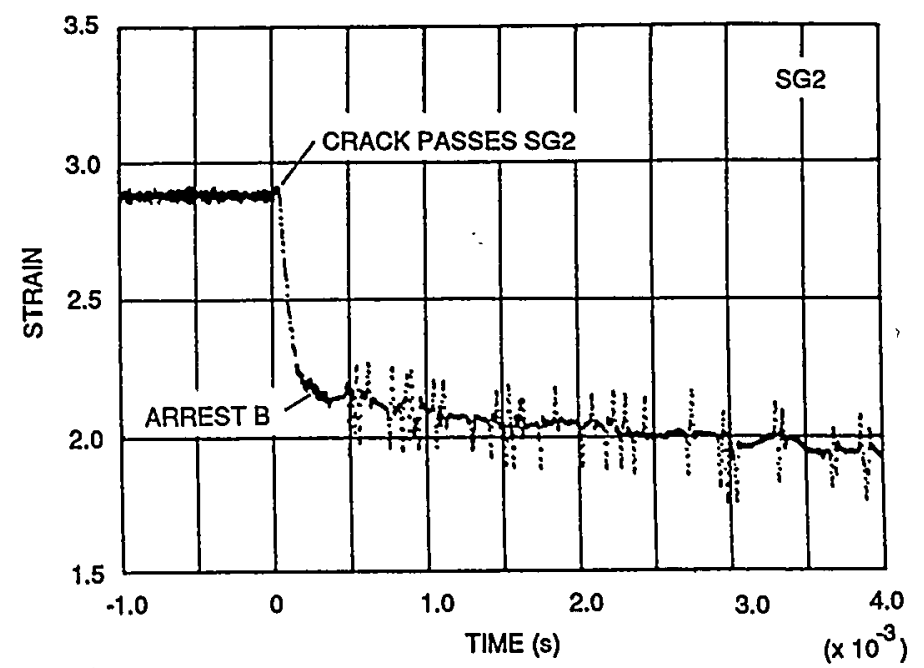

$\left(\times 10^{-3}\right)$

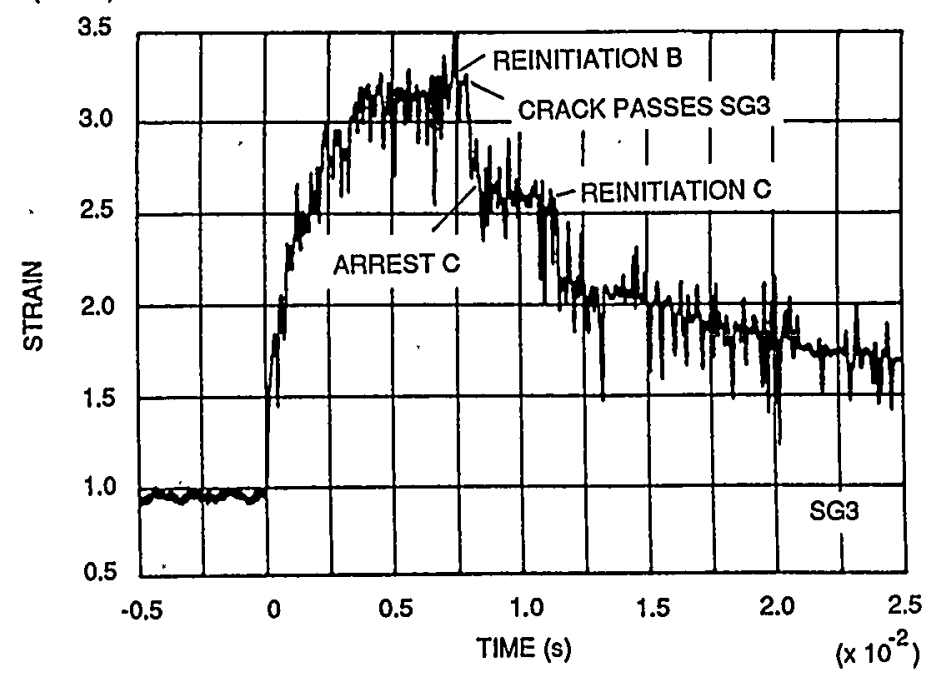

Fig. A.63. Strain histories for front-face gages 1-3, indicating that crack passes gages 1 and 2 and arrests before reaching gage $3(t=0.344 \mathrm{~ms})$ : test WP-2.5. The longer-duration strain history for gage 3 shows reinitiation $(t=7.87 \mathrm{~ms})$ and the crack passing gage $3(t=7.88 \mathrm{~ms})$. 

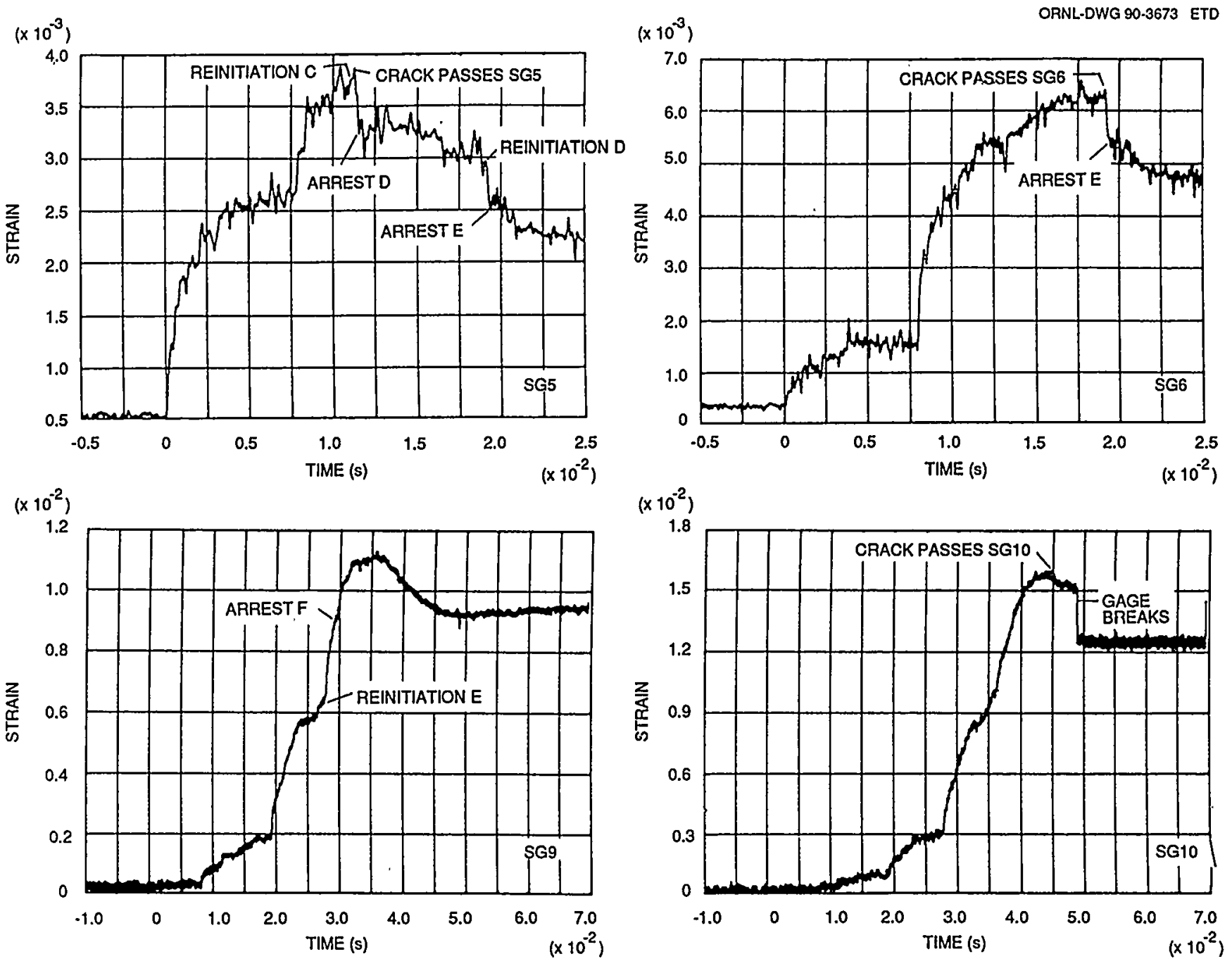

$\left(\times 10^{-2}\right)$

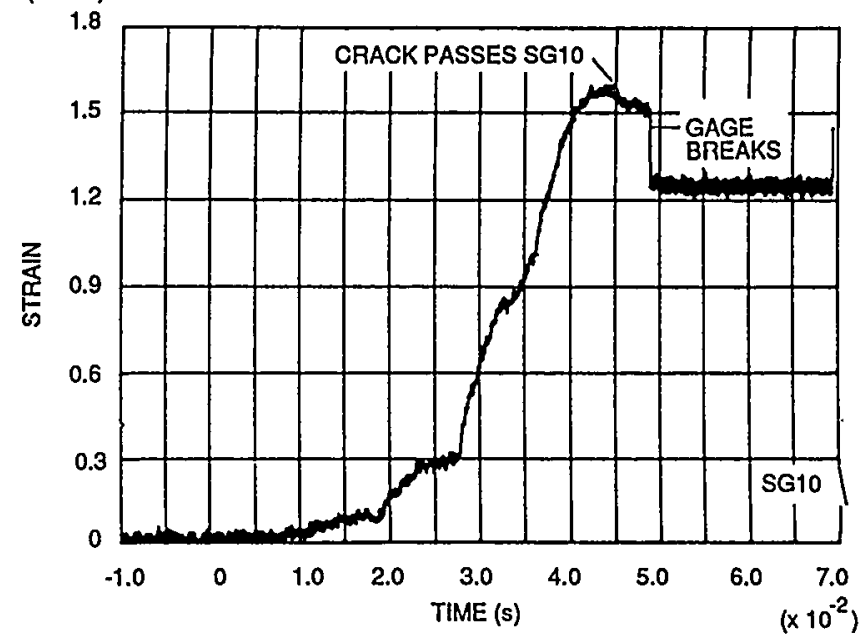

Fig. A.64. Strain histories for front-face gages $5,6,9$, and 10 indicating multiple crack run-arrest events (see Table 5.6): test WP-2.5. 
$\left(\times 10^{-3}\right)$

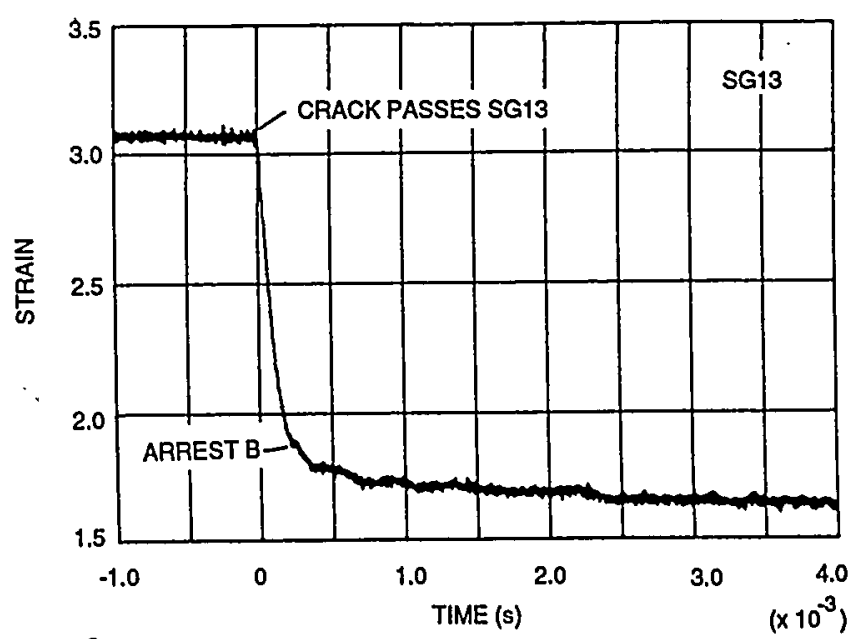

$\left(\times 10^{-3}\right)$

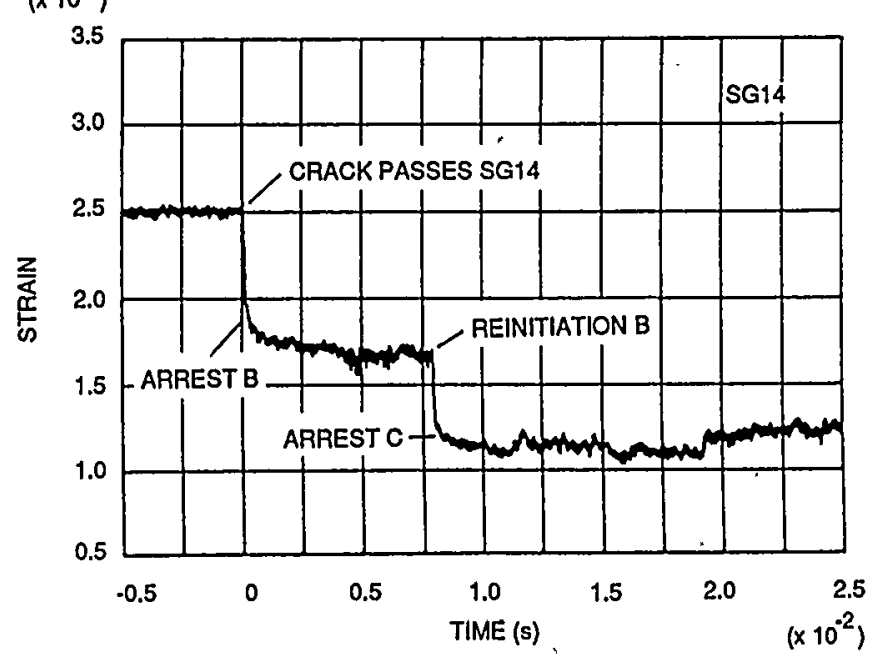

$\left(\times 10^{-3}\right)$

ORNL-DWG $90-3674$ ETD

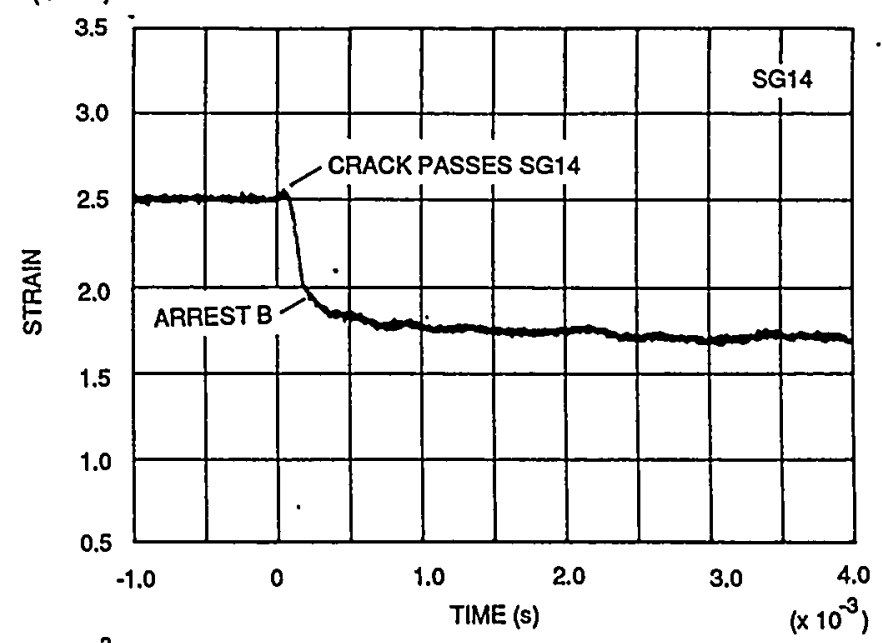

$\left(\times 10^{-3}\right)$

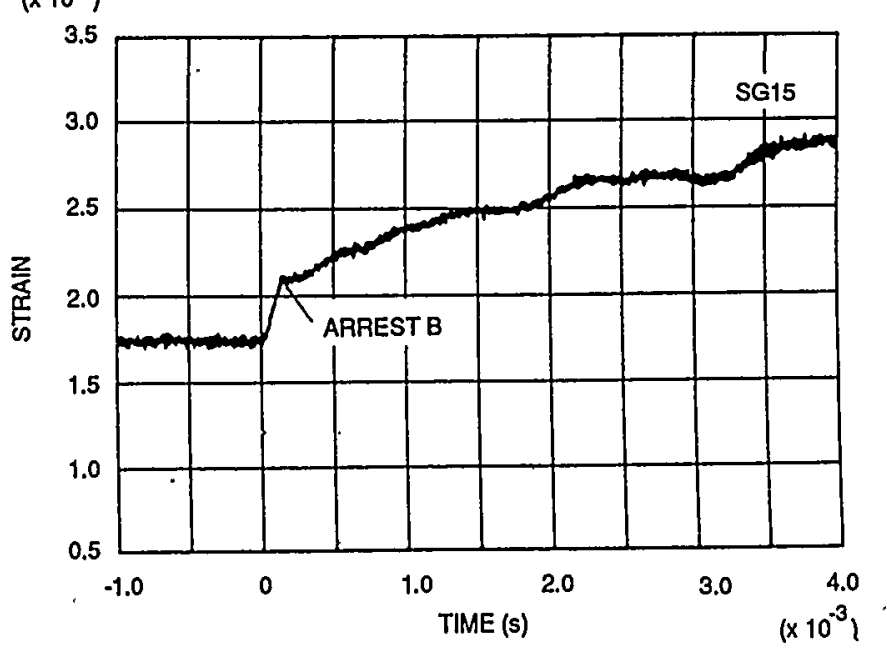

Fig. A.65. Strain histories for back-face gages $13-15$ indicating that crack passes gages 13 and 14 with a subsequent arrest $(t=0.54 \mathrm{~ms}$ ) before reaching gage 15: test WP-2.5. 

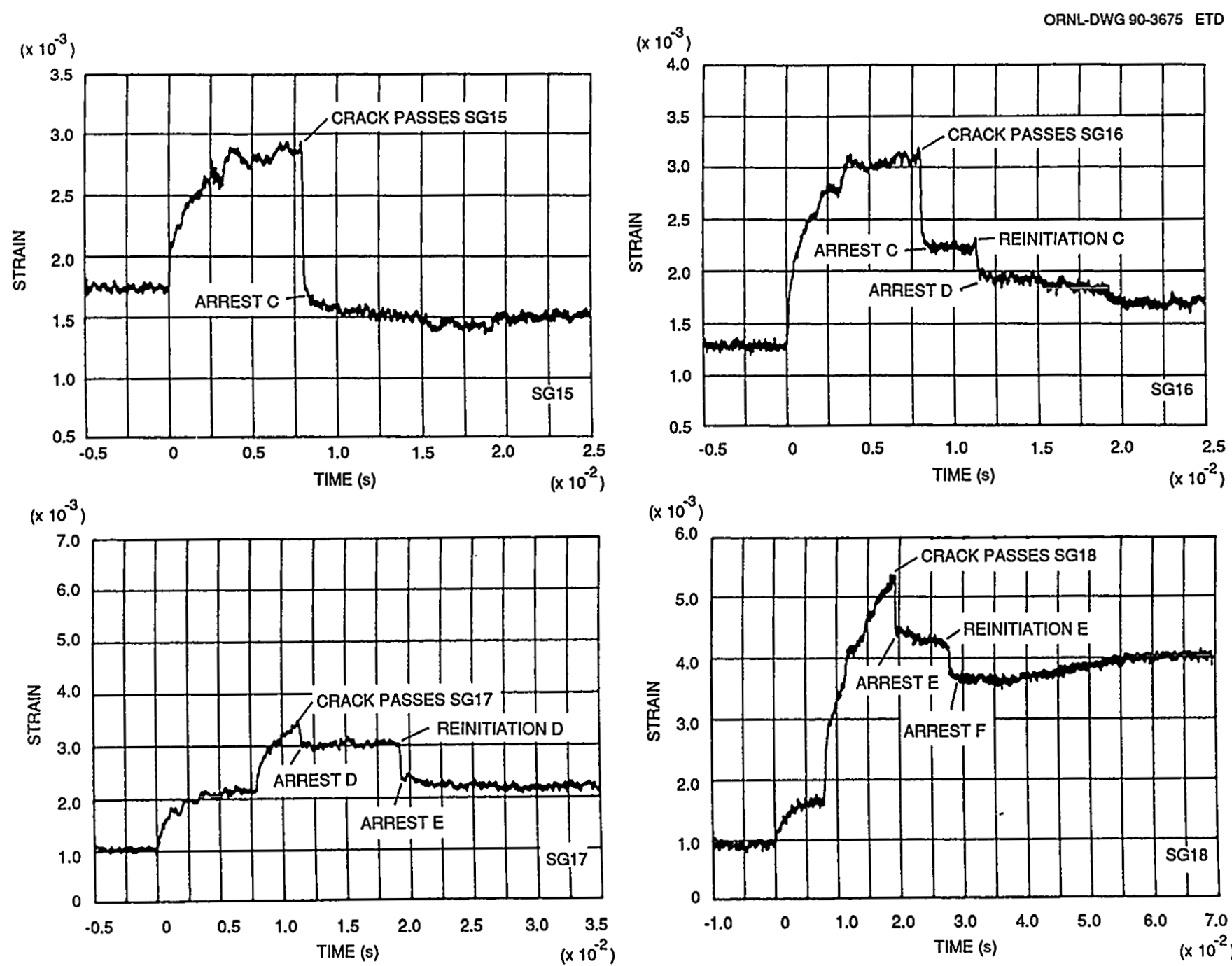

$\left(\times 10^{-3}\right)$

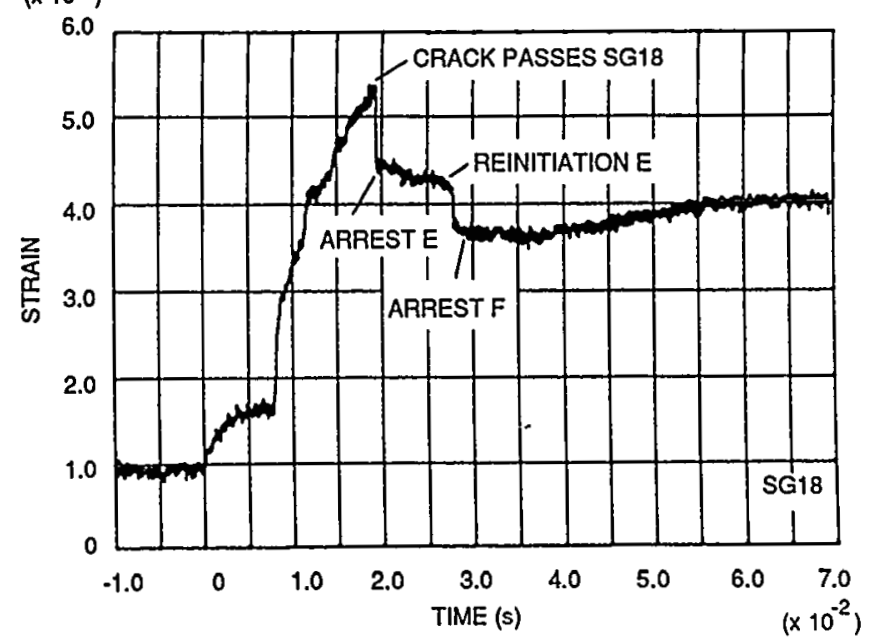

Fig. A.66. Strain histories for back-face gages 15-18, indicating that crack passes gages 15 and 16 , arrests $(t=8.16 \mathrm{~ms})$ before reaching gage 17 , reinitiates $(t=11.16 \mathrm{~ms})$, passes under gage 17 , arrests $(t=$ $11.49 \mathrm{~ms}$ ) before reaching gage 18 , reinitiates ( $t=19.11 \mathrm{~ms}$ ), and then passes under gage 18: test WP-2.5. 

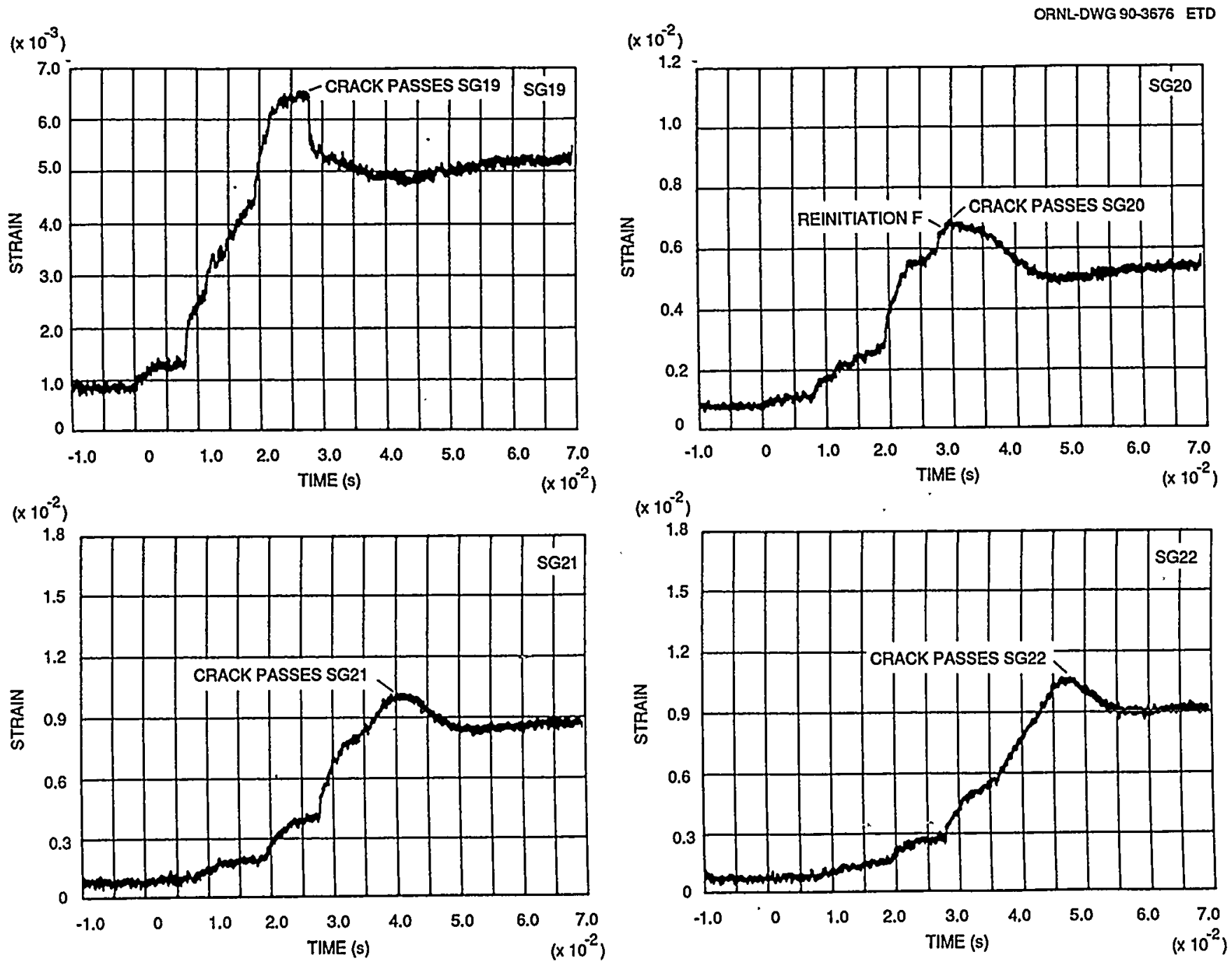

Fig. A.67. Strain histories for back-face gages 19-22 showing crack passing gage 19 , arresting ( $t=27.95 \mathrm{~ms}$ ), converting to fibrous tearing, and then passing under gages 20-22: test WP-2.5. 
reinitiation of crack propagation at $t=7.90 \mathrm{~ms}$. Strain histories for gages 15-18, shown in Fig. A.66, indicate that the crack passes gages 15 and 16 , arrests $(t=8.16 \mathrm{~ms})$, reinitiates $(t=11.16 \mathrm{~ms})$, passes under gage 17, arrests $(t=11.49 \mathrm{~ms})$ before reaching gage 18 , reinitiates $(t=19.11 \mathrm{~ms})$, and then passes under gage 18. Figure A.67 shows the crack passing strain gage 19 , arresting $(t=27.95 \mathrm{~ms})$, converting to fibrous tearing, and then passing under strain gages 20-22.

\section{A.5.2 Additional Instrumentation}

Longitudinal accelerations recorded by "damped" accelerometers mounted $3.911 \mathrm{~m}$ above (top) and $3.934 \mathrm{~m}$ below (bottom) the crack plane during the first crack run-arrest event are shown in Fig. A.68. Frontand back-face COD results obtained from gages located at $a / w=0.150$ are presented in Fig. A.69 (note that the first $15 \mathrm{~ms}$ of the fracture event was not recorded because of an error in the selection of triggering parameters for the gages).

\section{A.6 TEST WP-2.6}

\section{A.6.1 Strain Gages}

Figures A.70 to A.72 present strain histories for the front-face crack-1ine gages. (Gage locations are presented in Fig. 4.9.) Propagation of the cleavage crack past gages 1-4 with arrest of crack propagation just past gage 4 is shown in Fig. A.70. Also noted in the figure presenting the strain history of gage 4 is that a total of five crack run-arrest events occurred within $\sim 4 \mathrm{~ms}$ of initiation. Examination of the strain histories for gages 5-8 (Fig. A.71) shows two additional crack run-arrest events. Strain histories for gages 9-12 (Fig. A.72) indicate fibrous crack propagation past these gages with the gages breaking as the crack approaches and passes because of high strain levels.

Strain histories for the back-face crack-line gages are presented in Figs. A.73 and A.74. Note that these gages were rotated $45^{\circ}$ relative to the orientation of the crack-line gages positioned on the plate front face and that when the crack passes one of these gages the strain generally passes through zero. Figure A.73 shows the crack initiating near gage 13, with gage output being initially negative because the crack had been past this gage as a result of crack growth during the warmprestressing phase. Also shown in Fig. A.73 is crack propagation past gages 14-16. Crack propagation past gages $17-20$ is presented in Fig. A.74, with arrests evident by breaks or discontinuities in the strain records.

Figure A.75 presents the strain history for near-field gage 21 at two levels of time resolution. Complete separation of the plate is indicated by a leveling off of the strain output, which occurs $\sim 34.5 \mathrm{~ms}$ after initiation. Far-field strain histories for gages 22-25 are presented in Fig. A.76. 

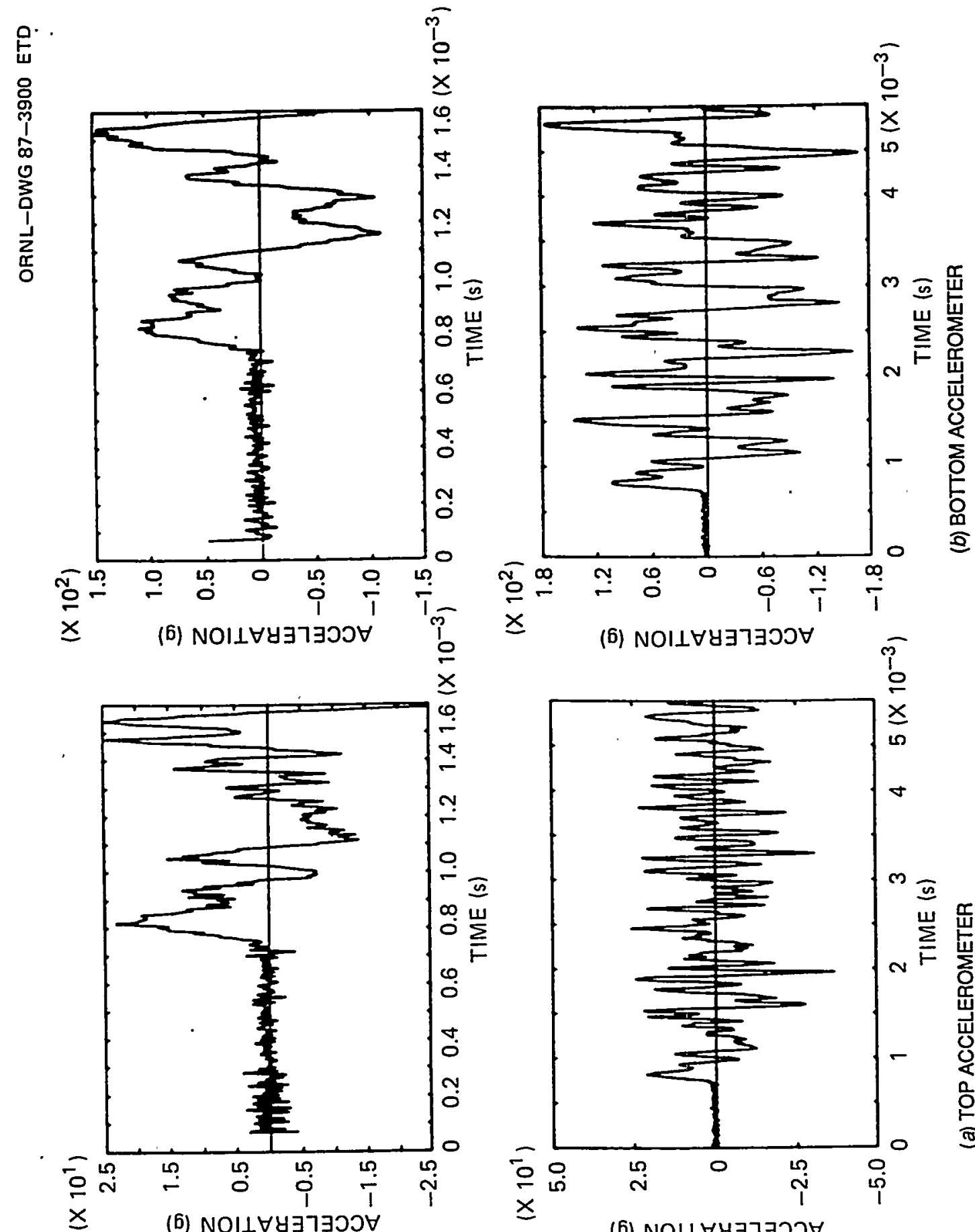

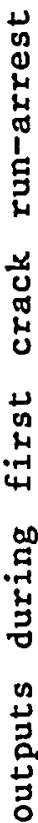

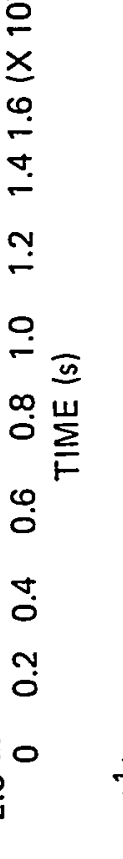

(5) NOIL $\forall 8 \exists า \exists ว ว \forall$

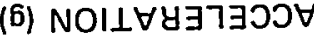

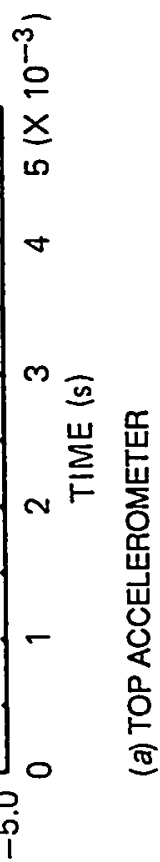

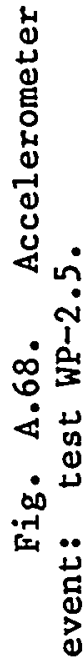

음

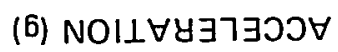



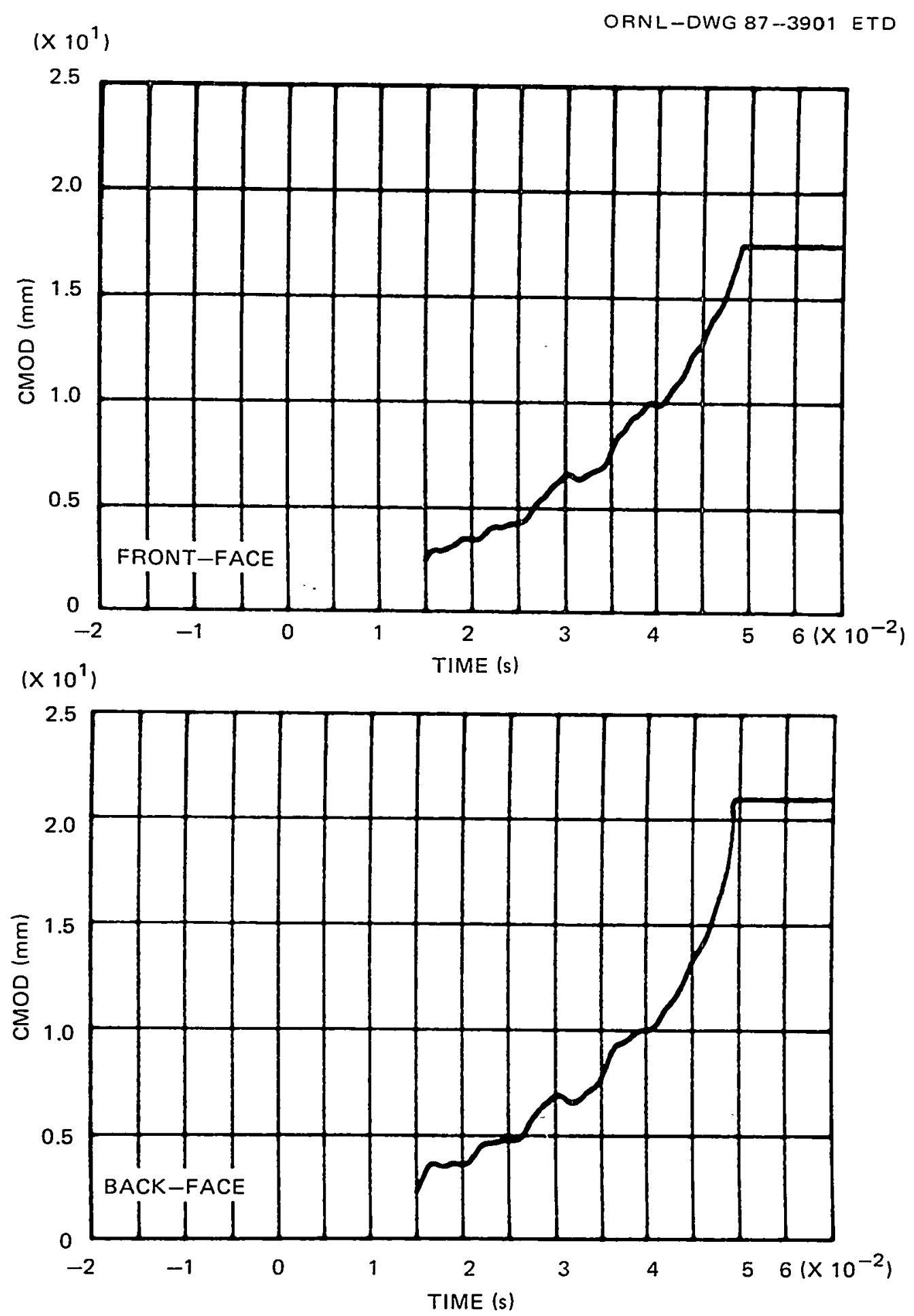

Fig. A.69. Front- and back-face CODs during the fracture event: test WP-2.5. 

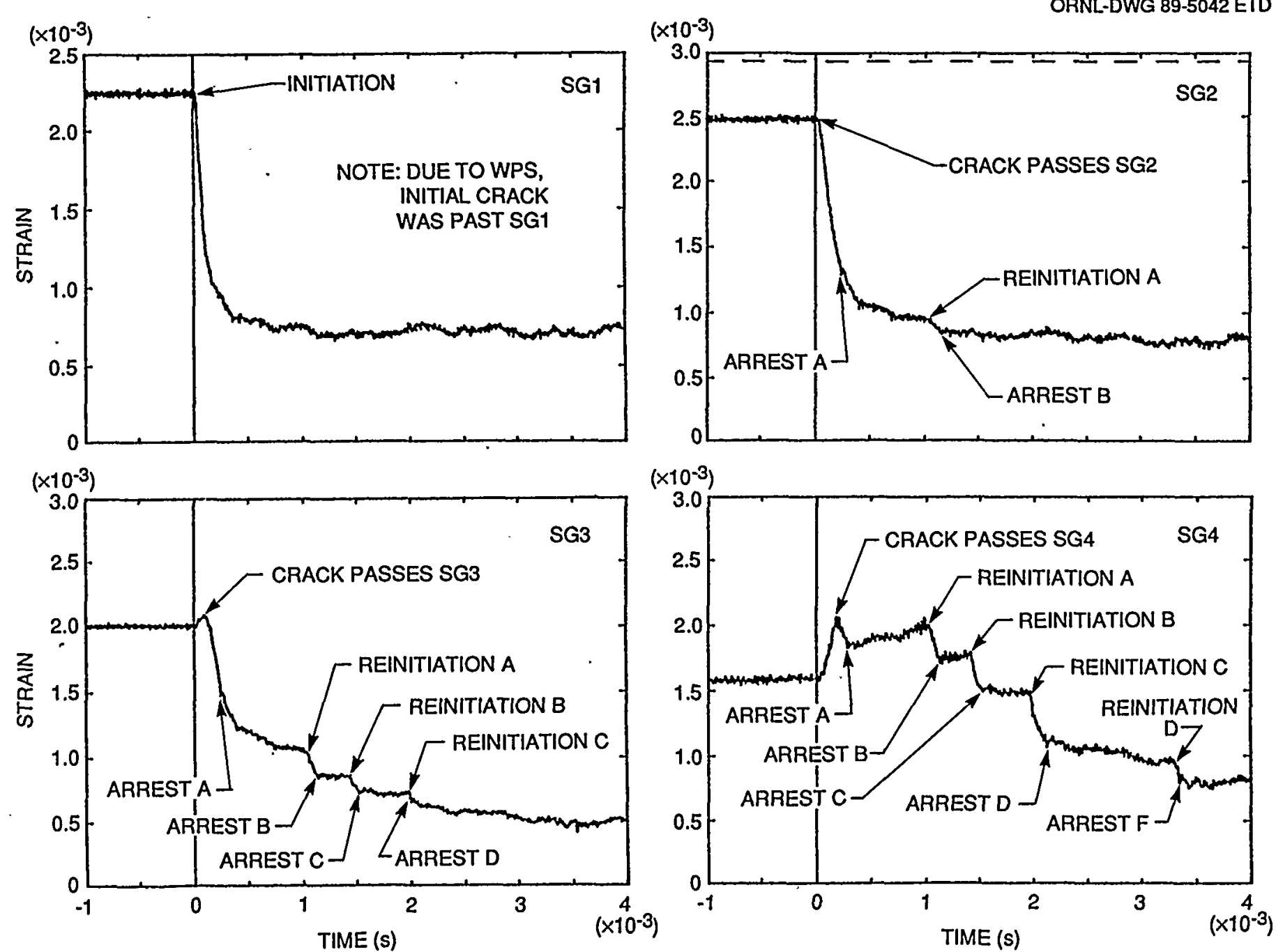

Fig. A.70. Strain histories for front-face crack-line gages: test WP-2.6 (gages 1-4). 
ORNL-DWG 89-5043 ETD
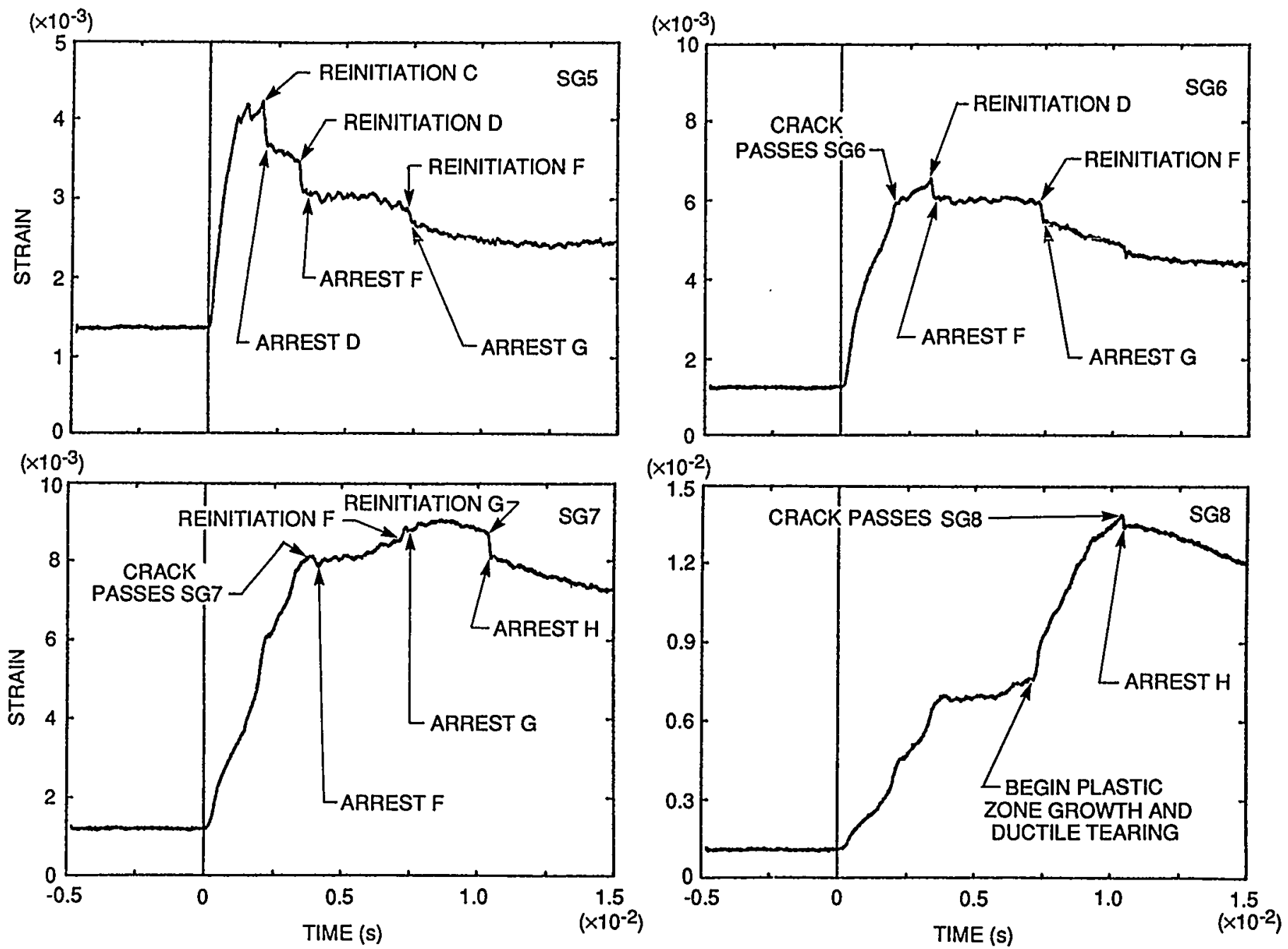

Fig. A.71. Strain histories for front-face crack-1ine gages: test WP-2.6 (gages 5-8). 
ORNL-DWG 89-5044 ETD
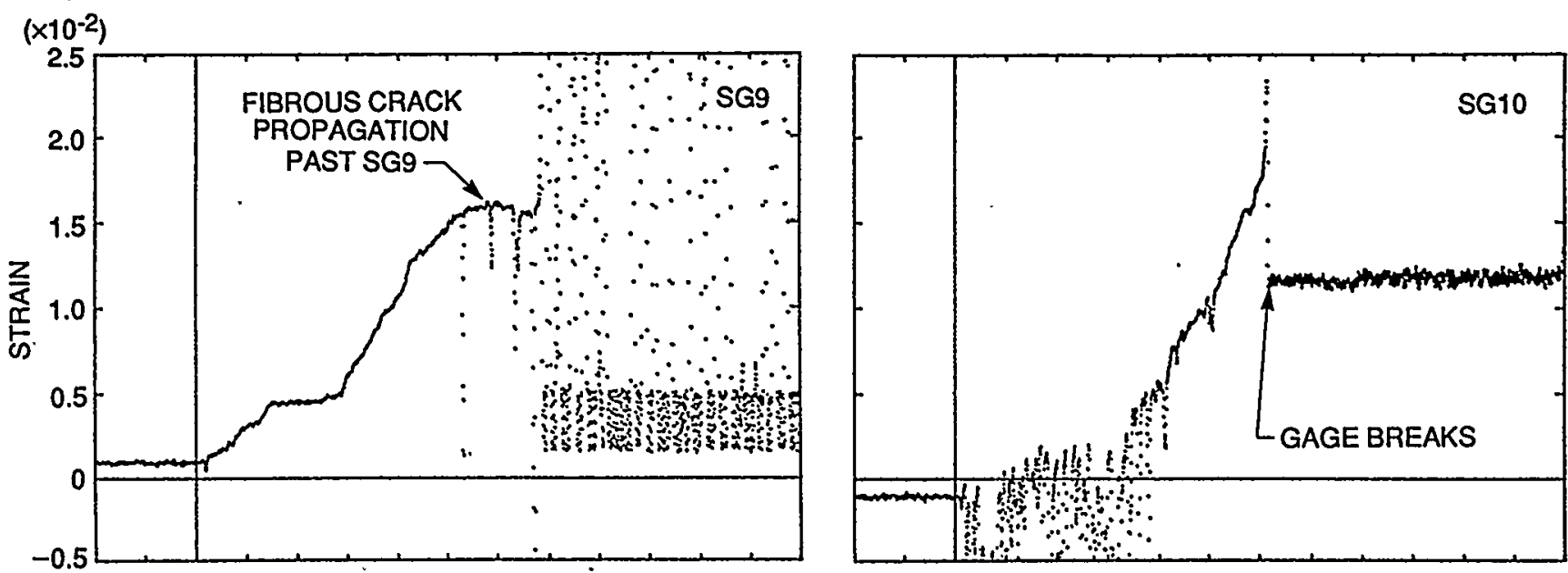

$\left(\times 10^{-2}\right)$
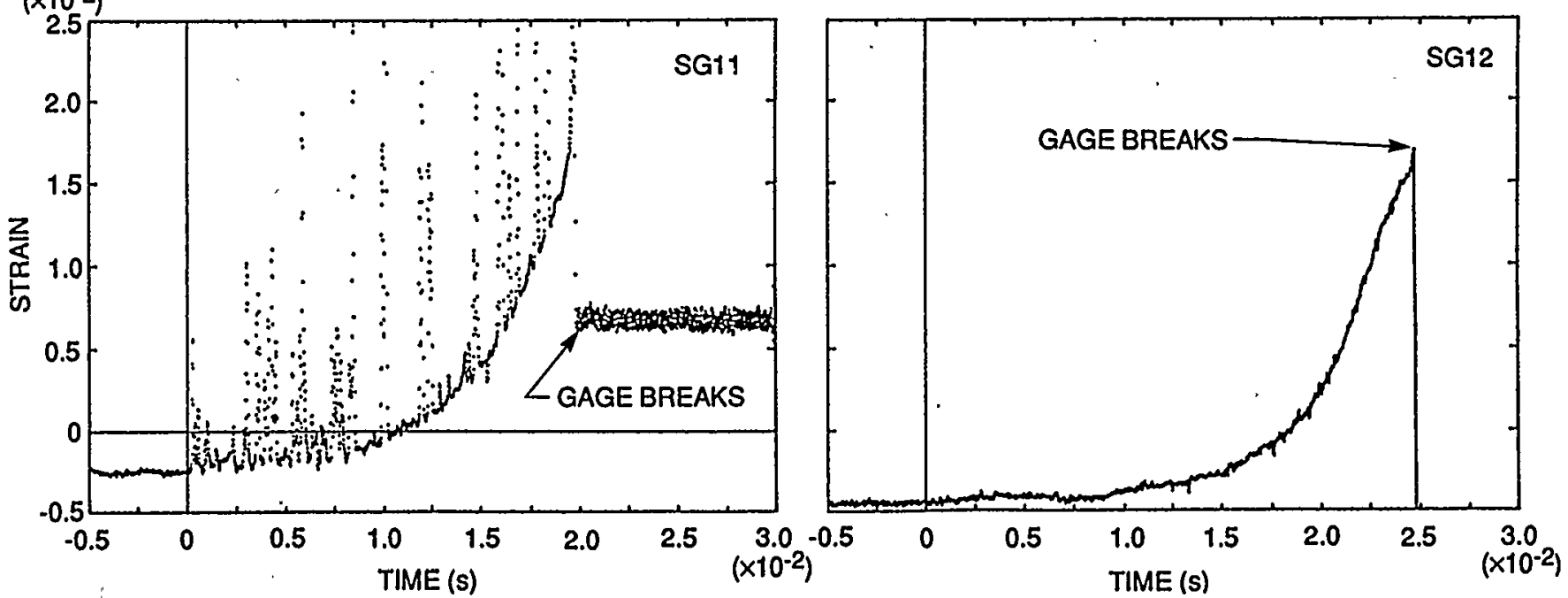

Fig. A.72. Strain histories for front-face crack-1ine gages: test WP-2.6 (gages 9-12). 
ORNL-DWG 89-5045 ETD

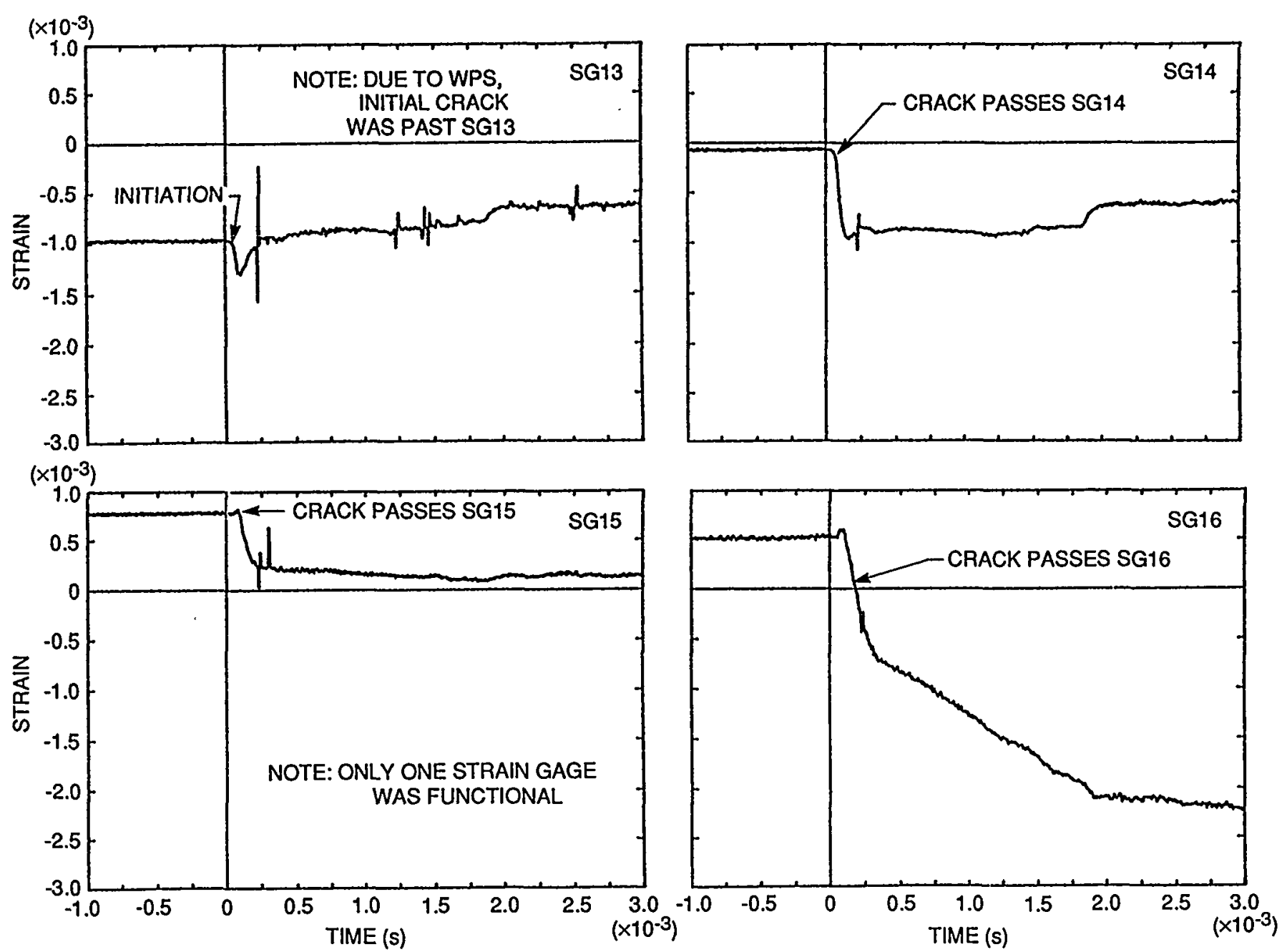

Fig. A.73. Strain histories for back-face crack-line gages: test WP-2.6 (gages 13-16). 

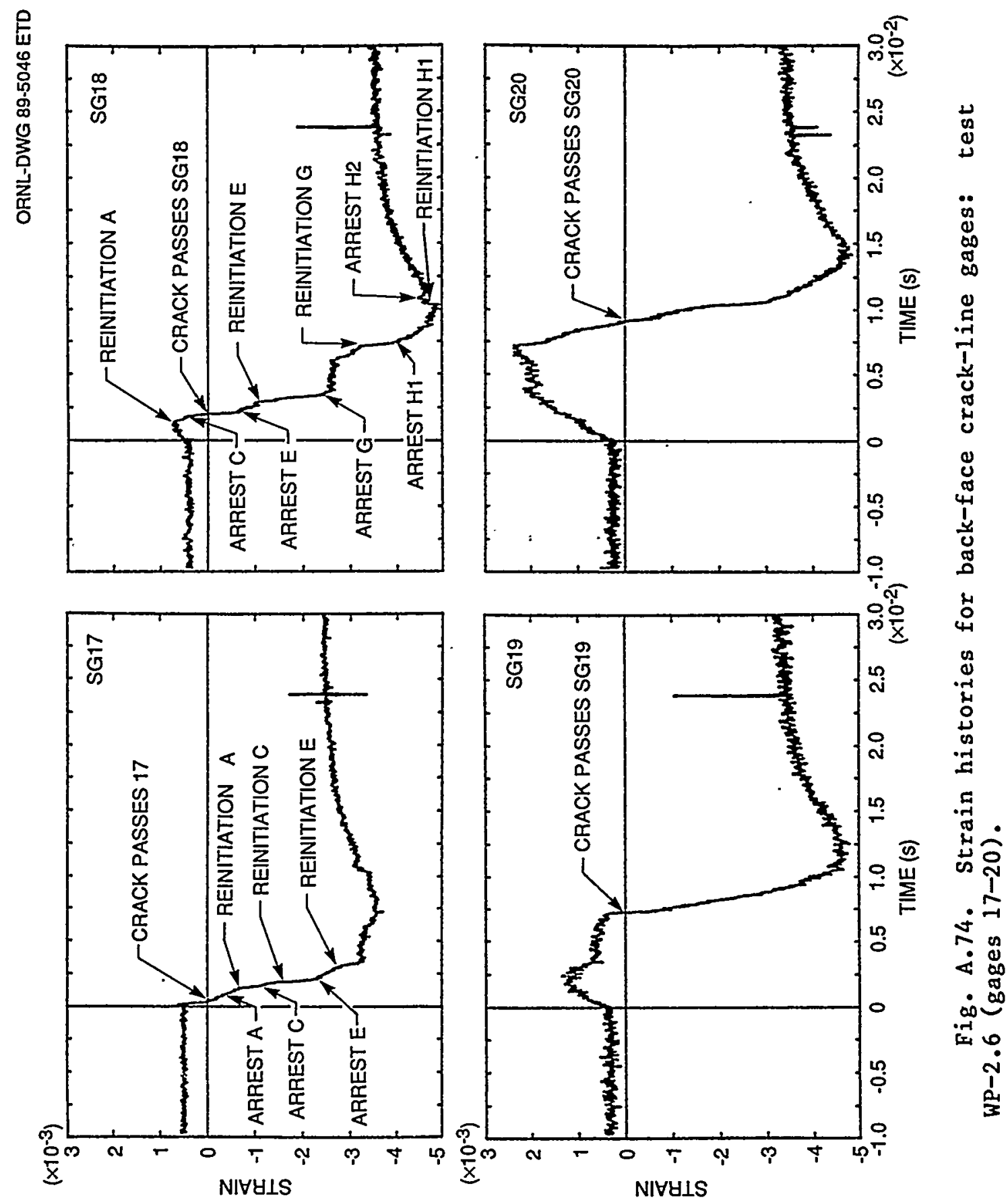

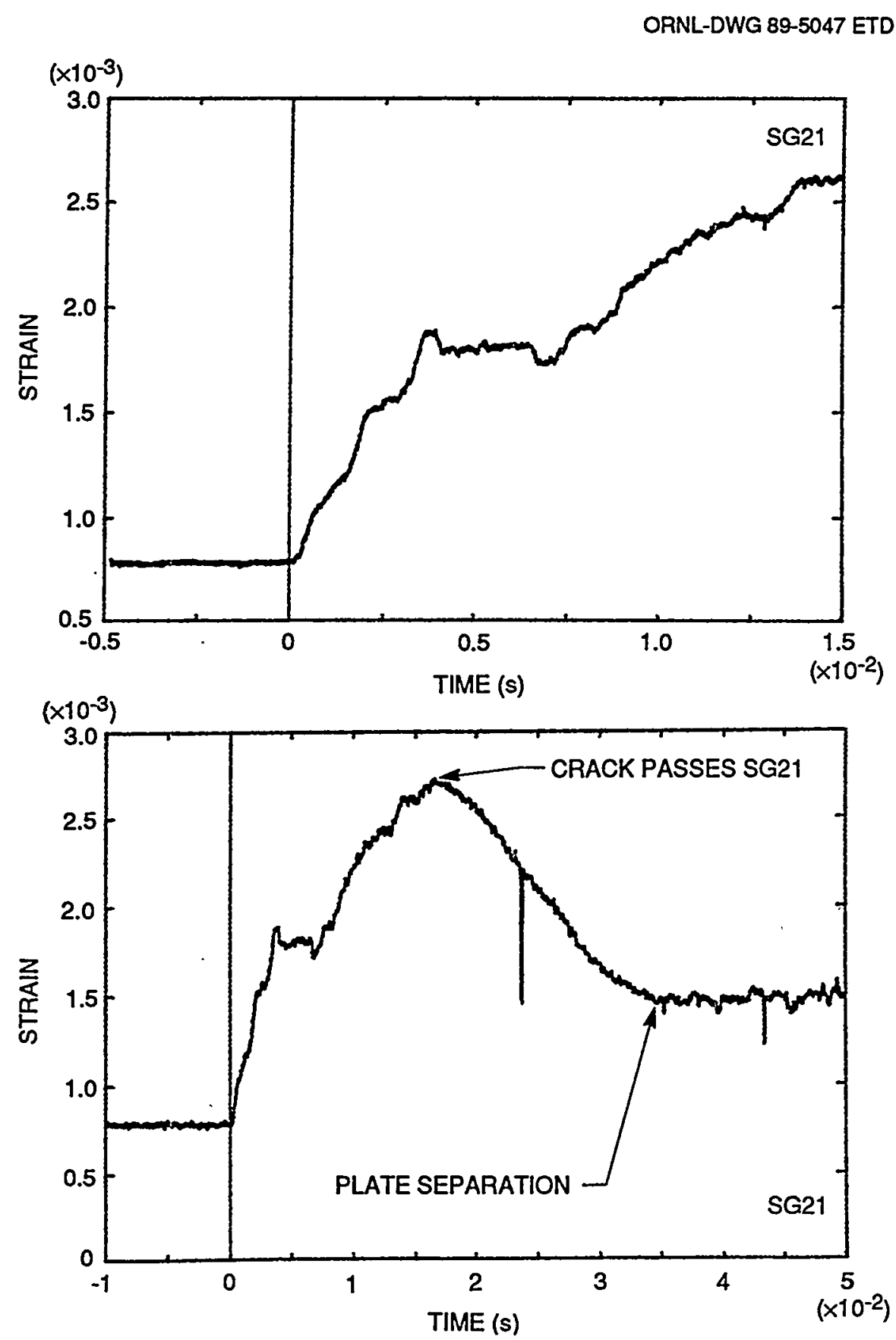

Fig. A.75. Strain history for near-field gage 21 at two time resolutions: test WP-2.6. 

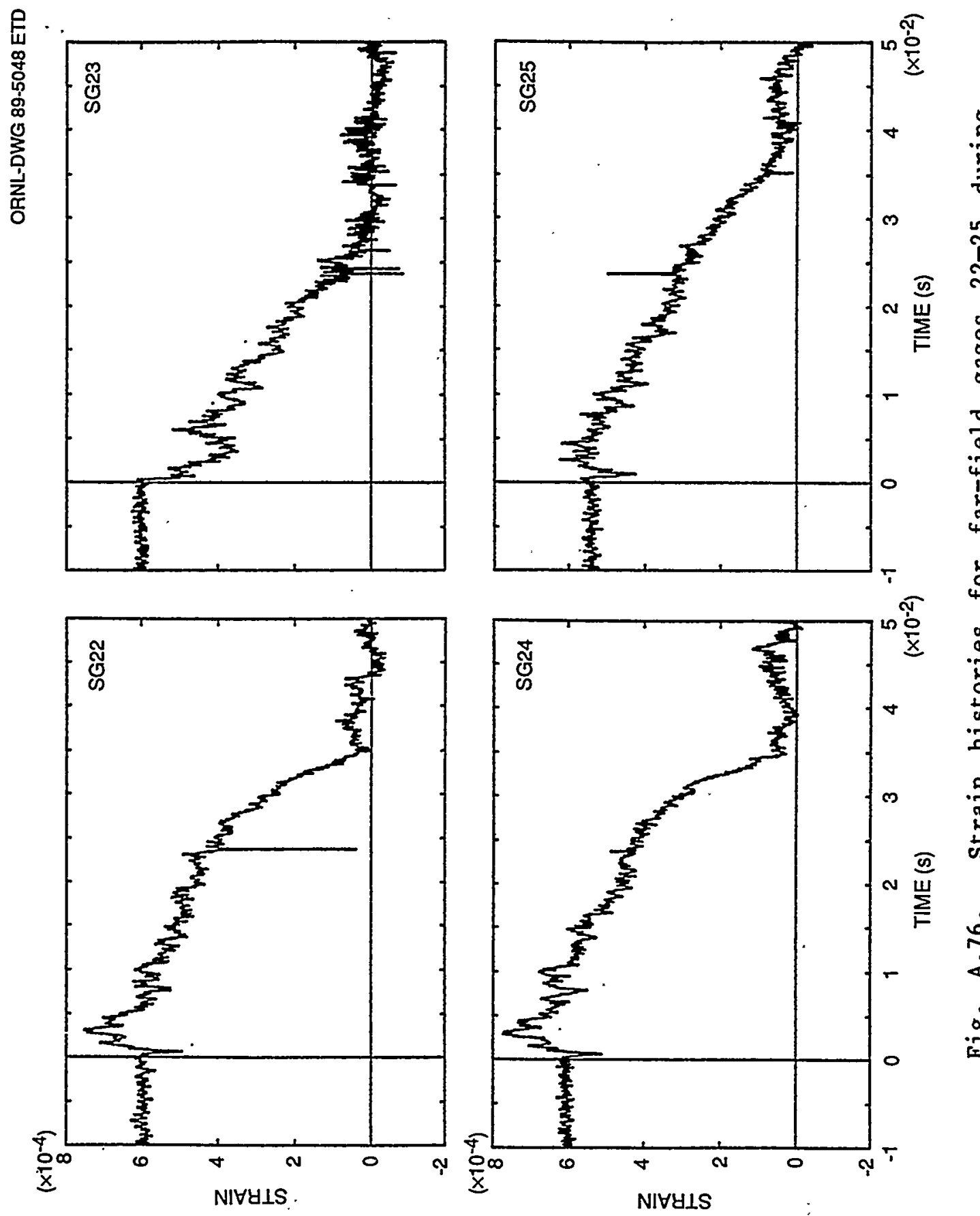

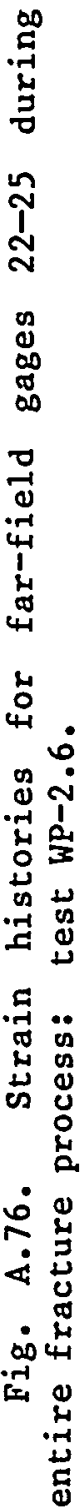




\section{A.6.2 Additional Instrumentation}

Front- and back-face COD histories at two time resolutions are presented in Fig. A.77. Longitudinal accelerations recorded by "damped" accelerometers mounted on the specimen's centerline $3.491 \mathrm{~m}$ above (top) and $3.398 \mathrm{~m}$ below (bottom) the crack plane are presented in Fig. A.78. Dynamic displacement of the specimen, relative to that of the large columns of the testing machine, as measured $3.393 \mathrm{~m}$ below the crack plane, is presented in Fig. A.79 at two time scales. 

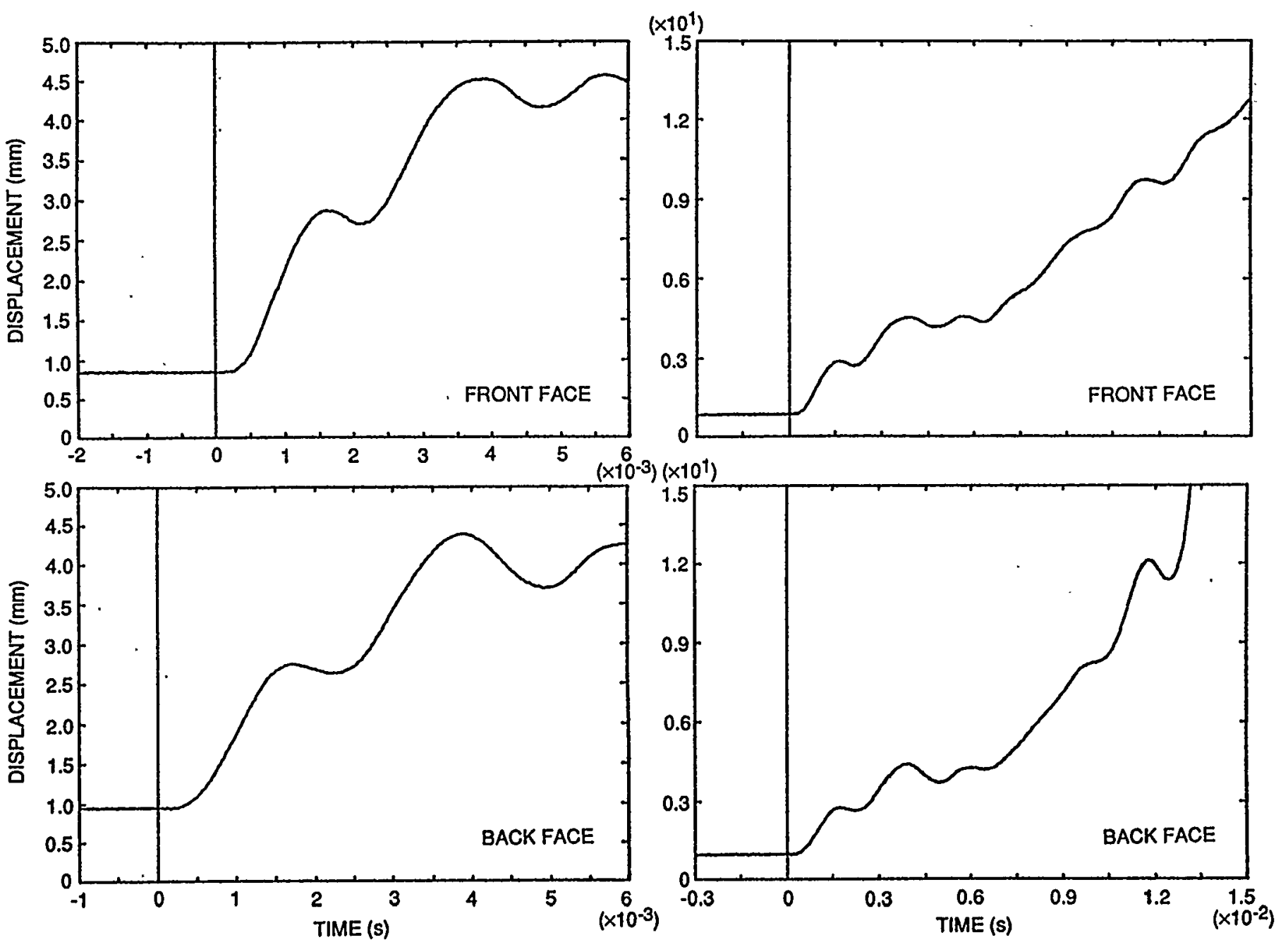

Fig. A.77. Front- and back-face COD histories at two time resolutions: test WP-2.6. 


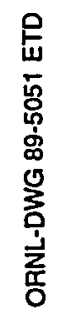
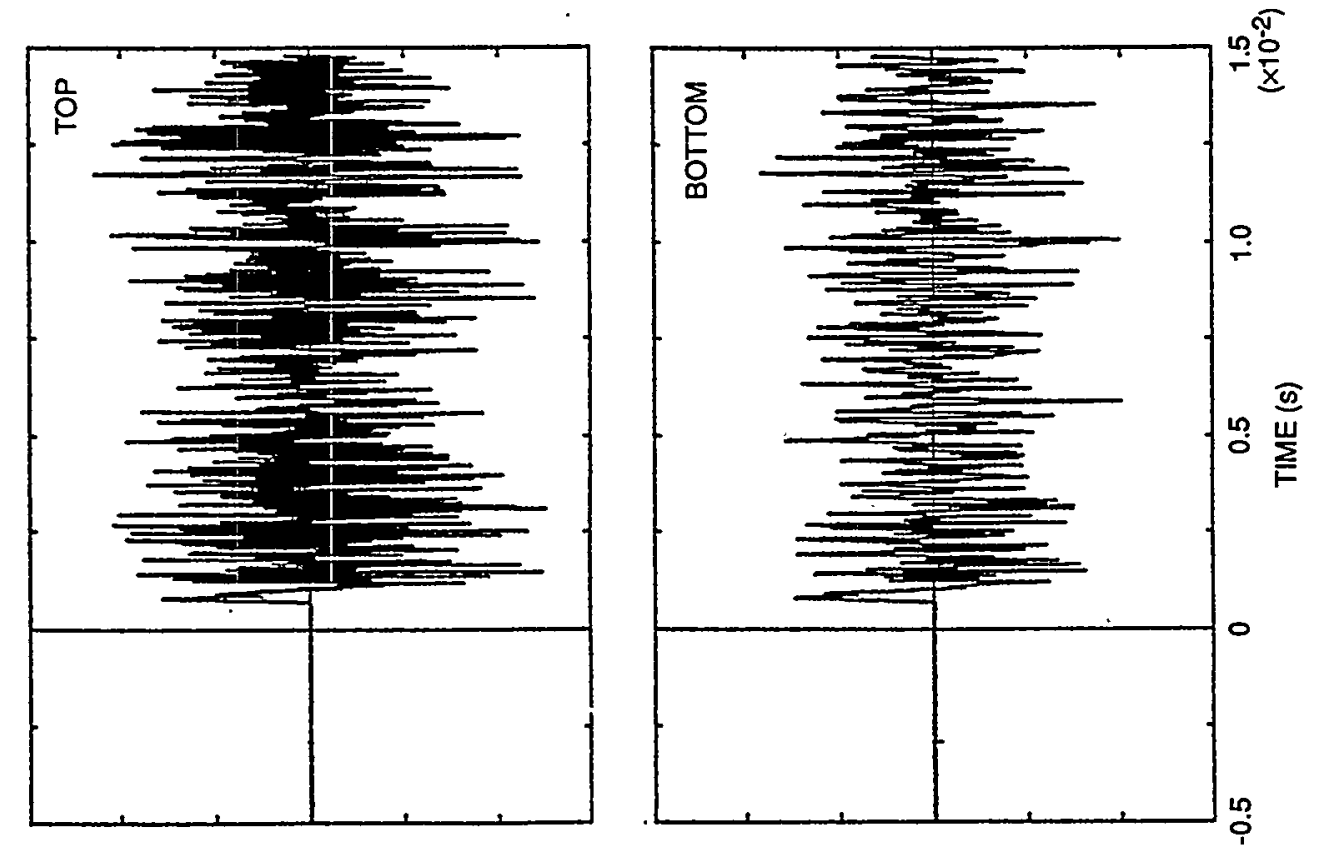

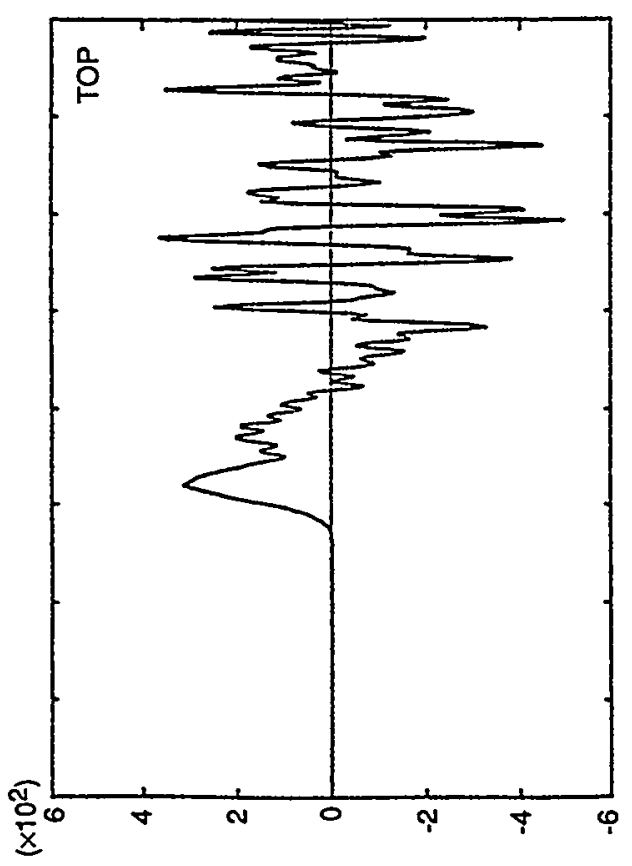

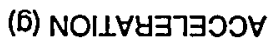

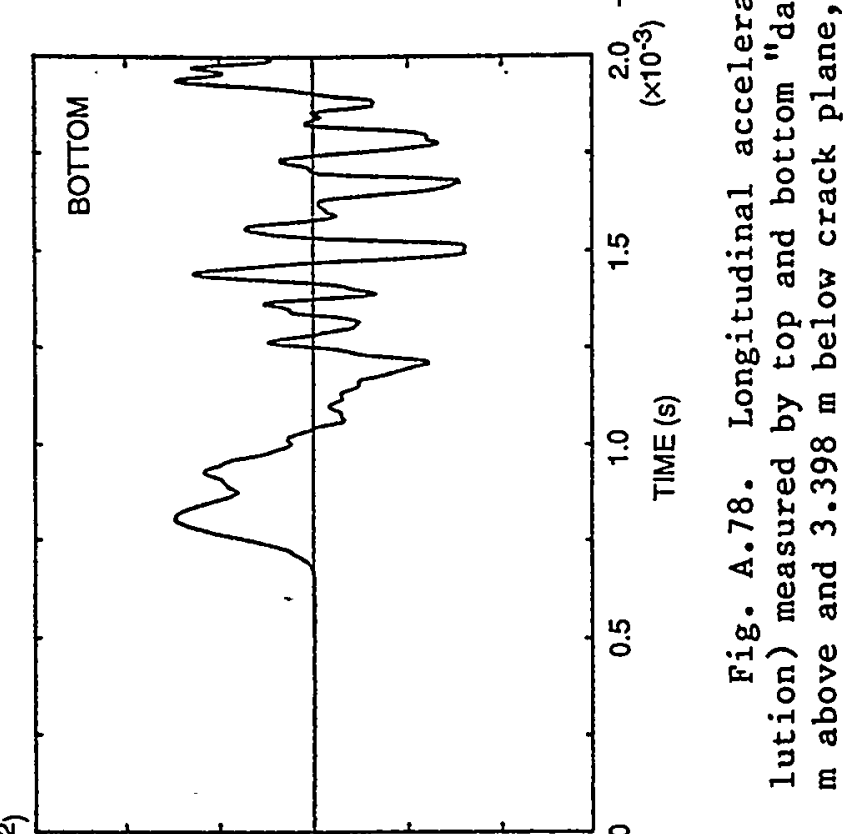

$\begin{array}{ll}1 & -1 \\ 0 & 0 \\ 0 & 0\end{array}$

斗

出苨

I

㟧首则

为点㟔

品

光

일

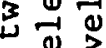

幽导苔

$=$ a

ธี

-

ह

㟧

要

造

$\pi x$

$\rightarrow$ 잉

\%

ปี

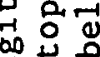

이

\%

$\infty \stackrel{0}{\circ}$

Фै

ह

政

戛

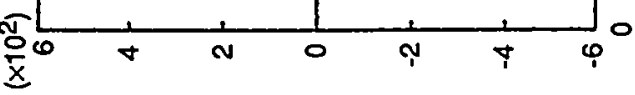

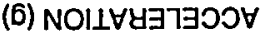




\section{$239 / 240$}

ORNL-DWG 89-5052 ETD
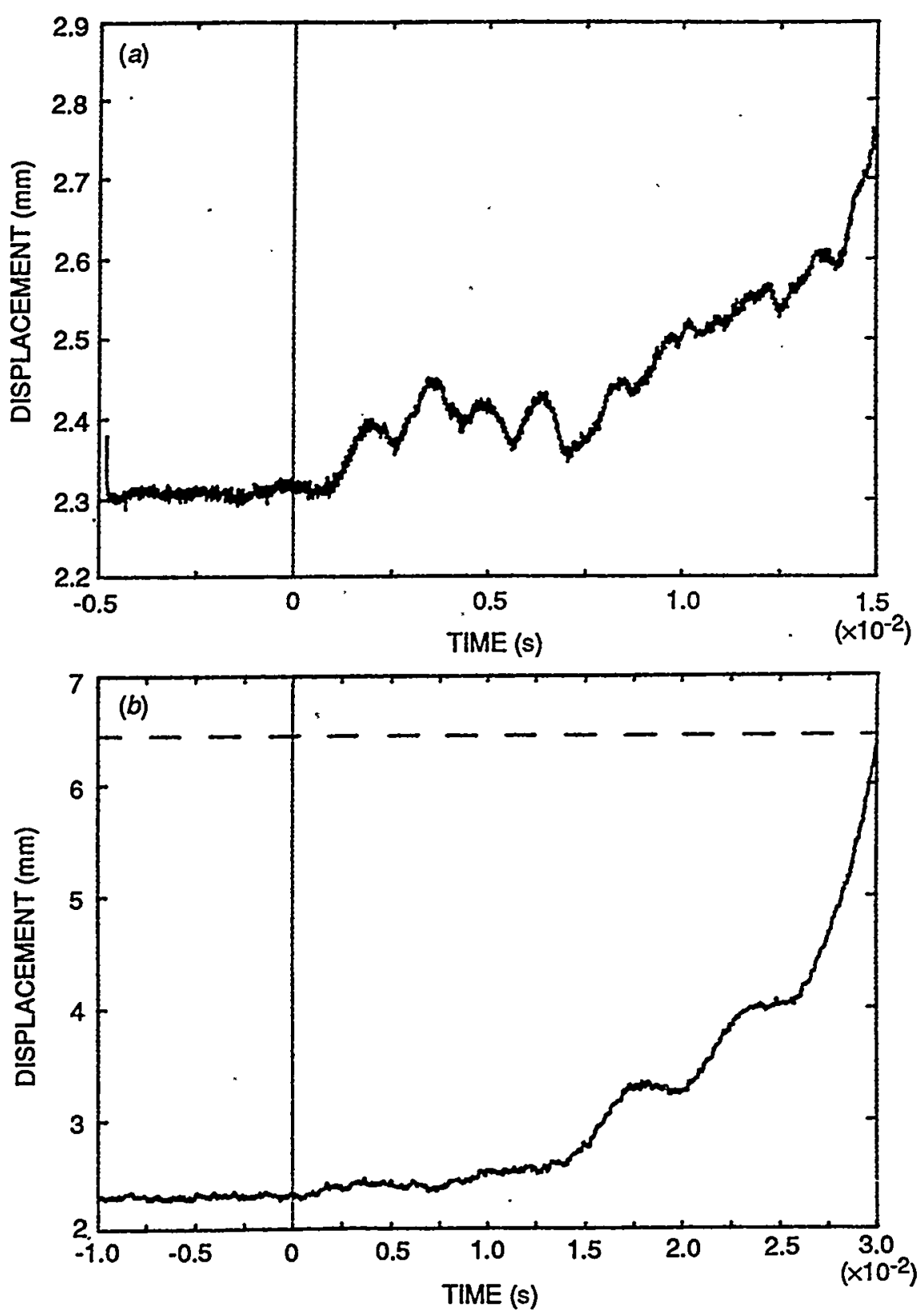

Fig. A.79. Dynamic displacement history at two levels of time resolution of a point $3.393 \mathrm{~m}$ below the crack plane during (a) cleavage crack run-arrest events and (b) entire fracture: test WP-2.6. 


\section{Appendix B \\ EFFECTS OF LOAD-POINT BOUNDARY CONDITIONS \\ AND ANALYSIS METHOD ON WIDE-PLATE \\ CRACK-ARREST TEST RESULTS}

\section{B.1 EFFECT OF LOAD-POINT BOUNDARY CONDITION}

Long-duration (7- to 10-ms and longer) viscoplastic analyses of the wide-plate geometry will be influenced significantly by the boundary conditions imposed at the specimen load points. The two limiting cases for the load point are a fixed-load boundary condition, in which the specimen is free to stretch axially during the analysis, or a fixeddisplacement boundary condition. In the fixed-displacement case, the effective axial load decreases with time as the test specimen compliance increases during crack advance.

A series of generation-mode analyses based on data measured during test WP-2.4 were conducted to investigate the influence of the loadpoint boundary conditions. All analyses were performed using the linearly elastic dynamic fracture code SAMCR (Ref. 1) and were carried out for $40 \mathrm{~ms}$ of specimen response. During this response duration, seven crack jumps were observed in the test. The computed $\mathrm{K}$ values for each fracture event are summarized in Table B.1.

Figure B.1 compares the computed $K$ vs time values for the two limiting cases of fixed-load and fixed-displacement boundary conditions. The two analyses produced identical results for the first millisecond of response. After $\sim 10$ to $15 \mathrm{~ms}$ of response, the two cases begin to diverge significantly; at $40 \mathrm{~ms}$, the fixed-load $\mathrm{K}$ value was $75 \%$ greater than the corresponding value for the fixed-displacement case. Similar results for the crack-mouth-opening displacement (CMOD) vs time are shown in Fig. B.2 along with the experimentally measured data from the test; in this figure, CMOD is defined as one-half of the total symmetric crack separation. Again, significant differences between the fixed-load and fixed-displacement cases appear only after $15 \mathrm{~ms}$ of response. The computed CMOD values begin to diverge from the experimentally measured data at $\sim 10 \mathrm{~ms}$; at $40 \mathrm{~ms}$ the measured data are several times larger than the largest computed values. Recalling that the analyses assumed linearly elastic constitutive behavior, the deviations between the measured and computed CMOD values are most likely the result of plastic yielding in the test.

Although the fixed-load and fixed-displacement boundary conditions represent the upper and lower limits for the dynamic response of the specimen (assuming linear behavior), the true boundary condition for the test specimen is most probably somewhere between. There will be inertial coupling between the specimen and the test frame because of the stiffness and effective mass of the test frame at the load point. To define the actual boundary conditions during the test, accelerometers were placed near the load points of the specimen in test WP-2.4. Two types of accelerometers were installed: damped and undamped. The records from the undamped accelerometers were unfortunately plagued by a 


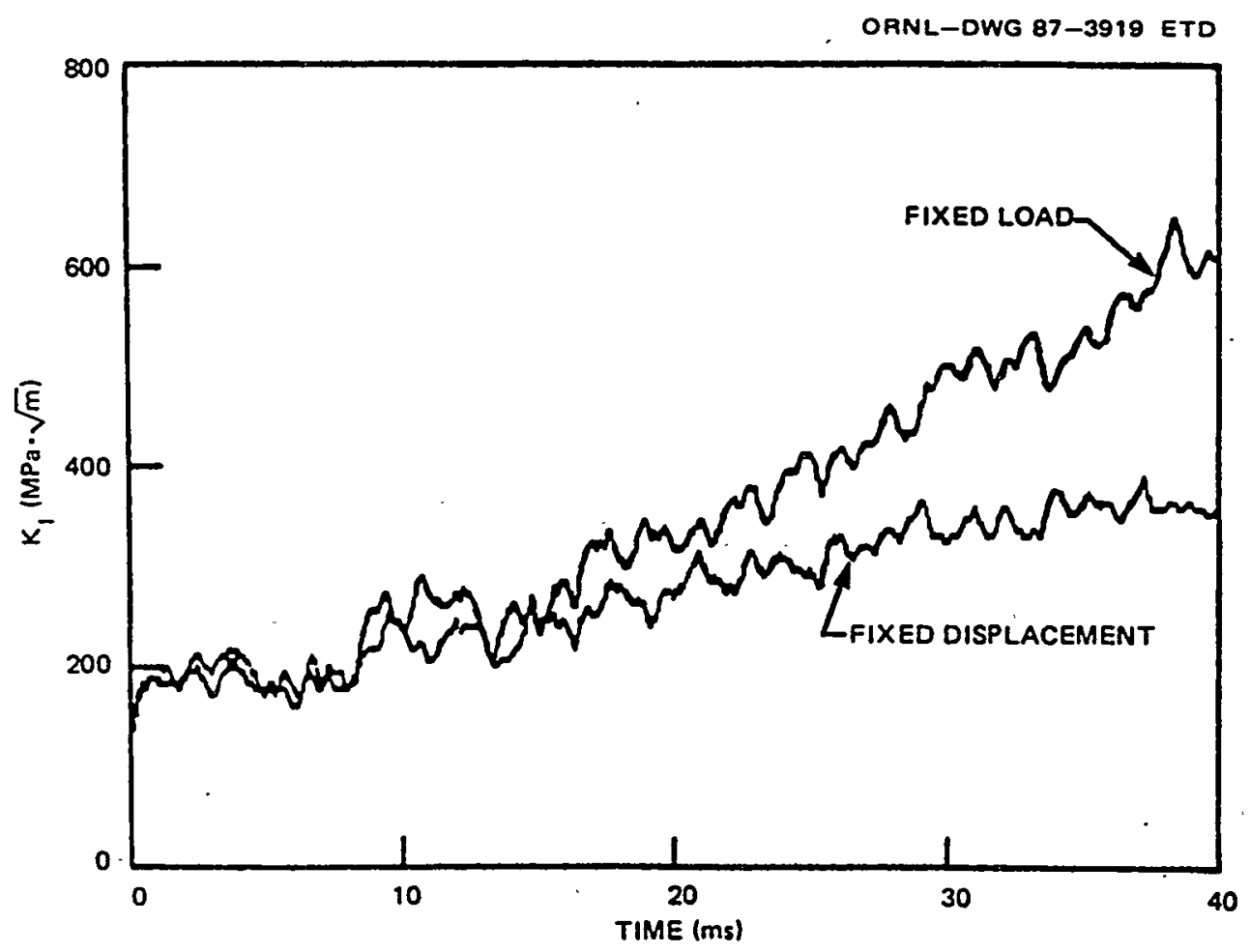

Fig. B.1. K vs time results from linear generation-mode analyses: test WP-2.4.

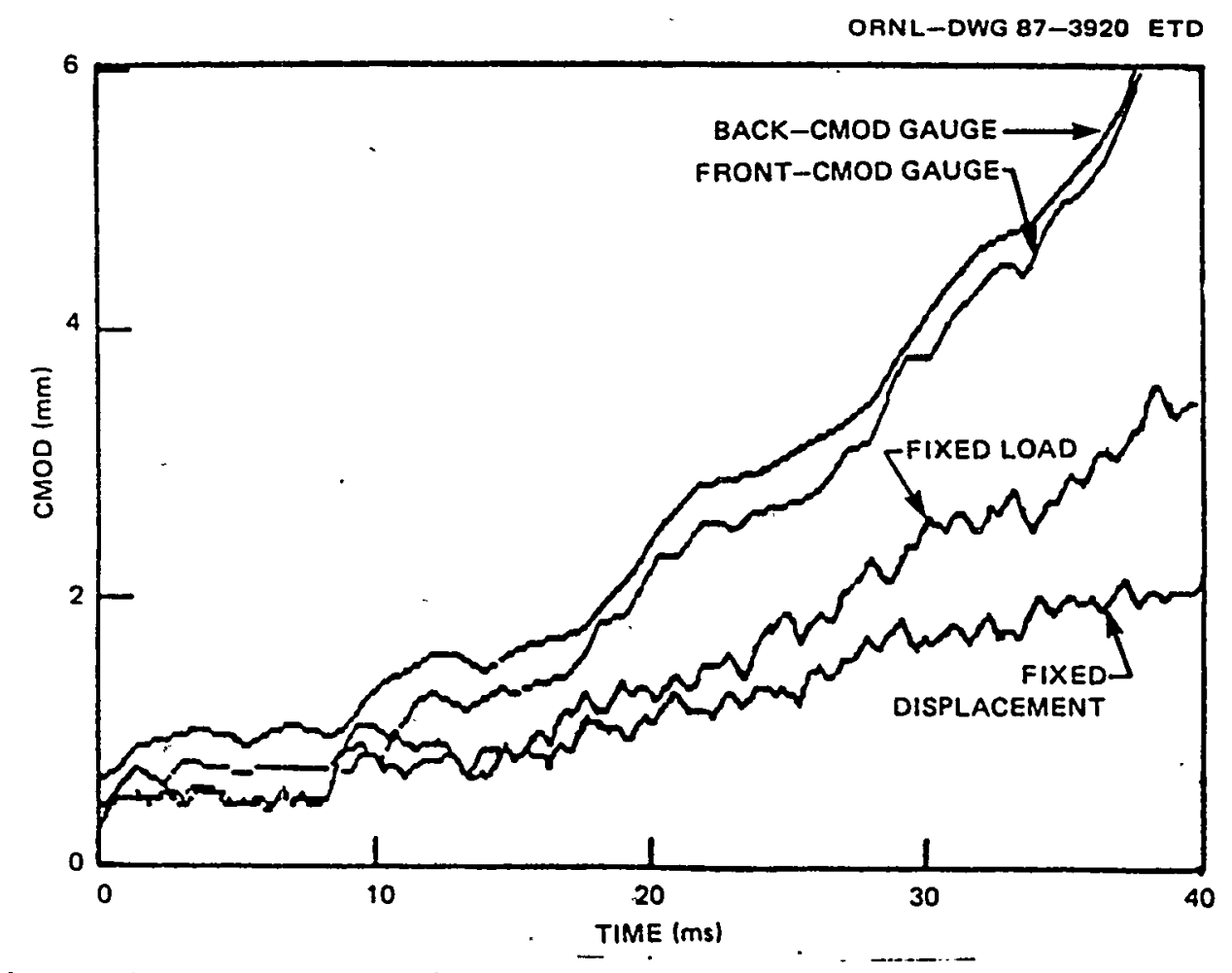

Fig. B.2. CMOD from linear generation-mode analyses: test WP-2.4. 
Table B.1. Summary of computed results for test WP-2.4

\begin{tabular}{|c|c|c|c|c|c|}
\hline \multirow{3}{*}{ Event } & \multirow{3}{*}{$\begin{array}{l}\text { Time } \\
\text { (ms) }\end{array}$} & \multirow{3}{*}{$\stackrel{A}{(m)}$} & \multicolumn{3}{|c|}{$\mathrm{K}(\mathrm{MPa} \cdot \sqrt{\mathrm{m}})$} \\
\hline & & & \multirow{2}{*}{$\begin{array}{c}\text { Fixed } \\
\text { displacement }\end{array}$} & \multicolumn{2}{|c|}{ Fixed load } \\
\hline & & & & No mass & Lumped mass \\
\hline Initiation & 0.0 & 0.250 & 152.2 & 152.2 & 152.2 \\
\hline $\begin{array}{l}\text { First arrest } \\
\text { Reinitiation }\end{array}$ & $\begin{array}{l}0.190 \\
8.121\end{array}$ & $\begin{array}{l}0.334 \\
0.334\end{array}$ & $\begin{array}{l}145.9 \\
190.2\end{array}$ & $\begin{array}{l}145.9 \\
185.7\end{array}$ & $\begin{array}{l}156.2^{a} \\
214.4\end{array}$ \\
\hline $\begin{array}{l}\text { Second arrest } \\
\text { Reinitiation }\end{array}$ & $\begin{array}{r}8.350 \\
15.160\end{array}$ & $\begin{array}{l}0.408 \\
0.408\end{array}$ & $\begin{array}{l}187.9 \\
247.4\end{array}$ & $\begin{array}{r}193.3 \\
242.2\end{array}$ & $\begin{array}{l}207.8 \\
273.7\end{array}$ \\
\hline $\begin{array}{l}\text { Third arrest } \\
\text { Reinitiation }\end{array}$ & $\begin{array}{l}15.990 \\
17.180\end{array}$ & $\begin{array}{l}0.421 \\
0.421\end{array}$ & $\begin{array}{l}239.4 \\
257.4\end{array}$ & $\begin{array}{l}283.7 \\
326.2\end{array}$ & $\begin{array}{l}266.5 \\
302.2\end{array}$ \\
\hline $\begin{array}{l}\text { Fourth arrest } \\
\text { Reinitiation }\end{array}$ & $\begin{array}{l}17.420 \\
18.550\end{array}$ & $\begin{array}{l}0.468 \\
0.468\end{array}$ & $\begin{array}{l}263.9 \\
261.8\end{array}$ & $\begin{array}{l}320.4 \\
317.5\end{array}$ & $\begin{array}{l}296.2 \\
301.1\end{array}$ \\
\hline $\begin{array}{l}\text { Fifth arrest } \\
\text { Reinitiation }\end{array}$ & $\begin{array}{l}20.390 \\
23.440\end{array}$ & $\begin{array}{l}0.487 \\
0.487\end{array}$ & $\begin{array}{l}279.2 \\
296.9\end{array}$ & $\begin{array}{l}321.3 \\
347.6\end{array}$ & $\begin{array}{l}328.7 \\
367.7\end{array}$ \\
\hline $\begin{array}{l}\text { Sixth arrest } \\
\text { Reinitiation }\end{array}$ & $\begin{array}{l}23.940 \\
26.230\end{array}$ & $\begin{array}{l}0.514 \\
0.514\end{array}$ & $\begin{array}{l}307.0 \\
323.7\end{array}$ & $\begin{array}{l}387.6 \\
414.9\end{array}$ & $\begin{array}{l}372.0 \\
417.4\end{array}$ \\
\hline $\begin{array}{l}\text { Seventh arrest } \\
\text { Reinitiation }\end{array}$ & $\begin{array}{l}27.260 \\
28.860\end{array}$ & $\begin{array}{l}0.555 \\
0.555\end{array}$ & $\begin{array}{l}314.0 \\
352.0\end{array}$ & $\begin{array}{l}422.4 \\
441.2\end{array}$ & $\begin{array}{l}418.2 \\
472.3\end{array}$ \\
\hline
\end{tabular}

${ }^{a}$ Differs from fixed-displacement and fixed-1oad/no-mass values because of minor differences in specification of crack history during first jump.

large amount of high-frequency oscillations that made interpretation difficult; in the damped accelerometers, this high-frequency component is inherently filtered from.the records. Figure B.3 provides the acceleration vs time data measured by the damped accelerometer located at the bottom load point of the specimen. The peak acceleration measured during the test was $\sim 300 \mathrm{~g}$.

Some caution must be exercised in interpreting the data in Fig. B.3, however. Double integration of this acceleration record yields a final load-point displacement of $8 . \mathrm{cm}$ at $40 \mathrm{~ms}$. This unrealistically large value implies an average elastic'stress increase of $>3000 \mathrm{MPa}$ in the specimen; clearly, this cannot occur. The most plausible explanation for this high-displacement prediction is that it includes a large rigid body component; that is, both the top and bottom load points moved in the same direction by approximately the same amount during the test. Unfortunately, an accelerometer record for the top load point is unavailable for verifying this hypothesis. 


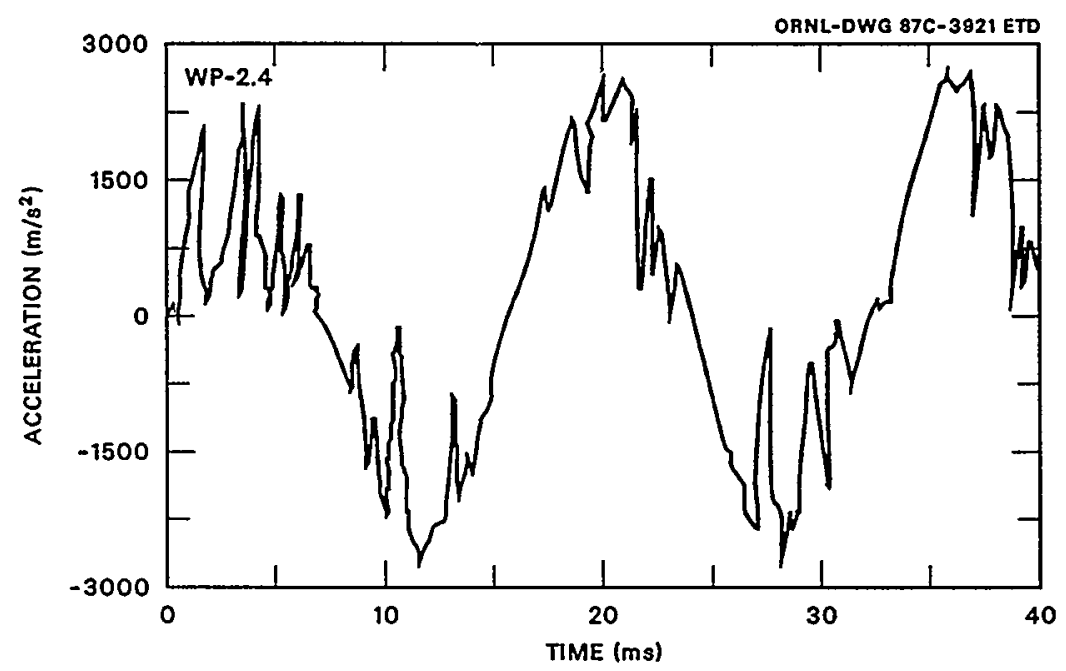

Fig. B.3. Acceleration vs time data measured by "damped" accelerometer near the lower load point: test WP-2.4.

Although the magnitudes of the accelerations and the derived displacements are suspect, the record shown in Fig. B.3 nevertheless contains valuable information regarding the natural periods of the response. Initially, there is an $0.8-\mathrm{s}$ interval during which there is no accelerometer response; this corresponds to the stress wave transit time from the crack plane to the load point. Overall, the accelerometer record suggests that the specimen vibrates in an axial fundamental mode for $\sim 16.5 \mathrm{~ms}$. Superimposed on this global vibration mode is a higherfrequency mode with a period of $\sim 1$ to $2 \mathrm{~ms}$; this again appears to correspond to stress wave reflections within the specimen.

The period of the specimen vibration modes can be used to estimate the inertial coupling between the specimen and the test frame at the load point. As a first approximation, the test frame stiffness and effective mass can be treated as a simple spring and 1 umped mass attached to the load point. The solution for the longitudinal vibration modes for a uniform bar having a supplementary lumped mass and stiffness at its end is given by ${ }^{2}$

$$
\xi_{i} \tan \xi_{i}=\frac{n \zeta_{i}}{\zeta_{i}-n} \text {, }
$$

in which

$$
\begin{aligned}
& \xi_{i}=\frac{\rho_{i} \ell}{V_{L}}, \\
& \eta=\frac{m \ell}{M}, \\
& \zeta_{i}=\frac{m \ell \rho_{i}^{2}}{k},
\end{aligned}
$$


and where

$$
\begin{aligned}
\rho_{i} & =\text { natural frequency for mode } i, \\
m & =\text { mass per unit length of bar, } \\
\dot{\ell} & =\text { length of bar, } \\
V_{L} & =\text { longitudinal, wave velocity for bar, } \\
M & =\text { additional lumped mass at end of bar, } \\
k & =\text { spring constant for additional stiffness at end of bar. }
\end{aligned}
$$

The test frame compliance had been estimated previously ${ }^{3}$ as approximately five times the compliance of the specimen itself. Consequently, little error is introduced by neglecting the test frame stiffness contribution at the load point [i.e., $k=0$ in Eq. (B.1)] and considering only the effective mass from the test frame cross arm. Equation (B.1) can then be solved for the effective mass of the test frame at the load point given the WP-2.4 test geometry and the measured fundamental period of $16.5 \mathrm{~ms}$, yielding a value of $27,100 \mathrm{~kg}$ for the effective mass.

The fixed-1oad generation-mode analysis for test WP-2.4 was repeated with this additional $27,100-\mathrm{kg}$ mass at the load point. As before, linearly elastic constitutive behavior was assumed for the specimen, and the analysis was performed for $40 \mathrm{~ms}$ of specimen response. Comparisons between the fixed-load analyses with and without the additional lumped effective mass for the test frame are given in Fig. B.4 for $K$ vs time, Fig. B.5 for CMOD vs time, and Fig. B.6 for load-point axial displacement vs time. As is clearly shown in all three figures, the differences in the computed results between the two cases are negligible.

Unfortunately, the accelerations computed in the analyses cannot be directly compared with the measured accelerometer data. The computed nodal accelerations vs time at the accelerometer location are plotted in Fig. B.7. The computed accelerations are characterized by a very high level of high-frequency oscillations; no low-frequency periodicity can be detected in the computed record, and the peak accelerations are nearly four times the corresponding measured values. It is believed that these features of the computed accelerations are spurious products of the numerical algorithms employed in the finite-element code.

At the load point, the large added lumped mass severely damps the computed nodal accelerations, as shown in Fig. B.8. The computed peak acceleration at the load point is substantially lower than the peak value measured in the test, and any low-frequency periodicity is masked by the comparatively large amplitude high-frequency vibration modes. The period of this high-frequency vibration is on the order of 1 to $2 \mathrm{~ms}$, which matches closely the period of the high-frequency component in the measured accelerometer response. Low-frequency periodicity is evident in the velocity vs time record for the load point, as shown in Fig. B.9; it is also evident to a lesser extent in the load-point displacement record shown previously in Fig. B.6. The period of this lowfrequency component is $\sim 20 \mathrm{~ms}$, which is close to the target period of $16.5 \mathrm{~ms}$ measured during the test. 


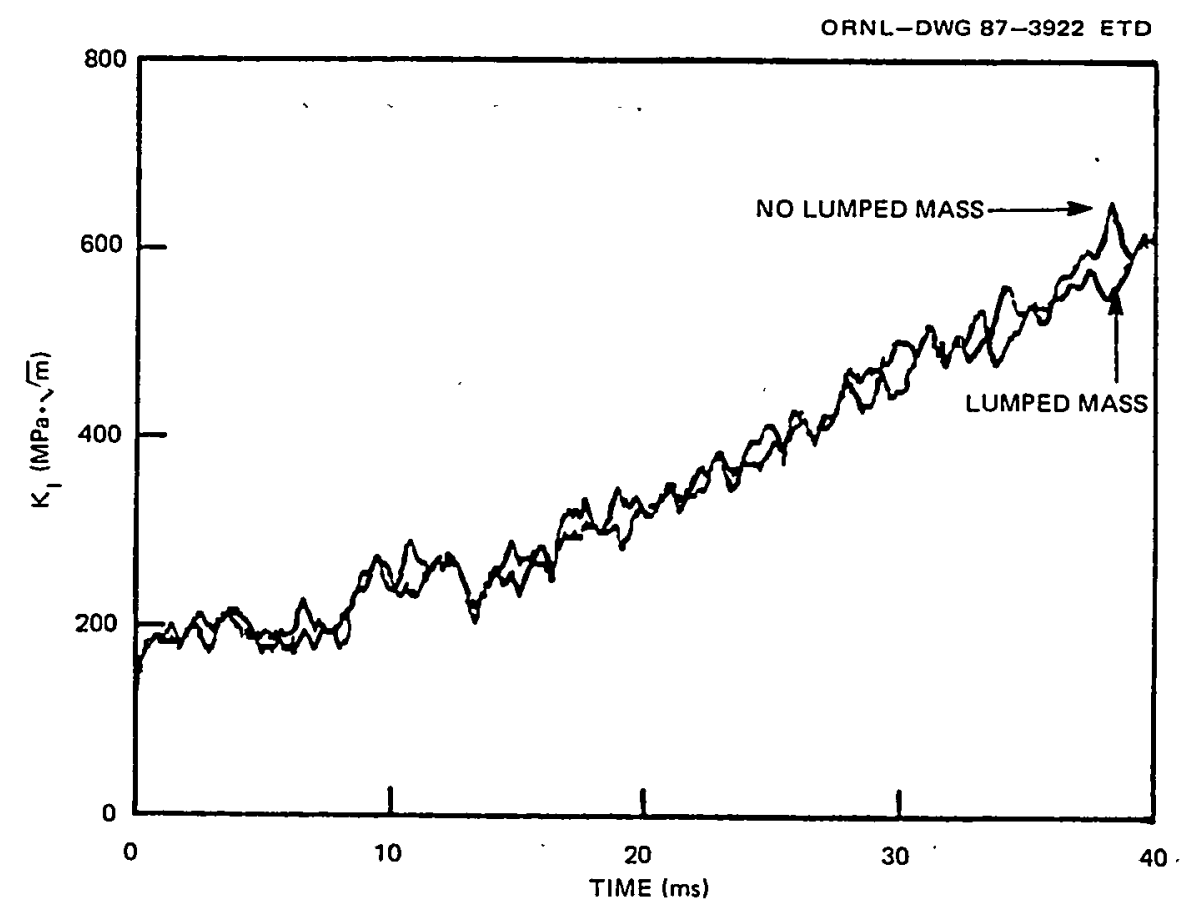

Fig. B.4. Influence of test frame inertia on computed $K$ vs time: test WP-2.4.

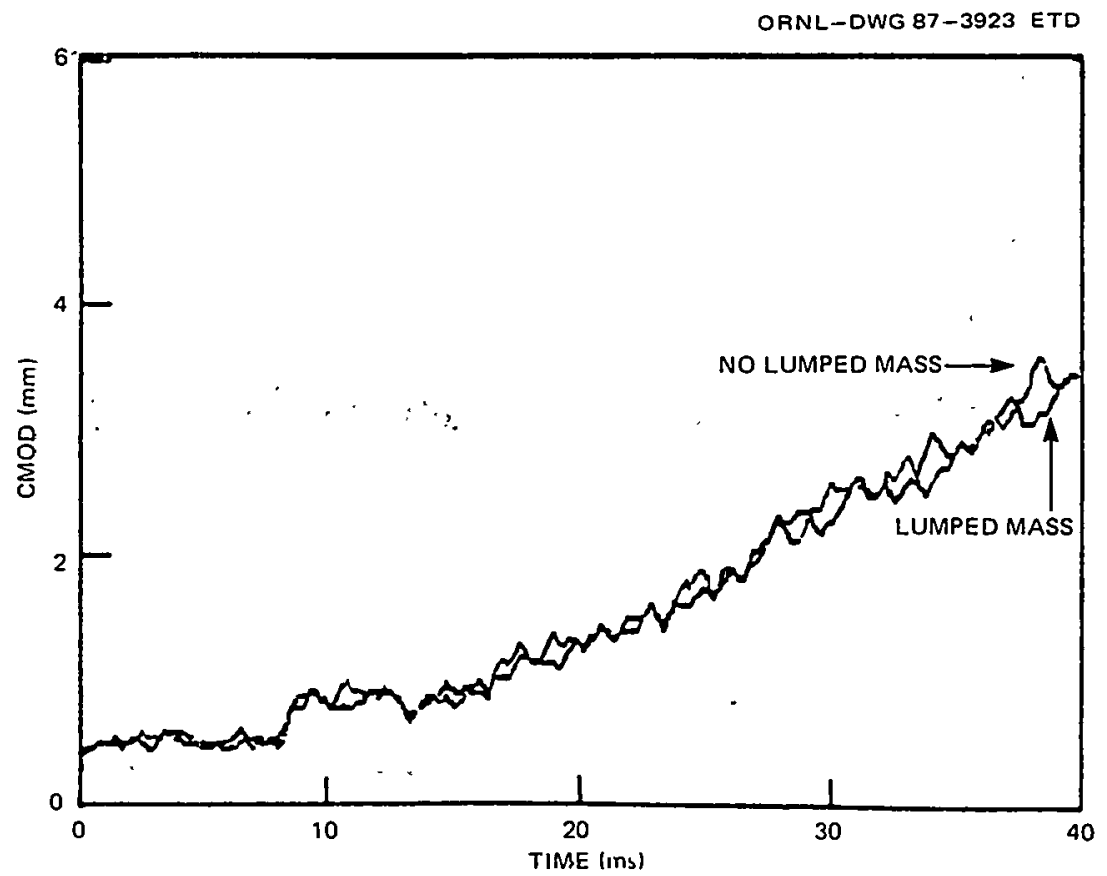

Fig. B.5. Influence of test frame inertia on computed CMOD: test WP-2.4. 


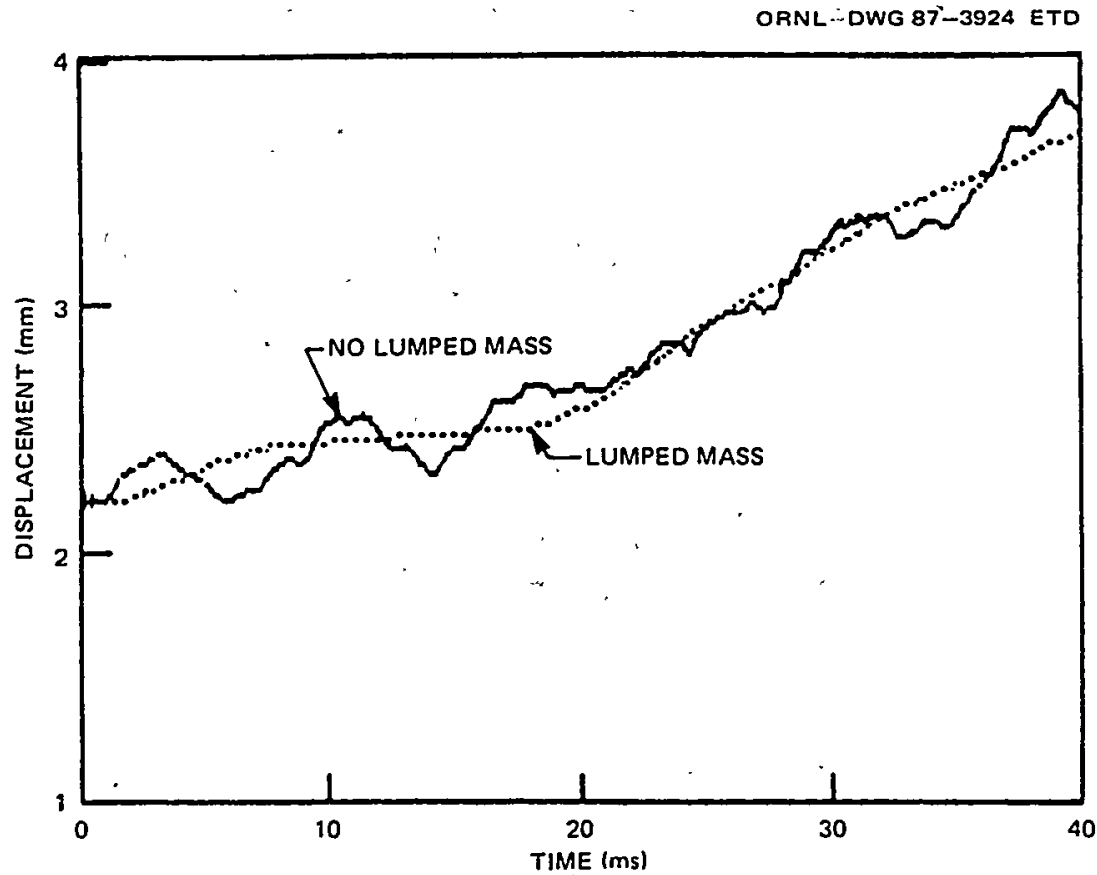

Fig. B.6. Inf1uence of test frame inertia on computed load-point axial displacement: test WP-2.4.

ORNL--DWG 87-3925 ETD

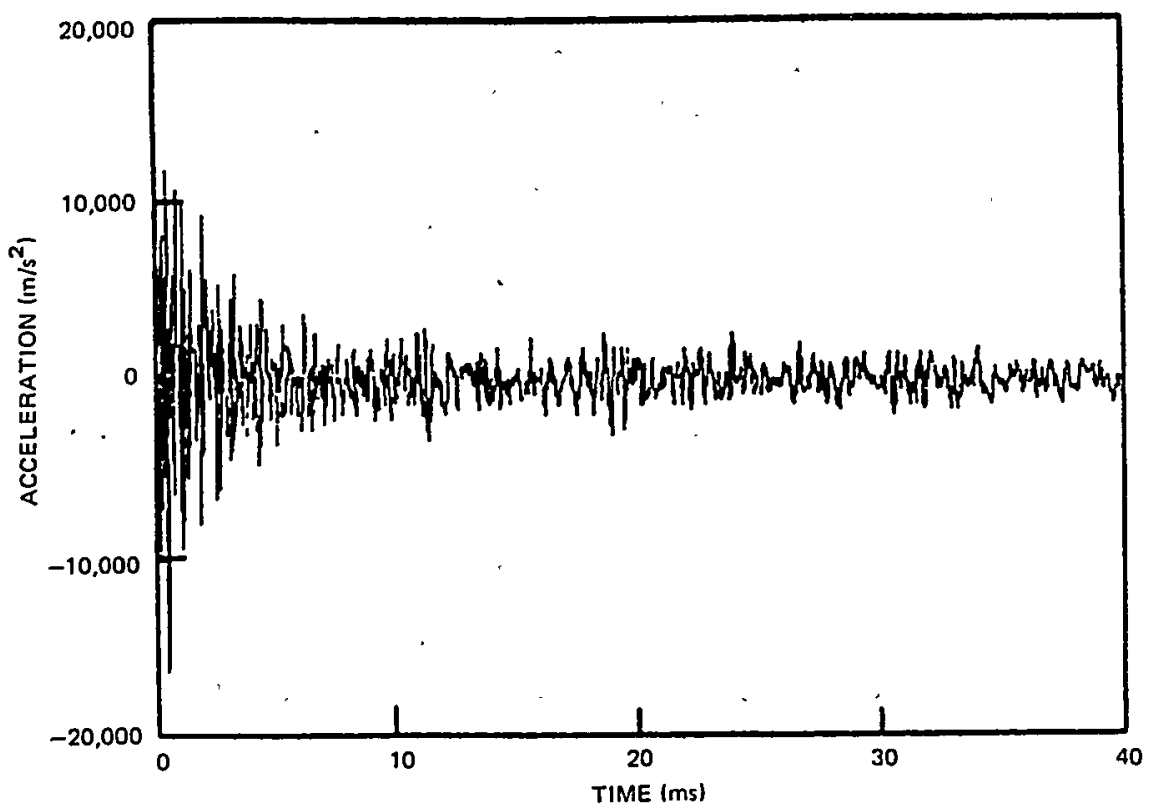

Fig. B.7. Computed nodal accelerations at "damped" accelerometer location near lower load point ( 1 inearly elastic fixed-load analysis, lumped mass at load point): test WP-2.4. 


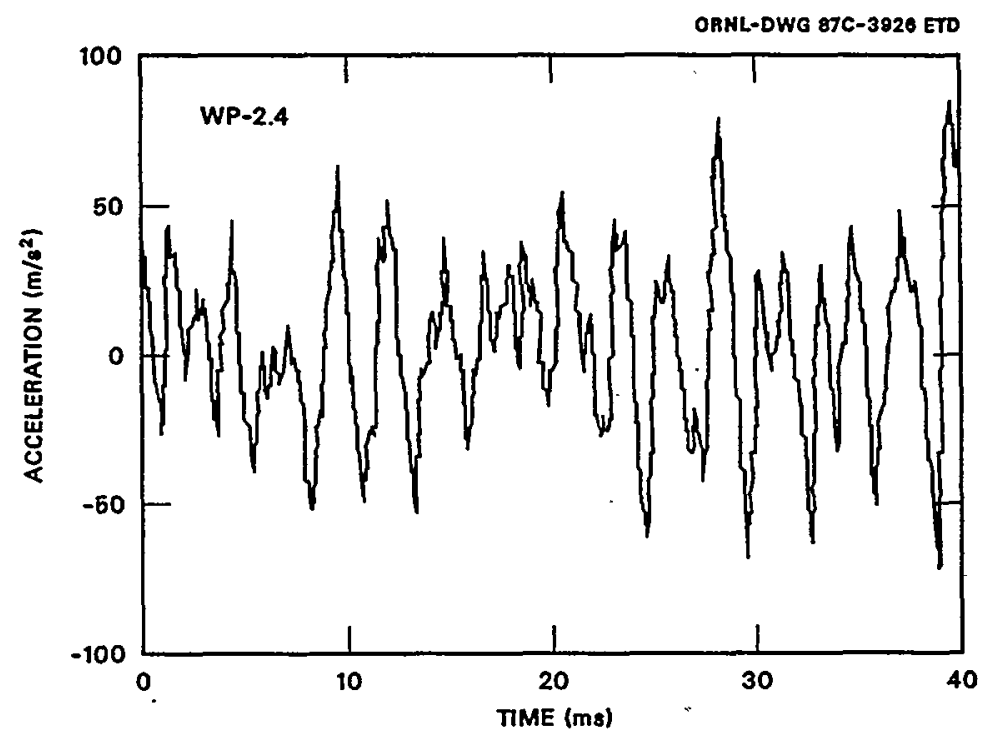

Fig. B.8. . Computed nodal accelerations at load point (linearly elastic fixed-1oad analysis, lumped mass at load point): test WP-2.4.

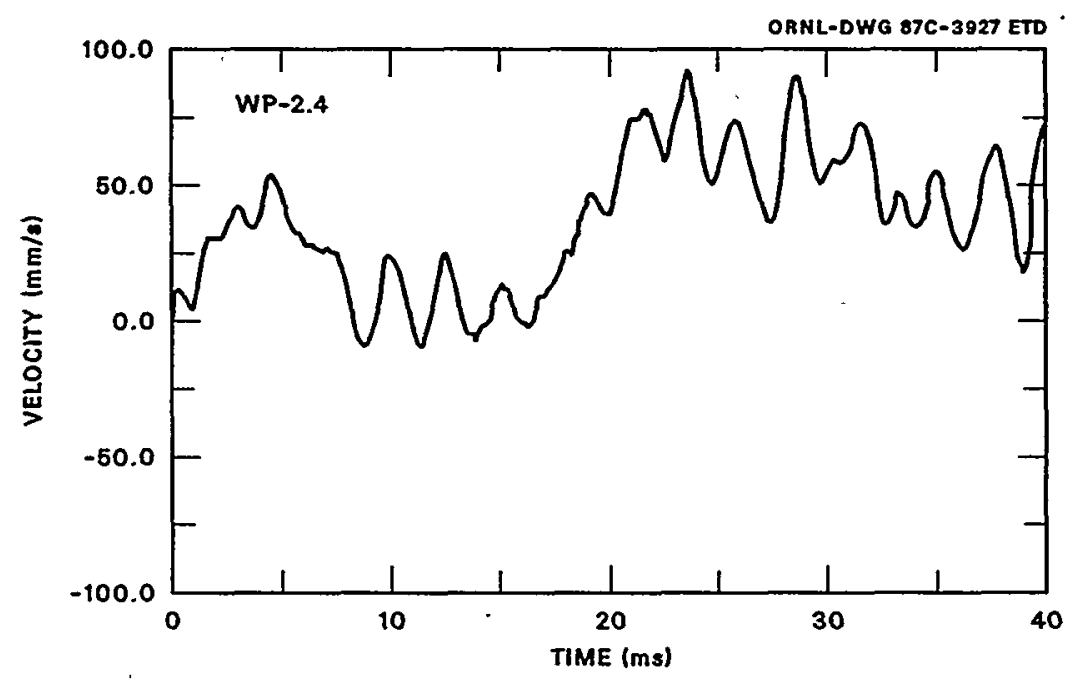

Fig. B.9. Computed velocities at load point (1inearly elastic fixed-load analysis, lumped mass at load point): test WP-2.4.

These conclusions were drawn from this investigation of boundary condition effects: (1) fixed-load and fixed-displacement analyses for the wide-plate test geometry produce identical results for the first millisecond of response; (2) substantial discrepancies between fixedload and fixed-displacement analysis results. do not occur until after $\sim 10$ to $15 \mathrm{~ms}$ of response; (3) reasonably good agreement between computed and measured load-point behavior (at least in terms of vibration 
periods) can be obtained by neglecting the test frame stiffness and considering only the test frame inertia as a lumped effective mass; and (4) the influence of the test frame inertia on the computed results along the crack plane (e.g., $K$ vs time) is negligible. These conclusions suggest that a fixed-load boundary condition without additional lumped mass is an appropriate and adequate boundary condition for medium- and long-duration dynamic viscoplastic analyses.

\section{B.2 EFFECT OF ANALYSIS METHOD}

Crack-arrest toughness values have been determined by static and dynamic analyses, as well as by handbook techniques. Table B.2 summarizes values for test WP-2.4. The effects of the analysis method (static vs dynamic) and the boundary condition (fixed load or fixed load-pin displacement) used to interpret the wide-plate crack-arrest tests are demonstrated by comparing values listed in Table B.2. These effects are illustrated in Fig. B.10, which presents selected $\mathrm{K}_{\mathrm{Ia}}$ results in Table B.2 vs T - DW NDT for the pop-in and seven crack run-arrest events of

Table B.2. Computed crack-arrest toughness values for wide-plate crack-arrest test WP-2.4

\begin{tabular}{|c|c|c|c|c|c|c|}
\hline \multirow{4}{*}{ Test } & \multicolumn{6}{|c|}{$\begin{array}{l}\text { Crack-arrest toughness values } \\
(\mathrm{MPa} \cdot \sqrt{\mathrm{m}})\end{array}$} \\
\hline & \multicolumn{2}{|c|}{ Static SEN } & \multirow{3}{*}{$\begin{array}{l}\text { Fedderson } \\
\text { alternate } \\
\text { secant } \\
\text { formula } c\end{array}$} & \multicolumn{3}{|c|}{ Dynamic finite element } \\
\hline & \multirow{2}{*}{$\begin{array}{l}\text { Displacement } \\
\text { control }^{a}\end{array}$} & \multirow{2}{*}{$\begin{array}{l}\text { Load } \\
\text { control }^{b}\end{array}$} & & \multirow{2}{*}{$\begin{array}{l}\text { Application } \\
\text { mode }\end{array}$} & \multicolumn{2}{|c|}{ Generation mode } \\
\hline & & & & & $\begin{array}{l}\text { Fixed } \\
\text { load }\end{array}$ & $\begin{array}{c}\text { Fixed } \\
\text { displacement }\end{array}$ \\
\hline$W P-2.4 A$ & 104 & 113 & 79 & & & \\
\hline$W P-2.4 B$ & 155 & 186 & 111 & 122 & 137 & 137 \\
\hline$W P-2.4 C$ & 168 & 234 & 124 & 155 & 188 & 193 \\
\hline$W P-2.4 D$ & 171 & 249 & 128 & 166 & 281 & 249 \\
\hline$W P-2.4 E$ & 181 & 303 & 140 & 207 & 249 & 232 \\
\hline $\mathrm{WP}-2.4 \mathrm{~F}$ & 185 & 332 & 145 & 229 & 307 & 276 \\
\hline WP-2.4G & 191 & 378 & 153 & 269 & 381 & 257 \\
\hline $\mathrm{WP}-2.4 \mathrm{H}$ & 198 & 451 & 165 & & -397 & 276 \\
\hline
\end{tabular}

${ }^{a}$ From Ref. 4 (pp. 2.10-11), while assuming $a=a_{f}$ and no further bending occurs because of propagation of the crack.

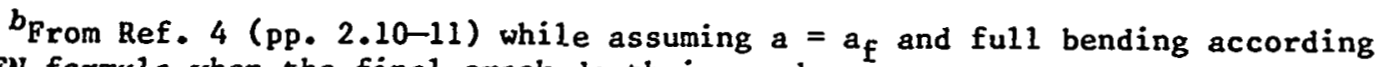
to SEN formula when the final crack depth is used.

$$
c_{K_{I}}=\sigma\left[\pi a \sec \left(\frac{\pi a}{2 W}\right)\right]^{1 / 2} \text {, where } \sigma=\text { far-field tensile stress, } a=a_{f}=\text { final }
$$
crack length, and $w=$ full plate width.5 


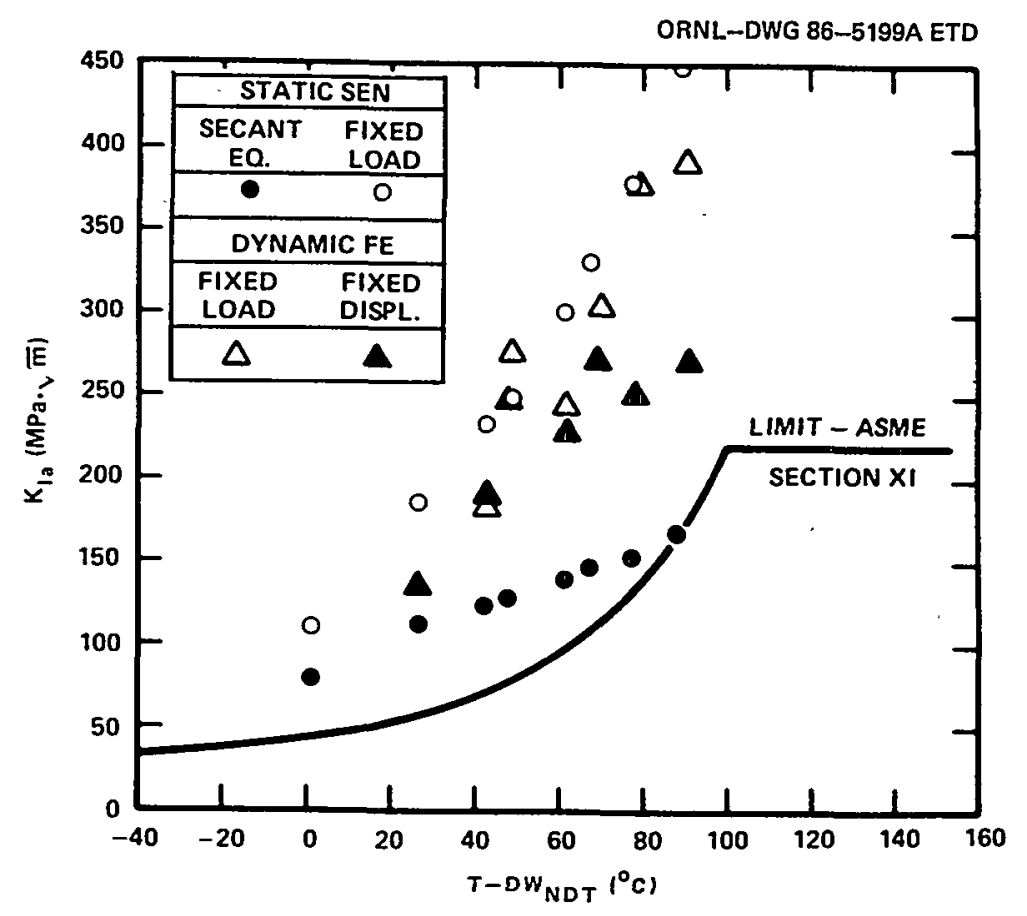

Fig. B.10. Effect of analysis method and boundary condition on calculated crack-arrest toughness values for test WP-2.4.

test WP-2.4.* As shown in the figure, values of $\mathrm{K}_{\mathrm{Ia}}$ determined using the secant equation and the Tada fixed-load condition represent approximate lower and upper bounds, respectively, for the results. For longduration crack run-arrest events ( $>10 \mathrm{~ms}$ ), considerable load adjustment can take place as a result of specimen pull-plate compliance. Therefore, the most meaningful values of $\mathrm{K}_{\mathrm{Ia}}$ should reflect this occurrence and would involve a dynamic finite-element generation-mode analysis.

*For test WP-2.4 the duration of the crack run-arrest events was $\sim 27.3 \mathrm{~ms}$. 
1. C. W. Schwartz et al., University of Maryland, College Park, SAMCR: A Two-Dimensional Dynamic. Finite Element: Code-for: the Stress Analysis of Moving Cracks, USNRC Report NUREG/CR-3891 (ORNL/Sub/79$7778 / 3$ ), November $1984 . *$

2. S. Timoshenko, D. H. Young, and W. Weaver, Vibration Problems in Engineering (4th ed.). J. Wiley and Sons, Inc., New York, 1974.t

3. C. E. Pugh et al., Martin Marietta Energy Systems, Inc., Oak Ridge Natl. Lab., Heavy-Section Steel Technology Program Semiann. Prog. Rep. October 1985-March 1986, USNRC Report NUREG/CR-4219, Vol. 3, No. 1 (ORNL/TM-9593/V3\&N1), June 1986.

4. R. Tada et al., The Stress Analysis of Cracks Handbook, Del Research Corp., Hellertown, Pa., 1973.t

5. C. F. Fedderson, "Current Status of Plane Strain Crack Toughness Testing of High-Strength Metallic Materials," Crack Arrest Methodology and Applications, ASTM STP-410, 77-79, 1967.

*Available for purchase from National Technical Information Service, Springfield, VA 22161.

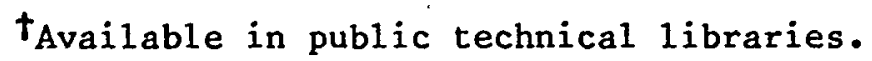

FAvailable from American Society for Testing and Materials, Philadelphia, Pa. 


\section{Appendix C}

\section{EFFECTS OF TUNNELING}

Crack tunneling is commonly observed during the fracture of tough and ductile materials. The loss of constraint near the free surface of the specimen permits development of yielded ligaments that may extend for considerable distances behind the leading edge of the crack front. These yielded ligaments restrain the crack-tip displacements and alter the crack-tip stress fields. A significant portion of the apparent fracture toughness measured for a deeply tunneled crack may be caused by the restraining effects of these yielded ligaments.

Calculations by Popelar ${ }^{1}$ suggest that correcting for the restraining effects of tunneling may substantially reduce the actual fracture toughness inferred from test data. Because considerable tunneling has been observed in several of the wide-plate tests, notably the WP-1 test series, ${ }^{2}$ questions have been raised regarding the appropriateness of 2-D analytical models that implicitly ignore tunneling.

\section{C.1 ANALYTICAL APPROXIMATIONS TO TUNAELING EFFECTS}

Several analytical approximations have been proposed in the literature to account for the restraining effect of the yielded ligaments flanking a tunneled crack in Mode I fracture. All are based on simple superposition principles; that is, the restraining effects of the tunneling can be simply subtracted from the conditions existing at the crack front in the absence of tunneling. Superposition requires assumption of linear-elastic fracture-mechanics (LEFM) small-scale yielding conditions; that is, no shielding because yielding ahead of the crack tip is considered (small-scale, yielding assumption), and the crack tip state can be characterized by the stress-intensity factor $K$. The approximations all assume self-similar crack growth once the ligaments have fully developed. The ligament stresses are replaced by an equivalent set of crack-face tractions, and the stress-intensity factor as a result of these tractions represents the tunneling correction. This correction is subtracted from the stress-intensity factor for the corresponding cracked body without tunneling.

Popelar ${ }^{3}$ considered the two cases for the ligament geometry shown in Fig. C.1: (a) strip ligaments, characteristic of low-toughness ductile materials, and (b) parabolic ligaments, characteristic of hightoughness ductile materials. The superposition approach for approximating the effects of the yielding ligaments is illustrated in Fig. C.2, where

$$
\mathrm{K}_{\alpha}=\mathrm{K}_{\beta}-\mathrm{K}_{\gamma}
$$

in which $K_{\beta}$ is the stress-intensity factor in the absence of tunneling, $K_{\gamma}$ is the stress-intensity factor as a result of the crack-face 


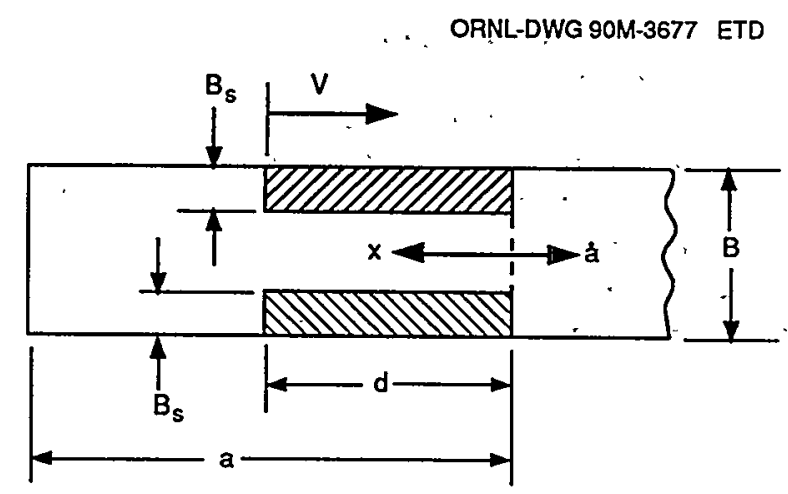

(a)

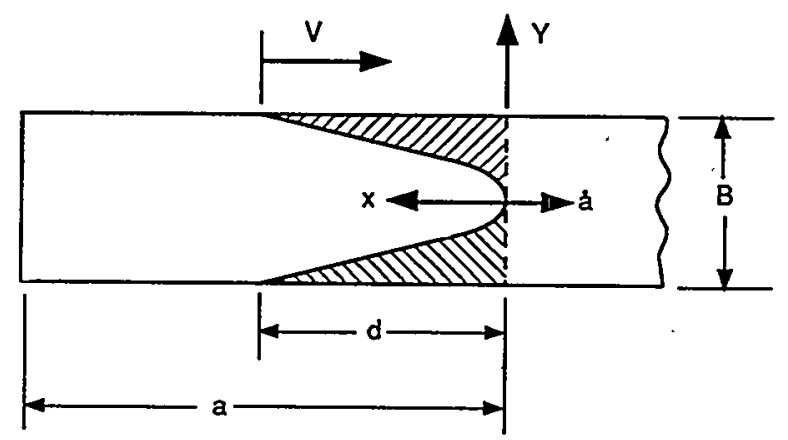

(b)

Fig. C.l. Idealization of crack tunneling in (a) 1ow-toughness and (b) high-toughness material (Ref. C.3).

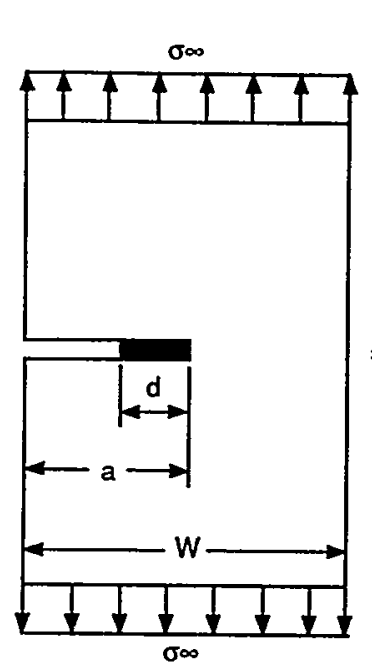

$(\alpha)$

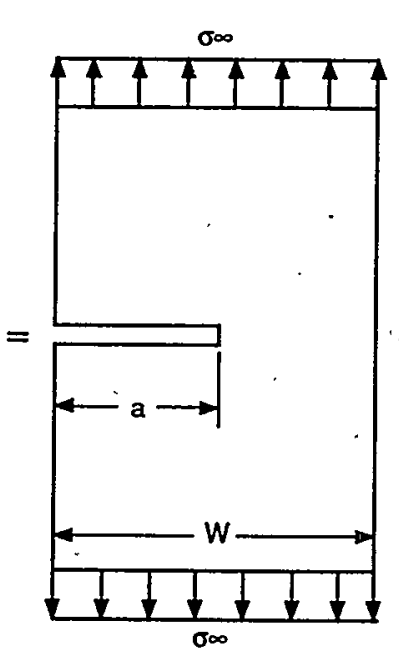

(B)
ORNL-DWG 90M-3678 ETD

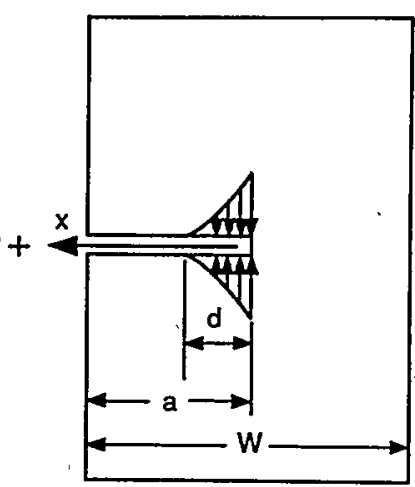

(v)

Fig. C.2. Illustration of superposition principle for determining the stress-intensity factor (Ref. C.3). 
tractions (i.e., the tunneling correction), and $k_{\alpha}$ is the net or corrected stress-intensity factor.

$K_{B}$ is calculated using standard 2-D LEFM solutions. $K_{\gamma}$ is computed using a weight-function approach assuming that the stresses in the ligaments equal the plastic flow stress $\sigma_{o}$ and that these 1 igament flow stresses can be averaged across the thickness. For the assumed strip and parabolic ligament geometries, respectively, these averaged or "effective" crack-face stresses off can be expressed as

$$
\sigma_{\text {eff }}=2\left(\frac{B}{B}\right) \sigma_{0},
$$

and

$$
\sigma_{\text {eff }}=\sigma_{0}\left[1-\left(\frac{x}{d}\right)^{1 / 2}\right]
$$

The corresponding stress-intensity values $K_{\gamma}$ as derived by Popelar ${ }^{3}$ using the weight-function approach are given for the strip and parabolic ligament geometries, respectively, as

$$
K_{Y}=4 \sigma_{0}\left(\frac{2 d}{\pi}\right)^{1 / 2}\left(\frac{B s}{B}\right)\left[1+\frac{m_{1}}{3}\left(\frac{d}{a}\right)+\frac{m_{2}}{5}\left(\frac{d}{a}\right)^{2}\right],
$$

and

$$
k_{Y}=\sigma_{0}\left(\frac{2 d}{\pi}\right)^{1 / 2}\left[1+\frac{m_{1}}{6}\left(\frac{d}{a}\right)+\frac{m_{2}}{15}\left(\frac{d}{a}\right)^{2}\right],
$$

in which $m_{1}$ and $m_{2}$ are geometry-dependent dimensionless coefficients having values of -5 and 2 , respectively, for the wide-plate specimen geometry at the typical arrest condition of $a / w \cong 0.5$.

Smith 4 had earlier proposed a solution for the influence of tunneling based on a superposition approach similar to Popelar's but with a different formulation for the $K_{\gamma}$. correction term. Smith considered an infinitely. long crack with an infinitely long crack front that contains regularly spaced ligaments of rectangular geometry, as shown in Fig. C.3. As an approximation, a finite-width crack front under planestrain conditions can be taken as the area between the centerlines of two neighboring ligaments. The stress in the ligaments is assumed equal to the flow stress for the material.

Smith's solution is not based on an averaging of the ligament restraining stresses acros's the thickness. Instead, $\mathrm{K}_{\mathrm{y}}$ is evaluated for the point (marked by a dot in Fig. C.3) on the crack front midway 
ORNL-DWG 9OM-3679 ETD

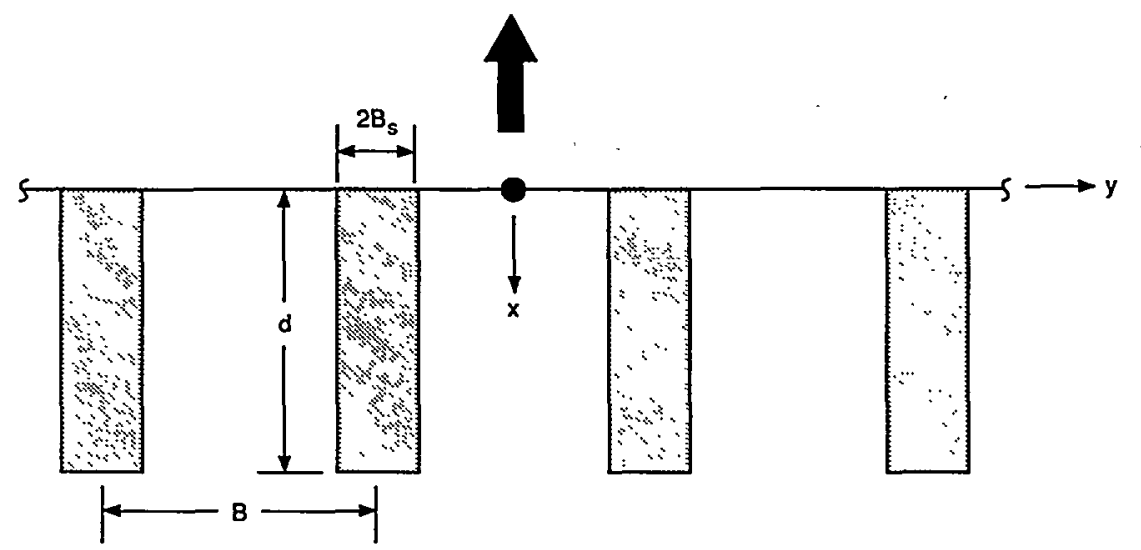

Fig. C.3. Smith's model for restraining effect of ligaments (Ref. C.4).

between two ligaments as the integral over the ligament areas of the solution for a point force applied to the crack face.5 Using Popelar's notation, Smith's solution for the rectangular ligament geometry is expressed as

$$
K_{\gamma}=\frac{2 \sqrt{2} \sigma_{0} B}{\pi \sqrt{B}} \int_{0}^{\pi d / B} \frac{\tanh x}{\sqrt{x}} d x
$$

For small values of $d / B \quad(<\sim 0.3)$, the integral in Eq. (C.6) can be approximated analytically as

$$
K_{Y} \simeq \frac{4 \pi}{3} \sigma_{0}\left(\frac{2 d}{\pi}\right)^{1 / 2}\left(\frac{B s}{B}\right)\left(\frac{d}{B}\right) .
$$

For large values of $d / B(>\sim 3)$, Eq. (C.6) approaches Popelar's thicknessaveraged solution. The integral in Eq. (C.6) must be evaluated numerically for intermediate value of $d / B$; for moderately deep tunneling, for example, when $d / B=1$, the value of the integral is $\sim 2$. Smith observes that thickness-averaging procedures (such as Popelar's) overestimate the restraining effect of the ligaments for small-to-moderate amounts of tunneling.

As noted by Popelar, rectangular ligament geometries are characteristics of low-toughness materials. Ductile reactor steels such as A 533 grade B typically exhibit parabolic or triangular tunneling geometries, as was often observed in the WP-1 test series. We have therefore extended Smith's methodology to parabolic and triangular ligament germetries. 
Consistent with Smith's approach, the crack front is treated as being infinitely long with regularly repeating ligaments of the specified geometry. Figure C.4 illustrates the assumed conditions for the triangular ligament geometry. As an approximation, a finite-thickness specimen under plane-strain conditions can be taken as the width between the centerlines of two neighboring ligaments. The restraining effect of the ligaments for both the parabolic and triangular geometries can be expressed as

$$
k_{\gamma}=\sigma_{0} \sqrt{B} \sum_{n=-\infty}^{+\infty} k_{n},
$$

where $n$ refers to the individual ligaments. The $k_{n}$ terms for the parabolic ligament geometry are given as

$$
\begin{array}{r}
k_{n}=\frac{1}{\pi \sqrt{\pi}} \int_{n-1 / 2}^{n+1 / 2} \mid \arctan (1+\sqrt{2} \phi)-\arctan (1-\sqrt{2} \phi) \\
\left.-\ln \left[\frac{1+\sqrt{2} p+\phi^{2}}{\left(1+\phi^{4}\right)^{1 / 2}}\right]\right\} \frac{d \xi}{\sqrt{\xi}}, \quad \text { (C.9a) }
\end{array}
$$

where

$$
\phi=\left[\frac{4(\mathrm{~d} / \mathrm{B})(\xi-\mathrm{N})^{2}}{\xi}\right]^{1 / 2},
$$

ORNL-DWG 9OM-3680 ETD

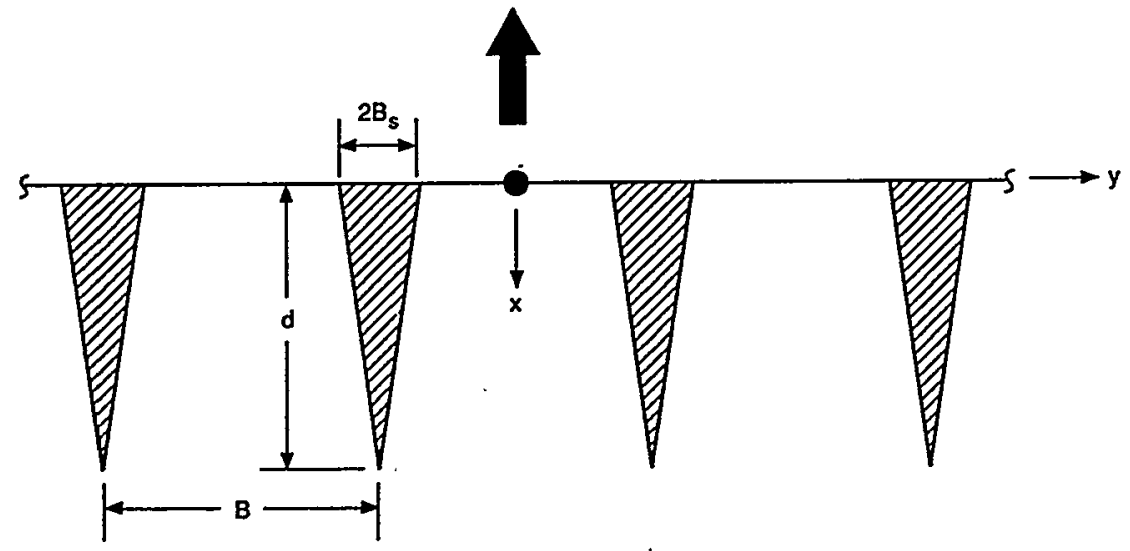

Fig. C.4. Extension of Smith's approach to triangular ligament geometry. 
and for the triangular ligament geometry as

$$
\begin{aligned}
& k_{n}= \frac{1}{\pi \sqrt{\pi}} \int_{n-1 / 2}^{n-1 / 2+B_{s} / B} \mid \arctan (1+\sqrt{2} \phi)-\arctan (1-\sqrt{2} \phi) \\
&\left.-\ln \left[\frac{1+\sqrt{2} \phi+\phi^{2}}{\left(1+\phi^{4}\right)}\right]\right\} \frac{d \xi}{\sqrt{\xi}}+\frac{1}{\pi \sqrt{\pi}} \int_{n+1 / 2-B_{s} / B}^{n+1 / 2}\{\arctan (1+\sqrt{2} \phi) \\
&\left.-\arctan (1-\sqrt{2} \phi)-\ln \left[\frac{1+\sqrt{2 p}+\phi^{2}}{\left(1+\phi^{2}\right)}\right]\right\}_{\frac{d \xi}{\sqrt{\xi}}},
\end{aligned}
$$

where

$$
\phi=\left\{\left(\frac{d}{B_{S}}\right) \xi+\left[1-(n+1 / 2)\left(\frac{B}{B_{S}}\right)\right]\left(\frac{d}{B}\right)\right\}^{1 / 2} \xi^{-1 / 2},
$$

where

$$
\xi=\mathrm{Y} / \mathrm{B}
$$

These integrals are evaluated numerically and summed to obtain the value for $\mathrm{K}_{\mathrm{\gamma}}$.

For completeness, we have also extended Popelar's approach to triangular ligament geometries

$$
K_{\gamma}=\frac{4}{3} \sigma_{0}\left(\frac{2 d}{\pi}\right)^{1 / 2}\left(\frac{B}{B}\right)\left[1+\frac{m_{1}}{s}\left(\frac{d}{a}\right)+\frac{2 m_{2}}{35}\left(\frac{d}{a}\right)^{2}\right] .
$$

A comparison of the solutions for parabolic and triangular 1 igament geometries using Popelar's and Smith's approaches is given in Fig. C.5, which plots dimensionless $K_{\gamma}$ vs depth of tunneling for a deep crack. Popelar's approach predicts tunneling correction factors that are considerably larger than those from Smith. This difference is largest for very shallow tunneling, where Popelar's approach is much more sensitive to tunneling depth. The differences decrease as the depth of tunneling increases, but at a tunneling depth of $\mathrm{d} / \mathrm{B}=2$ the discrepancies are still $>50 \%$. As indicated in the Fig. C.5, the ligament geometry has only a relatively minor influence on the tunneling correction factor. 


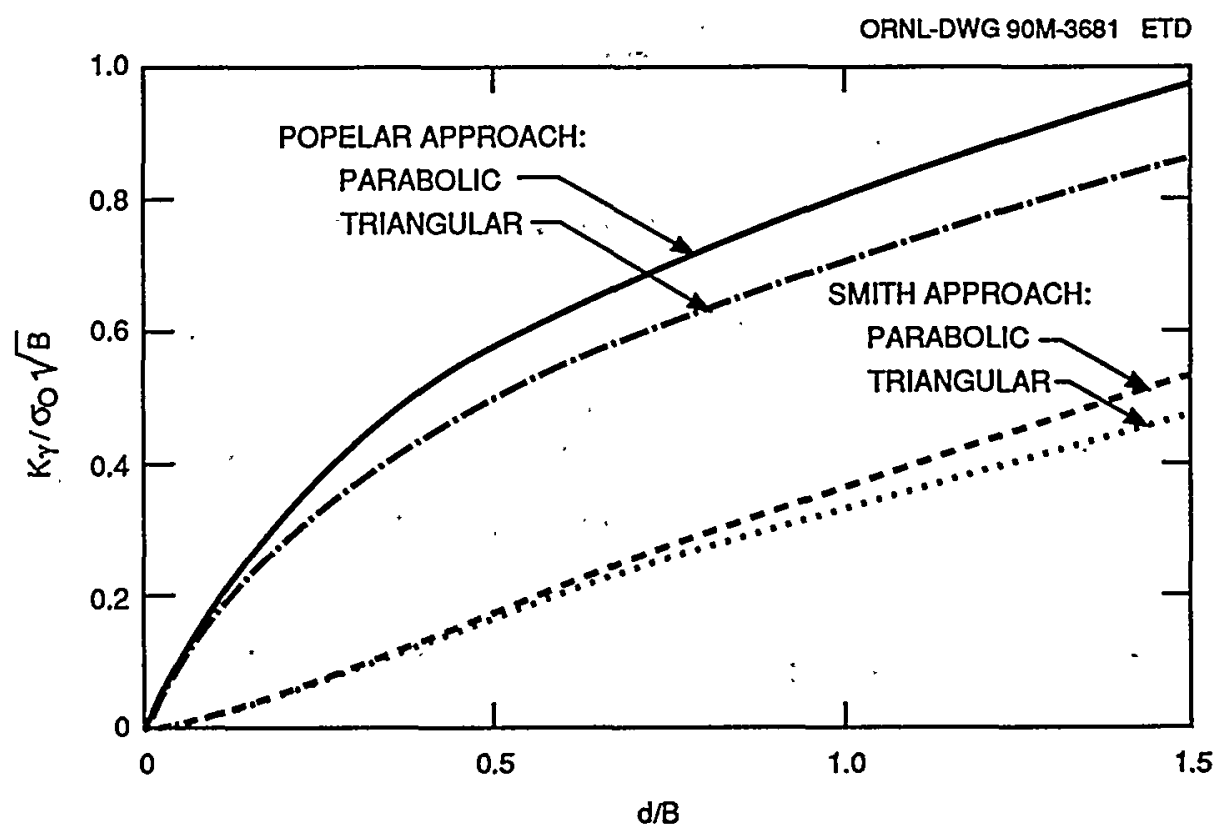

Fig. C.5. Comparison of Popelar's and Smith's tunneling correction approaches for parabolic and triangular ligament geometrics.

\section{C.2 APPLICATIONS TO WP-1 TEST DATA*}

The restraining effects of tunneling have been analyzed for $10-\mathrm{cm}-$ thick WP-1 test specimens WP-1.1 through -1.6 using Popelar's and Smith's solutions and our extensions to these solutions. These analyses have been performed independently from Popelar's earlier interpretations of the WP-1 tests. The material properties, loads, arrest points, and other test conditions are as described in Ref. 1. The flow stress is taken as the average of the static yield and ultimate strengths for A 533 grade $B$ steel at the crack tip arrest temperature. The uncorrected arrest toughness $\left[\mathrm{K}_{B}\right.$ in Eq. (C.1)] is taken as the elastodynamic generation-mode value. The interpretation of the tunneled crack front geometry frequently involves subjective judgments. Our estimates of the ligament geometries are summarized in Table C.1, which was developed from Fig. C.6.

The results from our tunneling analyses are summarized in Table C.2. As previously presented by Popelar, his approach predicts a large reduction in the computed arrest toughness, particularly for events WP-1.2B and $-1.4 \mathrm{~A}$, where the tunneling corrections are $\sim 30$ and $60 \%$, respectively, of the uncorrected arrest toughness values. The Smith approach, however, predicts a significantly smaller correction for

*The effects of tunneling have not been applied to the WP-2 series test results; however, it is anticipated that tunneling corrections to the crack-arrest toughness results for the WP-2 test series will be less than for the WP-1 test series because of reduced tunneling. 
Table C.1. Ligament geometry parameters for WP-1 test series specimens

\begin{tabular}{|c|c|c|c|}
\hline \multirow{2}{*}{ Event } & \multicolumn{2}{|c|}{$\begin{array}{c}\text { Triangular } \\
(\mathrm{mm})\end{array}$} & \multirow{2}{*}{$\begin{array}{c}\text { Parabolic } \\
\mathrm{d} \\
(\mathrm{mm})\end{array}$} \\
\hline & $d$ & $\mathrm{~B}_{s}$ & \\
\hline WP-1.2A & 120 & 28 & \\
\hline WP-1.2B & & & 87 \\
\hline WP-1.3 & 10 & $40^{2}$ & \\
\hline WP-1.4A & & & 50 \\
\hline$W P-1.4 B$ & 84 & 24 & \\
\hline WP-1.5A & 30 & $17^{a}$ & \\
\hline WP-1.5B & & & \\
\hline HP-1.6A & 15 & $58^{a}$ & \\
\hline WP-1.6B & 47 & $65^{a}$ & \\
\hline
\end{tabular}

${ }^{a}$ Assumed split symmetrically about specimen midthickness.

Table C.2. Corrections for the effects of tunneling in the WP-1 test series

\begin{tabular}{|c|c|c|c|c|c|c|}
\hline \multirow{2}{*}{ Test } & \multirow{2}{*}{$\begin{array}{c}\mathrm{T}-\mathrm{RT}_{\mathrm{NDT}} \\
\left({ }^{\circ} \mathrm{C}\right)\end{array}$} & \multirow{2}{*}{$\begin{array}{c}\mathrm{K}_{B}^{a} \\
(\mathrm{MPa} \cdot \sqrt{\mathrm{m}})\end{array}$} & \multicolumn{2}{|c|}{$\begin{array}{l}\text { Popelar approach } \\
(\mathrm{MPa} \cdot \sqrt{\mathrm{m}})\end{array}$} & \multicolumn{2}{|c|}{$\begin{array}{l}\text { Smith approach } \\
(\mathrm{MPa} \cdot \sqrt{\mathrm{m}})\end{array}$} \\
\hline & & & $\mathrm{K}_{\delta}^{b}$ & $\mathrm{~K}_{\alpha}{ }^{C}$ & $\mathrm{~K}_{\delta}^{b}$ & $\mathrm{~K}_{\alpha}{ }^{c}$ \\
\hline WP-1.2A & 85 & 440 & 88 & 352 & 35 & 405 \\
\hline$W P-1.2 B$ & 115 & 523 & 139 & 384 & 56 & 467 \\
\hline WP-1.3 & 77 & 243 & 29 & 214 & 23 & 220 \\
\hline$W P-1.4 \mathrm{~A}$ & 52 & 158 & 99 & 59 & 32 & 126 \\
\hline$W P-1.4 B$ & 83 & 397 & 56 & 341 & 21 & 376 \\
\hline $\mathrm{WP}-1.5 \mathrm{~A}$ & 79 & 229 & 22 & 207 & 5 & 224 \\
\hline WP-1.5B & 95 & 300 & 56 & 244 & $N / A^{d}$ & N/A \\
\hline WP-1.6A & 77 & 285 & 52 & 233 & 61 & 224 \\
\hline
\end{tabular}
analyses.

$a_{K_{B}}=$ Arrest toughness from generation-mode elastodynamic

$b_{\mathrm{K}_{\delta}}=$ Ligament correction.

$c_{K_{\alpha}}=\mathrm{K}_{\beta}-\mathrm{K}_{\delta}=$ net arrest toughness.

$d_{\text {Not applicable. }}$ 


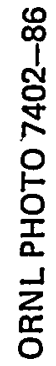

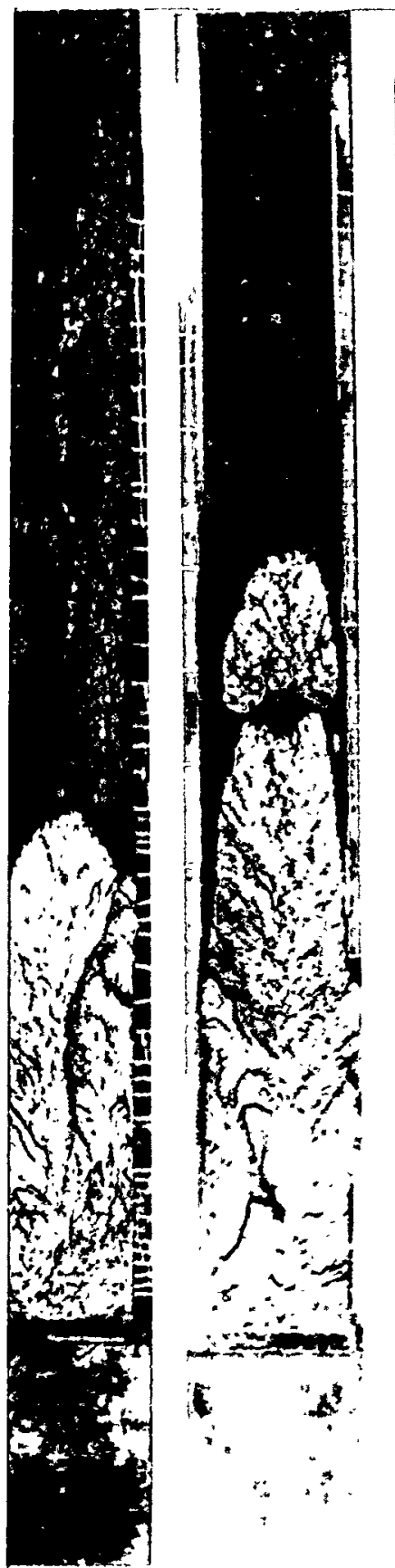

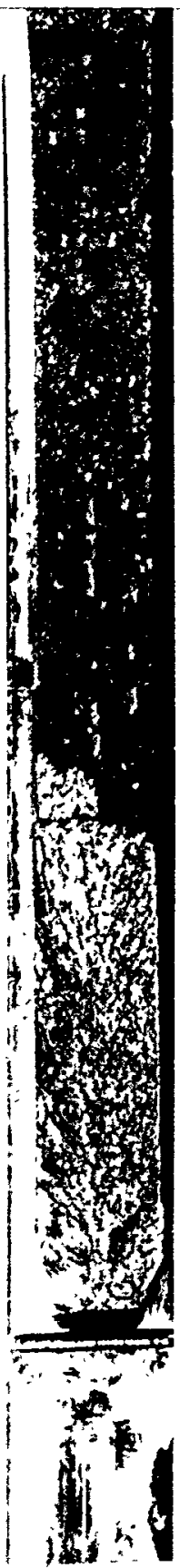
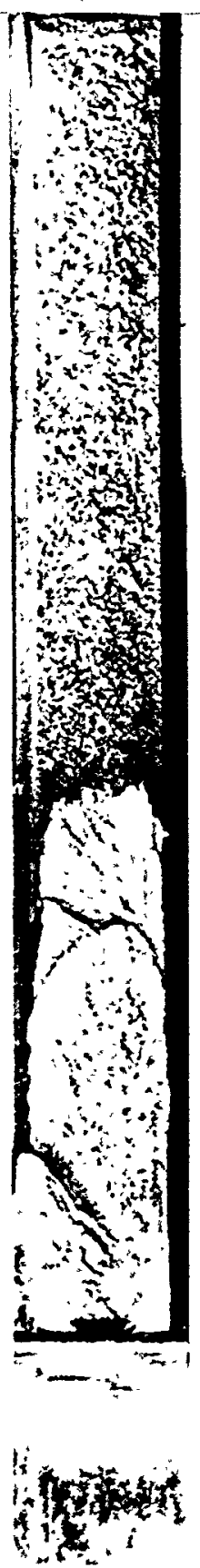

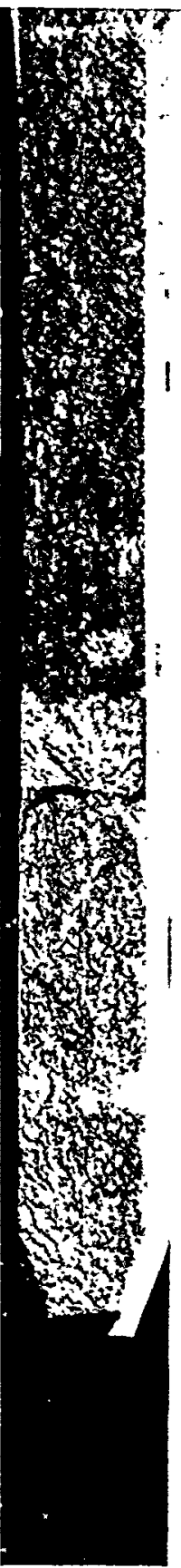

$\begin{array}{ll}\forall & n \\ i & -1 \\ 1 & 1 \\ 3 & \frac{1}{3}\end{array}$

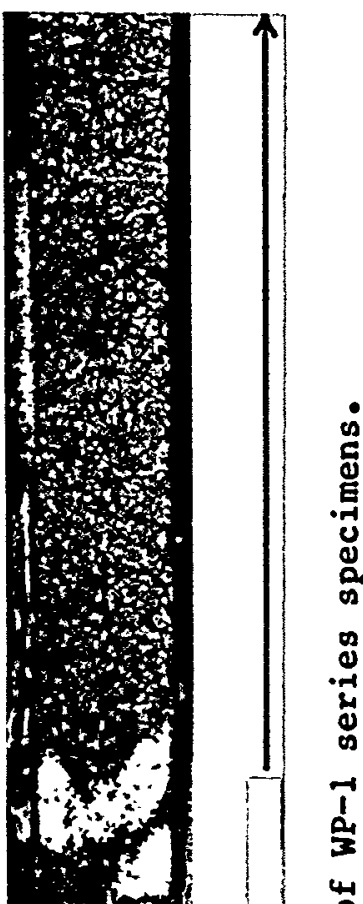

E

ت

of

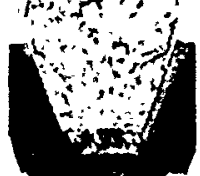

$-4$

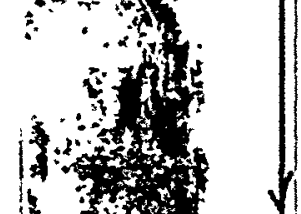

í

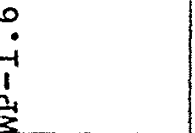

:

$\begin{array}{ll}\nabla & n \\ -1 & 1 \\ 1 & 1 \\ 0 & \frac{1}{3}\end{array}$

$m$
$\dot{1}$
$a$
$a$


tunneling effects; the tunneling corrections for events WP-1.2B and $-1.4 \mathrm{~A}$ now equal only $\sim 10$ and $20 \%$, respectively, of the uncorrected arrest toughnesses.

The variation with temperature of arrest toughness including the restraining effect of tunneling is illustrated in Fig. C.7. The corrected data based on Smith's approach lie between the uncorrected values and the corrected values from Popelar's approach in all cases. None of the Smith-corrected data points lies below the ASME reference curve. For both tunneling corrections, the trends in the data clearly show increasing toughness with temperature, continuing significantly above the cut-off in the ASME reference curve. This trend is more pronounced for data corrected using the Smith approach.

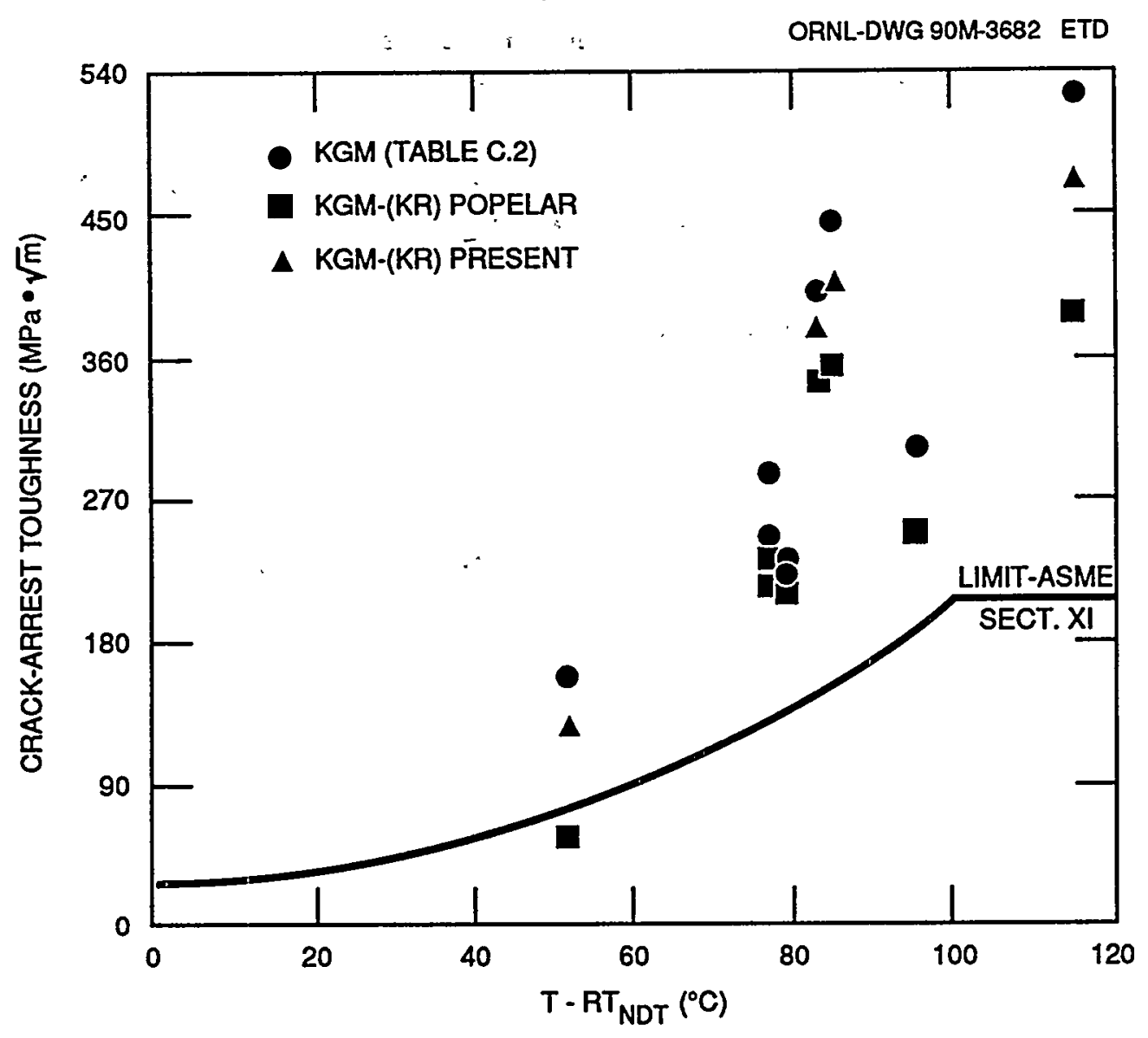

Fig. C.7. Corrected crack-arrest toughness vs temperature for WP-1 test series. 


\section{REFERENCES}

1. C. H. Popelar, "Tunneling Effects on Crack-Arrest Toughness Calculations," Paper E, Session IV, Constitutive Equation and FractureModel Developments, Third Annual HSST Workshop on Dynamic-Fracture and Crack-Arrest Technology, National Bureau of Standards, Gaithersburg, Md., May 13-15, 1987.

2. D. J. Naus et a1., Martin Marietta Energy Systems, Inc., Oak Ridge Nat1. Lab., Crack-Arrest Behavior in SEN Wide Plates of Quenched and Tempered A 533 Grade $B$ Steel Tested Under Nonisothermal Conditions, USNRC Report NUREG/CR-4930 (ORNL-6388), August 1987.*

3. C. H. Popelar, "A Quasi-Three-Dimensional Model for Crack Propagation in Materials that Exhibits Extensive Crack Tunneling," pp. 753-66 in Proceedings of the 4th International Conference on Numerical Methods in Fracture Mechanics, San Antonio, Tex., March $1987 . t$

4. E. Smith, "The Restraining Effect of Ductile Ligaments on Plane Strain Crack Propagation and Arrest in "Ferititic Steels," Eng. Frac. Mech. 19(4), 601-4, 1984.t

5. H. Tada et al., The Stress Analysis of Cracks Handbook, Del Research Corp., Hellertown, Pa., 1973.t

*Available for purchase for National Technical Information Service, Springfield, VA 22161.

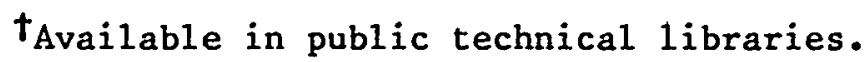



NUREG/CR-5451

ORNL/TM-6584

Dist. Category RF

Interna1 Distribution

$\begin{aligned} & \text { 1. } \text { D. J. Alexander } \\ & 2-3 . \text { B. R. Bass } \\ & \text { 4. S. H. Buechler } \\ & \text { 5. R. D. Cheverton } \\ & \text { 6. J. M. Corum } \\ & \text { 7. } \text { W. R. Corwin } \\ & \text { 8. T. L. Dickson } \\ & \text { 9. F. M. Haggag } \\ & \text { 10-11. S. K. Iskander } \\ & \text { 12. J. E. Jones Jr. } \\ & \text { 13-14. J. Keeney-Wa1ker } \\ & \text { 15. W. J. McAfee } \\ & \text { 16. J. G. Merkle }\end{aligned}$

$\begin{aligned} \text { 17. } & \text { R. K. Nanstad } \\ \text { 18-22. } & \text { D. J. Naus } \\ 23 . & \text { C. B. Oland } \\ \text { 24-26. } & \text { W. E. Pennel1 } \\ 27 . & \text { C. E. Pugh } \\ 28 . & \text { G. C. Robinson } \\ 29 . & \text { D. K. Shum } \\ 30 . & \text { T. J. Theiss } \\ 31 . & \text { ORNL Patent Section } \\ 32 . & \text { Central Research Library } \\ 33 . & \text { Document Reference Section } \\ \text { 34-35. } & \text { Laboratory Records Department } \\ 36 . & \text { Laboratory Records (RC) }\end{aligned}$

External Distribution

37. C. Z. Serpan, Division of Engineering, Nuclear Regulatory Commission, Washingt on, DC 20555

38-39. M. E. Mayfield, Division of Engineering, Nuclear Regulatory Commission, Washington, DC 20555

40. M. Vagins, Division of Engineering, Nuclear Regulatory Commission, Washington, DC 20555

41-43. R. J. Fields, Fracture and Deformation Division, National Institute of Standards and Technology, Gaithersburg, MD 20899

44. G. R. Irwin, Department of Mechanical Engineering, University of Maryland, College Park, MD 20742

45. C. W. Schwartz, Department of Mechanical Engineering, University of Maryland, College Park, MD 20742

46. W. L. Fourney, Department of Mechanical Engineering, University of Maryland, College Park, MD 20742

47. J. W. Hutchinson, Division of Applied Science, Pierce Hall, Harvard University, Cambridge, MA 02138

48. F. A. Leckie, University of California, Santa Barbara, CA 93106

49. R. J. Dexter, Engineering and Material Science Division, Southwest Research Institute, San Antonio, TX 78284

50. Office of Assistant Manager for Energy Research and Development, Department of Energy, Oak Ridge Operations Office, Oak Ridge, TN 37831

51-52. Office of Scientific and Technical Information, P.0. Box 62, Oak Ridge, TN 37831

53-302. Given distribution as shown in category RF (NTIS-10)

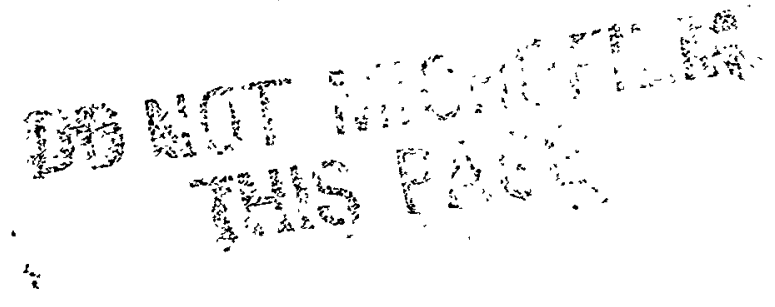




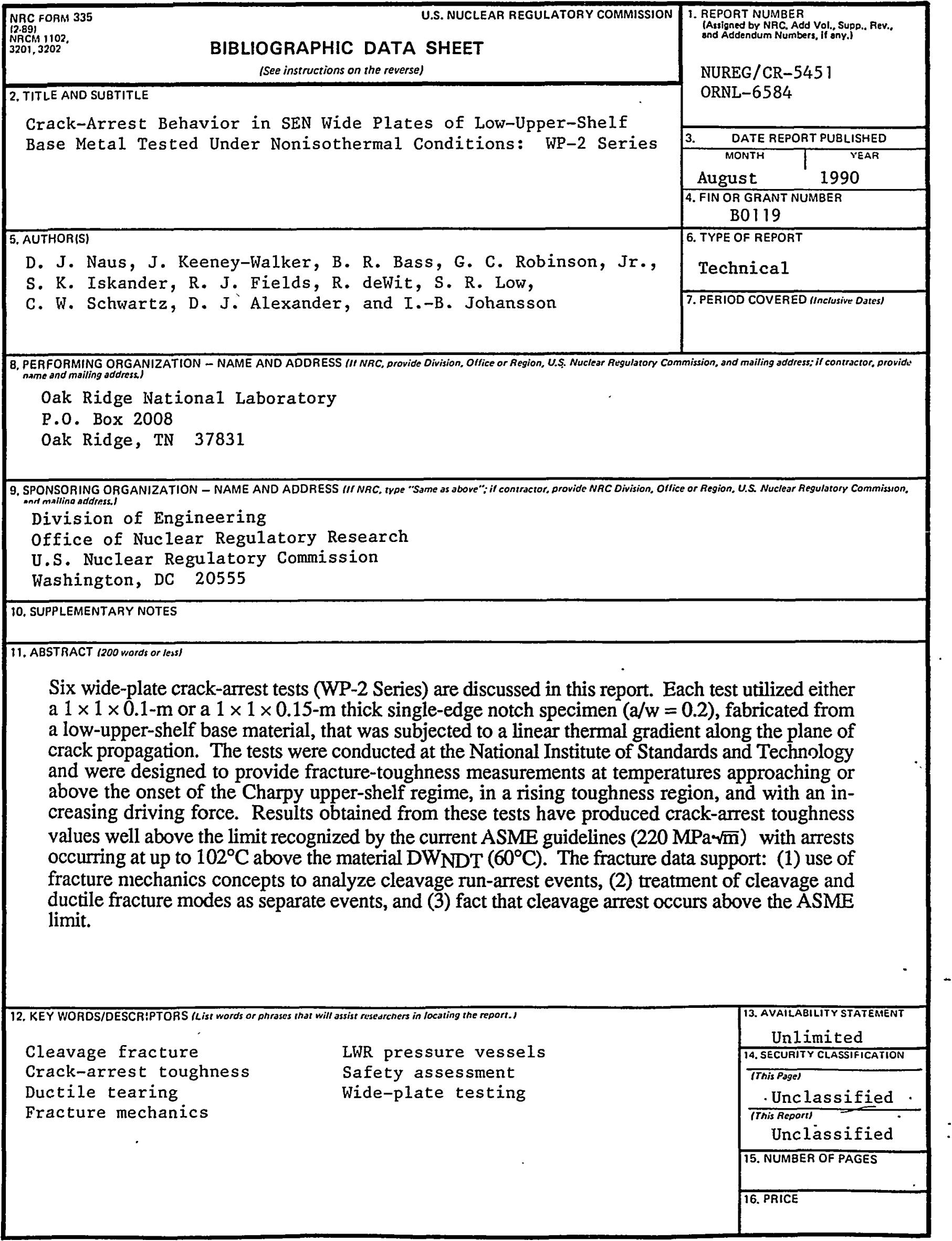

